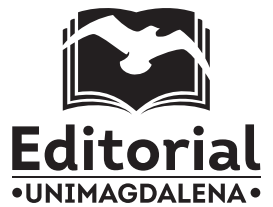



Vida campesina en el Magdalena Grande 



\title{
Vida campesina en el Magdalena Grande
}

\author{
Editores: \\ Alexander Rodríguez Contreras \\ Fabio Silva Vallejo
}

\author{
Autores: \\ Francisco Avella Esquivel \\ Fabio Silva Vallejo \\ Alexander Rodríguez Contreras \\ Dany Martínez \\ Erik Méndez \\ Elías Doria \\ Andrés David Franco \\ Luis Martínez \\ Luis Fontalvo \\ Ansehl Zúñiga
}


Catalogación en la publicación - Biblioteca Nacional de Colombia

Vida campesina en el Magdalena Grande / autores, Francisco Avella Esquivel ... [et al.] ; editores, Alexander Rodríguez Contreras, Fabio Silva Vallejo. -- 1a ed. -- Santa Marta : Universidad del Magdalena, 2020.

596 p. -- (Ciencias Sociales. Antropología y Sociología)

Incluye referencias bibliográficas.

ISBN 978-958-746-346-0 -- 978-958-746-347-7 (pdf) -- 978-958-746-348-4 (e-pub)

1. Vida en el campo - Magdalena (Región) 2. Campesinos - Vida social y costumbres - Magdalena (Región) 3. Magdalena (Región) - Vida social y costumbres I. Avella Esquivel, Francisco II. Rodríguez Contreras, Alexander III. Silva Vallejo, Fabio, 1962- IV. Serie

CDD: 305.963 ed. 23

CO-BoBN-a1066463

Primera edición, noviembre de 2020

2020 @ Universidad del Magdalena. Derechos Reservados.

Editorial Unimagdalena

Carrera 32 n. $^{\circ} 22-08$

Edificio de Innovación y Emprendimiento

(57 - 5) 4381000 Ext. 1888

Santa Marta D.T.C.H. - Colombia

editorial@unimagdalena.edu.co

https://editorial.unimagdalena.edu.co/

Colección Ciencias Sociales, serie: Antropología y Sociología

Rector: Pablo Vera Salazar

Vicerrector de Investigación: Ernesto Amarú Galvis Lista

Coordinador de Publicaciones y Fomento Editorial: Jorge Enrique Elías-Caro

Diseño editorial: Luis Felipe Márquez Lora

Diagramación: Eduard Hernández Rodríguez

Diseño de portada: Andrés Felipe Moreno Toro

Corrección de estilo: Juliana Javierre Londoño

Santa Marta, Colombia, 2020

ISBN: 978-958-746-346-0 (impreso)

ISBN: 978-958-746-347-7 (pdf)

ISBN: 978-958-746-348-4 (epub)

DOI: $10.21676 / 9789587463460$

Impreso y hecho en Colombia - Printed and made in Colombia

Xpress Estudio Gráfico y Digital S.A.S. - Xpress Kimpres (Bogotá)

Este proyecto ha recibido financiación del programa de investigación e innovación Horizonte 2020 de la Unión Europea, bajo el acuerdo Marie Skłodowska-Curie No. 823846. Este proyecto es dirigido por la profesora Consuelo Naranjo Orovio, Instituto de Historia - CSIC.

El contenido de esta obra está protegido por las leyes y tratados internacionales en materia de Derecho de Autor. Queda prohibida su reproducción total o parcial por cualquier medio impreso o digital conocido o por conocer. Queda prohibida la comunicación pública por cualquier medio, inclusive a través de redes digitales, sin contar con la previa y expresa autorización de la Universidad del Magdalena.

Las opiniones expresadas en esta obra son responsabilidad de los autores y no compromete al pensamiento institucional de la Universidad del Magdalena, ni genera responsabilidad frente a terceros. 


\section{Contenido}

Presentación ................................................................................. 19

Características del campesinadodel Magdalena Grande ............... 31

La colonización rocera......................................................................... 33

Asentamientos de grupos afrodescendientes .................................. 36

¿Cómo surgió esta "polvareda" de pequeños asentamientos? ... 37

Pescadores y agricultores tradicionales de las riberas de los ríos y las áreas inundables....................................................................... 38

Vida campesina en la Sierra Nevada de Santa Marta ..................... 41

Poblamiento ....................................................................................... 42

Colonización de la vertiente noroccidental de la Sierra Nevada de Santa Marta.......................................................................... 42

Colonización de la vertiente occidental de la Sierra Nevada de Santa Marta........................................................................... 47

Campesinos y conflicto en la Sierra Nevada de Santa Marta .......... 54

La bonanza marimbera ........................................................... 55

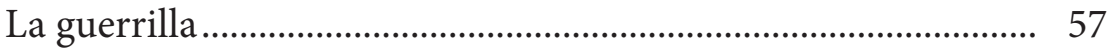

Autodefensas de los Rojas....................................................... 67

Las autodefensas unidas de Colombia (AUC)............................ 69

La guerra contra los Rojas........................................................... 74

La guerra de las autodefensas campesinas del Magdalena y La

Guajira (ACMG) contra el Bloque Norte- AUC .......................... 75

EL BRT: control social y militar en los corregimientos de Minca, San Pedro de la Sierra y Siberia. 
Ahora somos ecológicos ................................................................ 85

Las buenas prácticas ............................................................... $\quad 90$

Conclusiones ................................................................................. 94

Vida campesina en La Guajira ................................................. 97

Nostalgia de la bonanza: campesinos del valle de Tomarrazón ....... 100

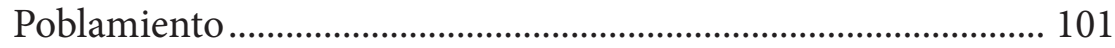

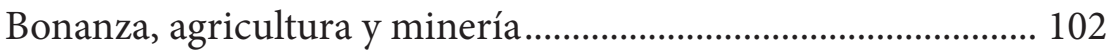

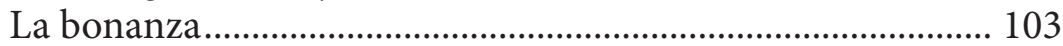

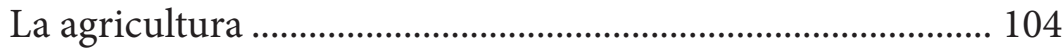

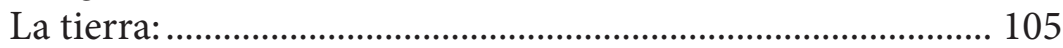

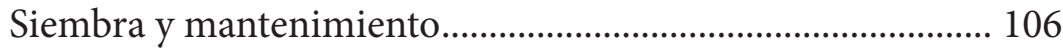

Transporte y comercialización ................................................ 107

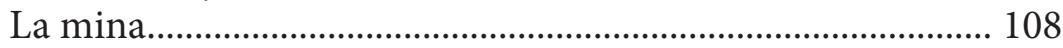

Organización campesina en el valle de Tomarrazón..................... 110

Elementos culturales de la vida campesina en Tomarrazón........ 116

Tensiones en la frontera: campesinos de Carraipía .......................... 116

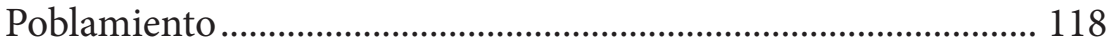

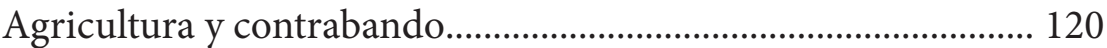

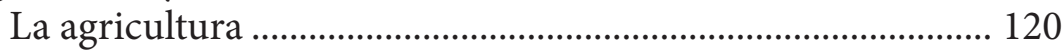

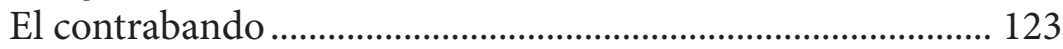

Organización campesina en Carraipía .......................................... 127

Elementos culturales de la vida campesina en Carraipía............ 132

El campesino fantasma: territorio y minería en la comunidad de

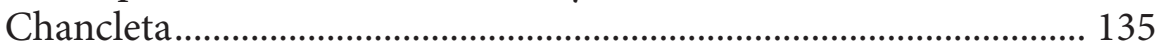

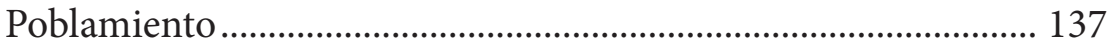

El fantasma del carbón .................................................................... 139

La mina acabó con todo ............................................................ 143

Organización ancestral de la comunidad afrodescendiente

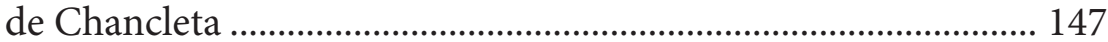

Una ancestralidad a punto de desaparecer .................................. 153

El Sur de La Guajira y la sombra de la montaña: voces campesinas de Villanueva, el Molino, Urumita y la Jagua del Pilar...................... 155

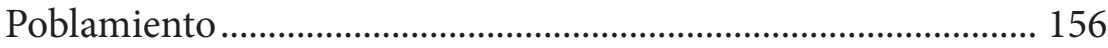


Nostalgias y esperanzas de una bonanza agrícola ....................... 158

Organización campesina en el Sur de La Guajira ......................... 165

Cultura y tradición en el Sur de La Guajira ................................. 170

Vida campesina en el norte del Cesar .......................................... 175

"La época de la violencia"................................................................ 178

El fantasma de la amapola y la esperanza de la mora: la vereda el

Cinco en la Serranía del Perijá.......................................................... 181

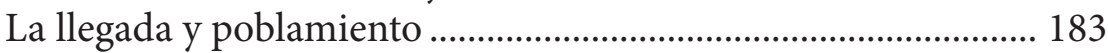

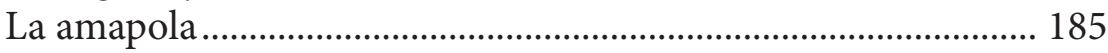

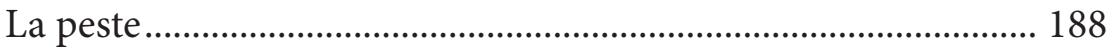

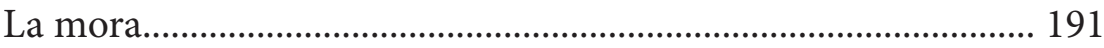

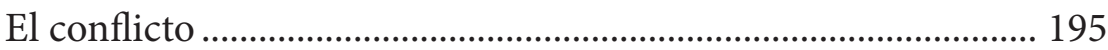

Como extraños en nuestra tierra: el Toco y la lucha por el territorio en el valle del río Cesar........................................................... 199

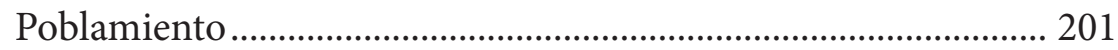

ASOCOMPARTO y la organización comunitaria de la vereda

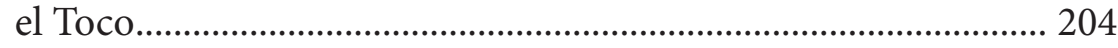

El retorno y los dilemas de la justicia transicional ...................... 209

De colonos a invasores: campesinos de la vereda La Guitarra, en

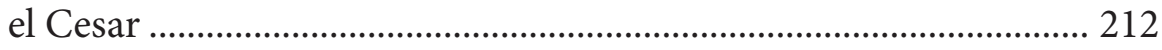

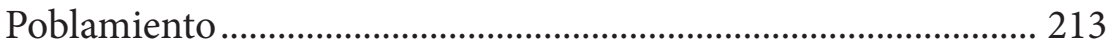

Las primeras cosechas y la consolidación de un sueño................ 215

La disputa por el territorio............................................................ 217

"Nos acusan de invasores y por eso no hay inversión"................. 219 Agricultura y minería: tensiones por el territorio en la vereda

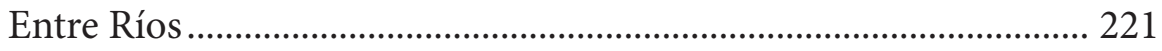

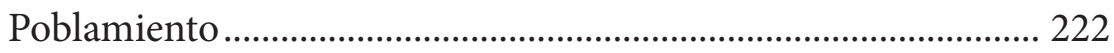

Afectaciones al medio ambiente por la actividad minera........... 223

La vida Entre Ríos ............................................................................ 227

La lucha por la permanencia en el territorio................................ 232

De campesinos a rebuscadores: el caso del barrio Bello Horizonte de Valledupar ...................................................................................... 239

Reproducción de las formas de vida del campo en la ciudad .... 240 
La bonanza algodonera: origen y poblamiento de la subregión Sur del Cesar

Cotidianidad campesina: saberes locales y modos de vida en el sur de la Serranía del Perijá.

Conflictos sociales y ambientales en el piedemonte de la Serranía del Perijá 295

Del algodón a la minería de gran escala 295

Conflicto armado interno en el piedemonte de la Serranía del Perijá: memorias y voces sobre la violencia. 305

Vida campesina en el Centro y Sur del Magdalena

El campesino ribereño 312

Poblamiento y colonización de la Ribera del Río

Los tiempos de cultivo y las tierras de la ribera del río

Magdalena.

"Somos el espejo de nuestros padres": el aprendizaje y

conocimiento sobre la tierra.

El fruto de la tierra: el proceso de la siembra y cosecha

El campesino y la pesca: un acercamiento a la actividad pesquera

"El problema es que la tierra no es de quien la trabaja": el problema de la tierra en los pueblos ribereños. 352

El campesinado del Centro del Magdalena 362

Poblamiento y colonización de campesinos hacia el Centro del Magdalena.

A la espera de las lluvias y el milagro de la cosecha: el trabajo de la tierra en el Centro del Magdalena 372

El campesino y la ganadería 383 "Haga paja y no cultive": el problema de tierra en el Centro del Magdalena.

Vida campesina en el Norte del Magdalena

Zona Bananera Histórica

Dinámicas de poblamiento y ordenamiento del territorio. 


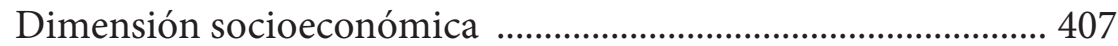

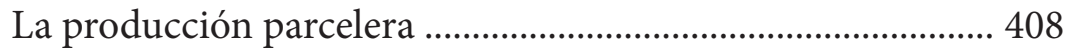

La producción y el trabajo en la plantación bananera ............ 419

Condiciones laborales en las plantaciones .............................. 425

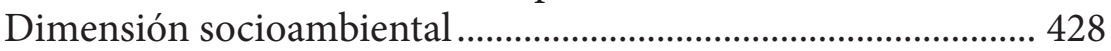

Dimensión sociopolítica ............................................................. 434

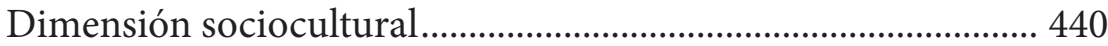

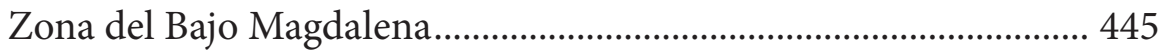

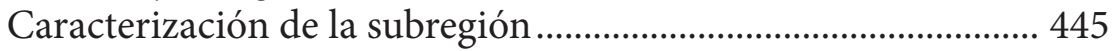

Dimensión socioeconómica .......................................................... 453

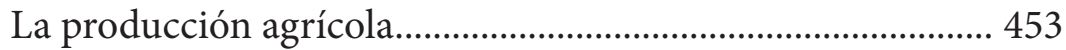

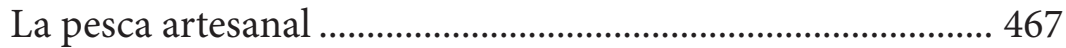

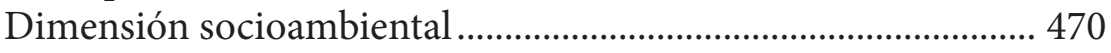

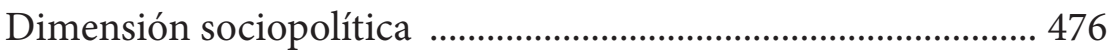

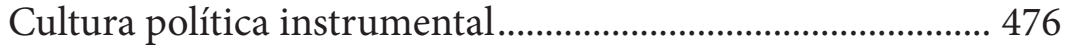

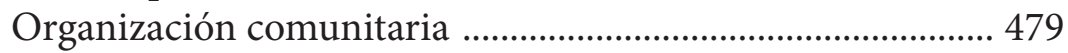

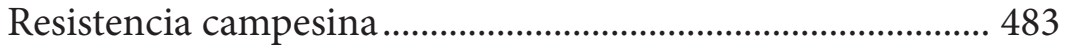

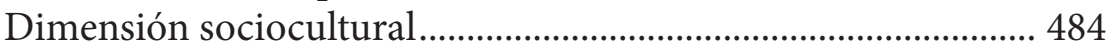

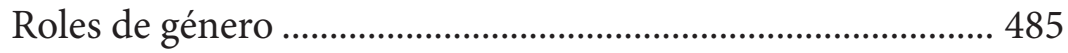

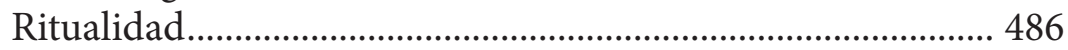

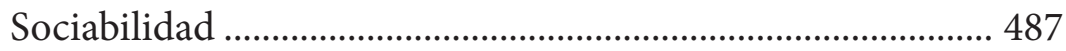

Expresiones culturales: fiestas patronales ................................... 490

Elementos que generan rupturas en la vida comunitaria ..... 490

Campesinos urbanos en la ciudad de Santa Marta ...................... 493

Vida campesina en la vereda el Mosquito, de Santa Marta.............. 494

Poblamiento de la vereda el Mosquito: realidad del conflicto social y armado del país .............................................................. 499

El conflicto armado y la seguridad en el territorio....................... 504

Ser campesino en la vereda Mosquito: memoria oral y realidades concretas .......................................................................... 512

Saberes locales y dinámicas de subsistencia ................................ 515

La agricultura y su relación con la naturaleza.......................... 517

La economía campesina en contextos urbanos............................. 519

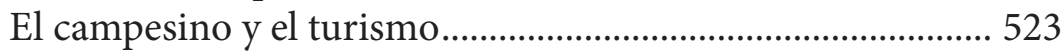

El mango .............................................................................. 523 


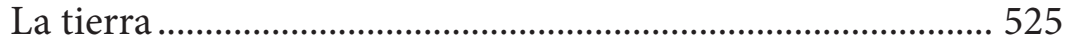

Ser campesino: orgullo, resistencia y esperanza........................... 525

Vereda Altos de Don Jaca .......................................................... 529

Historia de poblamiento de la vereda Altos de Don Jaca ........... 536

Saberes, siembras y cultivos: el campesino y su relación con

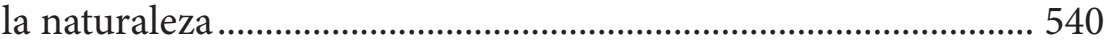

Las paradojas de la vida campesina .......................................... 545

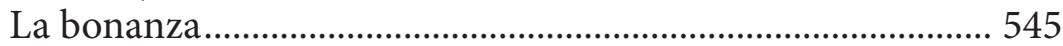

El problema del agua ................................................................. 549

Tecnologías de subsistencia y adaptación al clima ................. 550

Vías de acceso: limitaciones para la comercialización ........... 554

Los retos y ganancias de la asociatividad ..................................... 556

"Dejar el sombrero": la emigración como consecuencia de la apatía gubernamental ..................................................................... 561

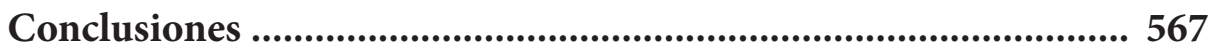

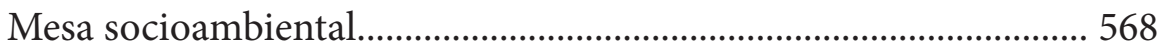

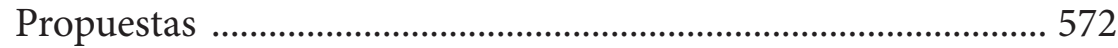

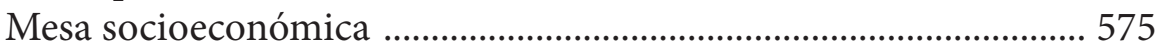

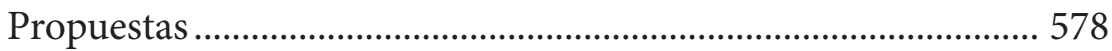

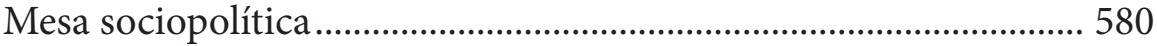

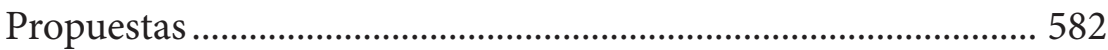

Dimensión sociocultural................................................................. 582

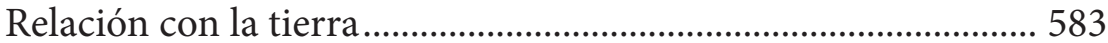

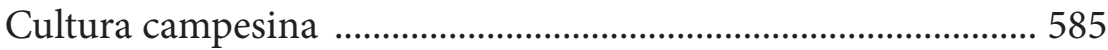

Conflicto y cultura ......................................................................... 587

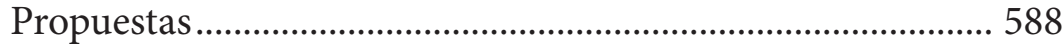

Referencias bibliográficas ........................................................... 591 


\section{Lista de figuras}

Mapa 1. Sierra Nevada de Santa Marta y sus municipios ..................... 41

Imagen 1. Corregimiento de Siberia .................................................. 48

Imagen 2. Casa campesina en la vereda Corea ..................................... 54

Imagen 3. Peaje vía Kennedy............................................................... 62

Imagen 4. Cortando leña ........................................................................ 72

Imagen 5. Casa campesina en el corregimiento de Siberia .................. 77

Imagen 6. Mujer campesina de la vereda Cantaranas........................... 81

Imagen 7. Panel solar en la vereda Sacramento ................................... 85

Imagen 8. Jardín en Corea ................................................................ 89

Mapa 2. La Guajira y sus municipios ................................................ 97

Imagen 9. Valle de Tomarrazón ........................................................... 100

Imagen 10. Calle principal de Tomarrazón............................................. 101

Imagen 11. Cultivos de maíz en Tomarrazón ....................................... 105

Imagen 12. Vías de acceso en Tomarrazón ............................................. 107

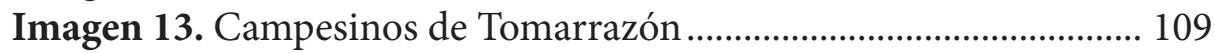

Imagen 14. Paisaje rural en Tomarrazón .................................................. 111

Imagen 15. Campesinos de la vereda San Pablo, Tomarrazón ............. 113

Imagen 16. Reunión Campesina en Tomarrazón.................................... 114

Imagen 17. Calle de Carraipía adornada ............................................. 117

Imagen 18. Dirigentes campesinos de Carraipía .................................... 118

Imagen 19. Campo de fútbol y, al fondo, los Montes de Oca .............. 123

Imagen 20. Calle principal de Carraipía................................................... 124

Imagen 21. Mujer trabajando con hacha............................................. 125

Imagen 22. Casa del campesino en Carraipía ....................................... 128

Imagen 23. Cultivo y maleza en Carraipía ............................................. 129

Imagen 24. Parcela en Carraipía ................................................................ 130 
Imagen 25. Casa encomendada a San Gregorio, en Carraipía............. 132

Imagen 26. Campesinos de Carraipía .................................................... 134

Imagen 27. Puente del Cerrejón en la vía a Chancleta .......................... 135

Imagen 28. Vivienda campesina en Chancleta, La Guajira................... 136

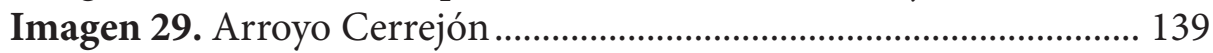

Imagen 30. Extracción de carbón............................................................ 143

Imagen 31. Comunidad de Chancleta, La Guajira................................ 147

Imagen 32. Líder campesina en Chancleta, La Guajira......................... 149

Imagen 33. Caminando por las calles de Chancleta, La Guajira ......... 152

Imagen 34. Preparando bollos de maíz en Chancleta, La Guajira ...... 153

Imagen 35. La Serranía del Perijá desde Urumita .................................. 155

Imagen 36. Cultivos en la zona rural del Molino ................................... 159

Imagen 37. Acceso al Perijá desde Urumita............................................ 161

Imagen 38. Iris Zabaleta, campesina y empresaria del Molino ........... 164

Imagen 39. Euclides Romero, dirigente campesino ............................... 166

Imagen 40. Gilberto Frangoso, campesino y dirigente sindical .......... 168

Imagen 41. Tostando café en barrio de Villanueva ................................ 170

Imagen 42. Alfonso Olmedo, campesino caficultor.............................. 171

Imagen 43. La Serranía del Perijá desde el Molino ................................ 172

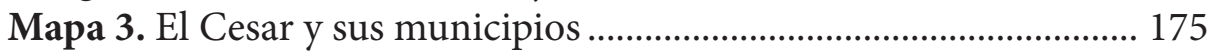

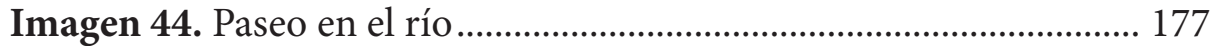

Tabla 1. Corregimientos y veredas de Manaure, Cesar......................... 182

Imagen 45. Vía de acceso a la vereda el Cinco......................................... 183

Imagen 46. Planta de amapola, vereda el Cinco ..................................... 185

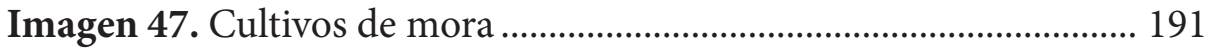

Imagen 48. Joven campesino cosechando mora..................................... 193

Imagen 49. Campesina asistiendo la mora en la vereda el Cinco ....... 194

Imagen 50. Pablo Contreras, campesino de la vereda el Cinco............ 196

Imagen 51. Vía de acceso de Manaure hacia el Perijá............................. 198

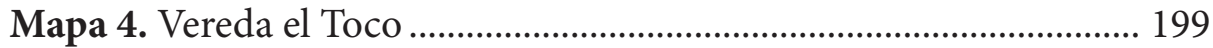

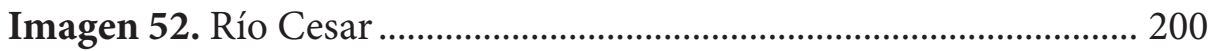

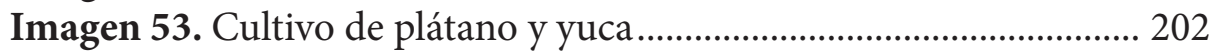

Imagen 54. Olla comunitaria ................................................................... 210

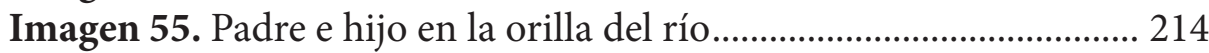

Imagen 56. Campesino a caballo ............................................................ 215

Imagen 57. Concesión minera en la vereda Entre Ríos......................... 221 
Imagen 58. Deforestación en la vereda La Guitarra............................... 223

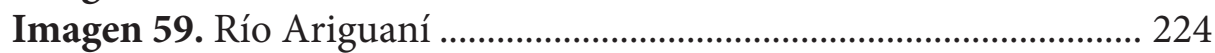

Imagen 60. Puente de acceso a la vereda Entre Ríos.............................. 229

Imagen 61. Escuela rural en la vereda Entre Ríos ................................. 230

Imagen 62. Paisaje en la vereda Entre Ríos .......................................... 232

Imagen 63. Casa campesina en la vereda Entre Ríos .............................. 236

Imagen 64. Cultivo de ají en el barrio Bello Horizonte .......................... 245

Mapa 5. Subregión sur del Cesar .......................................................... 247

Imagen 65. Buturama, antigua hacienda algodonera ........................... 251

Imagen 66. Campesino del Sur del Cesar............................................... 252

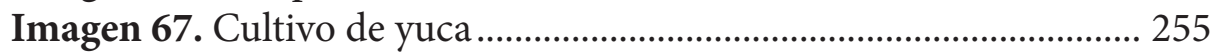

Imagen 68. Sembrado de maíz en Pailita, Cesar.................................... 256

Imagen 69. Monumento al maíz en Pelaya, Cesar ................................. 258

Imagen 70. Antiguas bodegas de ColCesar en Aguachica .................... 261

Imagen 71. Campesino del Centro del Cesar .......................................... 263

Imagen 72. Cultivo de plátano en Codazzi, Cesar .................................. 264

Imagen 73. Eduardo Torres, campesino de Llerasca............................... 265

Imagen 74. Sistema de riego, Cesar..................................................... 266

Imagen 75. Patio de casa en Llerasca, Cesar ............................................ 269

Imagen 76. Joven campesino caminando hacia su parcela ................... 271

Imagen 77. Cultivo de plátano y yuca en Llerasca, Cesar ..................... 274

Imagen 78. Casa campesina en la Victoria de San Isidro...................... 282

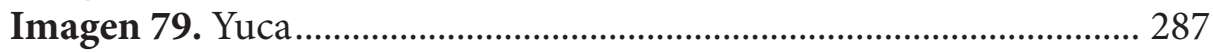

Imagen 80. Mujer campesina .................................................................. 289

Imagen 81. ASOMAVIC en la Victoria de San Isidro............................ 291

Imagen 82. Cultivo de aromática.............................................................. 292

Imagen 83. Líder campesina de la Victoria de San Isidro ..................... 294

Imagen 84. Antigua algodonera en Aguachica, Cesar........................... 298

Imagen 85. Mina de carbón en la Victoria de San Isidro ...................... 303

Imagen 86. Río Sororia en La Jagua de Ibirico, Cesar ............................ 304

Imagen 87. Casa abandonada en Llerasca, Cesar................................... 308

Mapa 6. Recorrido realizado para la realización de este capítulo........ 312

Mapa 7. Sitios y misiones fundados en el siglo XVIII............................ 313

Imagen 88. Calle de San Felipe ................................................................ 317

Imagen 89. Casa de bahareque ............................................................... 319

Imagen 90. Ribera del río Magdalena ..................................................... 321 
Imagen 91. Caño en el corregimiento de los Negritos............................ 324

Imagen 92. Campesino ribereño ..................................................... 330

Imagen 93. Transporte de productos en canoa....................................... 338

Imagen 94. Medio de transporte en los pueblos ribereños ................... 339

Imagen 95. Ciénaga de Zarate............................................................ 347

Imagen 96. Construcción de casa de bahareque .................................... 351

Imagen 97. Asociación Campesina y Pescadores de Zarate.................. 357

Imagen 98. Ejercicios organizativos del campesino ribereño ............... 359

Imagen 99. Recuerdos del Día del Campesino ...................................... 360

Mapa 8. Zona Centro del Magdalena................................................. 362

Imagen 100. Campesino de Sabanas de San Ángel ............................... 363

Imagen 101. Vía Chibolo ...................................................................... 365

Imagen 102. Juan Evangelista Sabayé..................................................... 368

Imagen 103. Parcela de Giovanni Gutiérrez ......................................... 374

Imagen 104. Preparando la tierra para cultivar................................... 375

Imagen 105. Transportando productos en burro ..................................... 379

Imagen 106. Camiones recolectores de productos campesinos .......... 381

Imagen 107. Preparación del bollo de yuca ............................................ 382

Imagen 108. La casa del campesino en Chibolo...................................... 386

Imagen 109. Campesino vendiendo helado .......................................... 388

Mapa 9. Mapa subregión CGSM.............................................................. 391

Mapa 10. Zona Bananera Histórica .................................................... 394

Mapa 11. Vocación y conflicto de uso del suelo en Zona Bananera ... 400

Imagen 110. Pozo artesanal para la extracción de agua ........................ 404

Imagen 111. Vivienda campesina en Varela, Zona Bananera............... 406

Imagen 112. Parcela de banano en Orihueca.......................................... 410

Imagen 113. Vivero de COFRUMAG, en Ciénaga.................................. 414

Imagen 114. Plantación de banano en Candelaria................................... 418

Imagen 115. Planta de banano y sus retoños ........................................... 421

Imagen 116. Transporte de banano en las plantaciones........................ 422

Imagen 117. Represa y reservorio en predios de los Cadavid ............. 429

Imagen 118. Agua de la CGSM entrando al río Frío ............................. 431

Imagen 119. Extracción de agua de pozo artesanal ................................ 431

Imagen 120. Campesinos desmontando talanquera en Caño Mocho 433

Imagen 121. Sede SINTRAINAGRO, en Ciénaga, Magdalena ............ 438 
Imagen 122. Espacios de socialización en el Bajo Magdalena.............. 442

Mapa 12. Subregión Bajo Magdalena de la CGSM................................. 445

Imagen 123. Vocación y conflictos de uso del suelo en el

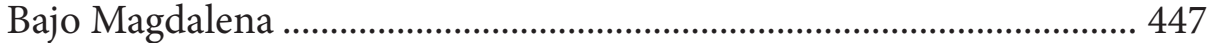

Imagen 124. Cotidianidad en Santa Rita, Magdalena............................ 450

Imagen 125. Rancho para sombrear durante el jornal .......................... 455

Imagen 126. Cultivos ahogados en Sitio Nuevo y Piñón ....................... 461

Imagen 127. Campesinos en el "rebusque" ............................................. 466

Imagen 128. Contando el pescado ......................................................... 468

Imagen 129. Plantación de palma de aceite en el Piñón ....................... 473

Imagen 130. Salón comunal en Playón de Orozco, Magdalena ........... 478

Imagen 131. Comida campesina del Bajo Magdalena en la CGSM.... 488

Mapa 13. Mapa de la vereda el Mosquito ................................................ 494

Imagen 132. Calle principal de la vereda el Mosquito.......................... 497

Imagen 133. Horno artesanal para la extracción de carbón ................. 499

Imagen 134. Altar de San Martín de Loba ............................................. 503

Imagen 135. Árbol de bonga en la vereda el Mosquito ......................... 506

Imagen 136. Papaya en manos campesinas............................................. 512

Imagen 137. El campesino y su parcela ................................................. 514

Imagen 138. Adaptación para el sistema de riego .................................. 515

Imagen 139. Manguera del sistema de riego de la vereda Mosquito.. 516

Imagen 140. Extracción artesanal de carbón ........................................ 520

Imagen 141. Campesino recolector de mango ....................................... 524

Mapa 14. Vereda Altos de Don Jaca ........................................................ 529

Imagen 142. Sendero en Altos de Don Jaca ........................................... 534

Imagen 143. Cultivo de col en la vereda Altos de Don Jaca................. 535

Imagen 144. Cultivos de col en Altos de Don Jaca................................. 541

Imagen 145. Pasos de campesina............................................................... 544

Imagen 146. Campesino cultivador de ají................................................ 547

Imagen 147. Transporte de agua hacia las parcelas................................. 551

Imagen 148. Cría de cerdos................................................................. 553

Imagen 149. Tostando café en Altos de Don Jaca ................................. 556

Imagen 150. Pisadas campesinas en Altos de Don Jaca ........................ 558

Imagen 151. Sombrero campesino .......................................................... 561

Mapa 15. ZRC en el Magdalena Grande.................................................. 570 



\section{Presentación}

El Grupo de Investigación sobre Oralidad, Narrativa Audiovisual y Cultura Popular del Caribe Colombiano (ORALOTECA) tiene más de diez años de trabajo en diversos territorios de la geografía regional. Durante este tiempo nos hemos acercado a las realidades que viven los pueblos y las comunidades que nos unen como un territorio pluriverso y multicultural, procurando constituirnos como un puente entre los conocimientos populares y el saber académico; lejos de pretender asumir la voz de las comunidades, hemos ensayado herramientas y canales por medio de los cuales estas comunidades puedan enunciarse a sí mismas. Más allá de pretender llevar los conocimientos populares a los escenarios del debate académico, nuestra apuesta es por acercar los escenarios académicos a las epistemes de las comunidades y los pueblos del Caribe. Por esta razón, la publicación de este libro se convierte en una nueva apuesta por acercar el mundo académico a la realidad que viven las comunidades de campesinos y campesinas que habitan los departamentos del Cesar, Magdalena y La Guajira, al tiempo que son un aporte fundamental para el reconocimiento del campesinado como sujetos sociales de derecho, ya que desde sus territorios, han configurado formas propias de relacionarse con el territorio que les permiten generar procesos de organización, lucha y resistencia para su dignificación como población.

Conocer la vida, las cotidianidades y formas de ser de los pueblos campesinos y pescadores del Magdalena Grande (Cesar, Magdalena y La Guajira) es un reto que debió ser asumido mediante 
un método que permitiera a las personas expresar los significados de lo que hacen y por qué lo hacen (Restrepo, 2016); esto fue posible mediante el diálogo e intercambio de saberes, pero fundamentado desde el saber escuchar como un instrumento de acercamiento que rompiera con la verticalidad en la interpretación de la realidad y generara una horizontalidad en la construcción de conocimiento sobre lo que significa "ser campesino" en una región tan diversa como es el Caribe colombiano. En ese sentido, los recorridos etnográficos, el diálogo de saberes, las historias de vida, las entrevistas semiestructuradas, los talleres participativos y la observación dinamizan la búsqueda de relatos que representan la historia y el presente de dichas comunidades como sociedades dignas que han configurado y codificado su mundo mediante la relación constante con la naturaleza, el universo y la sociedad.

Para dar inicio al desarrollo de la investigación se planteó la idea de abordar la realidad de las comunidades campesinas del Magdalena Grande a partir de las formas de relacionarse con el territorio, no solo en términos productivos, sino también a partir de las representaciones, los valores y significados que sobre este se construyen. Así, el análisis de las relaciones establecidas con el territorio puede ser abordado desde la perspectiva naturalista, política, económica y culturalista (Rincón, 2012). El trabajo de los etnógrafos no se limitó a describir prácticas económicas en relación con la tierra y el agua, sino que la mirada del investigador pretendió conocer cómo la tierra y el agua han configurado unas identidades, corporalidades y saberes propios que expresan la historia y la realidad concreta de pueblos marginalizados que han resistido dignamente por el sostenimiento de sus tradiciones y memorias como elementos estructuradores de sus modos de vida.

En ese sentido, los procesos de colonización, poblamiento, saberes locales, economías, conflictos y procesos organizativos guían cada uno de los apartes del documento, que resalta la complejidad y heterogeneidad que atraviesan las realidades campesinas en los departamentos del Magdalena, La Guajira y Cesar (Magdalena Grande), lo cual es un ejercicio de memoria que aporta una lectura actual cuando se refiere a pueblos campesinos y pescadores que aún siguen luchando por mejorar sus condiciones de vida y por ser escuchados como sujetos activos en la construcción de región y país. 
La etnografía como método crítico y dialogal (Vasco, 2000) arroja insumos que permiten comprender la territorialidad, la identidad y la memoria desde las mismas voces de los actores; es decir, conocer el territorio de la mano de las comunidades permitió comprender las realidades contadas desde la experiencia, lo emocional y lo sensorial como forma significativa en las dinámicas sociales, culturales y de resistencia de las comunidades campesinas y de pescadores. Los recorridos etnográficos, el diálogo de saberes, las historias de vida, las entrevistas semiestructuradas, los talleres participativos y la observación dinamizan la búsqueda de relatos que representan la historia y el presente de dichas comunidades como sociedades dignas que han configurado y codificado su mundo mediante la relación constante con la naturaleza, el universo y la sociedad.

Para el desarrollo de las etnografías sobre las formas de vida de la población campesina en el Magdalena Grande abordamos el territorio desde sus particularidades geográficas, para lo cual decidimos dividir los departamentos del Cesar, Magdalena y La Guajira en siete subregiones geográficas: Sierra Nevada de Santa Marta, La Guajira, Norte del Cesar, Sur del Cesar, Centro y Sur del Magdalena, Norte del Magdalena o Ciénaga Grande de Santa Marta y una última subregión de análisis que corresponde a las realidades de los campesinos en zonas urbanas.

Las salidas de campo o "recorridos etnográficos" a cada uno de estos territorios permitió recoger la información de acuerdo a las categorías de estructuración de la vida cotidiana propuestas, a saber: producción o satisfacción de necesidades básicas; política o toma de decisiones colectivas; cultura o formas de reproducción de identidades colectivas, prácticas tradicionales y valores comunes, y ambiental o las relaciones con el entorno y los recursos naturales. Asimismo, durante la realización de los recorridos etnográficos se consideró adicionar la dimensión "conflicto", referente a los efectos sociales derivados de la exposición de las comunidades al conflicto armado interno; esto, dada la recurrencia con que las comunidades señalaban los variados tipos de afectaciones físicas, simbólicas y psicológicas que sufrieron y siguen sufriendo. Sin embargo, dada la alta densidad de producción académica e institucional en años recientes sobre conflicto armado y sus efectos en el territorio, en los ejercicios etnográficos y entrevistas realizadas la dimensión de "conflicto" solo se abordó al final, dando espacio a las otras dimensiones menos estudiadas. 
Vida campesina en el Magdalena Grande

Finalmente, las "conclusiones" se elaboraron a partir de una jornada de trabajo con los campesinos, pescadores y voceros más representativos de las comunidades de cada subregión y se aplicó la metodología de diagnóstico participativo mediante el instrumento de "árbol de problemas y árbol de soluciones".

De esta manera, encontramos que en el primer capítulo se realiza una aproximación a tres de las principales dinámicas del poblamiento campesino en los departamentos del Cesar, Magdalena y la Guajira, poniendo de relieve la importancia de entender los diferentes conflictos históricos del país para comprender las diferentes oleadas de poblamiento de otras regiones hacia estos territorios. Así mismo, la herencia de las comunidades afrodescendientes representa una profunda huella en la historia de las comunidades campesinas del Magdalena Grande, al extenderse y mezclarse con otras culturas y generar un proceso de empoderamiento del territorio - más fuerte en unas zonas que en otras- que, sin duda, ha marcado el desarrollo histórico de las comunidades campesinas. Finalmente, la roza como actividad económica permite entender oleadas migratorias que son permanentes en el tiempo y el territorio, debido a la búsqueda constante de la tierra en la cual tener un cultivo permanente $y$, de esta manera, un proyecto de vida.

Para el desarrollo del segundo capítulo de este libro se realizó un estudio de caso de exploración a tres poblaciones que están asentadas en la Sierra Nevada de Santa Marta: este aborda el contexto de la colonización, las relaciones históricas que se construyeron con las guerrillas y los paramilitares y el café. Para este capítulo se escogió el corregimiento de Minca, ubicado en el municipio de Santa Marta, y los corregimientos de San Pedro de la Sierra y Siberia, ubicados en el municipio de Ciénaga. Estos tres corregimientos son poblados a partir del proceso de colonización agrícola, del proceso de colonización espontánea y de un efímero proceso de colonización armada.

Los tres corregimientos han tenido una dinámica económica a lo largo de su historia por el cultivo del café y el cultivo de marihuana - entre otros aspectos-, que han sido dignos representantes de la economía local, regional, nacional e internacional. Por otro lado, en estas tres localidades hicieron presencia la guerrilla de las FARC-EP, el ELN y grupos paramilitares. Así mismo, estos tres corregimientos hacen parte del 
denominado "cinturón cafetero de la Sierra Nevada de Santa Marta" y sobre sus habitantes se han construido estereotipos que van desde "destructores del bosque", hasta "marimberos", "guerrilleros" y "paramilitares".

Los corregimientos de Minca, San Pedro de la Sierra y Siberia se construyeron a partir de los periodos de colonización: una colonización dirigida por el Gobierno local, que se llamó la "colonización extranjera", y otra colonización ligada al periodo de la violencia política de los años cincuenta. Los extranjeros y los campesinos se sostuvieron a partir de la economía del café y, por último, de los cultivos de marihuana. Todo lo anterior, empatado o cruzado con los periodos de violencia de los grupos guerrilleros y paramilitares; periodos que generaron distintas dinámicas sociales y relaciones con el actor que controlara la zona.

Es importante resaltar que en este capítulo, además de la búsqueda de información primaria, en las etnografías se trianguló dicha información con fuentes secundarias: es decir, con datos obtenidos de documentos oficiales como los provenientes de los planes de desarrollo municipales, de los informes de organizaciones defensoras de derechos humanos, del Centro Nacional de Memoria Histórica, del DANE, de los planes de ordenamiento territorial, de artículos y textos de carácter científico, entre otros. Esto permitió, así, una mirada complementaria sobre lo que se argumenta de los pueblos campesinos frente al sentir y vivir de estas comunidades que han sido marginalizadas históricamente de los escenarios de poder.

En el desarrollo del tercer capítulo las historias de vida fueron fundamentales a la hora de acercarnos a las realidades de las comunidades campesinas de La Guajira, territorio en el que nos encontramos con problemas como la minería a gran escala, la economía ilegal de contrabando, la presencia de grupos armados ilegales y la aridez de la tierra. Sin embargo, a pesar de todos estos obstáculos, las poblaciones campesinas han construido una profunda relación con el territorio, sorteando estos problemas y haciendo de la tierra un lugar productivo para sus familias y para la comunidad.

Durante el cuarto capítulo, la historia del conflicto marcó un papel fundamental en las narraciones, en la medida en que los hechos violentos que marcaron a las comunidades se convirtieron en un punto de referencia en sus narrativas, permitiendo describir un "antes" y un "después" en el desarrollo de las formas de vida campesina en el Norte del Cesar. 
Por esta razón, para realizar nuestra aproximación etnográfica a las formas de vida campesina en los territorios del Norte del Cesar llegamos a poblaciones que, debido a su ubicación geográfica y a las condiciones medioambientales de sus territorios, nos permiten obtener elementos de análisis sobre las formas en cómo las comunidades se adaptan al territorio para el desarrollo de sus proyectos de vida, los cuales están directamente relacionados con la producción de la tierra.

Por eso, en este ejercicio llegamos hasta poblaciones como la vereda el Cinco, ubicada en la Serranía del Perijá, donde las condiciones del territorio y el abandono estatal llevaron a las comunidades a realizar cultivos de amapola como única opción de supervivencia; este hecho, como resultado, dejó "la peste" sobre la tierra, impidiendo el desarrollo normal de sus cultivos, por lo que la mora aparece como única opción de salir adelante.

También recorrimos las tierras de la vereda la Guitarra, ubicada en las faldas de la Sierra Nevada de Santa Marta —en su vertiente suroriental_, cuyos pobladores han tenido que adaptar sus cultivos a las difíciles condiciones del terreno y a la escasez del agua, condición a la que se suma el hecho de que no existe ningún tipo de acompañamiento institucional (dado que se les considera como invasores).

Así mismo, transitamos por las trochas y los caminos de la vereda Entre Ríos, ubicada en el municipio del Copey, sobre las faldas de la Sierra Nevada - en su vertiente suroccidental-, cuyos pobladores han retornado por su propia voluntad luego de ser desplazados: ahora deben luchar por mantener su vocación agrícola frente a la proliferación de proyectos mineros en su territorio.

De igual forma, y a pesar de todas las dificultades, pudimos recorrer los territorios y las memorias de los pobladores de la vereda el Toco, ubicada en el municipio de San Diego, sobre la margen izquierda del río Cesar, cuyos pobladores desplazados viven en el casco urbano del municipio de Agustín Codazzí: allí se han organizado para exigir su derecho a retornar al territorio con las garantías mínimas de seguridad que les permitan permanecer en él y poder reconstruir sus proyectos de vida.

Finalmente, en nuestros recorridos tuvimos la oportunidad de visitar el barrio Bello Horizonte, en Valledupar, donde conocimos a campesinos 
y campesinas desplazados por la violencia y quienes, en medio de nostalgias, tristezas, pero también de sueños y fortalezas, nos cuentan cómo ha sido el proceso de adaptación de sus vidas a las dinámicas propias de la ciudad, obligándolos a desempeñarse en lo que popularmente se conoce como "el rebusque" y a tratar de reproducir sus conocimientos sobre la agricultura en los limitados espacios que ofrecen sus patios en los ahora llamados "barrios de invasión".

En el capítulo cinco, "Vida campesina en el Sur del Cesar", se detallan los recorridos etnográficos realizados durante los meses de diciembre del 2016 y enero del 2017 en los municipios de Agustín Codazzi, Becerril, la Jagua de Ibirico, Pailita, Pelaya y Aguachica; para el desarrollo de este trabajo, a esta última, que limita directamente con la Serranía del Perijá - principal frontera agrícola, área limítrofe entre Colombia-Venezuela y escenario de diversas disputas y conflictos sociales, ambientales y culturales - la hemos denominado "Subregión: Sur del Cesar".

Para la caracterización sociocultural realizada en los municipios que conforman esta subregión se realizaron, en un primer momento de la investigación, recorridos etnográficos fundamentados en la observación participante de los diferentes territorios de estudio y entrevistas semiestructuradas a diferentes líderes campesinos de la región con el objetivo de estrechar lazos, socializar la investigación y conocer así la vida de las poblaciones campesinas desde su propia visión.

Los recorridos se realizaron en compañía de los líderes de las veredas y los corregimientos que se visitaron, dado que conocer el territorio de la mano con las comunidades permite reconocer y legitimar el conocimiento que poseen las poblaciones sobre su entorno, geografía y región, además de identificar los lugares que poseen relevancia colectiva en las memorias de los habitantes desde sus conocimientos e intereses.

Por este motivo, las entrevistas semiestructuradas se utilizaron como un elemento que permitió dejar hablar al campesino. El "saber escuchar" es un ejercicio que media el proceso investigativo, puesto que son los saberes de los campesinos y su representación sobre el mundo los elementos de interés para los investigadores y la investigación. En ese sentido, durante este capítulo se presentan elementos como origen-poblamiento, saberes locales y modos de vida, producción económica, conflictos sociales y afectaciones medioambientales. 
En el capítulo seis se exponen las experiencias y los recorridos junto a comunidades campesinas en el departamento del Magdalena, específicamente en dos zonas que delimitamos como subregiones, comprendiendo esta delimitación geográfica no como una línea de división o frontera, sino como áreas culturales dinamizadas por el ambiente natural y por relaciones sociales históricas mediadas por el trazado de caminos en el departamento. Es así que esta etnografía busca acercarnos a una metodología para los estudios sobre el campesino en estas dos zonas del Magdalena.

En este capítulo es recurrente encontrar una narración en la que prima la voz del entrevistado y no la voz del antropólogo como la autoridad intelectual que posee el conocimiento (situación recurrente en la Academia); por ende, se encontrarán frases que quizá no se encuentren en los diccionarios de la Real Academia de la Lengua Española o en nuestro vocabulario cotidiano, pero que nos brindarán un acercamiento a comprender el significado del territorio. Por este motivo, la investigación puede no simplemente acercarnos a un público académico o interesado en estos asuntos, sino también permitirle al protagonista de estos relatos (como lo es el campesino) leer (aunque en muchas ocasiones las realidades de los territorios no han permitido a muchos campesinos el acceso a la educación, por lo que no poseen la habilidad de leer, pero con esfuerzo sus hijos sí) sus conceptos y conocimientos desde el territorio.

Para acercarse a las comunidades campesinas en la subregión Sur del Magdalena hay que comprender el territorio desde los referentes culturales y económicos, como pobladores de la Depresión Momposina o el Sur del Magdalena, por lo que es recomendable acercarse a los antecedentes y a las investigaciones sociológicas que relatan contextos similares en la Historia doble de la costa (Fals, 1979) e Historia de la cuestión agraria en Colombia (Fals, 1975), por Orlando Fals Borda, los cuales son documentos recomendados para ilustrarnos sobre historia, cultura y política de la identidad campesina regional.

El recorrido inició por el principal foco en la economía de la región: el Banco, conocida por ser llamada "Ciudad Imperio de la Cumbia" (un referente a la danza que surgió por todo el río Magdalena y que puede evidenciarse como un ejemplo del mestizaje cultural y la diversidad de esta geografía). Así mismo, este lugar representa el último momento en 
el trabajo campesino, como es el momento de retribución y transformación en valor monetario, con la comercialización con el mayorista (la persona que se encarga de la compra de los productos agrícolas en grandes cantidades y a precios bajos) o en los graneros (los lugares de compra y venta de víveres en los centros poblados) para, finalmente, llegar a tiendas y supermercados.

Por su parte, la zona Centro del Magdalena se caracteriza por sus paisajes de llanuras y montañas (El Difícil) y por la influencia del río Magdalena (Plato, donde la ausencia de precipitaciones y tierra polvorienta es una constante). Por ello, el acercamiento al campesino estuvo mediado por las constantes referencias al trabajo ganadero, el cual posee diferencias sustanciales en la economía, territorio, cultura y política, que permiten resaltar las dificultades y la escasa población que se dedica a trabajar la tierra. Al recorrer esta región encontramos zonas rurales distantes de las cabeceras municipales en las que fue necesario brindar explicaciones y usar la identidad de estudiante universitario para poder acceder, pues existían personas en motocicletas que manifestaban brindar seguridad en los territorios.

En el capítulo siete se realizó una aproximación a las realidades de las comunidades campesinas que viven en los alrededores de la Ciénaga Grande de Santa Marta. Los recorridos fueron realizados por el investigador principal y un asistente. En promedio, debido a las distancias a recorrer y los medios de transporte disponibles en esta subregión en particular (mototaxi, lancha, carromoto, ferry, etc.), además de la dificultad de desplazamiento en un sistema cenagoso, cada recorrido se completaba en cuatro días con sus noches. Se realizaron en total cuatro salidas de campo. La primera, del 21 al 24 de diciembre de 2016, en la que se recorrieron los municipios de Sitionuevo, Remolino, Salamina, Piñón y Pivijay; la segunda, del 6 al 9 de enero de 2017, en la que se recorrieron los caseríos Varela, Orihueca y Prado Sevilla, en los municipios de Ciénaga y Zona Bananera; la tercera, del 3 al 6 de febrero de 2017, en la que se visitaron los caseríos de Sevillano, La Mira y Candelaria, en los municipios de Ciénaga y Zona Bananera; y la cuarta, del 24 a 26 de marzo de 2017, en la que se recorrieron los municipios de Aracataca y Zona Bananera.

Se llevaron dos diarios de campo, uno por cada microrregión, y se realizaron en total 30 entrevistas, cada una de las cuales fue conducida por 
el investigador, mientras que el asistente sistematizaba de acuerdo a las dimensiones establecidas. Durante todos los recorridos se llevó registro fotográfico de los diferentes aspectos de la cotidianidad campesina y se recopiló material audiovisual producido por las comunidades. A partir de los insumos recogidos, se organizó la estructura del documento de tal manera que correspondiera a las dimensiones de la vida campesina -que se habían usado en la recolección de información primaria- y a los principales hallazgos.

En el capítulo ocho nos trasladamos a las veredas Puerto Mosquito y Don Jaca, pertenecientes al área rural del distrito de Santa Marta, Magdalena. Nos propusimos conocer y describir el pasado reciente del poblamiento campesino, los conflictos sociales y ambientales, la economía familiar y los rasgos identitarios de la cultura en veredas tan cercanas a la jurisdicción urbana.

Los recorridos fueron realizados en jornadas de mañana y tarde, visitando a cada familia campesina para entrevistarla sobre las diferentes transformaciones del territorio. Por medio de los relatos reconocimos la importancia de localizar las primeras familias que habían llegado a las veredas como portadoras vitales de la memoria, los cambios y las nuevas relaciones campesinas. Nos fue crucial ubicar aquellos lugares más importantes para visitar y describir (donde estaba situada la memoria) para cada familia que visitamos, así como preguntar sobre otras familias que pudieran enriquecer los relatos fundacionales del pueblo y la historia de sus vidas. Los relatos evidencian los testigos y hechos violentos en las veredas, la llegada de nuevos campesinos desplazados de otras regiones y la conformación de una región diversa con habitantes procedentes de municipios golpeados por el conflicto armado interno que consiguieron opciones de trabajo en áreas periféricas de la ciudad.

Entendimos que para etnografiar la vida campesina se debían tener en cuenta las otras formas económicas que se implementan en las veredas y que impactan directamente en la agricultura familiar. En la vereda el Mosquito fue importante observar las relaciones que se construían con estaderos, billares, balnearios turísticos y reservas naturales en las márgenes del río Gaira; mototaxistas y taxistas que transitaban constantemente por la carretera principal; miembros ette-ennaka del resguardo Naara Kajmanta, y operarios de la planta de tratamiento de agua de Gaira, due- 
ños de galpones de pollo y hornos artesanales de carbón. Tales sectores económicos y poblacionales mantienen una relación diferente con la tierra, presentando tensiones en la ecología, propiedad, vocación del suelo e inseguridad, así como poco interés en la producción de alimentos y en la transmisión de saberes que le permita producir la tierra a las siguientes generaciones campesinas.

En Don Jaca fue importante observar los periodos en los que la población se siente identificada con la parte alta de la montaña y sobre la parte baja cerca al mar Caribe. En el primer periodo se desempeña la vocación campesina en la producción de alimentos como el plátano, la ahuyama, el ají, el repollo, la col, el cilantro, el cebollín, el tomate, la naranja, la yuca, la malanga, la papaya y el café, así como en la cría de gallinas y cerdo; este periodo es diferente a los momentos de vocación pesquera con relación cercana a la navegación y pesca a mar abierto, la venta de comida en restaurantes y la prestación de servicios turísticos para los huéspedes de los hoteles cercanos a la zona marítima. Tanto a la parte alta como a la parte baja les afecta el puerto carbonífero Drumond Ltda., ejerciendo un impacto ambiental sobre la tierra y el mar, y acumulando restos del polvillo del carbón. También se presentan difíciles condiciones para el abastecimiento de agua, a pesar de contar con la quebrada Don Jaca, motivo por el cual los campesinos no siempre mantienen los cultivos temporales con los aspersores necesarios para la producción.

En definitiva, la experiencia etnográfica de documentar los acontecimientos y las autoconcepciones de las personas sobre la vida colectiva e individual nos ubicó en la vida rural de la ciudad, haciéndonos conscientes de la falta de estimulación de la tierra y la venta de alimentos locales en las plazas de mercado de Santa Marta. Aún se desconoce la agricultura familiar en las montañas que rodean la ciudad y sus habitantes continúan sin tener los medios óptimos para producir y comercializar los productos, sin el respaldo suficiente para competir con los precios que se imponen desde la ciudad. En ese sentido, cada uno de los relatos campesinos nos dejó ver el potencial productivo a lo largo de la historia y cómo fue desplazado por cultivos de uso ilícito, hidroeléctricas, extracción de carbón, conflicto armado, turismo y balnearios de fin de semana; todo esto, dejando atrás el potencial para producir alimentos, generar mercados locales y desarrollo rural. 



\title{
Características del campesinado del Magdalena Grande
}

\begin{abstract}
Al hablar del Magdalena Grande debemos tener claro que este nombre hace referencia a los territorios comprendidos por los actuales departamentos del Cesar, Magdalena y La Guajira, y que fue definido de esta forma a partir de 1886, cuando el Magdalena fue reconocido como departamento. Este amplio territorio, que comprende montañas, sabanas, llanuras, ciénagas y ríos, ha sido escenario de confluencia para muchos grupos de indígenas, campesinos, afros y pescadores que van y vienen por estos paisajes motivados por la esperanza de una mejor vida y huyendo de los múltiples conflictos que han afectado sus territorios y que han convertido el Caribe en la mayor diáspora campesina del país.

Los orígenes del campesinado del Magdalena Grande parecen tener diferentes vertientes: por un lado, entre los años de 1948 y 1964 una gran cantidad de colonos llegó del interior del país huyendo de la violencia y refugiándose en las zonas montañosas de los departamentos de Magdalena, Cesar y la Guajira. Por otro lado, una minoría es proveniente de un proceso de mestizaje entre los arrochelados o libres que se refugiaron en los palenques y que pudieron mantener pequeñas propiedades o posesiones precarias aledañas a las grandes haciendas ganaderas que se expandieron desde mediados del siglo XX - mantenidos como reservas de mano de obra para dichas haciendas ganaderas - , pero sin mezclarse con los indígenas, como sí sucedió en el caso de la margen occidental del Bajo Magdalena en lo que hoy son los departamentos de Atlántico, Bolívar, Sucre, Córdoba y parte del Urabá chocoano y antioqueño.
\end{abstract}


En el Magdalena Grande los indígenas que perdieron sus tierras bajas (a excepción de los chimilas, que se mantuvieron hasta la segunda mitad del siglo XX) fueron desplazados y tuvieron que refugiarse en las partes medias y altas de las montañas, especialmente en la Sierra Nevada y la Serranía de Perijá, hacia donde fueron empujados por los procesos de colonización que se dieron a raíz de las diferentes bonanzas económicas que se desarrollaron en estos territorios. Queda un grupo más reducido de pequeños agricultores y pescadores que vive aún a orillas de las grandes ciénagas de la margen derecha del río Magdalena; sin ninguna propiedad de las tierras, solo las utilizan en verano cuando no están inundadas, aunque también buscan ser utilizadas por los ganaderos cuando no hay pastos en las sabanas y deben llevar el ganado a donde hay agua. Estas tierras son disputadas por los agricultores no solo por su fertilidad, sino porque aún sin tener títulos (pues están inundadas más de seis meses al año y legalmente son tierras de la nación) permiten un manejo adecuado del pulso de inundación, para luego, durante la bajada de las aguas, sembrar cultivos de secano como el arroz, la yuca y el maíz. Sin embargo, actualmente, con el avance de la mecanización, los grandes ganaderos han hecho diques inmensos en sus fincas y en los linderos de los parques nacionales (Semana, 2015) con el fin de desecar amplias zonas para solicitar su adjudicación como baldío, aunque estos sean espacios protegidos por convenciones internacionales como la Convención Ramsar.

En resumen, los campesinos del Magdalena Grande, a título de hipótesis, se pueden caracterizar como el resultado de procesos sociales en tres grandes grupos:

La colonización rocera en las zonas montañosas, proveniente del interior del país hacia la mitad del siglo XX (la llamada "colonización cachaca").

Los pequeños asentamientos de grupos de afrodescendientes en los lugares de los antiguos palenques y rochelas, muchos de ellos propietarios de sus parcelas en las zonas planas ("el campesinado negro y mestizo", que se declara mayoritariamente como afrocolombiano en el Censo de Población de 2005, caso Chiriguaná, el Paso, Pailitas).

Los pescadores y agricultores tradicionales de los bordes de los ríos y de las áreas de inundación de más de seis meses al año (de ascendencia indígena predominantemente, en muchas partes mezclados con grupos 
negros, pero que no se declaran mayoritariamente como afrocolombianos, caso Ciénaga Grande de Santa Marta, por ejemplo).

Es evidente que estos grupos son solo un tipo ideal que no puede existir en su estado puro, pues hay toda clase de mezclas posibles, lo que aumentaría la tipología del campesinado hasta hacerla prácticamente incomprensible. Sin embargo, una característica constante en cada comunidad es la falta de claridad frente a la tenencia de la tierra, pues según Reyes (2009) no están inscritos en los catastros rurales o estos catastros están completamente desactualizados. Por ello, solo tienen compraventas avaladas por notarios e inspectores de policía rurales, como predios adquiridos de "buena fe", pero que no están registrados, por lo cual no son papeles suficientes para probar la "buena fe" a la hora de un litigio. No obstante, aunque la posesión en "propiedad" predomina en los Censos Agropecuarios de 1960, 1970, 1971 y 2014, no ha sido suficiente para evitar que más de 20 mil campesinos hayan sido desplazados en la Costa Caribe durante el período comprendido entre 1996 y 2005 (Defensoría del Pueblo, 2016).

Además, todas las comunidades fueron sometidas a procesos de dominación paramilitar y guerrillera en los últimos años del siglo XX $\mathrm{y}$, en algunos sitios, persiste la presencia de bandas criminales derivadas, desde el 2005, del proceso de Justicia y Paz con los paramilitares (caso Zona Bananera, Alta y Baja Guajira), así como la guerrilla del ELN que, actualmente, hace presencia en algunas zonas de la Sierra Nevada de Santa Marta y de la Serranía del Perijá.

\section{La colonización rocera}

"Roza" es el proceso de deforestar pequeños parches de bosque primario o secundario con el fin de sembrar cultivos de pancoger - es decir, de subsistencia, como el maíz, el fríjol, la yuca- para entregarlos en pastos a los dueños de la tierra cuando la tierra es "prestada" (en arriendo o aparcería, principalmente; esto es, cuando hay un propietario que la entrega informalmente al campesino para desarrollar su roza). También puede ser "apropiada" cuando la "roza" es hecha por colonos sobre tierras baldías; es decir, pertenecientes al Estado y que podrían ser reclamadas como propias después de un proceso de reclamación ante las autoridades 
competentes, demasiado dispendioso para un campesino pobre. La principal característica económica es que la roza no da para que el campesino viva. Solo sobrevive endeudado con el tendero o el prestamista que le da el dinero para comprar los productos que el rocero no produce (ropas, herramientas, medicamentos, etc.). Como por lo regular el producto de la roza (lo que logra vender en los lejanos mercados) no le permite pagar las deudas al rocero, este está obligado a seguir a otras tierras esperando encontrar una mejor producción después de dos cosechas como máximo. Sin embargo, la tierra rápidamente se agota y el rocero debe convertirla en pastizales: así la puede vender o entregarla como parte de las deudas a sus acreedores y seguir a otra roza hasta que, al fin, se da cuenta de que no queda más selva que tumbar y sigue a otro sitio más distante de colonización. Estas secuencias están ampliamente documentadas en los principales procesos de colonización de baldíos en la Costa Caribe de Colombia, como los descritos por Fals Borda (1976; 1986), Rodríguez Navarro (1990), Molano (1988), Reyes Posada (1976; 2009) y Zambrano (2002).

Este proceso de la "colonización rocera" se inició, al parecer, en los municipios del Sur del Cesar a mediados del siglo XX, especialmente en lo que hoy son los municipios de González y la Gloria, Pailitas, Río de Oro, que en el Censo Agropecuario de 1970-71 fueron los lugares en los que más tierras estaban ocupadas en la forma de colonato y aparcería (esto es, a título precario), por lo que se puede inferir que son las tierras de los pequeños colonos roceros que, desde mediados del siglo pasado, ascendían hacia el norte por la Serranía de Perijá. También está Valledupar con una amplia población campesina con títulos precarios (aparcería y colonato) $y$, en menor medida, campesinos con pequeñas fincas de menos de cinco hectáreas. En el mismo período se da una intensa colonización de la Sierra Nevada en su vertiente suroriental, especialmente en las tierras bajas de los indígenas arhuacos y kankuamos que se creían protegidos por las espesas selvas del piso cálido. Sin embargo, en muy poco tiempo se ocupó toda la parte de Pueblo Bello y de Atanquez, la mayoría de las tierras en ganadería luego de haber acabado con la selva o monte alto. Solo se detuvo esta colonización con la expedición, por parte del entonces Ministerio de Gobierno, de la resolución 02 de 1973, por medio de la cual "se demarca la Línea Negra o zona teológica de las comunidades indígenas de la Sierra Nevada de Santa Marta" (Ministerio del Interior, 1973, p. 35). 
Esta colonización estuvo alimentada también por trabajadores rurales que venían a recoger algodón de los cultivos mecanizados que, por esa época, se desarrollaron ampliamente en el valle del río Cesar; estos trabajadores vieron la oportunidad de dedicarse a la rocería tanto en la Sierra Nevada de Santa Marta como en Perijá.

Desde un poco antes de mediados del siglo XX se tiene noticia de la colonización de la vertiente occidental de la Sierra Nevada en las regiones de San Luis y el Mico, pero solo es hacia 1960 cuando empieza el auge del café como cultivo principal en la hacienda California, fundada con capitales nacionales sobre las tierras de los indígenas y San Pedro de la Sierra, que luego se amplió hacia Palmor, desalojando completamente a los indígenas de esta parte de la Sierra Nevada (Krogzemis, 1967).

Otra de las colonizaciones más prósperas por la misma época fue la de los ríos Manzanares y Gaira, buscando tierras cafeteras en donde se fundaron fincas de más de 50 hectáreas de café (como Cincinatti y Jirocasaca) con relativo éxito. Otra colonización rocera de comienzos del siglo XX se da en la vertiente norte de la Sierra Nevada de Santa Marta, en inmediaciones de Río Ancho y Don Diego hacia las tierras de los indígenas Kággaba; esta solo logró ocupar las tierras bajas por parte de grupos de afrodescendientes de Dibulla y La Punta. También hay que anotar que, si bien se trató de una colonización rocera, no inicia con esta intención pues lo que se buscaba era fundar plantaciones como las de las demás islas del Caribe insular (Barbados, Jamaica, Martinica, Guadalupe, etc.). Al menos en tres ocasiones inmigrantes franceses, bajo la dirección del geógrafo francés Elisé Reclus, en 1855, Jean Elie Gaguet, en 1873, y, posteriormente, el antropólogo Joseph de Brettes, en 1890, se intentaron instalar sin ningún éxito (Krogzemis, 1967).

Pero el área de la Sierra Nevada de Santa Marta de más reciente colonización rocera se encuentra también en la vertiente norte, entre el río Piedras y el río Palomino, impulsada por la construcción, en 1972, de la vía que comunica a Santa Marta con Riohacha. Sin embargo, amplias zonas empezaron a ser ocupadas por campesinos, especialmente en las cercanías de Santa Marta, en el Parque Tayrona y hacia los ríos Guachaca, Buritaca, Mendiguaca, Palomino y Río Ancho, en La Guajira actual. Esta colonización de campesinos venidos del interior - especialmente santandereanos, tolimenses y algunos antioqueños- ocupó muy rápido la 
vertiente norte en la parte baja, logrando algunos campesinos ascender y pasar las tierras ya delimitadas como "línea negra" en territorio Kággaba. Estos campesinos se instalaron y su apoyo a los grupos paramilitares para luchar contra la guerrilla, que limitaba sus avances para las siembras de marihuana y coca, los llevó a conformar una de las ramas mejor organizadas del paramilitarismo en Colombia, hasta el punto de que se enfrentó a los comandos centrales de las AUC (Autodefensas Unidas de Colombia). Finalmente, se acogieron a los términos del proceso de Justicia y Paz en 2006; sin embargo, estos campesinos siguen manteniendo un control sobre la vertiente de la Sierra Nevada de Santa Marta.

También es necesario anotar que este proceso de colonización rocera en el Magdalena Grande se detuvo brutalmente desde el enfrentamiento entre guerrilla y paramilitares con población campesina interpuesta, hacia el año de 1990, ya que la mayor parte de los muertos los pusieron los campesinos y no los grupos en contienda. Mediante masacres y acciones de retaliación de parte y parte de los combatientes la mayoría de los colonos que quedaron vivos fueron desplazados.

Hoy se puede decir que el campesino rocero no existe en el Magdalena Grande y que se extinguió porque la frontera - es decir, las selvas de los baldíos nacionales - fue apropiada a la fuerza por los "señores de la guerra" de todas las facciones (Duncan, 2006), lo que no se podría llamar la clásica descomposición del campesinado, sino su violenta desaparición física.

\section{Asentamientos de grupos afrodescendientes}

Estos pequeños asentamientos nucleados de grupos de campesinos, en su mayoría afrodescendientes, se ubicaron en su mayor parte en las llanuras del Caribe, conformando una red entre los intersticios de las grandes haciendas ganaderas y tratando de explotar pequeñas parcelas de tierra que lograron conservar después de numerosos reasentamientos hechos durante el siglo XVIII, subsistiendo a la dominación colonial y republicana a partir de la siembra de cultivos de pancoger para su subsistencia y trabajando temporalmente en las haciendas ganaderas cercanas.

Sin embargo, si se analiza la ubicación de estos pequeños asentamientos rurales nucleados en la extensa geografía del Magdalena Grande se 
puede ver que Valledupar, por ejemplo, tiene 23 corregimientos, cerca de 40 inspecciones de policía rurales y por lo menos unos 60 poblados de menos de 300 habitantes (es decir, unas 50 familias de 6 habitantes en promedio). Con Santa Marta sucede lo mismo en las tierras bajas de la Sierra Nevada. También desde Riohacha hasta San Juan del Cesar, en los valles de los ríos Ranchería y Cesar; es decir, en toda la Media y Baja Guajira la mayoría de los 200 pequeños poblados son campesinos claramente diferenciados de las rancherías indígenas, por su organización lineal o su malla "urbana" en cuadrícula, con plaza principal.

\section{¿Cómo surgió esta "polvareda" de pequeños asentamientos?}

Seguramente, como lo afirma Marta Herrera, de los deseos de libertad que siempre mantuvieron "los libres de todos los colores" durante la colonia, quienes no se dejaron confiscar sus pocas tierras durante la Primera República (en el siglo XIX) que llegó hasta la Constitución de 1886, ni por la Segunda República, que llegó hasta 1991 y que para algunos sectores de la política aún no existe.

No obstante, en general, como lo señala Diana García (2016), el estudio de pequeños asentamientos nucleados, rurales, no cabía en la historia económica y social, pues fuera de la fuerza de trabajo que aportan a las grandes haciendas ganaderas ni siquiera eran tenidos en cuenta como pequeños productores rurales de auto subsistencia. Solo empezaron a aparecer en las crónicas judiciales de los años de 1970, pero como invasores de tierras ociosas. Posteriormente, en los años de 1980, hacia finales del siglo XX, constituyen las noticias más importantes de la crónica roja de la prensa nacional y regional como los lugares en donde se desarrollan las masacres más aterradoras de la historia del conflicto armado colombiano.

La mayoría de estas masacres fueron cometidas con el argumento de evitar que los comunistas invadieran las tierras prometidas por la reforma agraria. Para los militares, estas gentes humildes estaban apoyadas por guerrillas de todo tipo que se tomaron el poder por las armas, por lo que era correcto suponer que todas las personas pobres y sin tierras que trabajaban como obreros en las haciendas o que reclamaban los derechos prometidos por la reforma agraria también eran comunistas o, por lo 
Vida campesina en el Magdalena Grande

menos, "colonos de mala fe" en el argot de las notarías y las inspecciones de policía. Sin embargo, tal vez la razón más importante fue la de someterlos por la fuerza a reasentarse en las ciudades o a situarse cerca de las plantaciones que se empezaron a desarrollar a fines del siglo XX, especialmente de palma africana, como mano de obra barata, temerosa y dócil, lo que parece haberse conseguido en amplias regiones como, por ejemplo, en el caso de Guacoche, Cesar.

\section{Pescadores y agricultores tradicionales de las riberas de los ríos y las áreas inundables}

Estos campesinos se diferencian de los anteriores en la medida en que combinan las actividades de la pesca y la agricultura para subsistir y solo en casos de extrema penuria trabajan como jornaleros en las fincas ganaderas. Han sido estudiados para la margen izquierda del río Magdalena por Fals Borda (2006) quien, como se anotó, los llama "pueblos anfibios". En este sentido, las caracterizaciones hechas para la margen izquierda son igualmente válidas para la derecha. Sin embargo, hay una serie de materiales que recogen una base etnográfica con matices parecidos para el Magdalena Grande. Las principales referencias son las de Krogzemis (1967), quien describe la vida diaria, hacia mediados del siglo en la Ciénaga Grande de Santa Marta, como la de pueblos dedicados a la pesca y aislados de los demás por las grandes extensiones de agua de las zonas inundables.

Tal vez el principal trabajo es el de Mouton y Goldberg (1986), quienes recogen los comienzos del cambio propuesto por los programas del Desarrollo Rural Integrado (DRI), que buscaba hacer pasar a los campesinos de la producción para la subsistencia a la producción mecanizada para el mercado, especialmente con la yuca (manihot sculenta), el sorgo y el maíz para la alimentación de aves. En este análisis crítico se hacen evidentes las dificultades de los campesinos para asumir las actividades empresariales, no solo por la falta de formación técnica, sino también porque en los procesos productivos importaba más la subsistencia de las familias que la acumulación de capital.

En medio de estas dificultades —que se podrían llamar "técnicas"aparece la violencia guerrillera y paramilitar, que estigmatizó y victimizó 
Vida campesina en el Magdalena Grande

a los campesinos anfibios, siendo señalados como auxiliadores de los grupos paramilitares por las guerrillas y como auxiliadores de las guerrillas por los paramilitares y las fuerzas armadas en sus luchas antisubversivas.

El caso de estudio de las tierras comunitarias de "la Colorada", en el corregimiento de Medialuna, jurisdicción del municipio de Pivijay, es esclarecedor de estos procesos de tecnificación del campesinado, habituado a producir para los mercados locales, pero que no había tenido experiencia con los productos comerciales (almidón extraído de la yuca para la industria). Finalmente, el programa del DRI fracasó estruendosamente, no solo por los problemas técnicos, sino especialmente por los problemas políticos que generó el uso de las zonas de pancoger comunitarias, de pastos y los playones, cuando las aguas de la Ciénaga Grande de Santa Marta bajaban, ya que empezaron a ser reclamadas por los ganaderos que necesitaban el agua y los pastos para el ganado.

Estos enfrentamientos tuvieron como combustible los procesos de paramilitarización de estas áreas inundables, abandonadas por las guerrillas hacia el año de 1990, entrando los campesinos del área en un proceso de confinamiento (Avella, 2002) que empieza a ser descrito por el Centro Nacional de Memoria Histórica (CNMH) en los trabajos sobre Nueva Venecia, Santa Rita, La Avianca y otras comunidades que están siendo documentadas. Este campesinado anfibio, a pesar de haber sido completamente desplazado, es el que más ha tendido a volver a sus tierras después de la aprobación y puesta en aplicación de la Ley de Víctimas.

Teniendo en cuenta estos elementos, y para el desarrollo de este trabajo, hemos dividido el territorio en seis subregiones, las cuales - a partir de sus condiciones geográficas y culturales- nos permiten ver el complejo entramado de relaciones que han construido y constituyen al campesinado en la región del Magdalena Grande, en el Caribe colombiano. 



\section{Vida campesina en la Sierra Nevada de Santa Marta}

Mapa 1. Sierra Nevada de Santa Marta y sus municipios

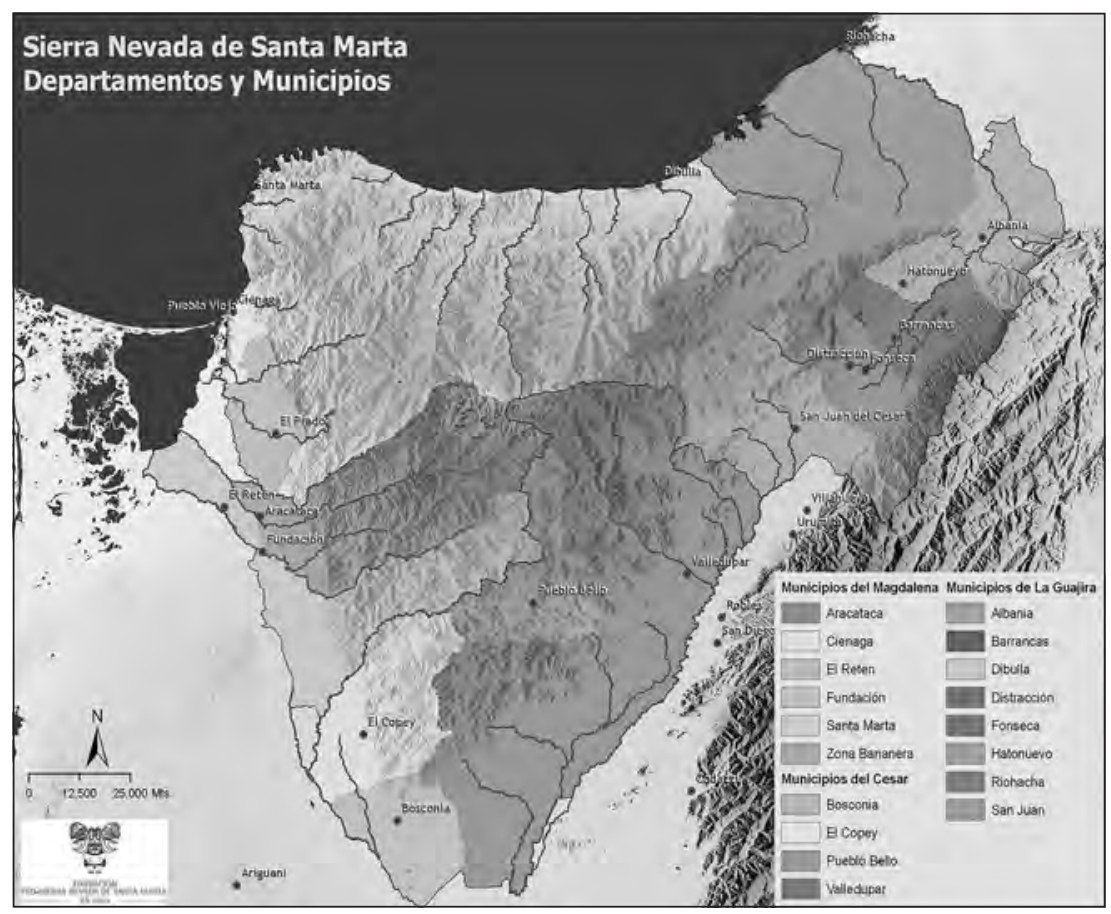

Fuente: Fundación Pro Sierra (2020). 


\section{Poblamiento}

\section{Colonización de la vertiente noroccidental de la Sierra Nevada de Santa Marta}

El poblamiento del corregimiento de Minca, en la Sierra Nevada de Santa Marta, fue posible gracias a muchas dinámicas que se iniciaron desde la época de la colonia y que se mantienen hasta nuestra época. Este poblamiento va desde que se conformaron las haciendas esclavistas en lo que hoy corresponde al corregimiento de Minca, ubicado a veinte kilómetros del centro histórico Santa Marta, hasta la llegada de campesinos del interior del país, quienes colonizaron en gran parte la Sierra Nevada de Santa Marta. En la época de la colonia la hacienda Minca tuvo un papel importante en la economía regional y transnacional, dada la importancia del cultivo de café: "Entre 1800 y 1818, la familia Oligós Díaz Granados empezó a desarrollar los cafetales de Minca, reconocida como una las primeras haciendas cafetaleras de Colombia" (Viloria, 2019, p. 166).

Posteriormente, la hacienda Minca es vendida a Joaquín de Mier y Benites, dueño de la hacienda San Pedro Alejandrino: "A partir de 1838, Minca fue propiedad de Don Joaquín de Mier y Benítez, el comerciante más próspero de la provincia de Santa Marta durante gran parte del siglo XIX" (Viloria, 2019, p. 166). Los nuevos propietarios introdujeron el cultivo de caña en la hacienda, haciendo que la economía de la finca se sostuviera con los cultivos de café y caña para la producción de panela, miel y aguardiente, y el café para la exportación y consumo local. Las haciendas Minca y San Pedro Alejandrino se mantenían con mano de obra esclava. Cuando se da la abolición de la esclavitud, en 1851, la mano de obra esclava abandona la finca y los cultivos de café son abandonados; por lo tanto, la producción de café decae, como lo sostiene Eliseo Reclus (1861) en su visita a Minca:

Desgraciadamente su cafetal no está mejor conservado que el ingenio de San Pedro. Los árboles de café, plantados en quincunces, de tres en tres metros, están cubiertos de musgo; muy pocas frutas mezclan su brillante rojo al verde de las hojas; las yerbas abatidas por el aire, se abren paso a través de la tierra, donde se colocan las bayas para hacer secar las 
Vida campesina en el Magdalena Grande

cáscaras. Los obreros parecen también mucho más inclinados a dormir la siesta y a cuidar los campos (p. 69).

El desespero por no tener mano de obra esclava llevó a Joaquín de Mier a traer mano de obra del extranjero, buscando devolverle a la hacienda Minca la prosperidad que tenía antes de la abolición de la esclavitud. Para realizar esta labor, Joaquín de Mier fue hasta Génova, Italia, a traer la mano de obra (Viloria, 2019). Los extranjeros se instalaron en la hacienda Minca, pero no cumplieron el compromiso de establecerse por completo y a los tres meses de estar instalados se esparcieron por toda la Sierra Nevada de Santa Marta. La mayoría de ellos se ubicaron en el caserío de Fundación, donde hicieron su propia colonia agrícola, convirtiendo a Fundación en el centro agrícola más importante de la Nueva Granada, como lo describe Eliseo Reclus (1861):

Algún tiempo después de mi partida de Santa Marta, el señor Joaquín Mier hizo llevar de Génova unos cincuenta agricultores, con los cuales esperaba transformar de nuevo a Minca en una floreciente propiedad. Estos italianos pasan en el ferviente más absoluto los tres meses de su compromiso, y enseguida se dispersaron por diferentes puntos, trabajando y desmontando por su propia cuenta; el mayor porte se reunió a inmediaciones de la Ciénaga de Santa Marta, en un pueblo de formación reciente, la Fundación. Allí se han entregado al cultivo del tabaco y de los árboles frutales cerca de cien familias europeas en el espacio de cuatro o cinco años; y bajo el solo impulso del trabajo libre, este punto ha venido a ser el centro agrícola más importante de las costas de la Nueva Granada (pp. 70-71).

Más adelante, en 1892, la propiedad de la hacienda Minca pasa a manos de José María Leiva, hijo de Manuel Julián de Mier (Viloria, 2019). Dentro del inventario que fue vendido a José María Leiva se encuentran "una extensión de diez caballerías de tierra, de las cuales catorce cabuyas tenían cultivos de café" (Viloria, 2019, p. 166). Los nuevos dueños de la hacienda Minca siguieron explotando el café como su principal producto de comercialización, lo que permitió a José María Leiva invertir en el cultivo y, para el año de 1925, la hacienda Minca tenía 100 mil plantas de café sembradas (Viloria, 2019). Para finales de la década de los años treinta, José María Leiva sustituyó los cultivos de café por el cultivo de caña de azúcar; la información precisa que se tiene es "que en diciembre de 
Vida campesina en el Magdalena Grande

1931 los caficultores de la Sierra Nevada tuvieron una pérdida que pasó de 230.000 kilogramos, como consecuencia de las fuertes lluvias" (Bosch, citado en Viloria, 1997, p. 24). Estos acontecimientos hicieron que José María Leiva vendiera una parte de la hacienda Minca, en el año de 1943, a la familia Dávila Riasco (Viloria, 2019).

Paralelo a la hacienda Minca, en el sector que hoy se conoce como el Campano, se comenzó a desarrollar, para el año de 1892, un proyecto de explotación de café. Estos proyectos de haciendas para la explotación de café fueron impulsados por personas extranjeras provenientes de Inglaterra y Estados Unidos. La presencia de extranjeros como propietarios de fincas para la explotación de café hace parte de los datos aportados por diferentes historiadores que han estudiado a estos empresarios cafeteros:

Los mismos cafeteros eran a la vez exportadores de su producto a Europa y EE. UU., como el norteamericano Orlando L. Flye a través de su empresa "Santa Marta Coffee Company", la Hacienda Jirocasaca, propiedad del español Baldomero Gallegos, los samarios Pedro Manuel Dávila y José Ignacio Díaz Granados, así como Andrés Yanet, el exportador oficial de los empresarios europeos Bowden y Kunhardt. De acuerdo a los testimonios que brindaron descendientes de estos precursores se conoce que el principal mercado del café serrano [o café caracolí, como lo llamaría Diego Monsalve] se localizaba en Europa, especialmente en países como Alemania y Holanda (Viloria, 1997, p. 16).

Los datos aportados por Joaquín Viloria, en su trabajo sobre la economía cafetera en la Sierra Nevada de Santa Marta, permiten conocer algunos aspectos acerca del momento en que se establecen estos extranjeros y la manera en cómo estos constituyen el café en su principal producto de exportación. Una vez establecida la finca la Victoria y Cincinati, esta última se constituye en la más importante en la producción de café en la región:

Orlando Flye y su hacienda se convirtieron en referente en la economía cafetera del Magdalena: construyó caminos, instaló puentes y una microcentral hidroeléctrica, entre otras obras. Además, desde los primeros años del siglo XX empezó a exportar café a Europa (Viloria, 2019, p. 169). 
Vida campesina en el Magdalena Grande

Los trabajos de Joaquín Viloria confirman el establecimiento de la finca la Victoria para el año de 1892 y Cincinati para el año de 1896; estos no aportan información sobre la mano de obra que fue contratada por los dueños de las dos fincas en sus comienzos. El historiador Joaquín Viloria sostiene que el año de 1917 fue contratada mano de obra de personas provenientes del interior del país y personas que fueron traídas de Puerto Rico:

En 1917, algunos campesinos santandereanos llegaron hasta la ciudad de Santa Marta con la intención de viajar a Cuba. Ante los inconvenientes para viajar, estos campesinos se quedaron trabajando en Santa Marta, aunque seguían con la ilusión de viajar a Cuba para trabajar en los cañaduzales, cosa que nunca hicieron. Así, los Balagueras, Reátiga, Becerra, Pineda y Cucunubá, entre otros, empezaron a trabajar en la hacienda Vista Nieve, propiedad de Melbourne Armstrong Carriker, ornitólogo norteamericano casado con una hija de Orlando Flye. En esos mismos años, Orlando Flye contrató a 25 familias campesinas de Puerto Rico, con experiencia en la recolección de café, para trabajar en su finca cafetera (Viloria, 2019, p. 169).

Todo lo descrito nos permite sostener que los primeros procesos de colonización por parte de personas del interior del país y personas de Puerto Rico, en la zona de Minca, se dieron en el año de 1917. A finales de la década de los cuarenta las tierras abandonadas de la finca Minca fueron el detonante para que se dieran las condiciones para la creación de un asentamiento que, luego, daría a la conformación del corregimiento de Minca: "Los miembros [de] una familia originaria de Santander, los Balaguera, invadieron y luego negociaron con Leiva un globo de terreno de 125 hectáreas, de donde surgiría el caserío de Minca" (Viloria, 2019, p. 167). Los campesinos se organizaron y comenzaron a distribuir tierras baldías para que otros las colonizaran; así, comienza la colonización de las riberas del río Córdoba. Estos colonos crean las veredas de la Tagua, Central Córdoba, el Campano:

Mi papá vino en el año 1920 de Cachira - Norte de Santander-y fue uno de los fundadores de parte de la Sierra, donde llegaron como colonizadores con los primos de él que eran los Pineda, los Balagueras y 
Vida campesina en el Magdalena Grande

Riátiga. Había un señor que era el cacique de los Riátiga, que se llamaba Pedro Riátiga Angarita, él era el que movilizaba el personal y todo el mundo atendía sus órdenes iporque lo que él decía eso era lo que hacían! Entonces él se encargó de repartir montañas vírgenes a los colonizadores donde cada quien iba haciendo su finquita y en ese tiempo, pues era muy poca la mano de obra que había porque no había casi personal para trabajar en la Sierra. Le estoy hablando de los años de 1925-1928, que eso nos lo contaba nuestro padre, de que tuvieron que traer unas familias de Puerto Rico para sembrar café, para recolección del mismo café, para la tumba de montañas. De esta familia todavía hay arraigo de ellos allí, como son la Familia González, la Familia Sierra, el señor Eugenio Sierra, lo mismo que la Familia Villanueva, que hoy también se encuentran asentados en La Tagua, una vereda de Minca. Los Pérez se encuentran en la región del Campano y los Sierra en la Central Córdoba (Entrevista citada en Ortiz, 2017, p. 3).

Los trabajadores del interior del país que fueron contratados por el señor Flye para trabajar en la finca Cincinati inician un proceso de colonización hacia el occidente la Sierra Nevada. En el afán de tener tierras, estas personas colonizan la zona del río Córdoba y fundan las veredas los Moros y Central Córdoba. Otros colonos provenientes de Cachira Norte de Santander - llegan hasta la cuenca media del río Córdoba y fundan la vereda Canta Rana. Esta vereda es después anexada al corregimiento de Siberia. Con el paso de los años, la colonización avanzó hacia la parte media del río Toribio, debido a que los nuevos recién llegados buscaban colonizar las tierras baldías:

Mi papá era del Carmen de Bolívar, mi mamá era puertorriqueña. Ellos eran unos de los puertorriqueños que llegaron aquí a cultivar café. Fueron contratados por mis abuelos. Eso fue hace más de 60 años por ahí. Los abuelos llegaron contratados por un señor Mr. Fly. Ellos trajeron un personal a sembrar café aquí, lo trajeron de Puerto Rico, en eso llegaron mis abuelos. Ellos llegaron por aquí eso eran unas zonas selváticas y mis abuelos hicieron una finca que se llama "El Parque" en San Pedro de la Sierra ellos fueron los primeritos, estas eran puras montañas. Y ahí fue donde mi papá conoció a los hijos de mi abuelo a los puertorriqueños 
Vida campesina en el Magdalena Grande

y él se casó ahí, después mi papá compró unas tierras por los lados del Guaimaro e hizo una finca ahí "La Unión", todavía la tenemos (Entrevista citada en Ortiz, 2017, p. 5).

Las tierras ocupadas por las personas del interior del país fueron legitimadas por los extranjeros que eran propietarios de las grandes fincas productoras de café; algunos terminaron vendiéndoles globos de las tierras y otros los cedieron para que las familias colonas se establecieran, lo que hizo que se acabara el conflicto de intereses en la propiedad de las tierras. Luego de comprar un globo de tierras y poblar lo que se conoce como Minca, se puede decir que estos colonos entraron en la producción de café a pequeña escala y comenzaron a comercializarlo en Santa Marta.

\section{Colonización de la vertiente occidental de la Sierra Nevada de Santa Marta}

El corregimiento de San Pedro de la Sierra era un pueblo de los indígenas kogui llamado San Andrés y estaba ubicado en la cuenca del río Frío. Los indígenas kogui que poblaron este espacio llegaron a la cuenca del río Frío a finales del siglo XIX (Reichel, 1953). San Andrés fue un poblado próspero y con estabilidad económica, debido a que los indígenas se dedicaron a la cría de cerdos, gallina, ganado y panela que vendían a las poblaciones de colonos que estaban ubicadas en la parte baja de la Sierra Nevada. Para el año de 1944 llegan a la cuenca personas que se especializaban en la guaquería, provenientes del departamento de Antioquia, y se establecen cerca del pueblo de San Andrés, tal como lo describe Gerardo Reichel (1953):

Poco después de fundada, un antioqueño emprendedor, quien estaba atraído por las leyendas populares sobre los tesoros de Posiguica, estableció sobre una colina, a una hora de San Andrés, la hacienda San José de la Montaña, Su numerosa familia empezó a limpiar el monte, abrir caminos y pronto el pequeño centro colonizador estuvo rodeado de cultivos, cercas y corrales (p. 93). 
Vida campesina en el Magdalena Grande

Imagen 1. Corregimiento de Siberia

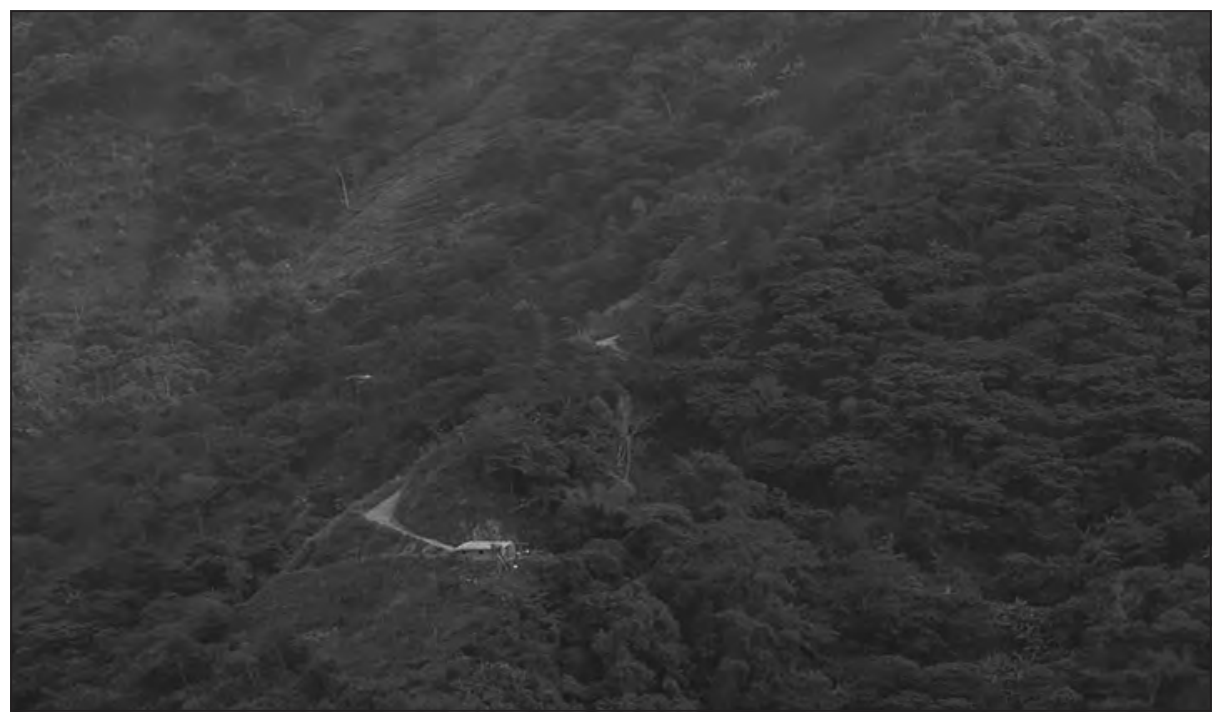

Fuente: Archivo Oraloteca (2020).

La presencia de estos primeros colonos hizo que la estabilidad económica y armoniosa que tenían los indígenas se fuera poniendo tensa. Los primeros colonos comenzaron a construir carreteables para conectar a las poblaciones de la Zona Bananera con el pueblo de San Andrés. Los colonos construyeron alambiques para la fabricación de aguardiente que era vendido a los indígenas; los indígenas cayeron en el consumo de alcohol y el pueblo de San Andrés cayó en una completa anarquía:

Las mujeres, quienes nunca tomaban parte en las borracheras, peleaban con sus maridos y como resultado recibían tremendas palizas y hasta fueron abandonadas. En 1949 los hombres efectuaban actos de sacrilegios, tales como fumar y cocinar en la casa ceremonial; los ancianos eran agredidos y aún máma Julián fue atacado en una ocasión, por uno de sus propios hijos y varias veces por otros jóvenes (Reichel, 1953, p. 99).

El caos, el descontrol y la desidia social en los que cayó el poblado de San Andrés fueron aprovechados por los colonos. Lo mismo hizo un empresario samario llamado Alfonso Campo Serrano, quien decidió hacer 
Vida campesina en el Magdalena Grande

la finca Maroma para la explotación de café a escasos cinco minutos de San Andrés (Reichel, 1953). Los colonos habían rodeado por completo a San Andrés; los indígenas kogui, para no tener contacto con estos, deciden abandonarlo y venderles todo a los colonos, partiendo hacia la cuenca media del río Don Diego:

Pero pocos meses después operó un cambio. Con excepción de máma Julián y de su familia y de unos pocos indios, simultáneamente el resto de los kogi de San Andrés vendieron a los colonos sus casas, cultivo, ganado, trapiches y se retiraron otra vez del contacto, migraron hacia las cabeceras del río Don Diego, sobre la vertiente norte, a una distancia de casi a una semana a pie desde San Andrés, por caminos difíciles e intransitables durante muchos meses del año. Ya en 1947 y 1948 algunas familias habían precedido esta migración, pero ahora todo el grupo migró hacía allá (Reichel, 1953, p. 100).

De San Andrés no quedó ningún vestigio. Los grandes finqueros le pasaron una máquina al pueblo y lo arrasaron por completo, sin contemplación con las sepulturas de los indígenas. El terreno donde estaba ubicado San Andrés fue aplanado por completo y los nuevos dueños lotearon los terrenos y los comenzaron a vender. Los colonos construyeron sus casas y decidieron cambiar el nombre de San Andrés por el de San Pedro de la Sierra. El pueblo de San Pedro de la Sierra se constituye en el epicentro de la colonización de la parte occidental de la Sierra Nevada de Santa Marta; esto llevó a que nuevos empresarios crearán grandes fincas para la explotación del cultivo de café:

Existían estas casitas de aquí, había tres casas, está aquí donde estamos nosotros una aquí enfrente y una allá arriba, San Pedro se llamaba San Andrés, era un caserío poquitico, quizá más poquita gente que más caserío que ahora, San Pedro está más poblado. San Javier no existía, era un caserío una finquita regá y después se pobló y se fundó San Javier que hoy en día es una región muy buena... ahí siguieron otras (Entrevista citada en Ortiz, 2017, p. 5). 
Vida campesina en el Magdalena Grande

El poblamiento del corregimiento de San Pedro de la Sierra se da por la llegada de personas del interior del país; estas personas llegaron huyendo de la violencia partidista. Después del asesinato de Jorge Eliecer Gaitán, en el año de 1948, la violencia se recrudeció en los departamentos de la Zona Andina. Para no ser asesinados o masacrados en sus pueblos, los campesinos decidieron huir a otras zonas del país. Algunos se trasladaron a la capital del país y otros se fueron a las áreas periféricas del país, como los Llanos Orientales y el Caribe colombiano. Muchos campesinos se trasladaron hacia la Sierra Nevada de Santa Marta a trabajar en las fincas de café y colonizar tierras para hacer sus fundos y tener una prosperidad económica:

Nos radicamos en San Pedro de la Sierra hace 54 años aproximadamente. La razón de la migración fue también la violencia, en ese tiempo había unos grupos que denominaban la chusma, le decían los pájaros, entonces se peleaba por colores. Entonces en razón de que mi madre era, según ella liberal, entonces los grupos contrarios decidieron atacar a esos otros contrarios [...]. O sea, había liberal y conservador: conservadores perseguían a liberales y liberales a conservadores, y nosotros éramos el blanco, los indefensos porque como todo el mundo andaba armado pero el que no estaba armado si pertenecía a algún color entonces ese era perseguido y le daban muerte. Y si no huía, se retiraba del lugar, pues lógicamente que moría con su familia, entonces en virtud a eso mi madre decidió emigrar para la costa, nos venimos en el mes de octubre como del sesenta, 1960. Nos bajamos de un tren desde Mariquita hasta Puerto Berrío, Antioquia. De Puerto Berrío cogimos un remolcador de esos que bajaba por el río Magdalena llamado "El Medellín”; llegamos a Barranquilla, gastamos como seis días más o menos... seis noches para llegar a Barranquilla, de Barranquilla cogimos hacía Ciénaga la carretera estaba destapada era un poco de huecos lleno de agua había que pasar por un ferri desde Barranquilla hacia acá al Magdalena, del Atlántico al Magdalena. Llegando a Ciénaga y ahí orientándonos más o menos a la Sierra Nevada (Entrevista citada en Ortiz, 2017, pp. 6-7).

En la colonización del corregimiento de San Pedro de la Sierra no solo estuvieron las personas que llegaron del interior del país: algunos 
empresarios de Santa Marta, Ciénaga y Santander ya tenían grandes fincas de cultivo de café. El cultivo de café se había convertido en una obsesión para la clase dirigente samaria y cienaguera debido a que, aunque el café daba buenos dividendos económicos, no tenía el conocimiento para explotarlo porque se había convertido en monopolio de los empresarios extranjeros, quienes tenían el conocimiento sobre cómo sembrarlo y exportarlo. Estos empresarios locales que empezaron a cultivar café en esta parte de la Sierra Nevada tuvieron que traer la semilla de la finca Jirocasa, propiedad de Georges y Guy Opdenbosch:

Jorge Sumbattoff, Julio Dangond, Mateo Vives, la familia Fernández de Castro y Celio Villalba. Este empresario santandereano estaba radicado en Barranquilla y era propietario de la tostadora "Café Almendra Tropical”. Dangond y Sumbattoff fueron los encargados de conseguir las semillas de café en la hacienda Jirocasaca, que diseminaron por toda la zona de San Pedro de la Sierra (Viloria, 2019, p. 168).

Estos empresarios consolidaron la economía cafetera en la cuenca del río Frío, pero hay que tener en cuenta que fueron los colonos de la zona andina quienes la afianzaron, extendiendo las zonas de producción de café con la consolidación de pequeñas fincas que, a su vez, se constituyeron en veredas. Muchas personas del interior fueron contratadas como mano de obra para realizar diferentes labores en las grandes fincas. Las grandes fincas - productoras de café- y las pequeñas fincas de los campesinos le dieron un dinamismo económico a la zona, convirtiendo a San Pedro de la Sierra en el principal centro de servicios. Este dinamismo se da porque los empresarios y los campesinos ampliaron el carreteable que uniría a San Pedro con la carretera Troncal de Occidente. Esto llevó a que se consolidara un flujo comercial entre San Pedro de la Sierra y el casco urbano de Ciénaga y, a la vez, hizo que en el pueblo se instalaran comercializadoras de café, tiendas, restaurantes, panaderías y billares. Además, el carreteable hizo que fluyera la mano de obra en tiempos de recolección del grano de café.

El cultivo de café estabilizó a algunos campesinos en sus pequeños fundos de café en San Pedro de la Sierra; otros trabajadores de las grandes fincas que no tenían tierras decidieron fundar el corregimiento de 
Siberia, ubicado entre el río Frío y el río Córdoba. El poblamiento del corregimiento de Siberia comienza en la década del cincuenta y fue realizado por campesinos provenientes de la finca Cincinati y Vista Nieve, campesinos provenientes de la finca la Dilia en San Pedro de la Sierra y, por último, campesinos provenientes de la finca Lourdes, propiedad de la familia Fernández de Castro. Los primeros colonizadores que llegaron al río Córdoba fueron los que se independizaron de la finca la Dilia. La primera vereda que fundan se llamó Nueva Granada; esta vereda fue fundada por familias provenientes de Santander que lograron estabilizarse con el cultivo de café. El centro de abastecimiento de estas familias era San Pedro de la Sierra; este contacto hizo que el cultivo de café se desarrollara de manera satisfactoria debido a que podían comprar los insumos químicos para el sostenimiento del cultivo.

Otros trabajadores de la finca la Dilia se dirigen a la quebrada el Congo y fundan la vereda del mismo nombre. A diferencia de los campesinos que estaban en Nueva Granada, estos se dedicaron al cultivo de arroz, maíz, fríjol, y a la cría de ganado. Algunas familias de las dos veredas antes mencionadas no lograron sostenerse y regresaron de nuevo a San Pedro de la Sierra; otras, migraron hacia Ciénaga y Santa Marta. La migración hacia estos dos municipios hizo que se desvincularan de sus fundos completamente. La otra ola de migración que llegó a la parte media del río Córdoba provino de los trabajadores que salieron de la finca Cincinati y Vista de Nieve y que fundaron la vereda de Canta Rana. Las personas que fundaron esta vereda eran oriundas de Cáchira, Norte de Santander, y se dedicaron a los cultivos de hortalizas y a la cría de ovejos. Las zonas de abastecimiento de estos campesinos fueron Minca y Santa Marta, debido a que para esa época no existía un carreteable que conectara a la vereda con Ciénaga. Cuando comenzaron a cultivar el café, lo comercializaban en Santa Marta y tenían que llevarlo a los puntos de venta que tenía Almacafé allí.

En la parte media del río Córdoba la familia Fernández de Castro era la dueña de la finca Lourdes, donde tenían cultivos de café para la exportación y el consumo local. Los Fernández de Castro también tenían la finca llamada las Pampas para la cría y venta de ganado. En la parte de abajo tenían la finca La Isabel, dedicada a la explotación de banano. Estas tres fincas eran el sostenimiento económico de la familia Fernández de 
Vida campesina en el Magdalena Grande

Castro. La finca Lourdes atrajo mucha mano de obra de personas del interior para la recolección de café y la finca las Pampas contrataba personas del Caribe para el cuidado del ganado. Son estos trabajadores quienes, posteriormente, colonizaron las tierras que estaban en los alrededores de estas dos grandes fincas y fundaron las veredas de Corea y Lourdes:

Todavía la caficultura en este sector no era fuerte, de hecho quiero mencionar que por los lados de Ciénaga había una finca que ya existía, cuyos propietarios eran los Fernández de Castro quienes hacían parte de la administración de Ciénaga, políticamente pertenecen a un grupo muy fuerte y tenían la facilidad de invertir en el sector y lógicamente en su finca que posteriormente fue llamada La hacienda cafetera, su vecindario era la zona plana, lo que hoy llamamos la Isabel y parte de las goteras de Ciénaga, ellos allí hicieron una finca muy importante y eso sirvió también de camino, digamos de interés de que otras clases de personas llegarán a la vereda cuyo nombre posterior fue Lourdes, eso sirvió para [que] más adelante por los años 60 y comienzos de los 70 [se] conformar[a] una gran vereda muy grande, por cierto donde estoy hoy aquí relatando estos acontecimientos se llama vereda Corea, entonces por aquel entonces ya existía la Nueva Granada, la vereda Lourdes (Entrevista citada en Negrete, 2020, p. 12).

Los Fernández de Castro construyeron un carreteable desde la finca Lourdes hasta la finca la Isabel para llevar insumos y sacar la cosecha de café. Este carreteable también sirvió para que los campesinos de las veredas de Lourdes y Corea bajaran hasta Ciénaga para hacer sus abastecimientos de víveres y comprar insumos para el sostenimiento de las fincas de café. Los campesinos, en sus trabajos comunales, lograron llevar el carreteable hasta la vereda Corea. Para mediados de los años ochenta el proceso de colonización no había terminado y, con la llegada de la guerrilla a la Sierra Nevada de Santa Marta, se dieron nuevos procesos de colonización. La guerrilla no solo llegó a imponer su ley, sino que también llegó a generar un proceso de colonización. La guerrilla dio un insumo para que campesinos sin tierras invadieran las tierras de la reserva forestal y fundaran la vereda la Reserva, la Unión, Nueva Unión y Siberia; esta última, en la parte más alta y fría de la zona (Camacho, 2020). El caserío 
Vida campesina en el Magdalena Grande

está conformado por 50 familias que tienen sus fincas en las veredas Siberia y la Reserva.

A comienzos de los noventa el carreteable que llegaba hasta la vereda Corea fue construido hasta la vereda Siberia, convirtiendo a Siberia en el centro económico de la zona debido a que muchos campesinos de todas las veredas llegaban a hacer sus compras de víveres para el sostenimiento de la familia. Además, siendo Siberia el último poblado que se funda, se le da el nombre de "corregimiento". La construcción del carreteable hasta Siberia hizo que las personas que vivían en las demás veredas comenzaran a bajar hasta la parte urbana del municipio de Ciénaga para hacer sus diligencias comerciales.

\section{Campesinos y conflicto en la Sierra Nevada de Santa Marta}

Imagen 2. Casa campesina en la vereda Corea

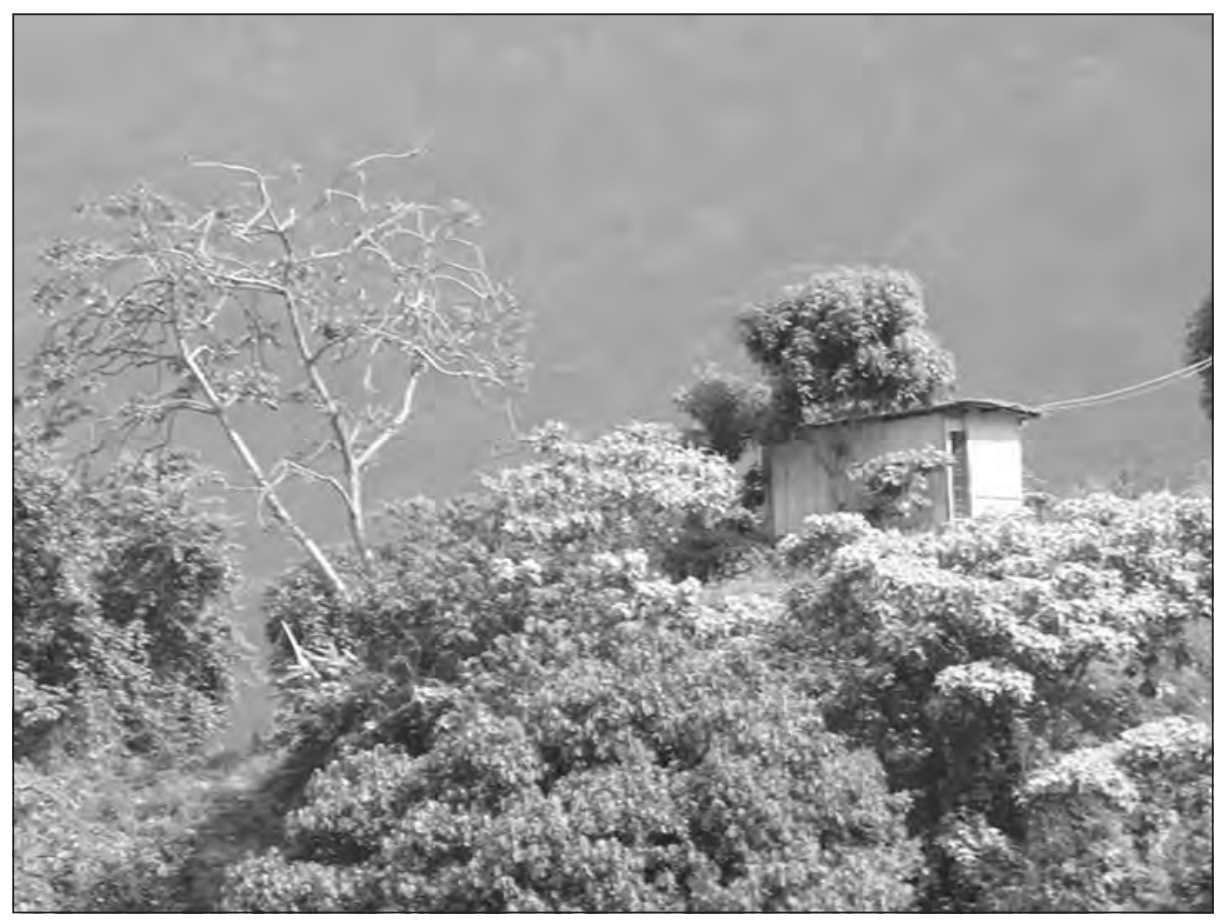

Fuente: Archivo Oraloteca (2020). 
Vida campesina en el Magdalena Grande

\section{La bonanza marimbera}

Los corregimientos de Minca, Siberia y San Pedro de la Sierra estuvieron ligados al proceso de producción, transporte y comercialización de marihuana. Esta bonanza económica ligada a cultivos ilícitos produjo una imagen de los campesinos como "violentos" y "despilfarradores de dinero". La marihuana que se producía en la Sierra Nevada se posicionó tan rápido en los mercados internacionales que llevó a los grandes marimberos a posicionarse en el mercado local y, a la vez, a que distribuyeran las labores dentro de la cadena de producción, recolección, transporte y comercialización. En la cadena de producción encontrábamos a los que descombraban las montañas para que se diera el cultivo, al que distribuía las semillas, al encargado de cultivar la marihuana y darle el mantenimiento al cultivo, a los "raspachines" y a los prensadores. En estas labores intervienen personas de la localidad y de otras partes del país. A todas esas personas que intervienen en la cadena de producción se les designaba como "marimberas". En la cadena de producción, el "raspachín” tenía un trabajo importante:

Los raspadores armaban ranchos que les servían de lugar de trabajo durante la raspada y el empaque de la yerba, después estos ranchos servían de caleta mientras llegaba el momento de transportarla, los ranchos igualmente eran utilizados en las noches como dormitorios. Después de armar el rancho al siguiente día se comenzaba el corte, separaban la florescencia de la mata hembra, que era lo que llamaban el desmoñe, donde se separaban las semillas que servían para la próxima cosecha. La mata de marihuana era cortada y puesta en horquetas de madera que estaban clavadas en la tierra, las cuales eran sostenidas por largas hileras de varas en las cuales se enganchaban las matas ya cortadas. Alrededor de los cultivos de marihuana, algunos colonos siempre observaban grandes cantidades de pájaros volando debido a que las semillas de marihuana les servían de alimentos. El desperdicio de la mata como los tallos y las ramas eran arrumados en cantidad para echarle candela, debido que estos no lo compraban. A los tres días la marihuana quedaba prensada en sacos de papel, solo en el momento de transportarla se envolvía en los sacos para evitar un posible deterioro con la lluvia (Ardila, Acevedo y Martínez, 2013, p. 62). 
Vida campesina en el Magdalena Grande

Los transportadores también eran personas de la localidad y eran contratados por los dueños del cultivo. En los cultivos de marihuana no hubo actor armado que regulara las compras ni quiénes podían acceder a ellos. El cultivo generaba tanta ganancia que cualquiera podía entrar al negocio sin restricciones. Como todo negocio ilícito, hubo personas que todavía están en las memorias de los campesinos por sus excentricidades, parrandas o menciones en una canción vallenata. Los transportadores de marihuana eran los arrieros del café; estos transportadores eran móviles y tenían que transportar marihuana hasta donde lo exigiera el dueño del cultivo. Cuando transportaban las cargas de marihuana, los arrieros se proveían de alimentos para el viaje. En el cultivo de marihuana los productores y transportadores ganaban mucho dinero a pesar de que el ciclo de producción del cultivo era de nueve o diez meses. El cultivo generó muchas fuentes de empleos y ganancias; tantas, que muchos trabajadores de la Zona Bananera, productores de café y recolectores dejaron sus trabajos abandonados para insertarse en el negocio ilícito:

Las fincas cafeteras que estaban en la zona rural de Santa Marta en la época de la bonanza decayeron porque el jornal de trabajo lo pagaban a 300 pesos y los trabajadores de las fincas preferían raspar marihuana que recolectar café o jornalear en las fincas de la Zona Bananera. Muchos de estos trabajadores se dedicaron a talar, sembrar, recoger, transportar y custodiar marihuana, así las grandes fincas perdieron mucha producción de café inclusive el contrabando de café hacia Venezuela se incrementó debido a que los propietarios de las finas no encontraban trabajadores y además la Federación de Cafeteros estaba pagando mal el grano de café (Ardila, Acevedo y Martínez, 2013, p. 61).

El cultivo de marihuana generaba dinero fácil; así como los trabajadores ganaban, así se despilfarraba. En los tiempos de la bonanza de la marihuana las personas que se dedicaban al cultivo, a raspar y transportar, gastaban su dinero en cantinas, ropa y cadenas de oro. El comercio de estos pueblos se vio favorecido debido a que los marimberos no tenían seguridad alimentaria en sus fincas y compraban cantidad de víveres en las tiendas; lo anterior se convirtió en otra forma de gastar dinero. Cuando decayó el cultivo de marihuana, muchos de los que participaron en 
Vida campesina en el Magdalena Grande

la cadena de producción quedaron sin dinero. La bonanza marimbera generó violencia en la zona rural y urbana: todos los que participaban en el negocio estaban armados y estaban fuera de control. Las transacciones de dinero, armas, carros y mulas se hacían en los cascos urbanos de los corregimientos. Estas transacciones terminaban en consumo de licor, peleas y, por último, en muertos.

Para muchos habitantes de estos tres corregimientos el cultivo de marihuana se volvió tan legal como cultivar café. Había personas que la producían, otras que la compraban y otras que la vendían. Como con cualquier negocio, se hacía en los cascos urbanos de los tres corregimientos a la vista de todo el mundo. Algunos productores de marihuana invirtieron en construcción de casas, graneros, cantinas y almacenes de ropa en los cascos urbanos de los corregimientos y otros, más osados, invirtieron dinero en Santa Marta o Ciénaga. Como toda felicidad tiene su final, en la década de los años ochenta el negocio de la marihuana decayó y la violencia se incrementó porque todos los que participaban en la cadena de comercialización querían controlarlo. Para el año de 1986 el gobierno de turno comenzó un plan de erradicación manual y fumigación aérea para acabar con los cultivos. Las fumigaciones aéreas acabaron con los cultivos de marihuana y con los cultivos de pancoger de los campesinos, sin mencionar que las fumigaciones ocasionaron problemas de contaminación en los ríos y quebradas que bajan de la Sierra, así como problemas de salud a la población campesina e indígena de la Sierra Nevada de Santa Marta. Los pobladores de estos tres corregimientos no se apartaron de los cultivos de marihuana porque todos ganaban dinero. Nunca tuvieron una posición en contra del cultivo porque tanto el cultivo de café como el de marihuana les generaban ganancias económicas, viendo al cultivo de marihuana como una oportunidad para generar ganancias.

\section{La guerrilla}

Según el análisis propuesto por algunos investigadores, el frente 19 de las FARC, conocido como "José Prudencio Padilla", fue creado el 22 de octubre de 1982. La conformación de este frente se da por el desplazamiento que hizo el frente $10 \mathrm{y}$ varios integrantes de los frentes $4,12 \mathrm{y}$ 20 (Santrich y Granda, 2008). Los desplazamientos de estos frentes se 
Vida campesina en el Magdalena Grande

dan desde la zona de Pueblo Bello y Nuevo Colón hasta las cabeceras de las veredas Santa Clara y Tucurinca en el departamento del Magdalena (Molano, 1988; Santrich y Granda, 2008; Martínez, 2011). La aparición de la guerrilla de las FARC en la Sierra Nevada de Santa Marta se da por órdenes del secretariado como una medida para expandirse hacia otros territorios periféricos, ofreciendo en primera medida:

La oferta de "limpieza" de pequeños delincuentes indeseables, que conducía a ejecuciones sin fórmula de juicio, por lo menos en el periodo de implantación del grupo guerrillero. 2) La instalación del grupo guerrillero en una zona segura, un área de retaguardia, en donde operaba con un campamento principal o con campamentos móviles, para evitar su ubicación. 3) La creación o el uso de un conflicto social para promover la movilización y la simpatía en torno a sus objetivos. 4) La expropiación de bienes de personas adineradas y el éxodo de los campesinos pudientes. 5) El reclutamiento de jóvenes hombres y mujeres, y el éxodo de familias que trataban de evitar el enganche de sus hijos en las filas guerrilleras. 6) El establecimiento de controles sobre la población. 7) Los fusilamientos de presuntos sapos e informantes. 8) La instrumentalización de la población para contener al Ejército (CNMH, 2014, p. 164).

Estos argumentos fueron encontrados por la guerrilla para legitimar su presencia en los corregimientos de San Pedro de la Sierra, Siberia y Minca. Por un lado, la guerrilla no encontró un aparato de justicia que administrara el poder. Por otro lado, encontró una crisis ambiental, social y económica que había arruinado la producción agrícola de los campesinos. Por último, encontró una violencia desbordada por los combos de marimberos, tal como lo confirma el señor José Leopoldo Muñoz quien, para esa época, era transportador de marihuana:

Después ya llegó, llegó la guerrilla, llegó la guerrilla... bueno, cuando llegó la guerrilla yo todavía estaba en ese cultivo, pero ya no... ya me patrocinaba yo mismo, ya sembraba yo mismo... entonces llegó la guerrilla con unos, pues... apareció la guerrilla en esa Sierra y dijo: "señores, nosotros somos las FARC, vinimos a ver cómo era la situación en esta Sierra porque ya tenemos entendido que hay muchos muertos a causa de 
Vida campesina en el Magdalena Grande

la droga y esto se va a tener que acabar. No más droga, no más siembra de esto, ¿̇isto? Están acabando con la Sierra, con esto deforestando y matándose la gente. No es válido; tienen que buscar otra alternativa: busquen el café, busquen otros ingresos que sean sanos, que no sean con la violencia”. Bueno, y ahí ya empezó a operar la guerrilla (J. Muñoz, comunicación personal, marzo del 2015).

Del anterior relato podemos analizar dos motivos que llevaron a las FARC a incursionar en la Sierra Nevada de Santa Marta: por un lado, administrar justicia, debido a la inseguridad que se estaba dando en la zona; por otro lado, mostrarse como respaldo para el campesinado frente a los atropellos de los combos de marimberos. Lo cierto de todo eso fue que las FARC se constituyeron como un grupo de justicia, un grupo que ayudaría a resolver los problemas sociales que, en esa época, estaban viviendo los campesinos. Además de esto, es posible sostener que, para tener el control de los tres corregimientos, la guerrilla tenía que enfrentarse primero con los combos de marimberos que tenían pleno control de ese espacio y asegurar o garantizar así la seguridad de los habitantes. El llamado a la población civil para abandonar los cultivos ilícitos era un claro respaldo hacia los colonos, pero para garantizar ese respaldo se debía dar una confrontación armada contra el combo de Hernán Giraldo; esto se convertiría en otro ciclo de violencia para los campesinos de los tres corregimientos:

Ah, bueno... eso... yo estuve cuando comenzó eso, yo estuve, yo tenía la [...] de mi papá, yo estaba esperando, estaba en una caleta esperando la transportada de esa; o sea, para llevarla a la playa, y cuando en ese momento...en esos días esa caleta era de un señor Hernán Giraldo, el narco más grande que estuvo acá en la Sierra. Estábamos ahí en el manejo de la caleta (o sea, haciéndole la prensada ahí y todo eso) y un día de esos, cuando ya se estaba haciendo todo el manejo de la prensa, o sea cuando ya estaba lista pues para embarcarse en las mulas, como a las cinco de la mañana llegó la guerrilla, pero eran poquitos los guerrilleros, ellos entraron con unas armas no muy... cualquier clase de armas. Entonces ellos aprovecharon la coyuntura, ya en ese entonces se oía decir que Hernán Giraldo era de los paramilitares y acá había gente ya con la guerrilla (L. Núñez, comunicación personal, abril del 2015). 
Vida campesina en el Magdalena Grande

A través del control de los cultivos de marihuana, los combos de marimberos tenían el control de las armas y de la economía de la zona. Sin embargo, la guerrilla de las FARC aprovecharía la coyuntura que por esa época estaba viviendo la Sierra Nevada de Santa Marta. La crisis por el desplome del cultivo de marihuana en los mercados internacionales hizo que los precios de la marihuana cayeran por el piso. Los combos se negaban a pagar un precio justo por la yerba. Para no pagar, algunos comenzaron a asesinar a cultivadores, transportadores, caleteros y hasta a darse plomo entre ellos mismos para robarse la mercancía. Esta coyuntura fue aprovechada por las FARC: mientras los combos se asesinaban entre sí, las FARC comenzaron a reclutar antiguos socios de los combos y personas de la localidad:

Entonces ellos armaron el resto de marimberos esos con [...] lo que fue y se apoderaron de eso. Entonces fue cuando la guerrilla comenzó a hacer fuerza, a coger fuerza, entonces ellos aprovecharon esa coyuntura: ya de ahí pa' lante la guerrilla comenzó a reclutar. Nosotros de los siete hermanos somos seis. Mi papá en ese entonces tenía una finca en un área que llama Nuevo Mundo, una vereda que está aquí a cuatro horas, Nuevo Mundo, llegaban allá a cada rato a decirle a mi papá que sí, que nosotros éramos de aquí, que los acompañáramos, y nosotros no, gracias a Dios no nos gustó eso (L. Núñez, comunicación personal, abril del 2015).

El establecimiento de la guerrilla de las FARC como nuevo actor armado pone de relieve que llegó a controlar y a dominar el espacio controlado por los combos de marimberos. El primer propósito que se establecieron fue el de crear comisiones para asesinar a los socios y pistoleros de los marimberos; por último, les advirtieron a los combos que debían poner fin a los cultivos de marihuana y a los asesinatos que se estaban dando en la zona. Hay bastantes relatos sobre el accionar de la guerrilla de las FARC contra los combos de marimberos que hoy se conocen en estos tres corregimientos. El señor Luis Alfredo Núñez, quien recorrió la Sierra Nevada de Santa Marta como arriero, recuerda lo siguiente:

Entonces, ¿qué hacía la guerrilla? Ellos tenían un reo, un reo era una persona [a la] que ellos le pagaban para que fuera matando uno por uno a 
los socios a los marimberos, ¿sí me entiende? Yo como socio buscaba la forma de hacerme venir al pueblo, ir a ver la finca y por ahí en el camino me mataban. Entonces por eso yo le decía que ese río Frío y río Sevilla, que son los más cercanos acá al área de San Pedro, fueron unos ríos que cargaron bastante[s] difuntos, porque los esperaban por ahí en esas áreas para desaparecerlo[s] dentro del río, o sea los tiraban al agua y [...] caño abajo (L. Núñez, comunicación personal, abril del 2015).

$\mathrm{Al}$ expulsar a los combos de marimberos de la zona, las FARC consolidarían, en los tres corregimientos, un proyecto político denominado "tácticas políticas". Para eso, tuvieron que recurrir a la conformación de núcleos de campesinos, conformados a su vez por ocho personas de cada vereda; estas personas estaban bajo el mando de las milicias. La función de estos núcleos era ejercer un control sobre las juntas de acción comunal que no eran afines a la ideología del grupo subversivo. Estos métodos de imposición hicieron que muchos presidentes de juntas de acción comunal discreparan de las órdenes de los milicianos y, a la vez, confrontaran a los comandantes del grupo. Por este motivo, la relación de la guerrilla de las FARC con la población civil era desagradable, principalmente porque los "núcleos de campesinos" presionaban a los presidentes de las juntas de acción comunal a que ejercieran presión sobre las comunidades y estas presionaban por su parte al Gobierno. Estos "núcleos de campesinos" estaban adscritos a la comisión de organización llamada "Víctor Carrillo", comandada por alias "Ciro", el "Flaco" y el "Profe" (estas tres personas eran los instructores políticos del Frente 19). Este fue un nuevo contexto y un desafío para la organización campesina; así lo cuenta Pablo Emilio Padierna Hernández:

yo era miembro del Comité Municipal de Cafeteros del Magdalena y había un señor Jorge Castillejo que vivía allí donde ustedes se quedaron más adelantico [...], montañita ahí [...], un líder muy prestante, muy honorable [...]. Entonces lo llamó la guerrilla. Nos dijo que: "ustedes que hacen reuniones necesitamos de participar ahí", y nosotros le dijimos que no, que nosotros éramos población civil; entonces se formó un desacuerdo y nos dijeron que nos teníamos que ir. Entonces vivía uno muy tensionado. Una vez, creo que ya está preso un comandante guerrillero 
Vida campesina en el Magdalena Grande

que se llamaba Ciro, entonces yo les ponía problema, les decía yo: “¿cómo así que nosotros nos tenemos que ir?". Obligaban a los campesinos a hacer marcha. Una marcha sonada fue a principios del 90, que bajó toda la Sierra, que estuvieron en el estadio Eduardo Santos, ¿sí se acuerda? Bueno, esa fuimos obligados por la guerrilla (E. Padierna, comunicación personal, marzo del 2015).

Imagen 3. Peaje vía Kennedy

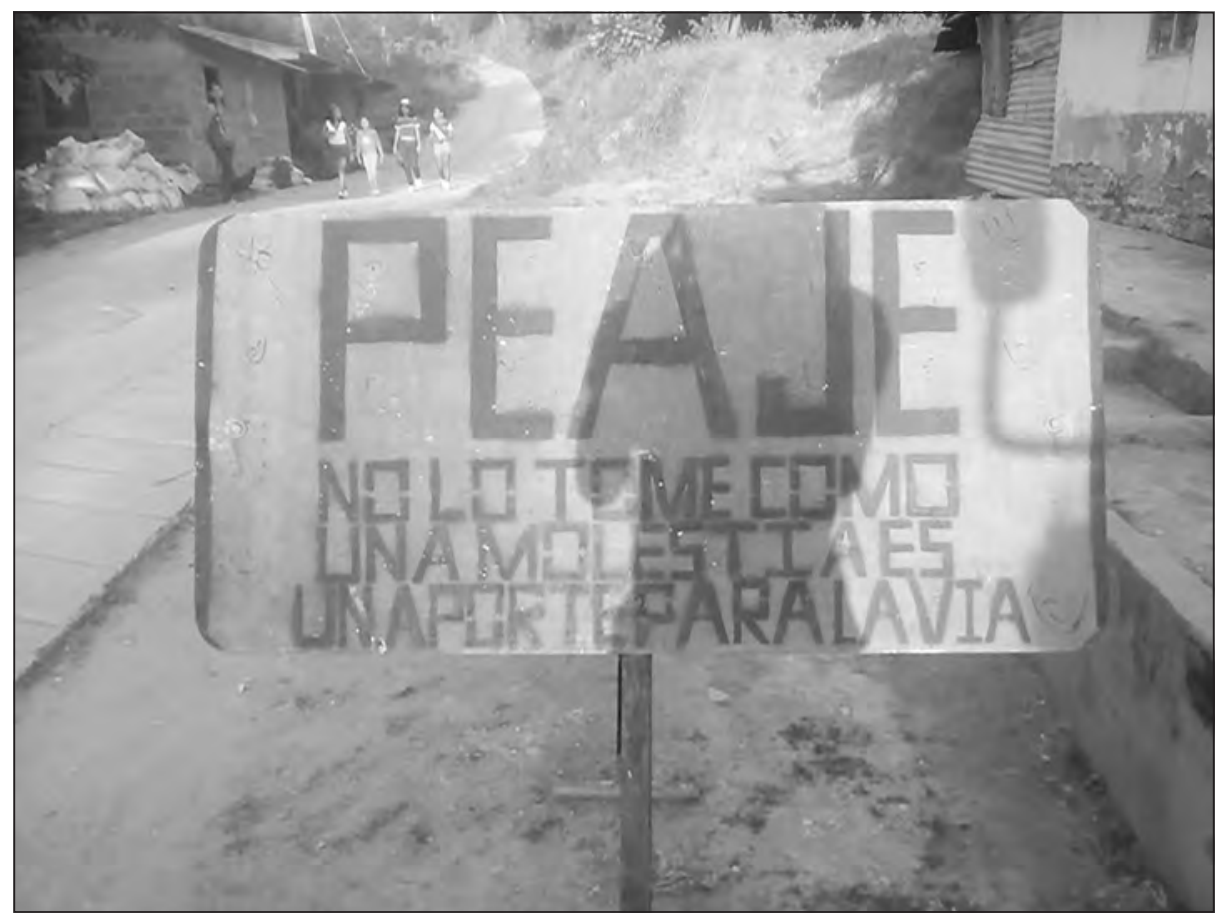

Fuente: Archivo Oraloteca (2017).

Paulatinamente, la guerrilla de las FARC fue tomando el poder. Comenzó a deliberar en la vida cotidiana de la gente por intermedio de los milicianos. Estos instauraron mecanismos de control y solución de conflictos que afectaron a los campesinos. Algunos métodos utilizados por las FARC para controlar a la población civil fueron repudiados por los presidentes de las juntas de acción comunal y por la población en general. Los milicianos comenzaron a prohibir las peleas entre vecinos, hablar 
Vida campesina en el Magdalena Grande

con personas extrañas, hablar con la policía o con el ejército, beber y no pagar la cuenta, robar café, asesinar, portar armas, hurtar ganado y tener cultivos ilícitos. Las personas de la localidad que no acataran esas reglas recibían castigos disciplinarios. Algunos campesinos se acercaban a los milicianos a poner quejas o denuncias. Esta situación condujo a que muchos de estos castigos se convirtieran en ejecuciones practicadas por el grupo guerrillero contra campesinos acusados de robo o asesinato:

Aquí abajito hay un señor, creo que era del Tolima, se llamaba el señor Toño Pabón. Vivía solo ahí...solo, solo... un señor ya de 80 años, tenía su finca [...] y ahí él pertenecía a una congregación evangélica y una familia al lado, unos pelaos inquietos, el viejo era inquieto, o más bien mal vecino, y al hijo mayor una vez se le entraron, se le robaron unos pesos que tenía ahí, como 500 mil pesos y una motosierra, cuando él estaba en el culto aprovecharon y sacaron [y] como aquí no había presencia del Estado, ¿qué hicieron? El señor se les quejó a la guerrilla, vinieron y los cogieron y les quitaron la motosierra, la plata y les dijeron: "el día que se vuelvan a meter con ese señor ya saben.... Resulta que como en el trámite del arreglo del problema le preguntaron al [...] señor [si] tenía armas: tenía un revólver de esos antiguos [...] y los milicianos vieron el revólver y, después de eso, un día el señor se fue para el cafetal suyo y apareció ahí, apareció muerto, lo mataron a garrote, a un señor de 80 años [...]. Fueron los Castros, de apellido Castro, la familia vecina. Existiendo el antecedente de la motosierra y de la plata que le habían quitado, entró la guerrilla y se llevó dos muchachos de esos, muchachos trabajadores que no tenían nada que ver [con lo] de los menores, se los llevaron y los... ¡se los llevaron! Al otro día, esa tarde, mandaron una razón y le dijeron que se presentara en la finca la Dilia, que se presentara el papá de los muchachos y el hermano mayor, que era[n] los que decía yo que eran malos vecinos. Era pa' entregar los muchachos. Resulta que ya los mataron, [a] los otros dos muchachos los desaparecieron y en el entierro de esos dos cogieron a los otros dos pelaos que quedaban [ $\dot{i}$ ?] aquí. i¿ Usted cree que eso es justo?! Y lo irónico de eso es que, después, apareció uno de los milicianos que estuvo... con el revólver... lo mató, le quitó el revólver que tenía ahí el escudo y eso... acabaron con esa familia que habían matado al otro señor (E. Padierna, comunicación personal, marzo del 2015). 
Esa toma del poder local y el control sobre las personas de la localidad también ameritaba arrebatarles el control a las autoridades locales; en este caso, la policía, que tenía un puesto de policía en San Pedro de la Sierra y Minca: "es de advertir que en algunos de esos episodios gravitó el objetivo de expulsar a las autoridades y a la policía, y que este interés era mayor en zonas estratégicas para los planes de las FARC" (CNMH, 2014, p. 261). La arremetida contra puestos de vigilancia de la policía no solo fue en San Pedro de la Sierra. Para el año 1987 la guerrilla de las FARC tomó el puesto de policía del corregimiento de Palmor; al año siguiente, se tomó el puesto de policía del corregimiento de Minca (Observatorio del Programa Presidencial de Derechos Humanos, 2001). El puesto de policía de San Pedro de la Sierra fue tomado en dos ocasiones: la primera fue en el año de 1990 y la segunda en el año de 1996 (Observatorio del Programa Presidencial de Derechos Humanos, 2001). La incursión de las FARC en el puesto de policía de San Pedro de la Sierra, en el año de 1996, dejó como resultado la destrucción del puesto de policía, 23 fusiles hurtados y 4 policías muertos. Debido a los constantes ataques, la policía fue retirada del corregimiento de San Pedro de la Sierra, dejando la zona al control de la guerrilla y convirtiéndola en su zona de retaguardia. Con todo lo anterior, la guerrilla pretendía dejar la zona occidental de la Sierra Nevada de Santa Marta sin presencia del Estado y eso los llevaría a reforzar su aparato militar:

Sin duda, la guerrilla buscaba convertirse en una especie de Estado emergente en algunas regiones, generando inestabilidad política y las condiciones para lanzar una ofensiva militar de acuerdo con lo presupuestado en el llamado Plan Estratégico y a reajustes como los delineados en el Pleno de 1997 (CNMH, 2014, p. 264).

El avance militar de la guerrilla de las FARC en la vertiente occidental de la Sierra Nevada de Santa Marta multiplicó los enfrentamientos con el Ejército Nacional. Fueron innumerables los choques armados entre el ejército y la guerrilla en las veredas El Congo, Parranda Seca, Siberia: todas ellas situadas en los alrededores del corregimiento de San Pedro de la Sierra. Hay que tener en cuenta que la guerrilla no solo hizo su arremetida contra la fuerza pública, también la hizo contra la infraestructura eléctrica y vial: 
Vida campesina en el Magdalena Grande

Una patrulla del Batallón de Policía Militar frustró la voladura del puente de la Aguja, ubicado en el corregimiento de río Frío, jurisdicción del municipio de Ciénaga (Magdalena), por parte de un grupo de las Fuerzas Armadas Revolucionarias de Colombia (FARC), tras sorprender a los guerrilleros cuando instalaban los explosivos (El Tiempo, 1991, p 1.).

El continuo desgaste militar llevó a la guerrilla de las FARC a cobrar un impuesto de guerra al sector agroindustrial de la Zona Bananera (Zúñiga, 2004). Este impuesto también le fue cobrado a los dueños de grandes fincas cafeteras, mientras a los pequeños productores de café y comerciantes se les pedía que colaboraran con alimentación, botas, machetes y el reclutamiento de sus hijos para el grupo. El no pago de los impuestos por parte de los dueños de las grandes fincas y la no colaboración de los pequeños productores hicieron que los milicianos arremetieran drásticamente contra ellos; todo lo anterior produjo inconformidad en los comerciantes, los pequeños caficultores y grandes finqueros y esto hizo que muchos abandonaran la zona:

El problema de la guerrilla por aquí no es ni el mismo jefe de la guerrilla, sino que ellos como andaban por ahí cogían un personal, decían "vamos a poner a una persona encargada de esta región" que fueran como miliciano. Esa gente llegaba y maltrataba mucha gente, gente inocente, gente buena... la finca... esto era una región de fincas grandes, aquí no faltaba trabajo, por ejemplo, nosotros tenemos una finca pequeña y en una cosecha de café manteníamos 20 trabajadores, una cosecha en dos, tres meses, finca para arriba eso era una cosa muy bonita, inmensa, el trabajo que había, pero ya [...] esa guerrilla comenzó a extorsionar a las fincas grandes, sobre todo a las fincas grandes, con comida, con las cosas, y ya a la gente no le daba... mucha gente se fueron, dejaban esas fincas ahí abandonadas y se perdió mucha fuente de trabajo aquí por eso [...]. Una finca como Platanal, que era de los Noguera, Dangond, de los Vives, los Fernández de Castro, que eran unas fincas grandes, eso aquí había mucha gente que trabajaba en esa vaina, entonces toda esa gente se fueron y esas fincas quedaron ahí y muchas de esas fincas las ha comprado el Estado, el INCODER las ha repartido, las han parcelado, y esto quedó muy malo (Entrevista citada en Ortiz, 2017, p. 24). 
Vida campesina en el Magdalena Grande

Las personas que no pagaban el impuesto y no tenían para darle la colaboración a la guerrilla de las FARC eran secuestradas. Era tanto el temor que muchos finqueros dejaron de ir a las fincas. Unos optaron por venderlas y otros las dejaron al cuidado de sus trabajadores (Grajales, 2015). En su afán por controlar el poder local de la zona, la guerrilla de las FARC comenzó a intimidar, secuestrar, atentar y asesinar a políticos locales que, supuestamente, tenían delitos de corrupción o apoyaban a grupos paramilitares. Ese método de guerra lo tuvieron que sufrir el alcalde y los concejales del municipio de Ciénaga. Para el año de 1994 fueron asesinados tres concejales en el municipio de Ciénaga: Lázaro Serrano, Próspero Meriño y Alfonso Maiguel Guerrero; en ese mismo año se realizó un atentado contra el alcalde de Ciénaga, Víctor Dangond; por último, se cometió el homicidio de Wilfrido Vives, un dirigente político sobrino del senador Edgardo Vives (El Tiempo, 1994).

Cuatro de estas víctimas pertenecían al Partido Liberal y una era militante de la Unión Patriótica. La arremetida contra el poder local, las emboscadas a patrullas militares, la toma de poblaciones y el ataque a los puestos de policía habían convertido a la guerrilla de las FARC en un actor con estatus de beligerancia, pues era el único que se mostraba con verdadero poder en el departamento del Magdalena. Con la llegada de los paramilitares de las ACCU las reglas de poder se desequilibraron y las FARC tuvieron que enfrentarlos en su propio territorio. Es tanto que, para demostrar que no estaban acabadas militarmente, decidieron atacar, en el año 2000, a Hernán Giraldo Serna, el comandante de las autodefensas campesinas del Magdalena y La Guajira (ACMG). El grupo guerrillero se dirigió hasta la vereda Quebrada el Sol, donde quemó la finca Playa Linda y se robó el ganado. En esa misma incursión asesinaron a tres trabajadores de la finca y emboscaron a Hernán Giraldo:

Por allá se metió la[s] FARC a eso de las cinco de la mañana, rodearon la finca Playa Linda, que es del patrón, cogieron a los tres trabajadores que estaban en la finca y los mataron. A la hija del patrón, no sé si fue a Gladys o Amparo, la amarraron, pero no se metieron con ella. La guerrilla fue a los corrales de la finca y se llevó el ganado, esas vacas eran finas, lo que uno llama "productoras de leche". Cuando sacaron el ganado, quemaron la finca. Al patrón le avisaron que la guerrilla se le había metido a la finca 
Vida campesina en el Magdalena Grande

y salió para allá. Cuando iba llegando a Quebrada el Sol, la guerrilla lo emboscó y se salvó de vaina. Al que mataron fue al conductor. Cuando la gente del patrón llegó a Quebrada el Sol la guerrilla seguía en los alrededores y se dieron unos combates. No sé quién llamó el avión fantasma, pero de esa forma fue que la guerrilla se pudo ir (J. Sánchez, comunicación personal, febrero del 2020).

Apenas terminaron los enfrentamientos, las FARC trasladaron el ganado hacia el corregimiento de Siberia y lo distribuyeron en diferentes veredas. Algunos campesinos del corregimiento de Siberia recuerdan que alias "Ciro" hacía reuniones los fines de semana, mataba vacas y distribuía la carne entre los campesinos como política social del grupo. Algunos campesinos veían "normal" que las guerrillas los apoyaran; otros, lo veían como un mal, porque serían víctimas de los paramilitares o del ejército el día en que estos entraran al corregimiento y los tratarían como auxiliadores y apoyadores de la guerrilla. Ese fue el estigma con el que tuvieron que convivir los campesinos.

\section{Autodefensas de los Rojas}

Desde la década de los ochenta existieron, en el departamento del Magdalena, tres grupos de autodefensas o paramilitares (Zúñiga, 2004), dos de los cuales operaban en la Sierra Nevada de Santa Marta: la unión de antiguos marimberos, quienes se aliaron para controlar los cultivos de coca y su derivado (la cocaína), entre los que se encuentran Hernán Giraldo, quien conformó las autodefensas del Mamey, el grupo de autodefensas de Palmor, conformado por Adán Rojas, y el grupo de José María Barrera, quien conformó el grupo de autodefensas los Cheperos. Las autodefensas del Mamey controlaron la parte norte de la Sierra Nevada de Santa Marta, mientras las autodefensas de Adán Rojas ejercían control sobre la parte occidental. Las autodefensas del Mamey se dedicaron a controlar el negocio del narcotráfico en la producción, el procesamiento y la distribución.

Las autodefensas de Palmor se dedicaron a hacer trabajo de sicariato para los grandes cultivadores de banano y palma. Este grupo armado era contratado para asesinar sindicalistas y dirigentes de la Unión Patriótica. 
Vida campesina en el Magdalena Grande

Desde el momento en que se crearon, los dos grupos armados compartieron sus espacios debido a que Hernán Giraldo y Adán Rojas eran amigos desde la época de la bonanza marimbera. Para finales de los años setenta se crean las primeras autodefensas en Palmor, llamadas la Defensa Civil (Molano, 1988). Cuando la guerrilla hace su aparición en el año de 1982 los primeros que le hacen la contraposición son los integrantes de la Defensa Civil. Para el año de 1983 los conflictos entre la guerrilla y la Defensa Civil se tensionaron y continuó el enfrentamiento armado entre los dos grupos:

después vinieron los de la guerrilla y comenzaron a darle a los paras, por ejemplo, que hubo gente, a mí me mataron a un cuñado, y empezó la guerrilla a dar clavija a los paras, yo recuerdo que mataron a un señor que era familia de los Rojas, lo mataron por allá, mataron a otro ahí, ahí en la vuelta más acá donde una señora, mataron a un señor Martínez, el hijo del señor se metió debajo del carro y se les voló, y el señor sí lo mataron [...], lo llevaban al río y mataron a Néstor Villamil, otro paramilitar, cuando lo mataron a él, y mataron a otro en el río. Entonces ellos se fueron, pero quedó la guerrilla aquí, pero bueno, nosotros teníamos una bendición de Dios, ese tipo, porque por ejemplo ahí uno encontraba gente del pueblo y no porque quería, sino porque los obligaban a ir, y por allá llegaba el uno, el otro con la botella de brandy, gallinas al hombro y así, y a mí nunca me pidieron ni una panela gracias a Dios (Entrevista citada en Alfonso, 2017, p. 115).

La guerrilla no solo arremetió contra los socios de la Defensa Civil, sino que fue por el cabecilla Adán Rojas. La orden que le dio la guerrilla fue que tenían que desalojar las fincas y abandonar la vereda. Adán Rojas, sus hijos y sobrinos se dispusieron a enfrentar a la guerrilla, pero "la guerra con el ELN comenzó muy pronto, le quemaron las casas de sus fincas San Martín y Santa Gertrudis, y se le llevaron cientos de reses. Sin embargo, aguantaron" (Verdad Abierta, 2009, p. 7). La guerrilla tomó el control del pueblo y expulsó al grupo de los Rojas de Palmor en el año de 1983. Adán Rojas y su familia se trasladaron a San José Kennedy, en la Zona Bananera. En ese corregimiento el grupo armado instaló su base de operaciones y comenzó a hacer trabajos de sicariato para los grandes 
Vida campesina en el Magdalena Grande

finqueros, con asesinatos sistemáticos contra los trabajadores bananeros afiliados a Sintrainagro:

Lista en mano, otra vez lista en mano, un grupo armado mató ayer a cinco miembros de Sintrainagro en la Zona Bananera de Ciénaga (Magdalena). La matanza provocó una parálisis en el corte y el embarque de la fruta. Los habitantes acusaron a presuntos paramilitares del hecho, que se sumó a los asesinatos de tres concejales y otro dirigente en menos de dos meses (El Tiempo, 1994, p. 1).

La guerra de los Rojas con la guerrilla no terminó en Palmor: para el año de 1994 la guerrilla del ELN se tomó el corregimiento de San José de Kennedy y atacó a los Rojas. Durante el enfrentamiento con el grupo de los Rojas fueron asesinados dos sobrinos del viejo Adán Rojas. A partir de estos acometimientos, el grupo de los Rojas se trasladó a la vereda Girocasaca, corregimiento de Bonda, con el consentimiento de Hernán Giraldo, quien tenía el dominio del territorio. Aun así, los Rojas no dejaron de operar en la parte occidental de la Sierra Nevada de Santa Marta y convirtieron en objetivo militar a todas las personas que vivían en San Pedro de la Sierra, Siberia y Palmor; para este grupo armado estas personas eran auxiliadoras de las guerrillas. La estrategia del grupo de Adán Rojas era asesinar a las personas estigmatizadas como guerrilleras y sindicalistas en la zona plana, debido a que la guerrilla no tenía control sobre esos territorios. Por lo tanto, desde el municipio de Ciénaga hasta el municipio de Fundación la violencia del grupo de los Rojas fue fuerte, en el sentido de que cometieron asesinatos y masacres contra personas que creían que eran la base social de la guerrilla.

\section{Las autodefensas unidas de Colombia (AUC)}

Para finales de 1996 las dinámicas de la guerra cambiaron en el departamento del Magdalena con la llegada de las ACCU. Este grupo paramilitar hizo sus primeras incursiones en los municipios del centro del Magdalena como Sabanas de San Ángel, Ariguani, Chibolo, San Ana y Pivijay (Fiscalía de Justicia y Paz, 2006). Para tener el control de esta zona del departamento del Magdalena las ACCU tuvieron que negociar con 
Vida campesina en el Magdalena Grande

el grupo de autodefensas de Chepe Barrera, que operaba desde los años ochenta en esa zona. También buscaron el apoyo económico de las familias ganaderas. Estas familias tenían el control económico y político de estos municipios del departamento del Magdalena y terminaron apoyando el proyecto paramilitar. En el departamento del Magdalena y Cesar el comandante general del grupo era Salvatore Mancuso y el segundo comandante era Santiago Tobón, alias René Ríos. El comandante de grupos en el departamento del Magdalena era Baltazar Durango Mesa, alias Baltazar: este comandante paramilitar operaba en los municipios de Ariguaní, Chibolo, Bosconia y el Copey. El Grupo Zona Bananera, a cargo de William Rivas, alias 4.4. En el departamento del Cesar operaba Martín Alberto Medina Camelo, alias el Negro Medina, y Juan Andrés Álvarez, alias "Daniel", y en el sur del departamento de la Guajira el grupo estaba bajo el mando de Martín Velasco Galvis, alias Jimmy.

Para el año de 1997 las ACCU se convierten en Autodefensas Unidas de Colombia (AUC). Para ese mismo año entra al grupo de Edgar Córdoba Trujillo, alias 5.7, y se le asigna como comandante del grupo de la Zona Bananera, que era comandado por William Rivas, alias 4.4. Edgar Córdoba Trujillo, alias 5.7, ordenó el grupo y lo dividió en tres escuadras: la primera escuadra se llamó "héroes de las bananeras", al mando de alias Martín o 17; la segunda escuadra era "conquistadores de los planes", al mando de William Rivas, alias 4.4; la última escuadra era "vencedores de Santa Rosa", al mando de Bernardo Escobar, alias Rubén o 07 (Fiscalía de Justicia y Paz, 2006). Edgar Córdoba Trujillo, alias 5.7, instaló su base de operaciones en la vereda los Braciles - corregimiento de Estación Villa-, municipio de Sabana de San Ángel. Desde esta base se coordinaban los asesinatos y masacres que se hicieron en la Zona Bananera, la Loma del Bálsamo, Santa Rosa de Lima y la Cristalina. Para octubre de 1998 el grupo paramilitar coordina una operación en la Sierra Nevada de Santa Marta; esta operación fue dirigida por Juan Andrés Álvarez, alias Daniel, y segundo al mando iban alias 5.7 y Adán Rojas. Los que guiaron al grupo hacia el corregimiento de Siberia y San Pedro de la Sierra fueron guerrilleros que habían desertado del ELN. En la operación de la Sierra el grupo paramilitar ejecutó una masacre en el corregimiento de Siberia, en las veredas de La Secreta, Lourdes, la Unión, Corea, el Congo y San Pedro de la Sierra: 
Vida campesina en el Magdalena Grande

La denuncia fue hecha por la defensora regional del Pueblo en Santa Marta, Lisett Peñaranda. Según ella, varios pobladores de la zona informaron que hace cuatro días llegaron unas 300 personas que luego se dispersaron en varias direcciones y prácticamente se tomaron el corredor entre la vereda Siberia y San Pedro de la Sierra, en jurisdicción de Ciénaga. La situación cada día es más tensa. Las autodefensas no dejan subir a los campesinos que se dirigen a sus lugares de trabajo y tampoco dejan bajar a los que se encuentran allá, explicó la funcionaria, quien llamó la atención de las autoridades policivas y militares para que asuman el control de la situación. Según Peñaranda, el grupo dio muerte a los campesinos Alfredo Murcia Bohórquez y a su sobrino José Antonio Pacheco Murcia, cuyos cuerpos con heridas de machete, signos de tortura y maniatados, fueron encontrados en predios de una finca cercana a la vereda La Unión, donde residían. En otro sitio, dijo la funcionaria, fueron encontrados muertos a tiros el anciano José Domingo Clavijo Pita, de 78 años; los hermanos Edgar Orlando y Uriel Poveda Ortiz; Ana María Legarda y su hijo Darwin Trigo Legarda; Jorge Julio Parra y Florentino Castillo Acosta, todos labriegos. Las identidades de las otras cinco personas asesinadas no han podido ser establecidas por las autoridades, porque los cuerpos permanecen en el sitio de los hechos. Su traslado hasta la morgue del Hospital San Cristóbal de Ciénaga se prevé para las próximas horas $(E l$ Tiempo, 1998, pp. 1-5).

Como se puede analizar, el grupo paramilitar inició su recorrido de la muerte desde la vereda La Aguja - Zona Bananera- y en su recorrido no fue atacado por la guerrilla. En su recorrido detuvo los carros en la vía, entró a las viviendas de los campesinos e interrogó a presuntos colaboradores de la guerrilla, los cuales eran reconocidos por los guías guerrilleros. Muchos campesinos fueron avisados por integrantes de la guerrilla para que abandonaran la zona porque podían ser asesinados por el grupo paramilitar; otros, por sus propios medios abandonaron sus fincas y se desplazaron hasta el municipio de Ciénaga a esperar que el grupo de paramilitares abandonara la zona. Los campesinos que no se desplazaron fueron sacados de sus casas e interrogados para saber si eran guerrilleros. El grupo paramilitar asesinó a las personas que eran señaladas por los guías como presuntos colaboradores de la guerrilla. La 
Vida campesina en el Magdalena Grande

mayoría de las muertes fueron causadas con armas blancas (cuchillo y machete) y tiros de gracia para no generar ruido y así no tener que enfrentar a la guerrilla:

Imagen 4. Cortando leña

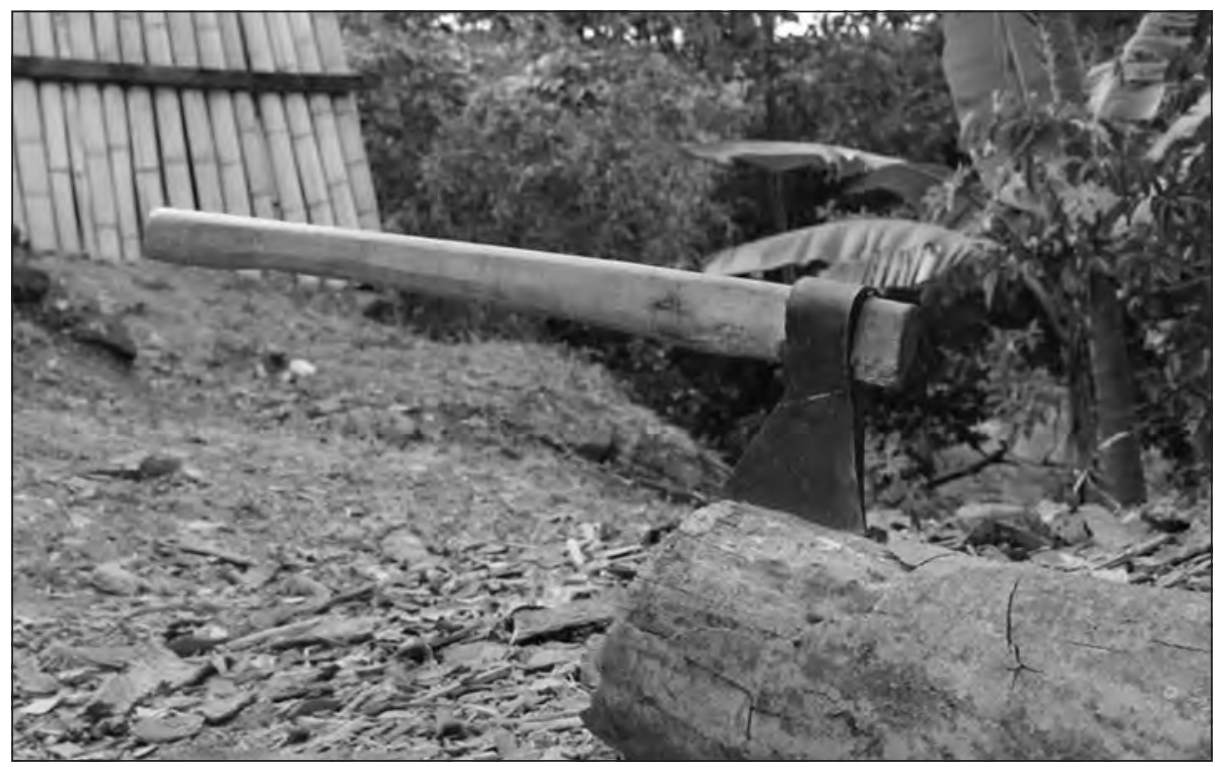

Fuente: Archivo Oraloteca (2020).

El que llevó a los paramilitares allá fue un guerrillero al que le decían Jesús; él era guerrillero del ELN. Él era conocido por allá porque pasaba mucho en la base que tenía la guerrilla más arribita de Siberia. Cuando llegaron los paramilitares a nosotros nos avisó un vecino que nos fuéramos porque venían subiendo los paramilitares matando gente. Cuando los paramilitares llegaron a la casa de mis papás, la encontraron vacía. Nosotros nos fuimos para los corrales de las mulas y eso está un poquito lejos de la casa. Allá duramos tres días escondidos y salíamos a buscar comida a la casa y regresábamos. Cerca de Siberia la guerrilla tenía la base y ellos vieron pasar a los paramilitares, pero no los enfrentaron porque ese día había unos quince guerrilleros y había como cuatro guerrilleras embarazadas y por eso no los enfrentaron (V. Meriño, comunicación personal, febrero del 2020). 
Vida campesina en el Magdalena Grande

El grupo paramilitar siguió el camino a San Pedro de la Sierra sin que se registraran combates con la guerrilla. A diferencia de lo que hicieron en Siberia, en el corregimiento de San Pedro de la Sierra el grupo paramilitar ejecutó la mayoría de los crímenes en la plaza del pueblo. Por lo tanto, la tortura y los asesinatos colectivos se hicieron para que todas las personas los vieran, los escucharan y lo supieran. El grupo paramilitar dirigido por alias Daniel, 5.7 y Adán Rojas se sintió con el poder absoluto frente a una población indefensa, sin tener un contendor legal o ilegal que les hiciera contrapeso:

Anoche al cierre de la presente edición, se confirmó que seis cadáveres sin identificar fueron bajados desde San Pedro de la Sierra a la morgue del Hospital San Cristóbal de Ciénaga, donde las autoridades procedieron a la identificación de los mismos con la ayuda de algunas personas que se acercaron hasta el sitio. Las informaciones que hemos recibido en este despacho también dan cuenta del ajusticiamiento de 10 hombres en el corregimiento de San Pedro de la Sierra. Estos campesinos inicialmente fueron maniatados y mantenidos durante varias horas en la plaza principal y posteriormente asesinado [s] a tiros y machete, sostuvo la funcionaria (El Tiempo, 1998, pp. 6-7).

La masacre cometida por el grupo paramilitar estuvo asociada al estigma que siempre se le tuvo a los campesinos de estos dos corregimientos de ser auxiliadores de la guerrilla. Desde mediados de la década de 1980, la guerrilla le dio duros golpes a las fuerzas militares en estas dos zonas, donde murieron varios soldados pertenecientes al batallón Córdoba. La Policía Nacional y las Fuerzas Armadas no encontraron el apoyo de los campesinos por temor a represalias de la guerrilla. Otro motivo por el cual se les estigmatizaba como colaboradores de la guerrilla estaba relacionado con el ocultamiento y traslado de los secuestrados hacia el corregimiento de Siberia o San Pedro de la Sierra. Este estigma hacia estas dos poblaciones las puso en la mira de los grupos paramilitares, poniendo en riesgo la vida de los campesinos de estos dos corregimientos. Para el grupo paramilitar todas aquellas personas que no eran de la localidad eran estigmatizadas como guerrilleras y eran asesinadas. 
Vida campesina en el Magdalena Grande

\section{La guerra contra los Rojas}

En 1996 fue capturado Adán Rojas Ospina, sindicado de los delitos de concierto para delinquir y porte de armas. El 16 de septiembre de 1999, Rigoberto Rojas Mendoza y su grupo liberan a su padre de la cárcel Rodrigo de Bastida de Santa Marta. En esa misma operación también se fugaron Eliseo Beltrán Cadena, alias el Gordo; Javier Enrique Llaruro, alias Cianuro; alias la Leona, y Eduardo Bengoechea Mola, alias el Flaco. En su fuga, el grupo de los Rojas decide robar un carro. En este acto delictivo participaron José Gregorio Rojas y Álvaro de la Pava Valencia, alias el Cabo de la Pava, miembro activo de la Policía en ese momento:

El día 24 de Septiembre de 1999, se produce el homicidio de Emérito Rueda Ríos, amigo cercano de Hernán Giraldo Serna, a manos de hombres del grupo de los Rojas, en hechos que se dice apuntaban a un secuestro, pero los Rojas han manifestado, que se trató del hurto de una camioneta; lo cierto es que fue interceptada la camioneta donde se desplazaba Emérito Rueda, ganadero de la región, que venía de su finca, en compañía de su medio hermano Andreino Isaza Ríos, presentándose un cruce de disparos muriendo en el lugar Emérito Rueda Ríos, y el Cabo de la Pava, quedando herido Andreino; el cuerpo del suboficial de la Policía, Cabo de la Pava fue enterrado en Girocasaca por el grupo de los Rojas, pero el GAULA de la Policía exigió su entrega, por lo que fue desenterrado el cuerpo, y abandonado en los predios del SENA Agropecuario de Santa Marta donde fue recogido por la Policía y reportado como muerto en actos propios del servicio, expidiéndose la resolución No. 003889 de 27 de Septiembre de 1999 (Fiscalía de Justicia y Paz, 2006, p. 24).

Dentro de la estructura armada que comandaba Hernán Giraldo, Emérito Rueda jugaba un papel importante: por un lado, era amigo de Hernán Giraldo desde la época de la bonanza marimbera; por otro lado, era un narcotraficante que le dejaba grandes ganancias a la estructura armada. El asesinato de Emérito Rueda fue el punto de inflexión para que el grupo de los Rojas, comandado por Adán Rojas y las Autodefensas Campesinas del Magdalena y La Guajira (ACMG), comandadas por Hernán Giraldo, se fueran a una confrontación militar (El Tiempo, 2000). 
Vida campesina en el Magdalena Grande

Entre Adán Rojas y Hernán Giraldo siempre existió una amistad, hasta delinquían en el mismo territorio. Para comienzos del año 2000, Hernán Giraldo decide atacar militarmente al grupo de los Rojas. Antes de hacerlo, les informa a los hermanos Carlos y Vicente Castaño y son estos los que dan el aval de atacarlos. Los hermanos Castaño comisionan a alias Tolima y Mono leche para que apoyen militarmente al grupo de Hernán Giraldo durante los enfrentamientos:

la casa donde vivía la esposa de Adán Rojas fue atacada con granadas. Giraldo envió un grupo de 150 hombres para matarlos, durante la guerra se registraron muertes en la región de Jirocasaca en la Sierra Nevada, y en Santa Marta y otras poblaciones aparecían muertos diariamente (Verdad Abierta, 2009, p. 32).

Las primeras víctimas de estos enfrentamientos se dieron en la vereda El Cúrval y en la vereda Girocasaca, donde los Rojas tenían su campamento. Después de varios días de combate, Adán Rojas y Rigoberto Rojas fueron heridos; en esa misma acción murieron alias el Loco, el Caleño y un mecánico que prestaba sus servicios a los Rojas. Las ACMG logran la expulsión de los Rojas del territorio, lo cual obliga a Rigoberto Rojas y Adán Rojas a huir hacia Barranquilla. En el peaje de Tasajera es capturado por la Policía Rigoberto Rojas; Adán Rojas es capturado en un centro médico de la ciudad de Barranquilla mientras se recuperaba de las heridas. Un grupo de hombres que pertenecía a las filas de los Rojas se pasó a las ACMG; entre ellos, alias el Gordo y alias el Flaco Bengoechea, quienes se entregan a Pacho Musso, entregándole las armas que los Rojas tenían en caletas. El grupo de los Rojas se desestabiliza y se repliega: algunos de sus miembros se van al interior del país y otros buscan protección de las AUC.

\section{La guerra de las autodefensas campesinas del Magdalena y La Guajira (ACMG) contra el Bloque Norte- AUC}

La expansión de las AUC hacia la parte norte de la Sierra Nevada de Santa Marta se concretó para junio del 2001. Jorge 40 decide trasladar un grupo al mando de Juan Hipólito Mejía Rodríguez, alias Caucasia, al 
Vida campesina en el Magdalena Grande

corregimiento de Minca, para crear una base paramilitar y a la vez entablar conversaciones con Hernán Giraldo para que anexara a las ACMG a la estructura de las AUC. Es así como se inicia el acercamiento de cooptación por parte de las AUC a las ACMG. En esta etapa de negociación no armada el grupo de los Rojas instigó la guerra contra Hernán Giraldo. El conflicto contra la estructura armada de Hernán Giraldo se decidió en el momento en el que las AUC vieron en ella una oportunidad que se acomodaba a sus intereses estratégicos dentro de una coyuntura nacional. Esta determinación no solo estaba ligada a la confrontación armada, sino que también estaba relacionada con los cultivos de coca, el transporte de cocaína y el tráfico de armas. Sin embargo, el hecho que desencadenó la ofensiva contra esta estructura fue, en primer lugar, la pérdida de un embarque de cocaína que le pertenecía a Carlos Castaño y, en segundo lugar, el asesinato en 2001 de dos miembros de la Policía Antinarcóticos por parte de Pacho Musso, el comandante militar de Hernán Giraldo, en el sector de Mendihuaca:

Pero el detonante, fueron los hechos ocurridos el día 9 de octubre del 2001, en que miembros de la policía nacional antinarcóticos adelantaban labores de inteligencia con el fin de ubicar para dar captura a Jairo Antonio Musso Torres conocido con el alias de Pacho Musso, y éste fue alertado de la presencia de los agentes por miembros de la organización que prestaban sus servicios como radio chipas en el sector del hotel Mendihuaca Caribean Resort; por lo que alias Pacho Musso envió un grupo de paramilitares conformado por personas de su seguridad y patrulleros, al mando de Omar Martín Ochoa Ballesteros alias El Viejo, que terminan dando muerte a los tres agentes de la policía antinarcóticos, y a tres civiles que se encontraban en el Restaurante El Pechiche, ubicado sobre la Troncal del Caribe, al frente del citado Complejo turístico (Fiscalía de Justicia y Paz, 2006, p. 30).

Estos hechos influyeron en el endurecimiento de la perspectiva y el discurso de Vicente y Carlos Cataño hacia la estructura paramilitar de Hernán Giraldo y estos hermanos dan la orden de atacar a Hernán Giraldo. Este ataque fue comandado por Rodrigo Tovar Pupo, alias Jorge 40, quien pidió a Hernán Giraldo que entregara a Pacho Musso, pero Giraldo 
Vida campesina en el Magdalena Grande

no aceptó unirse ni entregar a su lugarteniente. Al ver la negativa del jefe de las ACMG, Jorge 40, este decide atacarlo:

Esto se torna en el motivo para que Carlos Castaño decida atacar a las ACMG, enviando de distintas partes de la costa norte miembros de grupos de autodefensas como Héroes de los Montes de María, ACCU de Fundación, del Elmer Cárdenas y por supuesto del Bloque Norte, los cuales llegaron por La Guajira (entrando por Mingueo, Palomino y Perico Aguao) y el Magdalena (por Fundación y Ciénaga), con más de trescientos hombres, y material de guerra, contando con la ayuda de Adán y José Gregorio Rojas, quienes conocían la región, para el ingreso a la zona, y la identidad y ubicación de los miembros de las ACMG (Fiscalía de Justicia y Paz, 2006, p. 30).

Imagen 5. Casa campesina en el corregimiento de Siberia

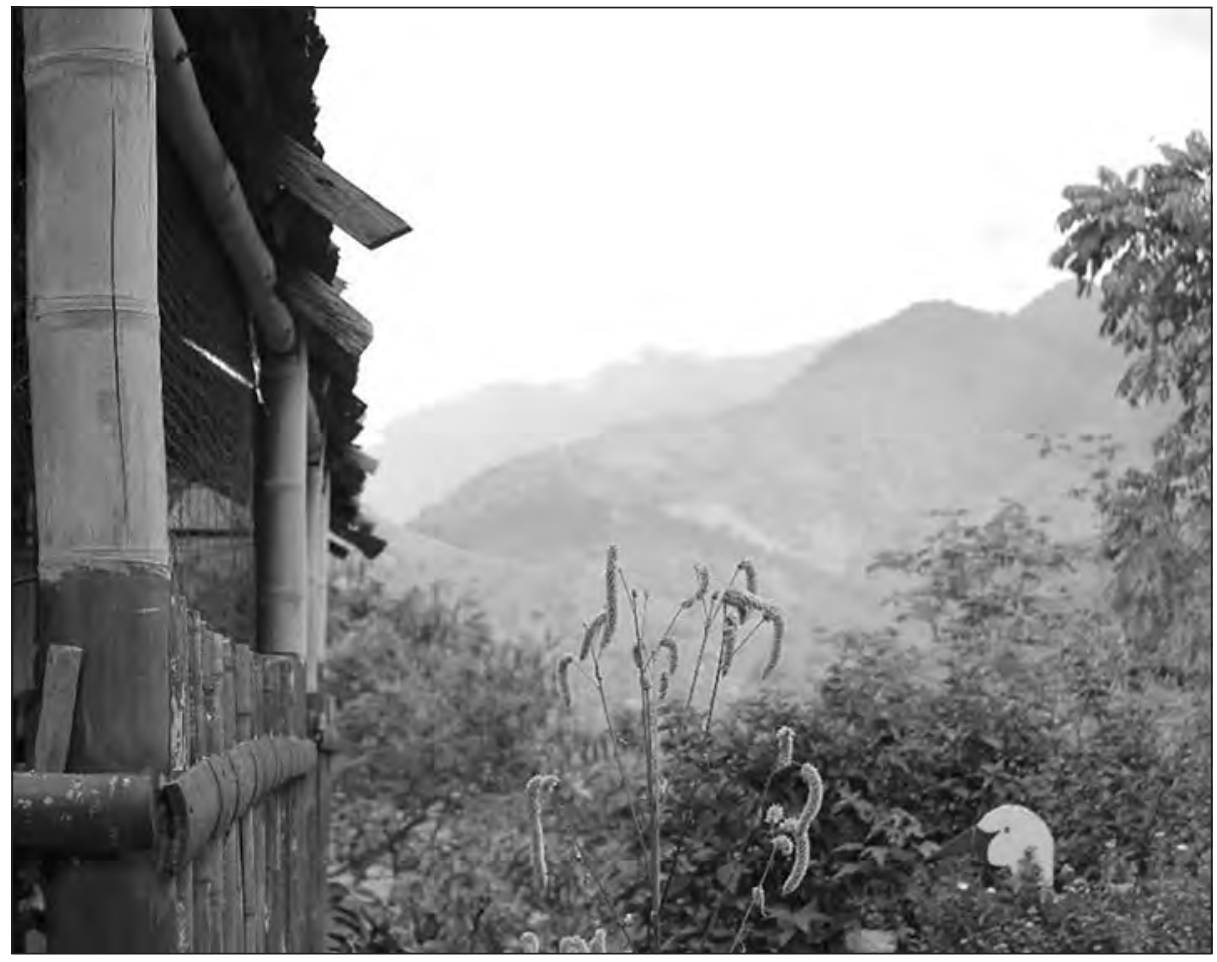

Fuente: Archivo Oraloteca (2020). 
La guerra entre las dos estructuras armadas trajo como consecuencia un impacto social y económico para la región. Hubo desplazamiento de miles de campesinos de las veredas de la Sierra Nevada para la Troncal del Caribe, durante los meses de enero y febrero del 2002, ya que como estrategia para evitar el acceso de los miembros de las AUC a la región Hernán Giraldo Serna ordenó a los presidentes de las juntas de acción comunal convocar a todos los residentes del sector a instalarse en la Troncal del Caribe, a la altura de las veredas de Calabazo, en el corregimiento de Guachaca, Magdalena, y en el corregimiento de Río Ancho, municipio de Dibulla, La Guajira; así como para lograr la atención del Gobierno Nacional con el fin de que enviara tropas del Ejército. El 23 de febrero de 2002 se da la tregua entre los dos grupos y en el carro del general Mario Montoya trasladan a Jorge 40 hasta la vereda Los Cocos para reunirse con Hernán Giraldo Serna.

El grupo de Autodefensas Campesinas del Magdalena y La Guajira fue absorbido por el Bloque Norte de las AUC y se transformó en el Bloque Resistencia Tayrona (BTR). En este momento Hernán Giraldo queda subordinado a Jorge 40, creando una nueva estructura de mando militar. Hay que tener en cuenta que el BRT inició una ofensiva contra la guerrilla para anexar territorios y expandirse militarmente a los corregimientos de Siberia, San Pedro de la Sierra y Palmor, pertenecientes al municipio de Ciénega, que están en la Sierra Nevada de Santa Marta.

\section{EL BRT: control social y militar en los corregimientos de Minca, San Pedro de la Sierra y Siberia}

La expansión del BRT comienza en el mes de junio del año 2002 con la llegada de combatientes pertenecientes a los frentes Bernardo Escobar y Mártires del Cesar. Los combatientes del Frente Mártires del Cesar fueron trasladados desde el corregimiento de la Mesa hasta la vereda Quebrada el Sol, donde recibieron un reentrenamiento militar. Estos combatientes permanecieron por tres meses en la base de Quebrada el Sol; después, fueron trasladados a la vereda la Tagua, corregimiento de Minca, donde alias Caucasia tenía una base paramilitar. Por los lados del municipio de Ciénaga entraron combatientes que pertenecían al Frente Bernardo Escobar; estos fueron trasladados desde la finca el Vergel — corregimiento 
Vida campesina en el Magdalena Grande

de Santa Rosa de Lima - hasta la vereda La Aguja, mientras que otros fueron trasladados a la finca La Isabel. La incursión paramilitar en el corregimiento de Siberia fue dirigida por alias "5.7", quien fue designado como comandante militar del BRT:

En la operación de Siberia participaron los frentes que estaban en la Guajira, Magdalena y Cesar. Para esa operación participamos seiscientos hombres y la comandaba alias 5.7, alias 8.1, alias 5.5 y otros comandantes. Todas esas personas estaban a cargo de alias 5.7. Nosotros entramos por la finca el Vergel y nos transportamos en veinte camiones; esos camiones salieron de la vereda el Brasil y nos dejaron más arriba de la vereda La Aguja, cerca de la quebrada. Nosotros comenzamos a subir, pero reventando monte, mejor dicho, nosotros éramos la avanzada los que íbamos limpiando la zona. Detrás de nosotros venían los comandantes montados en los carros, ellos avanzaban cuando nosotros le[s] avisábamos que la zona estaba limpia. Cuando íbamos avanzando nos detuvieron para hacer un receso y a nosotros nos reemplazó la contraguerrilla de Águila, uno[s] que fueron los que siguieron adelante limpiando la zona. A los cinco minutos de ellos pasar la guerrilla mata a media contraguerrilla. Esa contraguerrilla estaba conformada por unos treinta hombres y ellos eran un comando especial. A esa contraguerrilla la emboscó la guerrilla del ELN a las doce del mediodía. Duramos peleando hasta las siete de la noche; después, la guerrilla se nos vino encima y nosotros le preparamos una emboscada a las diez de la noche. En esa emboscada hubo más de veinte guerrilleros muertos. En esa emboscada la guerrilla arrojó cilindros bombas que cayeron cerca [de] donde nosotros estábamos. Ahí caí herido y me llevaron para el puesto de salud de Sabana de San Ángel (J. Sánchez, comunicación personal, febrero del 2020).

En esta incursión armada las tropas del Bloque Resistencia Tayrona logran posicionar una base en las veredas en Chimborazo y Parranda Seca, mientras las escuadras de choques seguían avanzando hacia el casco semiurbano de Siberia. Estas escuadras de choques, en su trayectoria hacia Siberia, iban arrasando con todo lo que encontraban en el camino e iniciaron una ofensiva militar contra los campesinos que, presuntamente, eran auxiliadores de la guerrilla o guerrilleros vestidos de civil. Estas 
Vida campesina en el Magdalena Grande

escuadras de choque ingresaron a las casas de los campesinos en busca de armas y también arremetieron contra la población joven, a quienes tildaban de ser combatientes de la guerrilla:

Nosotros éramos la contraguerrilla de choque e íbamos arrasando con todo. Recuerdo que llegamos a una casa que estaba sola y solamente estaban los animales, a nosotros nos tocó comernos todos los animales porque teníamos cinco días sin comer. Recuerdo que en esos combates la gente de 8.1 mató a dos civiles que iban bajando por la carretera. La gente de 8.1 decía que esos pelaos eran guerrilleros, los de las otras contraguerrillas decían que eran civiles porque no llevaban armas ni estaban uniformados. Después de ese suceso a nosotros nos bajaron a la vereda la Secreta y después nos llevaron al Chimborazo. En ese sitio nos tocó esperar a las otras contraguerrillas para después subir para el corregimiento de Siberia. [En] esa subida iban matando civiles porque decían que eran guerrilleros vestidos de civil, la mayoría de esos civiles eran pelaos de veinte años de edad. Subiendo a más arriba de Siberia nos encontramos una casa vacía y dentro de ella había como unos treinta fusiles. Como a veinte minutos de la casa nos prendimos con una móvil del ELN que se llamaba Héroes de las Bananeras. La verdad que esa operación duró como veinte días y los combates eran día y noche (J. Sánchez, comunicación personal, febrero de 2020).

Los enfrentamientos entre la guerrilla del ELN y el Bloque Resistencia Tayrona produjeron pánico y zozobra en los campesinos del corregimiento de Siberia que tuvieron que salir desplazados hacia el corregimiento de San Pedro de la Sierra y otros hacia el casco urbano del municipio de Ciénaga. Los campesinos que se desplazaron en el corregimiento de San Pedro de la Sierra se ubican en el colegio de bachillerato y la escuela primaria. En estos dos sitios los campesinos esperaron a las entidades humanitarias para que les prestaran ayudas y algunos fueron bajados hasta el casco urbano de Ciénaga por integrantes de la Cruz Roja y la Defensoría del Pueblo. Lo anterior fue excusa para que los integrantes del Bloque Resistencia Tayrona hicieran retenes en la vía, deteniendo los carros de la Cruz Roja y, con lista en mano, buscando a campesinos señalados como presuntos colaboradores de la guerrilla: 
Vida campesina en el Magdalena Grande

A partir de esos combates hubo muchas personas que se desplazaron, eso se veía la gente bajar en los carros. Algunas de esas personas fueron bajadas por la Cruz Roja. En los caminos nosotros hacíamos retenes y parábamos los carros para saber si llevaban algún guerrillero (J. Sánchez, comunicación personal, febrero de 2020).

Al terminar la confrontación armada, el BRT ocupó los territorios que eran dominados por el ELN, replegando a esta guerrilla hacia otros sectores de la Sierra Nevada de Santa Marta. Esto permitió que el BRT afianzara bases en las veredas Cuatro Caminos, Siberia, Corea, Chimborazo y Nueva Granada, el Mico y San Pedro de la Sierra. Además, desplegó doce columnas móviles en el territorio para taponar el suministro de víveres hacia las partes altas de la Sierra y, a la vez, obstaculizar el tránsito de la guerrilla hacia las zonas bajas de la Sierra.

Imagen 6. Mujer campesina de la vereda Cantaranas

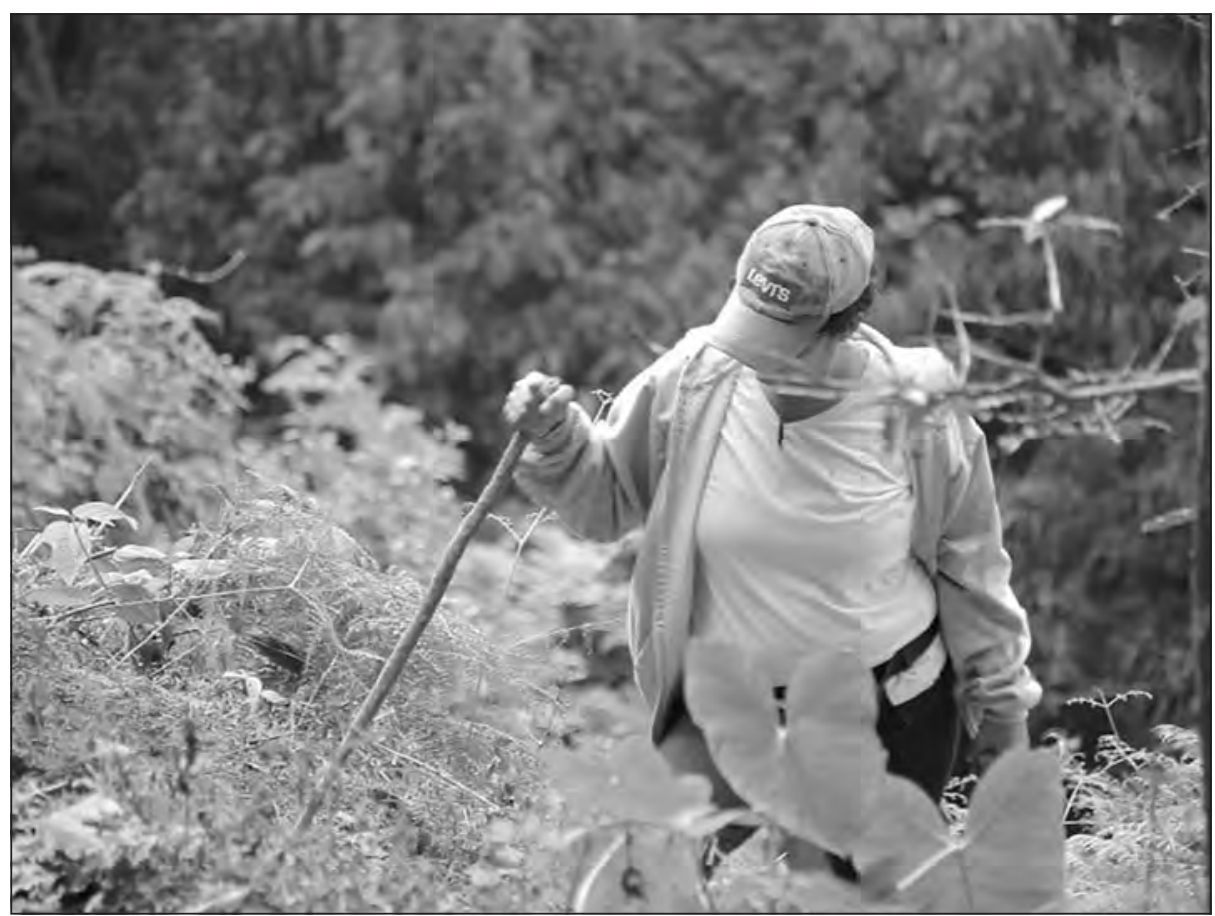

Fuente: Archivo Oraloteca (2020). 
Vida campesina en el Magdalena Grande

Apenas tuvo el control de la zona, el BRT le impuso normas y directrices a los campesinos; entre otras, se les prohibió tener relación con la guerrilla y transitar por los caminos en las horas de la noche. El grupo paramilitar también desarticuló todas las organizaciones de base; estas, fueron aniquiladas: "nosotros teníamos una asociación de mujeres en el Congo, esa asociación la hicimos por medio de la fundación Pro-Sierra. Apenas llegaron los paramilitares nos dijeron, que no querían ver más reunión porque nos mataban" (Camacho, 2020, p. 12). Los integrantes del BRT también se dedicaron a desaparecer y asesinar a campesinos, robándose las reses y los enseres, como lo demuestra el siguiente informe:

Se informó a la comisión sobre la desaparición de un grueso número de campesinos, los cuales fueron sacados por la fuerza de sus ranchos o del campo cuando laboraban, por miembros presuntamente de las AUC. Cuando por primera vez incursionaron las AUC reunieron a la población y les manifestaron que el que no tuviera vínculos con la guerrilla se podía quedar y no le ocurriría nada, pero que el que tuviera relación con la guerrilla se fuera o lo matarían. Los campesinos que se quedaron no tenían vínculos con ningún grupo; sin embargo, las AUC hicieron desaparecer algunas de dichas personas, les robaron reses, mulas y enseres, lo cual las atemorizó y obligó a abandonar fincas y pertenencias (Defensoría del Pueblo, Procuraduría General de la Nación y Pastoral Social, 2003, p. 19).

En su afán por controlar a la población y por no dejar entrar a grupos guerrilleros, los paramilitares comenzaron a controlar la vida cotidiana de los campesinos de los tres corregimientos. Todas aquellas personas que habitaban en la zona eran vigiladas estrictamente por los paramilitares. Los campesinos que no acataran las normas implantadas por el grupo paramilitar eran castigados, expulsados de la zona o asesinados. Los campesinos que se quedaron se sometieron a las reglas; otros, temiendo las represalias de los paramilitares, dejaron abandonadas sus pequeñas fincas: 
El grupo le tenía prohibido a las personas hablar con uno, acercarse a las bases, jugar futbol con los patrulleros y transitar por los caminos a altas hora de la noche. También se les prohibía las peleas entre campesinos, llevar gente extraña a las fincas, también se les prohibía cortar árboles, cazar animales y arrojar desechos a los ríos. El grupo hacía retenes para verificar para qué finca iba y con qué persona iba a trabajar. Los dueños de las fincas tenían que responder por los recolectores de café y no querían que los recolectores anduvieran de finca en finca. No permitían que los civiles consumieran drogas [ni] robos. A las personas que no acataban las reglas los sancionaban con arreglar caminos o trabajar en las fincas. [A] estas personas que trabajaban en fincas no les pagaban. También los ponían [a] arreglar, cercar y tirar machete en los caminos (J. Sánchez, comunicación personal, febrero del 2020).

Los campesinos que huyeron de los paramilitares dejaron sus fincas abandonadas y estas fueron tomadas por los paramilitares. En algunas de ellas construyeron bases paramilitares; otras, las tomaron para sembrar cultivos de coca y, en otras, se beneficiaron de la producción de café. Los paramilitares implantaron un sistema de endeudamiento a los campesinos: en los meses donde no había producción de cosecha de café, les daban a los campesinos los víveres y les prestaban dinero para que sostuvieran a los trabajadores y compraran insumos para las fincas. Los paramilitares también implementaron el cobro de vacunas a los campesinos: a unos les cobraban por hectáreas de café sembradas y a otros por latas de café vendidas. En la temporada de cosechas, los campesinos tenían que pagar los víveres consumidos, el dinero prestado y la vacuna exigida por los paramilitares. Todo lo anterior trajo grandes pérdidas económicas y ocasionó la crisis para los campesinos:

En el año 2000, que empezó la guerra, que se fajó ya la violencia aquí, fue cuando ya vino la otra cara de la moneda, que volvimos nuevamente a caernos y sinceramente pues el campesino ahora mismo está endeudado con los bancos, con el gobierno, porque no hemos podido pagar las deudas, entonces todo esto es algo que nos trae bastante[s] preocupaciones y dificultades a la familia porque nunca habíamos estado en tal, tal estado de pronto de deudas porque yo antes de eso del desplazamiento 
pues tenía carro, tenía ganado, tenía mi buena finca bien arreglada, cogía 3 mil galones de café ahora estoy cogiendo por ahí ciento y pico, 150 galones de café, es algo que a nosotros nos ha... nos ha dañado completamente, nos ha echado a perder el modo de vivir, este otro vino se robó lo que podía servir para la educación de nuestros hijos, para la alimentación de nuestros hijos, yo era un hombre que tenía 10, 15 mulas propias, propias mías y hoy en día pues apurao tengo una para... para solventar pues la situación de llevar mercadito a la casa. Y así sucesivamente estamos todos cortaos por la misma tijera (Entrevista citada en Ortiz, 2017, p. 26).

En febrero del año 2006 se desmovilizó el Bloque Resistencia Tayrona; las bases y fincas que estaban en posesión de la estructura armada fueron desocupadas. En ese mismo año, el Estado hace presencia con el Ejército para recuperar el territorio y garantizar la seguridad de los campesinos. Después fueron retornando los campesinos a buscar sus tierras despojadas con ayuda del Ejército. Algunos campesinos encontraron sus fincas abandonadas y otros las encontraron ocupadas por terceras personas, por lo que se vieron obligados a resolver ese conflicto de derecho de posesión en los estrados judiciales. 


\section{Ahora somos ecológicos}

Imagen 7. Panel solar en la vereda Sacramento

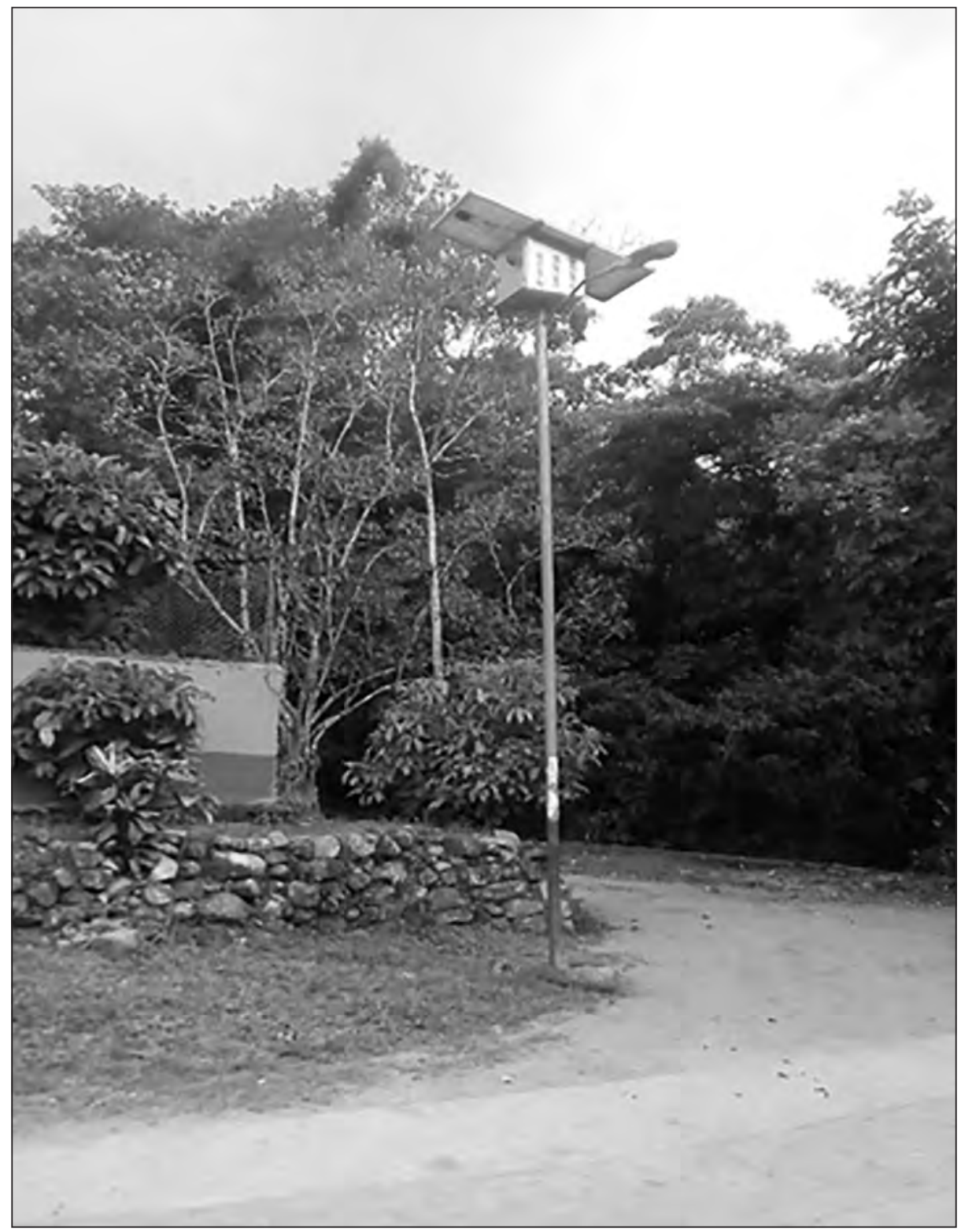

Fuente: Archivo Oraloteca (2017) 
Cuando se terminó el conflicto armado los campesinos fueron retornando y ocupando sus fincas de manera gradual; de la misma forma, aparecieron las instituciones del Estado y organizaciones internacionales y los ayudaron en la adecuación de puestos de salud, aulas de clase y mejoramiento de vías de acceso a los corregimientos. La Cruz Roja implementó capacitaciones de derechos humanos, a las que asistían presidentes de juntas de acción comunal y de organizaciones de víctimas. De esta misma forma, pero desde el año de 1997, la Fundación Pro-Sierra venía implementando el Programa de Desarrollo Sostenible de la Sierra Nevada de Santa Marta. Desde ese mismo año, los campesinos productores de café se insertaron a los circuitos de sostenibilidad ambiental de la ONG ambientalista y en el año de 1997 crearon la Red Ecolsierra con el apoyo de la Fundación Pro-Sierra y el Comité de Cafeteros del Magdalena (Red Ecolsierra, 2016). Los campesinos comenzaron a producir café con sostenibilidad ambiental y pasaron de ser destructores del bosque a ser campesinos ecológicos; esto debido a que sus fincas entraron en el circuito de cafés orgánicos, turismo comunitario o turismo ambiental, contando con certificación orgánica de agencias nacionales e internacionales.

Los corregimientos de Minca, San Pedro de la Sierra y Siberia basan su economía en la producción de café. El único corregimiento que ha diversificado su economía ha sido Minca, con el turismo ecológico y el agroturismo. Algunos campesinos del corregimiento han vendido sus fundos para darle paso a la construcción de hostales. La llegada de personas extranjeras y del interior del país le ha dado otra dinámica al corregimiento. Los pobladores de Minca se han volcado al turismo como guías turísticos o han sido contratados como mano de obra en los hostales. Esto no quiere decir que los agricultores hayan abandonado el cultivo de café. En los tres corregimientos, cuando hay temporada de recolección, comienza a llegar personal de otras partes del país que se dedica a la recolección del grano de café; eso hace que el grupo de trabajadores que entran a laborar a la localidad sea numeroso. Son muchas las personas que entran a laborar en las fincas de café que están en las diferentes veredas que conforman estos corregimientos. Muchas de estas fincas contratan personal para las labores de recolección de café y de cocina. En la recolección de café se emplean mujeres, pelaos y hombres adultos. Las 
fincas donde más empleados se contratan son las fincas grandes: estas fincas emplean demasiados trabajadores porque tienen grandes hectáreas de café cultivado y los dueños estiman la producción que estas pueden dar en el año.

Los dueños de fincas grandes y pequeñas contratan mujeres para las labores de cocina y para las labores de recolección de café. En la cocina de las fincas de café por lo regular hay amas de casa que se encargan, junto a las ayudantes de cocina, de la alimentación para el personal que labora en la finca. Estas mujeres que sirven de ayudantes llegan en los tiempos de cosecha; la mayoría de ellas llegan con sus esposos y son de otras partes del país. Algunas son contactadas por teléfono por los dueños de las fincas y otras, por lo general, llegan al pueblo el día domingo, debido a que los dueños o administradores de las fincas bajan al pueblo a hacer compras. Los dueños o administradores de las fincas siempre contratan mujeres que estén recomendadas por personas de confianza del pueblo. En los meses que dura la recolección de café se reactiva el comercio en los tres corregimientos: en los almacenes, las tiendas, las cantinas, las cafeterías y los restaurantes, en los meses de cosecha, contratan mujeres para que atiendan.

Cuando llegan a las fincas, a los recolectores se les hace una inducción sobre cómo deben recoger el grano y cómo tratar la mata de café. Los recolectores escogen los granos de café que están maduros y los llevan a la despulpadora: una máquina eléctrica que tiene una especie de cajón donde echan el café, del que sale despulpado a una alberca. Después de despulpado, el café se deja 24 horas en la alberca, donde dos operarios se encargan de hacerle el lavado. Para preservar el ambiente, los campesinos han adoptado prácticas amigables con el medio ambiente. Anteriormente, el despulpado del café se hacía en agua y las aguas contaminadas llegaban hasta las fuentes hídricas y las contaminaban. Ahora, los campesinos están despulpando los granos de café en seco; todo esto para no generar contaminación en las fuentes hídricas. El desperdicio de la pulpa del café y la poca agua que utilizan les sirve como abono orgánico.

El café solo da una producción al año; esto ha hecho que los campesinos se inserten en otras economías o que busquen otros cultivos para generar ingresos. Después del cultivo de café, en Minca, San Pedro de la Sierra y Siberia se siembra mora, lulo, tomate de árbol, cacao y caña de 
azúcar, y se crían abejas para la producción de miel. Los cultivos que dan mejor rentabilidad, después del café, son el lulo y la mora; estos ayudan a la economía de los campesinos. El lulo se comenzó a cultivar hace veinte años; por su parte, la mora es más reciente: tiene diez años de estar cultivándose. Los campesinos no están especializados en sembrar esos cultivos, pero han hecho que en sus fincas se cultiven. En los tres corregimientos no hay finca que esté produciendo solamente cultivo de café. Para el cultivo de lulo, tomate de árbol y mora los campesinos estiman una hectárea o media hectárea, buscando que ayuden en la economía de la finca cuando no haya producción de café. En 1974 se comienza a transportar lulo a Barranquilla debido a que este tiene una buena aceptación en el mercado regional. El lulo, la mora y el tomate de árbol se cultivan en las partes altas de los corregimientos, pero debido al mal estado de las vías los campesinos no cultivan demasiado porque las cosechas se les pierden. Por este motivo, a los campesinos les da más tener media hectárea de lulo que tener siete hectáreas. La mora, el lulo y el tomate de árbol son comprados por intermediarios a un precio supremamente irrisorio. Estos compradores pagan a 700 pesos el kilo de mora (por lo general, ese es el precio que ellos pagan), pero los cultivadores se dan cuentan cuando bajan a Ciénaga o Santa Marta del precio al que venden un kilo de mora: este se multiplica por cuatro o cinco veces en relación al precio del kilo de mora al que ellos lo venden.

La caña de azúcar es otro de los cultivos que se produce en las fincas de café; esta se utiliza para la producción de panela. Cada finca tiene un trapiche donde hacen la molienda de la caña para producir la panela que se utiliza para el consumo personal y comercial. La mayoría de las fincas producen panela para vender en San Pedro de la Sierra o en Siberia y, a veces, es llevada a Ciénaga, donde se comercializa con el nombre de "panela orgánica". Las fincas que tienen una buena producción de panela son las fincas grandes. La producción de panela que se produce en estas fincas es llevada a los supermercados que están en Santa Marta. La producción de panela que tienen las fincas pequeñas es muy baja porque se hace molienda cada dos meses y eso da una producción de 145 panelas por molienda, pero esta panela que se produce en la mayoría de las fincas es para el consumo de la propia finca y si algún vecino ayuda a moler se le da panela. 
Vida campesina en el Magdalena Grande

Imagen 8. Jardín en Corea

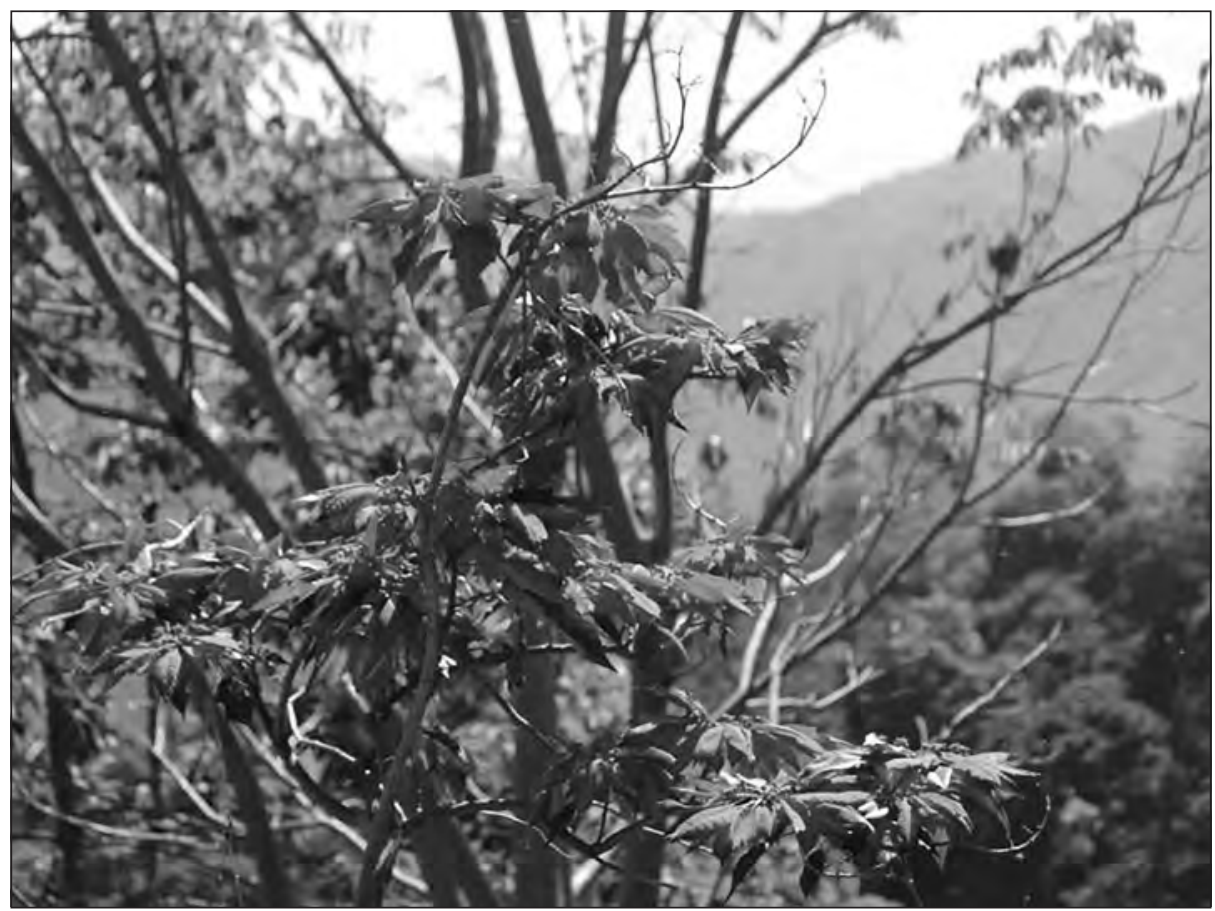

Fuente: Archivo Oraloteca (2020)

En cuanto a la cría de abejas para la producción de miel, este fue un proyecto de la Fundación Pro Sierra Nevada de Santa Marta. El objetivo del proyecto era desarrollar alternativas alimenticias para los campesinos, pero buscando que estos tuvieran prácticas productivas con el medio ambiente (Red Ecolsierra, 2016). Para desarrollar el proyecto se organizaron campesinos de los corregimientos de Minca, Siberia y Palmor; de esta forma, se dio inicio a la Asociación de Apicultores de la Sierra Nevada de Santa Marta (Apisierra). La cría de abejas para la producción de miel les genera ganancias a los campesinos y, a su vez, ayuda a la conservación (o, como dicen los campesinos, es amigable con el bosque). La cría de abejas no necesita mucho personal y para que deje una buena rentabilidad el campesino debe tener mínimo veinte colmenas. Los campesinos que se dedican a la apicultura tienen que estar dentro de la Red de Caficultores Orgánicos; esto se hace para que no haya una 
Vida campesina en el Magdalena Grande

contaminación de los apiarios. La miel que producen estos campesinos es comercializada por la Red Ecolsierra y los clientes son los almacenes de cadena como el Éxito, Carulla, Jumbo, etc. Los campesinos también generan ingresos económicos por los cultivos de aguacate y mango, aunque dada la dificultad de transportar estos productos a los centros de comercio, se pierden en las fincas. Los campesinos en sus fincas poseen su seguridad alimentaria con cultivos como el maíz y fríjol de diferentes variedades (el rojo, caraotas o bogotano, cabecita negra y el fríjol caqui); también se ha cultivado arroz, presentando dificultades para la trillada. Hay cultivos de guineo y plátano dentro de los cultivos de café; también se siembran tubérculos como la malanga y la yuca, y hay varios proyectos de gallinas ponedoras y cerdos.

\section{Las buenas prácticas}

Los campesinos de estos tres corregimientos eran vistos por las ONG ambientalistas, entidades gubernamentales y antropólogos como los destructores del medio ambiente que, en su afán por colonizar territorios, destruyen los bosques. A los campesinos no solo se los vio como depredadores ecológicos, sino que también se los vio como narcotraficantes, guerrilleros y paramilitares. Esta asociación comienza cuando se dan los cultivos de marihuana y coca en la Sierra Nevada de Santa Marta. En el imaginario de las personas de Santa Marta o Ciénega todas aquellas personas que vivían en la Sierra Nevada eran bandidos o pertenecían a algún grupo al margen de la ley. Ahora esa imagen está cambiando: los campesinos se han insertado en diversos proyectos dedicados a la sostenibilidad ambiental en producción orgánica que están siendo ejecutados por entidades ambientales y comercializadoras de café. Lo otro es que estas entidades están incentivando a los campesinos a que se vinculen al turismo ecológico, pero con turistas que estén interesados en las formas de producción del café.

Por años, los campesinos de la Sierra Nevada de Santa Marta han tenido prácticas tradicionales para cultivar el café; estas prácticas están ligadas a la conservación ambiental en sus fincas cafeteras. Una de las prácticas tradicionales que han mantenido los cultivos de café es la siembra de árboles en las plantaciones para generar sombrío en las plantas de café y 
lograr así que estas no se vean afectadas por el sol. Los campesinos también dejan una zona de bosque para la conservación de los nacimientos de agua y destinan unas áreas para la siembra de cultivos para el consumo familiar. El bosque les proporciona madera para el consumo de la cocina. En cuanto a la siembra de árboles en los cultivos de café se hace con un doble propósito: por un lado, las hojas de los árboles son materia orgánica para el cultivo de café porque mejoran la calidad del suelo; por otro lado, los árboles sirven para producir madera y si son árboles frutales como el guamo y el aguacate le van a dar otra entrada económica a la familia. Cuando siembran de sombrío plátano o bananos estos sirven de consumo para la familia o los venden en los cascos urbanos de los corregimientos. Lo cierto es que los campesinos utilizan el sombrío en sus plantaciones de café para regular el efecto del sol:

El sombrío es calidad, el sombrío es protección de suelo, es lo más recomendable del sombrío es el guamo, porque el guamo es un árbol de que crece muy rápido, se eleva; a él hay que hacerle tratamiento de crecimiento y se le hace el tratamiento y él se eleva, pero no es por eso, el guamo es porque diariamente él está botando mucha materia, bota la hoja, bota la guama y se descompone muy rápido entonces eso ayuda al mejoramiento de los suelos, donde hay buenos suelos hay buena producción de café, si no tenemos sombrío la producción del café es muy baja (Negrete, 2020, p. 15).

Los campesinos siembran, primero, los árboles que le van a dar sombrío a las plantas de café. Los árboles se fertilizan, se podan y se les retira la maleza durante el proceso de crecimiento. Cuando los árboles están grandes se procede a sembrar las plantas de café y a estas no se les suministran insumos químicos. La tradición de no usar insumos químicos en las plantaciones de café ha hecho que muchos de estos campesinos reduzcan los costos de producción al eliminar los agroquímicos como los plaguicidas, fungicidas y herbicidas. La institución que regula que los campesinos hagan buenas prácticas en sus cultivos de café es el Comité Cafetero; este ha destinado a sus técnicos expertos en caficultura para que los campesinos tecnifiquen sus cultivos de café. Para esto, los campesinos tienen que estar de acuerdo con las sugerencias que haga Cenicafé 
Vida campesina en el Magdalena Grande

sobre las semillas que se van a sembrar, el control de broca, roya, maleza e insectos y, por último, las medidas en que se tiene que sembrar el café:

Habían cafés que se sembraban regaos en almacigo, y pero entonces la gente fue cambiando, porque surqueado era mejor para trabajarlo o mejor para cogerlo, para controlarlo y empezaron a tratarlo surqueada mente, luego llegó el comité y ya colocó las medidas de siembra de café. Hoy existen muchas clases de medidas de intensidad de siembra de café (Negrete, 2020, p. 16).

Los campesinos de estos tres corregimientos han optado por no fertilizar las plantas con químicos. Aunque esto acelera la producción en las plantas, también es un efecto negativo para el suelo dado que este perderá sus nutrientes naturales. Para algunos campesinos, suministrarles fertilizantes a las plantas de café acelera el proceso de crecimiento de la planta, pero a su vez acorta los años de productividad. En sus experiencias cuentan que la utilización de químicos hace que las plantas se trastornen y pierdan sus hojas; por lo tanto, esto produce pérdidas cuantiosas a los campesinos. Estos trastornos, por lo general, se dan en plantas jóvenes; lo que recomiendan los técnicos - extensionista del Comité de Cafeterosa los campesinos es hacer una nueva resiembra de plantas. Para evitar estos casos y no generar pérdidas económicas, los campesinos han optado por no fertilizar con químicos, lo que alarga la vida de producción de la planta hasta quince años:

Ah sí, eso es el proceso del químico... el proceso del químico eso es como cuando aceleran la mata digamos así... no quiero comparar pues la naturaleza con la mujer, pero es casi igual. Es como cuando la mujer se deja coger macho digámoslo así muy joven el proceso de vida es muy lento... Entonces eso pasa con la planta, si la planta aquí en esta Sierra se acelera... una planta de café de ellos el proceso de vida son cinco años porque se acelera con lo[s] químicos, entonces ella se crece rapidísimo produce bastante, pero así mismo como se le echa así mismo queda muy aporreada y se palotea, lo que llamamos palotear es que queda sin hojas muy poca hoja (Ortiz, 2017, p. 16). 
Vida campesina en el Magdalena Grande

Algunos de estos campesinos planifican la siembra, la poda y la cosecha de café o cualquier otro cultivo de acuerdo a las fases de la luna. Las fases de la luna también le indican al campesino la época en que comenzarán las lluvias y la sequía. La otra práctica tradicional que todavía tienen algunos campesinos es la de hacer quemas para preparar el terreno para los cultivos que van a abastecer a la familia mientras se da la cosecha de café. Esta práctica de quemar el rastrojo ha hecho que los campesinos se enfrenten a las instituciones ambientales porque las quemas a veces se salen de control, generando incendios de grandes proporciones. Los incendios provocados por las quemas ponen en peligro la fauna y flora y hasta la vida de las comunidades campesinas e indígenas que habitan en el macizo montañoso. Aun cuando estas quemas generan desastres ambientales cuando se salen de control, los campesinos las siguen practicando para preparar el terreno para cultivar. Los campesinos sostienen que si no se hacen las quemas la tierra no producirá lo suficiente y se morirían de hambre:

Aquí siempre se trabajaba con la luna, aquí siempre con los cambios de luna. Aquí siempre se preparaban las tierras en el mes de enero... hasta en diciembre porque llovía mucho, ya después la gente siempre hacía su guardarraya, quemaba su pedazo de tierra. Anteriormente uno tumbaba una tierra, un ejemplo tumbaba tres o cuatro hectáreas de tierra, y nosotros le teníamos que hacer el guardarraya para que las candelas no se nos pasaran. Nosotros cuidábamos mucho las aguas, sobre todo nosotros allá en las tierras [...] dejábamos un trayecto más o menos casi de 100 metros de la quebrada a donde teníamos la siembra, incluso es hora y las únicas tierras de esos lados en "La Unión", tenemos más de 20 hectáreas de montaña que nosotros no las tocamos, eso fue intocable (Ortiz, 2017, p. 15).

Para evitar que los campesinos sigan utilizando las quemas para cultivar la tierra, las instituciones encargadas de preservar la Sierra Nevada de Santa Marta les están enseñando otras prácticas de sembrar la tierra sin utilizar las quemas. Muchos de estos campesinos quieren tener experiencias de intercambios para olvidar la práctica de la quema y así quitarse el estigma de "depredadores ambientales". 
Vida campesina en el Magdalena Grande

\section{Conclusiones}

El corregimiento de Minca tuvo una colonización dirigida por el Gobierno Local y Nacional; los extranjeros llegaron al territorio gracias a las políticas de poblamiento. El Gobierno Local y Nacional tuvo a la Sierra Nevada de Santa Marta como una zona de frontera y, por lo tanto, tenía que ser anexada al Estado. La llegada de población extranjera hizo que la Sierra se incorporara a las políticas económicas del Gobierno Nacional, por medio de la explotación y comercialización de café. La llegada de las personas del interior del país, como marginados de la violencia partidista que se estaba dando en los departamentos andinos, reconfiguró el orden establecido por los colonos extranjeros. En los tres corregimientos las personas del interior del país no coordinaron ni planificaron la colonización y esta se desbordó hasta los territorios de los indígenas; en esta perspectiva, los colonos fueron vistos como invasores de tierras de la reserva forestal.

En principio, los colonos se insertaron al cultivo de café y se vio que asimilaron las políticas económicas y ayudaron en la economía regional. Cuando se desligaron de la economía legal del cultivo de café y entraron en la economía ilegal del cultivo de marihuana fueron vistos como violentos y fuera de la ley. El cultivo de marihuana hizo que el territorio de los campesinos fuera visto como zona de frontera, zona roja o marginal, debido a que el Estado no tenía control sobre esos territorios. Todas aquellas personas que habitaban esos territorios fueron consideradas marimberas y, por lo tanto, tenían que ser controladas y los cultivos de marihuana acabados. Esto generó violencia en los tres corregimientos, una violencia que el mismo Estado no pudo controlar. Este desorden social y económico fue asumido por la guerrilla de las FARC mediante el control y ajusticiamiento de los generadores de violencia. La ausencia del Estado hizo que la guerrilla controlara a los campesinos; aunque estos se distanciaban de las políticas del grupo guerrillero, fueron estigmatizados como guerrilleros o colaboradores.

El estigma como "zona de guerrilleros" propició la arremetida violenta de los paramilitares contra los campesinos. La llegada de los paramilitares a la zona complicó la situación: estos aislaron la zona con los cascos urbanos de Ciénaga y Santa Marta, mientras asesinaban y masacraban a 
los campesinos por ser supuestos colaboradores o guerrilleros. El despojo de tierras estuvo a la orden del día y el número de desplazados hacia los cascos urbanos se desbordó. A los campesinos les quitaron sus fincas y los pusieron a pagar cuotas financieras para el sostenimiento de la estructura armada. Aunque el territorio estaba controlado por la estructura paramilitar Bloque Resistencia Tayrona, a los campesinos todavía se les estigmatizaba como guerrilleros o colaboradores. La estructura paramilitar controló el orden público y regulaba todo lo que pasaba en el territorio. Hay que tener en cuenta que los grupos paramilitares tenían el control de todo el departamento del Magdalena y la Sierra Nevada tenía que entrar a ese modelo político, económico y militar. Por lo tanto, controlar y dominar los tres corregimientos era anexarlos al modelo paramilitar que en esos momentos estaba de moda en toda Colombia; a pesar de todo lo anterior, los campesinos no vieron inversión de los paramilitares y, mucho menos, de los gobiernos local y nacional.

Cuando se desmovilizaron los paramilitares del BRT ocurrieron muchas cosas en la zona: por un lado, la violencia que se había incubado en la zona desapareció, llegaron los organismos de derechos humanos, las ONG ambientalistas, y el Estado comenzó a hacer una leve presencia. Todo lo anterior representó para los campesinos la retoma de los cultivos de café, pero desde una perspectiva de sostenibilidad ambiental. El fin de la violencia creó expectativa entre los campesinos sobre las inversiones en obras de infraestructura como colegios, vías y puestos de salud; eso en la zona de consolidación campesina no se ha reflejado totalmente. Lo que hizo el Estado fue copar los puestos de policías que fueron destruidos por la guerrilla en años anteriores y reforzar la presencia de las fuerzas militares con batallones de alta montaña. Este nuevo periodo de tranquilidad hizo que los habitantes de los tres corregimientos comenzaran a tener dinámicas de negociación con las instituciones del Estado. Por un lado, los campesinos han entrado en las políticas de conservación de la Sierra Nevada de Santa Marta y quieren resignificar el estigma que han llevado por años; esto lo están haciendo con las prácticas económicas que están realizando en sus fincas y el discurso con el que promueven la conservación de la Sierra Nevada de Santa Marta, a través de la conservación ambiental de los ríos, quebradas, bosques y fauna. Incluso los paramilitares, dentro de sus normas y reglas, les prohibían a los campesinos la caza, 
la pesca y la tala de árboles cerca de los ríos. No hacer eso contribuyó a salvar sus vidas y a que no fueran sometidos a castigos severos por parte del grupo paramilitar. 


\section{Vida campesina en La Guajira}

Mapa 2. La Guajira y sus municipios

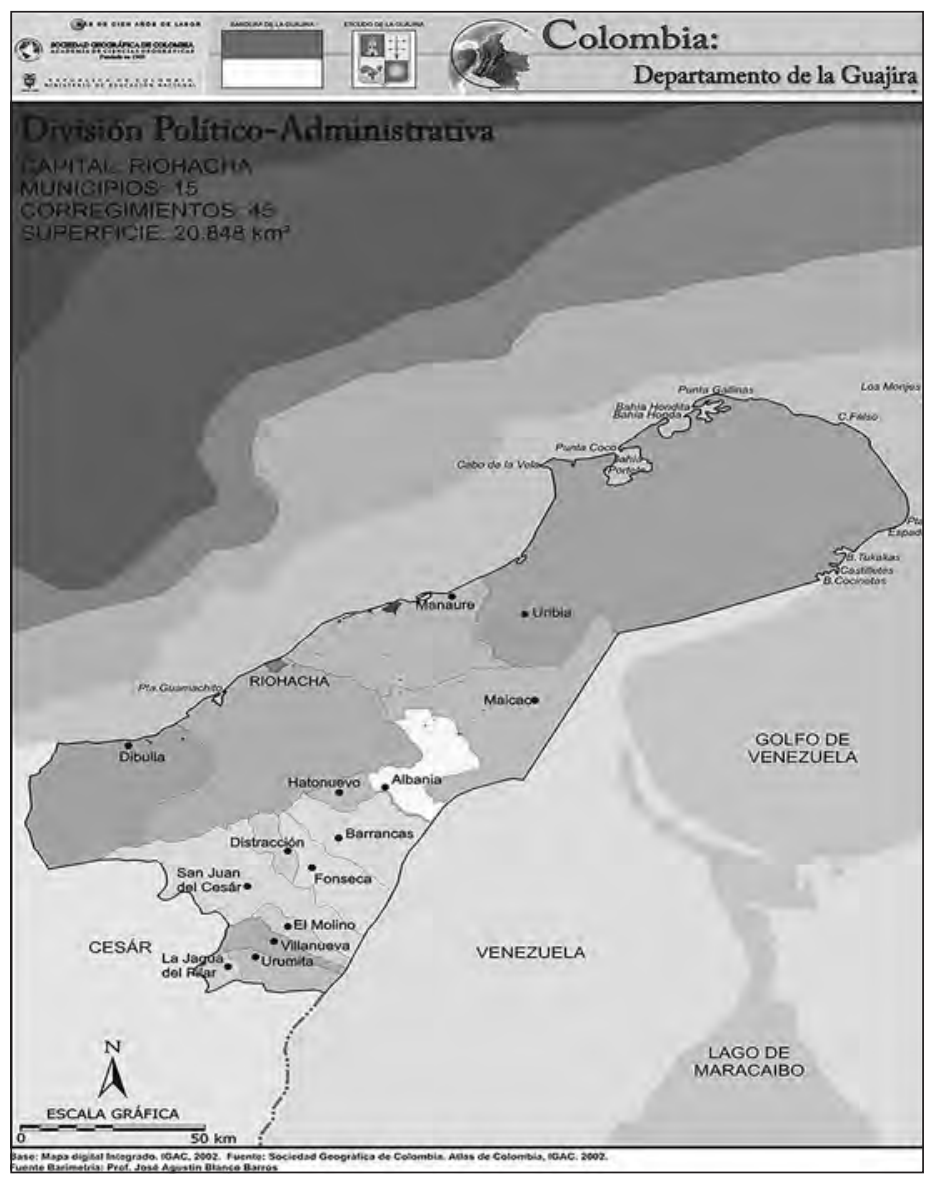

Fuente: IGAC (2002). 
El departamento de La Guajira se encuentra ubicado en el extremo nororiental del país, con una extensión aproximada de $20.848 \mathrm{~km}^{2}$. En él podemos encontrar paisajes que van desde desierto, pasando por bosques tropicales, hasta zonas montañosas como la Sierra Nevada de Santa Marta y la Serranía del Perijá. Es normal escuchar hablar al común de la gente de la "Alta, Media y Baja Guajira", reflejo de las relaciones entre las comunidades que habitan cada uno de estos territorios (CNMH, 2017).

La Alta Guajira es la parte que se encuentra al norte del departamento, en jurisdicción del municipio de Uribía, aunque vale la pena mencionar que se extiende hasta la hermana República Bolivariana de Venezuela. Su población está constituida, en su mayoría, por indígenas pertenecientes a la nación wayuu. La Media Guajira hace referencia a los territorios ubicados en las estribaciones de la Sierra Nevada de Santa Marta y a la zona de frontera con Venezuela. Su población está compuesta por indígenas de las comunidades wiwa, kogui, wayuu, comunidades afrodescendientes y campesinos. Finalmente, encontramos la Baja Guajira, ubicada al sur del departamento, en el valle conformado por la Sierra Nevada de Santa Marta y la Serranía del Perijá. Su población, al igual que en la Media Guajira, está compuesta por indígenas wayuu y wiwas, comunidades afrodescendientes y poblaciones campesinas que llegaron de otras regiones huyendo del conflicto y buscando mejores opciones de vida.

Según el Centro Nacional para la Memoria Histórica (2017), “en los municipios de Dibulla y Riohacha durante la década de los cincuenta existió la OCC (Organización Campesina de Colombia), quienes se organizaban principalmente alrededor de la producción y comercialización de café". Así mismo, el Sindicato de Agricultores de Urumita y las Organizaciones Campesinas de Maicao serían los primeros esfuerzos organizativos de las comunidades campesinas en el departamento de la Guajira. Así lo señala el CNMH (2017) al mencionar que desde la década de los sesenta existían organizaciones campesinas a lo largo y ancho del territorio guajiro, pero a finales de esa década estas asociaciones comienzan a identificarse con un proyecto organizativo común: ANUC.

Durante la década de los setenta la ANUC venía ganando gran reconocimiento en el departamento y el país; sin embargo, con la aparición de las guerrillas en algunos territorios del departamento las organizaciones campesinas empezaron a ser señaladas, lo que generó el asesinato de 
líderes campesinos, quienes eran acusados de colaborar con estos grupos armados. Según entrevistas realizadas por el CNMH (2017) a líderes campesinos del departamento, esto se produjo a raíz de la división interna de la ANUC en la línea Sincelejo y en la línea Armenia, dado que la línea Armenia era más que todo reformista y allegada al Gobierno mientras que la línea Sincelejo predicaba su independencia; esto generaba señalamientos desde el establecimiento, que no concebía la organización social por fuera de los partidos políticos tradicionales:

A partir del 82 el Estado catalogaba a la dirigencia campesina como de izquierda, más que todo aquí en el Caribe y aquellos que estaban de acuerdo con las políticas de Estado eran gobiernistas, entonces recuerdo que aquí se dio una división cuando Julio Cesar Turbay era presidente. ¿Y cómo se sintió aquí? Pues por la persecución a los líderes y el debilitamiento, el decaimiento de las organizaciones, como que se perdió el ánimo, muchos se alejaron (CNMH, 2017, p. 35).

Es así como en las décadas siguientes la violencia contra los campesinos del departamento de La Guajira, reunidos en la ANUC, se recrudeció, ya fuera por las guerrillas (FARC, EPL, ELN), por los paramilitares o por bandas delincuenciales herederas de la "bonanza marimbera". De esta forma podemos reseñar eventos como las masacres de La Punta de los Remedios y Mingueo, en el municipio de Dibulla; la masacre de Conejo, en el municipio de Fonseca; la masacre de Distracción, el 14 de diciembre del 2000; la masacre del barrio Cafetal, en el municipio de Villanueva; entre muchos otros hechos violentos que generaron una disminución en el accionar de las organizaciones campesinas del departamento de la Guajira debido al miedo generado por el accionar de los grupos violentos que veían en el campesinado un aliado fundamental para uno u otro grupo.

Posteriormente a la desmovilización paramilitar y con la firma, más recientemente, de los acuerdos de paz entre el Estado y las FARC, las organizaciones campesinas han reanudado sus esfuerzos por organizar a las poblaciones para "trabajar en la consecución de tierra, la facilitación de créditos e impulsos de programas de capacitación para el campesinado" (CNMH, 2017, p. 41); sin embargo, esto no significa que la violencia hacia sus líderes haya desaparecido. De igual forma, deben afrontar la poca 
credibilidad que las poblaciones tienen hacia el Estado, que privilegia los intereses de otros actores en el territorio por encima de las comunidades que lo habitan ancestralmente.

\section{Nostalgia de la bonanza: campesinos del valle de Tomarrazón}

El corregimiento de Tomarrazón pertenece al distrito de Riohacha y se encuentra ubicado en la zona suroriental. Está al pie de las faldas de la Sierra Nevada de Santa Marta, en una zona de complejo acceso y cercada por varios ríos y arroyos que hacen del paisaje de esta región uno de los más verdes del departamento de La Guajira.

Para llegar a Tomarrazón se toma la vía que conduce de Riohacha al sur del departamento; posteriormente, hay un desvío hacia la derecha en dirección a la Sierra Nevada. Al cabo de unos 15 minutos en una angosta vía se llega a esta centenaria población. Por su cercanía a los ríos, por estar en un fértil valle y, evidentemente, por depender de las estaciones de lluvia de la Sierra, en esta zona se da mucho la actividad agrícola.

\section{Imagen 9. Valle de Tomarrazón}

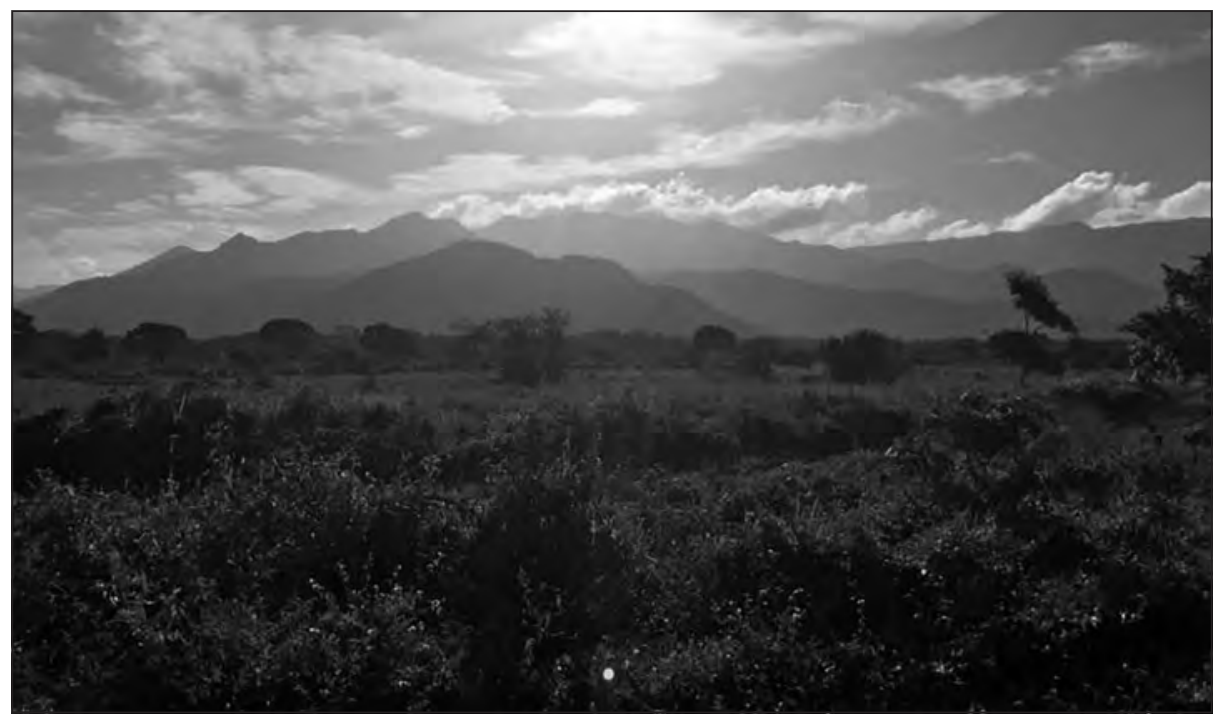

Fuente: Archivo Oraloteca (2017). 


\section{Poblamiento}

Por su ubicación geográfica y condiciones ambientales, el corregimiento de Tomarrazón ha sido un lugar de encuentro de múltiples culturas indígenas en el que se han dado procesos de emancipación afrodescendiente y diversos momentos de colonización. Sin embargo, podemos decir que en la actualidad la mayoría de su población se autorreconoce como afrodescendiente:

Bueno, Tomarrazón, en los años de 1940, todavía era una etnia de indígenas. Todavía hay en partes que se consiguen tinajas y todo eso de la cuestión indígena. Después de indígena, pasó a afrodescendiente, que es en lo que vivimos hoy en día. El corregimiento de Tomarrazón, como todos sabemos, como todo pueblo de Colombia y uno más del Caribe, aquí este pueblo está conformado y constituido por colonos que vienen inclusive de otros países, por ejemplo, aquí llegaron personas de origen africano en su mayoría, de origen español, de origen italiano, un sinnúmero de países vinieron a colonizar aquí desde la época del descubrimiento y quedaron un sinnúmero de familias aquí plantadas, entonces este es uno de los pueblos que dependemos de esas familias (W. Toro, comunicación personal, diciembre del 2016).

Imagen 10. Calle principal de Tomarrazón

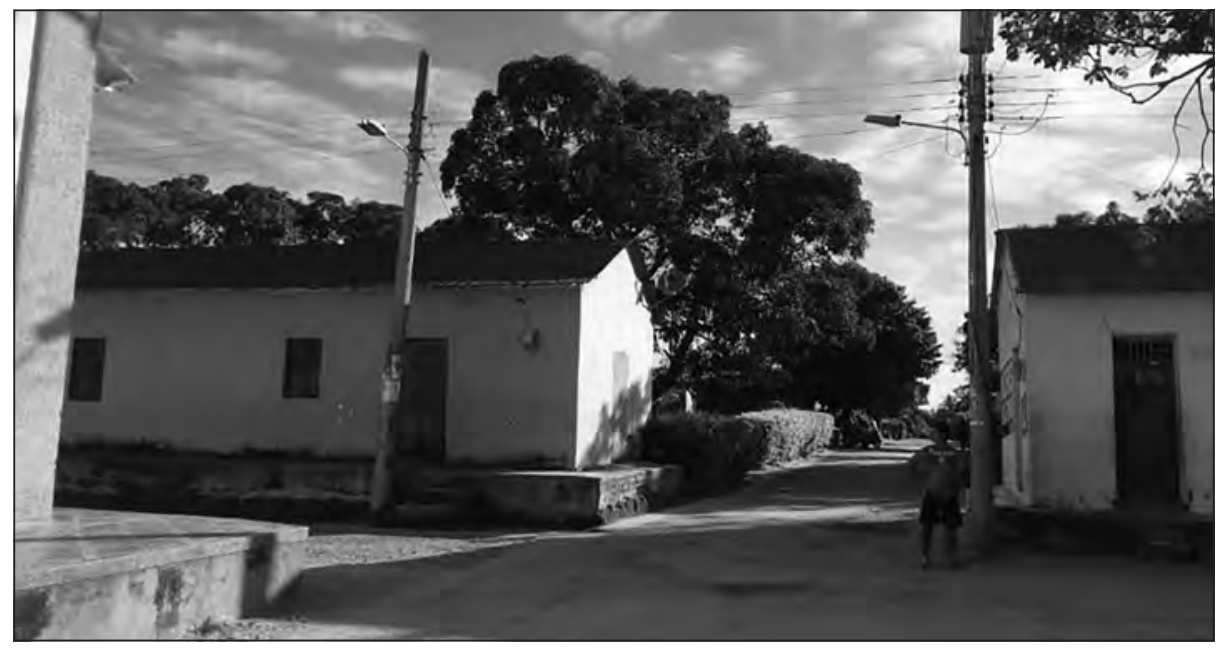

Fuente: Archivo Oraloteca (2017). 
Vida campesina en el Magdalena Grande

Walter Toro es un líder y miembro de varias organizaciones agropecuarias desde las cuales vela por los intereses de los miembros de su comunidad, lo que le ha representado un profundo respeto y apoyo por parte de las veredas que componen el corregimiento de Tomarrazón. Sobre los orígenes del pueblo, nos cuenta que el nombre de Tomarrazón

era de que cuando la cuestión del almirante Padilla, es lo que dice la leyenda, de que todos los telegramas que llegaban, llegaban era ahí hasta Tomarrazón. Y pues Tomarrazón es de la época de la guerra de Simón Bolívar, mejor dicho, que Tomarrazón es uno de los pueblos más antiguos del departamento de La Guajira. Todo esto era una casta indígena, por todas estas tierras usted coba y encuentra tinajas, en todas estas tierras por aquí encuentras tinajas, encuentras pilones, porque yo los he encontrado, de barro, horneados. Eso es lo que tengo que decir de Tomarrazón. Y pues del poquito de conocimiento que tengo es que Tomarrazón se llama "30 Tomarrazón". Dicen los viejos antepasados de que a Tomarrazón le pusieron así porque eran 30 viviendas. Y en esas 30 viviendas era donde llegaban todas las comunicaciones del almirante Padilla, cuando era la época de la conquista del almirante Padilla, acá en la Guajira, entonces ahí era donde llegaban todas las comunicaciones, ahí era donde hacían todas las agremiaciones y por eso fue que le pusieron Tomarrazón (W. Toro, comunicación personal, diciembre del 2016).

\section{Bonanza, agricultura y minería}

En términos de producción económica, la población del corregimiento de Tomarrazón mantiene una profunda vocación agrícola, aun frente a las dificultades que esta actividad representa en un Gobierno más preocupado por dinamizar y garantizar la permanencia de la minería en su territorio que por la seguridad alimentaria de la población del departamento. En el desarrollo de la entrevista al señor Walter Toro podemos resaltar tres momentos que dan cuenta de las dinámicas económicas de la población en este territorio. Por un lado, se relatan momentos de la bonanza marimbera, ajena a su voluntad e introducida en su territorio sin consultarles previamente; por otro lado, se percibe la ineludible nostalgia por los tiempos de antaño y la abundante producción agrícola, los cuales se ponen en 
Vida campesina en el Magdalena Grande

contraste con la situación actual del campesinado en este corregimiento; finalmente, se relata el panorama actual del campesinado de Tomarrazón en relación con la producción minera del departamento de la Guajira.

\section{La bonanza}

Durante los años setenta y ochenta, como está contado por la historia oficial del país, surgieron como bonanza en toda Colombia los cultivos de marihuana y coca. El negocio del narcotráfico buscaba zonas donde las propiedades para el cultivo fueran adecuadas y donde las condiciones de acceso y visibilidad no fueran tan fáciles, características que se podían encontrar en regiones cercanas al mar. Por esta razón, la Sierra Nevada de Santa Marta fue uno de los lugares favoritos para el cultivo y la producción por quienes estaban involucrados en este negocio. Teniendo en cuenta, además, que la zona de Tomarrazón - es decir, el piedemonte de la Sierra del lado del departamento de La Guajira- era la zona que mejor cumplía con los criterios de preferencia para este negocio:

Bueno, esta zona por aquí antes más que todo era de café, cacao, aguacate, la malanga, la yuca; después llegó, cuando el mandato de López Michelsen (que vino con la vagancia que trajo la semilla de la yerba maldita) la marihuana. Aquí Tomarrazón fue un punto muy crítico cuando eso: ponían a las personas de por allá abajo a trabajar, a cultivar la yerba maldita porque así le digo yo, sembraban esa cantidad de marihuana, buscaban más que todo a la gente de por allá de Bolívar, Córdoba, para trabajar; si se ponían pesaos los mataban. Entonces aquí se conformó una cadena de unas bandas que hacían retén y todo el que venía bajando de cargar marihuana tenía que dar tanto y si no te mataban y te quitaban la marihuana. López Michelsen fue el que llegó aquí a La Guajira y dio el aval para que el pueblo guajiro sembrara la marihuana. Eso fue público, él fue el que dio la ordenanza de la marihuana. Él dijo que la cultivaran, que a él no le interesaba si los gringos se morían a punta de marihuana o no, pero que se la llevaran. Mejor dicho, que él no lo hizo como un doble sentido, él lo hizo como un propósito para que el pueblo surgiera o saliera adelante porque los gringos venían a comprarla (W. Toro, comunicación personal, diciembre del 2016). 
Vida campesina en el Magdalena Grande

\section{La agricultura}

En la narración del señor Toro viven esos tiempos de abundancia gracias a la agricultura; sin embargo, deja ver también el malestar generado por el estado actual del campesinado en el departamento de la Guajira y el abandono al que se ven sometidos por parte de todas las instituciones, estatales o no estatales:

han sido pueblos que, por su ubicación en las estribaciones de la cordillera, buscaron lo más fresco y, en principio, vivían es del campo; lastimosamente que hasta ahora no ha habido un pleno desarrollo en esa actividad, siendo que fue una de las primeras actividades en que se basó la alimentación de toda la población. Sin embargo, usted está viendo que casi no hay apoyo: el Estado tiene muchos pueblos de Colombia, este es uno más, en el abandono, aquí es poco el apoyo que ha habido, [a] uno aquí como campesino le toca duro. La parte pecuaria es la que más ayuda a las personas. Yo vine aquí en primera instancia con la idea de que la parte pecuaria tiene mucho impacto negativo en el ecosistema. Yo tenía la idea de sembrar y hacer parcelas; sin embargo, tuve que desistir de eso porque sembrando, primo, sembrando me estaba consumiendo. Yo practiqué el cultivo se puede decir hasta hace tres años atrás. Entonces empecé, no quería, pero me tocó llegar a echar animales, empasté y, en el primer año, yo me hice tres millones sin echar un machetazo. Yo dije: ¿Qué estoy haciendo yo? ¿Me voy a consumir ahí a pulso sin apoyo? Y tengo tres millones en efectivo. Entonces cambié la actividad por fuerza, por subsistencia, y así me imagino que es la misma historia de muchos campesinos también, eso es una realidad (E. Deluque, comunicación personal, diciembre del 2016). 
Vida campesina en el Magdalena Grande

Imagen 11. Cultivos de maíz en Tomarrazón

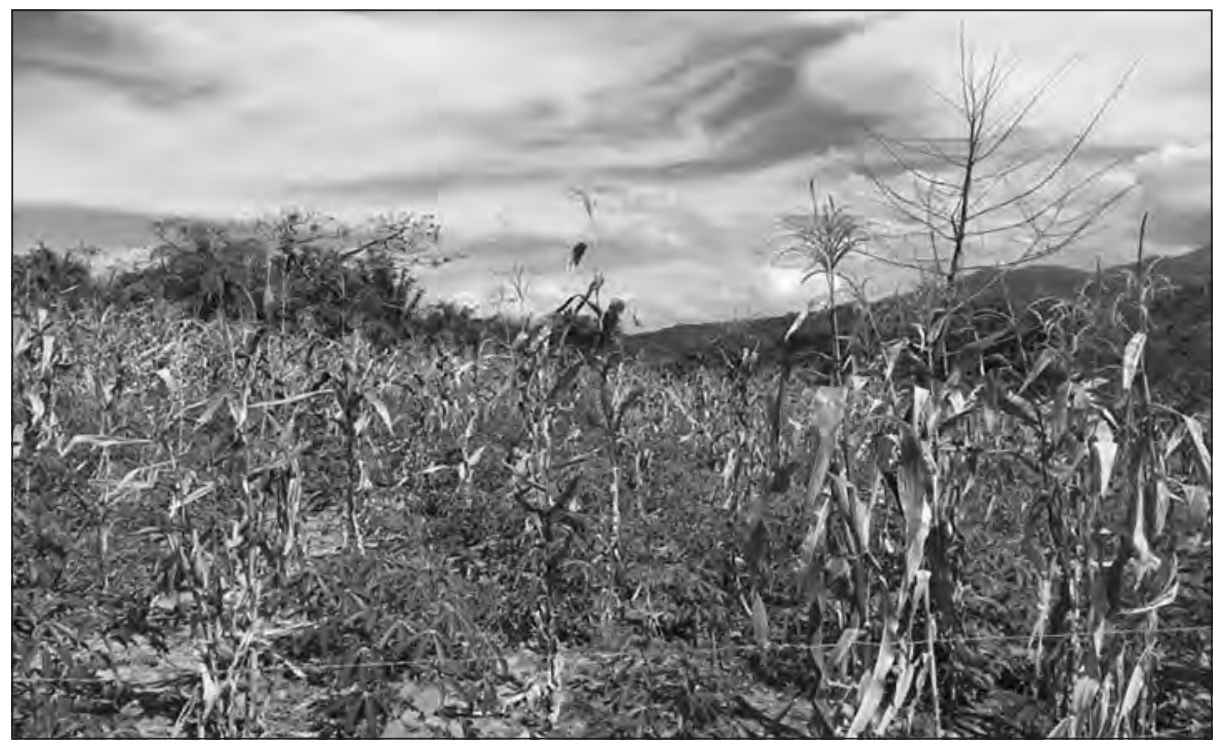

Fuente: Archivo Oraloteca (2017).

Así mismo, el señor Walter Toro nos cuenta sobre las principales problemáticas que hacen que los campesinos dejen de cultivar y prefieran dedicarse a otras actividades desligándose, en muchos casos, de su relación con la tierra. De esta forma, nos aproxima a la realidad del campesinado, identificando dificultades y obstáculos que se le presentan al campesino en cada una de las fases de producción.

\section{La tierra:}

Primero que todo y como en muchas otras comunidades campesinas de la región y el país, el acceso a la tierra se convierte en la principal dificultad para el desarrollo de una economía agrícola estable. El no poder demostrar los derechos de propiedad sobre un predio limita el acceso a créditos, programas o apoyos del Gobierno hacia la población campesina y, así mismo, el no sentirse dueños de la tierra que trabajan genera desmotivación en las poblaciones que se ven obligadas a sembrar con la incertidumbre de no saber si lograrán cosechar antes de que les toque entregar la tierra, si la producción final de la cosecha será lo suficiente para 
Vida campesina en el Magdalena Grande

pagar el arriendo del predio o, peor aún, si el dueño del predio lo venderá para otra actividad y les tocará salir a buscar tierra en otra parte. En estas condiciones de inseguridad social y económica vive el campesinado de Tomarrazón y nos atrevemos a decir que todo el campesinado sin tierra:

Bueno, de los cultivos por acá ahora mismo, que está cultivando la gente con su sudor sin la ayuda de nadie sino de su fuerza propia, hay unos que están cultivando el tomate, el ají, pero pedacitos, y la mayor parte no son propietarios, sino que piden a los que tienen la tierra que les den un pedacito o una hectárea para trabajar; entonces le[s] dicen: "ah, bueno, trabaja aquí, pero la mayor parte no son propietarios de tierra, sino que trabajan en tierra ajena (entrevista a campesino de Tomarrazón. Archivo Oraloteca).

\section{Siembra y mantenimiento}

El señor Deluque recuerda cómo anteriormente la tierra se sembraba por cantidades y no había problemas de propiedad ni nada por el estilo; sin embargo, hoy en día, aun teniendo la tierra, es imposible asistirla toda porque no existen los recursos ni el apoyo. En estos momentos el campesinado de Tomarrazón está asistiendo los cultivos de manera artesanal ante la falta de capacitación y apoyo para la tecnificación de la producción agrícola en el corregimiento:

Anteriormente, el que menos sembraba, el más pobre hace en 10 años hacia [a] trás, como mi difunto padre, mi difunto padre sembraba hasta 15 hectáreas de maíz, 5 hectáreas de yuca, y hoy nadie alcanza [a] hacer eso porque los recursos no dan, porque unas hectáreas de monte hoy en día están cobrando 500 mil pesos para hacerla[s]. Los cultivos se están manejando como de los años anteriores: artesanales. Se manejan artesanales porque no hay ninguna clase de maquinaria para el campesino. Sea la tierra mecanizable o no mecanizable, el campesino todavía hace el trabajo artesanal. Hoy en día lo que siembran es media hectárea, una hectárea porque el sustento no les da para sembrar más. Como no tenemos técnica de riego, de mejoramiento de suelo, no tenemos nada, aquí dependemos como de una especie de suerte. Entonces, cuando uno va a vender todo el mundo tiene el mismo producto y aquí dependemos del 
Vida campesina en el Magdalena Grande

pequeño mercado como el de Riohacha y el de Maicao y, además, vienen otros productos de partes tecnificadas como Venezuela, Valledupar, y queda el producto de nosotros por el suelo, esa es la gran problemática (E. Deluque, comunicación personal, diciembre del 2016).

\section{Transporte y comercialización}

El conocido mal estado de las vías de acceso hacia las zonas rurales en todo el país incrementa los costos de producción y comercialización debido al alto costo de los fletes para subir los insumos de producción y para extraer la carga hacia los mercados locales. Hoy en día la población campesina está produciendo a pérdida debido a que el gasto realizado en una parcela de tierra no se refleja en el valor del producto cuando es puesto en los mercados. Sumado a esto, hoy en día se privilegian los productos traídos desde el extranjero a raíz de los tratados de libre comercio, lo que deja sin garantías de comercialización al pequeño campesino.

\section{Imagen 12. Vías de acceso en Tomarrazón}

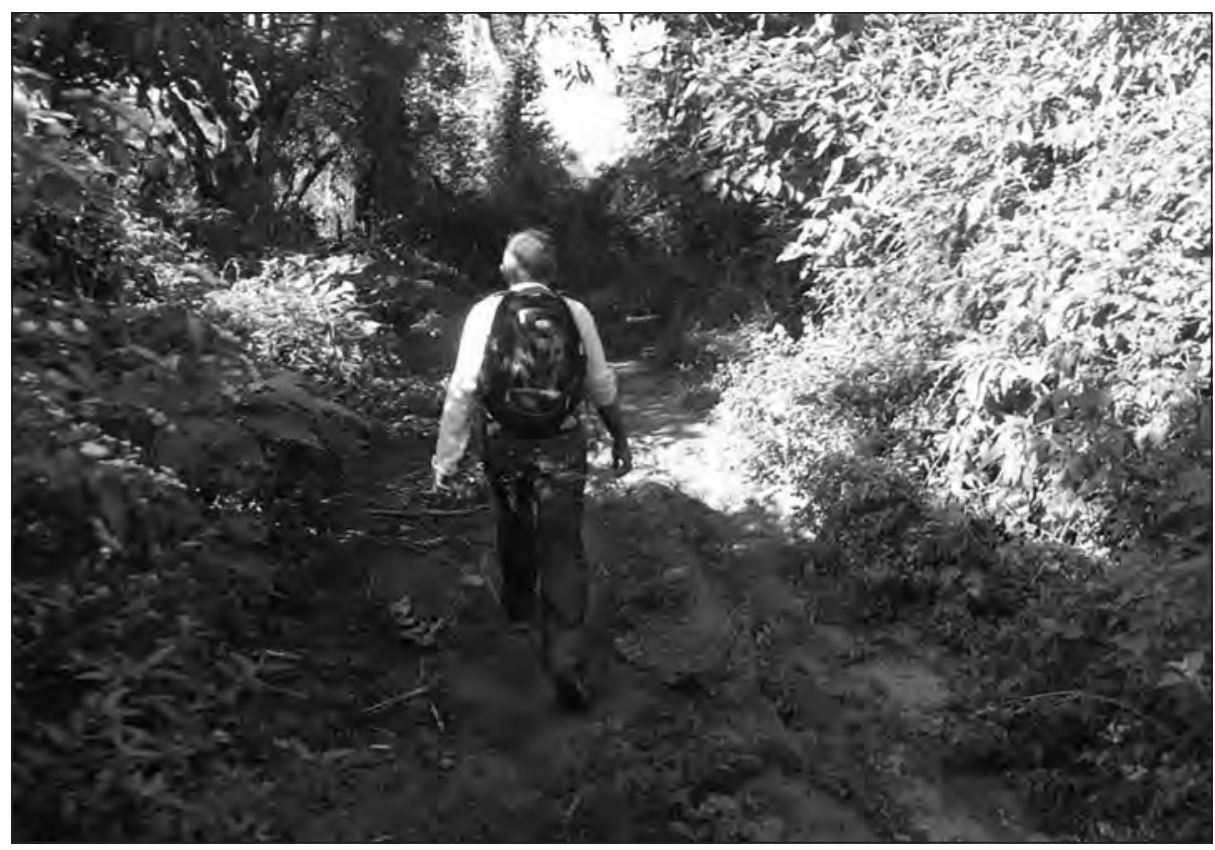

Fuente: Archivo Oraloteca (2017). 
Vida campesina en el Magdalena Grande

Una carga de un viaje - y el viaje son 2 bultos de yuca a 15 mil pesosson 300 mil pesos: 100 que le paguen al del carro y 100 que le pagan al arrancador, ya son 200 mil pesos; al campesino le quedan 100 mil pesos. Por ese motivo no hacen nada y, a causa de eso, el agro se ha acabado aquí en el departamento; eso es más la necesidad. Entonces, cuando llegan a Riohacha a vender el poquito que recogen, los acaparadores, que es el mercado negro, lo quieren comprar a 15 o 20 mil pesos, de ahí no le pasan. Ellos lo están vendiendo a 80 o 100 mil pesos, entonces esa es la idea que vengo peleando yo con los gobiernos departamentales y municipales, peleando un mercado seguro para el agro campesino de Tomarrazón y de toda la región, para que ellos tengan un sustento mayor y una rentabilidad mejor. Parece que el cultivo aquí se ha acabado con la cuestión del mercado negro, el campesino no gana na'. Y, de remate de eso, un carro de Tomarrazón de aquí pa' allá un bulto de yuca está cobrando al campesino [a] 15 mil pesos y, si ellos lo venden aquí a 10 les está[n] quedando 10 mil pesos, y allá a cada arrancador por bulto les pagan a 5 mil. Entonces, al campesino lo que le está quedando son 5 mil por cada bultico (W. Toro, comunicación personal, diciembre del 2016).

\section{La mina}

Sumado a las problemáticas ya expuestas, la llegada de la minería de carbón al departamento de La Guajira ha afectado el ecosistema en general y el corregimiento de Tomarrazón no ha sido la excepción. El polvillo del carbón, el secado de las fuentes de agua, el calentamiento global, son entre otros los factores que profundizan la crisis del campesino. Con evidente impotencia reflejada en sus ojos, nos cuenta el señor Toro que lo más preocupante es que mucha población sigue viendo la Mina como una fuente de progreso y desarrollo para el departamento, sin importar todo el daño que le hace al ecosistema:

Con esa explotación minera hay un sinnúmero de personas también que, a pesar del impacto ambiental y [de] salud que hay, la gente tiende es a buscar el billete. [A] la gente de aquí no le interesa. Hay muchos colegios, por ejemplo, que han perdido el objetivo en el perfil académico que tienen. Este colegio es netamente agropecuario; sin embargo, por la 
Vida campesina en el Magdalena Grande

realidad de la vida [de] los estudiantes ellos se levantan es con la idea de irse para el sector industrial, sin importar la enfermedad a raíz de la intoxicación que hay del carbón, pero la gente busca allá... y la prueba está porque yo terminé de estudiar en el 99 y me vine en el 2001 y a mí me ha tocado duro en el campo. En cambio, una persona que trabaja en la mina en dos o tres años ya tiene casa, carro, no se sabe cómo anda de salud, pero la gente se perfila es para allá, esa es una de las problemáticas que hay aquí en el pueblo de Tomarrazón. De igual forma, aquí en el departamento de La Guajira hasta un vendedor de yuca ambulante tiene que pagar impuesto, mientras que [en] la mina no paga impuesto; a lo contrario, la Nación tiene que pagarle a la mina, ellos son los que le pagan. Lo que la mina le quita al Estado, los colombianos lo pagamos, eso yo no le veo ninguna producción (E. Deluque, comunicación personal, diciembre del 2016).

Imagen 13. Campesinos de Tomarrazón

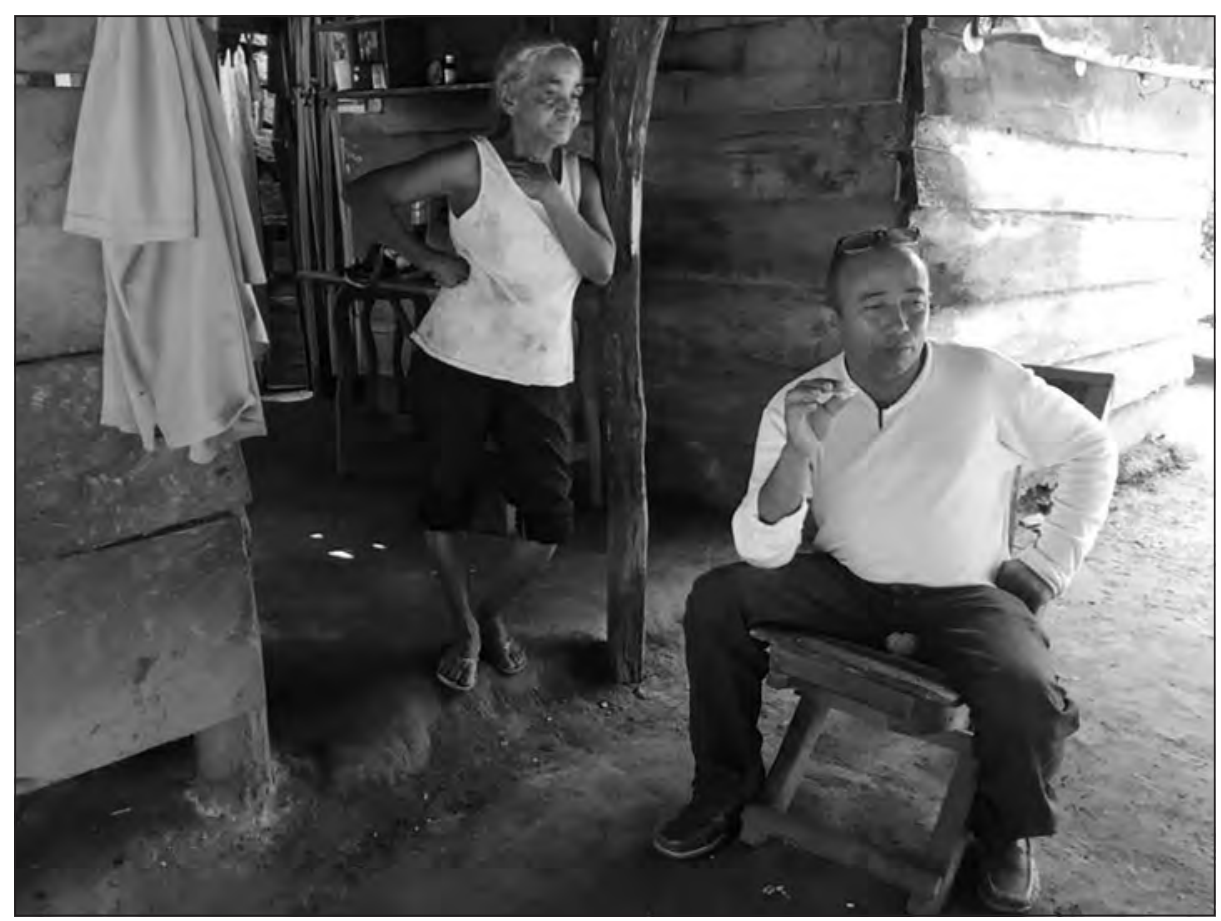

Fuente: Archivo Oraloteca (2017). 
Vida campesina en el Magdalena Grande

\section{Organización campesina en el valle de Tomarrazón}

Por razones de seguridad, la estancia en Tomarrazón suele ser corta, pero en lo poco que se puede conversar en la zona el conflicto armado es un elemento que aparece en las conversaciones que se puedan tener con habitantes de esta región. La violencia guerrillera se acentuó mucho en esta zona y, posteriormente, la paramilitar, pues era un corredor que unía con bastante agilidad la Sierra Nevada de Santa Marta con la Serranía del Perijá y, por supuesto, con todos los negocios ilícitos que se pueden manejar en las fronteras no resguardadas. Además, la mina del Cerrejón no se encuentra tan lejos, siendo sus ferrovías objetivo militar permanente durante mucho tiempo por parte de las FARC-EP:

En Tomarrazon ahora mismo la agricultura no se está produciendo porque la mayoría de la población fue desplazada y, como lo estoy explicando, no eran dueños de tierra, entonces quedaron en el aire, no tienen. Todos los de esta región fueron desplazados por las autodefensas, pero todos no han declarado, ellos aparecen como vulnerables, pero, en sí, sí son desplazados porque toda esta zona fue desplazada por la violencia. Esto fue terrible por aquí, más que todo para acá por la vía de Cascajalito, Juan y Medio, para allá fue terrible, para allá una vez hubo un ataque de las FARC con las AUC donde mataron 120 de la AUC el mismo día. Eso fue un desplazamiento que fue para las Casitas, Naime (W. Toro, comunicación personal, diciembre del 2016).

Sin embargo, a pesar de las complejas tensiones que se viven en una comunidad como Tomarrazón, el campesino de la zona intenta superar las fricciones resultado del conflicto y mantener una serie de tradiciones y de naturaleza organizativa que fueron silenciadas durante mucho tiempo. Este corregimiento termina siendo un retrato vivo de la añoranza de tiempos mejores que el conflicto, las realidades económicas y la corrupción le negaron al campesino guajiro. 
Vida campesina en el Magdalena Grande

Imagen 14. Paisaje rural en Tomarrazón

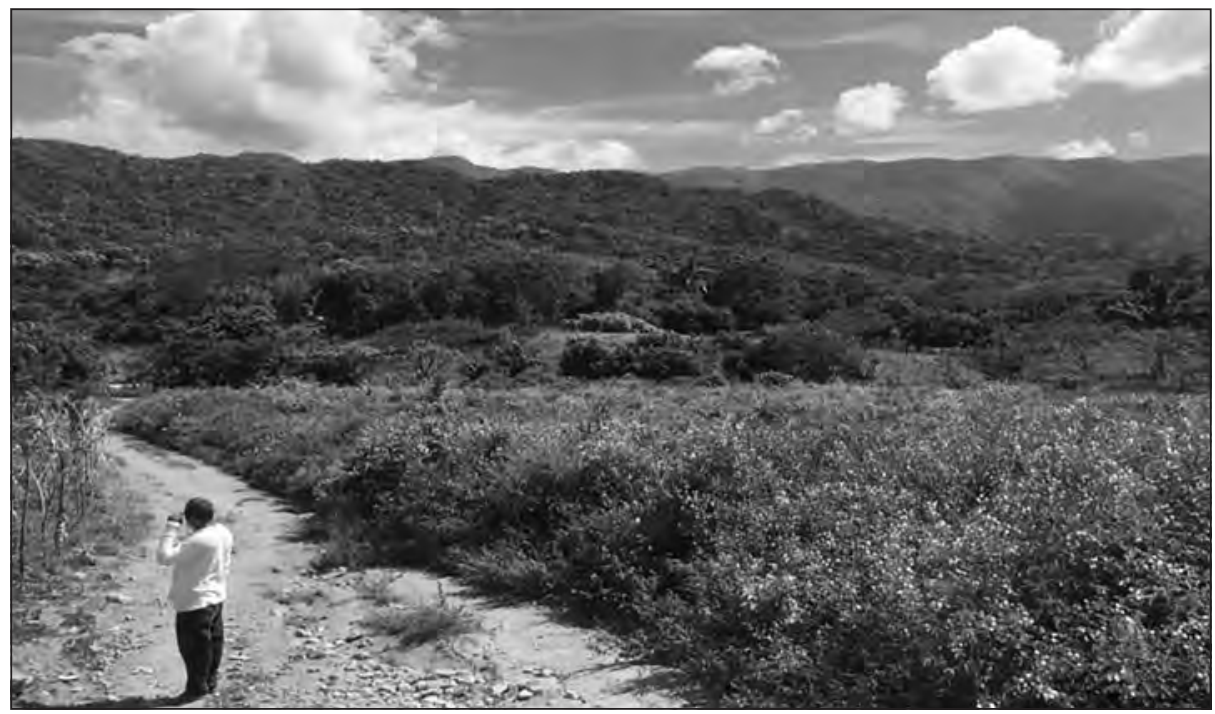

Fuente: Archivo Oraloteca (2017).

En los años 90, aquí en esta Sierra de San Pablo había muchas producciones. Cuando llegó el mandato de Gaviria las producciones aquí se fueron mermando y todo fue decayendo. Los campesinos por aquí nunca han tenido ningún beneficio del Estado. Aquí el campesino siempre se ha sostenido con sus propias fuerzas. Han venido hablando de tantos proyectos... Ahora mismo el alcalde, que es este Fabio Velásquez, comenzó con unas huertas caseras (casas mallas), está por 12.7 millones de pesos cada casa malla y vayan a ver ustedes esas casas mallas para que vean cómo están. Pues hoy en día esos campesinos aparecen en el sistema como que el gobierno municipal ya les dio un subsidio para que salgan adelante y están diciendo que los campesinos son los que no sirven y los que no sirven son ellos porque se quedaron con la plata, porque no le han dado un peso al campesino y los campesinos aparecen como si hubieran recibido la plata, los pusieron a firmar unos documentos, pero vaya y mire para que vea usted que nunca han sembrado una plantación. ¿Qué hicieron? Llegaron a donde los terratenientes, donde el difunto Vicente Borrego, llegaban a las tierras del difunto Alcides Cholo, que son familias que pasan de más de mil hectáreas de tierra en el corregimiento de Matitas y Tigreras... 
Vida campesina en el Magdalena Grande

Entonces, ¿qué hicieron con esos campesinos? Les arrendaban la tierra. Entonces llegaban los dueños de ese pedacito de tierra y a los campesinos se los estaban arrendando por millón quinientos. ¿A quién le quedaba la plata? Al contratista y al dueño de la tierra y el campesino jodido. Entonces ese campesino tenía que llegar a la Alcaldía con un contrato de arrendamiento firmado con los dueños de las tierras. Vayan y miren a la Alcaldía quiénes son los dueños de los contratos: Vicente Borrego, Moisés Enrique, la familia Chole y los Rodríguez. Donde ellos tienen inscritos más de 500 campesinos que están disfrutando del beneficio que les dio el municipio. Así mismo están en el municipio de Riohacha y en el municipio de Dibulla, están peor que aquí, porque al menos aquí no le están exigiendo a esa gente que firmaron los documentos que tienen que pagar. En Dibulla el señor alcalde, Bienvenido, tiene asustados a los campesinos a que tienen que pagar no sé cuánto para darles el subsidio (W. Toro, comunicación personal, diciembre del 2016).

El campesino de esta zona, en particular, tiene la característica de estar muy enterado de los programas y de las políticas del sector agropecuario que afectan directamente sus intereses. No es gratuito que ASOCASAGUA, que es hoy en día la asociación de campesinos más grande del departamento de La Guajira y con miras a organizarse en otros departamentos vecinos como Magdalena y Cesar, haya nacido precisamente en la vereda San Pablo, del corregimiento de Tomarrazón, territorio con tradición organizativa en el departamento:

Las organizaciones campesinas que han habido en la zona, ahora mismo está lo que es puro afro, afro y como del año 80 para acá se ha venido implementando la cuestión de desplazado, hay unas organizaciones de desplazados. La organización de la que yo represento, que es ASOCASAGUA, es la Asociación de Campesinos de La Guajira. Aquí contamos con todas las etnias del departamento: con afro, con campesinos, personas desplazadas e indígenas. Esa asociación nace de aquí de esta región, pero le vamos a cambiar la sigla. Ya no va a ser Asociación de Campesinos de San Pablo y San Pedro, ahora va a ser Asociación de Campesinos de La Guajira, y estamos viendo cómo nos vamos a extender al Cesar y el Magdalena, entonces le vamos a poner ASOACOSTA (Asociación de Campesinos de 
la Costa) porque ya tenemos unos campesinos afiliados aquí dentro de la asociación, pero hacen parte del Magdalena. En el Cesar, por la vía del Copey y Caracolicito, y por acá por la vía de San Alberto, lejos (W. Toro, comunicación personal, febrero del 2017).

Imagen 15. Campesinos de la vereda San Pablo, Tomarrazón

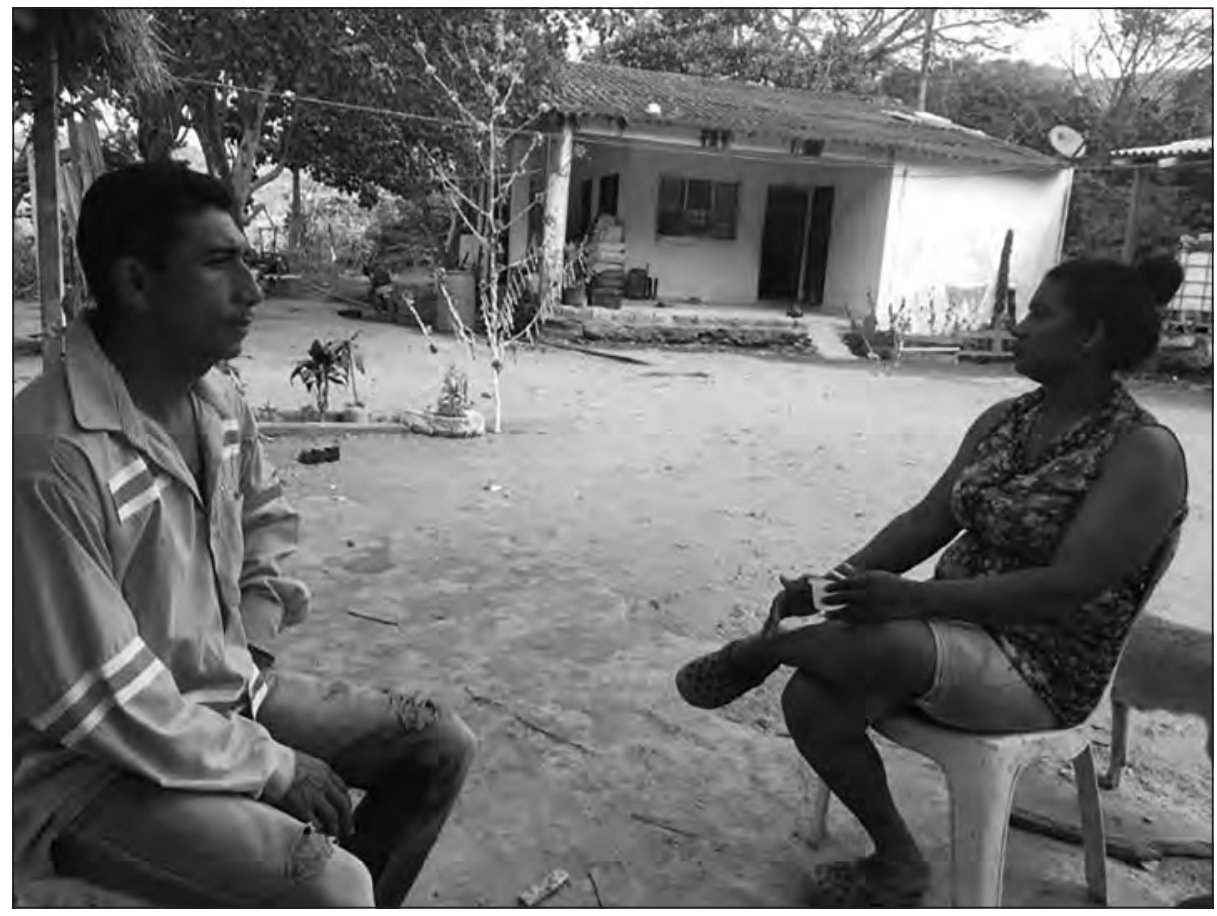

Fuente: Archivo Oraloteca (2017).

Las veredas del corregimiento de Tomarrazón tienen, en relación a muchas comunidades de la Guajira, un avance significativo en lo que concierne a los procesos para la legalización de predios para los campesinos. Esta situación se debe, en buena medida, a la cohesión del movimiento social de la zona y, por supuesto, a su capacidad de agencia, discusión y debate con el Estado. Las negociaciones de esta comunidad y su interlocución para definir estos asuntos de tierra - y también sobre tecnificación - han llevado a que los líderes del área se sienten a debatir directamente con altos funcionarios del Gobierno Nacional: 
Vida campesina en el Magdalena Grande

Yo soy el representante legal de la asociación de campesinos del departamento de la Guajira, ASOCASAGUA. Me conozco pie por punta cómo es la situación de los campesinos en el departamento de la Guajira: [a] la mayoría de los campesinos del departamento de la Guajira los despojaron de sus tierras, la mayoría trabajaba en tierras de dueños de fincas, los dejaban hacer una hectárea o dos hectáreas (W. Toro, comunicación personal, diciembre del 2016).

Los campesinos de Tomarrazón, a través de los procesos que han adelantado, dan una muestra clara de que, en últimas, las exigencias centrales de esta comunidad y, por supuesto, de la agenda de ampliación de ASOCASAGUA, tienen como discusión principal la tecnificación de la tierra, el mejoramiento de la infraestructura, las garantías de comercialización y legalización de predios. Por ejemplo, la desaparición de los intermediarios lograría, según sus denuncias, generar vínculos directos con las grandes cadenas de comercio y las centrales de abasto sin que el producto sea devaluado. Entonces, se puede afirmar que ASOCASAGUA, más allá de un discurso reivindicativo o reformista, exige el avance tecnológico y económico de los campesinos de La Guajira, a la vez que lucha por su reconocimiento como sujeto político de derechos y condiciones de vida digna para ellos y sus familias.

Imagen 16. Reunión Campesina en Tomarrazón

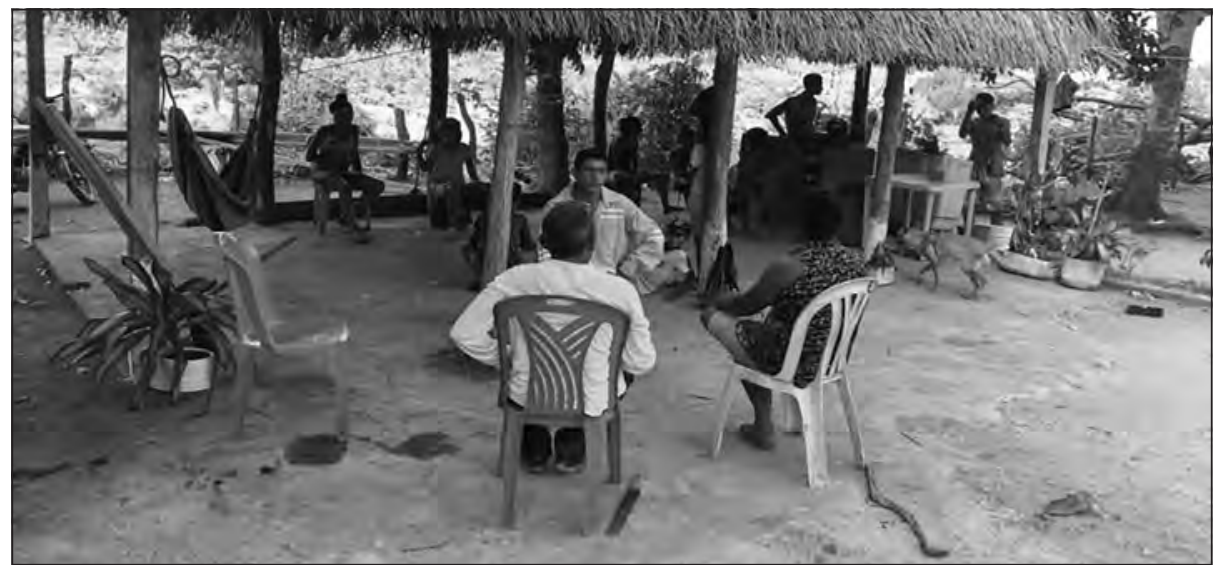

Fuente: Archivo Oraloteca (2017). 
Vida campesina en el Magdalena Grande

Hay una de las cosas que yo les vengo diciendo a los campesinos que están dentro de la organización: ustedes no piensen de que el Gobierno les da para que ustedes salgan adelante; hoy en día el Gobierno colombiano le da al campesino pobre para que sea más pobre, porque es que él llega y te dice: "ya yo te di 100 pesos, ya no tienes derecho a más nada", ya a ti se te cierran las puertas porque no tienes conocimiento de, en realidad, cuáles son los deberes y los derechos que tú tienes. En todos estos proyectos que estoy haciendo no estoy agarrado con ningún político de acá del departamento ni de otra parte, sino luchando con los mismos campesinos para, más tarde, no tener tropiezos y que no vayan a decir que "tú tienes que hacer esto porque yo te ayudé en esto", sino que nosotros mismos actuamos en nuestra propia defensa y le aplico al Gobierno las mismas leyes que él tiene. El Gobierno le lava el cerebro al pueblo colombiano diciendo que esto es del Estado. ¡No! Es que el Estado somos nosotros. Un presidente, ¿qué es? Un miserable líder, como lo soy yo, y un líder para hacer cualquier cosa tiene que pedirle la opinión al pueblo. El presidente aquí no lo hace. El presidente aquí dice: "se va o se va", por sobre la cabeza de quien sea que ahí eso nadie lo quita. Nosotros lo ponemos ahí es para que administre nuestros bienes, porque si en nuestro país hay oro es de nosotros, de todos los colombianos; si en nuestro país hay carbón es de nosotros, todos los colombianos; el gas es de todos los colombianos, no es del Estado, es de nosotros porque el Estado somos nosotros y nosotros somos los que conformamos el Estado (W. Toro, comunicación personal, diciembre del 2016).

Es la unidad del campesino del Valle de Tomarrazón la que ha generado que los procesos para adelantar la parcelación y formalización estén avanzando. Aunque es claro que este trámite generará muchos conflictos, pues la mayoría de tierras de esta zona es propiedad de influyentes personas de la política y economía de la ciudad de Riohacha. Hoy en día la agenda política de esta comunidad hace resistencia a las proyecciones de actividades de mega minería en el piedemonte donde nacen los ríos que surten de agua todo el valle de Tomarrazón. 
Vida campesina en el Magdalena Grande

\section{Elementos culturales de la vida campesina en Tomarrazón}

Finalizando su relato, el señor Walter Toro nos comenta cómo, a pesar de todas las dificultades y los trastornos generados por el conflicto armado -el cual dejó secuelas en el tejido comunitario-, la gente siempre busca las formas de restablecer ese tejido, lo que se logra principalmente a través de los espacios culturales de integración, resaltando la educación como principal herramienta de desarrollo económico, social y cultural del corregimiento de Tomarrazón:

Aquí la gente de todas maneras trata de pasarla bien. Hay ciertos eventos culturales: el 15 de diciembre fueron las fiestas patronales ahí en el pueblo, el 15 de mayo hay otra y la gente siempre trata de sacarle lo mejor a la vida pues, de todas maneras, hay muchas cosas positivas también. Tenemos ese sabor costeño de todo ese cruce de razas, también las fiestas patronales esas que te dije, aquí habían unos muchachos también que tenían ciertos grupos vallenatos, ahora hasta el mismo colegio ha perdido eso porque eso era para que lo siguiera él. Yo pienso que el colegio, no me canso de nombrarlo, es un pilar fundamental en el trascender siempre de la cultura y transmitirla, lo que es tecnología y cultura, todo, depende [de] una buena institución. Tenemos una muy buena planta física, pero yo pienso que ellos tienen que redireccionar muchas cosas, hay muchas cosas que hay que recuperar (E. Deluque, comunicación personal, diciembre del 2016).

\section{Tensiones en la frontera: campesinos de Carraipía}

El corregimiento de Carraipía está ubicado al suroriente del municipio de Maicao, en el departamento de La Guajira. Esta población colinda con el vecino país de Venezuela. Se encuentra en las faldas de los Montes de Oca, que son las últimas montañas del sistema de la Serranía del Perijá en Colombia. Por el lado noroccidental lo cruza la carretera que conecta al municipio de Maicao con el de Albania y, desde el otro lado de la vía, el inicio de las sabanas aluviales y semidesérticas del departamento.

El municipio de Maicao ha sido históricamente un centro de intercambio comercial con el vecino país de Venezuela, cuyo abasto de alimentos se hacía gracias a los corregimientos que quedaban en la zona de 
Montes de Oca, donde la calidad de las tierras, las condiciones ambientales, los distintos pisos térmicos, la abundancia de agua y su beneficiosa ubicación geográfica hacían de estos una de las promisorias despensas agrícolas del Caribe colombiano. Sin embargo, al referirse a Montes de Oca, al revisitar la historia del campesino y la agricultura de esta subregión y, por supuesto, al reconstruir los relatos sobre intercambio comercial en la frontera, es ineludible que la mayoría de personas de Maicao y sus alrededores recuerdan la importancia de la tradición campesina que ha tenido el corregimiento de Carraipía.

A Carraipía se llega por el municipio de Maicao: en su vía de salida hacia el Sur de la Guajira se toma un carro de una cooperativa de transportadores que va cada 15 minutos a este corregimiento, pues es uno de los lugares ideales para tomar a un precio más económico el transporte ilegal hacia Venezuela (vía por trochas hechas por contrabandistas, desde Carraipía hasta Majayura donde queda la frontera binacional). El trayecto Maicao-Carraipía tiene una duración de unos 30 minutos. Cabe anotar que esta carretera es sumamente peligrosa: los índices de atracos son bastante altos y la presencia de grupos armados es preponderante. Así mismo, asumir cualquier tipo de acción investigativa en la zona genera algunas desconfianzas y constantes preguntas.

Imagen 17. Calle de Carraipía adornada

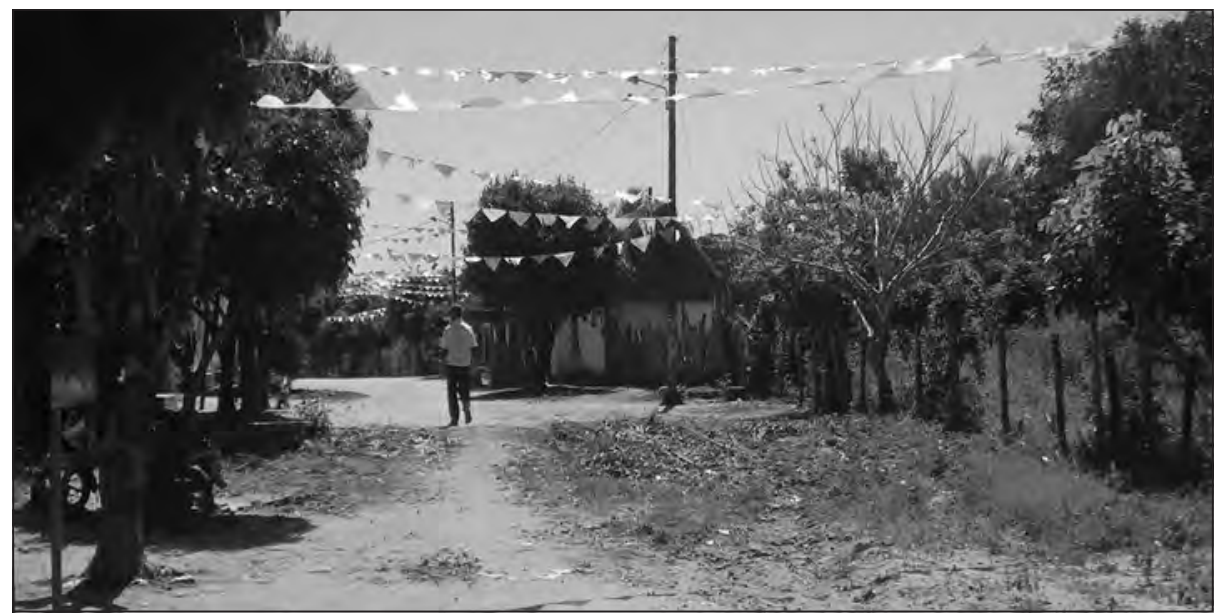

Fuente: Archivo Oraloteca (2017). 
Vida campesina en el Magdalena Grande

\section{Poblamiento}

Carraipía, cuyo telón de fondo está adornado con las alturas de los Montes de Oca, es un corregimiento de bastante actividad comercial y tránsito constante de personas. Tiene una sola calle pavimentada que, al adentrarse en la zona rural, se convierte en un carreteable utilizado por los contrabandistas y viajeros sin documentos. Los camiones de gasolina salen y entran de la llamada "avenida principal". Los canastos azules de cervezas venezolanas hacen parte del paisaje de casi todas las casas del lugar, indígenas wayuu también son parte de la población mayoritaria y, sobre todo, una inexistente presencia de la fuerza pública del Estado.

Imagen 18. Dirigentes campesinos de Carraipía

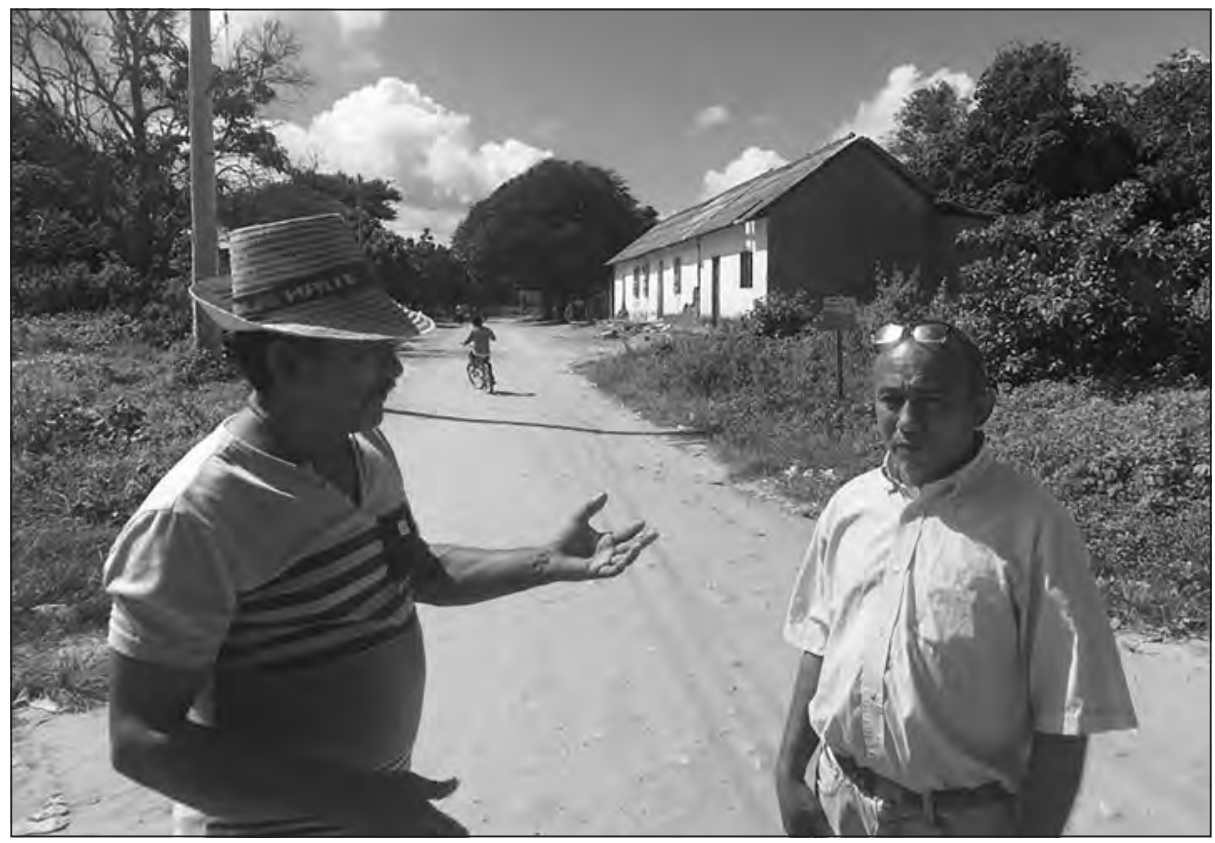

Fuente: Archivo Oraloteca (2017).

En la calle o "avenida principal” vive el señor Juan Álvaro Blanco Solano, un dirigente campesino reconocido en toda la subregión de Montes de Oca y excorregidor de Carraipía. El señor Blanco recuerda algunos elementos de cómo era el pueblo: 
Vida campesina en el Magdalena Grande

Yo nací en Carraipía en los años 53, tengo 63 años. Aquí, según cuentan nuestros antecesores, en el año 48 más o menos comenzó la bonanza aquí en Carraipía, cuando comenzaron a colonizar la tierra, más que todo en la sierra de Carraipía, con el negocio de la madera, el roble, el cedro, la caoba. Yo recuerdo que mi papá, el difunto Víctor Blanco Solano, comenzó a sembrar el maíz a medida que iban aserrando, derrumbando... las mejoras de tierra las civilizaban, sembraban el maíz y arriaban en mula. En aquel entonces los trabajos los hacían a machete y hacha porque eran los medios que existían en ese entonces, los años 50 por ahí.

Aquí hubo un señor apellido Guillén que, en esa época, llegó a sembrar bastante cantidad de caña, y sacaba una miel y la traía para vender, la traían en bestia también, pero más que todo, principalmente, el cultivo era el maíz, la yuca y árboles frutales también, porque la tierra de la serranía de Carraipía sí se presta para muchas cosas. Aquí en el plano habitaba en ese tiempo mi abuelo, que tenía finca allá en la Sierra. Él era dueño de la finca esa y ahí sembraban yuca. En aquel entonces ya tenía auge la ganadería. Él llegó a tener en aquel entonces 400 reses porque él vino aquí en los años veinte (J. Blanco, comunicación personal, diciembre del 2016).

Históricamente, se entiende que Maicao es un pueblo de la comunidad wayuu que se formó gracias al constante intercambio comercial, la cercanía con los puertos de contrabando en el mar de Castilletes y en la Alta Guajira que, entre los años treinta y la década de los cincuenta, tuvo una gran influencia de inmigrantes árabes con intereses comerciales. Sin embargo, Carraipía - relata el señor Blanco Solano-, por su vocación agrícola y por sus buenas vías de acceso a Venezuela a principios del siglo XX, sería la población que generó la bonanza misma de Maicao, siendo incluso el corregimiento más viejo en la práctica de la economía de contrabando:

Hay varias versiones de que Carraipía fue primero que Maicao. Carraipía es más viejo que Maicao. Entonces, entre los años 1912 a 1926, en ese lapso, está la fundación de Carraipía. La primera comisión para controlar el contrabando que mandaron de Bogotá llegó fue acá a Carraipía; entonces, en la plaza se instalaron, pero no demoraron. Cuando comenzaron a 
Vida campesina en el Magdalena Grande

llegar los árabes con el comercio entonces ya el movimiento del contrabando estaba allá. Entonces, toda esa gente que mandaron para acá, toda esa gente enseguida la trasladaron para allá porque era donde estaba el movimiento; eso fue en los años entre 1912 al 26 por ahí, está en ese trayecto (J. Blanco, comunicación personal, diciembre del 2016).

\section{Agricultura y contrabando}

Carraipía es una comunidad cuya población se desenvuelve entre dos dinámicas económicas: la agricultura y el contrabando. Aunque según los relatos la comunidad siempre ha tenido la vocación agrícola como su principal fuente de subsistencia, la ubicación geográfica, la llegada de los comerciantes y el abandono estatal han hecho de este territorio una de las rutas predilectas para los contrabandistas que, durante décadas, se han dedicado a mover productos desde Colombia hacia Venezuela o viceversa, según las variables políticas y económicas de cada momento.

\section{La agricultura}

Como nos venía contando el señor Blanco, desde la llegada de sus abuelos a estas tierras a inicios del siglo pasado la principal fuente de subsistencia de los pobladores de Carraipía era la agricultura y la cría de animales, siendo el principal punto de comercio la población de Maicao, hacia donde siempre han sacado sus productos o, como sucede recientemente, desde donde han venido a comprar sus productos. Esto demuestra que el sector agropecuario sigue siendo uno de los referentes económicos para la población, aunque actualmente viene siendo desplazado por el comercio; en especial, el comercio ilegal: el contrabando.

En la parte de abajo, lo que es "el plano", como lo llama uno, que es del pegue de la Sierra hacia acá, siembran el fríjol, lo que es la yuca, el maíz, y otros cultivos de pancoger. [De] la siembra, más que todo, se encargaban eran los hombres. En la Sierra sí se encargaban algunas mujeres; por ejemplo, se dedicaban a criar gallinas. Vea, yo recuerdo que mi mamá alcanzó a tener hasta 200 pavos, 100 cerdos que los criaban con los desechos de la cosecha, se alimentaban de la siembra (porque se sembraba 
Vida campesina en el Magdalena Grande

guineo, plátano, el "cuatro filo" ese que le llaman). Acá hubo un tiempo, creo que por los años setenta, donde muchas mujeres vivían en la orilla de la que venía el acueducto; le tenían sus tomas y ellas con el agua del acueducto hacían su siembra de hortalizas y eso lo llevaban para Maicao. Ahí trabajaban mujeres y hombres también, en la siembra de hortalizas que le llaman pancoger, sembraban que el pepino, el ají "pataecabra", el cilantro de castilla, col, rábano y una escobilla blanca que consumen mucho los turcos de Maicao.

Esos productos se llevan generalmente a Maicao. De pronto ahora, como se ha intensificado un poco más la siembra porque ya la gente siembra en más escala, entonces ya tienen contacto con el mercado y vienen y les compran el producto. De Maicao a veces vienen a cargar aquí: lo que es el maíz, las mulas vienen y pesan, se consiguen clientes mayoristas pues. Pero los que siembran a pequeña escala que sus cinco hectáreas, que sus dos hectáreas, ese maíz por lo general lo venden en Maicao, lo mismo que la yuca también la venden en Maicao.

Algunos vivían era de la pesca, por ejemplo, los indígenas por aquí vivían era de la pesca, de la pesca del río: sacaban el bocachico, el mocholo, el barbú, la bujeta, eso era su modus vivendi. Ellos iban los fines de semana, pescaban, traían la ensarta, diez, veinte, vendían en las tiendas y compraban su café, su azúcar para su mazamorra y de eso dependían más que todo los indígenas (J. Blanco, comunicación personal, diciembre del 2016).

De esta forma, el señor Blanco nos cuenta que la agricultura y la cría de animales fueron las principales actividades económicas de la población desde su nacimiento y así mismo deja ver las redes de intercambio entre las personas que llegaron a colonizar estas tierras y las poblaciones que ya transitaban en ellas cuando llegaron; a saber, los indígenas wayuu.

Actualmente, la agricultura viene en decadencia por la ya mencionada actividad del comercio ilegal, pero también porque aquellas personas que aún se mantienen en la agricultura y se niegan a hacer parte de las actividades propias del contrabando no tienen garantías para desarrollar 
Vida campesina en el Magdalena Grande

sus actividades. Por ejemplo, el señor Blanco reseña dos de las principales problemáticas que afrontan aquellas personas que desean seguir cultivando la tierra. Por un lado, el difícil acceso al agua desde la construcción del acueducto de Maicao dificulta el desarrollo de los cultivos, por lo que en la mayoría de los casos dependen de las lluvias; y, por otro lado, la informalidad en la tenencia de la tierra no les permite acceder a créditos o proyectos productivos que les permitan mejorar las condiciones de producción:

Pasa una cosa: desde los años setenta, cuando construyeron el primer acueducto para Maicao, el río de Carraipía — de la parte donde hicieron la bocatoma para acá- comenzó a secarse y fue una de las causas de que la gente no sembraba. La construcción del acueducto afectó bastante porque, ajá, las aguas se fueron retirando acá del río y esa gente ya no vivía de la pesca. Había sistemas de siembre en la parte del acueducto, que tenían unas tomas y sembraban las hortalizas. Eran cultivos constantes, pero eso ya no se da tampoco porque usted sabe que la población va aumentando, entonces el agua también se va agotando y ya no es lo mismo de antes. Y muchos siembran es en tierra ajena. Algunos tienen en la Sierra, pero no está legalizado. Acá en el plano, que llama uno, no tienen tierra. De las estribaciones de la Sierra hacia acá le llaman "el plano", o sea las tierras bajas, [a] eso le llaman el plano. La mayoría de esa gente siembra es en tierra por comodato que le dan, que son de grandes propietarios. La berenjena también la comen los árabes. Entonces esos productos los sembraban con sistema de riego, pero las tomas se las hacían del acueducto. Cuando construyeron la otra toma del acueducto, la tubería nueva, toda esa tubería quedó marginada, la anularon, la gente dejó de sembrar y se salieron de los predios de sembrar porque a dónde iban a sembrar sí no tenían con qué regar porque habían suspendido el agua porque el agua ya iba directa para Maicao (J. Blanco, comunicación personal, diciembre de 2016). 
Imagen 19. Campo de fútbol y, al fondo, los Montes de Oca

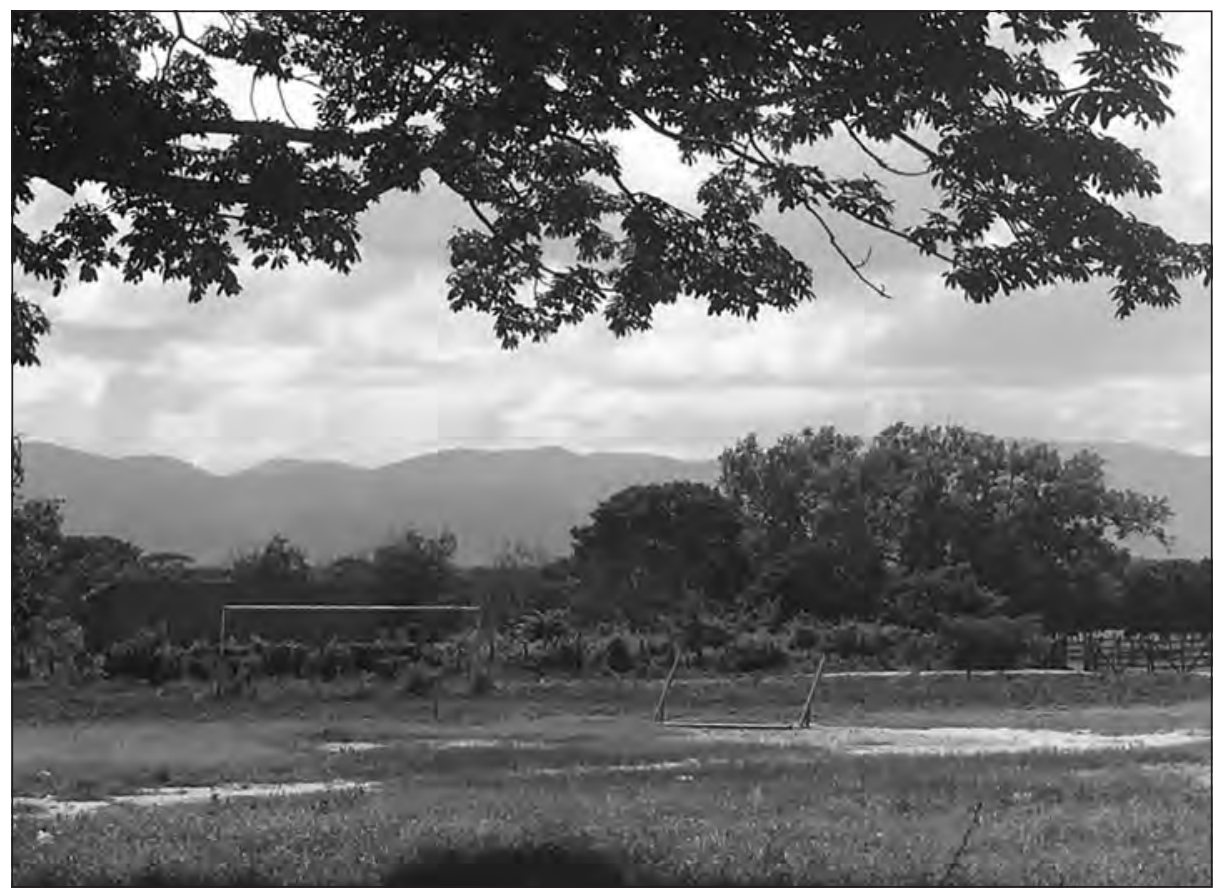

Fuente: Archivo Oraloteca (2017).

\section{El contrabando}

Otro punto importante es el tipo de intercambio comercial que se generaba, en el que el campesino era comerciante, contrabandista en algunos casos e, incluso, llegó a enviar productos a Venezuela. Los asuntos de seguridad se han ido tornando complejos, precisamente al moverse la bonanza comercial, donde a falta de tecnificación los campesinos se han convertido en su mayoría en comerciantes que dependen de la burbuja especulativa que es la economía de frontera. Los precios, las condiciones políticas, la situación de las trochas, entre otros elementos, han generado que se proliferen muchos asuntos de orden público en un lugar donde no hay mayor custodia de las Fuerzas Armadas de las dos naciones. Las tensiones entre campesinos e indígenas se tornan, en ocasiones, muy complejas; ejemplo de ello era la situación que vivía el señor Blanco a la hora de nuestra visita: 
Imagen 20. Calle principal de Carraipía

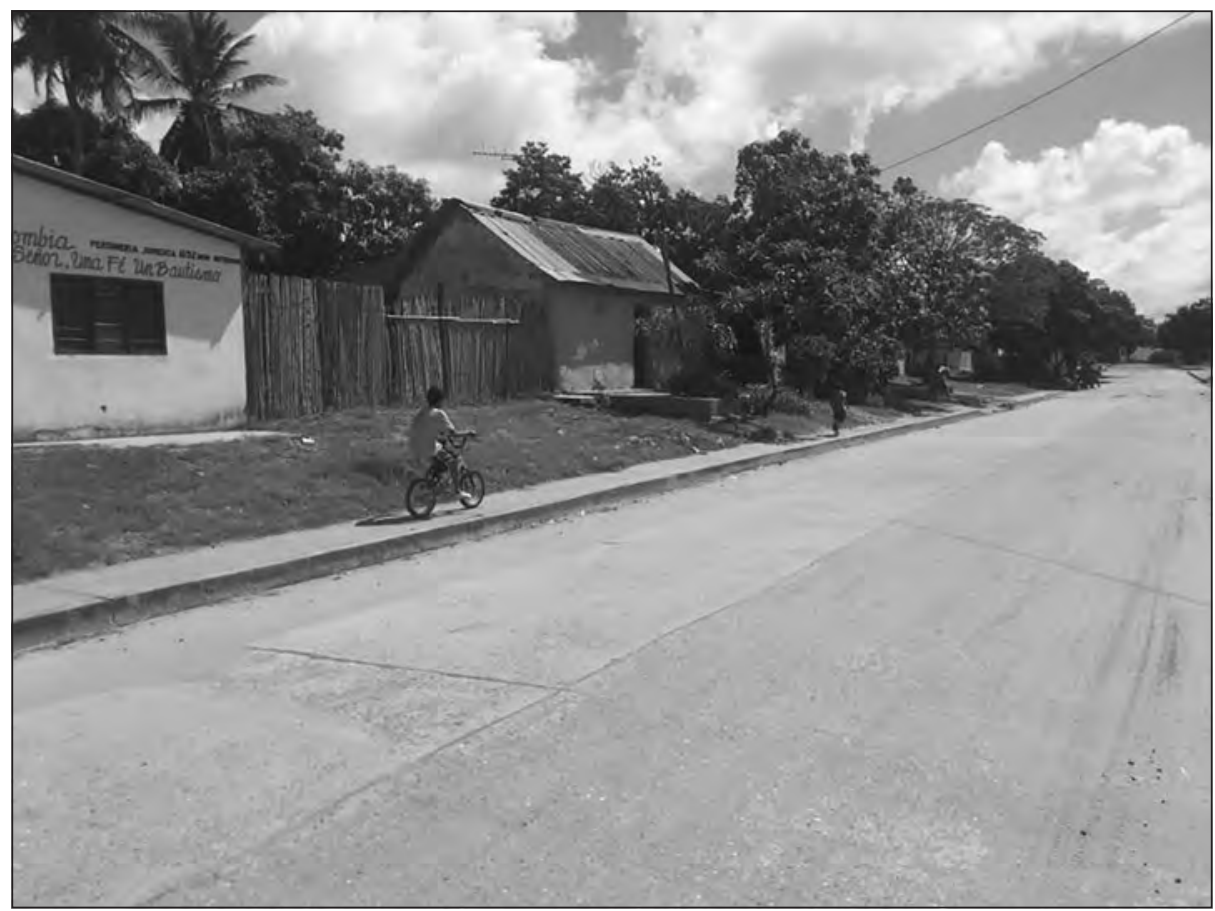

Fuente: Archivo Oraloteca (2017).

Ahorita, de grupos así armados al margen de la ley, aquí hay es problema de seguridad es con personal de por aquí mismo con la cuestión de los atracos; por ejemplo, al marido de ella, que es mi yerno, lo atracaron hace como 21 días. Iba a cargar gasolina y salieron unos chinitos y lo levantaron a tiros y lo mataron. Los chinitos son los indios (wayuu) de aquí. Aquí, a 3 kilómetros de aquí, para la vía de Montelada, por donde va el movimiento de la gasolina, pero de grupos al margen de la ley no, eso no hay. Es tranquilo. Aquí hay batallón ahorita, aquí a 300 metros hay batallón. El ejército tiene patrulla acá, tiene patrulla para acá, pero siempre hace falta que la policía entre a los establecimientos públicos así sea una vez a la semana, pero ya ellos viendo que llegan, que no sea el mismo día, por ejemplo, un viernes. Un sábado, un domingo que entren a un billar, a otro billar, que hagan requisa (J. Blanco, comunicación personal, diciembre de 2016). 
Imagen 21. Mujer trabajando con hacha

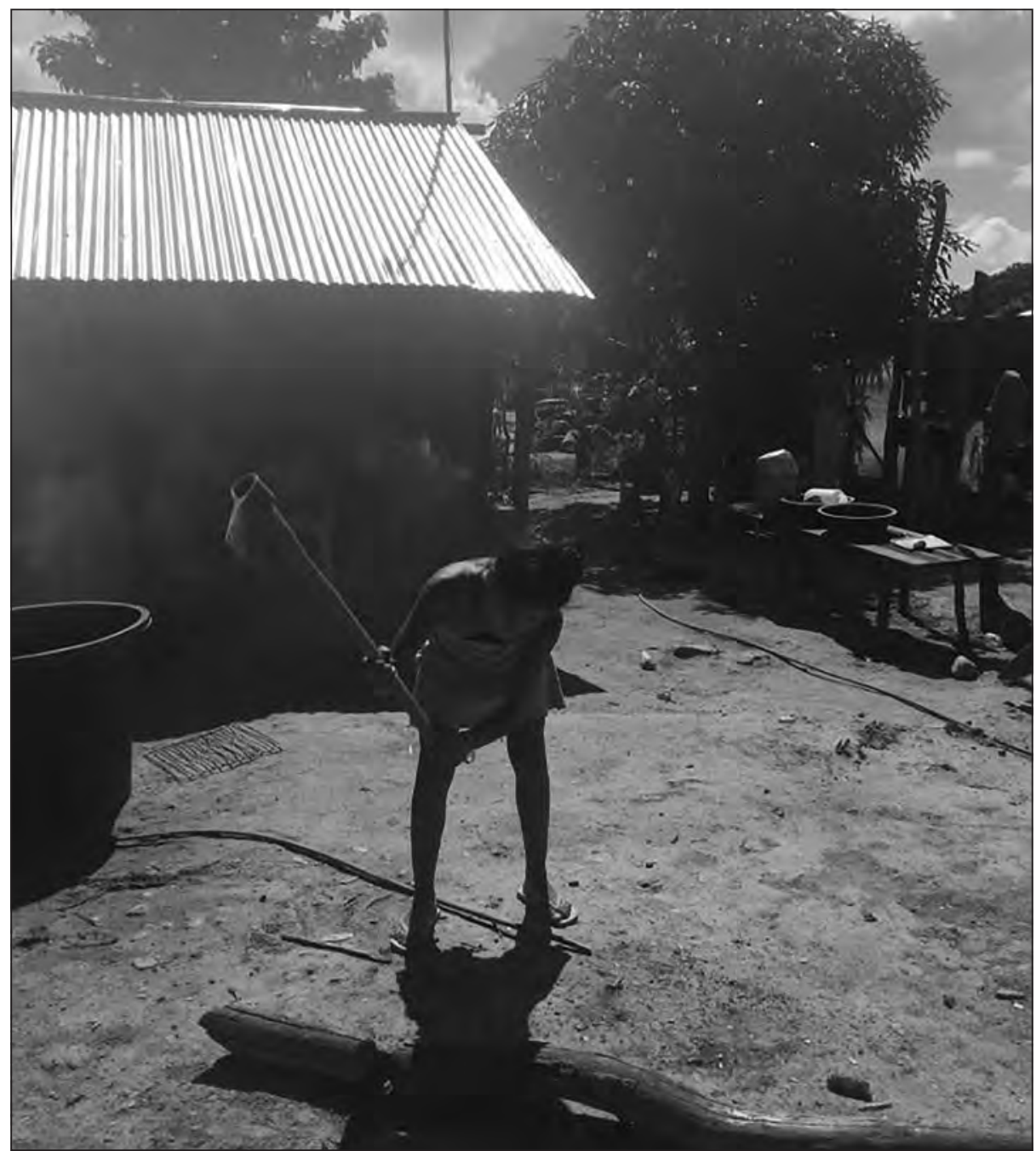

Fuente: Archivo Oraloteca (2017)

Las tensiones entre campesinos y los wayuu o "chinos", como les llaman popularmente en Carraipía a los miembros de esta comunidad, evidencian que los conflictos que se dan entre "arijunas" e indígenas se profundizan en cuanto a la necesidad de administrar u organizar el territorio y las dinámicas del mercado en el contrabando. Existe, en general, 
Vida campesina en el Magdalena Grande

una idea del campesino no indígena acerca de los "chinos", alrededor del hecho de estar, supuestamente, ligados a los atracos o a la negligencia al trabajo. Esta situación, por supuesto, ha sido una constante desde que las poblaciones de campesinos y comerciantes se empiezan a constituir en la Guajira, dado que las relaciones políticas en esta zona se enmarcan, en buena medida, en las reglas y la jurisprudencia relacionada con la autonomía indígena.

Otro tema importante que relata el señor Juan Álvaro Blanco Solano tiene que ver con el hecho de las relaciones comerciales con los campesinos y productores de Venezuela. En este asunto expresa que ha sido Colombia la que principalmente, durante décadas, había exportado productos para el mercado y la dieta alimenticia del vecino país. En este sentido, los intercambios económicos y la influencia de la dinámica indígena han contribuido a una disolución social de la frontera legal para convertirse en un límite integrador en medio de la crisis de estado en la zona:

No, para Venezuela no enviábamos nada. Venezuela más bien trae a vender a Maicao. Traen yuca, traen limón de Venezuela. De acá cerca de la frontera está Majayura, a 20 kilómetros, una vía que va por acá, no la Panamericana, esta es una vía que va a Majayura que utilizan los contrabandistas. Entonces, en ese sector, como por ahí siembran mucha agricultura, siembran el plátano, la yuca, las hortalizas, y muchos de ellos - y ahora con la situación de Venezuela con más razón- vienen a vender a Maicao porque es donde les da la base. Venden y compran en Maicao y llevan el producto ya invertido allá, como la harina. Como sabes que eso está escaso allá, pero siempre ha habido ese intercambio allá, pero ahora la baja del bolívar ellos son los que traen las cosas, antes era a lo contrario. Se vendía más que todo cuando el bolívar estaba alto; o sea, antes del infierno este que está ahora el comercio. Es que era a lo contrario: o sea, de aquí llevaban para allá, llevaban ganado, ganado que traían de los otros departamentos. Yo creo que aquí hubo una vez que Fedegan exportaba ganado, aquí había unos corrales y Fedegan los manejaba. No es que lo traigan en tanta abundancia, es más que todo los que siembran por esta zona porque los que siembran en gran escala, allá los llevan a supermercados allá a Maracaibo, al abasto. A su vez, compiten con los de Majayura, que es el pueblo que está en toda la frontera 
Vida campesina en el Magdalena Grande

en la trocha binacional del lado colombiano. Ese corregimiento surgió después de Maicao, es más nuevo. El pueblo surgió fue porque los dueños de finca, más que todo los González, que eran los que más tenían finca y haciendas, entonces toda esa gente que venían de abajo, por ejemplo, del Magdalena, del Cesar, los contrataban para limpiar potreros, para hacer loza fue que se fueron instalando ahí. Entonces la gente que se iba para Venezuela buscando mejores senderos se iban y una parte se fueron quedando ahí en Majayura. Por lo general, hay unos que no tienen tierra, creo que los proyectos, yo no sé si lo habrán aprobado (J. Blanco, comunicación personal, diciembre de 2016).

\section{Organización campesina en Carraipía}

El señor Juan Álvaro Blanco Solano reflexiona, para finalizar, sobre otro momento importante que convulsionó la población de Carraipía. Sucede cuando las luchas campesinas toman fuerza en el país. Como lo señalamos anteriormente, Carraipía fue una de las poblaciones referentes para los procesos de organización campesina en el departamento de La Guajira; sin embargo, nos explica el señor Blanco, no se manifestó al igual que en el resto del país, pues en este territorio no se dieron las grandes movilizaciones y los grandes avances se dieron en términos de fortalecimiento organizativo, tecnificación de producción, capacitación del campesinado y, en menor medida, el acceso a la tierra para algunos pobladores:

O sea que aquí no hubo un movimiento campesino, sino más bien organizativo, asociativo. Sí, cada quien tenía su carnet, hacían sus reuniones para meter proyectos para ver qué salía, pero nunca. Bueno, se vieron ahora después que parcelaron, pero ya con las cuestiones de los desplazados. Por ejemplo acá, donde Ángel Enrique, esas tierras sí las parcelaron, pero cuando hubo un desplazamiento que el Gobierno venezolano creó - que fue el de Hugo Chávez que sacó toda la gente campesina que vivía en la frontera del lado de ellos, de Molino, San José Oriente, hacia acá - toda esa zona la desplazaron para acá y todos los cultivos quedaron abandonados, le quedaron a ellos. Entonces de esa gente hubo un grupo que lo ubicaron como a 10 kilómetros de aquí, le compraron al señor 
Vida campesina en el Magdalena Grande

Enrique no sé cuántas hectáreas, creo que fue mil y pico, y las parcelaron por familia de 22 hectáreas, pero hacia atrás, que yo recuerde, aquí nunca se le ha dado tierra a los campesinos, que yo recuerde intentos sí, con proyectos, pero nunca les aprobaron nada así sobre proyecto de tierras. Acá venían, dictaban charlas, por ejemplo, que la junta de acción comunal, que la ANUC, pero así de beneficios, nada. Algo superficial (J. Blanco, comunicación personal, diciembre del 2016).

El asunto de la legalización de la tierra se convierte en una constante inquietud en el campesinado que existe en el departamento, sobre todo en el inicio de la zona más desértica de la península guajira; es decir, en los límites entre la Media y Alta Guajira. En esta zona los tímidos intentos de reforma rural no consiguieron hacer un mediano intento de parcelación y formalización de propietarios. Por el contrario, hoy existen familias de ganaderos y algunos cultivadores que provenían de otras regiones del país que, progresivamente, fueron vendiendo las tierras; otras, se quedaron en la región y acompañaban sus actividades productivas en relación con el circuito comercial y potencial para los negocios que fue la ciudad de Maicao hasta los años noventa.

Imagen 22. Casa del campesino en Carraipía

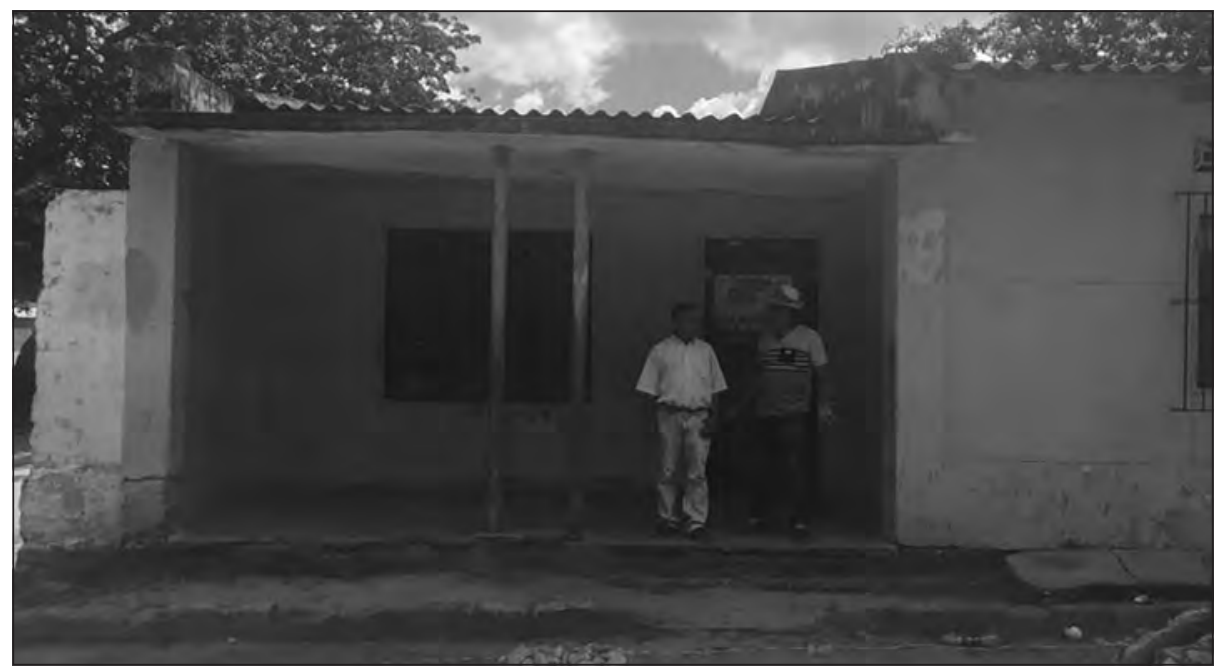

Fuente: Archivo Oraloteca (2017). 
Las únicas tierras que se han legalizado son las que corresponden a los Montes de Oca, que fueron declaradas reserva forestal de carácter departamental, lo que genera conflictos a propósito de la discusión sobre la conservación en una zona que vive prácticamente de la subsistencia y de la informalidad. Los campesinos que habitaban estas tierras tuvieron que dejar de sembrar y formalizar las tierras para venderlas:

Ahora es que están medio cultivando otra vez porque eso lo dejaron abandonado. La mayoría de las fincas esas se volvieron monte porque eso lo dejaron solo. Ahora, desde el año pasado hacia acá, es que la gente está volviendo a subir, los que dejaron su finca, y asistiendo, pero como el Gobierno la declaró zona forestal protegida, entonces ahora tienen que legalizarla para vendérsela, ahora dicen que no hay tiempo de legalizarlo los que no legalizaron porque esa etapa ya pasó, no sé cómo solucionan ellos porque hay muchos de los predios que no tienen documentación alguna del Gobierno y, sin embargo, la declararon zona forestal protegida, pero como ellos tienen que sobrevivir, van y tratan de sembrar $y$, aunque no la legalizaron para ellos, eso es de ellos (J. Blanco, comunicación personal, diciembre del 2016).

Imagen 23. Cultivo y maleza en Carraipía

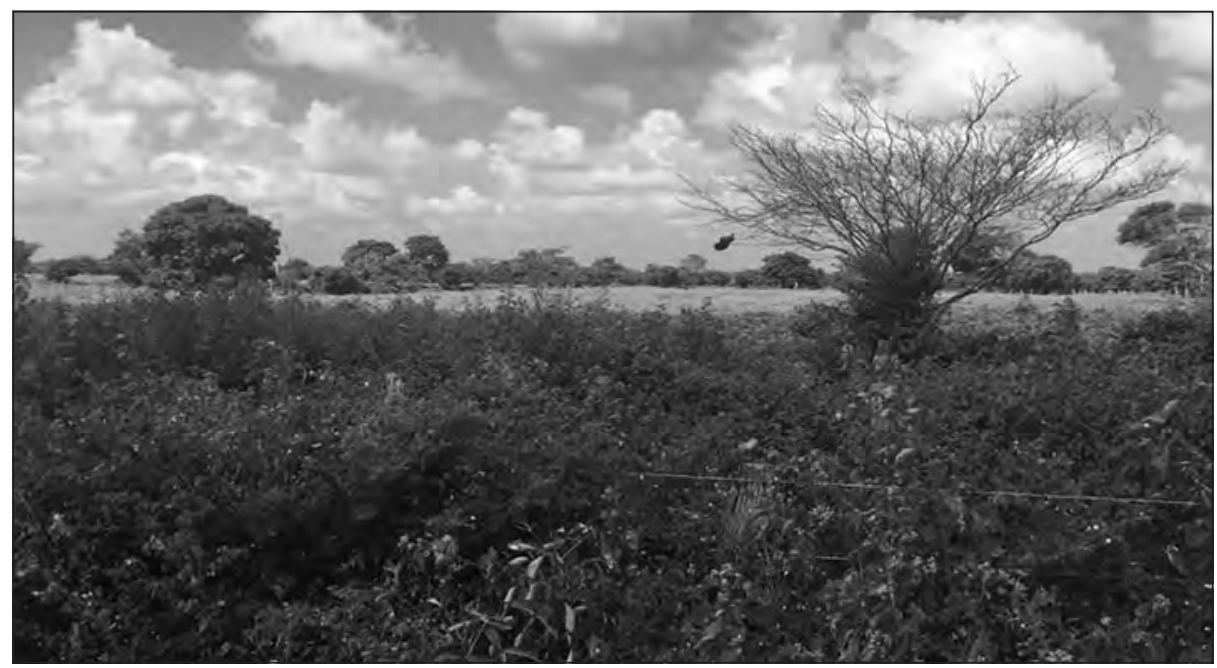

Fuente: Archivo Oraloteca (2017). 
Vida campesina en el Magdalena Grande

Contrario a un ordenamiento de la tierra con una vocación productiva más o menos clara, lo que hoy existe en Carraipía es responsabilidad de una centenaria ausencia del Estado y de una especie de "nación propia" donde el intercambio económico, el contrabando y la frontera son las únicas reglas supremas. El comando del ejército en el corregimiento da la impresión de ser un emplazamiento simbólico que dijera "esto es Colombia", más allá de proveer una real sensación de seguridad a los habitantes, viajeros o cualquier ciudadano que se refiera a este corregimiento. Precisamente sobre este abandono estatal en los últimos años hay un debate nacional que han suscitado las grandes cadenas de televisión y sus respectivos noticieros: tiene que ver con los casos de desnutrición infantil en La Guajira, sobre los cuales - y apelando a la capacidad de autogestión de las comunidades en el territorio- el señor Blanco nos refiere lo siguiente:

\section{Imagen 24. Parcela en Carraipía}

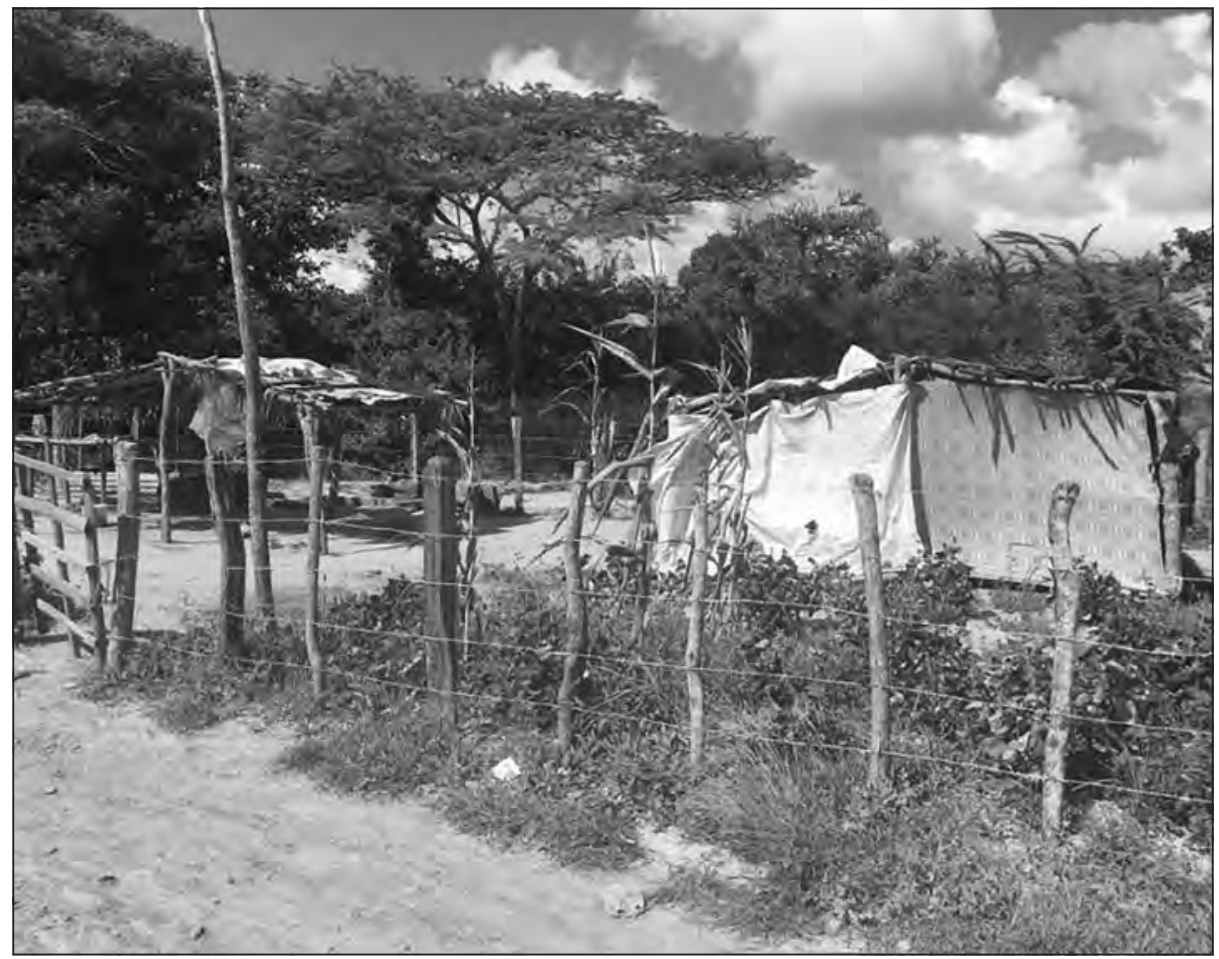

Fuente: Archivo Oraloteca (2017). 
Vida campesina en el Magdalena Grande

No, es que el Gobierno... por ejemplo, ahora es que yo veo con el tema de la desnutrición del Alta Guajira que le están construyendo granja integral, que si eso se lo hacen en aquel tiempo La Guajira fuera otro departamento, porque dependerían de ellos mismos, no [de] esperar que les manden una cajita de comida, sino que ellos mismos producen y ellos mismos venden, eso hace falta. Sin embargo, la soberanía alimentaria podría solucionarse. Aquí hay una institución agrícola, está a cuatro kilómetros y medio de aquí, se llama Institución Rural Educativa, antes se llamaba Vocacional Agrícola, esa institución trabaja la ganadería y la agricultura, pero no ha mejorado así en cuanto a mejoramiento tecnológico pero sí, los campesinos de aquel entonces a los de ahora sí se han mejorado, por lo que les dictan charlas; por ejemplo, yo el otro día estuve en una capacitación de 56 personas que nos la dictó agro no sé qué de la paz y nos capacitó con 50 horas sobre agricultura tecnológica y han venido dando charlas (J. Blanco, comunicación personal, diciembre del 2016).

En general, se puede entrever que aún existe un advenimiento y una necesidad de que aparezcan programas que desarrollen la capacidad técnica y tecnológica de los campesinos de Carraipía, una denuncia muy frecuente en el sector agrario del Caribe. La diminuta tecnificación que hay es asistida y administrada para uso colectivo por medio de la Umata, del Municipio de Maicao, banderas de lucha que viene impulsando la organización de la población para lograr condiciones de vida digna para el campesinado de Carraipía:

Hay cinco maquinarias: aquí hay una, en Majayura creo que hay otra, en Montelada otra, o sea que la[s] están repartiendo entre los corregimientos. Pero la mayoría de la siembra que ahorita creo que está en dos mil hectáreas en el municipio de Maicao, que en toda su historia creo que va a ser la mejor cosecha y la cosecha más grande. Ahora la tecnología ha mejorado, la mayoría de las tierras están sembradas con maquinaria, arado con maquinaria, sembrado con maquinaria, fumigación con maquinaria y cosecha con cultivadora, no del municipio, pero los que tienen siembran y contratan. Hace falta es como organización y hace falta tierra, que tengan sus tierras, no todos porque no se puede a todos, pero sí que a cierto grupo que se le vaya dando a medida del tiempo, porque 
Vida campesina en el Magdalena Grande

ellos teniendo sus tierras les ponen como más amor y el Gobierno está más pendiente, entonces eso hace falta. Fíjese, hay gente que no sembró porque no tenía ni para comer y para sembrar menos. Se ha mejorado y creo que se quiere mejorar, el campesino de aquí necesita que tenga su pedazo de tierra, organizarse y generar desarrollo, no tiene que estar mendigando para ver si le dan una hectárea para que siembre y que el Gobierno le apoye con sus incentivos en la primera cosecha porque ya que él tenga su primera cosecha ya depende de él mismo, pero hace falta eso. Un sistema de riego (porque aquí se siembra es con la época de lluvia) con la construcción de pozos, habilitar determinadas tierras y que los grupos de campesinos estén ahí trabajando, sembrando, produciendo. Por ahí este año se conformó una asociación de productores campesinos agropecuarios de Carraipia; eso es una asociación que está legalizada (J. Blanco, comunicación personal, diciembre del 2016).

\section{Elementos culturales de la vida campesina en Carraipía}

Imagen 25. Casa encomendada a San Gregorio, en Carraipía

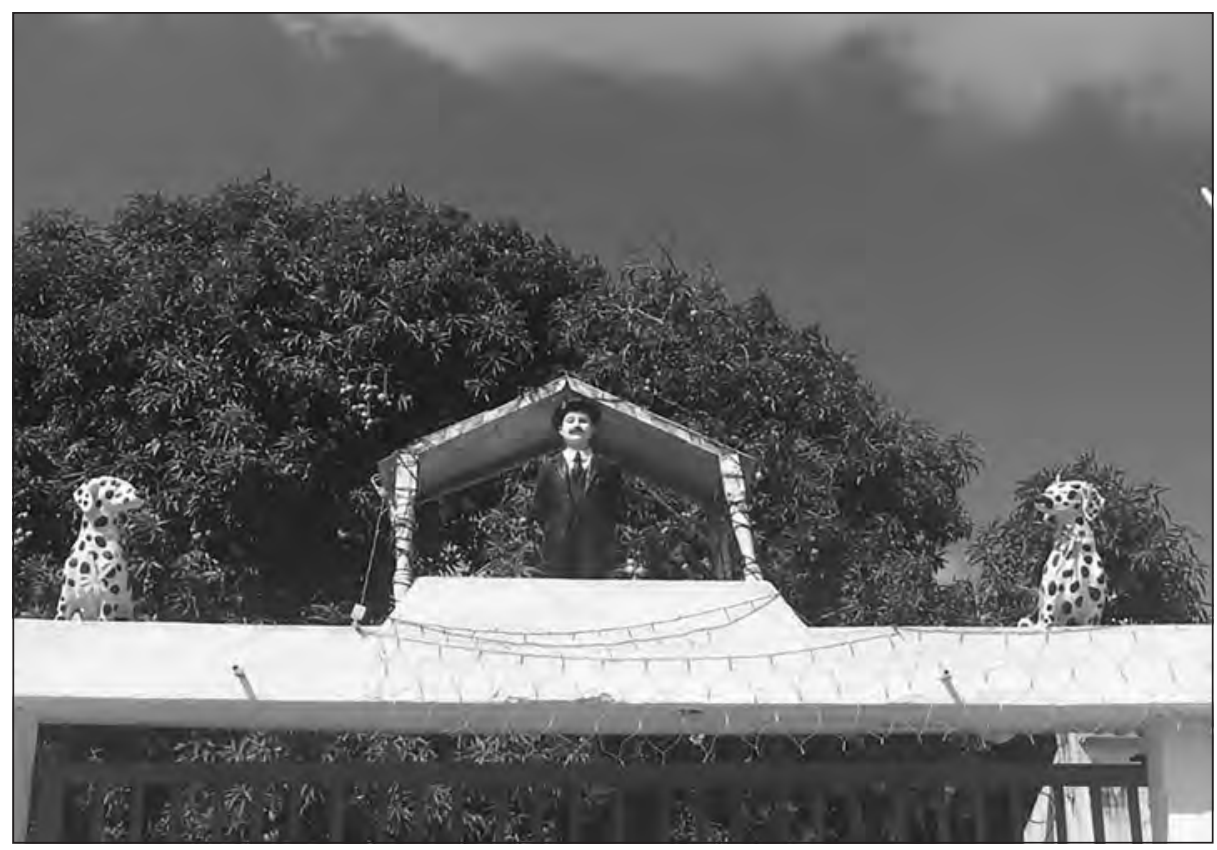

Fuente: Archivo Oraloteca (2017). 
Las dinámicas de diversión y esparcimiento del campesino de Carraipía están relacionadas con la mayoría de prácticas culturales del campesino del Caribe colombiano, sobre todo de los campesinos que emigraron desde lugares del interior como Tolima, Antioquia, Boyacá, hacia las zonas del macizo montañoso en la región costera norte. Ese es el caso de lugares como la Sierra Nevada de Santa Marta, la Serranía de San Lucas, la Serranía del Perijá y, por supuesto, los Montes de Oca: se puede entender por qué en los estaderos y en las calles se puede escuchar música de carrilera, guascas, rancheras o carrangas, sonidos propios de los departamentos andinos de Colombia. Aunque, a su vez, las zonas campesinas fueron, durante los años sesenta y setenta, objetivos de formación política de los movimientos de izquierda del país que difundían medios de comunicación como Radio Habana de Cuba y géneros musicales como la trova de ese país:

[De] las festividades aquí que yo recuerdo así siempre desde cuando estaba niño es la fiesta del 16 de julio, que es la patrona, nuestra señora la Virgen del Carmen, y hay otro santo que se festeja aquí el 28 de octubre que es San Judas Tadeo. Eso comenzó de los campesinos porque en ese tiempo eso surgió del campo y esas fiestas las hacían en la Sierra también. Bueno, anteriormente aquí la música en la Sierra, yo recuerdo que la música era... como la mayoría eran descendiente[s] allá del interior, eran cachaco[s], de Curumaní, ellos usaban guitarra y triple, y cantaban música carrilera, ranchera y esa música así, en aquel tiempo, allá en la Sierra. Acá la música, cuando comenzó la música acá yo recuerdo que la música de por aquí era la música cubana. Esa era la música que llegaba por aquí, la música de Daniel Santos, los boleros, esa fue la música que llegó primero aquí a Carraipía. Como venía mucha gente de las Antillas, sabes que el comercio vino fue de esa zona aquí, de las Antillas, llegó allá a Riohacha. Después apareció la música de viento, la de banda, la de papayera que llaman. En aquel tiempo, como no había emisora, la emisora que se sintonizaba aquí en Carraipía era Radio La Habana Cuba, cuando estaba Fidel Castro en su apogeo. Aquí había una señora, no [me] acuerdo [d]el nombre, de los Olarte, que ella era inclinada a ese partido, al movimiento de Fidel Castro, era comunista pues. Ella tenía un radio y ella vivía allá en la casa de la mamá y ella ponía ese radio todas las 
Vida campesina en el Magdalena Grande

tardes a todo timbal, a todo volumen, y la emisora que ponía era Radio La Habana Cuba. Entonces, como le digo, después de la música cubana que estaba la "Guantanamera, Guajira Guantanamera", los boleros de Daniel Santos, la ranchera, porque llegaba[n] los gitanos a dar cine. Sí, venían a dar cine. Los gitanos venían haciendo recorrido, del interior, de allá del Magdalena. En carpa se quedaban, duraban una semana, quince días. Pues, más que todo para las festividades del campesino, para festejar el día del campesino que es en el mes de junio. Ha habido época en que repartieron herramienta porque las fiestas del campesino se hacían ahí en el instituto agrícola o en la comunidad del garrapatero que es donde se instalaron los primeros desplazados de Venezuela desde los años setenta (J. Blanco, comunicación personal, diciembre del 2016).

Imagen 26. Campesinos de Carraipía

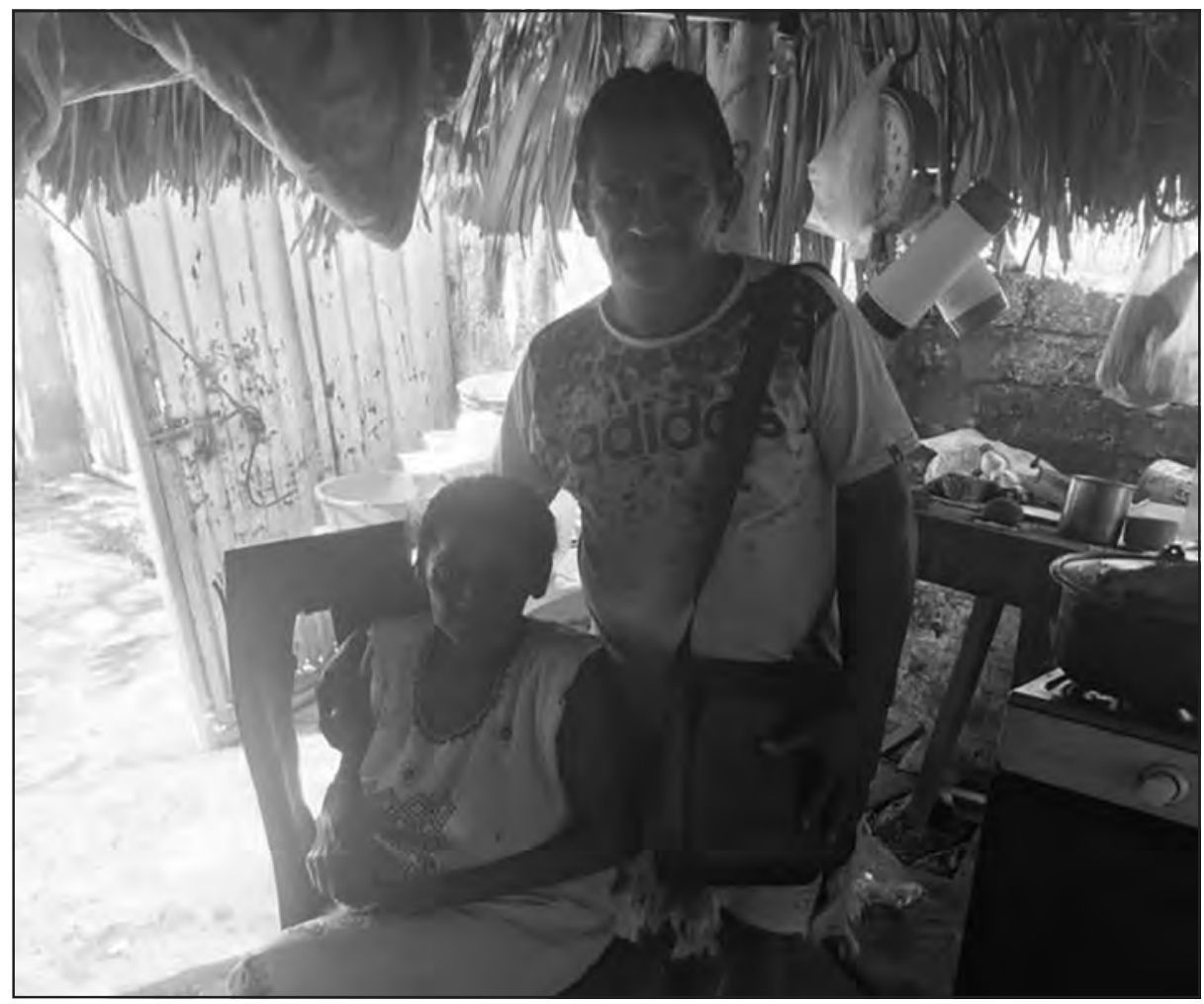

Fuente: Archivo Oraloteca (2017). 


\section{El campesino fantasma: territorio y minería en la comunidad de Chancleta}

El corregimiento de Chancleta se encuentra ubicado en el costado nororiental del municipio de Barrancas, en el departamento de la Guajira. Esta zona, fronteriza con el vecino país de Venezuela, hace parte de lo que se considera la planicie aluvial de La Guajira en la Media Guajira, entre la Serranía del Perijá y la Sierra Nevada de Santa Marta.

Para acceder a esta comunidad de forma rápida se debe tomar un moto-taxi desde el municipio de Hatonuevo, en un recorrido que tiene una duración aproximada de 10 a 15 minutos en dirección sur del departamento, donde a unos 500 metros de la cabecera municipal se encuentra la entrada del resguardo indígena el Cerro y, justo al frente, se encuentra el inicio de una modesta carretera destapada que conduce hacia Chancleta y que bordea gran parte del área de explotación de la empresa multinacional Carbones del Cerrejón, conocida además como la mina a cielo abierto más grande de América Latina.

Imagen 27. Puente del Cerrejón en la vía a Chancleta

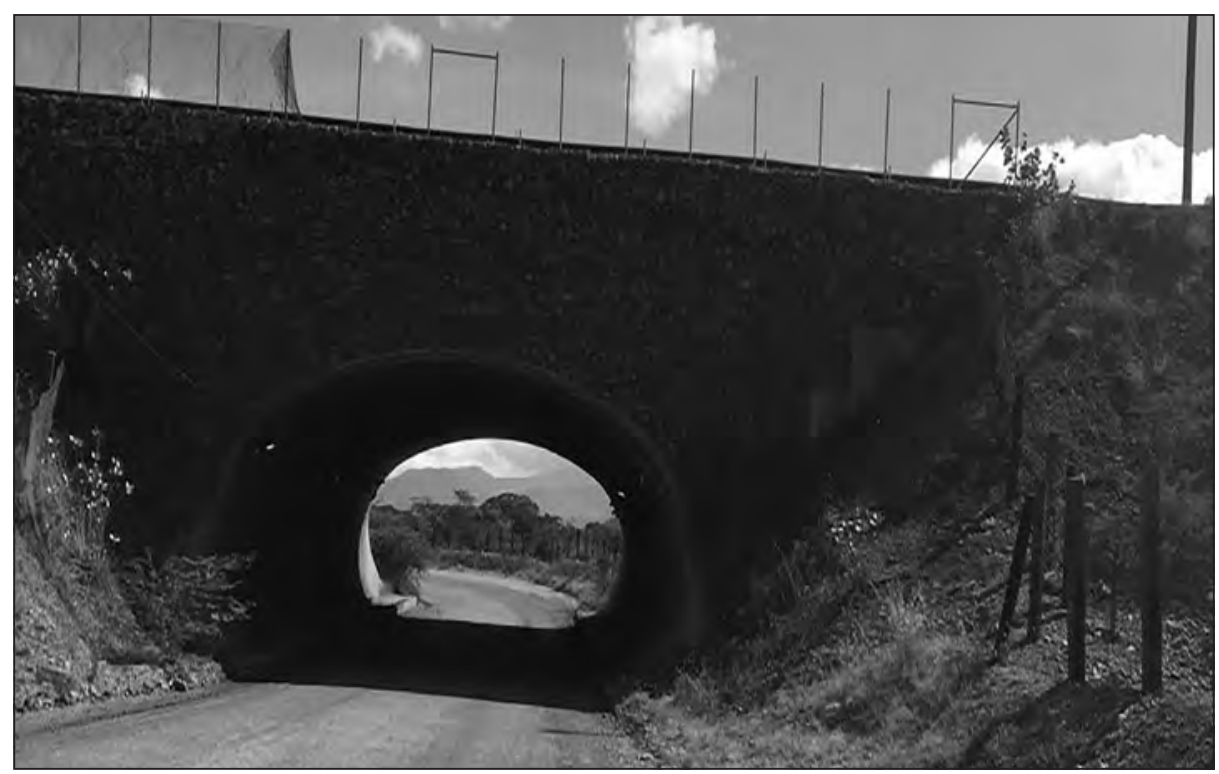

Fuente: Archivo Oraloteca (2017). 
La vía está en constante vigilancia por parte de los autos de seguridad de la empresa Cerrejón y es transitada por varios tractocamiones que llevan un distintivo que dice "Seguridad industrial", hasta llegar a Patilla, que es el primer pueblo "fantasma" que se encuentra en la vía. Se les llama "pueblos fantasmas" a las comunidades afrodescendientes y campesinas que han ido desapareciendo, según sus habitantes, por culpa del abandono del Estado, la pérdida de cultivos, la compra de tierras por parte de la empresa Cerrejón y algunos problemas de salud causados por la cercanía a la actividad minera. Sin embargo, un número considerable de habitantes de estas comunidades - entre las que están Chancleta, Roche, Tabaco, las Casitas y Oreganal - han decidido continuar su vida en sus territorios dependiendo casi que exclusivamente de la actividad agropecuaria.

Después de recorrer algunos kilómetros, en los que incluso se cruza varias veces por pequeños puentes vehiculares el río Ranchería, se llega a Chancleta, una población mayoritariamente afrodescendiente ubicada en cercanías del arroyo Cerrejón. Cuenta con unas treinta casas hechas en su mayoría con bahareque, tanques para el almacenamiento de agua donados por la multinacional, algunos animales de cría y un centro de salud abandonado; esto, dada la cohesión y solidez organizativa de la comunidad, pues son estas cuarenta familias las que han decidido mantenerse en condiciones complejas, en las que su agricultura artesanal está rodeada por un megaproyecto.

Imagen 28. Vivienda campesina en Chancleta, La Guajira

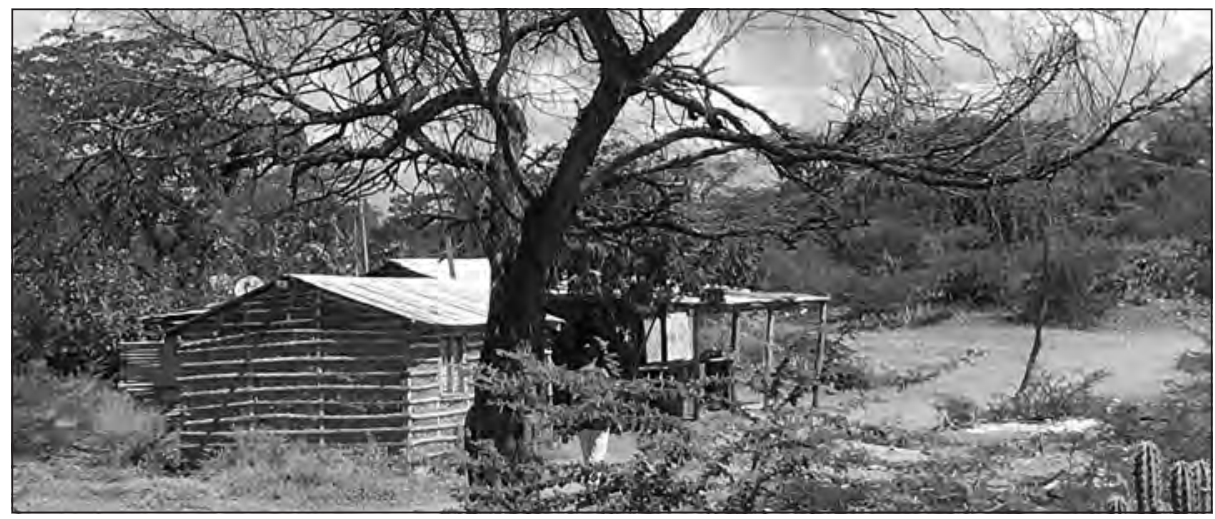

Fuente: Archivo Oraloteca (2017). 
Vida campesina en el Magdalena Grande

\section{Poblamiento}

El poblamiento de la comunidad de Chancleta se remonta, como muchas de las comunidades afrodescendientes que habitan en la Guajira, a la época de la esclavitud y los puertos negreros de Riohacha y Dibulla. Las poblaciones traídas de África para realizar las tareas que la población indígena ya diezmada no podía realizar aprovechaban la mínima oportunidad para huir usando las márgenes de los ríos; en este caso, la cuenca del río Ranchería:

El "relato de origen" de Roche se remonta a la época de la colonia, cuando negros esclavos huyeron del yugo colonial y se desplazaron desde la ciudad de Riohacha por la cuenca del río Ranchería hasta que encontraron las Tunas. En este paraje, ubicado a pocos kilómetros de la comunidad de Roche, se resguardaron los negros esclavos durante varios años para luego conformar las comunidades negras de Chancleta, Tabaco, Manantial, Patilla y Roche (Granados, 2014, p. 132).

Así mismo, el señor Wilman Palmesano, presidente de la Asociación de Negros Ancestrales de Chancleta y voz de la comunidad, especifica mencionando que:

Bueno, lo que yo sé de los orígenes de esta ciudad es que fue fundada por Gaspar Duarte en los años más o menos [de] 1770, estamos hablando de alrededor de 285 años de vida de esta comunidad. Posteriormente, se fueron anexando, fueron llegando otras familias como los Camargo, los Palmesano, los Carrillo (en Patilla) y los Arregocés (en Roche). El origen de estas familias es que venían huyendo del flagelo de la esclavitud. Se volaron algunos en Riohacha y cogieron por toda la vega del río Ranchería para arriba y se fueron quedando en estos alrededores: en Tabaco cogieron por el arroyo Tabaco para arriba y fundaron Tabaco; en Remedios se fueron por toda la boca del río Bruno y se estacionaron en los Remedios; en Chancleta hicieron lo mismo: dejaron el río Ranchería y se metieron por toda la desembocadura del río Cerrejón, algunos se quedaron en Patilla y otros siguieron adelante y se estacionaron en Chancleta (W. Palmesano, comunicación personal, diciembre del 2016). 
Vida campesina en el Magdalena Grande

El señor Palmesano nos cuenta cómo era la vida en la comunidad de Chancleta en tiempos pasados y sobre las grandes extensiones de tierra que había para trabajar la agricultura: tantas que las personas no se preocupaban por cercar o delimitar, pues con poca tierra tenían suficiente para sobrevivir. Diversificaban sus labores en relación con las temporadas de lluvia o sequía, no sufrían por alimentos y siempre había agua para la cría de animales y sus familias:

La comunidad de Chancleta tenía una extensión grandiosísima; es más, nosotros de aquí miramos al cerro Cerrejón que ya hoy casi no se ve porque ya le pusieron otro cerro artificial por delante, nos contaminaron el paisaje, entonces nosotros teníamos un espacio muy extenso: si salíamos por aquí llegábamos al cerro y pasábamos más adelante y si salíamos por acá llegábamos hasta la Sierra; hoy en día ya no podemos hacer eso, incluso la Sierra también ya se acabó [...]. Era una comunidad que tenía una ventaja, que hacían siembras aquí en la tierra baja y se fueron a la Sierra en la parte fría, en la parte alta para, de esta manera, poder contrarrestar los ataques de los veranos, cuando aquí no se podía cultivar en la Sierra había cosecha y esto le dio la fortaleza porque nunca necesitaban pues de mayor cosa, porque todo lo tenían, cuando no lo tenían aquí, lo tenían allá (W. Palmesano, comunicación personal, diciembre del 2016).

Entre relato y relato deja ver las añoranzas de un sueño colectivo, arrebatado por la llegada de la mina y la violencia física y psicológica que ha traído su presencia en el territorio. Esta tranquilidad y las formas de vida que habían llevado por generaciones se vieron truncadas con la llegada de la mina, transformado radicalmente las condiciones del territorio $y$, por ende, las formas que ellos tenían de relacionarse con él. 
Imagen 29. Arroyo Cerrejón

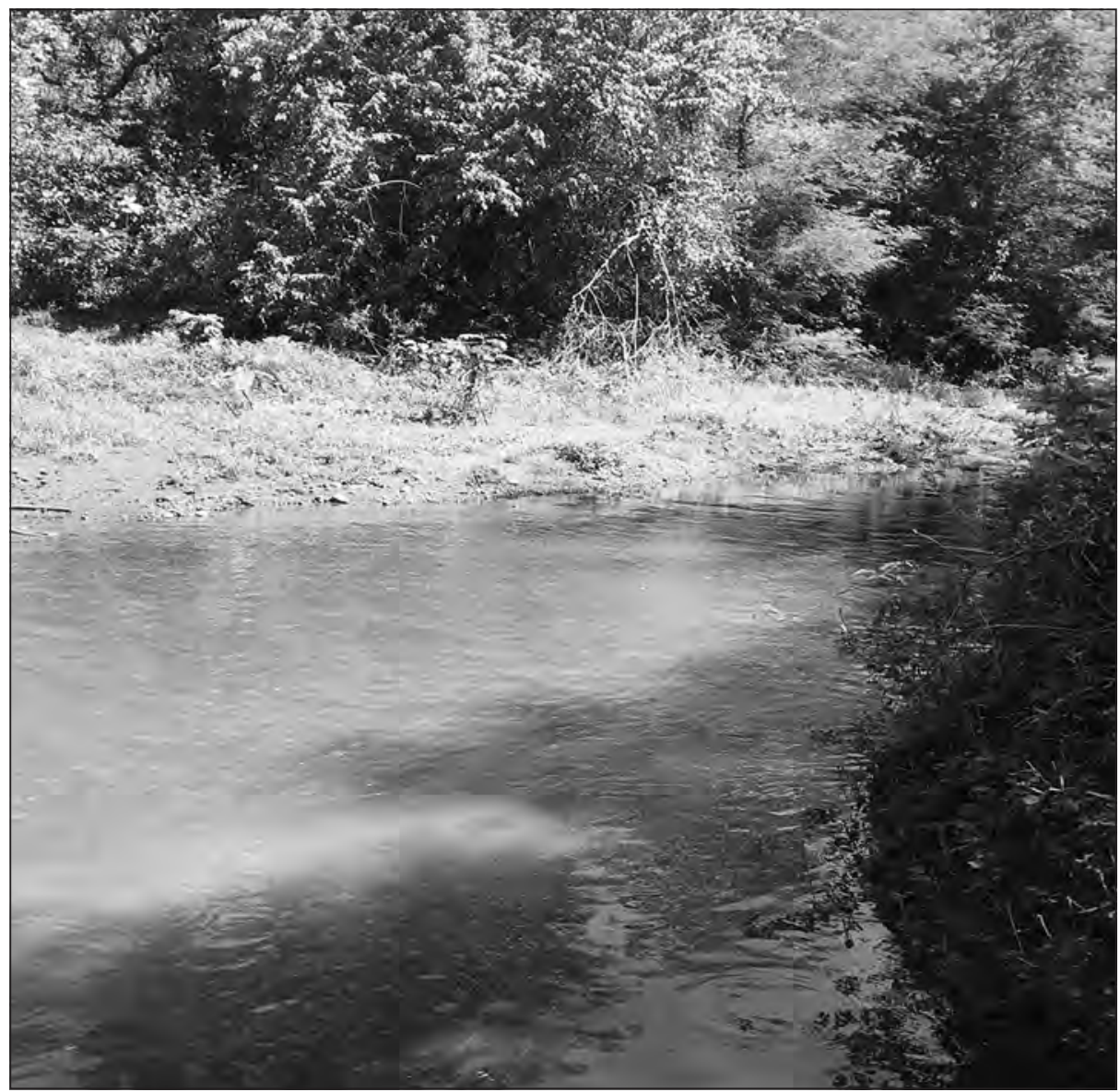

Fuente: Archivo Oraloteca (2017).

\section{El fantasma del carbón}

Los conflictos ambientales en los llamados "pueblos fantasmas" han generado nuevas formas de territorialidad, así como nuevos órdenes legales de cartografía, límites que suprimen y criminalizan a los campesinos que aluden a su ancestral y centenaria historia para mantenerse en sus modestas áreas de producción y cultivo, mientras que la mina sigue generando impactos sobre el medio ambiente con la complacencia de los gobiernos locales y del Gobierno Nacional. Dentro de las principales 
Vida campesina en el Magdalena Grande

afectaciones ambientales que la comunidad identifica desde la llegada de la mina a su territorio está el impacto producido sobre las fuentes de agua que durante décadas han garantizado la permanencia de los cultivos y la cría de los animales (que son el principal sustento de las familias chancleteras):

Desde que comenzó la explotación del tajo los Comuneros, el tajo Cien y de la cabecera del río, el Cerrejón comenzó a hacer botadores; entonces, por medio de esas excavaciones que ellos han hecho la cuenca del río se chupa para los huecos y el río se fue secando hasta que se secó. Aquí hace como el 2010 todavía se podía cultivar a las orillas del río el Cerrejoncito, pero de ahí para acá no se pudo porque ya el río perdió el cauce y pasó que la mayoría dejamos de cultivar lo que era plátano, tomate, ají, yuca, que era lo que uno siempre mantenía aquí en la orilla de la comunidad, pero ahora se encuentra puro monte, los animales se estaban muriendo de sed. Este río era la vida de uno, aquí uno pescaba bocachico, mojarra y todas esas especies de pescados, pero como ya el río murió se acabó todo y donde no hay agua, no hay nada (J. Fontalvo, comunicación personal, enero del 2017).

Esta situación es una clara evidencia de las transformaciones medioambientales generadas por la mina, las cuales no solo afectan a las comunidades que día a día conviven con su presencia en el territorio, sino que profundizan la grave crisis climática que vive el mundo actualmente y ante la cual a las empresas no se les ve ánimo alguno de revertir sus impactos:

De hace unos 5 años para acá se ha calentado esto que hasta ranchería se seca, el arroyo Cerrejón se seca, eso era una de las partes importantes para nosotros. La vega del arroyo Cerrejón era donde se producían los cultivos de yuca, maíz, plátano, aquí cada quien tenía sus plátanos, guineos de diferentes clases, el tradicional filuo; al tener el Cerrejón esa muerte así repentina muere[n] también los cultivos, no hay dónde cultivar. Aunque las tierras eran del Cerrejón, nosotros las utilizábamos, peleando con ellos, pero las utilizábamos, ahorita mismo sembramos en pleno invierno [...]. Allá está el socavón a menos de 100 metros del caudal del río, así 
Vida campesina en el Magdalena Grande

que yo pienso que le rompieron el acuífero. Al romper el acuífero toda el agua se va al socavón y de ahí para acá se seca el agua, tenemos ese perjuicio que nos ha dejado la minería, porque eso es lo que deja la minería: resequedad, enfermedad, hambre, desnutrición, muerte (W. Palmesano, comunicación personal, diciembre del 2016).

La comunidad manifiesta sentirse abandonada por parte del Gobierno, quien no hace nada para frenar el daño ambiental y social que las empresas del carbón vienen generando en La Guajira, específicamente en el Cerrejón. Así mismo, denuncian que constantemente están llegando las ONG y las universidades a realizar estudios sobre los impactos del carbón en las comunidades y en el medio ambiente, pero no se ve ningún cambio en el actuar por parte de la empresa; sigue pasando lo mismo:

A nosotros nos duele que todas las empresas multinacionales vienen acabando con La Guajira porque eso es una realidad por mucho que ellos la quieran tapar, ellos dicen que no hay contaminación, pero la contaminación es bárbara. Eso es una multinacional muy poderosa que lo que quiere conseguir lo consigue como sea y le ha mostrado al país cosas que no son. Estas comunidades... por acá estamos abandonados del Gobierno, aquí no se hacen valer los derechos de los seres humanos que vivimos por aquí; mejor dicho, nosotros estamos abandonados por todos, eso siempre lo hemos dicho, uno siempre tiene que arreglársela con el Cerrejón a su manera. Aquí han venido muchas organizaciones, muchos derechos humanos, cogen pruebas y yo no he visto ningún resultado, no sé qué está pasando, pero aquí han venido muchas organizaciones a coger información. ¿Qué se ha hecho? Nada (J. Fontalvo, comunicación personal, enero del 2017).

Por otro lado, la llegada de la mina ha significado para las comunidades la pérdida del territorio. Frente a la escasez de agua para realizar sus cultivos y la cría de animales, la comunidad perdió su principal fuente de sustento, lo que les ha obligado a vender sus tierras a muy bajos precios para desplazarse a los principales centros urbanos en busca de mejores oportunidades para sus familias, abandonando los proyectos de vida comunitarios que habían construido en sus territorios: 
Vida campesina en el Magdalena Grande

Todo lo que usted mira alrededor aquí, lo único que no es del Cerrejón es donde hay una casita de estas, ya donde usted ve monte es del Cerrejón, entonces como nosotros somos campesinos y no tenemos tierra donde ejercer lo que siempre hemos hecho, que es criar y cultivar. Ya criar no podemos; sin embargo, hay unos que han comprado chivos y los tienen por ahí, pero cuando truena como campesino al fin, inmediatamente nosotros pensamos en la siembra, a lo que truena y vamos buscando la forma de sembrar y sembramos en las tierras de la empresa. Todo, todo es del Cerrejón [...]. Por otro lado, se iban haciendo dueños de las tierras productivas, las compraban y se la daban a terceros en comodato y esto nos iba quitando el modo vivendi lentamente. Aquellas personas que se negaban a negociar con la empresa, la empresa era la que medía las tierras. Si en la escritura rezaba que tenía 50 hectáreas, a ellos les salían 45 o 40 y eso lo tenía que aceptar el dueño porque lo amenazaban con la expropiación [...]. Desde que usted llega allá, sale de la carretera negra allá en Puente Negro, todo eso de lado y lado es del Cerrejón hasta llegar allá a Piedra Amarilla y de Piedra Amarilla pasa para adelante. Mire cómo están deforestando allá, si uno por necesidad va a cortar un palo y CORPOGUAJIRA hasta lo pone preso; mire cómo están acabando con millones de árboles allá... hombre, si la ley debe ser igual para todos, no para el más débil, la ley se hizo para cumplirla todos, no uno. Ahora, al más débil es al que se tiene que apoyar para que camine de otra manera y aquí le dan la fuerza es al que más tiene fuerza, es algo inaudito y nadie dice nada. Estas negociaciones que nosotros hemos hecho no son las mejores negociaciones, pero las hemos hecho porque sabemos y tenemos algo que nos está persiguiendo siempre. Para verlo como una negociación ellos sacan a relucir el tercero y, ¿por qué lo sacan a relucir? Porque se debería entender que ese tercero podría ser para bien o para mal o puede ser imparcial, que eso es lo que se debería entender, pero nosotros sabemos que no es así, nosotros sabemos que ese tercero es un brazo del Cerrejón y tenemos que negociar prácticamente con las propuestas de ellos (W. Palmesano, comunicación personal, diciembre del 2016). 
Vida campesina en el Magdalena Grande

Imagen 30. Extracción de carbón

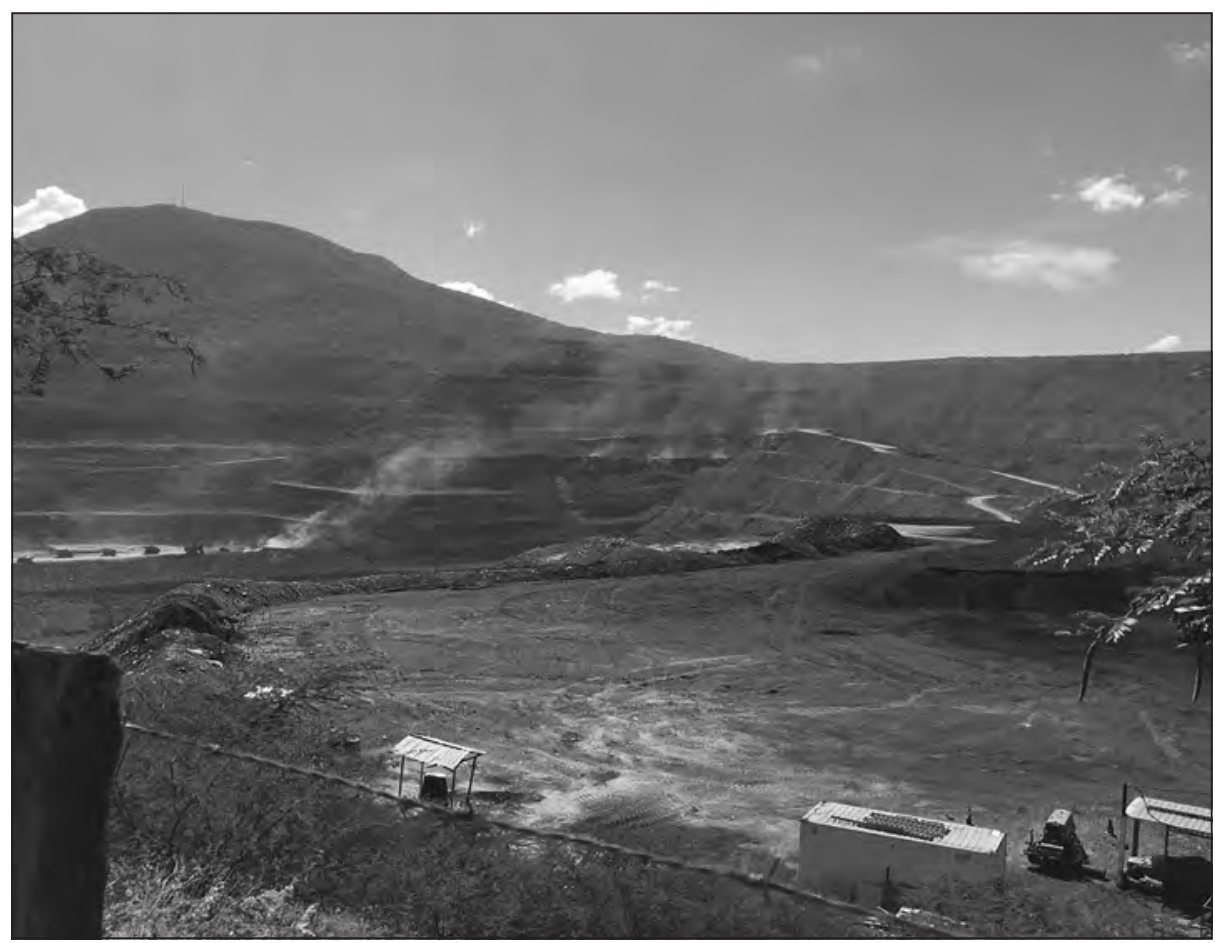

Fuente: Archivo Oraloteca (2017).

\section{La mina acabó con todo}

Sucede en esta comunidad que gran parte de lo descrito por el señor Palmesano, como portavoz de la comunidad de Chancleta, tiene como desarrollo y objetivo las denuncias del pueblo sobre lo que consideran afectaciones a su territorio. En buena medida se explica que la historia contemporánea de esta población tenga como columna vertebral las relaciones con la minería, pues la llegada de esta se constituye el punto de quiebre en la historia de las comunidades afrodescendientes asentadas alrededor de la mina:

La historia de esta comunidad siempre al final tiene que ver mucho con la minería porque fue quien nos acabó, y no de esta, sino de todas las comunidades: está Tabaco, está Manantial (que fue la primera comunidad 
Vida campesina en el Magdalena Grande

desaparecida), Roche, está Chancleta, Patilla, el Descanso, la Casita, Tamaquito... una cantidad de comunidades que han desaparecido y nadie dice nada, el Gobierno nunca dice nada de estas comunidades, de pronto ni siquiera se dan cuenta que han existido, nos dejan al merced del pulpo Cerrejón, que es el que ha acabado con estas comunidades y la gente todavía no se apersona de la situación [...]. Todo fue triste, porque eso fue como una bacteria: primero la empresa fue comprándole los terrenos a los campesinos, después ya todo el mundo fue vendiendo los animales porque no tenía dónde tenerlos. Las señoras ya fueron saliéndose al pueblo a trabajar porque no había cómo sobrevivir en el campo. La gente se dejó influenciar más por la empresa que por la comunidad, llegaban los funcionarios de la empresa y decían "esto no funciona así, lo mejor es vender e irse" y mucha gente todavía hoy le creen más a la empresa que a la comunidad (R. Palmesano, comunicación personal, diciembre del 2016).

La falta de agua solo permite la siembra durante una época denominada por los campesinos como "la segunda", que corresponde a los meses de lluvia entre septiembre y noviembre, aunque según los mismos campesinos esta época es cada vez más reducida. Así mismo, la pérdida del territorio y la contaminación por el polvillo del carbón han hecho que la comunidad transforme su vocación productiva, teniendo que desplazarse a otros lugares en la búsqueda de opciones económicas o permaneciendo en el territorio e insistiendo en la agricultura, principalmente de maíz (el único cultivo que logra sobrevivir los embates del clima y a la contaminación producida por la mina):

Al no haber agua ni en Cerrejón ni en Ranchería los cultivos se acaban. Yo tenía una rosa de plátano y se acabó en el verano del año pasado porque se secó, no había agua y de ahí comenzó la dificultad, porque es que con esa rosa se alimentaba casi toda la comunidad porque estábamos trabajando siete socios ahí, teníamos la soberanía alimentaria, pero cuando llega el verano el Ranchería se seca, nosotros lo regábamos con motobomba, pero se acabó todo en seis meses y era la única tierra que teníamos que no era del Cerrejón; hoy en día tuvimos que negociarla: ¿para que íbamos a tener esa tierra ahí si no podíamos cultivar nada? 
Vida campesina en el Magdalena Grande

El único cultivo que se mantiene es el maíz, de pronto porque el maíz es como una yerba, no sé, eso le dará resistencia y no se enferma, pero los demás cultivos no resisten, no sé por qué, pero se enferman [...]. Con los animales es más complicado porque la empresa sí se pasan los animales para allá y un guaco mata uno, no la pagan, si mata dos o tres, no la pagan, y si encuentra un lote en el monte como ha llegado a suceder los va tapando con la maquinaria, los tapa vivos la empresa, entonces el que tiene animal tiene que cuidarlo y no hay ya cerca y la poca que hay va rodeando la mina y ya hace mucho tiempo que no le hacen mantenimiento y el ganado se pasa para allá. Los animales generalmente son para nuestro consumo interno; ahora hay un pie de cría acá, pero ya estamos en la postrimería del viaje, ya de salida, y esto atrofia la cuestión de la cría porque no sabemos para dónde vamos, eso también es complicado. Algunos me han preguntado qué hacer, que si lo venden, que si se la comen, por una u otra razón siempre se perjudica uno (W. Palmesano, comunicación personal, diciembre del 2016).

Así mismo, la imposibilidad de cultivar y tener una cosecha permanente todos los año hizo que los compradores de sus productos buscaran otras comunidades que les pudieran asegurar un abastecimiento permanente de los productos $\mathrm{y}$, de esta manera, suplir las demandas del mercado local, generando que las comunidades perdieran las garantías de comercialización de sus cosechas, profundizando la crisis económica de estas comunidades que, frente a esta situación, optan por aceptar las ofertas de la empresa para comprar sus tierras:

El mercado lo perdimos en el momento [en] que la empresa se hace dueña de todas las tierras, entonces ya nosotros dejamos de cultivar porque ni en comodato, al no cultivar nosotros no tenemos el contacto de los mercaderes para llamar. Ya por aquí no vienen porque saben que ya por aquí no se cultiva eso. En caso de que nosotros lleguemos a cosechar tenemos que llevárnoslo y allá conseguir el mercado, un quintal de maíz cariaco [barato] vale 100 mil pesos y el otro, cuando este está a 100 mil pesos, el otro está a 50 mil y está caro (W. Palmesano, comunicación personal, diciembre del 2016). 
Vida campesina en el Magdalena Grande

Finalmente, la comunidad manifiesta que la mina ni siquiera representa una opción laboral para sus familias debido a que no se contratan personas de la comunidad, sino que, por el contrario, se les aísla, bloqueando cualquier actividad económica que puedan desarrollar en sus territorios sin tener que desplazarse a otras ciudades. Así mismo, expresan que la reubicación en otro lugar para ellos no representa ninguna garantía de mejora para sus vidas, pues han notado que las personas que se han ido tienen que regresar pronto ya que la dinámica en las ciudades es diferente a la del campo: las personas no tienen cómo desempeñarse en los oficios de la ciudad y los gastos de sostenimiento de una vivienda representan una carga que ellos no están acostumbrados a llevar, ya que en el trabajo del campo es poco lo que hay que comprar y la solidaridad entre familias es garantía de supervivencia para las comunidades:

El Cerrejón le cerró la puerta a todo el mundo: prefiere contratar gente de afuera, no tienen en cuenta a nadie de aquí de la comunidad, solo hay como seis personas de aquí de la comunidad que están trabajando con la empresa [...]. Tenemos la experiencia de los demás que han salido y han fracasado porque es que no cuentan con la suficiente fuerza para seguir parados y trabajar de otra forma, con lo que uno sale de aquí no es suficiente para mantenerse [...]. Otro mal que nos hacen es que nos dejan lejos de la vía porque es que está prohibido. Yo he visto que [a] todas las ciudades del mundo las carreteras les pasa[n] por el medio, [a] todos los municipios de La Guajira les pasa la carretera por el medio... ¿dónde está la prohibición? Y a todas estas comunidades les van a hacer ese perjuicio para terminarlos de acabar, porque es que esas comunidades así como están en poco tiempo tienen que dejar esa casa sola, tienen que salir a reclutar familias que sí puedan pagar los servicios, abandonan la casa, le huyen a la casa porque los servicios son muy caros. Nadie ve eso porque siempre nos dejan solos a negociar con una empresa tan poderosa como el Cerrejón (W. Palmesano, comunicación personal, diciembre de 2016). 
Vida campesina en el Magdalena Grande

Imagen 31. Comunidad de Chancleta, La Guajira

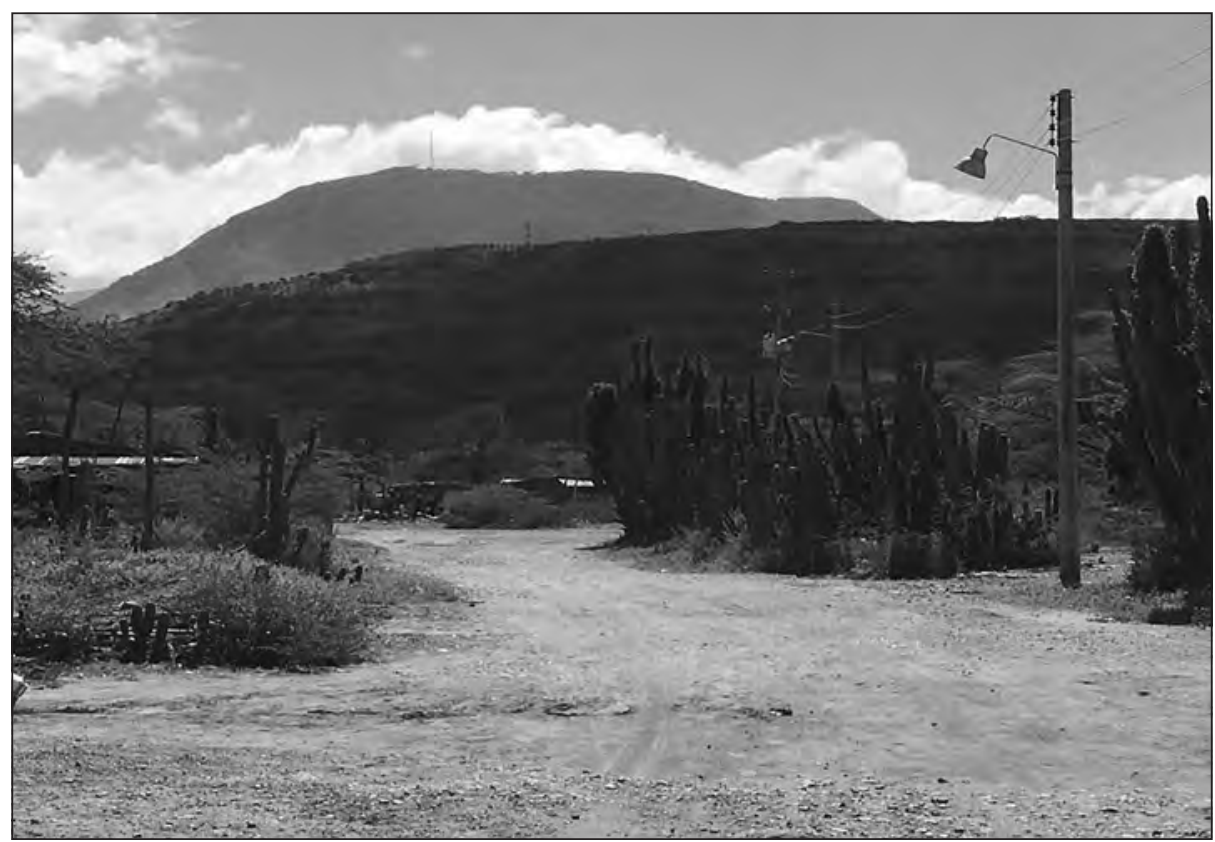

Fuente: Archivo Oraloteca (2017).

\section{Organización ancestral de la comunidad afrodescendiente de Chancleta}

La noción organizativa de la comunidad de Chancleta depende, principalmente - como se mencionó anteriormente-, de su principal y reconocido vocero que, en este caso, es Wilman Palmesano, quien a su vez coincide en agendas programáticas y de movilización con distintas organizaciones de indígenas que han colaborado en hacerle frente a la principal contradicción de este pueblo: la mina del Cerrejón. Una de las principales preocupaciones de los líderes de la comunidad es el tejido comunitario que se ve afectado por los procesos de reubicación, al quedar la población dispersa. Si bien, como lo reconocen los miembros de la comunidad, el consejo comunitario y las juntas de acción comunal son procesos organizativos recientes en su historia, ellos mantienen dinámicas socioculturales que mantienen este tejido comunitario, fortaleciendo a su vez las expresiones organizativas que hacen frente a la mina: 
Vida campesina en el Magdalena Grande

Nosotros estamos representados por un consejo comunitario, el consejo comunitario Negros Ancestrales de Chancleta y Patilla, todo el personal que habita en la comunidad son socios del consejo, debidamente registrados en el libro de afiliados. Esa es la organización que nos representa actualmente; en este momento de la salida va a quedar dispersa la comunidad porque, como le conté, yo tomé la decisión de no irme colectivamente por seguridad, esperaba que la gente se mantuviera en lo colectivo, pero no fue así, voy a ver qué pueda pasar y es posible que más adelante reorganice nuevamente la comunidad, pero ahora mismo no es posible. Anteriormente, eran juntas de acción comunal; en un tiempo más atrás no había ni junta de acción comunal, sino que era una comunidad normal, eso de juntas de acción comunal es más bien un poco nuevo, aunque es más viejo que eso de consejo comunitario, pero por aquí nunca llegaba gente del municipio a organizar a uno, ya eso fue como en los años 80 más o menos que apareció la junta de acción comunal y tuvimos por un tiempo hasta el 2004 que nos organizamos como consejo comunitario: hicimos la solicitud al municipio, pero el municipio no sabía nada de esto y, para colmo de males, la empresa supo la información y puso la zancadilla de que no se podía reconocer un consejo comunitario y nos quedamos ahí congelados hasta el 2013. En el 2013, cuando hubo la huelga del Cerrejón, que duró 33 días, en ese momento hice yo la solicitud nuevamente, había otro alcalde y gracias a Dios nos dieron el reconocimiento (W. Palmesano, comunicación personal, diciembre de 2016).

El señor Palmesano manifiesta que, en algún momento, había actividades específicas para hombres y mujeres y, aunque se desarrollaban de manera separada, siempre buscaban el bien común de toda la comunidad; sin embargo, con la aparición de la empresa esas relaciones comenzaron a cambiar hasta que se diluyeron las formas tradicionales de organización y se crearon las juntas de acción comunal y el consejo comunitario: si bien son espacios de representación e interlocución entre las comunidades, las empresas y el Estado, no responden a sus formas tradicionales de organización, lo cual pone en riesgo su legitimidad ante la misma comunidad, sobre todo los mayores y mayoras. 
Imagen 32. Líder campesina en Chancleta, La Guajira

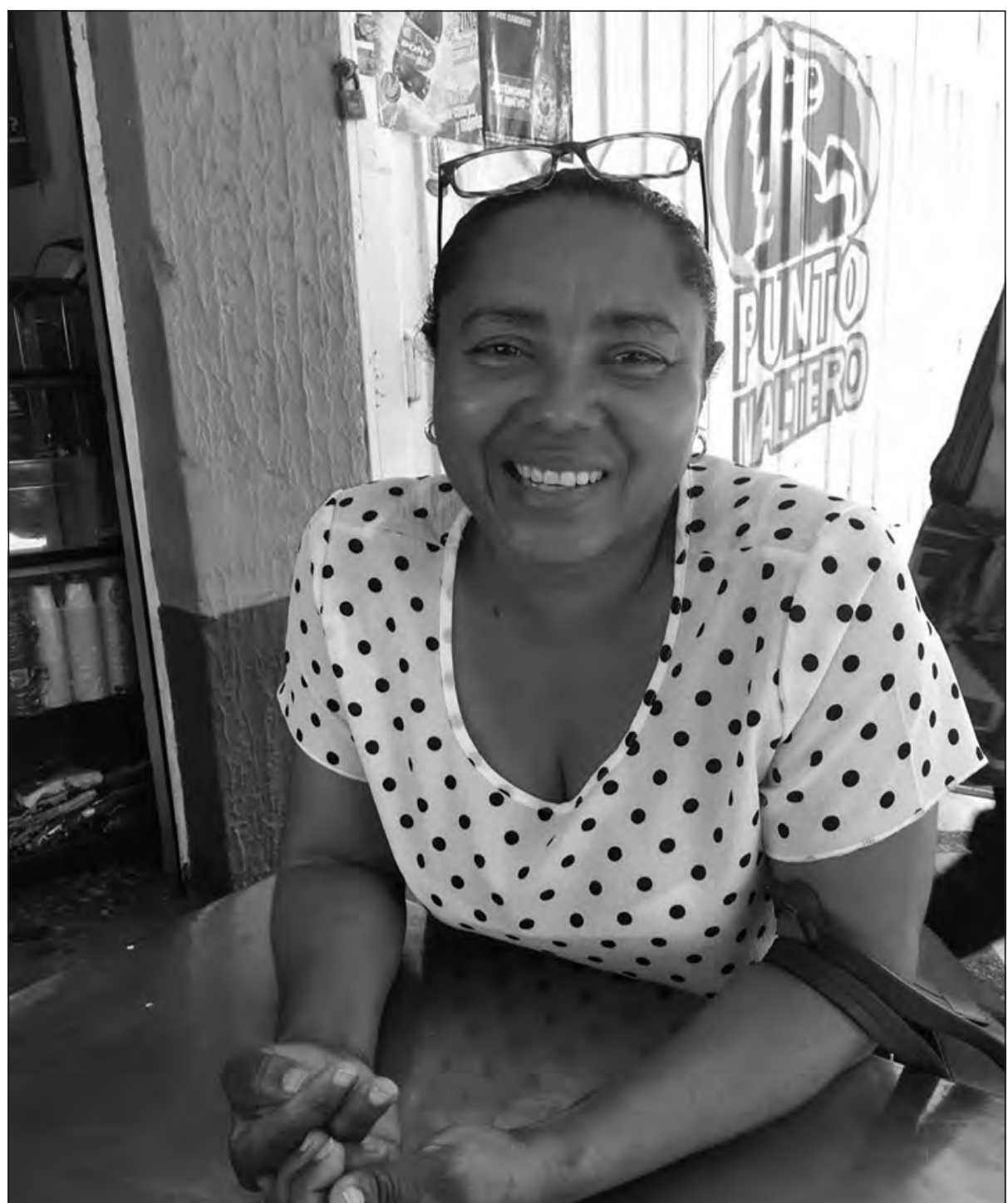

Fuente: Archivo Oraloteca (2017).

Aquí los trabajos son prácticamente individuales de mujeres: algunas lideran grupos y asociaciones de cuestiones de moda, talleres de confecciones y esas cosas. Aquí hubo un tiempo una asociación de mujeres, 
Vida campesina en el Magdalena Grande

la hermana mía era la representante legal, mujeres y hombres trabajaban aparte siempre enfocados en conseguir una mejor negociación, buscando, intentando salir mejor para que nuestros derechos no fueran tan vulnerados, pero aquí siempre nos falta[n] cosas que, al fin y al cabo, vienen es de la misma empresa. Entonces se acabó la asociación de mujeres y se continuó en las juntas de acción comunal y, posteriormente, en el consejo comunitario (W. Palmesano, comunicación personal, diciembre de 2016).

La historia poblacional y la memoria que existe alrededor del proceso comunitario de Chancleta dependen, sin duda alguna, de la identidad y territorialidad que han tenido que reafirmar sus habitantes a través de las tensiones que se generan en el conflicto con la multinacional. Es decir, ha sido en el ejercicio diario de resistencia, en la agencia institucional - plasmada en los distintos tipos de interlocución externa que han construido- y en la latente confrontación productiva que la identidad de esta población se reafirma, poniendo en discusión una eterna rivalidad de modelos: la agricultura y la minería.

En algunas ocasiones la empresa ha manifestado la disposición de mejorar las condiciones de vida de las comunidades afectadas por la extracción minera, pero esto se reduce a sus proyectos de reubicación. En las pocas ocasiones que han apoyado la capacitación de la población para el desarrollo de otras actividades económicas esta nunca llega a ejecutarse de manera completa pues, según los pobladores, la empresa ve que la comunidad se está fortaleciendo e, inmediatamente, frena todos los proyectos y apoyos, pues ellos necesitan que se retiren del territorio y no que se fortalezcan en él; por esta razón, solo insisten en la reubicación y el desarrollo de proyectos productivos en los nuevos territorios, proyectos que, como ya mencionamos anteriormente, no cumplen con las capacidades de los pobladores ni garantizan una vida digna y estable para las comunidades:

El Cerrejón nos dio la capacitación, pero cuando el Cerrejón ve que uno se va profundizando y la cosa va en serio saca el cuerpo. Nos dio la capacitación y, como nosotros nos organizamos y empezamos a trabajar, pues se alejó; entonces, nos estuvo colaborando una empresa pequeña que está 
Vida campesina en el Magdalena Grande

ahí al frente, pero como los cultivos estaban en tierra que no eran de ellos al prosperar ese cultivo pues obviamente que ellos al fin y al cabo iban a tener que bajarse de la mula y negociar con nosotros el cultivo porque también estábamos esperando la negociación (W. Palmesano, comunicación personal, diciembre de 2016).

En cuanto al proceso de reubicación, el señor Palmesano manifiesta que la empresa ha generado división entre la comunidad pues, arbitrariamente, han generado categorías de las personas que son reubicables y las que no, al punto de que algunas familias que quedaron por fuera del programa de reubicación se vieron en la obligación de interponer medidas legales que le garanticen el derecho a la igualdad y les permitan, de esta manera, seguir luchando por mantener el tejido social y comunitario de los "chancleteros":

La mayoría de gente reubicable se fue porque eran 57 familias y apenas quedamos 10, entonces se fue en $90 \%$ más o menos y se llevó todo. Quedaban 10 reubicables, pero quedaron una cantidad que no eran reubicables porque ellos no le daban ese reconocimiento a todo el mundo. Al fin y al cabo quedamos 48 familias y esas 48 familias entutelamos al Cerrejón y, por medio de esa tutela, hoy en día es que gracias a Dios estamos negociando con ellos, estamos cerrando la negociación, pero por la tutela porque, sino, de pronto nos hubiesen expropiado porque ya la expropiación la estaban dando (W. Palmesano, comunicación personal, diciembre del 2016).

Así mismo, manifiestan que otro de los grandes problemas que los aquejan son los intermediarios en cada uno de los procesos, proyectos o negociaciones que se desarrollan con la mina, pues son estos intermediarios quienes sacan la mayor ganancia, representando generalmente la voz de la empresa y sin estar nunca a favor de las comunidades:

Porque es que aquí todo lo dan es por contrato: esa alimentación que están haciendo por parte del ICBF, en vez de tratarlo directamente, hace un contrato por otro. Ese contratista obviamente va a exprimir todo lo posible ese contrato para que le quede la mayor parte a él; cuando hay 
Vida campesina en el Magdalena Grande

contrato de por medio eso no van a hacer las cosas bien. Es lo mismo que la alimentación de los restaurantes escolares: a veces a muchos niños los mandan sin alimento para que se alimenten allá y se encuentra uno que le dan una cosita y en la mano. Total: así es todo, tenemos esa gran desventaja y no sé cómo mejorar esa parte con los niños, pero van a seguir muriendo niños (W. Palmesano, comunicación personal, diciembre del 2016).

Imagen 33. Caminando por las calles de Chancleta, La Guajira

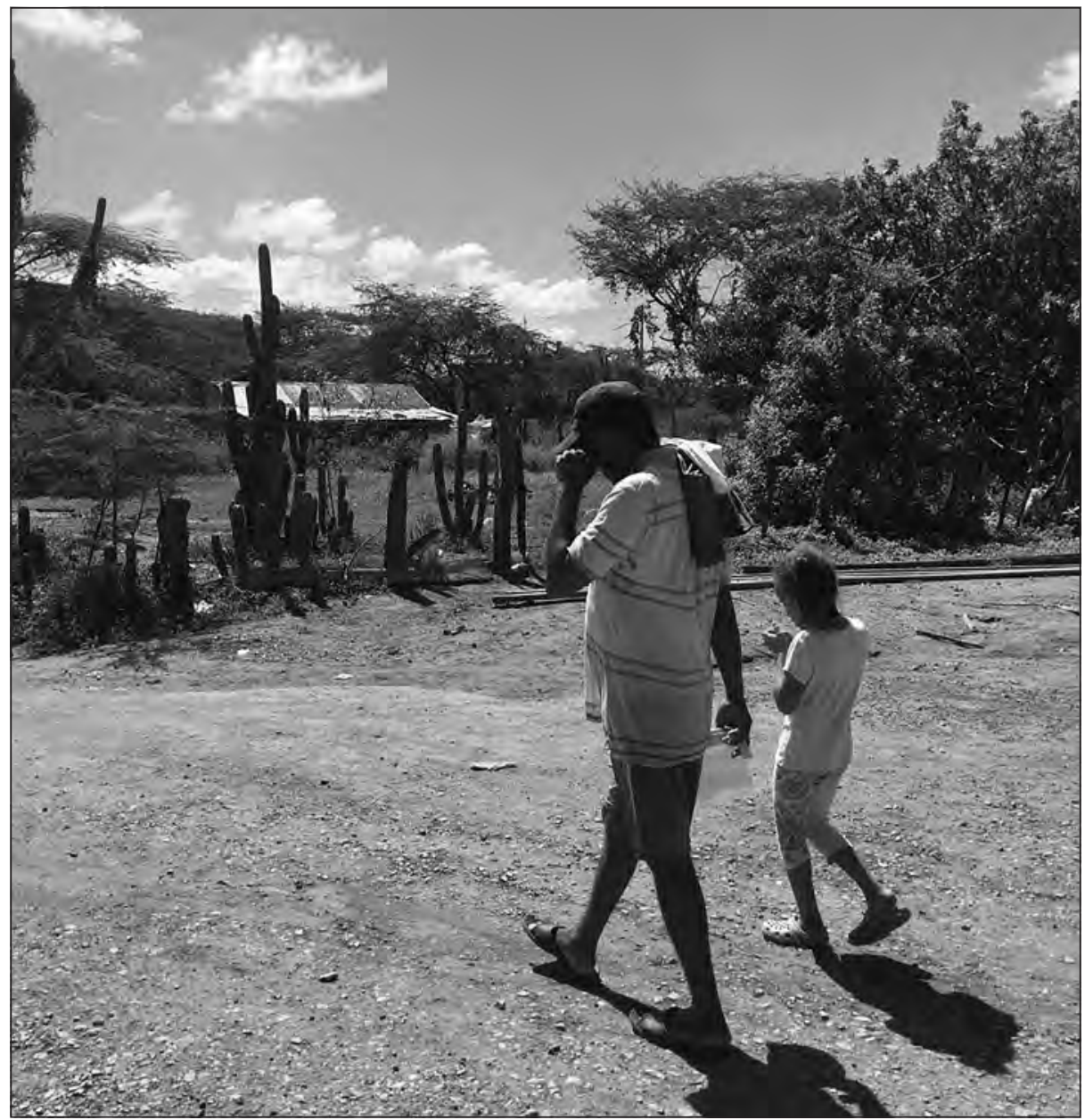

Fuente: Archivo Oraloteca (2017). 


\section{Una ancestralidad a punto de desaparecer}

Imagen 34. Preparando bollos de maíz en Chancleta, La Guajira

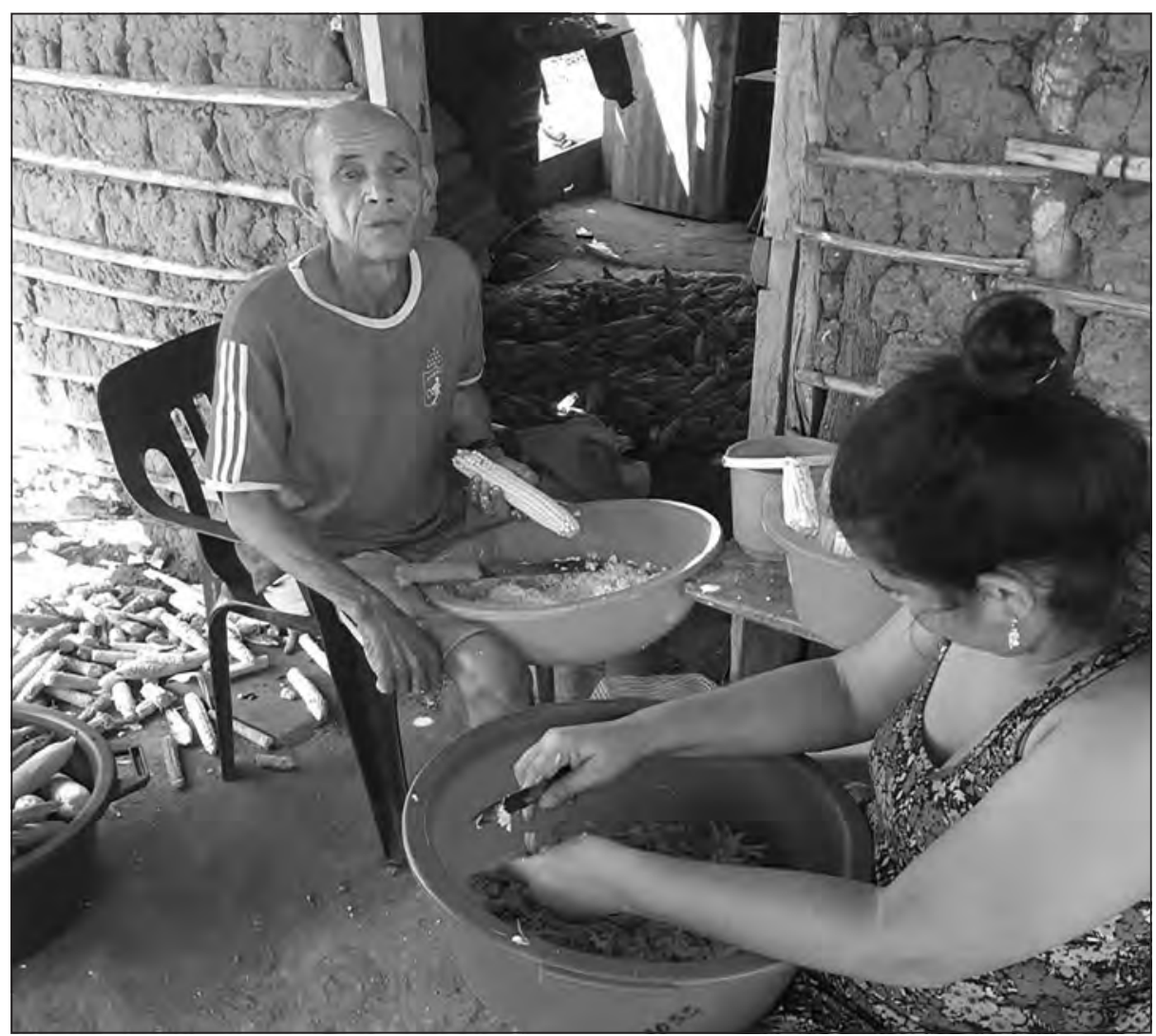

Fuente: Archivo Oraloteca (2017).

Las tradiciones y la identidad de esta comunidad como pueblo están hoy amenazadas, pues su historia ahora gira en torno a un conflicto ambiental con una empresa transnacional, ocasionando que su territorialidad se vaya desmembrando progresivamente y, con ello, la idea de un lugar llamado Chancleta:

Hemos pensado, para que el impacto del traslado no nos dé tan duro, radicarnos en un solo sitio todos y tener cada quien su casa en un conjunto cerrado. Aquí hay muchas cosas que van a cambiar: por ejemplo, 
Vida campesina en el Magdalena Grande

vamos a seguir siendo los chancleteros, pero nos vamos a radicar en el municipio de Barranca. Es difícil, estamos preocupados y asustados porque aquí nacimos y toda la vida hemos vivido acá, pero aquí se van a perder muchísimas cosas (R. Palmesano, comunicación personal, enero del 2017).

Así mismo, manifiestan que las personas mayores no han soportado el cambio de lugar; sin embargo, no hay las condiciones para que sigan viviendo en Chancleta. Esto preocupa profundamente a sus líderes y lideresas, ya que estas personas son la memoria viva de su cultura y tradiciones:

Esta comunidad ya va cumplir unos 300 años de existencia. Aquí ya carecemos de la compañía, de la presencia de nuestros abuelos, porque esto de la minería también fue acabando con cada uno de ellos. Los que se fueron duraron muy poco, unos 2 o 3 años, murieron... como que el traslado las enfermas, no sé qué pasa, pero al momento de trasladarse están durando poco nuestros adultos mayores. Hemos apreciado eso: los adultos mayores apenas salen de acá de la comunidad en seguida mueren.

Un ejemplo de cómo ha cambiado el territorio es el arroyo Cerrejón, que aún existe, pero apenas dura con agua unos 45 días más o menos después del invierno: acabaron con ese ícono que nosotros teníamos acá, el río era un espacio de esparcimiento y de diversión en donde se hacía pesca; en Semana Santa el río Ranchería era una fiesta. Obviamente, si no hay en la Ranchería, en el Cerrejón mucho menos porque la Ranchería es afluente del Cerrejón. Cuando digo Cerrejón es el arroyo Cerrejón porque hasta eso le usurparon al cerro. Ese cerro era muy importante para nosotros porque allá también había agua, pero la empresa ya nos quitó esa oportunidad de visitar al cerro, ya no se puede pasar para allá, está el ejército y no deja pasar a nadie para allá [...]. Esos eran sitios importantes para nosotros que hoy en día quedan en nuestras mentes, el recuerdo, la nostalgia de que existieron, pero ya hoy en día no podemos disfrutar ni del río Ranchería ni del arroyo Cerrejón, sino únicamente en el invierno. Ahorita mismo está corriendo, pero tiene como un mes que no llueve, ya en enero está seco (W. Palmesano, comunicación personal, diciembre de 2016). 


\section{El Sur de La Guajira y la sombra de la montaña: voces campesinas de Villanueva, el Molino, Urumita y la Jagua del Pilar}

Imagen 35. La Serranía del Perijá desde Urumita

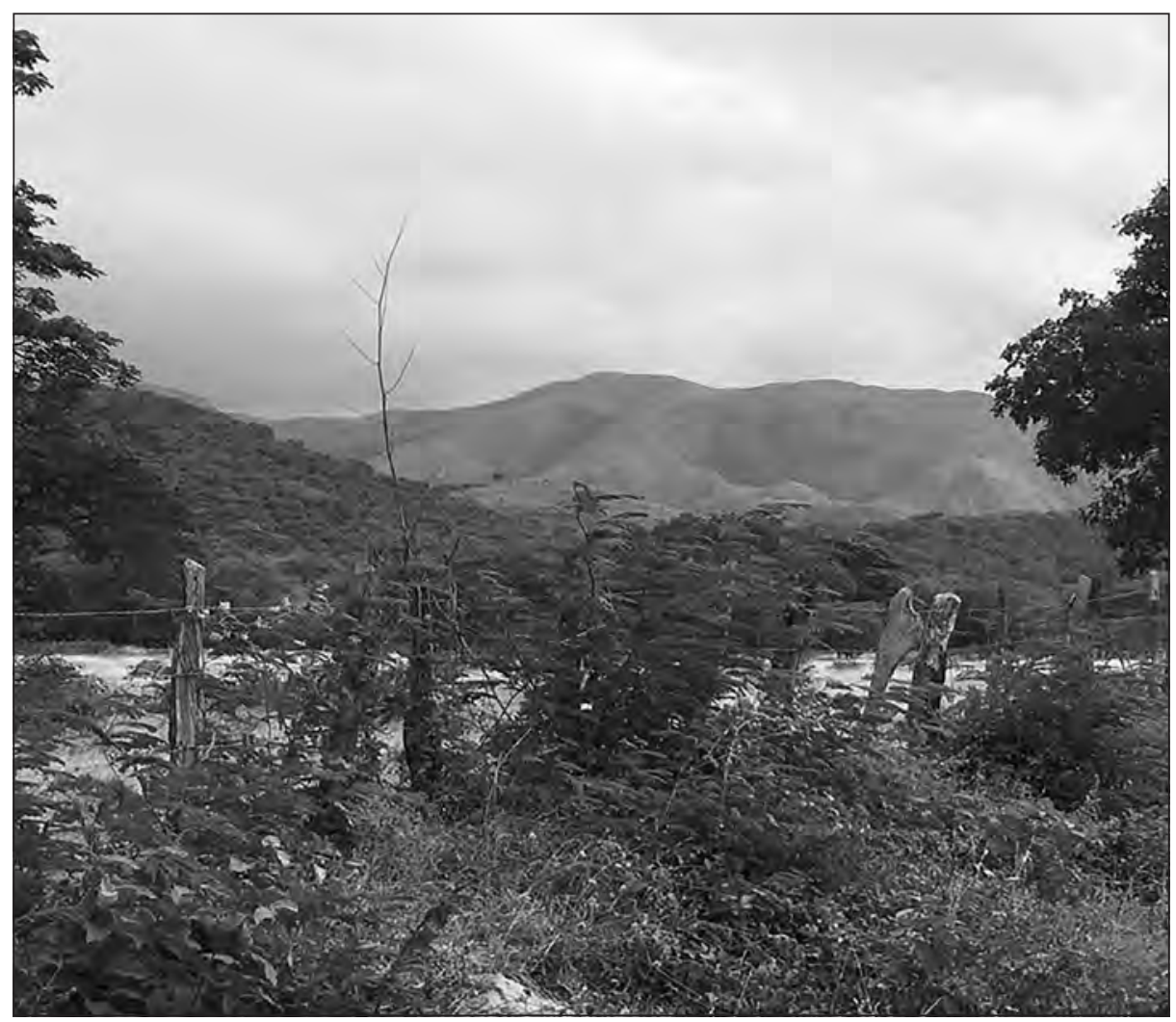

Fuente: Archivo Oraloteca (2017).

Los municipios de Villanueva, el Molino, Urumita y la Jagua del Pilar están ubicados en el extremo sur del departamento de La Guajira. Son cuatro municipios consecutivos, distanciados uno del otro por aproximadamente diez minutos, que se encuentran al pie de la Serranía del Perijá; además, todas estas localidades se encuentran en la frontera con Venezuela. Una de las particularidades de estos cuatro municipios en relación con el acceso desde San Juan del Cesar, La Guajira, tiene que ver con 
Vida campesina en el Magdalena Grande

las amplias y planificadas avenidas que conectan la carretera principal con cada municipio. Es decir, una especie de entrada especial para cada pueblo, algo que contrasta con el ordenamiento urbano de la mayoría de municipios del departamento de La Guajira, donde las carreteras intermunicipales cruzan y, en ocasiones, dividen los núcleos urbanos. No es gratuito que suceda esto, pues el ordenamiento planificado se debe, en buena medida, a que este circuito subregional del Caribe fue, sin duda alguna, uno de los más prósperos y organizados de la región. En esta zona hubo bonanza del café, el arroz, el algodón, entre otros.

\section{Poblamiento}

Para indagar sobre la historia del poblamiento de estos territorios debemos remontarnos a finales del siglo XVI, cuando los misioneros capuchinos "fundaron los pueblos de Camarones, el Molino, Cañaverales y Villanueva" (Mackenzi citado en Polo, 2009, p. 49), mientras que otros procesos fueron un poco más recientes, como el caso de la Jagua del Pilar, el cual narran sus pobladores de esta manera:

la Jagua del Pilar es un municipio nuevo, uno de los más nuevos del departamento de La Guajira. Tiene aproximadamente 18 años de ser municipio y fue descubierto por la señora María Concepción Loperena. Del Plan podemos decir que es el único corregimiento que tiene la Jagua Del Pilar y tiene tres veredas: Sierra Montaña, el Piñal y Berlín. El Plan fue descubierto por el señor que era administrador de un terrateniente oriundo de Villanueva y [al] que se le estaba perdiendo el ganado. El administrador siguió los pasos por donde se llevaron el ganado y subiendo loma arriba logró llegar a una parte en la cual había cinco chozas habitadas por indígenas. Él, al percatarse de que había cinco chozas con indígenas y él andaba solo, se devolvió. Al día siguiente, fue con los trabajadores de la finca y el ganado se lo trajeron y los indígenas habían quemado las chozas y se habían marchado de ahí. De ahí él fabricó unas casitas en compañía de los compañeros: fabricaron una, fabricaron dos, y así fueron fabricando, y fue de ahí [de] donde se originó el Plan y Sierra Montaña porque fue descubierta por el señor Juan Montaño (G. Fragoso, comunicación personal febrero del 2017). 
Vida campesina en el Magdalena Grande

El campesino de esta zona tenía un acceso a la tierra mucho más fácil y libre que en otras zonas del país, lo que generó que se diera una colonización importante en la zona del Perijá. Al mismo tiempo, fue tan próspera la producción que había trabajo incluso para campesinos que venían de otras zonas del país y que terminaban trabajando para algunos campesinos de la zona que se convertirían en medianos productores de la zona y cuyo rol cambiaba, pues pasaban de ser un tipo de campesino que trabaja con sus propias manos a ser productores que contrataban mano de obra para mayor capacidad de explotación de sus tierras. Sin embargo, según manifiestan sus pobladores, este fenómeno es reciente, pues la tradición de las comunidades era heredar la tierra de sus familiares para, de esta forma, mantener cohesionado el tejido social y asegurar la pervivencia de las familias en el territorio. Sobre esto nos relatan pobladores de Urumita y Villanueva respectivamente:

Bueno, estos municipios eran anteriormente corregimientos de otra cabecera municipal y dependíamos todos del campo. Esto se ha dividido en varias etapas. Acá ancestralmente la finca, inicialmente los propietarios eran familiares; en el caso mío, era mi abuelo. Él, con todos sus hijos, mi abuelo tuvo 20 y pico de hijos... fue la tierra cediendo. Hoy e[n] día yo soy el propietario nieto y así se ha venido trabajando la mayoría, se va cediendo como una herencia. Hace unos 15 o 20 años atrás era netamente poblado por personas de acá, nativas del propio municipio. El dueño de la finca era de acá y, en conjunto con su familia, sacaban adelante las actividades que había que hacer. Hoy en día no, hoy se encuentran bastantes personas e, incluso, propietarios de tierra que no son de acá de Urumita (E. Saurith, comunicación personal, enero del 2017).

De la edad mía, casi todos éramos de aquí y a lo último fue que vino gente del interior y se fue metiendo. Primero vinieron con el negocio del tomate, le[s] fue gustando la tierra, fueron comprando y algunos se metieron a la cordillera. Ya lo último fueron los que vinieron con negocio grande ya en el centro de graneros. Aquí todos los negocios grandes que hay son cachacos (J. De Los Reyes, comunicación personal, enero de 2017). 
Vida campesina en el Magdalena Grande

\section{Nostalgias y esperanzas de una bonanza agrícola}

Una de las características que beneficia la producción agrícola en estos municipios es la presencia de la Serranía del Perijá, la cual brinda a la población diversidad de climas propicios para la diversificación de productos según las estaciones del clima. Sin embargo, algunos pobladores reconocen que en el ejercicio de poblamientos de estos territorios fue mucho el daño que se produjo sobre este sistema montañoso, al punto de que algunos páramos desaparecieron y las fuentes de agua perdieron su caudal, obligando a las poblaciones a crear estrategias comunitarias para compartir el preciado líquido en tiempos de verano:

Anteriormente, todo eso era montaña. Hace unos 40 o 50 años para acá fue que comenzaron a descombrar el páramo y todo eso se ha acabado ya por culpa de nosotros será, porque eso echaron a descombrar y descombrar y los páramos se desaparecieron de por ahí. Ahora la gente como que está llegando al paramito otra vez me dicen [...]. Aquí hay una acequia maestra, se turnan los campesinos para regar sus cultivos; por decir, hoy le toca a Juan, mañana le toca a Ovidio, al día siguiente le toca a Gilberto, y así sucesivamente, pero contamos con la desdicha de que, como lo había anotado antes, el río Marquesote se nos está secando porque necesitamos...qué será de pronto por el verano largo porque aquí los veranos son largos, son desde noviembre hasta marzo. Esos veranos largos secan cualquier cantidad de árboles. Necesitamos de pronto que Corpoguajira meta la mano y nos plante árboles en la rivera de los ríos para que en el mañana tener nuestra propia agua (A. Olmedo y G. Frangoso, comunicación personal, Villanueva, la Guajira, enero del 2017).

Al visitar cada uno de estos municipios del Sur de La Guajira y conocer su arquitectura se tiene la impresión de un pasado próspero, propio de un pueblo que, durante buena parte del siglo XX, tuvo que dinamizar la economía de la región. A su vez, se nota que existieron allí grandes empresarios o que, por lo menos, fueron puntos clave de abastecimiento de ciudades grandes de la región Caribe. La Serranía del Perijá ha sido el principal testigo de la historia agraria de estos municipios. 
Por supuesto que esto tiene sentido, pues este sistema montañoso ofrece la mayoría de pisos térmicos, lo que permite el desarrollo de multiplicidad de cultivos, haciendo que las familias campesinas, en muchas ocasiones, se dedicaran a rotarse durante los tiempos de cosecha y producción. Esto generaba una especie de población flotante que durante una temporada estaba en la Serranía y durante otra se mantenía en el casco urbano, lo que generaba una relación campo-ciudad atravesada por relaciones de parentesco.

Imagen 36. Cultivos en la zona rural del Molino

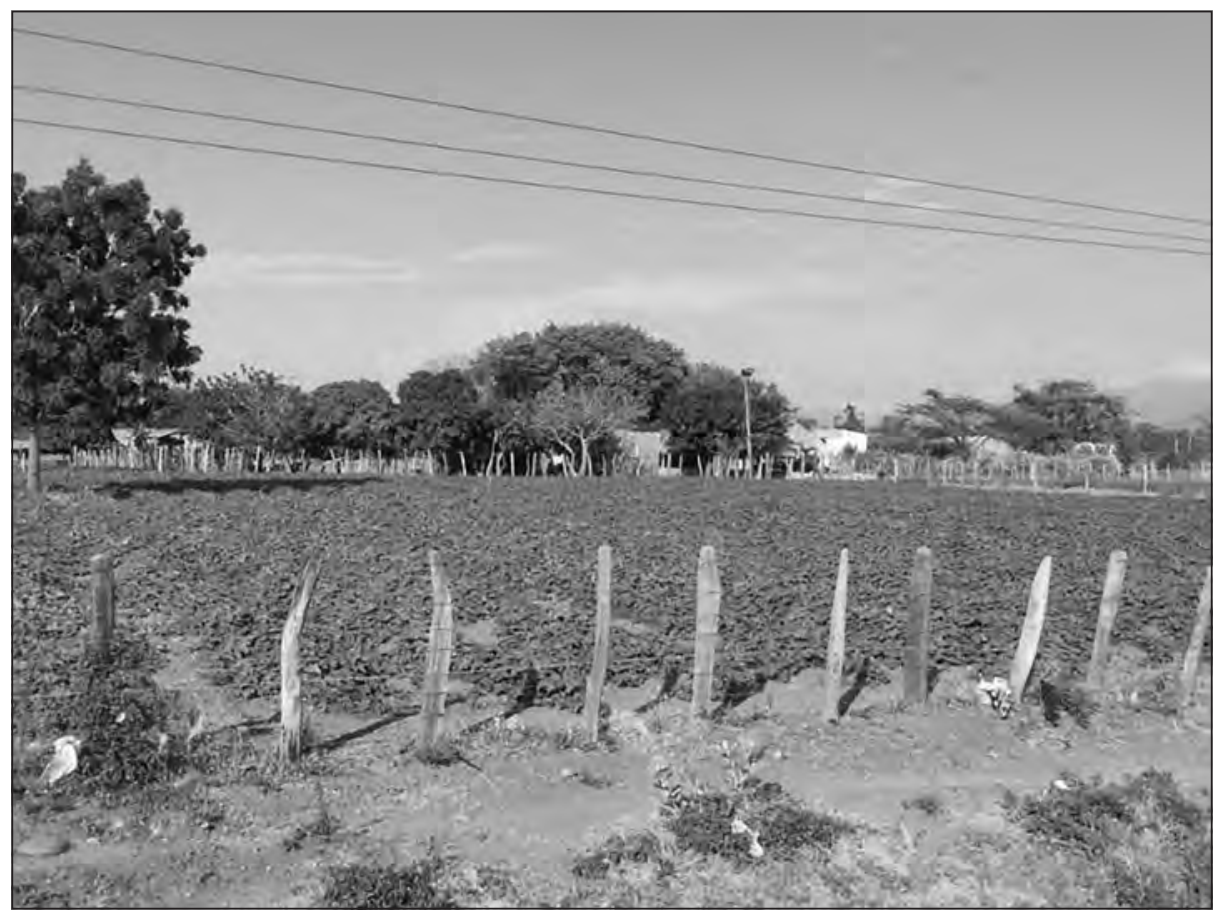

Fuente: Archivo Oraloteca (2017).

Los campesinos y campesinas de estos municipios relatan con orgullo las épocas de antaño, tiempos de una próspera producción agrícola que llevaban a los municipios al punto de ser despensa de los principales centros urbanos de la región y fuente de generación de empleo para pobladores de todo el país: 
Vida campesina en el Magdalena Grande

Aquí el 90\% vivimos del campo. El que no tiene el potrerito, tiene la finquita de café; en fin, tiene acceso al campo todo el tiempo. Somos netamente campesino[s] y vivimos es de eso, de la cordillera, y hemos pasado mucho trabajo. Desde que mi papá nació, en el año 1892, y él nos contaba cómo eran las cosas cuando no había ni siquiera vías de penetración en carro, sino camino de herradura, todos nos íbamos para la finca a ayudar a mi papá $[\ldots]$. En ese entonces la pasaba muy rico porque yo criaba mis animales, venía al pueblo y vendía las verduras, los huevos de la gallina, me iba otra vez en mi burrito porque en ese entonces no había carreteable, sino animales [...]. Era una zona de agricultura de todo, porque daba de todo: plátano, malanga, yuca, cebollín, el repollo, arracacha; yo sacaba en mi finca, para que vea usted, semanal de 40 a 60 quintales de arracacha, toda la semana, todo el año [...]. Nosotros cultivábamos el plátano, la yuca, [el] aguacate, [la] naranja y, ya a lo último, llegué a tener 70 reses y con eso nos sosteníamos, traíamos el queso y vendíamos la leche. Nosotros éramos de tener un cultivo de papa y salían [de] 100 a 130 quintales de papa, cebollín, arracache era por cantidad [...]. En mi época tuve la oportunidad [de] que mi padre fuera agricultor; se hacían muchos cultivos de maíz, yuca. Esas épocas eran buenas: se veían cultivos de algodón, sorgo, esos cultivos eran muy buenos y la gente de escasos recursos, en las épocas de cogidas de los productos, se generaba mucho empleo porque le tocaba a uno buscar personal para coger el maíz, sacar la yuca, cortar el sorgo... esas épocas fueron muy buenas (E. Saurith, S. Ramírez, I. Zabaleta y J. De los Reyes, comunicación personal, enero del 2017).

Y aunque, como lo mencionamos anteriormente, existía una fuerte relación campo-ciudad, esta se fundaba solo en las relaciones de parentesco y de propiedad sobre la tierra porque a nivel de infraestructura no existe relación más efímera que la de los centros poblados y las zonas rurales en la Serranía del Perijá. En cualquiera de estos cuatro municipios sus respectivas entradas a los carreteables que dirigen a las partes altas del Perijá ejemplifican lo que precisamente sucede a los pocos kilómetros de adentrarse: desaparece el carreteable e inician los caminos de herradura de lo que se puede decir es una de las áreas más fértiles de Suramérica. Muchos campesinos insisten en que no hay forma de mantener sus producciones; su reflexión gira constantemente en torno al abandono del Estado. 
Imagen 37. Acceso al Perijá desde Urumita

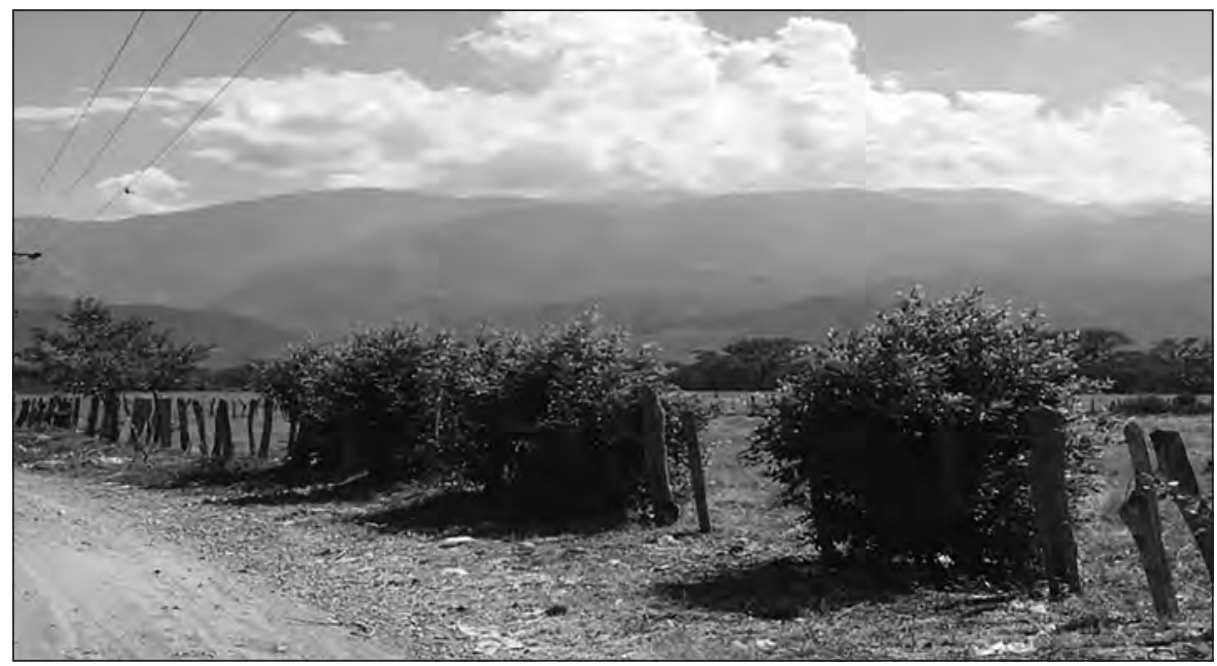

Fuente: Archivo Oraloteca (2017).

Era bueno, para allá era bueno, ahora es que está poco porque ahora toda la gente coge para vías de Manaure. Los de aquí habemos como tres nada más que corremos para acá, por las vías de acceso, y hoy nos tiene acabado con todo eso, las veredas, los caminos. Estamos sin vías. A uno le da dolor pasar en esos caminos de comunicación [...]. Los habitantes de allá no bajan los productos hacia la Jagua porque les cuesta más el transporte que producirlo. Entonces Manaure es un municipio aledaño que ya pertenece al departamento del Cesar, entonces los campesinos prefieren bajar los productos hacía Manaure porque ya la vía de acceso está mejor, o sea que ya pueden subir carros porque hay placa, huellas y eso. De la vía de aquí de La Jagua al Plan le hace falta tres kilómetros de placa huella que ojalá el Gobierno Nacional o Departamental nos colaborara en ese sentido para que nuestros campesinos nos bajaran los productos aquí a la Jagua del Pilar, porque ya estando la vía de acceso en buen estado sería el transporte más barato y así ellos podrían bajar sus productos que producen en el campo [...]. Para el interior la gente trabaja porque tiene mucha ayuda, pero aquí no, por aquí no hay la ayuda que tienen para allá, allá los carros llegan a las casas y fincas, por aquí no, tenemos que ir a seis horas a lomo de mula porque no tenemos ni siquiera vías, entonces eso 
Vida campesina en el Magdalena Grande

ha echado a perder también a la gente que no quiere trabajar, ya la gente no quiere trabajar (O. Castellanos, G. Fragoso y A. Olmedo, comunicación personal, febrero de 2017).

Otro problema que afectó y que aún sigue afectando en cierta medida el normal desarrollo de las actividades campesinas por parte de los pobladores de los municipios del Sur de La Guajira es la situación de orden público que se vivía y aún se vive en el territorio. El conflicto armado, sumado a la diminuta presencia del Estado en la zona, generó que el campesino de esta subregión se fuera desplazando progresivamente hacia los sectores urbanos:

Bueno, el principal problema que teníamos es que no nos dejaban trabajar los grupos armados, esa es una de las cosas que acabó más este pueblo. Si yo estaba trabajando y llegaba a mi casa un grupo: "me llevo esto", coge esto y esto también; los grupos aquí acabaron con la agricultura y con todo. En mi finca había 100 gallinas ponedoras; cuando yo salía y llegaba otra vez a la casa estaban $4,6,8$. Llegaba[n] 3, 4 mula[s] y cargaban sin decirle a uno, cargaban y se iban. ¿Usted qué hace cuando está trabajando y que otro llegue y se lleve lo que tiene?, ¿para qué trabaja entonces? No debe trabajar y uno tiene que vivir humillado porque llega un grupo de esos a su casa y usted está solo, tiene que dejarlo que haga lo que quiera (A. Olmedo, comunicación personal, enero de 2017).

$\mathrm{Y}$ aunque algunos han intentado regresar, manifiestan que no tienen ningún tipo de garantías para permanecer en el territorio y que, mucho menos, se les ha ofrecido algún apoyo desde el Estado, pues lo único que les ofrecen son créditos:

Aquí ha[n] llegado a Urumita unos programas de crédito: el alcalde dice que va a servir de fiador: "les vamos a prestar 5 millones de pesos para que vuelvan al campo", pero resulta que nosotros vamos al campo y la cosecha no sale buena para pagar esos intereses tan altos y cuando venimos a ver está un visitador del Banco Agrario acá y nos dice que "su cuenta va a cobro judicial y está debiendo tantos millones de pesos"... ¿con qué lo pagamos? Nosotros aquí los campesinos de Urumita, y creo 
Vida campesina en el Magdalena Grande

que de todo el Sur de La Guajira, no estamos en condiciones de adquirir crédito; estamos en condiciones es [de] que nos subsidien nuestra actividad" (E. Saurith, comunicación personal, enero del 2017).

Otro factor que ha afectado la actividad agrícola en estos territorios es el envejecimiento del campo, como lo manifiestan sus habitantes. Hoy día la población que sigue cultivando la tierra está conformada por personas mayores que ya no tienen la misma fuerza que antes; por su parte, la población joven no está interesada en trabajar la tierra, sino que prefiere otras actividades como la mina o empleos informales en los centros poblados:

En mi finca, en los tiempos que cogía café, yo tenía hasta 30 hombres trabajando allá; hoy en día aquí en el pueblo no consigue usted, hay que buscar a los indios que vengan del Alta Guajira para que vayan a ayudar a uno porque la gente ya no quiere trabajar. Y la agricultura de aquí se ha acabado con eso porque los que trabajaban ya se han muertos y la juventud no quiere el campo. ¿Quién quiere coge[r] pal' campo? Nadie, hoy en día el trabajito que hay como las motos, anteriormente no había chanceros, no vendían nada de eso, hoy casi todo el mundo quiere estar vendiendo chance también [...]. Los que están en la Sierra son los mismos viejitos aquellos que yo dejé en ese entonces porque los jóvenes no quieren ir al monte, la gente no quiere trabajar, yo no sé qué está pasando, será que no hay los recursos también para irse para el campo (A. Olmedo y $\mathrm{S}$. Ramírez, comunicación personal, enero del 2017).

A pesar de todas estas dificultades, estos municipios siguen siendo reconocidos en el departamento por su alta capacidad de producción, la capacidad de emprendimiento de sus pobladores y el anhelo de volver a ser el emporio agrícola de antaño:

Por aquí por la Jagua siempre se ha cultivado maíz, yuca, fríjol cabecita negra (que es el de clima caliente), algodón se cultivó por muchos años, pero ya ese cultivo está en vía de extinción, ya no se cultiva, y se vive también de pequeñas ganaderías. Ahorita últimamente se ha implementado un cultivo que le ha dado muy bien al campesino que es el cultivo del melón de variedad "magallan" y "expedition" variedad FL, el cual en 51 
Vida campesina en el Magdalena Grande

días se está recogiendo el producto. Lo costoso del producto es la asistencia técnica, por eso se está cultivando en pequeñas cantidades, porque cultivar una hectárea de melón está costando alrededor de 12 a 14 millones de pesos, entonces no hay campesino que tenga esa cantidad de dinero. Para eso también le pedimos al Gobierno Nacional o Departamental que nos haga préstamos con bajos intereses para poder nosotros mejorar nuestra calidad de vida. Por aquí se está pensando organizar la cooperativa de meloneros de la Jagua Del Pilar, eso está en proyecto. Lo demás ha sido, cada quién: o sea cultivo tradicional, o sea cada quién hace su cultivo (G. Frangoso, comunicación personal, febrero de 2017).

Imagen 38. Iris Zabaleta, campesina y empresaria del Molino

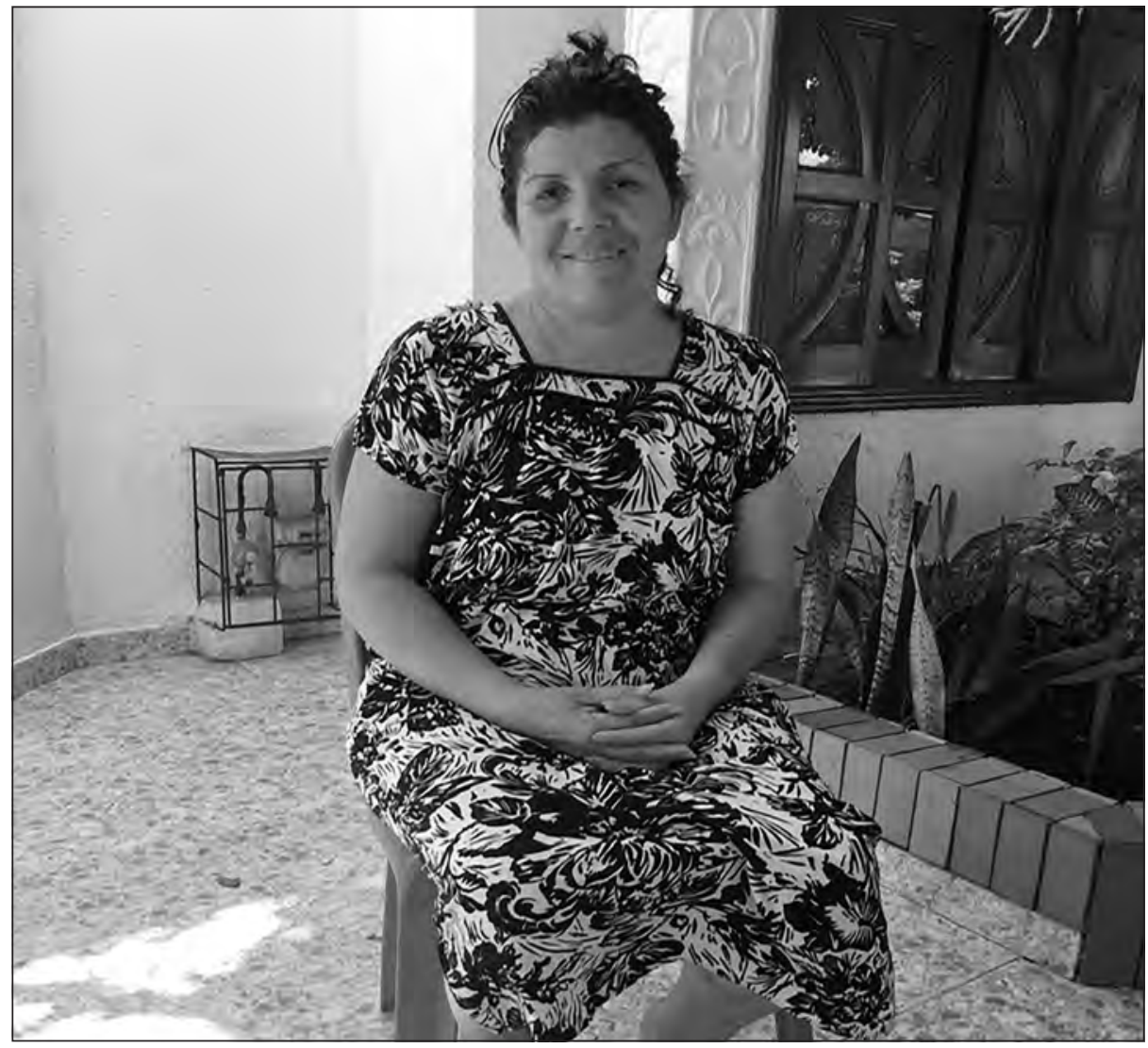

Fuente: Archivo Oraloteca (2017). 
Vida campesina en el Magdalena Grande

Uno de los elementos más importantes a resaltar en las formas de vida campesinas de las comunidades que habitan los municipios del Sur de la Guajira es el papel de la mujer en todos los espacios de la vida cotidiana, pues gran parte de las actividades económicas, políticas y culturales cuentan con una fuerte representación de las mujeres:

La mujer campesina es una mujer luchadora, le gusta mucho trabajar. Para mí ser campesina es un orgullo. Para mí coger un machete afilado e irme para el monte a tirar machete era una felicidad. La gente de antes trabajábamos y veníamos del monte y llegábamos a hacer almuerzo y lavábamos los "coroticos" y volvíamos a tirar machete, sembrábamos una cosa, sembrábamos la otra, era bello. Venía gente de afuera a trabajar también porque era una vereda de bastante movimiento. Había puesto de salud, había colegio, en ese entonces había mucho ambiente. Nosotros teníamos la finquita y llegaba gente a buscar trabajo y nosotros le dábamos trabajo, pero la mayoría de la gente era de ahí [...]. Las mujeres de Riohacha, Fonseca, San Juan, llegaban aquí los sábados a las seis de la mañana y recogían la carga; no quedaba nada aquí porque todo se lo llevaban [...]. La mujer en nuestra región, la mujer guajira es muy emprendedora y ejemplo de ella [es] Iris, quien te está hablando. Soy docente y a mí no me da flojera ir hasta el campo y si me toca recoger, cortar, lo hago; la mujer guajira es muy emprendedora y trabajadora, así como va a los cultivos personal masculino, así van mujeres: a coger maíz, a coger yuca porque es que uno es trabajador (S. Ramírez, I. Zabaleta y A. Olmedo, comunicación personal, enero de 2017).

\section{Organización campesina en el Sur de La Guajira}

En esta dimensión de la vida campesina en los municipios del Sur de la Guajira son pocas las referencias que se hacen a las formas tradicionales de organización campesina en estos territorios y es que el conflicto armado dejó heridas en las comunidades que no han podido sanar, siendo las organizaciones campesinas los principales objetivos de uno u otro grupo que hiciera presencia en el territorio. Las condiciones geográficas y el difícil acceso a este sistema montañoso, con la característica especial de ser zona de frontera, fueron un objetivo muy seductor para grupos 
Vida campesina en el Magdalena Grande

armados como las FARC y las AUC. Muy pocos en la zona se atreven a hablar del tema, pues todo indica que fueron episodios muy fuertes $y$ existe aún hoy en día alguna influencia de estos grupos en la región.

Imagen 39. Euclides Romero, dirigente campesino

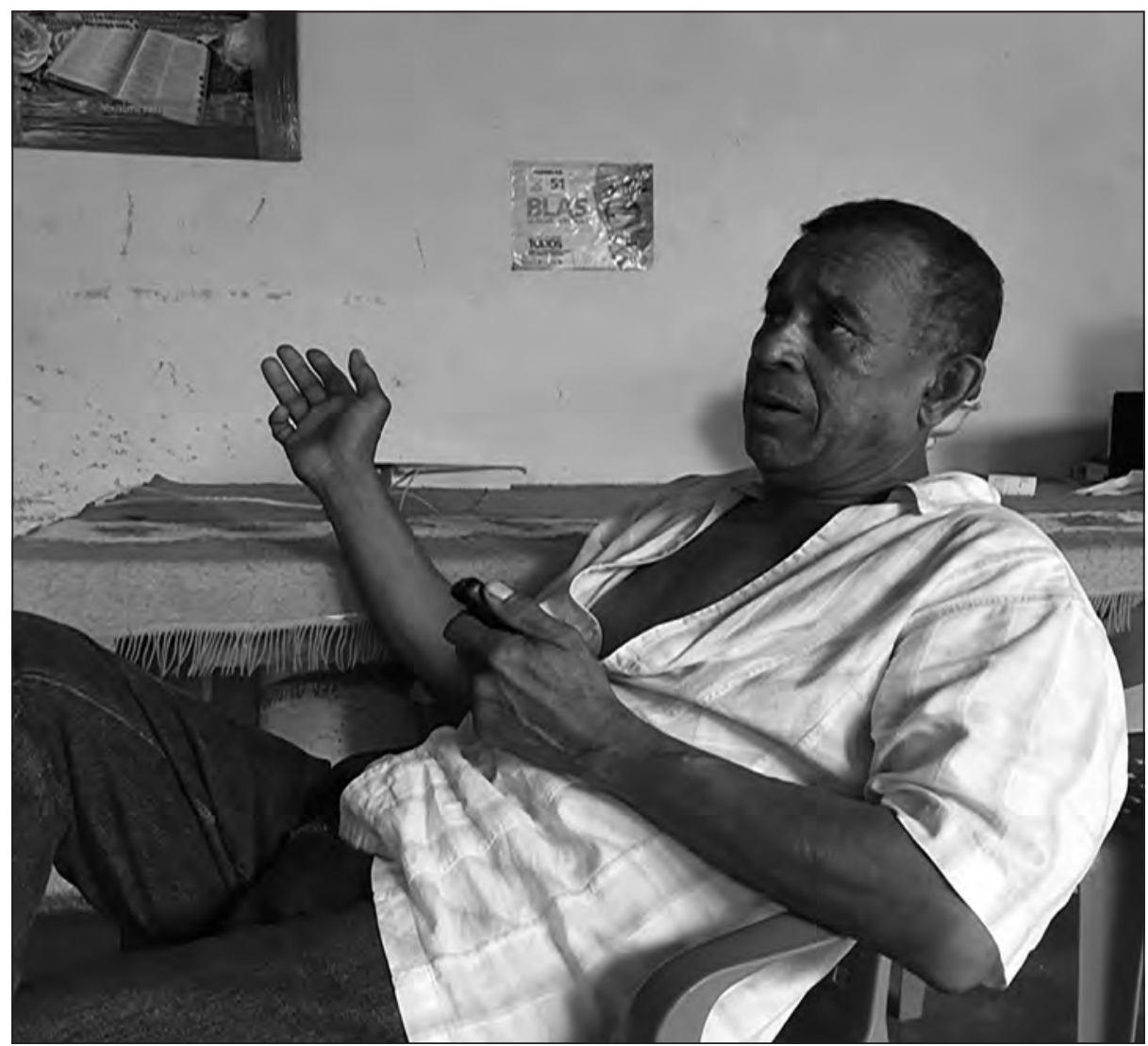

Fuente: Archivo Oraloteca (2017).

Esto, teniendo en cuenta también que en el momento de realizar este proyecto se encontraba ubicada en el Perijá guajiro una de las zonas veredales transitorias para el desarme y el reintegro de los combatientes de las FARC a la vida civil. Los campesinos del Sur de La Guajira manifiestan las grandes esperanzas que tienen en el cumplimiento de los acuerdos, pues esto garantizaría su regreso al campo: 
Vida campesina en el Magdalena Grande

Villanueva ahora es que se ha calmado porque Villanueva era zona roja y uno de los pueblos sanos que tenía la Guajira era Villanueva y después lo volvieron zona roja por la misma vaina. Por la situación que tenemos, este era un pueblo que usted podía amanecer ahí y no le pasaba nada, estaba cuidado, hoy en día no, hay tanto maleante [...]. Como en el 98 aparece la violencia. A nosotros aquí la familia, en el 99 todavía estábamos en la finca; en el 2001 para acá ya nos tocó salir de la finca. Por la delincuencia diría yo, los grupos unos con los otros y nosotros estábamos en el medio, de tal manera que nos tocó abandonar la finca porque había mucho de un lado y del otro, y usted sabe que cuando está así uno tiene que ser [im] parcial, ni para allá ni para acá, salirse uno [...]. Cuando ya esta gente se metió aquí a la cordillera toda la gente se fue desmoralizando de lo que hacía porque si usted tenía gallina llegaban ellos diciendo que se le mande la gallina, el que tenía la vaca y sacaba el queso y se le llevaban el queso, ¿para qué trabaja uno entonces? Ni lo que trabaja puede llevárselo a los hijos porque cuando viene a ver llegan por él y se lo llevan y no tiene uno ni a quién reclamarle. Así se fue perdiendo mucha finca y se fue la gente saliendo del monte [...]. Fue pasando el tiempo y con la llegada de la violencia ya la gente se fue atemorizando. Después, me fui para Venezuela y tenía una finca productiva, pero vino un desalojo de allá y se quedó el Gobierno venezolano con esas tierras. Entonces, en convenio con el Gobierno colombiano, quedaron en que el Gobierno colombiano nos iba a traer aquí y nos iba a indemnizar las tierras que nos quitaron allá y hasta la hora de esto, tengo 86 años, [no] he visto un peso, ni tierra ni nada. Yo como pude compré una finca con mi trabajo y crie mis hijos [...]. Ahorita mismo queremos volver a ese territorio, pero estamos con las manos vacías porque nosotros fuimos desplazados, estamos aquí volviendo a nuestro pueblo y queremos retornar a nuestra vereda, estamos esperando que se componga, aunque ya supuestamente la paz está lista, entonces queremos volver al campo a sembrar como antes lo hacíamos: sembrábamos el dominico, la malanga, el arracache, café, maíz, yuca, todo eso, y ya ahorita mismo casi ni se ve por aquí. Esa era mi vida en el campo: una vida agradable, sabrosa (S. Ramírez, A. Olmedo y J. De los Reyes, comunicación personal, enero de 2017). 
Vida campesina en el Magdalena Grande

Imagen 40. Gilberto Frangoso, campesino y dirigente sindical

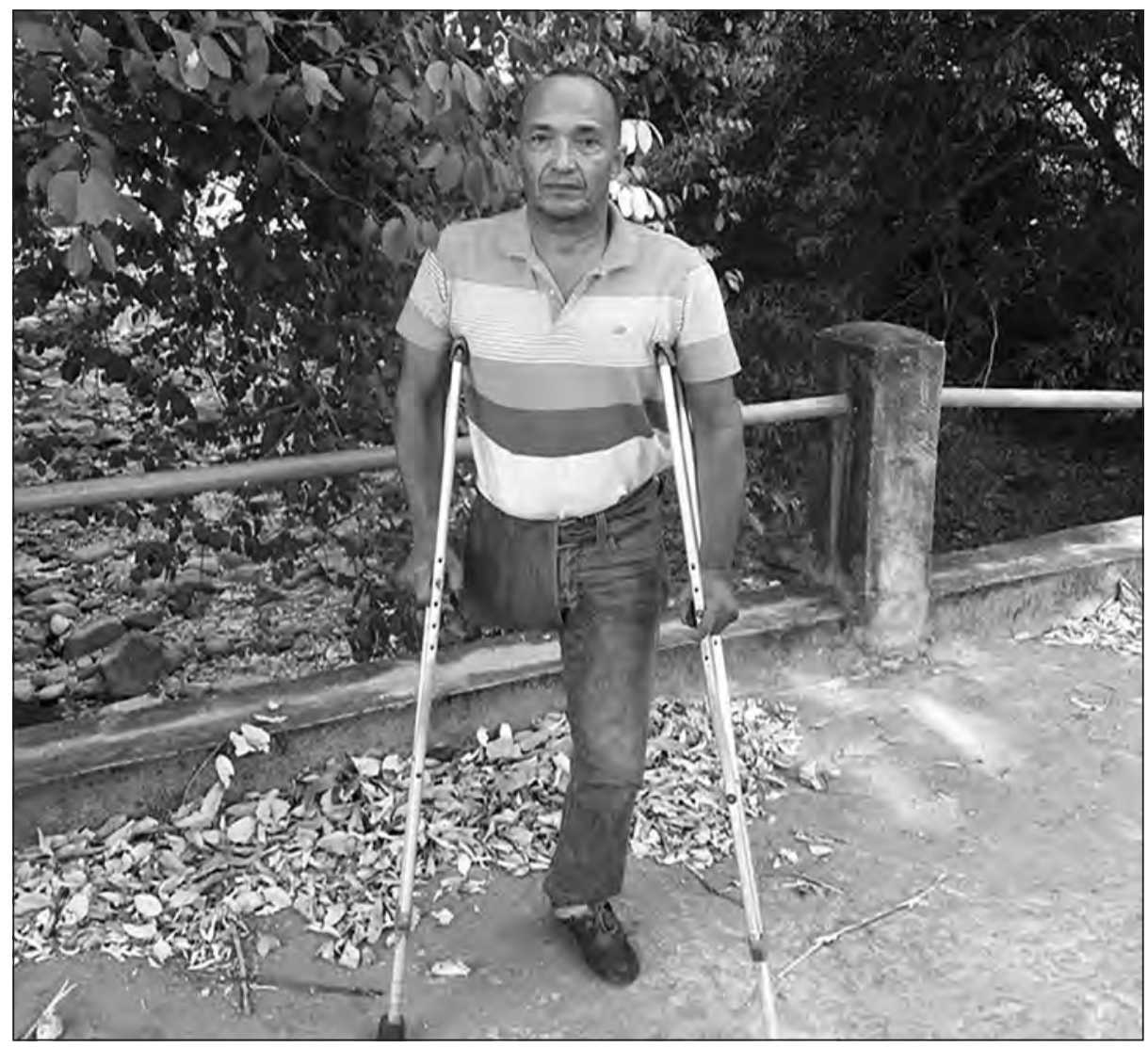

Fuente: Archivo Oraloteca (2017).

Y con ese anhelo y esperanza el campesinado del Sur de La Guajira prefiere pensar en el futuro que se avecina y dejar atrás las huellas de una época que solo dejó heridas en la población. Por eso ponen todos sus esfuerzos en generar nuevos espacios de organización que les permitan mejorar las condiciones de vida de sus pobladores y, aunque reconocen que no es fácil, consideran que con el apoyo del Estado a través de las administraciones locales se puede lograr este propósito, siempre y cuando el apoyo constante y las ayudas no sean de carácter paternalista que, como denuncian sus pobladores, son la mayoría de los proyectos que les envían: 
Nosotros necesitamos subsidios y que sean subsidios vigilados porque nosotros somos un poco indisciplinados, así como hace la Federación Nacional de Cafeteros: ella nos subsidió a nosotros una siembra de café, pero nos las vigilaban. Ese tipo de cuestiones nos dio resultado en nuestra zona [...]. Yo me atrevo a decir que el $80 \%$ de los campesinos de Urumita y [d]el Sur de la Guajira están reportados; todos quedaron mal y no porque querían quedar mal, sino por lo que le he comentado, [por] la violencia, [por] los cambios climáticos. Ese es el tropiezo que vamos a tener en cuanto a crédito [...]. Aquí llegaron unos programas regalados, pero yo les pregunté: ¿será que una familia vive con 4 gallinas? ¿Será que una familia con 4 hijos vive con 500 metros cuadrados? Como vino el Ministerio de Agricultura a traernos a nosotros las famosas casas malla, eso no da para vivir [a] una familia de 3 o 4 personas [...]. Ahorita se está trabajando con la cooperativa de caficultores que, en este momento, la sede la tenemos en Villanueva y cobija Fonseca, San Juan, el Molino, la Jagua y no sé si hasta Manaure esté poniendo café, acá en el municipio de Villanueva estamos trabajando con ella, nos están ayudando con recursos en cuanto a la mejoría locativa de las casas beneficiadas. Hay una gran expectativa y no solamente con el café, sino con otros productos, y contando que hay varios programas del Gobierno, estamos trabajando con la UMATA municipal, en donde muchos campesinos estamos inscritos. El día primero de enero me informaron de un proyecto de cultivo de malanga, pero me hablaron que era una malanga especial; por ejemplo, ahoritica estamos sembrando y nos está produciendo de 2 a 2 años y medio, pero esta es una malanga especial que de un año a año y medio se saca el producto y no solamente se va a sembrar en lo frío, sino que aquí en la parte plana se puede sembrar. Mientras estén llegando esas ayudas así el campesino se haya en ánimo y hoy más cuando ya de pronto estamos pasando el flagelo de la violencia en el que muchos campesinos se vieron obligados a venirse de las fincas [...]. Nosotros sabemos hacer café, nosotros sabemos hacer de todo, nosotros sabemos injertar aguacate, a nosotros nos ha capacitado lo que es el SENA, la Federación Nacional de Cafeteros, la Corporación Autónoma de La Guajira, el mismo Ministerio de Agricultura, lo que no tenemos es recursos para hacer las cosas que sabemos hacer porque, por un lado, estamos comprometidos en los bancos y, por otro lado, no tenemos recursos para empezar (J. De Los Reyes, E. Romero, E. Saurith, comunicación personal, enero de 2017). 
Vida campesina en el Magdalena Grande

Imagen 41. Tostando café en barrio de Villanueva

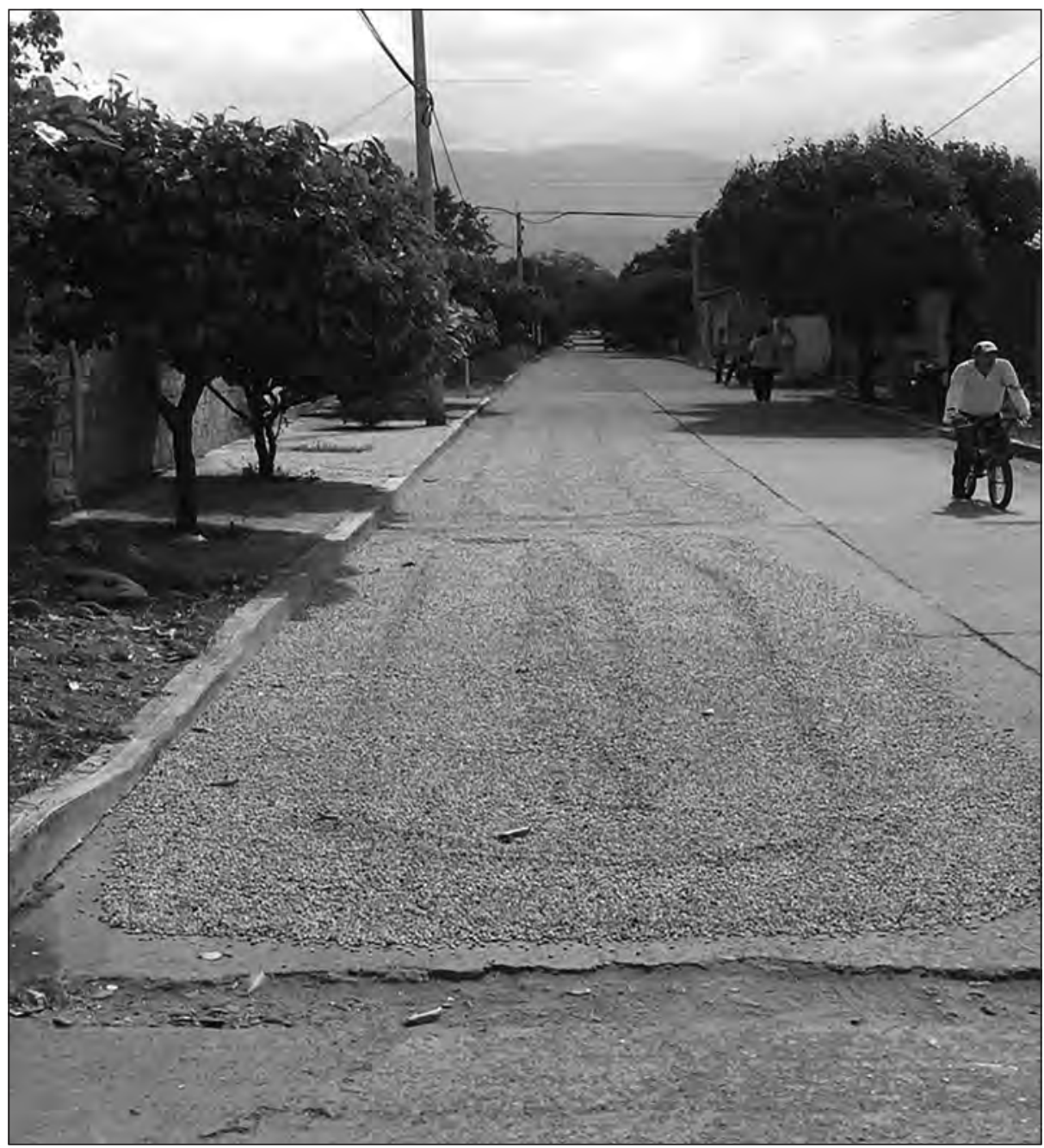

Fuente: Archivo Oraloteca (2017).

\section{Cultura y tradición en el Sur de La Guajira}

Hoy en día el campesino del Sur de La Guajira cree que el desapego a la tierra se fue generando por las condiciones que el conflicto armado generó, así como por la situación de infraestructura que, a su criterio, condicionó a su vez la ética y las costumbres de la región: 
Vida campesina en el Magdalena Grande

No sé qué decirle porque para arreglar las cosas como lo anterior es muy trabajoso, en las tradiciones de antes que teníamos había mucho respeto, ¿oyó? Ya hoy en día el respeto se perdió, ya hoy en día no hay respeto ni con los padres ni con los hijos, entonces eso está como trabajoso. Nosotros fuimos criados con mucho respeto en aquel tiempo, ya hoy en día no, no es igual, ya los papás no les pueden hablar a los hijos porque contestan mal, anteriormente no, anteriormente de pelao' usted le hablaba mal a un mayor y ese mayor lo acusaba con el papá y le pegaba un... hoy en día no, porque si usted le va a poner la queja al papá, el papá lo coge más bien a muñeca a usted y el hijo... Anteriormente se respetaba mucho, había mucha humildad en la gente, ya la humildad se acabó (A. Olmedo, comunicación personal, enero de 2017).

Imagen 42. Alfonso Olmedo, campesino caficultor

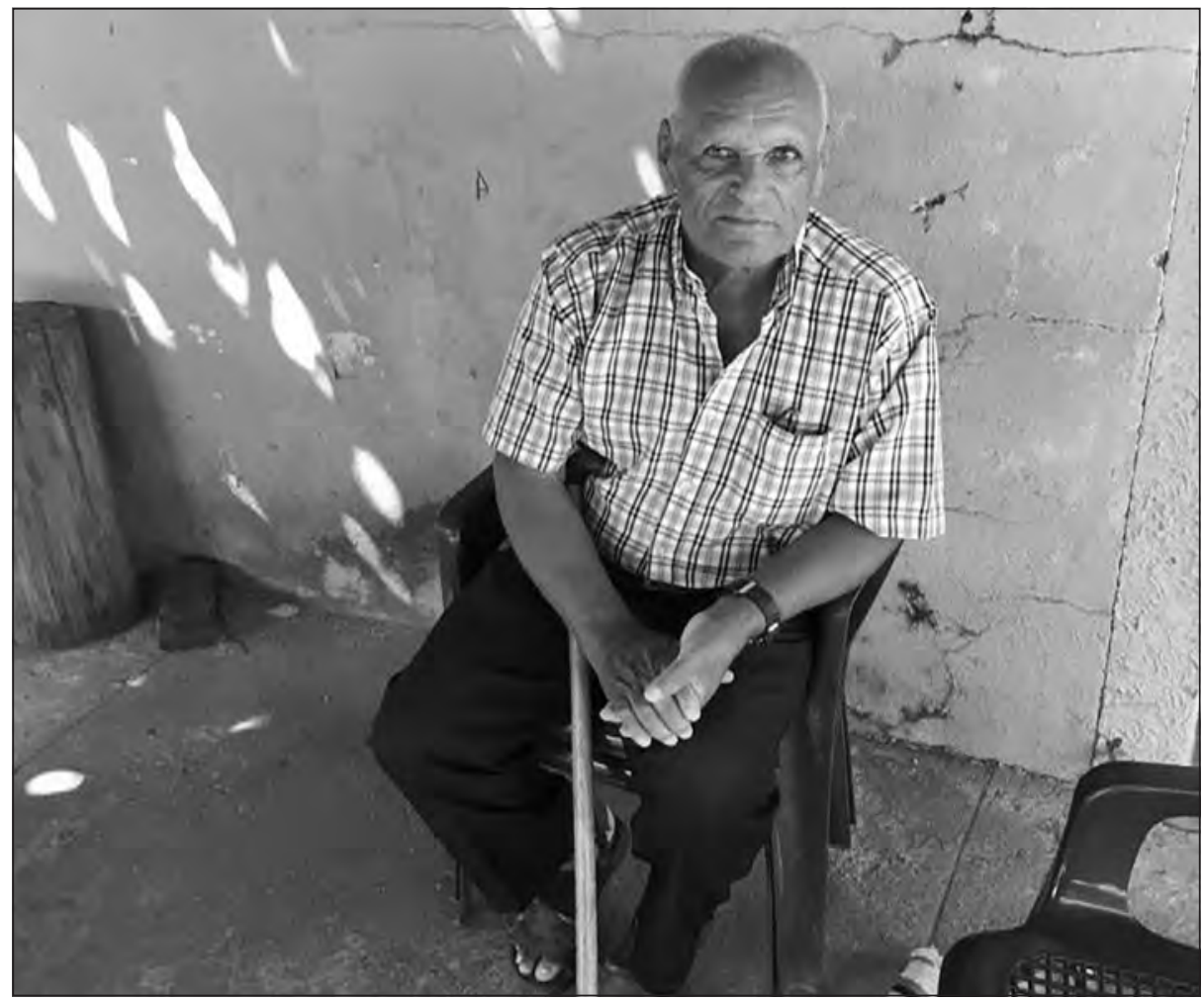

Fuente: Archivo Oraloteca (2017). 
Vida campesina en el Magdalena Grande

Es recurrente escuchar, según las fuentes consultadas, que las "tradiciones" y la identidad campesina están en proceso de desaparición; sin embargo, a su vez, la nostalgia de los buenos tiempos, contrastada por situaciones políticas, da pistas para comprender que el campesino de la zona es, sobre todo, un repositorio de costumbres y valores comunitarios que intentan sobrevivir en un mundo que predica la individualidad como credo.

Imagen 43. La Serranía del Perijá desde el Molino

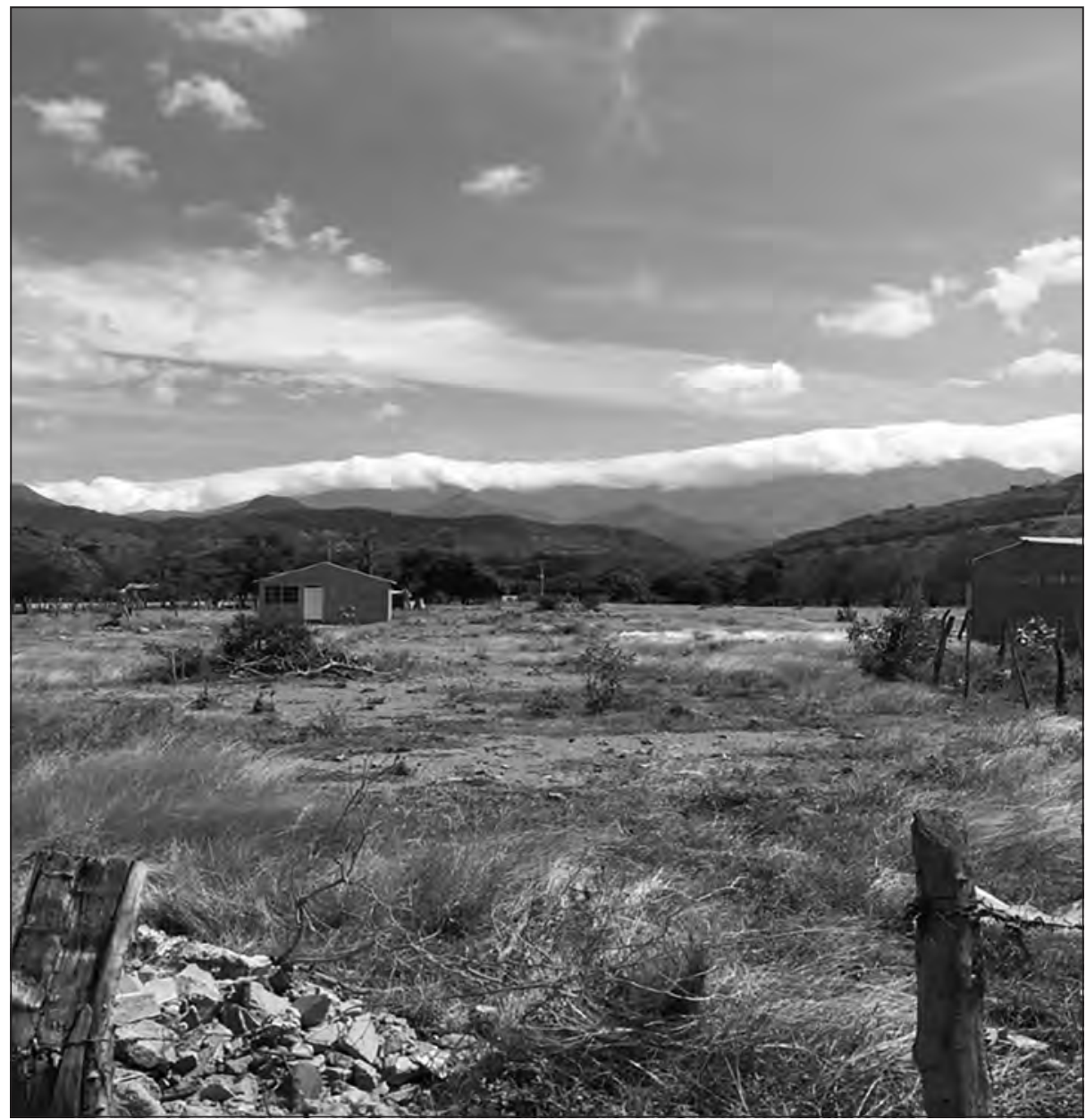

Fuente: Archivo Oraloteca (2017). 
Antes, por aquí había una tradición, por allá por la Sierra, que se llamaba "la gustadera". Eso era un hueso. Es la tradición de un hueso que tenía el ganado. Entonces, como se les acababa la carne y había una tradición de un hueso grande, y como tenían bastante gente, personal para darle la sopa, eso son tres días de tomar sopa (lunes, martes y miércoles), hacíamos tres días de tomar sopa. Entonces, decían: "vamos hoy a apartarle el hueso a Poncho Núñez, que es el marido mío", se lo devolvía: "la gustadera". El hueso era para darle sustancia a la sopa. No se lo podían comer, era como decir "vamos a apartarle el hueso a Juancho Núñez", entonces venía Poncho [a] hacer la sopa, entonces se hacía la sopa. Vamos a prestársela allá donde al primo Gilberto, o a Enrique Rumbo, o allá donde los Herrera, o allá donde Varón, o allá en el tal... y así, porqué las fincas quedaban cerca (A. Ustariz, comunicación personal, febrero de 2017). 



\title{
Vida campesina en el norte del Cesar
}

\author{
Mapa 3. El Cesar y sus municipios
}

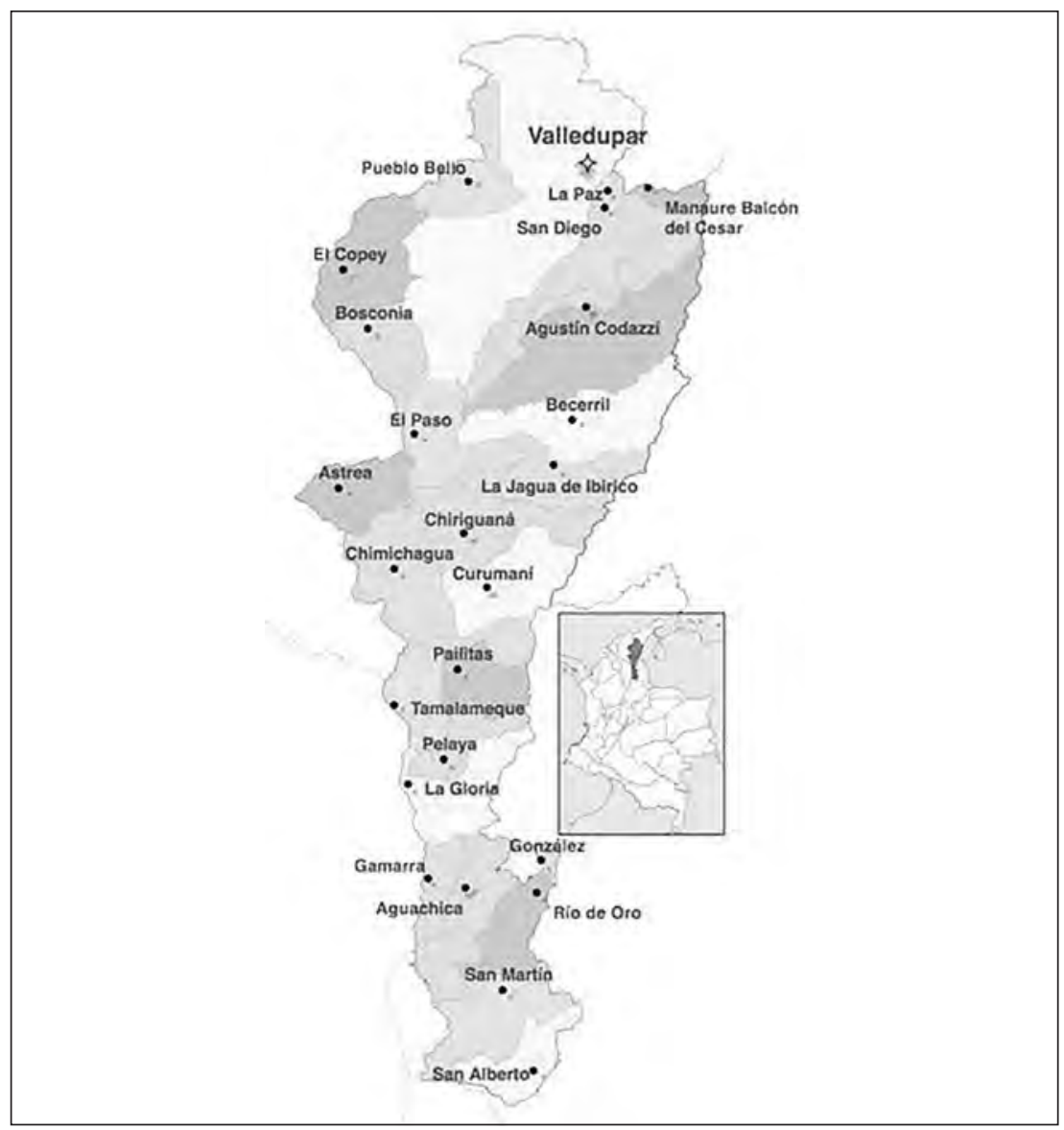

Fuente: Gobernación del Cesar (2020). 
El departamento del Cesar está ubicado al norte de Colombia, en la margen derecha del río Magdalena. Limita al sur con el departamento de Santander, al oriente con el departamento de Norte de Santander y con la República Bolivariana de Venezuela, al norte con los departamentos de La Guajira y Magdalena, y al occidente con los departamentos de Bolívar y Magdalena. En él podemos identificar como subregiones geográficas: la Sierra Nevada de Santa Marta, ubicada el norte del departamento, que es la montaña más alta al nivel del mar y que es compartida con los departamentos de La Guajira y el Magdalena; la Serranía del Perijá, al oriente del departamento, que sirve como frontera natural con la República Bolivariana de Venezuela, y la subregión del valle del río Cesar, conformada por los territorios planos del departamento y que, a su vez, está dividida en dos grandes zonas (el sur del departamento, cuyos territorios hacen parte del valle de la margen derecha del río Magdalena, y los territorios planos ubicados al norte del departamento, cuyos territorios hacen parte del valle que se extiende hacia ambas márgenes del río Cesar, el cual termina su recorrido en el complejo lagunar de la ciénaga de Zapatosa).

La principal actividad económica del departamento es la explotación minera, especialmente de carbón. Esta actividad representa más del 40\% de los ingresos del departamento, destacándose la presencia de multinacionales dedicadas a esta actividad como Drummond, Glencore, Vale y Goldman Sachs, las cuales se encuentran asentadas principalmente en los municipios de Agustín Codazzi, Becerril, Chiriguaná, el Paso y la Jagua de Ibirico, según datos de INDEPAZ, en el 2010. Por otro lado, la actividad agrícola se desarrolla en los pocos territorios no usados para los dos primeros renglones de la economía del departamento y representa tan solo un 9\% del PIB del departamento. En el intermedio de estas actividades económicas encontramos la ganadería extensiva y la agroindustria - representada en los monocultivos de palma- como actividades de gran relevancia para la economía del departamento y como variables fundamentales para entender las dinámicas territoriales del campesinado en esta zona del país. 
Imagen 44. Paseo en el río

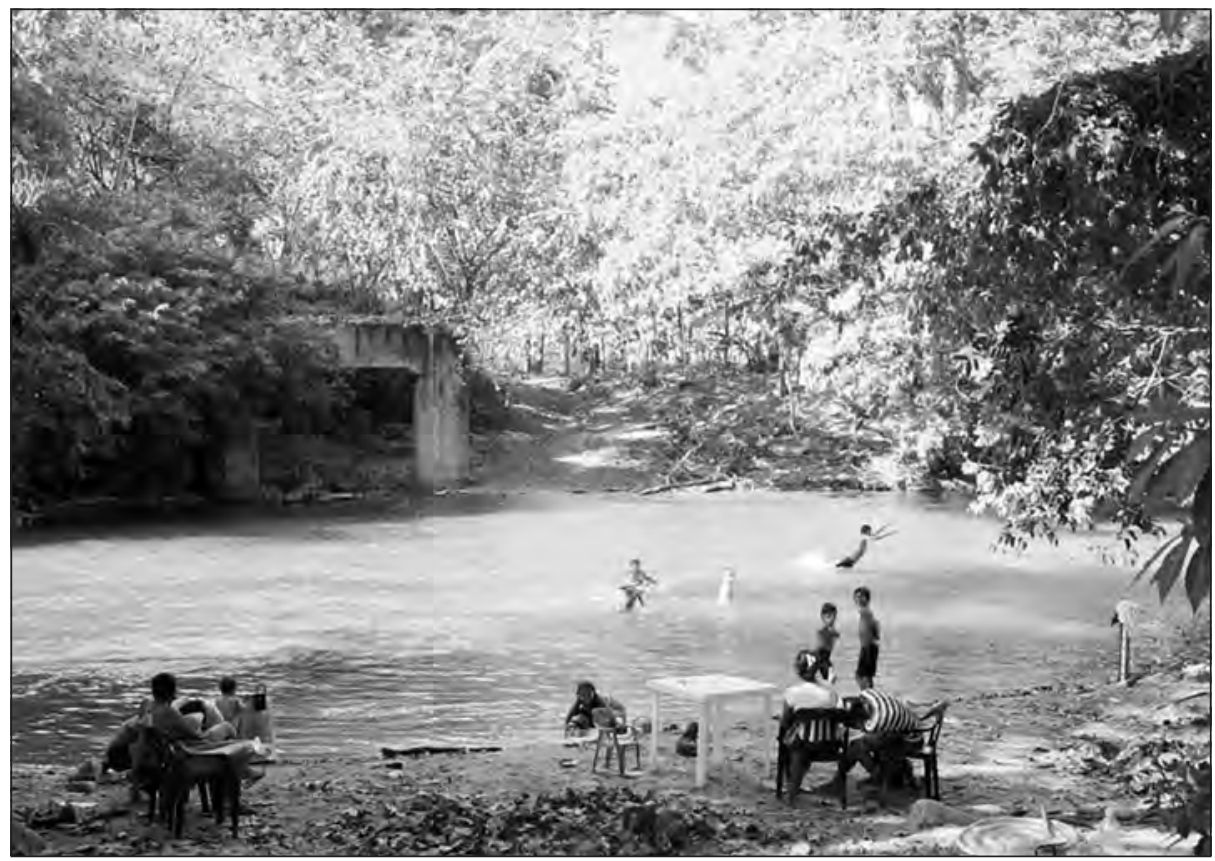

Fuente: Archivo Oraloteca (2017).

Aunque la pesca en el río Cesar no ha sido una actividad económica de relevancia para el departamento, muchas comunidades alternaban sus actividades cotidianas con pequeñas faenas en el río, lo que representaba una fuente de acceso a las proteínas necesarias para asegurar la dieta de sus familias. Sin embargo, todo cambió drásticamente desde la construcción de la laguna de oxidación en la ciudad de Valledupar, la cual no tiene un plan de manejo adecuado para sus aguas, que son depositadas de manera directa sobre este río. Algunos pobladores manifiestan que el problema viene incluso desde mucho antes, porque la ciudad de Valledupar nunca ha visto como un problema el manejo de sus aguas residuales y, si bien la construcción de la laguna de oxidación buscaba darle tratamiento a este problema, empeoró la situación para las poblaciones que viven río abajo. De igual manera, al interior de la ciudad el río es utilizado por la población vallenata como uno de sus principales lugares de esparcimiento y recreación; sin embargo, no se cuenta ni con infraestructura 
ni con el personal adecuado para el manejo de las basuras que resultan de la visita de las personas al río, que termina arrastrando estas basuras por su cauce, lo que acrecienta la problemática de contaminación que sufre este afluente.

Por otro lado, uno de los aspectos fundamentales que ha determinado las formas en las que el campesinado se ha constituido en el departamento $-\mathrm{y}$, para el caso de nuestra investigación, en la subregión del Norte del Cesar- ha sido el de las dinámicas del conflicto social y armado que ha vivido y que vive nuestro país. En esa medida, este capítulo aborda la descripción de las formas de vida campesina en este territorio, partiendo de la identificación de los puntos de ruptura entre el pasado y el presente a partir de las narraciones de las mismas comunidades y en las cuales este punto de ruptura está determinado principalmente por hechos violentos productos del conflicto, representados en masacres, desplazamientos, desapariciones y muchas otras de las formas en las que estas dinámicas del conflicto se han materializado en los territorios del Cesar. De esta manera, partimos de la necesidad de entender estas rupturas temporales no desde fechas específicas, sino desde las cicatrices que estas fechas han dejado en la memoria colectiva de las comunidades, enunciadas como "la época del conflicto". Por esto se hace necesario hacer un breve contexto de cómo este conflicto se configuró, consolidó y materializó en este territorio para poder tener un acercamiento mínimo a las formas en cómo este se ha interiorizado en el imaginario de la población y cómo repercute aún actualmente en las dinámicas de las poblaciones campesinas de esta subregión.

\section{"La época de la violencia"}

El departamento del Cesar se creó en el año de 1967 al separarse del departamento del Magdalena (impulsado principalmente por élites locales entre las que se destacan las familias Gnecco, Araujo y Cuello) y a partir de la prosperidad que en esta época prometía la bonanza algodonera. Sin embargo, en la década de 1970 la crisis del sector algodonero significó un gran inconformismo social, lo cual fue aprovechado por las insurgencias, que veían una gran oportunidad de consolidarse en estos territorios. Según la Unidad de Restitución de Tierras (2014), el ingreso 
de la guerrilla al departamento se da principalmente a través de los territorios del sur con la creación del Frente Camilo Torres del Ejército de Liberación Nacional -ELN_, el cual hacía presencia en los municipios de Aguachica, Gamarra, Pailitas, Pelaya, Chiriguaná, Tamalameque, la Gloria, entre otros. Posteriormente, en el año de 1987, según datos del Centro Nacional de Memoria Histórica, se crea el Frente 6 de diciembre y, después, en el año de 1989, se crea el Frente José Manuel Martínez Quiroz; estos centraron sus operaciones en el centro y norte del departamento, principalmente en las zonas de extracción minera, en las estribaciones de la Serranía del Perijá y en parte de La Guajira, manteniendo además operaciones constantes en la Sierra Nevada de Santa Marta. Por su parte, a finales de la década de los 80 e inicios de los 90 llega al departamento del Cesar la guerrilla de las FARC, penetrando el territorio desde el norte por la Sierra Nevada de Santa Marta, a través del Frente 19 o José Prudencio Padilla. Posteriormente, este frente se divide en dos y da origen al Frente 41 o Cacique Upar, estos comienzan a copar el territorio de la Serranía del Perijá (CNMH, 2016).

La presencia de estas guerrillas en el departamento generaba gran zozobra entre las familias potentadas del departamento, quienes veían con preocupación cómo sus intereses y el capital familiar estaba siendo amenazado. Tanto el ELN como las FARC hicieron del secuestro y la extorsión las principales modalidades de guerra contra estas familias y las multinacionales extractivistas que comenzaban a asomarse. Sin embargo, según Bernal, en los primeros años el ELN

se dedicó a fomentar invasiones de tierra con el objetivo de forzar actividades públicas de reforma agraria (para ello utilizó grupos de personas que, en ocasiones, no eran campesinas e invadieron muchas fincas de la región, las que fueron abandonadas por sus propietarios y algunas posteriormente adquiridas por el Incora [Instituto Colombiano de la Reforma Agraria] para su parcelación) (Bernal, 2004, pp. 87-88).

En el año de 1987, y después de realizado el gran paro del nororiente, se dan los primeros indicios de la aparición de grupos paramilitares en el departamento, a raíz de la persecución y posterior asesinato de líderes sociales que participaron en esta jornada de movilización. De esta 
manera, y con el creciente auge de la actividad minera en la región, las élites locales - dedicadas principalmente a la ganadería-, en alianza con las grandes multinacionales y amparadas por la potestad otorgada por el presidente Samper para la creación de pequeños ejércitos privados llamados en esa época "Convivir"-, dan pie a la consolidación de uno de los periodos de violencia más crueles para el departamento. De esta manera, en el sur del departamento se crean las Autodefensas del Sur del Cesar (AUSC), las cuales tuvieron como principal objetivo golpear las bases de apoyo de las insurgencias, lo que afectó directamente a la población campesina que fue señalada de ser auxiliadora de estos grupos. Posteriormente, desde mediados de los 90 , con la consolidación del proyecto nacional del paramilitarismo se crea el Bloque Norte de las Autodefensas Unidas de Colombia (AUC-BN) bajo el mando de Rodrigo Tovar Pupo, alias "Jorge 40", quien en conjunto con quien en ese entonces había sido dos veces gobernador del Cesar, Lucas Gnecco Cerchar, consolida la presencia de este grupo en el departamento con la intención de proteger los intereses de los grandes terratenientes y ganaderos de la región y brindar la seguridad necesaria para la creciente expansión de la explotación minera. De esta manera se configura un escenario en el que, según los datos registrados hasta el 2015 por la Unidad de Atención y Reparación Integral a las Víctimas _UARIV_, entre el 2000 y 2005 se registraron 364.489 casos de desplazamiento forzado.

Así mismo, es importante introducir en nuestro escenario de análisis la disputa por la tierra como elemento fundamental en la configuración de cada una de las dimensiones que nos proponemos investigar y describir en nuestro trabajo, siendo estas las relaciones ambientales, económicas, políticas y comunitarias. Y aunque este elemento es una realidad que varía de una comunidad a otra, vemos cómo se constituye en una variable relevante para el análisis, dado que aunque en algunos de los territorios escogidos para el desarrollo del proyecto en esta subregión la disputa por la tenencia y formalización de la tierra tiene grandes avances, en otros territorios esta disputa se encuentra en niveles de tensión altamente complejos, tornándose en ocasiones peligrosa para las comunidades debido a las constantes amenazas realizadas por las personas que reclaman estas tierras como suyas frente a aquellos que las han ocupado tradicionalmente. 
Vida campesina en el Magdalena Grande

De esta manera, tenemos que cada una de estas dimensiones están configuradas en el imaginario de las poblaciones en dos tiempos (pasado/presente) que representan el antes y después de la "época del conflicto"; a su vez, están atravesadas por un elemento constante en todas las comunidades ubicadas en ambas márgenes del río Cesar: la disputa por la tierra. A continuación, ejemplificaremos esta situación a partir de la descripción de dos comunidades que habitan cada margen del río y que nos permitirán observar los dos extremos de esta realidad.

\section{El fantasma de la amapola y la esperanza de la mora: la vereda el Cinco en la Serranía del Perijá}

La Serranía del Perijá atraviesa de sur a norte el departamento del Cesar, siendo la frontera natural con la hermana república de Venezuela, al oriente del departamento. Aunque los datos consultados en torno a su extensión difieren, se calcula que comprende alrededor de 556 mil hectáreas con un rango altitudinal de 500 a $3.630 \mathrm{msnm}$, destacándose, por tanto, Cerro Pintao (3.300 m), Sabana Rubio (3.250 m), Cerro el Avión $(3.550 \mathrm{~m})$ y Cerro Tres Tetas $(3.630 \mathrm{~m})$.

En cuanto a sus habitantes, posee una población bastante heterogénea conformada por indígenas yuko-yukpas, indígenas wiwas (el mayor número de habitantes en esta región), pobladores de los distintos municipios de los departamentos del Cesar y la Guajira, y campesinos del interior del país que se desplazaron durante la ola de violencia de los años cincuenta.

Manaure Balcón del Cesar está ubicado al nordeste de la Serranía del Perijá y es uno de los principales canales de acceso a la parte más alta de la Serranía; a diferencia de otros municipios que bordean la Serranía, por este lado no hay resguardos y la población es netamente campesina. Es un municipio con cuatro corregimientos, creados mediante el Acuerdo 07 de 1990, y once veredas clasificadas así: 
Vida campesina en el Magdalena Grande

Tabla 1. Corregimientos y veredas de Manaure, Cesar

\begin{tabular}{|l|l|}
\hline \multicolumn{1}{|c|}{ Corregimiento } & \multicolumn{1}{c|}{ Veredas } \\
\hline Pie del Cielo & $\begin{array}{l}\text { - Hondo del río } \\
\text { - Pie del cielo }\end{array}$ \\
\hline La Tomita & $\begin{array}{l}\text { - Nicaragua } \\
\text { - La de Jacob }\end{array}$ \\
\hline Sabanas de León & - Los Andes \\
& - Sabanas de León \\
\hline \multirow{2}{*}{ José Concepción Campo Urdiales } & - Canadá, \\
& - San Antonio \\
& - El Venao \\
\hline
\end{tabular}

Fuente: Elaboración propia (2017).

Tanto campesinos como indígenas vivieron, se beneficiaron y sufrieron durante el apogeo de cultivos como la amapola que, aunque en principio resultó bastante rentable e implicaba menos trabajo, trajo consigo el conflicto armado, las violaciones, los desplazamientos forzados y asesinatos. Así mismo, las políticas del Gobierno para la erradicación de cultivos ilícitos a través de las fumigaciones aéreas de glifosato generaron una gran problemática ambiental y sanitaria, porque no solo eliminaron los cultivos de amapola, sino que exterminaron también los cultivos de pancoger, ocasionando plagas tan fuertes que, aún hoy, la población no tiene la cura para ellas: todo lo que cultivan termina dañándose. De igual forma, los virus, las enfermedades, la muerte de animales e, inclusive, plagas de cáncer en la zona; todo esto la población lo considera producto de dichas fumigaciones.

De esta manera, la amapola fue como un cuento de hadas entre los campesinos de la Serranía del Perijá que, a la hora de la verdad, no trajo sino angustias y estigmatización; sin embargo, ante su constancia y persistencia lograron erradicar no solamente la amapola, sino la idea de la fortuna fácil, dedicándose a sembrar la mora con espina, el único cultivo capaz de resistir la plaga. Hoy en día, si bien esta zona de la Serranía es un remanso de paz en un país azotado por el conflicto, sus habitantes 
Vida campesina en el Magdalena Grande

necesitan de la ayuda estatal para que su producto tenga el trato justo y no tenga que ser vendido por unos cuantos centavos.

\section{La llegada y poblamiento}

Imagen 45. Vía de acceso a la vereda el Cinco

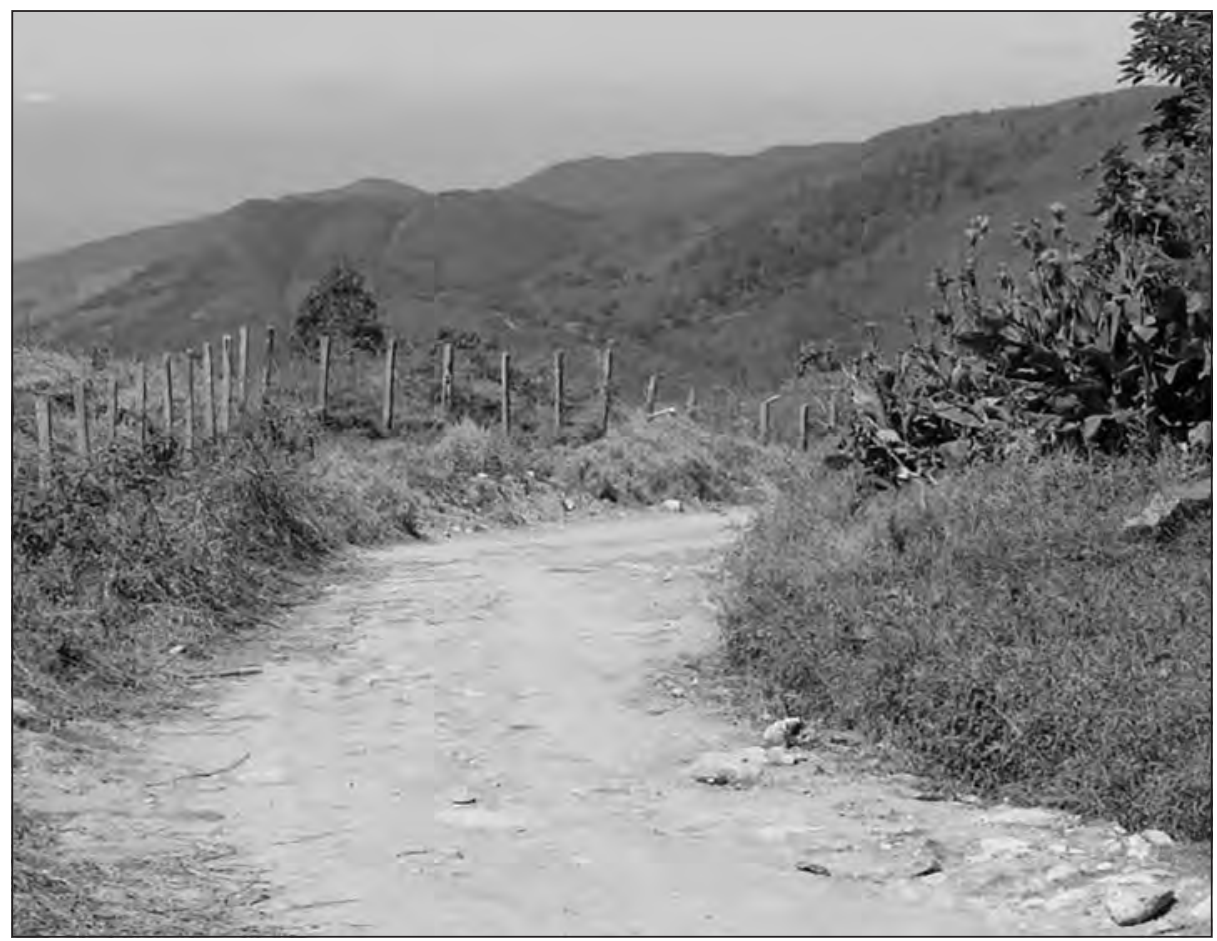

Fuente: Archivo Oraloteca (2017).

Como sucede con los procesos de colonización campesina en muchos otros territorios del Caribe colombiano, la colonización de la Serranía del Perijá se produjo a raíz del desplazamiento campesino generado por la violencia bipartidista de los años 40 y 50. Sin embargo, en el caso de esta subregión las bonanzas del algodón, marihuana y amapola, y la llegada de las minas al territorio, fueron atractivos económicos para que llegaran personas de todo el territorio nacional y comenzaran a asentarse en el territorio, colonizando, en muchos casos, aquellos territorios considerados baldíos: 
El conflicto también me tocó a mí. Y para esquivar todas estas guerras uno debe manejarse bien y echar mentiras también a veces, porque por allá en Pereira, Génova, Pijao, por allá eso era una guerra más verraca, eso era cogiendo café y otros encima de los guamos mirando a ver que no llegaran a darle candela a uno y eso. Entonces en unas partes tenía que decir uno que era liberal y en otra parte conservadora porque cuando eso sí era verraco, eso era así: del río para allá liberal, una comparación, y para acá conservador. $Y$ eso atacaban carros, matando gente, fincas, eso sí era tremendo. En las ciudades también, Caicedonia y Sevilla eso tiraba una bomba en un café liberal y cuando al rato o a los días tiraban una bomba a un café conservador... y esas matazones tan verracas (R. Cano, comunicación personal, enero del 2017).

Vengo de Cúcuta, me vine por circunstancias de la vida, los malos tiempos, por ejemplo, la violencia conservadora y liberal. Cuando llegué esto era muy abundante, muy bueno, Manaure, pues, porque esto era un monte, pero en Manaure el aguacate, el café, el plátano, todo era abundante. Ahora es que se acabó. Pues yo digo porque, por ejemplo, las personas antiguas que había eran las que sembraban, ellos ya murieron, entonces quedaron los hijos, no volvieron a la finca y entonces las fincas quedaron solas y se acabaron. Cuando llegué por aquí venía de Cúcuta, trabajaba por allá en las minas de carbón. Me vine con la familia y me vine a trabajar en los cultivos de amapola (F. Rodríguez, comunicación personal, enero del 2017).

En 1986 llegué a la vereda el Cinco, conocí la región. Posteriormente, regresé al lugar donde nací: Aguachica (Cesar). En 1989 supe que se iban a invadir las tierras de Sabana Rubia, entonces regresé porque me gustaron las tierras y empecé a trabajar en ellas. En ese entonces, llegamos con un grupo de personas de Valledupar y otros de Manaure; entre ellas, Margarita Pérez Monsalvo, con la cual fundamos allá una asociación que se llamaba UPACSAR (Unidad Proadquisión y Colonización de Sabana Rubio) y así nos dimos [a] la tarea de hacer extinción de dominio de esas tierras, de unas personas que venían teniéndolas hace mucho rato, que eran los hermanos Arturo Navarro y Arcesio Navarro (se llamaba ARNALEY Ltda.); desde allí quedamos nosotros trabajando en esta región. 
En el 92, 93, 94 y 95 empezamos a sembrar amapola en la región, pues daba buenos resultados porque llegó a valer más que el oro: 22 mil pesos, en ese entonces, el gramo de amapola. Esto condujo a que el municipio de Manaure se colonizara y se llenara de personas extrañas, personas que venían de otra parte a sacar productos aquí, a enriquecerse ilícitamente con la siembra de la amapola. Y se fundó la vereda el Cinco en 1995-96 y empezaron a ver subidas de más carros, más personal; entonces teníamos la vía, entonces había producción agrícola y, más que todo, de amapola. Pero se hizo dificultoso también sembrar amapola porque en ese entonces, pues en 1989 hasta el 92, un jornal lo que costaba por aquí era 1.700-1.800 máximo y con la entrada de la amapola se incrementó a 2.000-2.500 el jornal; esto conllevó a que muchas personas quisieran trabajar en la región, pero fue subiendo de precio, también la comida, los pasajes, el jornal y los insumos que se utilizaban para la siembra de amapola, también la dificultad que había por la presencia de grupos guerrilleros en la región, el ejército también haciendo control, la fumigaciones que hacía el Ejército Nacional, que también dañaban no solo los cultivos de amapola, sino los cultivos de pancoger y de tomate de árbol, lulo... en fin, todo lo que se cultivaba en la región (P. Contreras, comunicación personal, enero del 2017).

\section{La amapola}

Imagen 46. Planta de amapola, vereda el Cinco

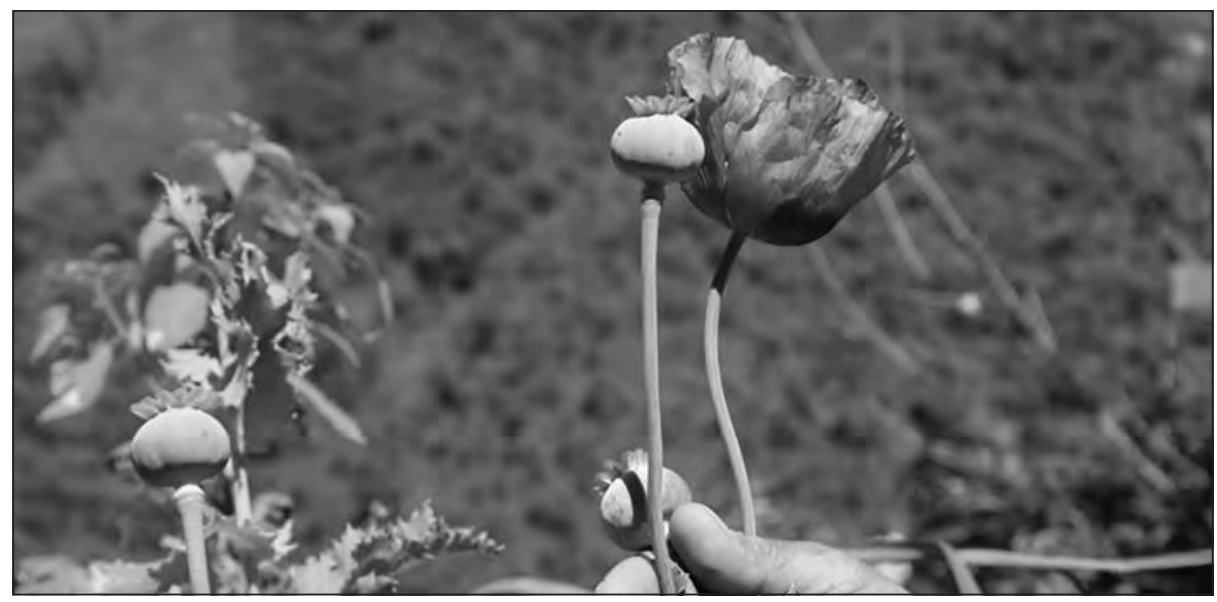

Fuente: Archivo Oraloteca (2017). 
Vida campesina en el Magdalena Grande

En las memorias de los pobladores de esta zona la bonanza amapolera es la que determina los procesos de lucha y organización; si bien ha sido una zona en la que la marihuana también fue parte fundamental de los cultivos ilícitos, los campesinos centran sus recuerdos en los procesos de siembra y venta de la amapola:

En ese entonces la gran problemática era la siembra de marihuana, que era con la que nosotros estábamos luchando, porque llegamos fue a sembrar hortalizas y la gran mayoría de las personas pues en ese entonces sembraba era marihuana, tenían esa actividad económica en la región y era la contradicción de nosotros, y pues eso nos acarreó dificultades con las personas porque las personas pensaban que nosotros podíamos a divulgar esos cultivos ilícitos y no nos veían con buenos ojos. Pero fue acabándose la marihuana por las fumigaciones [y los] bajos precios y se puso muy difícil, porque también en ese entonces la policía subía [a] hacer intervenciones en los cultivos y cogían a muchas personas. Entonces se desmejoró la producción de marihuana. Aproximadamente, en 1992 llegó por acá un personal de Pasto -Nariño-, de la región del interior, con una semilla nueva para nosotros que no conocíamos, que era la amapola. Se escuchaban los comentarios, que daban muy buena productividad, la semilla gratis y todo lo demás, y la presencia pues también de grupos subversivos hizo ir [a] mucha gente de la región, quedando poco personal que invirtiera en la tierra. Por eso no volvió a subir más Corpocesar, no volvió a subir ninguna persona que tuviera tenencia de tierras, que eran quienes nos daban trabajo para invertir en nuestra tierra, quedamos desprotegidos. Fue entonces cuando vino la época [de la] amapola: fue la única forma de producir algo para nosotros porque la semilla era regalada, teníamos la tierra y la semilla era regalada, era un precio bastante alto y pues eso condujo a que hubiera cultivos de amapola en la región (P. Contreras, comunicación personal, enero del 2017).

De esta manera, la economía de las poblaciones ubicadas en la Serranía del Perijá comenzó a depender del cultivo de amapola para el desarrollo de sus vidas campesinas, al punto de que casi el completo de la población se dedicaba a este negocio en cualquiera de sus fases de producción. 
Vida campesina en el Magdalena Grande

Sin embargo, aunque la economía de las familias campesinas gozaba de una fugaz bonanza, la rentabilidad de estos cultivos comenzaba a atraer otros actores al territorio que, posteriormente, afectarían profundamente la cotidianidad de los pobladores, específicamente grupos armados que, atraídos por las ganancias de estos cultivos, llegaban al territorio con la intención de recoger recursos para financiar su guerra:

Bueno, aquí era muy fácil y común ver cultivos de amapola y de procesar, compradores que llegaban de todas partes. El proceso era, pues, sin, simple, fácil, que se utilizaban amoniaco y acetatos para la producción de la pasta de amapola, se extraía el látex de la mata y por cada kilo de látex que se extraía se le echaba[n] 30 gramos de amoniaco, se subía a un $\mathrm{PH}$ de 6 y 6 y medio y se colocaba (esto se llamaba "extracción de chicle"), se le sacaba la parte "chicloza" y quedaba el agua negra, a la cual volvía y se le echaba el doble de la porción que se le echaba de amoniaco para sacarle la tierra, y esa agua negra que sobraba se le echaba un litro de acetato o limpiador de PVC para que saliera la pasta o el polvo de la amapola, que es lo que comúnmente se llamaba "morfina" [...]. Pero eso llevaba mucho gasto; para uno recoger un kilo eso era verraco. Uno no hizo nada con eso, eso es como todo y toda agricultura, había bastante, y cuando tenía bastante estaba por el suelo y cuando había poquita o no había estaba carísima, y así dicen todos esos artículos de agricultura, así han sido toda la vida [...]. Entonces salía[n] 30 gramos en polvo o 90 gramos de $\mathrm{M}$ y se vendía entre 15 mil hasta 22 mil pesos que llegó [a] estar; posteriormente, bajó mucho, que llegó [a] estar en 8 mil pesos y no daba margen de ganancias y fue cuando empezamos a ver dificultades (P. Contreras y R. Cano, comunicación personal, enero del 2017).

La[s] dificultad[es] pues, como le dije, de la guerrilla, del Ejército Nacional, de la fumigación, el incremento del costo de la producción, conllevó a que se fuera minorando la producción de la amapola, el precio bajo, los insumos subieron, la comida subió, el jornal subió, esto hizo que se tuviera que buscar otra alternativa de trabajo, empezando ya pues a cultivar los cultivos tradicionales: fríjol, maíz, alverja, zanahoria, repollo, papa, todo lo que hay en la región, y pues un cultivo alternativo que da muy buenos resultados que es la mora, pero una mora con espinas, y eso 
Vida campesina en el Magdalena Grande

fue minorando también la producción de la amapola hasta que desapareció completamente de la región (P. Contreras, comunicación personal, enero del 2017).

\section{La peste}

Esta parte de la Serranía del Perijá aun hoy en día es una gran extensión de tierra con muy pocos habitantes, lo que le ha permitido mantener cierto equilibrio ambiental en las partes más altas; sin embargo, el señor Rodríguez afirma que:

la Serranía tenía mucha más montaña de lo que tiene hoy en día, las aguas eran mucho más abundantes, pero por la causa de los cultivos ilícitos se comenzó a deforestar y a las aguas se han secado y las montañas se han acabado bastante (comunicación personal, enero del 2017).

En términos ambientales, uno de los principales reclamos que sale en todas las entrevistas realizadas es el evidente impacto que las fumigaciones contra la amapola dejaron sobre todo el territorio, no solo al punto de afectar los otros cultivos, sino también de deteriorar los bosques nativos y, así mismo, la salud de los pobladores de la región. Actualmente, las comunidades han probado variedad de cultivos tratando de encontrar aquellos que se adapten a los suelos deteriorados por el veneno de las fumigaciones:

Cuando yo vine aquí estaba José Arroyo. Yo le compré a él el terreno y él tenía unos palitos de tomate de árbol y lulo; luego, yo sembré papa. Y cuando empezó a producir, empezó a llegar la peste esa, el hongo. También sembré curuba, también llegó el hongo ese y lo acabó. A la mora también le ha entrado la peste, pero es más fuerte. Porque cuando uno la siembra en verano, tenía un retoñero, y ahora se pone que no retoña mucho, se achanta mucho, no como en esa época que había una serrana de mora. Esto por aquí da lidia, para cualquier agricultura que sea. Fue por las fumigaciones esas que hicieron (R. Cano, comunicación personal, enero del 2017). 
Hemos visto que desde que se empezó a fumigar los cultivos de amapola se afectaron también; no solamente los cultivos frutales, sino que también a los árboles nativos los llegó a secar. Era tan fuerte el veneno que acababa con todo lo que hubiera a su paso y nos dimos cuenta [de] que el terreno que fumigaban con esos químicos se llenaba de una mata u hongo que no dejaba producir más nada en la tierra. Entonces empezamos a picarlo para poder que la tierra saliera encima, no el musgo que empezaba a salir sobre la tierra, sino que le movíamos la tierra para que volviera a producir y pensamos que todavía son ingredientes activos que tienen la tierra de tantas fumigaciones que están ahorita, digamos dañando las producciones de tomate de árbol y de lulo no sirve en estos momentos, y la mora es un poco más resistente, pero también se ve afectada en la parte del tallo, de las hojas y [del] fruto también. Lo malo de por acá es el hongo que quedó de las fumigaciones que se hicieron para acabar la amapola. Eso por aquí sacaba unos palos secos gruesos, y allí más acasito se secaban palos gruesos. Acabaron con las palomas, los ratones, porque ellos se comían las semillas y el veneno mataba todo eso. La abeja se acabó por aquí por derecha. Una vez un vecino tenía abejas bastantes y yo le dije que me regalara un poquito de miel, él me dijo: "no, Pedro, eso se acabó, se agarró una peste que se van en la mañana y ya no vuelven más". Y me acordé y le dije: “¿sabe cuál es la peste? La fumigación está acabando con todo esto". Se quedó pensativo y me dijo: "verdad".

Las últimas fumigaciones se dieron del 2002 al 2004. Desde las primeras fumigaciones empezamos a notar que los cultivos se afectaban, se morían de una porque se amarillaban las hojas, se manchaba la hoja y la producción aminoraba y era más pequeño el producto que sacábamos. Posteriormente, se presentaban una clase de plagas que no estábamos acostumbrado[s] [a] ver en la región; se llama capote o musgo, el cual no permitía que le saliera monte a la tierra. Eso fue lo que empezamos a ver después de las fumigaciones. Al año siguiente era inservible la tierra a la que le caía veneno. Hasta ahora no se ha encontrado algo que elimine estos hongos. No se le han hecho los estudios respectivos a la tierra para saber qué deficiencias, afectaciones tiene el terreno para no permitir el desarrollo de los productos. Aquí hemos visto que se han perdido también unos cultivos que eran silvestres en la región, como la 
Vida campesina en el Magdalena Grande

curuba silvestre, una clase de mora silvestre también tiende a desaparecer (que no se veía afectada por nada y ahora se vuelve leñosa, se acaba, se seca, cuando antes era muy frondosa). La que nosotros sembrábamos no dábamos a basto para podarla, crecía muy rápido; ahora es muy lento el proceso (P. Contreras, comunicación personal, enero del 2017).

Sumado a las afectaciones ambientales que las fumigaciones contra la amapola le generaron al territorio, los pobladores manifiestan que esta[s] afectaciones pueden ir más allá de lo que se nota a simple vista; con esto se refieren a los impactos inmediatos sobre el territorio y los cultivos, pues ellos manifiestan que, a pesar de que no pueden demostrarlo, muchas de las enfermedades que hoy padecen los pobladores de las partes altas de la Serranía del Perijá son producto de los residuos químicos que las fumigaciones han dejado en el ambiente:

Ese veneno lo echaban puro. Claro, lo que agarraban se lo acababan; era un veneno muy fuerte. Aquí había una muchacha y estaba abajo trabajando, estaba embarazada, y cuando pasó la avioneta a ella le cayó el veneno y esa muchacha dio a luz como faltándole dos meses para el parto. La niña salió enferma. Siempre había gente que salía como borracha, la agarraba la fumigación. Pero había gente que le caía, eso era puro, eso acababa con lo que fuera, eso duraba tiempo en nacer hierba donde le caía así parejo. Yo tenía una yegua que estaba preñada y acá arriba botó el animalito. Y todavía el veneno continúa haciendo estragos. Bueno, yo digo, pues como ya hace tanto tiempo, pero sí eso hizo mucho daño; a veces no sé qué le pasa al Gobierno con el campesino: que lo van ayudar, que no sé qué... yo me pongo a pensar... vea, estas son las ayudas para los campesinos con estas fumigaciones (F. Rodríguez, comunicación personal, diciembre del 2016).

En ese momento las personas pensábamos que podría haber dificultades por las fumigaciones, pero yo pienso que eso no se ve en el momento porque la contaminación no es inmediata, pero sí pienso que hay un brote en Manaure, un brote de cáncer, en la vereda el Cinco han muerto dos personas y hay diagnosticado muchos casos de cáncer en el municipio, pues que hasta afectado está el alcalde de Manaure -Cesar-con 
Vida campesina en el Magdalena Grande

cáncer en el estómago. Entonces, yo pienso que es un derivado de las fumigaciones. Una consecuencia de la fumigación fue también la diarrea, problemas pulmonares, el brote que más ha afectado a Manaure es el cáncer. No se han hecho solicitudes de ayuda porque nosotros, las personas que vivimos en la parte alta, somos personas de escasos recursos y de escaso estudio: las personas que han estudiado han llegado a quinto de primaria y esto pues no nos lleva a tener una conversación muy fluida con los entes o como son las rutas de acceso a la salud, educación y, de pronto, nos frenan para pedir alguna solicitud y no sabemos cómo responderle (P. Contreras, comunicación personal, enero del 2017).

\section{La mora}

Imagen 47. Cultivos de mora

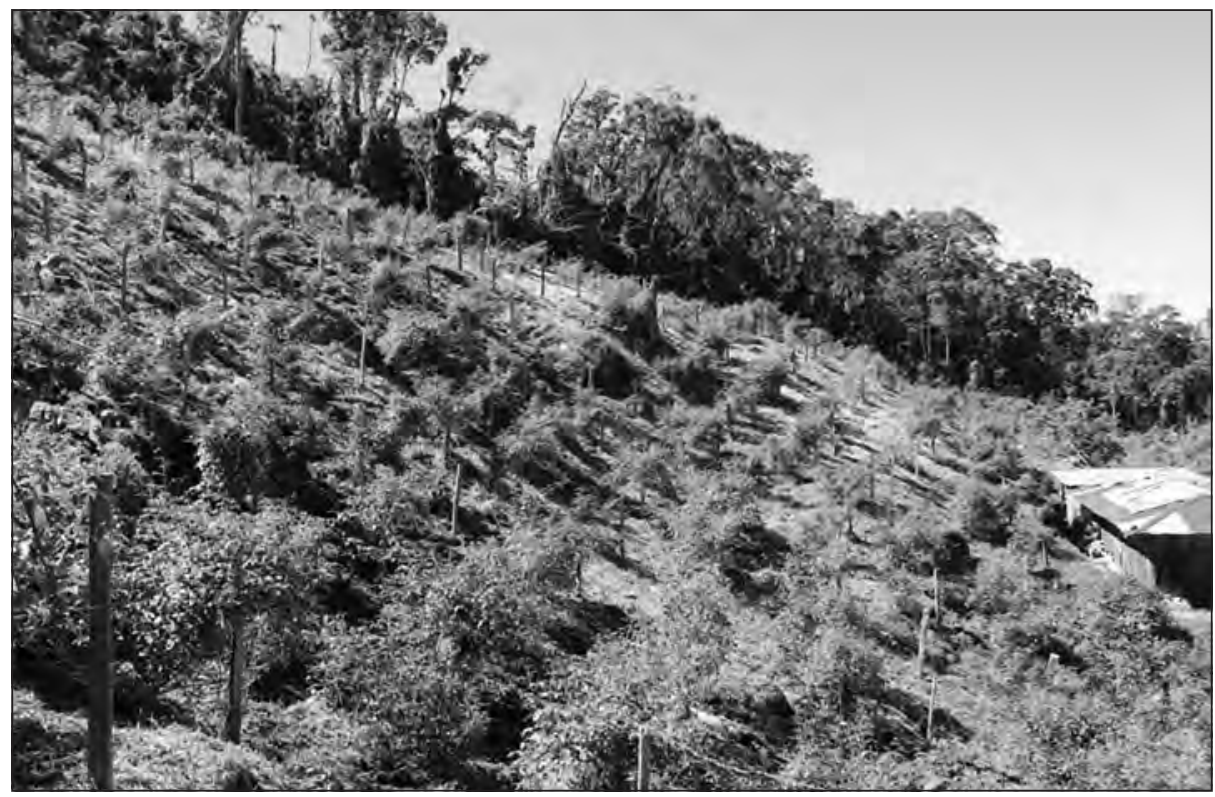

Fuente: Archivo Oraloteca (2017).

Por una trocha bastante maltrecha en algunos recorridos se sube hasta las veredas más altas de las montañas: Canadá, San Antonio, el Venao y el Cinco. De 500 m s.n.m. se sube hasta los 3.600 m s.n.m.; esta característica permite ver una variedad muy amplia de cultivos que van desde las 
Vida campesina en el Magdalena Grande

fincas cafeteras hasta los sembrados de mora que sustituyeron a la amapola cuando esta dejó de ser rentable, por allá a finales de los noventa:

Inicialmente, fue una sola persona que se vio a la tarea de sembrar mora porque decía que era productiva, pero en esa época nadie le prestó atención porque era más rentable la amapola y nadie le prestó atención a la mora porque tiene mucha espina, y uno lidiar con espina era bastante tedioso; entonces, nadie le prestaba atención. Pero desde que se acabó la amapola, al no haber rentabilidad y al ver que la mora soportaba todo el embate de los climas, veneno y todo lo demás, entonces algunos empezaron a sembrar mora y los demás, al ver que había buena producción, empezaron a sembrar la mora en la región.

Pues yo pienso que fue un beneficio pasarnos a la mora porque digamos que la amapola tenía muchas dificultades, por lo que por ser ilícita había mucha persecución de muchas partes, de la parte del ejército, la policía, la comercialización tenía que hacerse clandestina, era muy fácil que [a] cualquiera lo matara[n] para robarle la producción y que no le pagaran a uno la plata, y nadie podía denunciar porque era ilícito. Otra parte era que los grupos armados querían cobrar sobre la producción y los campesinos no estaban dispuestos a dar plata porque nos estábamos esforzando por trabajar. Entonces, pienso que era más perjudicial sembrar amapola que mora, porque el producto o frutales como tomate de árbol y lulo, aunque se demoraran un poquito más, porque la amapola demoraba 3 o 4 meses para estar de raye y 2 meses rayando, eran 6 o 7 meses máximo, mientras que el cultivo de mora demora un año, el cultivo de tomate de árbol demora año y medio, el de lulo otro año, pero la rentabilidad es continua, cuando ya empieza a producir demora 5 a 6 años, hasta 10 o más produciendo la mora, el tomate de árbol o el lulo, entonces, es más rentable porque se está sacando, cada 8 días estamos sacando producción, de mora estamos sacando cada 8 días, se podía sacar cada 4 días, pero no tenemos transporte continuo. El tomate de árbol también: nosotros con media hectárea de tomate estábamos sacando entre 8,10 y 16 quintales; de lulo, 10 quintales también, y de mora estábamos sacando entre 35 o 40 kilos semanales, entonces esto es más rentable que tener amapola porque estos cultivos son mejores (P. Contreras, comunicación personal, enero del 2017). 
Vida campesina en el Magdalena Grande

Si bien es cierto que la mayoría de los campesinos tienen más de 20 años de habitar estas montañas, los procesos organizativos no son muy fuertes y están sometidos, muchas veces, a la venta injusta de sus productos; sobre todo para el caso de la mora, que es la base primordial de la economía en la vereda el Cinco. En las otras veredas, por la variante climática, ya se comienzan a ver sembrados de café, maíz y otros productos.

Imagen 48. Joven campesino cosechando mora

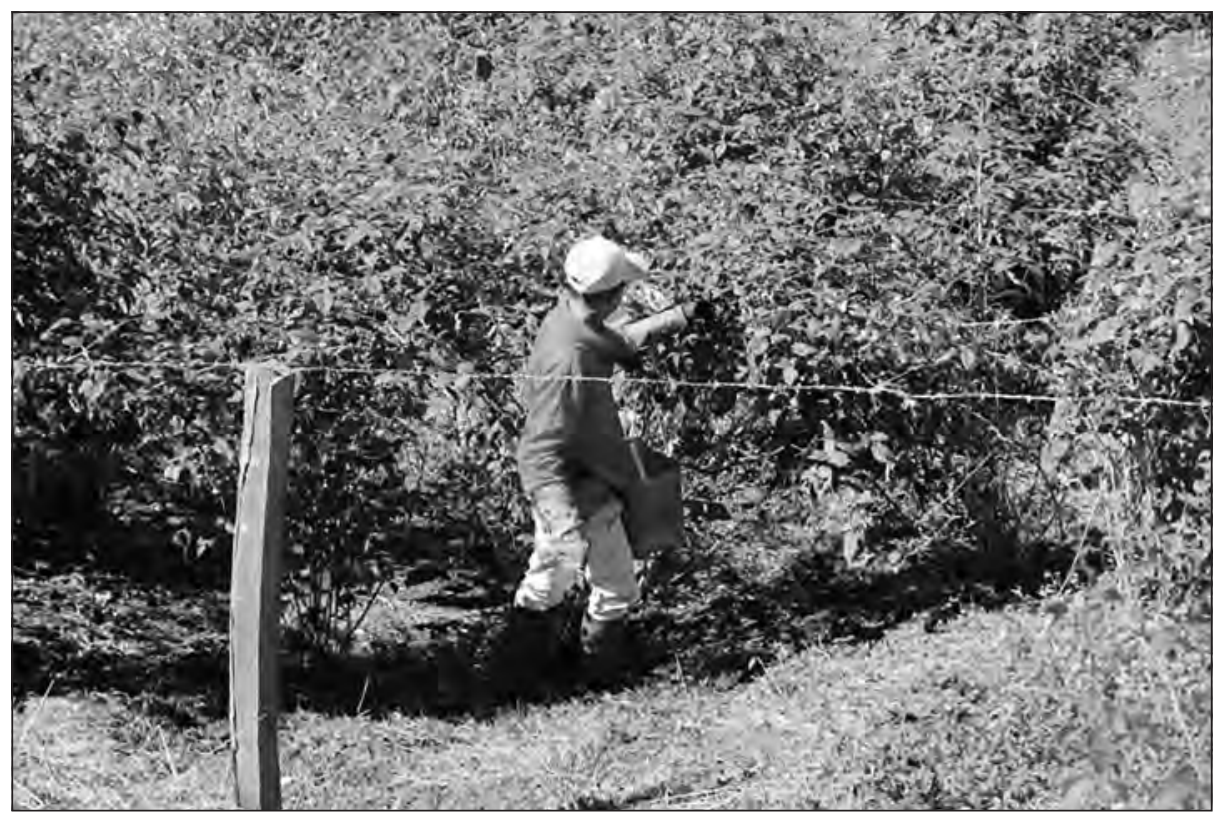

Fuente: Archivo Oraloteca (2017).

Bueno, con la mora estamos empezando, es una ayuda que nos están dando, eso hace casi 11 meses, ese producto ya se está empezando a ver. Es un producto que apenas está empezando, pero es un cultivo que es permanente y que es un cultivo sin miedo de nada. También se siembra fríjol (por ejemplo, ahora están arrancando fríjol que está muy bravo para el invierno), se siembra arracacha, papa, cilantro, maíz (también, sino que ahora no es tiempo) [...]. Tengo sembrados de mora, que es lo que me ha quedado, porque tenía otro cultivo y me los acabó la peste. Eso se siembra 3 metros de calle por 2 metros de mata, mata. Después, hay 
Vida campesina en el Magdalena Grande

que ponerle madera, ponerle alambre y amarrarla para que no se caiga. Esto hay que estarle podándolo y poniéndole cuidado y amarrándolo de nuevo. Estamos cogiendo cada 8 días. Todo el año, o todo el tiempo, porque eso produce diario [...]. Yo limpio la mora, cada 8 días la cojo, me pongo de martes a jueves cogiendo los potecitos, cojo 2 potes, 1 y así. Se la entregó al profesor, él me trae las compritas y yo lo mando a apuntar en un libro para que cuando hagamos las cuentas entonces se sabe si le quedo debiendo o no. Yo no recibo plata, solo trueque (R. Cano y A. Florinda, comunicación personal, enero del 2017).

Imagen 49. Campesina asistiendo la mora en la vereda el Cinco

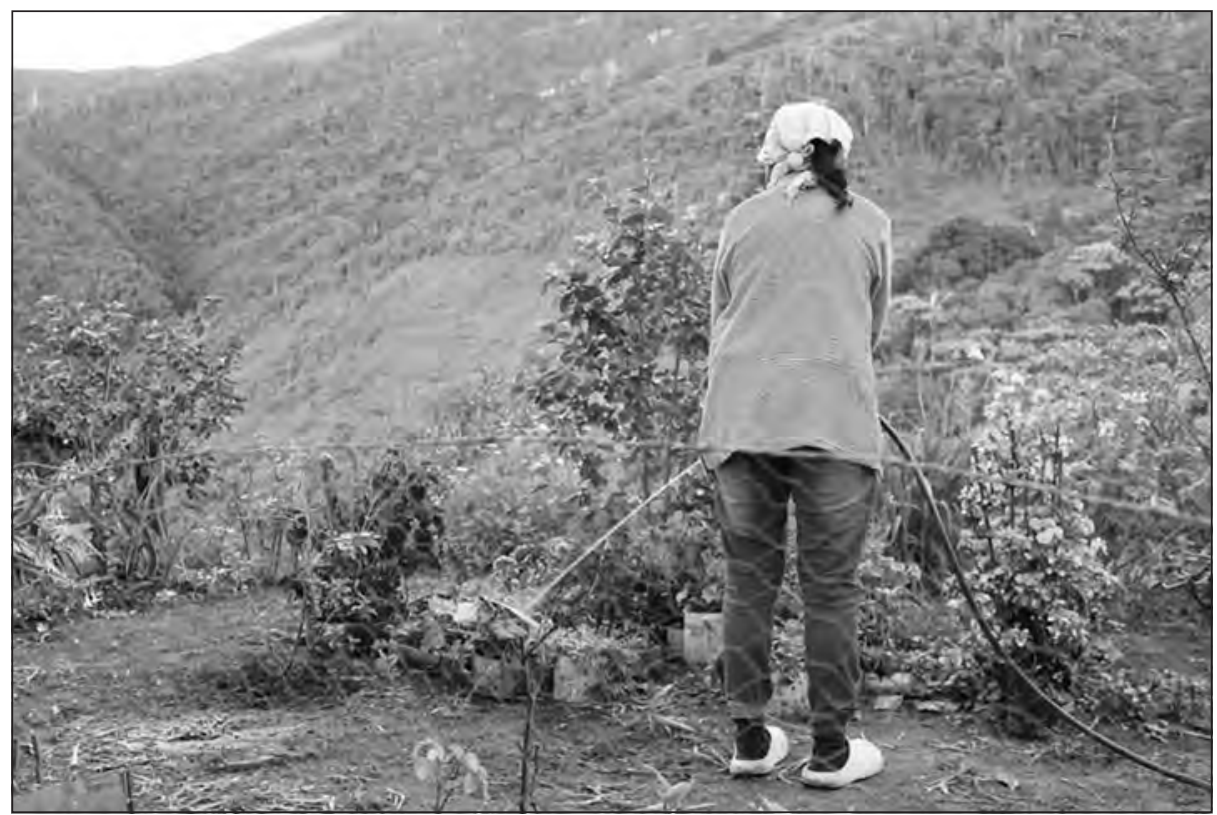

Fuente: Archivo Oraloteca (2017).

Y ahora tenemos un proyecto de mora, de siembra de 10 hectáreas de mora sin espinas, el cual también nos está ayudando a salir adelante. Es un proyecto que tenemos a través de la Gobernación del Cesar en la vereda el Cinco, que ya casi estamos culminando, pues ese es el paso que se dio de la amapola a la mora por la necesidad de buscar otro modo de subsistencia (P. Contreras, comunicación personal, enero del 2017). 
Vida campesina en el Magdalena Grande

\section{El conflicto}

El conflicto armado ha sido un eje transversal en las historias de los pobladores de la zona rural de Manaure, Cesar. El constante tránsito de las guerrillas, el miedo ante la llegada de los paramilitares y el abuso por parte del ejército hacían parte de la cotidianidad de las comunidades de la Serranía del Perijá, obligando a las comunidades a diseñar estrategias para mantenerse al margen del conflicto, permanecer en el territorio y no ser señalados por ninguna de las partes:

La presencia del Ejército Nacional desde 1986 [hasta] 1992 fue casi nula. El Ejército no hacía presencia por esta región. En 1992 me acuerdo muy bien porque subió un grupo del Ejército Nacional [a] la Popa. Estuvieron por castigo y estuvieron un mes en Sabana Rubia; fue la única vez que vimos presencia del Ejército Nacional, Fuerza Armada, militar, porque en la región campeaba por todas partes [el] ELN, [el] EPL, [las] FARC (que en alguna vez reunieron a la comunidad en la región, sobre todo en Sabana Rubia, para que supiéramos que se había conformado la Coordinadora Guerrillera, que la habían hecho entre el EPL, [el] ELN y [las] FARC). En esta región se reunieron más de 400 hombres y nos reunieron para decirnos que el mando lo tenían ellos y que teníamos que obedecer lo que ellos dijeran.

El paramilitarismo en la región no se sintió mucho porque la región en sí es pobre, no es de mucha producción. Sí se escucharon comentarios, llegaron grupos, pero no encontraron digamos hospedaje muy bueno para ellos y no vieron qué podían sacar de la región y, por lo tanto, también fueron buscando a dónde irse; no había quién los patrocinara aquí en la región. Pasó igual con la guerrilla: hacía presencia, pero nunca tenía apoyo económico de las personas que habitaban en la región. Ellos hacían sus boletes por allá para mantenerse, pero no encontraban apoyo del pueblo; hicieron dos intentos para tomarse el pueblo y la gente salió a la calle y no les permitió tomarse el pueblo de Manaure, entonces esto conllevó a que ellos tampoco hicieran mucha fuerza para hacer incursiones en Manaure, no se les permitió (P. Contreras, comunicación personal, enero del 2017). 
Vida campesina en el Magdalena Grande

Imagen 50. Pablo Contreras, campesino de la vereda el Cinco

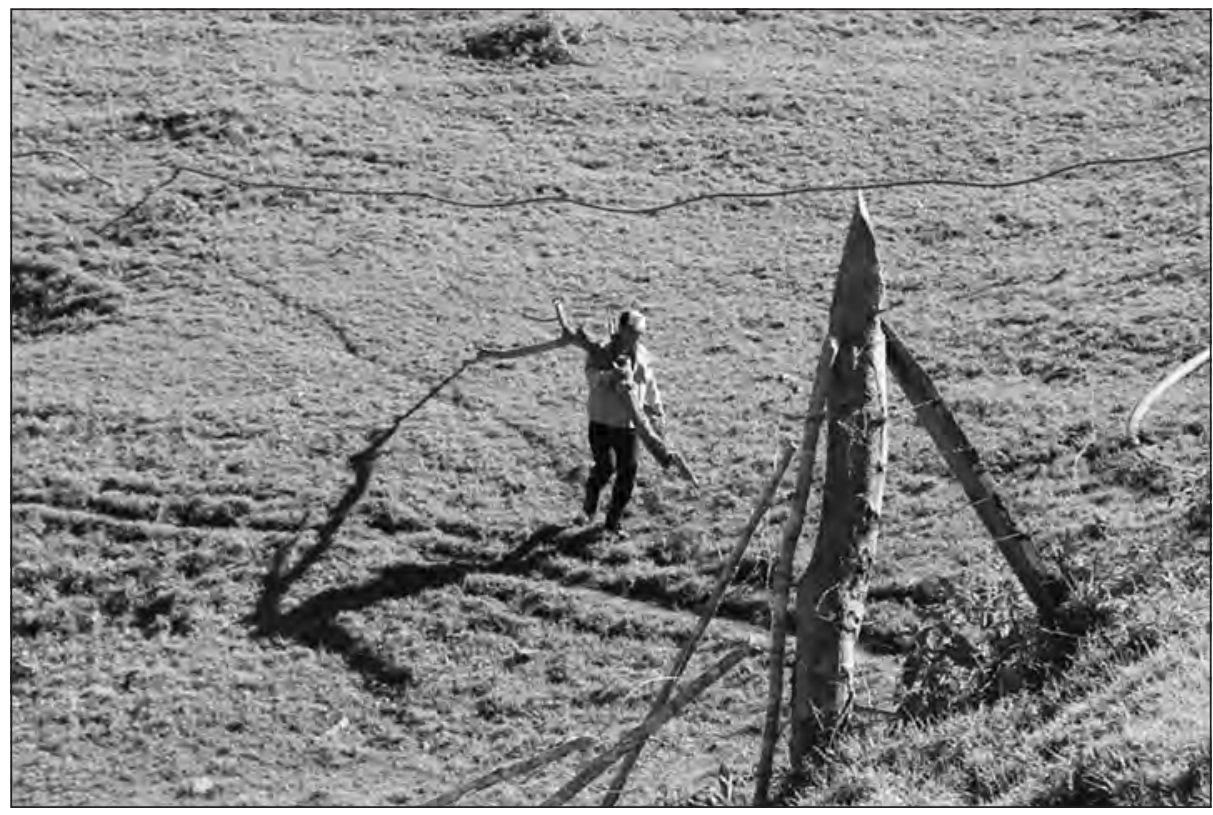

Fuente: Archivo Oraloteca (2017).

Así que, pues, digamos, la parte más difícil era ese enfrentamiento que había entre la guerrilla y el ejército y que los paramilitares de pronto pudieran entrar, ese era el miedo que nos causaba: nosotros estar en medio... y pues eso conllevó a que la mayoría de las personas se desplazaran a la cabecera municipal, habiendo un desplazamiento masivo de la vereda el Cinco y de la vereda San Antonio. Posteriormente, en Canadá, porque la presión de la guerrilla también era que teníamos que colaborar, que teníamos que estar con ellos, hacerles mandados, que hacer algo... entonces el que no estuviera de acuerdo tenía que irse de la región; eso conllevó a que muchas personas tuvieran que desplazarse de la región. Nos afectó bastante el conflicto, aunque no hubo tantas muertes como en otras veredas (P. Contreras, comunicación personal, enero del 2017).

En el 2002 había mucha presencia de guerrilla y presencia de ejército también bastante, entonces cuando venía el ejército venían era atropellándolo a uno porque la guerrilla permanecía; la guerrilla lo mismo y, de 
todas maneras, en el 2006 el ejército se llevó dos campesinos, dos parceleros acá de la vereda y los mataron por allá en otra vereda y los hicieron pasar por guerrilleros y lo cual nos tocó que desplazarnos.

Entonces hubo un desplazamiento masivo porque el ejército antes de venir por los compañeros había subido antes y habían puesto unos letreros de amenaza allá en la escuela y después vinieron por los muchachos, se los llevaron, y el rumor era que iban a seguir, pero como nosotros al fin nos organizamos y empezamos a establecer denuncias pararon la cuestión. Pero a mí personalmente sí me tocó que desplazarme en el 2006, me les volé del rancho. [El] día 12 de marzo habíamos retornado otra vez a la vereda y ese día, que por cierto eran elecciones del 2006, me llegaron ahí y yo me les volé y, desde ese entonces, no pude volver a la vereda. Duré unos meses en el pueblo y de ahí me tocó irme para Rionegro; allá hice mi declaración de desplazado. Después, regresé al siguiente año, pero después de eso me tocó desplazarme en dos ocasiones más porque supuestamente me hacían ir por informante del ejército o amenazas nunca directas, sino por medio de mensajes o intermediarios, porque tenía un hijo en el ejército que lo habían reclutado y, por esa causa, tenía que irme. Cuando ya el muchacho terminó de prestar el servicio y regresó, que miraron que todo estaba normal, me dejaron quieto (F. Rodríguez, comunicación personal, enero del 2017).

Desde allí [se] empezó a ver un desplazamiento masivo de las personas que invertían en la región, que eran profesores, empleados en la Gobernación, en el Corpocesar... en fin, se vino a pique un proyecto que teníamos con Corpocesar, que era la recuperación de casa de vidrio, la laguna de casa de vidrio donde habíamos echado 2 mil truchas de arco iris y las estábamos criando. Teníamos una persona que lo cuidaba porque era para la comunidad; entre todos lo hicimos con el apoyo de Corpocesar. Pero, posteriormente, subieron los grupos armado[s]. Empezaron a sacar las truchas para comérselas y, después, subió el ejército y terminaron casi de comerse las truchas que quedaban, quedando[nos] a nosotros nada más el trabajo y el cansancio. Y lo que alcanzamos a sacar de 2 mil truchas fueron alrededor de 100 truchas (P. Contreras, comunicación personal, enero del 2017). 
Vida campesina en el Magdalena Grande

A pesar de las dificultades que pasan los campesinos en el territorio (la peste de las fumigaciones, la presencia de actores armados, la falta de apoyo institucional a sus proyectos, la inestabilidad de los precios del intermediario, ente otros), la comunidad sigue apostando por el cultivo de mora y otros frutales que les permitan el desarrollo económico de sus familias sin tener que volver a sembrar ningún cultivo que sea ilícito. Para eso se están formando y vienen gestionando con las administraciones locales proyectos que les permitan tener mejores condiciones de producción y garantías de precios justos a la hora de la comercialización.

Imagen 51. Vía de acceso de Manaure hacia el Perijá

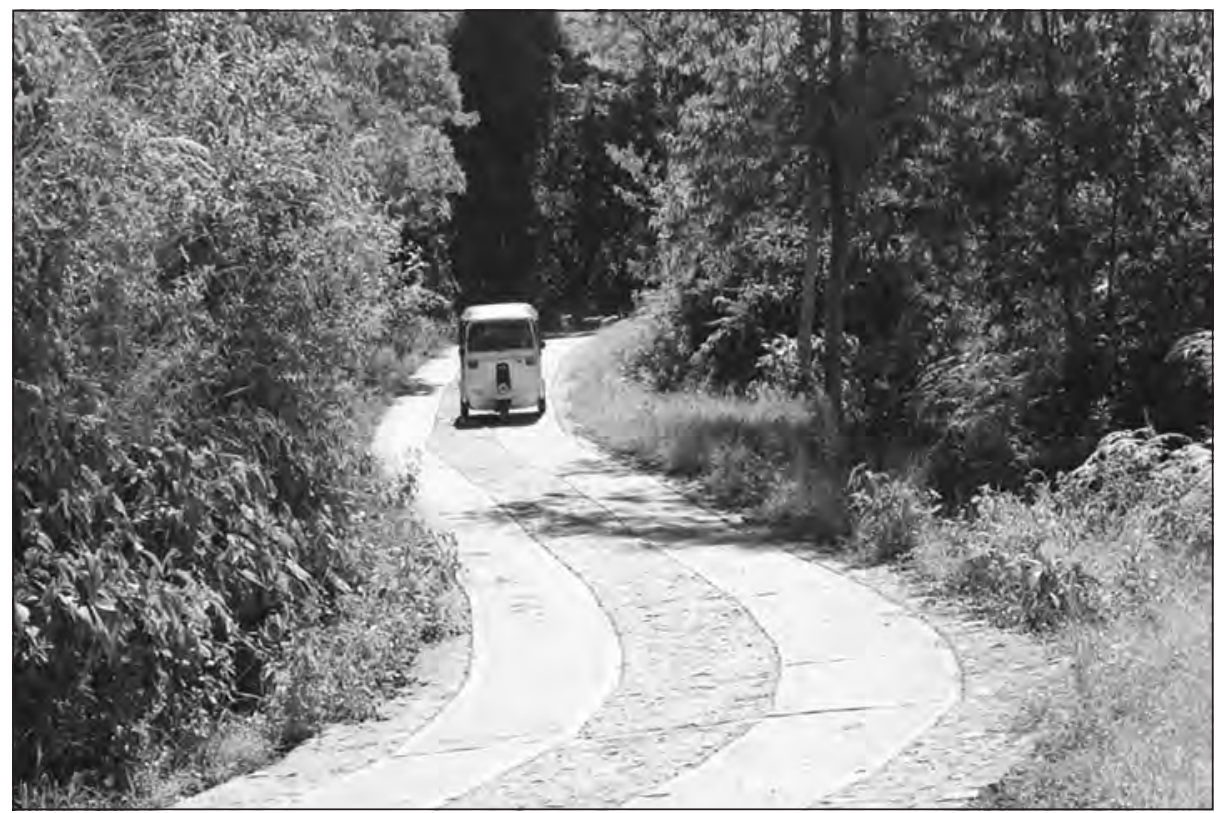

Fuente: Archivo Oraloteca (2017).

Tuvimos una capacitación sobre transformación de frutas y hortalizas para poder comercializarla[s] de otra forma y no directamente el fruto; entonces decidimos asociarnos creando una asociación de moreros para, digamos, recoger toda la producción de la región y poder hacer una venta global y no individual, como se venía haciendo antes. Ahorita estamos en el inicio de la asociación, estamos en la parte de la organización, del 
Vida campesina en el Magdalena Grande

papeleo, todavía no le hemos dado fundamento a la asociación, no se ha empezado a trabajar asociativamente. Ahorita le entregamos la mora a Fabio Chávez, que es al que se la vendemos, y él la distribuye en Manaure y Valledupar. En Manaure hay personas que la compran para llevarla hasta La Guajira, el Sur del Cesar, donde no hay producción de mora. Entonces, esa es la comercialización que estamos haciendo porque no está organizada la asociación, apenas estamos en este proceso.

Lo de la cooperativa esto ha nacido a raíz del proyecto que tenemos con la Gobernación para poder hacer una comercialización mucho mejor; o sea, que no sea tan empírica como la hemos venido haciendo y que no sea solamente aquí donde se venda, sino que la podamos llevar más lejos, poderla vender a Postobón, Bavaria o porque poderla exportar, porque nosotros estamos cultivando ahorita la mora a base orgánica, ya recibimos una capacitación sobre cómo producir abonos orgánicos, microorganismos $\mathrm{y}$, en fin, todo lo que tiene que ver con la parte orgánica ( $\mathrm{P}$. Contreras, comunicación personal, enero del 2017).

\section{Como extraños en nuestra tierra: el Toco y la lucha por el territorio en el valle del río Cesar}

Mapa 4. Vereda el Toco

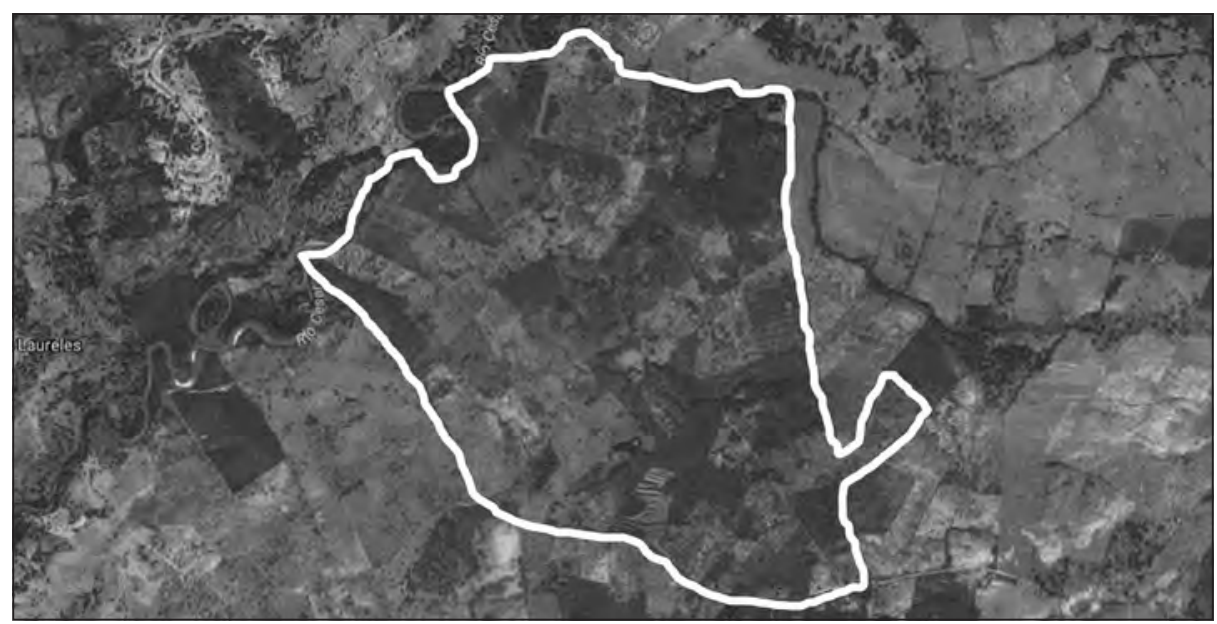

Fuente: Google Maps (2017). 
La vereda el Toco está conformada por población campesina que se encuentra ubicada en la margen izquierda del río Cesar, en el municipio de San Diego, el cual se encuentra al norte del departamento del Cesar, limitando con los municipios de la Paz y Valledupar. Cuenta con siete corregimientos: Media Luna, Tocaimo, el Rincón, los Tupes, las Pitillas, Nuevas Flores y los Brasiles; en este último, se encuentra ubicada la población del Toco. Debido al potencial hídrico del municipio, las principales actividades económicas son la cría de ganado vacuno y la producción agrícola.

La vereda el Toco es de relieve plano con muy pocas elevaciones en su superficie y tiene, como fuentes hídricas, la sequía del "Jobo" o "río del Encanto" y el río Cesar; estos, a su vez, funcionan como linderos al norte y occidente del predio. A pesar de esto, el recurso hídrico se constituye en una de las principales problemáticas para las personas que habitan este territorio ya que, por un lado, la sequía el Jobo no permanece todo el año con agua y, por otro lado, el río Cesar presenta altos índices de contaminación, lo que ha llevado a la comunidad a buscar el recurso a través de la excavación de pozos artesanales para, de esta forma, asegurar el agua necesaria para la supervivencia personal, de los cultivos y de los animales. Esta es una realidad reciente; según cuentan los pobladores, anteriormente el río Cesar brindaba el recurso suficiente para mantener los cultivos y los animales y su agua era apta para el consumo humano: muchas personas, incluso, alternaban la actividad agrícola y pecuaria con pequeñas faenas de pesca a lo largo del río.

\section{Imagen 52. Río Cesar}

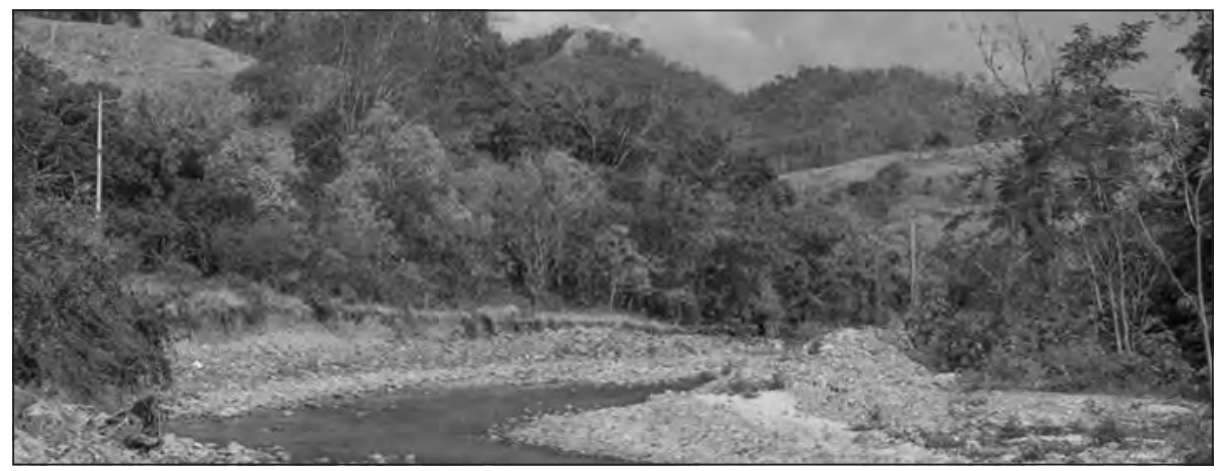

Fuente: Archivo Oraloteca (2017). 
Ese es un problema de vieja data ya [...], eso tiene más de 20 años; lamentablemente, contaminaron el río. Nosotros recién llegamos al Toco, cuando no teníamos la liga para el desayuno o para el almuerzo cogíamos la atarraya e íbamos al río o a la sequía el Jobo (que la sequía el Jobo colinda por el norte con las tierras del Toco), íbamos y tirábamos dos "atarrayasos" y teníamos la liga no solamente para el día, sino para 2 o 3 días porque por lo menos la sequía del Jobo era muy rica en pescado y lo mismo el río Cesar. El río Cesar, por ende, era muy productivo en la pesquería. Pero hoy en día esto ya prácticamente se acabó: el pescado del río Cesar lo consumen los que no conocen el problema a fondo (A. López, comunicación personal, diciembre del 2016).

\section{Poblamiento}

Esta vereda inicia su proceso de conformación el 13 de mayo de 1991 a partir de un proceso de ocupación por parte de familias campesinas provenientes principalmente del municipio de Agustín Codazzi y que buscaban por este medio conseguir tierras que, posteriormente, pudieran ser adjudicadas por medio del INCORA. La decisión de ocupar este predio se toma a partir del conocimiento que algunos campesinos que trabajan en los alrededores tenían sobre la situación en la que este se encontraba, el cual pertenecía en ese momento a Alfonso Murgas, reconocido palmero de la región y dueño de la empresa Palmeras del Cesar. Este predio se encontraba desocupado y embargado y era utilizado por ganaderos de fincas aledañas para el pastoreo de su ganado; en temporadas, era arrendado para el cultivo de algodón. Esta situación, sumada a la calidad de las tierras - que, como lo manifiestan sus pobladores, eran de gran riqueza hídrica, lo que aseguraba un futuro próspero para la producción agrícola - sirvió como argumentos principales para que los campesinos eligieran este predio para su ocupación. De igual manera, las campañas de invasión de tierras promovidas por la ANUC a nivel nacional también sirvieron de impulso para llevar a cabo este ejercicio:

Nosotros, como usuarios campesinos, nos organizamos en el municipio de Codazzi y viendo ese territorio, porque hicimos antes de entrar un estudio para bregar que INCORA, cuando eso, tuviera la oportunidad 
Vida campesina en el Magdalena Grande

de darnos a nosotros una adjudicación en la reforma agraria. Pasaron los años y nosotros hicimos todo el estudio de lo que era el Toco. Bueno, entramos por la vía de hecho, nos tomamos ese territorio a la fuerza como llamamos y para nosotros fue una alegría porque no teníamos dónde trabajar, siempre estábamos acostumbrados a trabajar en tierra ajena y al llegar a este territorio donde había hasta animales silvestres fue una alegría para nosotros porque era una tierra muy buena para el campesino (M. Ricardo, comunicación personal, diciembre del 2016).

La ocupación de este territorio se realizó inicialmente con la entrada de 80 familias. Durante los primeros meses no hubo ningún acompañamiento por parte de institución alguna, lo que obligó a los pobladores a dividir sus esfuerzos de trabajo en el trabajo de las tierras recientemente tomadas y jornaleando en fincas vecinas para conseguir los recursos necesarios y llevar a cabo la consolidación de la vereda.

Imagen 53. Cultivo de plátano y yuca

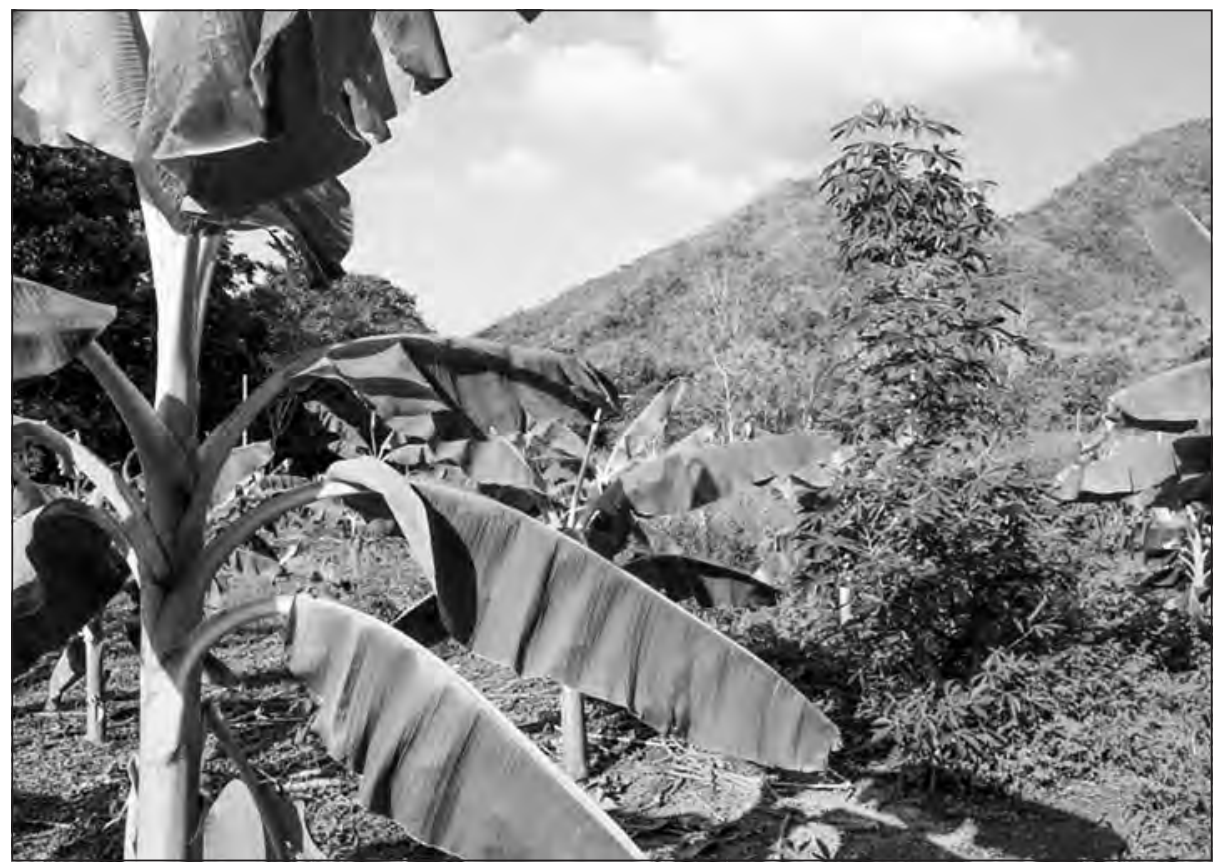

Fuente: Archivo Oraloteca (2017). 
Vida campesina en el Magdalena Grande

Al poco tiempo de haber llegado al territorio ya había cultivos de maíz, papaya, ajonjolí, cacao, entre otros. Y los propietarios de las fincas vecinas, quienes inicialmente veían este grupo de campesinos con malos ojos, comenzaron a ver en ellos una fuerza laboral de confianza, por lo cual los llamaban a trabajar en la recolección de sus cosechas de algodón y para el trabajo en el cuidado del ganado.

De esta manera, en los meses posteriores los campesinos se dispersaron por el territorio hasta ocupar otros lugares como el Ahogado. Se conformaron frentes de trabajo, los cuales se alternaban con el trabajo de jornalero realizado en las fincas vecinas, lo que les permitía a los campesinos conseguir los recursos para comprar los materiales y seguir expandiéndose en el territorio hasta ocupar un nuevo espacio conocido como las Delicias, el cual se encuentra ubicado a la orilla del río. Esta expansión de las familias y su trabajo en el territorio se realizaba procurando respetar siempre los cultivos de algodón ya existentes en él.

Así, al completar el primer año todo era felicidad porque la comunidad tenía recursos, producto de las actividades en las fincas vecinas, y se comenzaban a recoger las primeras cosechas de sus propias parcelas. Igualmente, había una pequeña producción de leche que era comprada en aquel entonces por la empresa Cicolac.

La producción de aquel entonces era comercializada principalmente en el mercado de Codazzi a través de un carro que hacía un viaje diario y era el principal medio de transporte para los campesinos de la vereda y sus productos:

Teníamos un carro, un señor que le decían Coroncoro, salía en la mañana y entraba en la tarde. Así como salía entraba: salía con los bultos de ahuyama, con los de maíz, con los de yuca. Ya [en] el Toco ya había una vida, ya no era un solo dueño, éramos 80 dueños y fueron tierras [en las] que sembraron algodón, arroz y ganadería (M. Ricardo, comunicación personal, diciembre del 2016).

Actualmente, a través de algunas sentencias han obligado al municipio de San Diego y a la Gobernación del Cesar a mejorar las vías de acceso a la vereda, lo cual les facilita a los productores sacar sus cosechas a los mercados locales, principalmente en el municipio de Codazzi y 
Vida campesina en el Magdalena Grande

Valledupar. Por otro lado, aquellos que tienen cría de ganado contratan con un proveedor que va desde el municipio de Codazzi, mientras que otros le venden al dueño de un cuarto frío en el corregimiento de los Brasiles; ambos entran a recoger el producto hasta la vereda.

\section{ASOCOMPARTO y la organización comunitaria de la vereda el Toco}

Desde la llegada al territorio se conformó una junta de acción comunal, llegando a la decisión de contactar al propietario de las tierras y entrar en diálogos con él ya que muchos de los propietarios de las fincas aledañas no veían con buenos ojos que llegaran unos colonos a ocupar las tierras que, en épocas de verano, eran usadas por ellos para el pastoreo de su ganado. Inicialmente, la relación con el propietario de las tierras fue de confrontación, hasta el punto de que en dos ocasiones miembros de la comunidad estuvieron presos. Pero, finalmente, se logró llegar a un acuerdo en el cual el señor Alfonso Murgas puso a disposición el predio para que el INCORA hiciese el proceso de adjudicación. Durante la negociación fue de vital importancia el acompañamiento que hicieron a este proceso organizaciones como el ANDRI (en el Cesar), AMUCI (que era una organización de mujeres campesinas e indígenas) y la ANUC, al igual que la UMATA (por parte del Estado).

De esta manera, la vereda se fue consolidando hasta que aparecieron las primeras escuelas, de las cuales una se construyó con el apoyo de un vecino de la comunidad, quien facilitó las tierras con título para la construcción de la misma:

Un señor llama[do] Lucho Amaya, que es vecino, dio un cuarterón de tierra porque no construían una escuela, porque eso no tenía escritura para nosotros, entonces como él tenía escritura nos regaló ese cuarterón y se hizo la escuela con un restaurante escolar: se les daba desayuno y almuerzo a los niños (M. Ricardo, comunicación personal, diciembre del 2016).

Posteriormente, el departamento hizo el nombramiento de los profesores, los cuales eran docentes residentes en la misma comunidad: 
Vida campesina en el Magdalena Grande

El 13 de agosto de 1996 se crea el Comité de Legibilidad por parte del INCORA, quedando oficialmente inscritas las 80 familias para el proceso de parcelación y adjudicación del territorio. Una vez formalizadas las tierras y creado el comité, se le solicitó a esta institución que se hicieran las medidas técnicas ya que nosotros habíamos dividido el territorio en 80 frentes de trabajo para cultivar y queríamos que la parcelación se hiciera a partir de las demarcaciones ya establecidas por estos frentes. Pero esto no se pudo realizar debido a las dificultades que manifestaba la institución: "INCORA como todo buen ente del Estado, todo instituto del Estado, cuando estaban los funcionarios no había presupuesto para el combustible y cuando había el combustible no había un funcionario dispuesto" (A. López, comunicación personal, diciembre del 2016).

De esta manera, la comunidad estuvo gestionando por todos los medios posibles la realización de las medidas técnicas de estos predios hasta el día 23 de abril de 1997, cuando los paramilitares llegaron por primera vez al territorio, asesinando a Darío Enrique Parada, quien era el secretario de la junta de acción comunal, y al hijo del presidente de la misma, Daniel Antonio Cogollo, a quien confundieron con el padre por tener el mismo nombre. El proceso de desplazamiento forzado que se da en esta fecha marca para la comunidad una ruptura en el tiempo - la cual se prolongó por varios años - y que la comunidad reconoce como "la época del conflicto". Posteriormente, el 18 de mayo del mismo año en el corregimiento de los Brasiles los paramilitares realizan una incursión, dejando como saldo ocho personas asesinadas, de las cuales cinco eran habitantes del Toco y miembros de la junta de acción comunal de esta vereda.

En medio de este panorama, el INCORA ordena realizar las medidas técnicas sobre el predio, para lo cual se realizaría una reunión en el predio, reunión de la cual nunca fueron notificados según las narraciones de los pobladores:

En plena violencia, INCORA ordena la medida de las tierras, lo que nosotros le veníamos pidiendo anteriormente [...]. Muchos no asistieron porque les había tocado irse para Bolívar, para el Tolima y así sucesivamente, pero los que quedamos por aquí cerca asistimos y eso porque había un compañero allá en INCORA y escuchó que iban a medir las 
Vida campesina en el Magdalena Grande

tierras, porque a nosotros no nos notificaron por ningún medio de que se iban a medir las tierras (A. López, comunicación personal, diciembre del 2016).

Una vez realizadas las medidas sobre las tierras, el INCORA determina que las tierras ya no eran aptas para las 80 familias, demarcando solo 55 parcelas en el predio y comprometiéndose a adquirir otro predio para la reubicación de las 25 familias restantes, lo cual quedó plasmado en las actas de dicho proceso. De igual manera, se comprometieron a que si, por alguna razón, una de las 55 familias titulares de las parcelas no pudiese habitarlas, estas no pasarían a manos de terceros, sino que se privilegiarían las 25 familias restantes para su adjudicación. Sin embargo, la institución no respetó estos acuerdos; ante la ausencia de algunas familias a la hora de la parcelación, comenzó a titularle los predios a terceras personas $y$, en ocasiones, a subastar las mismas. Esto ha generado tensiones entre los propietarios originales de las parcelas y aquellos poseedores a quienes instituciones como Acción Social y Restitución de Tierras han reconocido como desplazados del Toco a partir de estas titulaciones, aun cuando ellos en realidad no vivieron ese proceso de violencia.

Después de este periodo de violencia las tierras fueron ocupadas, según relatan los pobladores, por una sola persona: Hugues Rodríguez, más conocido como alias la Barbie. Según narran los toqueros, este señor ocupó todo el territorio con ganado, el cual era custodiado por los paramilitares que hacían presencia constante en el territorio, lo que hacía imposible cualquier intención de ir al territorio por parte de los campesinos que esporádicamente visitaban sus cultivos.

Posteriormente, el 7 de agosto del año 2000 se convocó a una reunión para tratar el tema de la titulación de las tierras, la cual contaría con la participación del INCORA y la Cruz Roja Internacional. Muchos de los campesinos decidieron no asistir por temor a entrar en confrontación con quien en ese momento estaba ocupando las tierras: Hugues Rodríguez. Dicha reunión estaba convocada para las 8:00 a.m., según relatan los "toqueros"; sin embargo, no se presentó ningún funcionario. A las 11:00 a.m. aproximadamente se presenta un grupo de paramilitares pertenecientes a las AUC entre los cuales iba un encapuchado, el cual señalaba entre los asistentes a los propietarios originales y a los nuevos 
Vida campesina en el Magdalena Grande

poseedores. De esta manera, en esa fecha fueron asesinados tres pobladores más de la vereda, sumando de esta forma diez campesinos muertos que hacían parte de las ochenta familias que, inicialmente, habían realizado la ocupación de este territorio:

Como el 5 de agosto dijeron que iba la Cruz Roja y el INCORA, que iban a hacer una reunión porque iban a solucionar el problema del Toco, me invitaron y yo dije: No. Fueron varios... fue tan cruel eso que los compañeros que fueron perdieron la vida. Mataron a la señora Natividad, a la señora Fabiola y al señor Carlos Miranda; todos compañeros de nosotros. El señor Hugues Rodríguez cogió ese territorio con ganadería extensiva: entraba el camión vacío y salía lleno de terneros. No vieron el dolor de una comunidad, mataron tres compañeros. Eso fue el 7 de agosto del 2000 (M. Ricardo, comunicación personal, diciembre del 2016).

Este periodo de zozobra y temor se vivió hasta el 2006 a raíz del proceso de desmovilización de los paramilitares y ante la posibilidad de beneficios que otorgaba el Gobierno a aquellos que entregaran bienes despojados durante su actividad delictiva. En ese momento Hugues Rodríguez devolvió al INCORA los predios pertenecientes a la vereda el Toco. Sin embargo, esta institución sigue irrespetando el acuerdo hecho: continuó titulando los predios a terceras personas y subastando algunas de estas parcelas, ante lo cual los compradores argumentan haberlo hecho de buena fe y, de esta manera, figuran como dueños legítimos de estas tierras.

Después del proceso de desmovilización, la comunidad comienza un proceso de reorganización para la disputa, nuevamente, de aquellas tierras que con tanta fuerza habían logrado levantar y las cuales representaban una opción de vida para ellos y sus familias. De esta manera, en el 2008 nace la Asociación Comunitaria de Parceleros del Toco (ASOCOMPARTO), que ha tomado en sus manos la disputa por la recuperación de sus tierras y la reconstrucción del tejido social de su comunidad, alzando como bandera de lucha la reparación colectiva de sus pobladores, argumentando que ellos fueron todos desplazados los mismos días; por lo tanto, el daño fue colectivo, así que la reparación debe tener el mismo carácter. Los "toqueros" manifiestan que la reparación debe ser de 
Vida campesina en el Magdalena Grande

manera colectiva, respetando el tejido social construido por la comunidad y truncado con la llegada del paramilitarismo.

Sin embargo, dicha institución ha hecho caso omiso a esta petición de la comunidad y, agravando la situación, sigue reconociendo a terceras personas como poseedores originales de las parcelas, perjudicando a los propietarios originales quienes, en muchos casos, han quedado excluidos de las bases de datos de la URT.

La mayoría de los nuevos poseedores de las parcelas responden a lazos familiares de funcionarios de las instituciones encargadas de asegurar el retorno de las familias a sus tierras; según manifiestan los toqueros:

La mayoría [de los nuevos poseedores] son lazos familiares de los directores de las instituciones. Por lo menos, los que están ahorita en su gran mayoría son oriundos del municipio de San Diego y entraron cuando un director de INCODER, de raíces "sandieganas", les avaló esta posesión. Es por eso que nosotros decimos que hemos recibido más perjuicios del mismo Estado que de los grupos al margen de la ley (A. López, comunicación personal, diciembre del 2016).

Hoy en día algunos de los "toqueros" poseen sentencias con fechas de más de un año de expedidas que les reconocen la propiedad sobre sus parcelas, pero las instituciones encargadas de hacer cumplir estas sentencias y formalizar la posesión sobre sus territorios no han hecho mayor esfuerzo por llevar a cabo su labor. En contraste con esta situación, encontramos sentencias de pocos meses de expedidas a favor de terceras personas que ya cuentan con el aval de estas instituciones, quienes garantizan todas las condiciones necesarias para que estas sean ejecutadas.

Frente a esta situación y ante las difíciles condiciones que estaban pasando, alrededor de 16 a 18 familias decidieron regresar al territorio asumiendo todos los riesgos que esta decisión les pudiera acarrear y poniendo de manifiesto con esta acción la incapacidad del Estado de hacer cumplir la ley 1448 y de brindar las garantías necesarias para que las poblaciones víctimas del conflicto y desplazadas de sus territorios puedan volver a establecerse y reconstruir el tejido social de sus comunidades. Al llegar al territorio estas familias encontraron que sus parcelas estaban ocupadas, ante lo cual decidieron retomarlas por la fuerza; sin embargo, 
el resto de la comunidad ha decidido no recurrir a estos métodos para no darle continuidad a un conflicto que todos se esfuerzan en dejar atrás. A pesar de todo, la comunidad manifiesta todo su apoyo a aquellas familias que han tenido que recurrir a las vías de hecho para poder recuperar las tierras que una vez fueron la esperanza de sus familias.

Después del desplazamiento y la persecución de los pobladores (no solo en el territorio, sino fuera de él), la comunidad ha comenzado a preguntarse: ¿cuál es el interés de permanecer y mantener el control sobre estas tierras por parte de aquellos que una vez los desplazaron?, llegando a la conclusión de que el suelo que habitaban tenía más riquezas que las que ellos podían ver a simple vista:

Resulta que hace como unos 30 años habíamos visto, los de esa época, que Ecopetrol había hecho unas trochas por allá y supuestamente estaban haciendo unas visitas, era lo que decían. Hoy en día, Petrosismica y la Drummond hicieron unas pruebas sísmicas en el Toco. Ellos le dijeron a la comunidad que únicamente era para ver qué pasaba, pero no, qué pasaba no. Esta gente nunca va a hacer una inversión tan grande pa’ venir a decir que qué pasaba. Ahí en el subsuelo debe haber algo y si vimos a la Drummond por ahí se confirma que algún mineral debe haber. Ahorita se rumora de que hay carbón y gas (A. López, comunicación personal, diciembre del 2016).

Por otro lado, ASOCOMPARTO ha decidido sumarse a la iniciativa de la Asamblea Campesina del Cesar para la Restitución y el Buen Vivir, la cual está conformada por 14 asociaciones campesinas del departamento, principalmente de los municipios del Copey, Bosconia, la Jagua de Ibirico, Codazzi, San Diego, entre otras, y que nace ante la necesidad de acompañarse unos a otros en las luchas por reclamar nuestros derechos y hacer más visible la situación del campesinado en el departamento.

\section{El retorno y los dilemas de la justicia transicional}

Una de las principales afectaciones que ha sufrido la comunidad del Toco después del desplazamiento forzado ha sido el rompimiento de las relaciones comunitarias y el tejido social que habían logrado construir 
Vida campesina en el Magdalena Grande

a partir de su trabajo. Cuando los campesinos llegaban al territorio el trabajo se hacía de manera colectiva de tal manera que construyeron un solo rancho donde habitaban todas las personas que habían iniciado ese proceso de ocupación: "la Anguilla" fue el nombre dado a ese espacio de reproducción de la vida comunitaria y de las esperanzas de una comunidad que comenzaba a nacer. En este lugar dormían todas las personas y se preparaban los alimentos en ollas comunitarias, lo cual fue creando lazos de afectividad que hizo que llegaran a ser, más que amigos y conocidos, una sola familia.

Imagen 54. Olla comunitaria

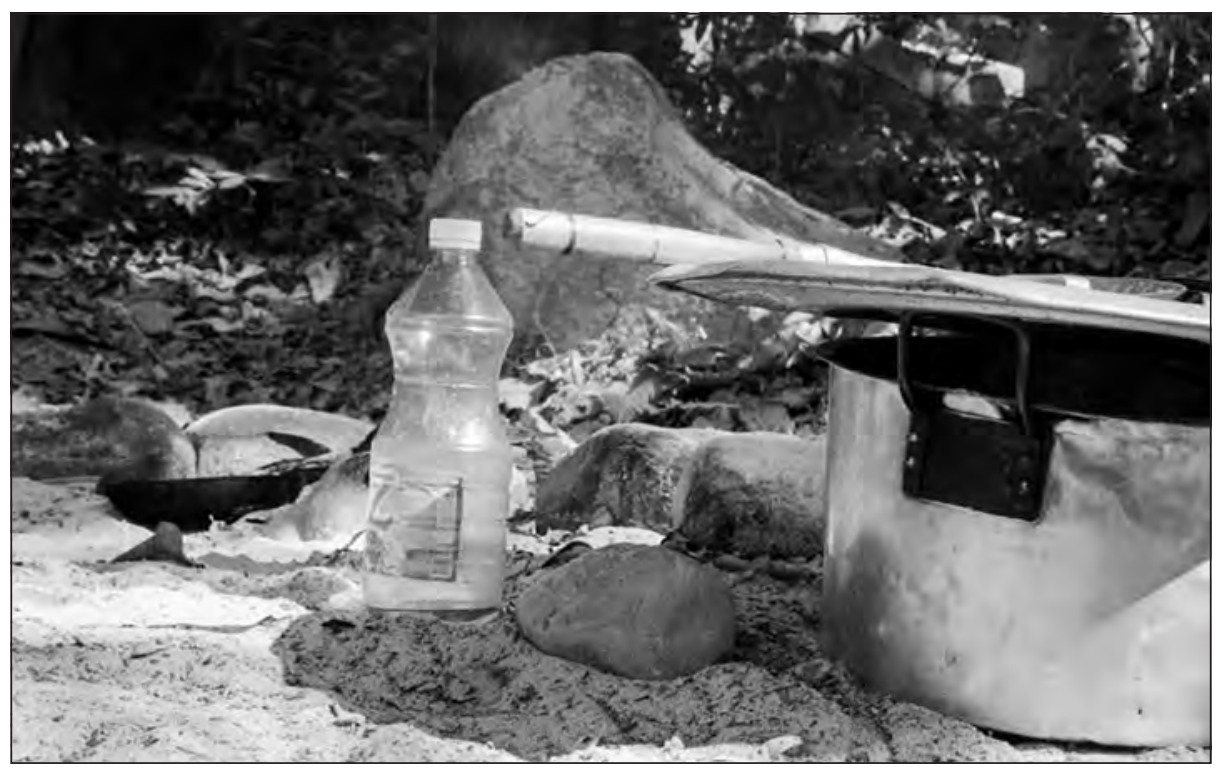

Fuente: Archivo Oraloteca (2017).

Así, los pobladores del Toco comenzaron a ser reconocidos tanto por los dueños de las fincas de alrededor como por las cabeceras de los municipios más cercanos, debido al esfuerzo que invertían estas personas por hacer de este lugar una despensa agrícola para la región. El objeto colectivo era la principal motivación de los "toqueros"; todas las actividades se realizaban de manera colectiva: la siembra, la pesca, el arreglo de las carreteras y caminos, etcétera. 
Vida campesina en el Magdalena Grande

Era tanta la productividad de la comunidad del Toco que se formalizó un refrán en todos los corregimientos y municipios vecinos que decía: "Vaya a coger ahuyama al Toco". En esos tiempos era tanta la felicidad que se vivía en esta vereda que muchas personas manifiestan que preferían ir a pasar todas las festividades allá, aun cuando no tenían luz, agua ni comodidades como las que podían encontrar en los municipios:

Antes, la gente de aquí del pueblo [Codazzi] se iba a pasar el 31 con nosotros. Ya teníamos puercos, ya teníamos chivos, teníamos gallinas. Matábamos un chivo, lo salábamos, el río Cesar botaba buen pescado, nos íbamos a pescar a la sequía del Jobo, salábamos el pescado. Ya había yuca, ya había ñame, porque había gente que metía sus matas de ahuyama, de ñame, había batata, había plátano. Entonces, era un cambio de vida de lo que había en el pueblo al campo: ya no teníamos que pagar un agua, ya no teníamos que pagar un recibo de luz. Y nosotros nos estábamos hasta la una o dos de la mañana de la alegría, nada más con el resplandor de la luna (M. Ricardo, comunicación personal, diciembre del 2016).

Después de los asesinatos de los miembros de la comunidad cometidos por los paramilitares, tanto en la vereda como en el corregimiento de los Brasiles los pobladores entran en un periodo de zozobra en el cual las relaciones comunitarias se rompen ante el temor de hablar. Muchos de los pobladores de la vereda decidieron irse para otros lugares como Venezuela, como el sur de Colombia, y algunos se asentaron en corregimientos y municipios aledaños desde donde realizaban pequeñas incursiones esporádicas al territorio para velar por los pocos cultivos que quedaban después del desplazamiento.

El presidente de la junta de acción comunal, a quien le asesinaron su hijo por confusión, se trasladó después del desplazamiento al municipio de Agustín Codazzi y, como opción de vida, estableció un negocio en el mercado de esta población; paradójicamente, el mismo paramilitar que le había asesinado el hijo le prestaba plata a paga diario ${ }^{1}$ para que pudiera sostener su negocio:

1. "Paga diario" es una modalidad de préstamo de dinero de manera informal y controlada principalmente por grupos paramilitares, en el cual el préstamo realizado debe tener una cuota 
Vida campesina en el Magdalena Grande

A este compañero que le mataron el hijo por confusión, cuando lo desplazaron también se vino para Codazzi, montó un negocito aquí en el mercado y resulta que el mismo paramilitar le prestaba plata a pago-diario. Entonces quiere decir que la cuestión no era personal, era porque necesitaban las tierras (A. López, comunicación personal, diciembre del 2016).

Actualmente, una de las principales luchas que tiene la comunidad con las instituciones encargadas de la reparación integral a las víctimas es la individualización de los hechos victimizantes, aun sabiendo que el daño realizado a la comunidad se hizo de manera colectiva.

Actualmente, frente a todas las tensiones que existen entre los pocos pobladores antiguos que están en el territorio y los nuevos poseedores u opositores de las demandas de restitución de las parcelas, se trata de construir un tejido comunitario. Esta tarea no es fácil debido a que los nuevos poseedores tratan de desgastar psicológica y moralmente a los antiguos a través del sabotaje y la intimidación. Los antiguos tratan de sobrellevarlos con la intención de que les permitan permanecer en sus tierras.

"La primera familia restituida es la familia Lozano Liñán. Ellos fueron restituidos el 13 de marzo del 2013 y han sido las únicas personas a las que les robaron prácticamente todo el proyecto productivo que les dieron. Entonces vemos que hay una persecución en contra de los antiguos" (A. López, comunicación personal, diciembre del 2016).

\section{De colonos a invasores: campesinos de la vereda La Guitarra, en el Cesar}

La Guitarra es una vereda ubicada en la margen derecha del río Cesar, perteneciente al corregimiento de Aguas Blancas, en los límites entre Mariangola y Valledupar, capital del departamento del Cesar. La superficie del corregimiento de Aguas Blancas es mayoritariamente plana,

de cancelación diaria. Las modalidades más usadas son: 10\% de interés a un mes o 20\% de interés a dos meses. 
Vida campesina en el Magdalena Grande

destacándose algunas elevaciones pertenecientes a los inicios de las faldas de la Sierra Nevada de Santa Marta. Las principales actividades económicas del corregimiento son la ganadería (ganado de engorde y producción de lácteos) y la producción agrícola.

\section{Poblamiento}

La vereda La Guitarra se conforma en el año de 1983, aproximadamente, con la llegada de campesinos que buscaban nuevas tierras para trabajar. La decisión de ocupar estas tierras se toma a partir de una investigación previa que algunos miembros de la comunidad realizaron en instituciones como el Instituto Agustín Codazzi, Instrumentos Públicos e INCORA, las cuales le certificaron a la comunidad que estas tierras eran baldías:

En el año 83, por la necesidad de trabajo - que la ciudad de Valledupar nunca lo ha tenido- cogimos el campo. Entramos a estas tierras por medio de la CUT y unos amigos sindicalistas de cuando eso: INCORA. Ellos me dijeron a mí que estas tierras estaban baldías y que estaban en programa de ocupar, de ocupación. Yo no pensé dos veces: entré, vi las tierras, conseguimos los amigos y la[s] ocupamos toda[s] (J. Lara, comunicación personal, enero del 2017).

Al llegar a esas tierras el caño tenía abundante agua y los campesinos en ocasiones extraían peces como moncholo, besote y mojarra. Este caño permitía a las personas que tenían ganado sostenerlo aun en tiempos de verano. De igual manera, los cultivos siempre daban cosechas porque no había problemas para regarlos. Sin embargo, hoy en día una de las principales problemáticas que presenta la comunidad es la escasez del agua, incluso para el consumo humano. 
Vida campesina en el Magdalena Grande

Imagen 55. Padre e hijo en la orilla del río

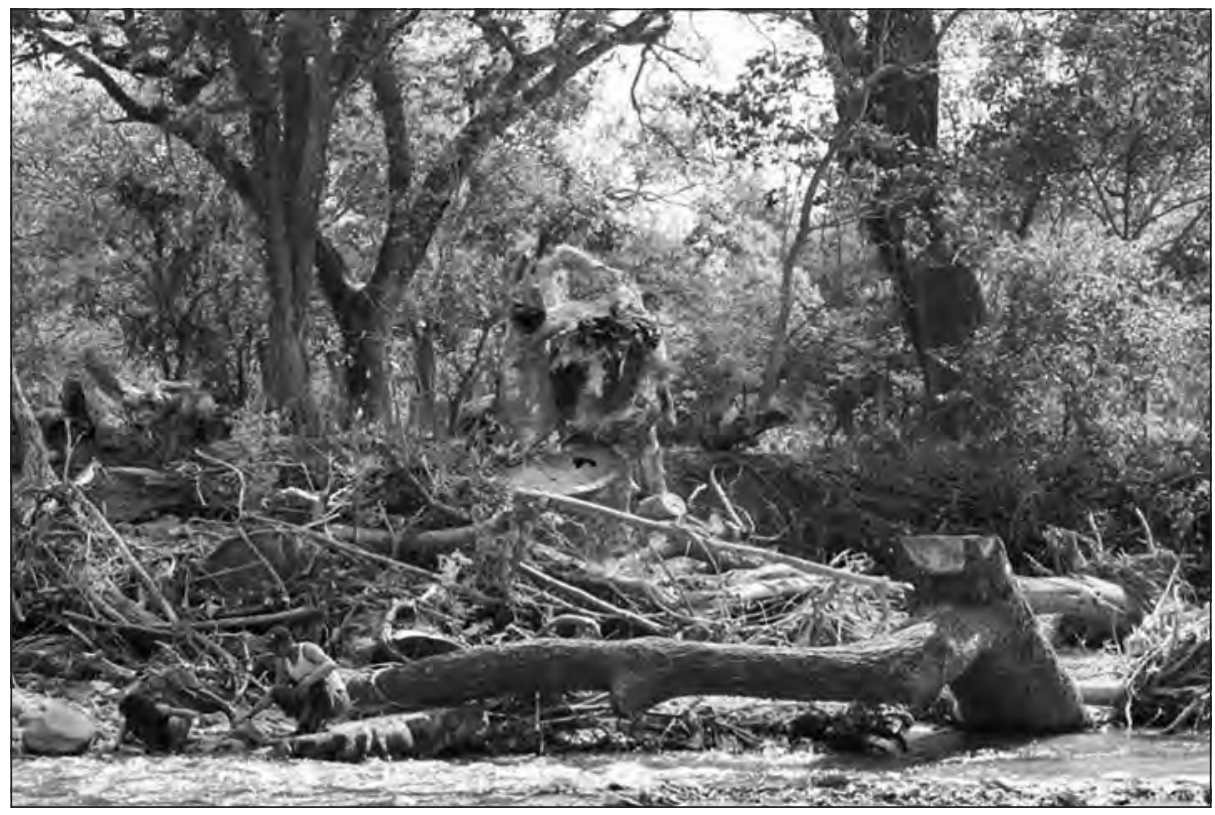

Fuente: Archivo Oraloteca (2017).

El caño, que en sus inicios era abundante en agua, ahora se seca constantemente, producto de la deforestación en todo su cauce. Cuentan los pobladores que incluso en los veranos más intensos el caño les proveía el agua necesaria para sus actividades cotidianas:

El fenómeno del Niño en ese tiempo, cuando la primera vez del fenómeno del Niño que fueron tres años de verano, ese manantial mantuvo agua y el personal aquí mantuvo el ganado en la vereda, y ese ganado bebía agua aquí y no hubo necesidad de sacar el ganado de aquí de la vereda, y se mantuvo con agua el manantial (N. Llorena, comunicación personal, enero del 2017).

En esos primeros años no había fuente de trabajo alguna para los campesinos que comenzaban a ocupar estas tierras, ya que los dueños de las fincas que había alrededor no se atrevían a darles empleo a las personas porque no las conocían. Otras poblaciones, como por ejemplo Aguas 
Vida campesina en el Magdalena Grande

Blancas, no estaban de acuerdo con que los campesinos hubieran ocupado estas tierras y, por tal razón, no les facilitaban ningún tipo de ayuda. Fueron tiempos difíciles, según narran sus propios pobladores:

Cuando mi papá llegó a estas tierras tenía yo como unos diez años. Esto era pura selva, pura montaña. Por aquí nada más las "trillitas" porque en ese tiempo los campesinos las hicieron, las trillas para poder entrar. Por aquí lo que vivía era el tigre, que paraba por aquí. Aquí la única casa que había era la Mayoría y otra finca por allá arriba: Santa Helena. Por aquí no había más casa, esto era pura selva, pura montaña. Incluso los que entraron por aquí en ese tiempo sobrevivieron porque hay un palo que llaman guáimaro, que bota una fruta que si se cocina parece papa, ese era el bastimento que esa gente se comía y la carne era en base a la cacería, porque sí había buena cacería. Con eso sobrevivieron los campesinos en ese tiempo aquí (N. Llorena, comunicación personal, enero del 2017).

\section{Las primeras cosechas y la consolidación de un sueño}

Imagen 56. Campesino a caballo

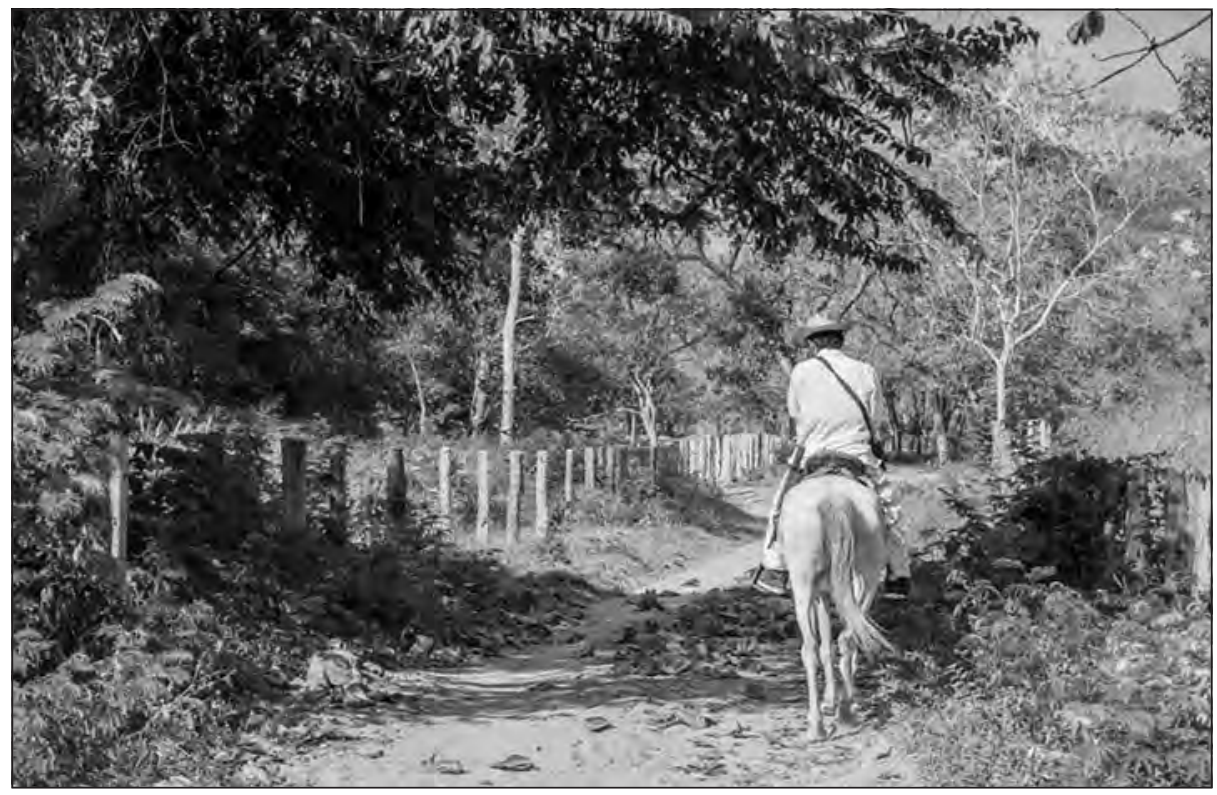

Fuente: Archivo Oraloteca (2017). 
Vida campesina en el Magdalena Grande

Después de los primeros ocho meses de habitar el territorio los campesinos comenzaron a recoger sus primeras cosechas, lo que les permitió ir solventado sus necesidades y las de sus familias. Estas primeras cosechas fueron de maíz, yuca y fríjoles. Anteriormente, existían personas que compraban las cosechas completas, principalmente personas provenientes del corregimiento de Aguas Blancas. De esa manera, se contrataba con estas personas, quienes asumían el gasto de traslado de los productos desde la vereda hasta los mercados donde se comercializaban. Actualmente, son muy pocas las personas que hacen esto debido al pésimo estado de las vías.

A los dos años de hacer presencia en el territorio se logra construir una confianza con los dueños de las fincas vecinas al punto de que estos buscaban a los campesinos de la vereda para que fueran a trabajar de jornaleros en sus tierras.

Actualmente, los productos que más se cosechan en el territorio son el maíz, el fríjol, la ahuyama y la patilla, siendo estos últimos los que más se recogen. También se cultiva la yuca, el tomate, el ajonjolí, y otros productos que se cosechan en menor medida y que sirven para la alimentación de las familias. Cuando se puede, estos productos se comercializan; sin embargo, muchas veces se pierden porque no hay vías adecuadas para transportarlos a los mercados más cercanos.

La comercialización de los productos se realiza dependiendo de la cantidad de quintales que salen por cosecha: cuando pasan de tres quintales los productos son trasladados directamente a Valledupar y cuando no superan este número son trasladados al mercado de Aguas Blancas para reducir los costos y permitir un margen de ganancia sobre el producto:

Entonces, nos queda más difícil ahora, porque ahora directamente tiene uno que salir es al Valle. Más de eso, pues si usted monta 5 bultos en una buseta son 25 mil pesos que tiene que pagar de flete por los bultos: le están cobrando 5 mil pesos por bulto, más el pasaje suyo. Entonces, sale más costoso porque a través de eso está el tiempo suyo, más la comida suya, más los fletes. Pero como no tiene uno otra opción sino... toca llegar allá, porque es allá donde hay el mercado más grande, hay más acceso donde le pueden comprar el producto al por mayor. Mientras que aquí le pueden comprar 1 o 2 quintales. Usted en Aguas Blancas lleva por lo menos 2 
Vida campesina en el Magdalena Grande

quintales de yuca y ya lo chichan. Anteriormente, usted sacaba la yuca que fuera y se la compraban: la patilla, la ahuyama, [al] por mayor. Ya no hay esos grandes compradores ahí en ese pueblo (N. Llorena, comunicación personal, enero del 2017).

\section{La disputa por el territorio}

Al llegar al territorio hubo una disputa legal por la tierra con quien figuraba en ese momento como legítima propietaria: la señora Eulalia Córdoba de Armas. Sin embargo, esta disputa fue ganada por la comunidad, a la que el Estado le reconoció la permanencia en el territorio, aun frente a la apelación del abogado de la propietaria.

En los inicios de los años 90, específicamente entre el 90 y el 93, comienzan a hacer presencia en el territorio grupos armados ilegales, lo que obliga a los pobladores de esta vereda a retirarse hacia los poblados más cercanos. Al salir, los campesinos fueron dejando sus parcelas abandonadas y otros las vendieron a muy bajos precios; todo con la intención de salir huyendo ante la presencia de estos grupos. Después de la retirada de las insurgencias, llegan los grupos paramilitares que operaron en estos territorios entre los años de 1994 y 1996. El accionar de estos grupos, los cuales estaban asesinando campesinos por toda la región, obligó a los pocos que quedaban en el territorio a abandonar sus tierras, las cuales fueron inmediatamente ocupadas por aquellos que ya venían comprando estos predios y que fueron los únicos que se quedaron en el territorio aun con la presencia de los paramilitares. Muchas de las personas que se encuentran disputándoles estas tierras a los campesinos compraron en aquella época hasta cuatro y cinco parcelas a muy bajos precios, aprovechándose del miedo y la zozobra que vivía la población en esos momentos. Sin embargo, nunca sacaron titulación alguna sobre estos predios y los dejaron nuevamente abandonados:

Todas estas tierras estaban solas y comenzaron a cooptarlas ciertos personajes. Ellos nunca les sacaron títulos a las tierras, de ninguna índole. Transcurrieron 20 y pico de años y las tierras siguieron inmersas sin títulos. Ahora unos amigos que hace dos años las ocuparon nuevamente porque estaban abandonadas total (J. Lara, comunicación personal, enero del 2017). 
Ahora que la comunidad ha vuelto a retomar las tierras, acompañados de un nuevo grupo de compañeros, la mayoría hijos y familiares de aquellos campesinos que entraron por primera vez, estas personas han querido sacarla a la fuerza, incluso haciendo uso de la policía para intimidar y presionar su salida del territorio.

En algunas ocasiones se han hecho investigaciones por parte de personas particulares sobre algunos de los miembros de la comunidad, lo que ha obligado a la comunidad a entablar denuncias ante la Procuraduría y la Fiscalía para esclarecer las causas de estos seguimientos que se les vienen haciendo.

La comunidad pudo constatar que, efectivamente, el señor Iván Santiago iba al batallón para pedirle a un coronel el acompañamiento de seguridad para visitar una finca que asegura ser de su propiedad, pero que los campesinos comentan que son tierras que él expropió a campesinos de la vereda. Este acompañamiento, según nos cuentan los "guitarreros", se hacía con la intención de intimidar a los campesinos con la presencia del ejército. Cuando se dieron cuenta de que pusimos las denuncias frente a los seguimientos, dejaron de hacer estas visitas al territorio con las fuerzas militares.

Posteriormente, ingresan en dos ocasiones al territorio personas de civil; la comunidad responde capturándolas en el territorio y entregándolas a la fuerza pública para que se hicieran las respectivas investigaciones sobre quiénes eran.

Nuevamente, se acercaron a la vereda con la policía y la Secretaría de Gobierno de la Alcaldía de Valledupar, repartiendo panfletos en donde se le anunciaba a la comunidad que debía desalojar los predios porque estaba invadiendo propiedad privada, argumentando que esos predios ya tenían titulación y pertenecían a otras personas. De esta manera, la comunidad tuvo que realizar marchas y otras actividades para frenar este proceso de desalojo que los amenazaba.

Ante esta situación, la comunidad realiza nuevas denuncias frente a las cuales un juez de Valledupar asumió el caso y les ha pedido a las personas que argumentan ser los dueños legítimos de las tierras que aporten las pruebas necesarias para demostrarlo, obteniendo como respuesta un silencio absoluto de estas personas. Así, en estos momentos la comunidad se encuentra a la espera de que el juez que lleva el caso emita el fallo final frente a esta problemática. 
Vida campesina en el Magdalena Grande

Actualmente, la comunidad se encuentra organizada a través de una junta de acción comunal debido a que la condición en que se encuentran ellos en las tierras les dificulta la legalización de otras formas organizativas como asociaciones o cooperativas. Es a través de esta junta que la comunidad establece todo tipo de interlocución con las entidades del Estado, las ONG y otras organizaciones. Las decisiones se toman de manera asamblearia, reuniéndose el segundo domingo de cada mes.

Por parte del Estado, la comunidad manifiesta que la policía ha hecho un par de visitas con actividades para los niños y brigadas de salud. Por su parte, el Bienestar Familiar también ha hecho presencia, pero de manera irregular debido a algunos intereses particulares de algunos de sus funcionarios:

La única [entidad] que ha estado aquí pendiente de los niños ha sido el Bienestar. Aunque como una de las supuestas dueñas de las tierras trabaja en el Bienestar, la mayoría de los supuestos dueños de las tierras tienen un empleo en la Alcaldía. El Bienestar aquí a los niños lo que les ha dado es lechita, pancito. O sea, no es lo esencial que se necesita porque hay niños que están bajo[s] de peso, como también hay casos especiales de dos o tres niños que están en estado de desnutrición. La ayuda que le compete el Bienestar de darle a esos niños en la situación que están no ha sido lo suficiente (N. Llorena, comunicación personal, enero del 2017).

\section{“Nos acusan de invasores y por eso no hay inversión"}

En temas como educación la comunidad ha logrado la construcción de una escuela en la vereda; sin embargo, esta solo cuenta con cursos hasta quinto de primaria, obligando a los estudiantes a dedicarse a actividades del campo una vez cumplido este ciclo. Aquellos que deciden continuar sus estudios deben trasladarse de manera permanente hasta otros corregimientos para lograrlo, desligándose de la vida familiar y comunitaria.

En el tema de salud la comunidad no cuenta con un centro de atención médica y cualquier enfermedad es tratada a través de un botiquín comunitario que posee un campesino de la vereda encargado de mantenerlo actualizado a partir de medicinas que cada quien puede conseguir cada vez que salen a la ciudad. Si el caso es de extrema gravedad, el enfermo 
Vida campesina en el Magdalena Grande

debe ser llevado de manera urgente al corregimiento de Aguas Blancas o a la ciudad de Valledupar.

La comunidad no cuenta con el servicio de energía eléctrica. Actualmente, hay unos proyectos para llevar la energía eléctrica a la región, pero le han manifestado a la comunidad que ellos no pueden ser incluidos por la situación en la que se encuentran, ya que la administración local los sigue considerando como invasores. En esa medida, siguen esperando que el fallo del juez pueda, por fin, quitarles ese estigma y poder gestionar los proyectos necesarios para el mejoramiento de las condiciones de vida en la comunidad.

La comunidad no cuenta con servicio de agua potable y agua para el consumo y las actividades diarias se toman de partes del caño - que aún mantiene un flujo mínimo-y de pequeñas charcas que se empozan, pero que no tienen ningún tipo de tratamiento. La comunidad ha presentado varias veces, y a través de varias instituciones, el proyecto para el desarrollo de un acueducto comunitario que aporte el recurso a la comunidad y a otras veredas vecinas; sin embargo, este siempre ha sido negado:

El Gobierno nos negó el año pasado, cuando estaba la gente recién metida, nos negaron el agua. Fuimos a Prevención de Desastres del municipio y nos dijeron que nos mandaban un carro tanque de agua al día siguiente; fuimos al departamental y [que] nos iban a dar las mangueras; estuvimos en la Gobernación... todos nos cerraron los espacios porque los dueños de las tierras tienen mucha influencia en el gabinete municipal y departamental y, por hacerle caso a ellos, nos negaron todas las ayudas (J. Lara, comunicación personal, enero del 2017).

Alrededor de la vereda encontramos, principalmente, grandes fincas ganaderas en las que la principal actividad es el ganado de engorde y la producción de lácteos. La relación de la comunidad con los dueños de estas fincas ha sido de mutuo respeto y cordialidad; incluso los campesinos manifiestan que el dueño de la finca de producción de lácteos les proporciona diariamente leche para el alimento de los niños de la comunidad. 
Vida campesina en el Magdalena Grande

De igual manera, hacia la parte de arriba de la vereda, en los inicios de las faldas de la Sierra Nevada de Santa Marta, se encuentra un asentamiento de la comunidad Aruhaca, con la que se mantiene una relación cordial, organizándose actividades de integración entre las comunidades:

Aquí arriba está la comunidad de... la zona indígena. Pues nosotros con los indígenas tenemos una integración muy mutua, pues de compartir, nos hemos familiarizado mucho con ellos y ellos con nosotros, y hemos compartido ratos de entretenimiento, en deporte. Ellos han venido aquí y nosotros hemos ido allá, nos hemos relacionado más como familia y compañeros de la misma zona sin entrar en contradicciones con ellos; todo lo contrario (N. Llorena, comunicación personal, enero del 2017).

Así mismo, manifiestan que, en ocasiones, han recibido visita de comunidades yukpas pertenecientes a la Serranía del Perijá y que tienen familiares por la Mina de Iracal, que es una población cerca de la vereda, al igual que miembros del pueblo Kamkuamo.

\section{Agricultura y minería: tensiones por el territorio en la vereda Entre Ríos}

Imagen 57. Concesión minera en la vereda Entre Ríos

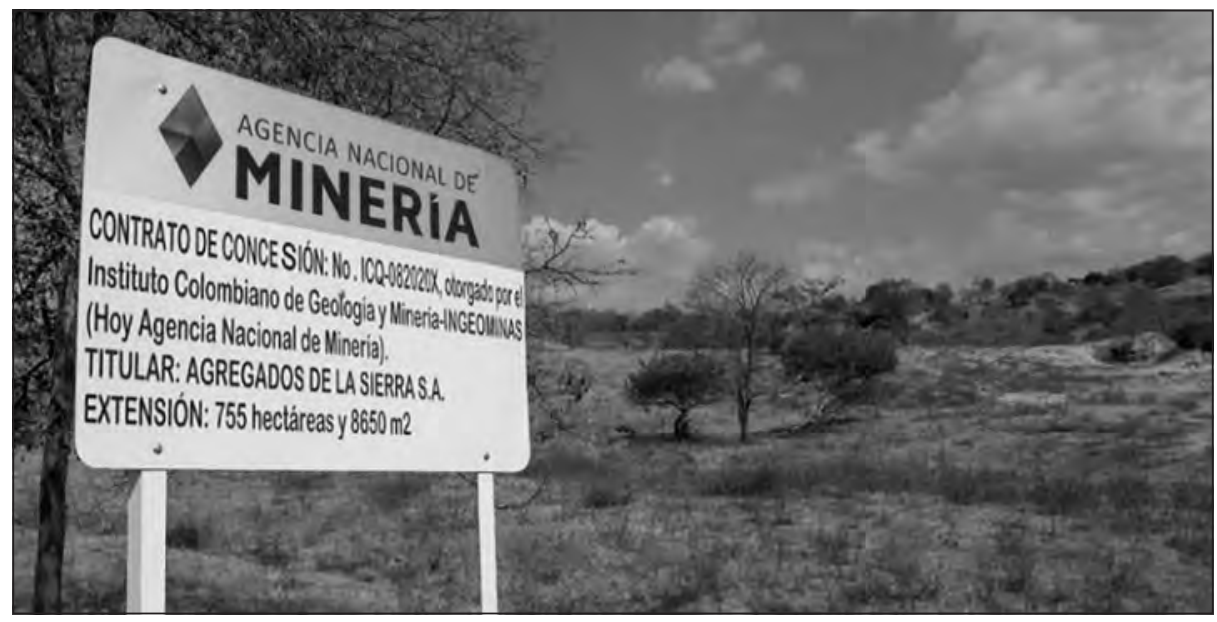

Fuente: Archivo Oraloteca (2017). 
Vida campesina en el Magdalena Grande

La vereda Entre Ríos se encuentra ubicada en el corregimiento de Caracolicito, en el municipio del Copey, al noroccidente del departamento del Cesar. Está situada, como su nombre lo indica, entre los ríos Ariguaní y Ariguanicito, los cuales se juntan para convertirse en uno de los principales afluentes que alimentan el río Cesar. La superficie de la vereda está inclinada por estar en las faldas de la Sierra Nevada de Santa Marta, destacando pequeñas elevaciones que sobresalen en el territorio mayoritariamente plano.

\section{Poblamiento}

La vereda nace a partir de la llegada al territorio de 18 familias procedentes de diferentes lugares de la región, ocupándolo de manera permanente hasta lograr su titulación en el año 1985: este año sobresale en las narraciones de los entrevistados como la fecha que divide el "antes" y el "después" de sus historias de vida, ya que lograr la titulación de las tierras se convierte en la gran victoria de la comunidad. La titulación de las tierras se logra mediante la compra de los predios al propietario de ese momento, el coronel Alfonso Rodríguez Rincón, quien al ver que las tierras estaban ocupadas y que el Estado estaba interesado en comprarlas accedió a vender:

La vereda nace en 1985 con un grupo de 18 familias. En ese momento se meten como colonos y el Estado, al ver la necesidad de estas familias de tener un pedazo de tierra, decide comprar la finca y repartírsela acá a las 18 familias; [fue] en 1985 que fue titulada. En ese momento le compran al coronel Alfonso Rodríguez Rincón, a un coronel del ejército, 648 hectáreas entre 18 familias que venían de diferentes lugares: vino gente del Copey, del Magdalena, vino gente de San Jacinto, un poco de pueblos de diferentes sectores (D. Carmona, comunicación personal, enero del 2017).

Al llegar al territorio, la población encuentra que había una vegetación abundante y que los animales andaban libres por los caños y pastizales; incluso en alguna ocasión llegaron funcionarios del Gobierno promoviendo programas de conservación en esta zona, argumentando que, por su gran riqueza medioambiental, debía ser una zona de reserva, por lo 
Vida campesina en el Magdalena Grande

cual había que procurar su conservación para la protección de la fertilidad de los suelos y la producción de oxígeno y el hábitat para las innumerables especies que habitaban el territorio.

\section{Afectaciones al medio ambiente por la actividad minera}

Actualmente, gran parte de estos bosques han sido deforestados por miembros de algunas familias que reclaman ser propietarias de estos predios y que, pasando por encima de todas las normas legales, les han metido motosierra a los bosques para utilizar la madera para hacer carbón o para ser comercializada en los centros urbanos, quedando desprotegida toda la fauna que utilizaba estos bosques para su refugio, principalmente en la época de verano:

Bueno, a ellos los trajeron e hicieron unos programas de siembra de árboles allá en la orilla del río, hicieron un programa de reforestación y lo primero que nos dijeron era que podíamos utilizar la tierra, pero sabiéndola utilizar, que por cada hectárea de tierra debíamos dejar mínimo siete árboles grandes porque la tierra se iba poniendo estéril, a la tierra la oxigena[n] son los árboles, entonces donde usted no le deje oxígeno muere y eso es lo que nos está pasando ahorita aquí (A. Tejeda, comunicación persona, enero del 2017).

Imagen 58. Deforestación en la vereda La Guitarra

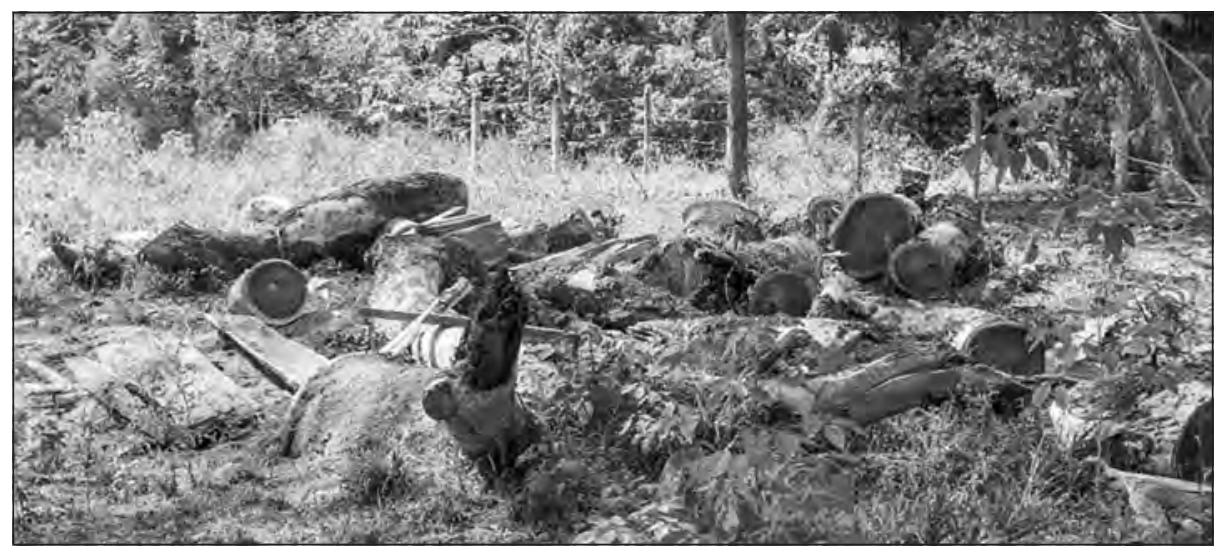

Fuente: Archivo Oraloteca (2017). 
Vida campesina en el Magdalena Grande

Actualmente, los pobladores identifican a la empresa LATINCO (Latinoamericana de Construcciones) como la principal responsable de los deterioros que viene sufriendo el territorio. Los territorios donde se desarrollan las actividades de esta empresa pertenecen al señor Alfonso Acevedo, quien se dedica principalmente a la ganadería extensiva y a la producción láctea. Sin embargo, en sociedad con los inversionistas de LATINCO ha dispuesto sus territorios como puntos para la extracción de material de arrastre de los ríos Ariguaní y Ariguanicito, generando deterioros no solo en el cauce de los afluentes, sino en la infraestructura comunitaria, como es el caso del puente de la vereda, única vía de comunicación entre los pobladores de Entre Ríos y el área urbana del corregimiento de Caracolicito y del municipio del Copey. Aunque esto ya ha sido denunciado en varias ocasiones, las instituciones encargadas no asumen ninguna responsabilidad sobre el hecho $\mathrm{y}$, al contrario, las personas que han denunciado han tenido que retirarse del territorio como resultado de las amenazas en su contra.

Imagen 59. Río Ariguaní

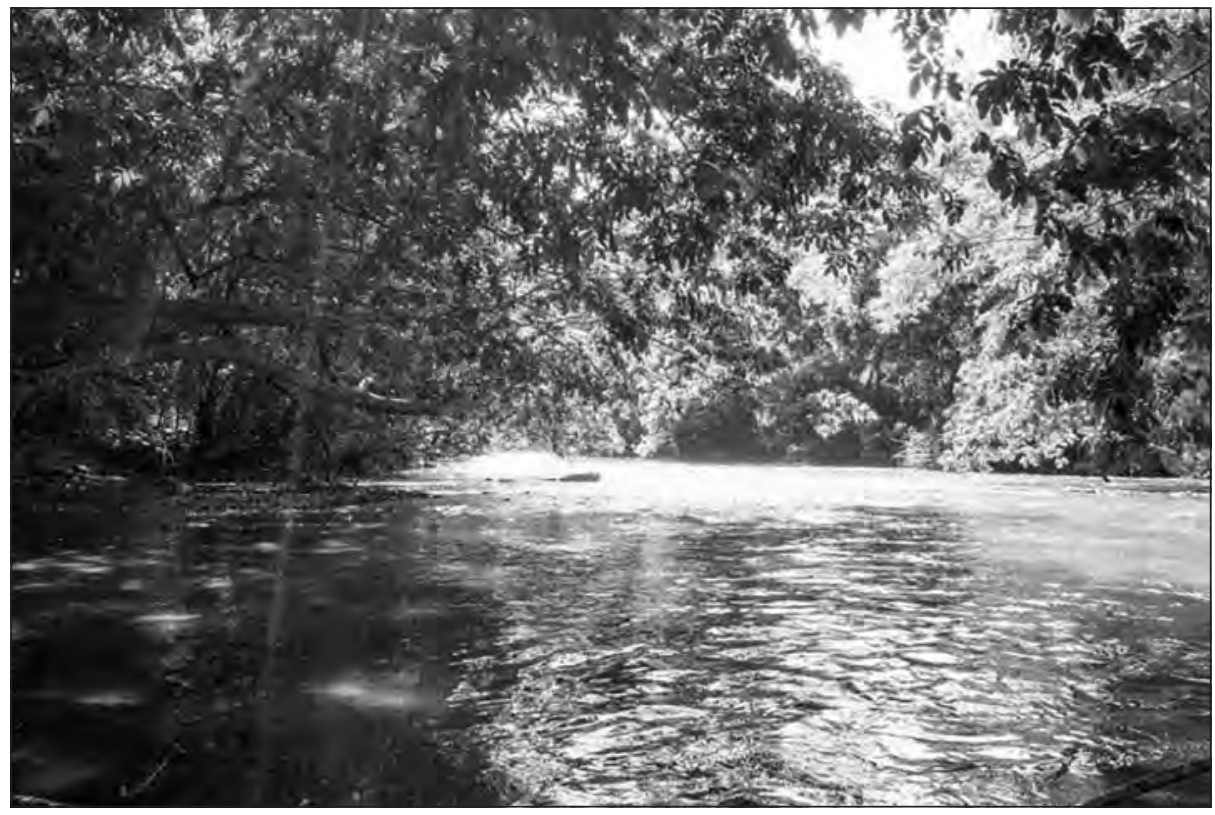

Fuente: Archivo Oraloteca (2017). 
Vida campesina en el Magdalena Grande

Por otro lado, una de las mayores afectaciones que ha ocasionado la presencia de esta empresa en el territorio es la imposibilidad de consolidar el tejido social de la comunidad, ya que la empresa emplea a algunos miembros de la comunidad, generando tensiones entre quienes tienen acceso a estos empleos y ven la empresa como una oportunidad económica para la vereda y para el futuro de sus familias y quienes ven en la empresa un peligro inminente que amenaza la permanencia de los campesinos en sus territorios:

La empresa, ella aparentemente nos está dando un beneficio, pero nos está explotando. Esa es una empresa de ganado y también tienen una trituradora de piedras, tiene un convenio con otra empresa para sacar material de arrastre del río, ese es otro perjuicio que nos ha ocasionado porque uno de los factores para que el puente se cayera fue que le sacaron todo el material de arrastre; ahora, como ya ese puente quedó afectado, entonces ahora cogieron el río Ariguaní grande por aquel lado [y] le están sacando todo el material de arrastre. Se hicieron denuncias, vino la policía, vinieron inspectores, vino gente del Copey, y ellos mostraron una base de documentos [en los] que, supuestamente, todo está legal; sin embargo, en la noche ellos no lo hacen: de día colocaron un letrero de "prohibido a particulares" en el río, parece que se apoderaron del río (D. Carmona, comunicación personal, enero del 2017).

Actualmente, esta situación con la empresa y otras empresas que vienen entrando al territorio es preocupante, manifiestan los pobladores. Ellos denuncian que la empresa, la cual se dedica a la construcción, está perjudicando a la población cuando su accionar debería producir el efecto contrario en la comunidad. Ellos esperaban que la empresa mejorara las vías, tener un mejor puente y, en general, mejorar la infraestructura comunitaria; en cambio, lo que han recibido son solo perjuicios:

Cómo es posible que eso es de todos y para todos, entonces una sola empresa se ha apoderado de eso porque ellos compraron las fincas, se llama el Paraíso, pero ni el río ni la vía, entonces las vías son de ellos, por eso es que por aquí ellos no gustan. Se formó el "coge-coge" y nosotros se lo dijimos: "ustedes son una empresa constructora, debían poner 
Vida campesina en el Magdalena Grande

mejor esto que lo que está, pero usted[es] fue[ron] aleves y por poco no dejan nada; encontraron el río con todos su materiales y no dejan nada, y ustedes por ley tenían era que los impuestos dejárnoslos en obras y nos han dejado es la destrucción, la desolación, ahí donde están esos letreros nadie puede pescar, nadie puede pasar ni bañarse ni nada". Usted va ahora a irse a bañar donde era un sitio turístico y usted no encuentra un árbol donde el sol no le pegue: eso está pelado, destruido (A. Tejeda, comunicación personal, enero del 2017).

De igual manera, una de las mayores afectaciones que manifiesta la comunidad en estos momentos es la construcción de la doble calzada de la Ruta del Sol, específicamente la variante que va desde Bosconia hasta la ciudad de Valledupar, proyecto ejecutado por la empresa YUMA, la cual, para la realización de esta vía, ha talado todo el bosque a los lados de la calzada actual y ha ido rellenando, a la vez, los humedales, bloqueando así el curso natural de los afluentes hacia el río Cesar:

La YUMA, ella supuestamente está haciendo un beneficio porque está dejando una troncal y todos esos árboles los ha arrasado. El perjuicio más grande que le ha ocasionado al Copey es que lo va [a] dejar por fuera, eso recogieron como 2 mil firmas para que al menos pasara por el centro del Copey y los comerciantes, la gente de los restaurantes, recibiera algún beneficio del comercio. Y no, que van a dejar al Copey por fuera, eso es lo que se ha dicho; entonces ya se va convertir en un pueblo aislado, como Fundación, como todos estos pueblos fantasmas (A. Tejeda, comunicación personal, enero del 2017).

Esto último es una de las mayores preocupaciones de los pobladores debido a la experiencia vivida con la realización de la anterior calzada nacional, cuando otras poblaciones como Fundación y la Loma, entre otras, quedaron aisladas de la calzada nacional, perdiendo la conectividad con el resto del país y perjudicando sustancialmente al campesinado que habita estas poblaciones debido a las dificultades que implica actualmente transportar los productos desde estas poblaciones hasta los centros de comercialización: 
Vida campesina en el Magdalena Grande

Así pasó con la primera carretera nacional que había entonces, que para mejorar[nos] la situación a nosotros y nos la empeoró. Antes, salíamos a pie a coger los carros, los buses, donde fuera; ahora si usted no tiene, tiene que irse allá a la central en moto o taxi. ¿Qué pasó? Que quedó Santa Rosa, Bella Vista, todos estos pueblos se acabaron, ya no existen. Ahí vivían era de eso, de lo que hacían para vender; ahora son pueblos fantasmas, muertos, tanto que ya Bella Vista dice la gente que ya no existe: hicieron un barrio Bella Vista, lo fueron a hacer a la Loma del Bálsamo, eso quedó horrible (A. Tejeda, comunicación personal, enero del 2017).

\section{La vida Entre Ríos}

Al llegar al territorio los pobladores encontraron un entorno violento debido a la presencia de diferentes grupos armados que merodeaban la zona con el fin de poder tener bajo control todo lo relacionado con las actividades de la Bonanza Marimbera que se mantenía en la región. De este modo, los campesinos fueron asediados, señalados, perseguidos y hasta asesinados con el objetivo de que abandonaran el territorio al punto de que, según las narraciones de los entrevistados, funcionarios públicos del Estado participaron de los hostigamientos a la población para que saliera del territorio:

Pues el territorio era productivo, aunque era bastante hostil porque en ese momento estaba la bonanza de la marihuana, entonces había mucho conflicto... hubo asesinados aquí. Iniciando la colonización asesinaron a un joven llamado David Mercado, fue el primer asesinado antes de la titulación; desaparecieron [también] a un líder comunitario, Miguel Jiménez Guardiola, que hoy en día la escuela lleva ese nombre en homenaje a él. Entonces fue bastante difícil, para obtener estas parcelas hubo asesinatos, instigaciones, hasta el propio alcalde del Copey en ese entonces vino y quemó todas las casas... fue complicado (D. Carmona, comunicación personal, enero del 2017).

Lo primero que hicieron los pobladores al llegar al territorio fue comenzar a sembrar sus productos, entre los que se destacan el maíz, la yuca, el plátano, el fríjol y, en algunos lugares, el arroz: 
Vida campesina en el Magdalena Grande

Fríjol, maíz, ñame, yuca, plátano, esto era una belleza, aquí la gente vivía de los cultivos, de la gallina; o sea, no tenía prácticamente mucho que ir a hacer al pueblo, cuando mucho el arroz y había en partes acá que se cultivaba, entonces, pues, eso fue antes de que viniera la violencia, pues cuando ya vino la violencia, que la gente se fue, todo esto la mayoría fue destruido, que comenzaron a meterle ganado, ellos, los paramilitares (D. Carmona, comunicación personal, enero del 2017).

En esos primeros años de cosecha las personas no tenían vías de comunicación, por lo cual sus productos eran principalmente para el consumo de la comunidad y el excedente que quedaba para la comercialización era transportado en burros por caminos de herradura hasta los poblados más cercanos, principalmente hasta Fundación porque el Copey, según manifiestan los pobladores, nunca ha sido una buena plaza para los productos del campesinado. Actualmente, los productos se siguen sacando hacía Fundación principalmente y, en algunas ocasiones, llegan vehículos de otras ciudades que entran hasta la vereda a comprar los productos directamente en el territorio; sin embargo, esto solo sucede en época de verano ya que en temporada de lluvias las vías de acceso se pierden en medio de las inundaciones y los derrumbes:

Bueno, en estos momentos la mayoría cae para Fundación o para el Copey o Bucaramanga... Lo compran a mejor precio, ahí lo están vendiendo para allá, para un carro que viene para Bucaramanga, un carro que entra ahora que estamos en verano por lo que te comentaba que el puente se dañó. La preocupación de nosotros es cuando llegue el invierno cómo vamos a hacer para sacar los productos si no arreglan la vía que está en mal estado y el puente también, eso nos preocupa: comienza a llover y se forman unos charcos horribles y el río no va [a] dar paso, esa es la preocupación de nosotros mirando a ver cómo nos resuelven eso (D. Carmona, comunicación personal, enero del 2017).

En el tema de infraestructura comunitaria la comunidad manifiesta que ha habido avances; sin embargo, deja claro que esto se ha logrado a partir de la presión de los mismos pobladores a nivel nacional ya que desde las administraciones locales el abandono de la vereda es total. 
Vida campesina en el Magdalena Grande

Imagen 60. Puente de acceso a la vereda Entre Ríos

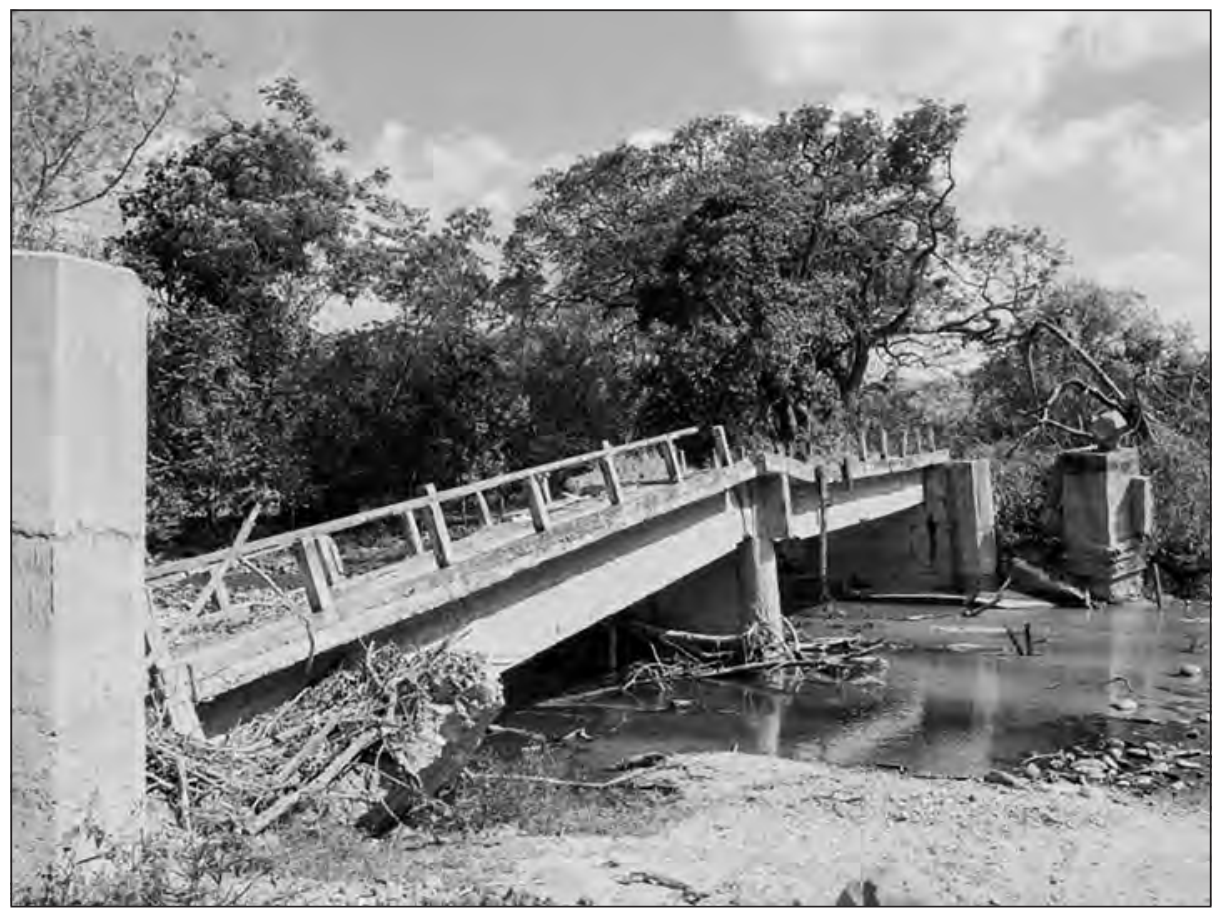

Fuente: Archivo Oraloteca (2017).

Para el caso de la educación existe una pequeña escuela que se logró construir a partir del esfuerzo comunitario, eligiendo a una lideresa de su comunidad como concejal del municipio, quien se encargó de realizar las gestiones necesarias para la construcción de la infraestructura mínima para el funcionamiento de la escuela. Sin embargo, aun teniendo la infraestructura la vereda no contaba con un docente nombrado debido a que había muy pocos niños en la población. Hubo la necesidad de mandar una carta al Presidente de la República para manifestar la situación frente al tema, a lo cual este respondió que de inmediato se debía garantizar la educación de los niños de la vereda, por lo cual se construyó la escuela y se nombró un docente de aula.

Esta escuela responde al nombre de uno de los primeros líderes asesinados en la vereda: Miguel Jiménez Guardiola. Actualmente, una de las preocupaciones de la comunidad es el acceso a las pocas escuelas que hay 
Vida campesina en el Magdalena Grande

en el territorio ya que, en muchas ocasiones, los estudiantes deben cruzar el río y, cuando este se crece, no hay posibilidad de asistir a clases. Algunas aulas se encuentran en terrenos prestados y solo poseen un techo de palma y sin paredes.

Imagen 61. Escuela rural en la vereda Entre Ríos

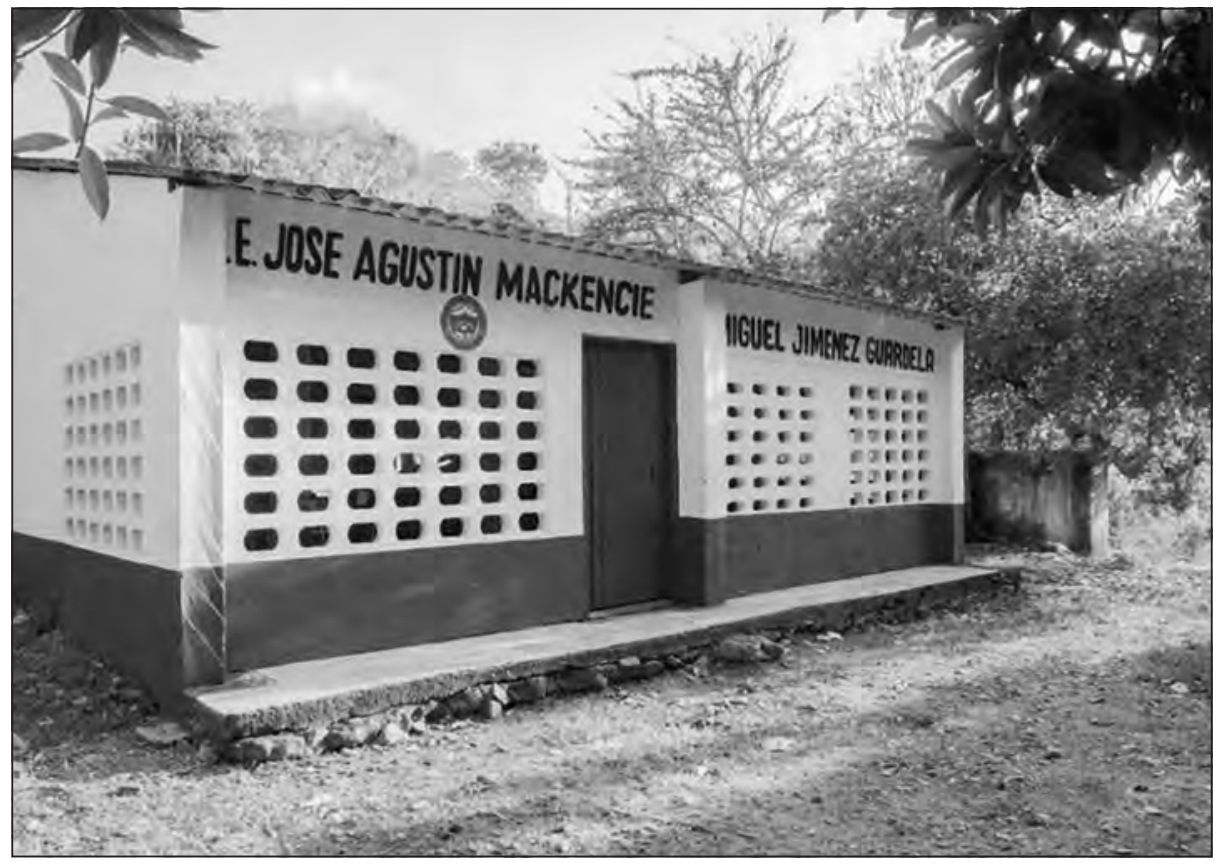

Fuente: Archivo Oraloteca (2017).

En el tema de salud la situación es preocupante ya que la comunidad no cuenta con los recursos mínimos para la atención de una emergencia y en Caracolicito, que es el poblado más cercano, tampoco hay las condiciones para atender a los pacientes debido a la falta de implementos, los cuales deben ser comprados por los mismos enfermos que, en muchas ocasiones, no cuentan con el dinero:

Pero la salud sí todos los que se enferman tienen que salir es al Copey porque ni siquiera Caracolito, ahí en Caracolito no se encuentra los recursos para auxiliar a alguien porque si la persona va herida le toca 
Vida campesina en el Magdalena Grande

comprar hasta el hilo de coser. La situación no es solo que las enfermeras estén, lo que no hay son los recursos que necesitan, el material para trabajar, entonces en salud el municipio está mal. Si es el hospital usted le hace una visita eso no hay ni camillas, eso está un desastre, no le brindan ni comida a los pacientes, en salud estamos mal. Acá se presentó un proyecto para un puesto de salud, lo presenté yo para el 2014, pues la excusa que sacaron es que a los predios del colegio les dictaron caducidad administrativa porque como la gente se fue desplazada y lo abandonó entonces ellos aprovecharon para otra vez la entidad apoderarse de la tierra; a la mayoría de parcelas que quedaron solas les dictaron caducidad administrativa, entre esas, cayó el colegio. Entonces, el único predio público donde se podía construir era el terreno del colegio; entonces dijeron que no se podía hacer porque si yo construía en ese colegio [me] podían coger preso porque eso era del INCODER, que el municipio tenía que hacer el trámite para que ese predio pasara al municipio. Y a la administración en su momento me cansé de decirle que era Wilfrido Ruiz Rada, el alcalde no hizo la gestión. Pues ahora, en el momento, USAID tiene un proyecto para veinte predios públicos legalizarlos, entonces estamos mirando si con esta administración, a ver si los predios de la escuela de acá pasan al municipio para nosotros poder gestionar los proyectos... así sea un puesto de salud, una cancha de futbol, una cosa que enriquezca la vereda, entonces en el tema de salud sí que estamos mal (D. Carmona, comunicación personal, enero del 2017).

En cuanto al tema de servicios públicos el agua es tomada de los afluentes que bañan la vereda y que, a su vez, proporcionan el líquido vital a los demás poblados del municipio; sin embargo, cuando se presentan las épocas de verano el recurso disminuye, de manera que se han sufrido varias jornadas de racionamiento producto de la escasez del agua en las partes altas de los afluentes. Por otro lado, cuando se presenta la época de lluvias los afluentes aumentan su caudal de manera que el agua se revuelve y se hace imposible su cooptación para el consumo humano. De esta manera, al no contar con una infraestructura mínima para garantizar el recurso en la comunidad, los pobladores dependen de las estaciones del clima para poder tener acceso al preciado líquido. 
Vida campesina en el Magdalena Grande

\section{La lucha por la permanencia en el territorio}

Imagen 62. Paisaje en la vereda Entre Ríos

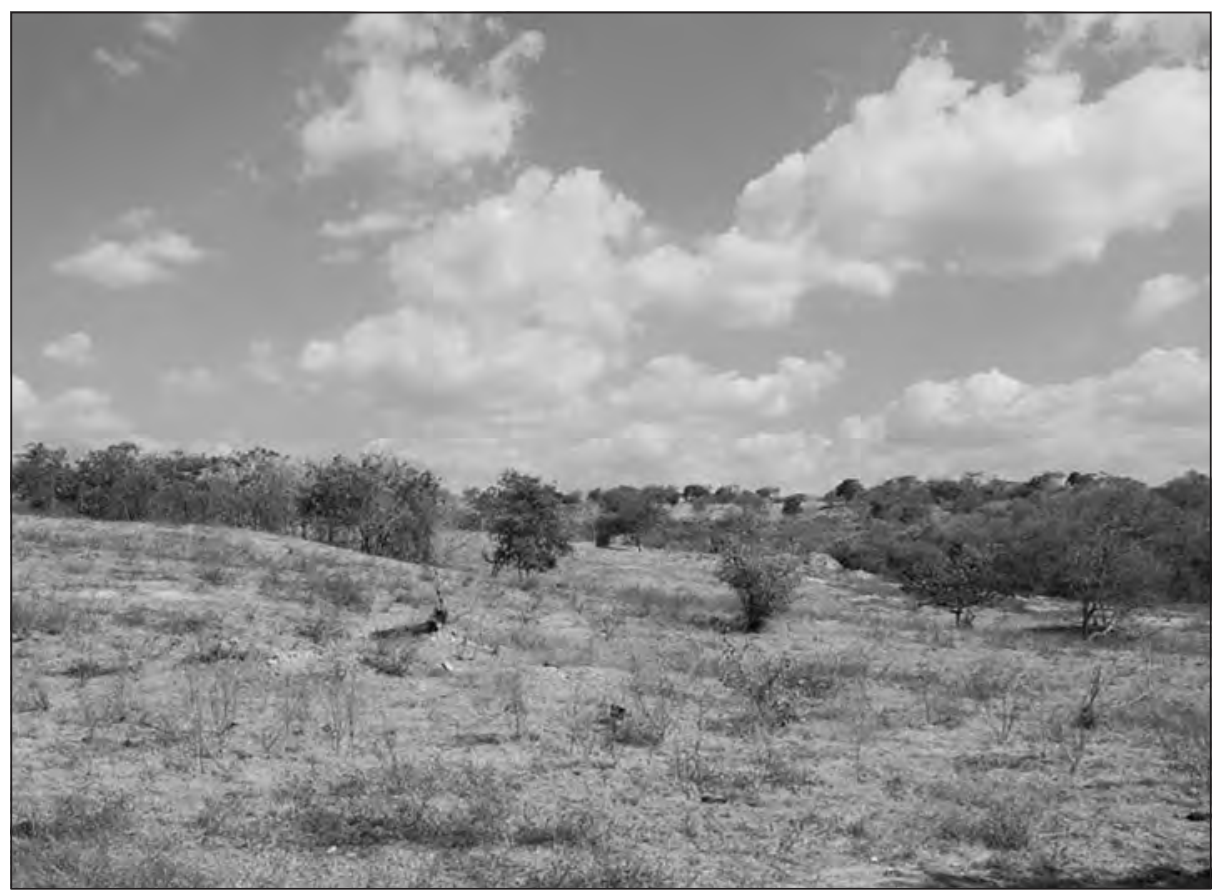

Fuente: Archivo Oraloteca (2017).

Para lograr la titulación de los predios la comunidad organizó una comisión de pobladores que se encargara de ir hasta la capital para gestionar los trámites ante el Ministerio de Agricultura, el Incoder y demás instituciones correspondientes. Los propietarios de los predios, al ver que ya la gente estaba en el territorio con cultivos, casas y demás, decidieron venderle al Estado, el cual — después de una caracterización- distribuye el territorio entre 18 familias de un total de 30, reubicando a las restantes en otras veredas.

Inicialmente, cuando las familias entraron al territorio los campesinos se organizaron de manera tal que trabajaban la tierra de manera colectiva y así tenían varias rozas colectivas y se iban turnando los lugares para dormir y para reunirse. De igual manera, los campesinos debían repartirse los turnos de vigilancia en las noches debido a los 
Vida campesina en el Magdalena Grande

hostigamientos constantes por parte de delincuentes contratados por el dueño de la finca para amenazar a los campesinos y lograr así que abandonaran sus cultivos:

Se escogía siempre un líder para reunirse, pues por lo general era en la casa de nosotros donde mi papá, Aníbal Carmona. Como estábamos más distantes porque estábamos allá donde mi abuelo, mi papá vivía en una casita donde mi abuelo, ahí entonces todos los colonos de aquí se iban y se refugiaban allá, cuando los sacaban de aquí iban y se refugiaban allá, pues y allá se le[s] colaboraba en todo. Mi papá trabajaba y, como él ordeñaba en una finca, se le colaboraba con el poquito de leche, con las cosas. Entonces una vez iban se reunían allá, entonces iban cogiendo casa dónde reunirse mientras que ya así fue adjudicado y ya cuando eso cada quien fue ubicado en su parcela y cada quien comenzó a trabajar en su parcela, pero antes no, antes se trabajaba es... una noche cuidaba uno, se celaba turnando porque se metían los pájaros, una gente que contrataba el coronel ese para asesinarlos, para quemarles las casas, entonces ellos se turnaban y en eso iba cada quien haciendo su ranchito, sembrando que la yuca, que el fríjol, e iban así cultivando (D. Carmona, comunicación personal, enero del 2017).

Cuando se da el proceso de adjudicación de las parcelas los campesinos se sienten con derechos sobre los predios y comienzan a ocuparlos de manera permanente.

Posteriormente, cuando la vereda estaba más consolidada deciden lanzar a una de sus líderes a un escenario político: el Concejo Municipal. Este ejercicio se hizo con el apoyo de otras veredas del rededor y de un comerciante que visitaba estas veredas constantemente y que decidió apoyar a esta líder en su intención de lograr mejores condiciones para las veredas del corregimiento, las cuales fueron visitas de manera auto gestionada por esta lideresa, quien logró el apoyo necesario para ser elegida y alcanzar este espacio de poder:

Él no era de aquí, era del interior del país, un cachaco, pero vamos a llevar el tema a ver qué dice la gente... bueno, yél fue así haciendo. Como él era comprador de café y conocía mucha gente, y muchas veredas, y 
Vida campesina en el Magdalena Grande

compraba maíz, bueno... él se metió por allá por Casa del Diablo y a mí me dijo: "estamos listos, yo hablé con la gente y yo mismo voy contigo porque necesitamos cuatro testigos, no sé qué más vaina pedían en la Registraduría"... y yo: "nada, yo voy contigo y vamos a hacer una alianza, aquí vamos a hacer una línea cruzada porque es la que nos va garantizar el triunfo. Vamos a cruzar con gente del hospital, con gente de la ciudad, con gente de todas partes, y hacemos una línea cruzada cosa de que cuando ellos quieran ver nosotros vamos a tener todos los pueblos agarrado[s]". Y así hicimos: le cogimos todos los puntos, fue una sorpresa grande que se llevaron porque nunca en la vida pensaron que de acá se podía sacar tanto voto (A. Tejeda, comunicación personal, enero del 2017).

En el momento en que las familias salieron de la vereda huyendo de la violencia traída por los paramilitares el territorio fue cooptado por Alfonso Acevedo, reconocido terrateniente de la región y principal opositor de los procesos de restitución de tierras que se venían dando en los territorios por él despojados. De esta manera, toda vez que inicia un proceso de reclamación sobre alguno de los predios de la vereda, inician las amenazas, los hostigamientos y la campaña de terror contra los líderes que vienen representando a la comunidad, lo cual, en muchas ocasiones, hace más lento el trabajo de los líderes en los territorios, ya que el Estado no brinda las garantías mínimas para el ejercicio de sus labores:

Él prácticamente tiene toda la vereda en su poder. Él lo que hizo fue que compró y embargó las tierra[s], hizo préstamos en los bancos... entonces ahora vienen los bancos, supuestamente lo embargan a él, pero las tierras no son de él porque se las quitó a otras personas. Entonces, viene el banco a desalojar a las víctimas, entonces ahí viene... eso ha sido una pelea dura que a nosotros nos ha tocado agarrarnos con la ley para no dejar que desalojen a la gente porque son víctimas, son despojados, entonces van a recibir maltrato del Estado y eso también ha traído discordia con lo que la policía, la inspectora de acá de Caracolicito ha venido a desalojar. Entonces, como eso no se le permite, entonces uno se gana una enemistad con eso (D. Carmona, comunicación personal, enero del 2017). 
Actualmente, de esas familias que entraron originalmente solo se mantiene una; las demás personas después de la violencia se desplazaron, fueron asesinadas o aún están en proceso de restitución. Las parcelas que habían quedado solas fueron ocupadas por otras familias que también son víctimas del conflicto y vienen desplazadas de otros territorios de la región. Según nos cuenta una de las líderes que está al frente del proceso de restitución de tierras en la vereda, este asunto ha sabido manejarse bien priorizando el diálogo y la concertación con las familias nuevas; sin embargo, ella considera que esto se convertirá en una problemática en algún momento:

Después del conflicto, la mayoría de los titulados, hay unos que fueron asesinados acá en la vereda; otros, se desplazaron por el conflicto; de los originales nada más queda mi familia porque los demás se desplazaron todos y pues están en un proceso de restitución (algunos) y están mirando cómo retornar, pero ahorita hay una problemática [y es] que han venido otros desplazados, otras víctimas, y están ahora en la vereda, y también tiene[n] cinco años de estar acá, han trabajado y están mirando cómo se resuelve la situación en la vereda porque a nosotros sí nos gustaría que la vereda volviera a ser lo que fue en un tiempo. Ahora poquito nos dieron la buena noticia de que vamos a entrar en un proceso de reparación colectiva; ya el 20 se va iniciar con la toma de declaraciones, eso ya es un paso que a nosotros nos alegra. Entonces, existe esa problemática, que hay personas que también fueron víctimas que están acá, entonces va a haber un conflicto (D. Carmona, comunicación personal, enero del 2017).

En estos momentos, la comunidad se encuentra organizada por medio de juntas de acción comunal —en cada una de las veredas- que están en el territorio y existe una asociación de víctimas. Después de la aparición de la Ley 1448 y de unas capacitaciones realizadas por el PNUD se logró consolidar la creación de esta asociación y, por medio de esta, emprender la lucha por los derechos de los pobladores de la vereda, superando el miedo existente frente a los procesos de reparación y reclamación de tierras debido a las constantes amenazas, hostigamientos y persecución hacia los liderazgos que desarrollan esta tarea. Sin embargo, no solo los terratenientes y ocupantes de los predios han ejercido oposición al ejercicio de 
Vida campesina en el Magdalena Grande

estos liderazgos, en muchas ocasiones algunos de los mismos pobladores se han opuesto al trabajo de los líderes, temerosos de que estos líderes se aprovecharan de la situación de ellos; por este motivo, se hizo necesario el desarrollo de talleres por parte de la unidad de restitución de tierras para aclarar esta situación y lograr el fortalecimiento del tejido comunitario de manera que se pudiera dinamizar el trabajo de estos líderes, procurando el cumplimiento de los derechos de las víctimas, establecidos en la Ley 1448:

Cuando llegó la unidad de tierras yo pedí varios talleres para que le explicaran a la gente que no era como ellos pensaban, que yo iba a llegar y ya le iba a quitar la tierra a Fulano y se la iba dar a otros porque de ahí es que ha venido la muerte de los líderes que no tienen claro lo que dice la ley y cómo se maneja el tema. Entonces, muchas personas como ellos han sido opositores, ellos han sido despojadores; ellos ven a un líder como una amenaza aquí. Gracias a Dios, a raíz de esos talleres y de las capacitaciones y de la explicación que yo le doy a la gente pues no he tenido esos problemas así como tan graves que se han dado en otras regiones, pero sin embargo no deja de existir siempre la preocupación por el tema (D. Carmona, comunicación personal, enero del 2017).

Imagen 63. Casa campesina en la vereda Entre Ríos

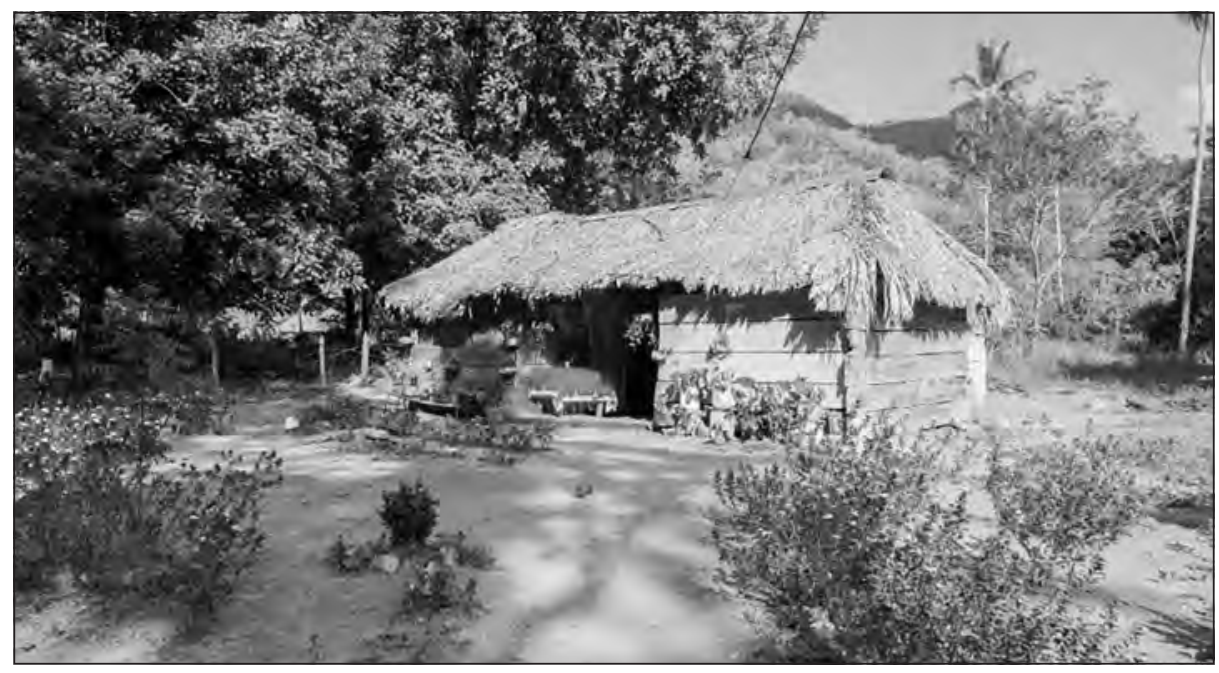

Fuente: Archivo Oraloteca (2017). 
Vida campesina en el Magdalena Grande

Gracias a esto se ha logrado construir un consenso entre los campesinos que ocuparon inicialmente el territorio y los pobladores que han llegado después de la época de la violencia. Estos pobladores son víctimas del conflicto que, por causa del desplazamiento forzado, han llegado a estos territorios buscando una nueva oportunidad para construir su proyecto de vida y el de sus familias. De esta manera, la Asociación de Víctimas ha logrado hacerle entender a todos los pobladores que la demanda y la lucha por sus derechos es con el Estado, ya que ellos son víctimas y, en palabras textuales, el que les falló fue el Estado:

Porque aquí la demanda es contra el Estado colombiano, porque el Estado nos falló a nosotros. La Constitución Nacional dice "salvaguardar honra y bienes de los ciudadanos" y a nosotros ni siquiera la vida, entonces el que falló fue él y tiene que responder [le] a todas las víctimas de Colombia por todos los hechos (A. Tejeda, comunicación personal, enero del 2017).

En cuanto a la relación con los diferentes grupos armados en el territorio, la comunidad manifiesta que las Fuerzas Militares fueron acompañantes en los actos perpetrados por los grupos paramilitares y argumentan que los militares se dedicaron a combatir a la población civil en vez de combatir a los actores armados ilegales que hacían presencia en el territorio:

Las Fuerzas Militares de Colombia no se dedicaron a combatir a los delincuentes; se dedicaron fue [a] combatir a los civiles. Supuestamente era para combatir la guerrilla, pero si él realmente hubiera combatido la guerrilla - como se ha llenado la boca- entonces hubieran diálogos guerrilleros, hoy existieran aquí. Si usted combate algo no existe, entonces si existe la guerrilla hoy día, si hay diálogos en la Habana o donde le dé la gana [es] porque no combatieron guerrilleros, él nos combatió fue a nosotros los civiles (A. Tejeda, comunicación personal, enero del 2017).

Por otro lado, por parte de las insurgencias la comunidad también recibió maltratos y, en una ocasión, una de las líderes de la comunidad fue secuestrada por ellos: 
Vida campesina en el Magdalena Grande

La guerrilla aquí llegó primero que las autodefensas, porque esta vaina aquí cuando entraron todas estas veredas fueron recuperadas por la guerrilla. Cuando entraron aquí la vereda ya estaba conformada y vinieron fue con el mismo cuento, a venir a matar a los de aquí, inclusive yo cuando eso era concejal y fui secuestrada por ella, por la guerrilla, pero entonces ellos le dan la oportunidad de usted expresarse, le dan la oportunidad de usted defenderse (A. Tejeda, comunicación personal, enero del 2017).

Por parte de las instituciones encargadas de garantizar el proceso de retorno de las víctimas a sus territorios el acompañamiento es nulo y, cuando se ha hecho presencia, ha sido por presión de los mismos pobladores que, a través de tutelas y demandas, hacen que las instituciones cumplan con su trabajo:

Al comienzo fue duro para hacerles entender a ellos la obligación. Eso me tocó demandar a la Procuraduría, demandar al alcalde; mejor dicho, hacer de cuanta cosa para que ellos pudieran entender que nosotros teníamos unos derechos y que ellos no podían revictimizarnos. Entonces, eso fue en el 2011 como hasta el 2014, fue una lucha tremenda; ahora es que han ido bajando porque la cuestión, porque ya ven que es de ley y ellos tienen que respetar. Entonces nos ha tocado duro y es que acá las instituciones nos han tenido abandonados, han venido a la fuerza. Pues la unidad de víctimas por acá no nos ha brindado ninguna garantía porque ni las ayudas: acá hay gente que no ha recibido nada desde la declaración, ya supuestamente tienen diez años y nunca les llegó una ayuda, entonces mandan derechos de petición y le[s] contestan; si ya tiene diez años que le sucedió el hecho ya usted no tiene derecho a recibir más ayuda y la persona está peor porque las instituciones están es en Bogotá, en aire acondicionado, y no vienen a mirar el territorio [...]. Entonces, por ejemplo, tiene este predio en restitución de tierras y usted está aquí, no puede hacer ningún préstamo, no puede vender ningún pedacito, pero restitución no le define nada, entonces está peor, el banco no le presta a una tierra en proceso de restitución, entonces no hay ninguna garantía, lo que han hecho es perjudicar prácticamente más de lo que está (D. Carmona, comunicación personal, enero del 2017). 


\section{De campesinos a rebuscadores: el caso del barrio Bello Horizonte de Valledupar}

El barrio Bello Horizonte se encuentra ubicado en el municipio de Valledupar, en el área urbana. El relieve es totalmente plano, aunque al fondo de su paisaje se puede divisar fácilmente la Sierra Nevada de Santa Marta. El barrio está constituido por personas de toda la región que llegaron al territorio desplazadas de sus lugares de origen a causa del conflicto social y armado que vive el país. Al llegar al territorio se instalaron en pequeñas casas improvisadas con la esperanza de volver pronto a sus hogares, pero ante la demora para que esto suceda se han enraizado en el nuevo territorio, reproduciendo dinámicas y lógicas propias de la vida en el campo (en la medida en que las dinámicas y lógicas de la vida urbana permitan la subsistencia de estos conocimientos y valores de la vida en el campo). Un habitante del barrio nos recuerda con nostalgia cómo era su vida en la vereda Sabanita, corregimiento de la Mesa, en Valledupar:

Eso es muy grande y la llegada de nosotros aquí a Valledupar eso fue muy catastrófico, diría yo, porque la vida del campo es muy diferente a la de aquí: uno se levanta, mira su gallina, mira su cultivo, el hombre se va a trabajar su cultivo y uno se queda viendo sus animales, de pronto viendo su huerta que uno hace, siembra uno tomate, cebolla, cositas así, y atendiendo sus animales, sus gallinas y los hijos (T. Fragoso, comunicación personal, febrero del 2017).

Actualmente, la población del barrio ha tenido que adaptarse a las formas de vida en la ciudad, transformando algunos roles, pero tratando de mantener aquellos roles y relaciones con el entorno, como por ejemplo los patios cultivados de manera estratégica para poder cosechar allí algunos alimentos de pancoger para la canasta básica de la familia y con la esperanza de poder cosechar en un futuro en sus parcelas:

En la casa yo he comido de todo: tengo plátano, guineo filo, de todo eso comí, la yuca, sembrábamos yuca, que es lo que más tengo allá, ñame también, que he sembrado así, ñame y, más que todo, tengo mata ornamental porque a mí me gusta la jardinería, preparo el abono también 
Vida campesina en el Magdalena Grande

para las matas y tengo es como un vivero, ahí en la casa tengo bastante mata y tengo la fe [de] que voy a sembrar en una parcela, tengo zapote, tengo aguacate, tengo arboles así. En Millo tengo tres potes con semillas, tengo papaya — allá en la casa tengo papaya —, guanábana — tengo como tres palos de guanábana-, también en bolsa tengo la semilla de yuca, también por ahí tengo filo, guineo largo, plátano (N. Chamorro, comunicación personal, febrero del 2017).

Al llegar a la ciudad surge una nostalgia constante al sentir que les han arrancado un pedazo de sus vidas y procuran, de una u otra forma, regresar al campo; por esta razón siempre están buscando la forma de hacerse a una porción de tierra para poder sembrar, ya sea insistiendo en instituciones públicas, pidiendo cooperación de instituciones privadas o, en muchos casos, por medio de vías de hecho. Sin embargo, mientras esto sucede y como lo mencionamos anteriormente, los campesinos urbanos trasladan la vida campesina a las grandes ciudades, consolidando pequeños espacios rurales dentro de las zonas urbanas y recordando con nostalgia cómo eran sus vidas en el campo, anhelando poder volver algún día:

Bueno, si me llego a morir es allá, en el monte. Que me saquen de allá del monte como muchas personas que, como han seguido en el campo, muchos compañeros de allá los han sacado de allá muertos, porque los coge la vejez y no quieren salir de allá porque están hechos de allá. Entonces, nosotros queremos también así, estar en el campo, criar la gallina, que se levanta uno a ver el popó de animales, que si tiene uno ganado oye uno el ganado en la madrugada bramando y se levanta uno a ordeñar la vaquita, esas cosas (Á. Méndez, comunicación personal, febrero del 2017).

\section{Reproducción de las formas de vida del campo en la ciudad}

Las familias que llegaron desplazadas de diferentes territorios del departamento y la región traen consigo el recuerdo de diversas formas de relacionarse con el medio y con los seres que lo habitan. Una de esas formas de relación estaba basada fundamentalmente en las actividades 
Vida campesina en el Magdalena Grande

económicas que cada uno desempeñaba en sus territorios de origen antes de que fueran desplazados. La vida económica de los campesinos antes de llegar a las zonas urbanas se sustentaba básicamente en la capacidad de preparar la tierra para sembrar, la siembra, la cosecha y la comercialización de los productos, actividades en las que la dependencia del área urbana era mínima y solo en el proceso de comercialización o en la compra de algún insumo existía algún tipo de relacionamiento con las ciudades, aunque esto se daba muy pocas veces al año (o, en ocasiones, se intercambiaban estos productos en el momento de la comercialización); el resto de la vida económica se desarrollaba de una manera autónoma:

Sembramos café, se cargaba la semilla de plátano y ya, sembrábamos. Yo estaba muy pequeñita y me tocaba coger galones de agua y echarle al hueco. No dejé morir la mata de plátano y andaba, buscaba de seis metros y la mata, la otra hacíamos otro hueco y de los huecos tenía que ser hondo porque la mitad del hueco pa' bajo tenía que tener abono para sembrar la mata de plátano. Antes de sembrar la mata de plátano echábamos una ponchera grande con lorba, de modo que no le naciera el hongo. Bueno, eso bien ramificado y, si era mata de tomate, teníamos nosotros un corte de tomate y un corte de cebolla. El cucho cargaba el mazate, la floralba. En flor, cuando esté en fruto todos esos venenos en frasco para poderlo esmigar con la esmigadora. Todo teníamos, por eso no necesitábamos comprar la sal ni la azúcar porque hasta teníamos un corte de caña (S. Serrano, comunicación personal, febrero del 2017).

De esta manera, las comunidades campesinas, abandonadas por el Estado en todos los aspectos de sus vidas, aprendieron a solventar, con lo que tenían a la mano, las necesidades más urgentes para el desarrollo de su economía y la consolidación de sus planes de vida. De esta forma, todos los insumos para la preparación de la tierra para la siembra de sus cultivos eran producidos de manera artesanal en cada uno de los territorios sin tener que bajar a la ciudad a comprarlos, disminuyendo gastos en la producción y obteniendo como resultado productos orgánicos de mejor calidad y a menor precio: 
Vida campesina en el Magdalena Grande

Sembraba café, malanga, la yuca, este la arracacha, porque allá es frío y así lo que sembraba más es tomate, la hortaliza (como decimos nosotros, [los] santandereanos); volteábamos de todo un poquito y producía. Le echamos abono, teníamos un pozo y echamos la pulpa del café, la ceniza fresca del monte, y hacíamos un pozo para sacar abono y así cuando completaba los seis meses ya eso se revolvía, se ponía un tubo y ya botaba ese humo, entonces ya botaba el humo, ya estaba descompuesto, cogían y lo sacaban para que le diera aire y volvía y se le echaba a las matas (S. Serrano, comunicación personal, febrero del 2017).

Existían algunas personas que tenían la facilidad de viajar a las ciudades ya que tenían algún familiar o conocido en los centros urbanos que les permitía quedarse mientras estaban de paso en la ciudad. Estas personas aprovechaban estas visitas a la ciudad para llevar algunos productos del campo y comercializarlos durante su estancia en las ciudades. Con el dinero recogido de la venta de los productos compraban los insumos necesarios en el campo o se compraban elementos que las personas del pueblo o la vereda le encargaban a la persona que ellos sabían iba a la ciudad:

También sembrábamos la ahuyama, eso era en cantidades, esa así yo traía aquí al Valle a venderla, la ahuyama. Y también cogía así, del maíz hacía bollo de mazorca y me venía pal' barrio y lo hacía y vendía. De ahí de los venados yo traía aquí al Valle, que traía el chivo y lo vendía acá, cerdo, porque allá se criaba cerdo y chivo y yo venía, en la puerta de mi casa yo vendía todo, yo no salía a vender a nadie. Cuando me veían que yo llegaba en el taxi: “iqué trajo?”, me preguntaban. Yo ponía una mesa afuera. Si llevaba el cerdo enseguida lo picaba y lo vendía, yo vendía bollo de mazorca (los traía hechos de allá) y, a veces, traía un bulto ahí de mazorca, ahí para la casa, y entonces eso uno le saca muchas cosas al campo [...]. Yo duraba cinco o cuatro días aquí en el negocio y también vendía mercancía. Con la misma plata que yo recogía yo compraba mercancía, compraba porque a mí me encargaban ollas, me encargaban ropa, me encargaban el toldo, que la hamaca; yo anotaba y yo iba desde el día ese, allá en la finca por todos los potreros me la pasaba y caminando, cobrando y vendiendo ( N. Chamorro, comunicación personal, febrero del 2017). 
Vida campesina en el Magdalena Grande

De igual manera, en muchos casos las comunidades campesinas tenían centros de acopio en las veredas que eran centrales a las parcelas o territorios donde ellos cultivaban sus productos, permitiendo de esta manera concentrar la producción y facilitando su venta, ya que los compradores sabían a qué sitio dirigirse específicamente para comprar los productos, reduciendo así los gastos de transporte de la producción, trasladando estos gastos a los compradores o intermediarios que tenían que visitar estas veredas para comprar los productos:

La yuca sí la vendíamos. Allá iban a la casa, le vendíamos medio bulto de yuca, un bulto de yuca, un maíz también. El maíz lo sacábamos y lo vendíamos por bulto y, cuando alguna persona quería maíz, [...] lo vendíamos [a] 20 mil pesos un bulto de maíz, de los vecinos vendíamos el maíz, de los Venados iba la gente y se lo llevaba[n] los carros, nosotros no salíamos a vender, allá iban a la casa a compra[r] (N. Chamorro, comunicación personal, febrero del 2017).

Con la llegada de los grupos armados a los territorios la dinámica económica de los territorios cambió, de forma que ya que las personas no podían comercializar libremente sus productos debido a la vacuna impuesta por estos grupos a los dueños de las cosechas y por la inseguridad que comenzó a vivirse en los territorios. Específicamente con la llegada de los grupos paramilitares aumentaron las presiones sobre los campesinos para que abandonaran el territorio o para que se acogieran a la nueva ley impuesta por ellos. De esta manera, muchas familias se retiraron del territorio, dejando todo atrás, y se trasladaron al perímetro urbano, principalmente a Valledupar, donde se instalaron en las zonas periféricas de la ciudad, construyendo barrios de invasión. Algunas familias siguieron visitando sus cultivos de vez en cuando con la esperanza de que la violencia pasara y pudieran regresar a sus tierras, pero por el contrario el conflicto se hacía cada vez más violento, obligando a las poblaciones a abandonar cualquier esperanza de volver al territorio y a transformar su vocación económica de campesino a asalariado en la ciudad: 
Vida campesina en el Magdalena Grande

Nosotros allá cultivamos el maíz, sembrábamos café, teníamos yuca, plátano, la siembra así más fácil era de... sembrábamos hortalizas, lo que es el tomate, el ají, la habichuela, esa habichuela corta, malanga, cuando nosotros nos venimos de allá mi compañero dejó dos hectáreas de malanga, una hectárea de plátano, una hectárea de guineo, sembrábamos ahuyama, aguacate, cacao, todo eso lo sembrábamos nosotros. Aparte de eso teníamos más de cien gallina[s] ponedora[s], fuera de los pollitos, y también a veces yo me iba, él se quedaba en la finca y yo me venía para acá pa' Valledupar. Aquí yo hacía, iba al mercado, compraba bollo de mazorca, compraba mazorca, hacía pasteles para hacer unas compritas y yo me las llevaba para allá y nos las llevamos. Él hacía su trabajito por ahí que le tocaban hacer, que lo buscaban otros compañeros de finca, y él los hacía y con eso se ayudaba, fumigaba todo eso, que la gallina, el pollo, nosotros recogíamos diario veinte huevos de gallina criolla (T. Fragoso, comunicación personal, febrero del 2017).

En este sentido, la reconfiguración de las relaciones económicas de las familias que vienen del campo a las dinámicas económicas propias de la ciudad convierte a los campesinos en asalariados, condición en la que toda su vida girará en torno al dinero, reemplazando las lógicas de la vida campesina en las que las relaciones se dan a partir de valores como la solidaridad y el respeto, contrarios al individualismo y a la competencia propios de la vida en la ciudad y atravesados por la mercantilización constante de la vida:

Porque uno en el campo vive muy diferente, se acuesta a la hora que uno quiera, come tranquilo, come lo que uno quiera y lo que se come es fresco, porque la yuca que venden en la tienda ya eso le echan cosas, el plátano, el guineo maduro le echan carburo para hacerlo madurar a la fuerza, el pollo que uno compra en la tienda ya está inyectado con formol y todo le hace daño a uno. En cambio, uno en el monte, en la finca, ya es diferente, y vive uno bien tranquilo de que si uno se acuesta más que sea tiene así sea un platanito que cocinarles a sus hijos, un pedazo de yuca, con un huevito criollo, pero aquí si uno no tiene plata no come, no le quieren fiar a uno y le ponen miles de pretextos para darle cualquier cosa. Yo pienso que como la vida del campo no hay, uno en el campo vive muy 
bien, a uno no le importa que le falte la luz, después que uno tenga su comida y tenga su cosa sembrada uno tiene comida, porque si usted está en el campo y tiene sus matas de yuca y le faltó para comprar la carne, va y se saca un saco de yuca o un saco de plátano, va y lo vende y con eso compra la comida que le haga falta (T. Fragoso, comunicación personal, febrero del 2017).

Actualmente, en el barrio Bello Horizonte la comunidad trata de reproducir, en los espacios reducidos que poseen en cada uno de sus lotes, aquellas formas propias de vida en el campo y adaptan el medio de manera que, a partir de los conocimientos que tienen de la tierra, puedan cosechar en el terreno más inhóspito alimentos que permitan ayudar a mantener una economía familiar basada principalmente en lo que podríamos denominar el "jornaleo urbano" o lo que se conoce popularmente como "la maraña". De esta manera, el barrio se constituye a partir de lotes en los que las mujeres principalmente desarrollan trabajos que asemejan la vida en el campo, pero con espacios más reducidos.

Imagen 64. Cultivo de ají en el barrio Bello Horizonte

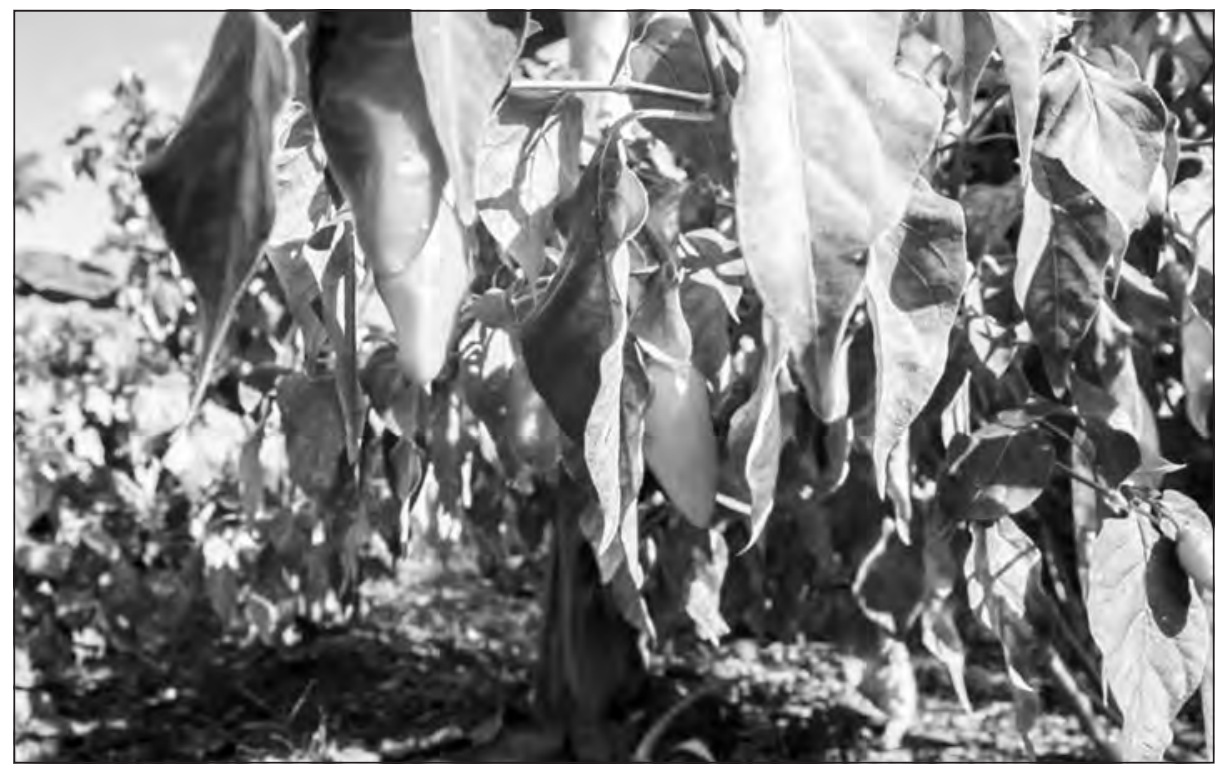

Fuente: Archivo Oraloteca (2017). 
Entonces encontramos que, al igual que en el campo, están los vecinos que también cultivan, con la diferencia de que no están a grandes distancias, sino que la parcela del vecino está a pocos pasos. La cría de animales es otra de las formas en las que la población se ayuda para mantener la economía familiar, al igual que los cultivos de pancoger que mencionamos anteriormente:

Eso es para nosotras porque cuando pare un gajo nosotros nos lo comemos, ahí nada de eso es para la venta porque, como es un patio pequeño, ahí no puede uno vender nada. Habichuela fue lo primero que yo sembré, tomate eran unos tomates así, grandes. Tomate, pimentón, ya después conseguí las matas de plátano y las sembré y todo lo que voy sembrando, todo produce. Yo he comido de toda habichuela bogotana, que la habichuela no se da aquí, la sembré cerquita de la pluma y eso un matorrón así, claro que no dio bastante. Ser campesino no es solamente labrar la tierra. Campesino es una persona que labra la tierra con amor, porque le tienen amor a la tierra, y con sacrificio porque a veces uno cuando se mete la primera vez, el primer año es con sacrificio porque uno va a sembrar, no va a consumir todavía, apenas va a sembrar. Entonces uno labra la tierra con sacrificio para el bienestar de uno y de los demás; también eso es ser campesino: tenerle amor a la tierra (N. Chamorro, comunicación personal, febrero del 2017). 


\title{
Vida campesina en el sur del Cesar
}

\author{
Mapa 5. Subregión sur del Cesar
}

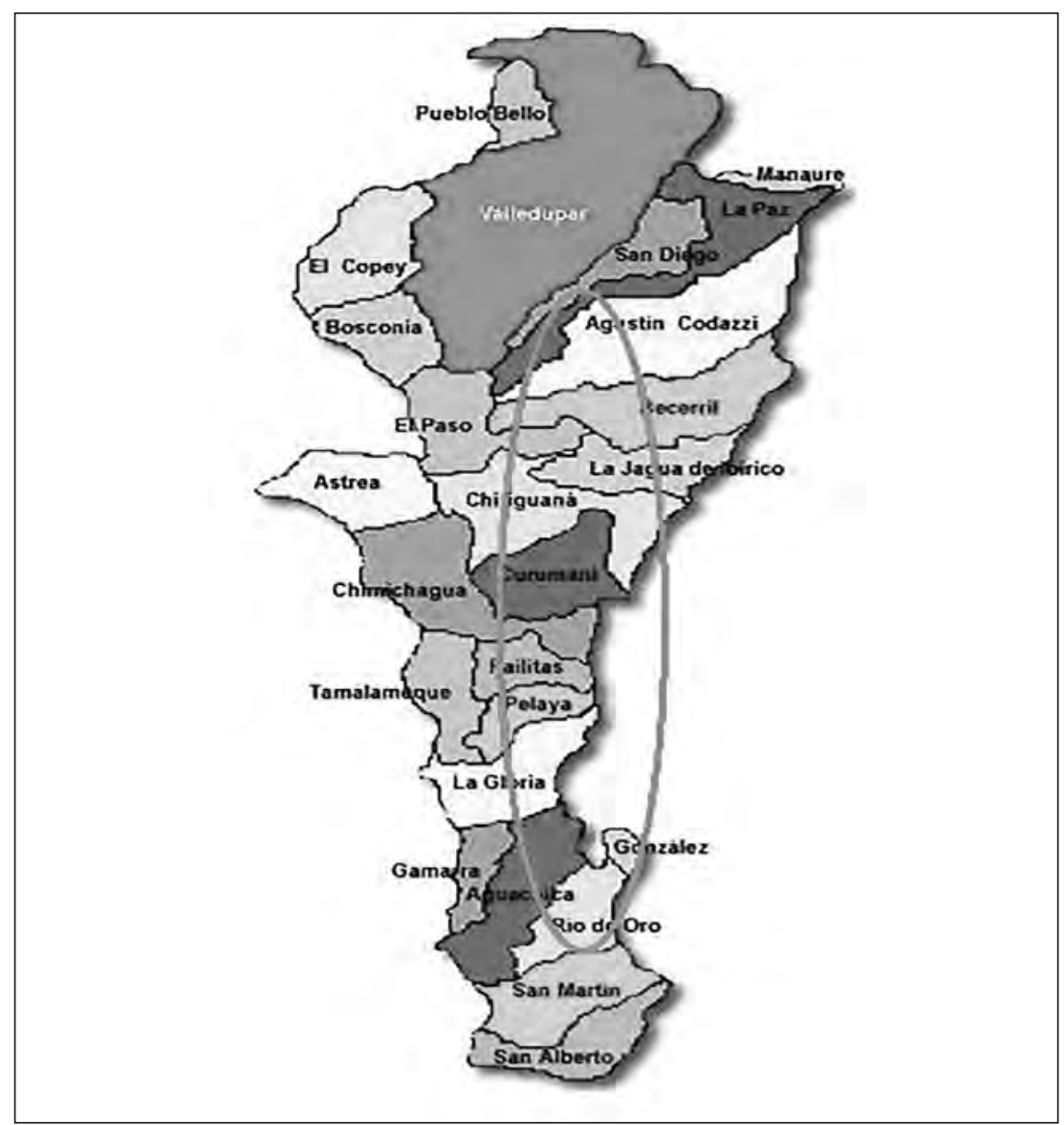

Fuente: Elaboración en base a mapa del IGAC (2002). 
Los municipios que conforman la región del Sur del Cesar comparten elementos históricos, culturales, económicos y sociales que dan cuenta de la realidad y de los diferentes procesos que se han desarrollado de acuerdo a diversos contextos históricos y políticos que serán explicados en detalle en las siguientes páginas.

La ubicación geográfica de dicha subregión, la comunicación directa con los departamentos del centro y norte del país, la riqueza tanto mineral como ambiental y la calidad de los suelos fértiles han propiciado procesos de poblamiento y construcción de identidad consolidados en las relaciones comerciales y en las dinámicas cotidianas que definen, representan y conservan las memorias de los municipios del Centro y Sur del Cesar.

La agricultura realizada en los diferentes pisos térmicos del departamento (maíz, yuca, plátano, aguacate, arroz, café, mora, fresas, entre otros) y la ganadería han fomentado el desarrollo socioeconómico de muchos municipios en esta región. Su cercanía al sistema montañoso del Perijá les proporciona diversas cuencas hídricas que abastecen de agua a las poblaciones y a las zonas agrícolas y pecuarias; de allí la importancia de esta región como un territorio de potencialidades ambientales e hídricas valiosas.

Por otro lado, la región Sur del departamento del Cesar se ha constituido como una de las principales despensas de explotación de carbón y como un corredor minero energético en la región Caribe colombiana, compitiendo al nivel de las grandes transnacionales extractivitas a nivel nacional dado que la minería a cielo abierto es un elemento fundamental en los modos de producción y en las dinámicas económicas de algunos municipios, lo que posiciona a la industria y al imperio carbonífero como empresas que proporcionan trabajo y mejores condiciones de vida a los pobladores.

Sin embargo, la actividad extractivista ha generado graves afectaciones ambientales y sociales como deforestaciones masivas de bosques nativos para procesos de exploraciones, desviación de arroyos, caños, ríos, y la presencia de un sinnúmero de actores dedicados a la explotación del carbón; estos son factores de riesgo frente al contexto socioambiental de la región. 
Actualmente, el monocultivo de palma de aceite, además de la industria carbonífera, se ha consolidado como una empresa que ha generado empleo en la región, aunque es la principal promotora de la privatización de los territorios, dada que su cultivo y comercialización se desarrolla con auge en las diferentes zonas rurales de los municipios.

En cuanto a las prácticas ganaderas, estas juegan un papel clave en las economías locales de la región. La cría de animales bovinos para la comercialización (principalmente de la leche) se ha consolidado como una de las principales fuentes de generación de ingresos de los diferentes campesinos, parceleros y terratenientes, pero es clave mencionar que la ganadería se ha apoderado de los territorios aptos para la agricultura. La ausencia de tierras para cultivar, debido a la privatización del campo, ha intensificado la demanda de trabajadores y jornales en las fincas y haciendas ganaderas que se encuentran en el territorio.

Actualmente, las prácticas agrícolas en los diferentes municipios han disminuido; según diferentes líderes campesinos, por diversos factores: "la privatización de los territorios, el conflicto armado y la minería en algunos sectores internos han generado una fuerte desintegración de los pueblos campesinos en los diferentes municipios del Sur del Cesar" (Edgar, comunicación personal, diciembre del 2016). Por este motivo, las prácticas rurales, la vocación campesina y el auge de los productos agrícolas - que en otras épocas caracterizó a los municipios del Sur del Cesar- ahora son tenues reflejos en la memoria de los habitantes del departamento.

Actualmente, son pocas las despensas agrícolas que se encuentran en los municipios del Sur del Cesar. Solo algunos corregimientos conservan la práctica de la agricultura relacionada con la cría de ganado como fuente de su economía local; otros, se debaten entre la ganadería, la agricultura, la minería y la informalidad, situaciones que imposibilitan el desarrollo fluido de los cultivos en la región.

Si bien es cierto que en los municipios de esta subregión existen pueblos campesinos dedicados al cultivo de productos agrícolas, el pancoger y la cría de animales, es valioso anotar que su presencia se ha reducido y focalizado principalmente en las zonas de pie de monte y en las partes altas de la Serranía del Perijá, lo que dificulta la comunicación de estas poblaciones con los entes territoriales y con la oferta institucional del Estado, lo que ha generado muchas veces condiciones de olvido. 
Además, el problema por la tenencia de la tierra y la ausencia de vías de comunicación para comercializar los productos agrícolas ha agudizado las problemáticas que sufren las poblaciones campesinas en dicho territorio, la constante transformación de la vocación económica de la tierra para la explotación minera y el monocultivo de palma de aceite han generado una encrucijada en la que las prácticas agrícolas y las comunidades campesinas se encuentran en procesos de resistencias sociales por mantener su vocación, historia e identidad campesina.

\section{La bonanza algodonera: origen y poblamiento de la subregión Sur del Cesar}

Para hablar sobre el origen, la conformación y el poblamiento de los territorios del pie de monte de la Serranía del Perijá, en los municipios del Centro y Sur del departamento del Cesar, se debe tener en cuenta un proceso sociohistórico como la bonanza del algodón. Esto, anotando que esta subregión posee una rica historia prehispánica y presencia de grupos étnicos que habitaron y aun habitan la Serranía del Perijá y los valles de los ríos Cesar y Magdalena: actualmente, el grupo étnico yuko yukpa habita en diferentes zonas rurales de los municipios de dicha región.

La bonanza del algodón en el territorio fue un hecho que se desarrolló paralelamente con la independencia y fundación del departamento del Cesar, antigua jurisdicción del Magdalena, lo que promovió la consolidación de un nuevo ente territorial reconocido geográfico, social y políticamente. 
Vida campesina en el Magdalena Grande

Imagen 65. Buturama, antigua hacienda algodonera

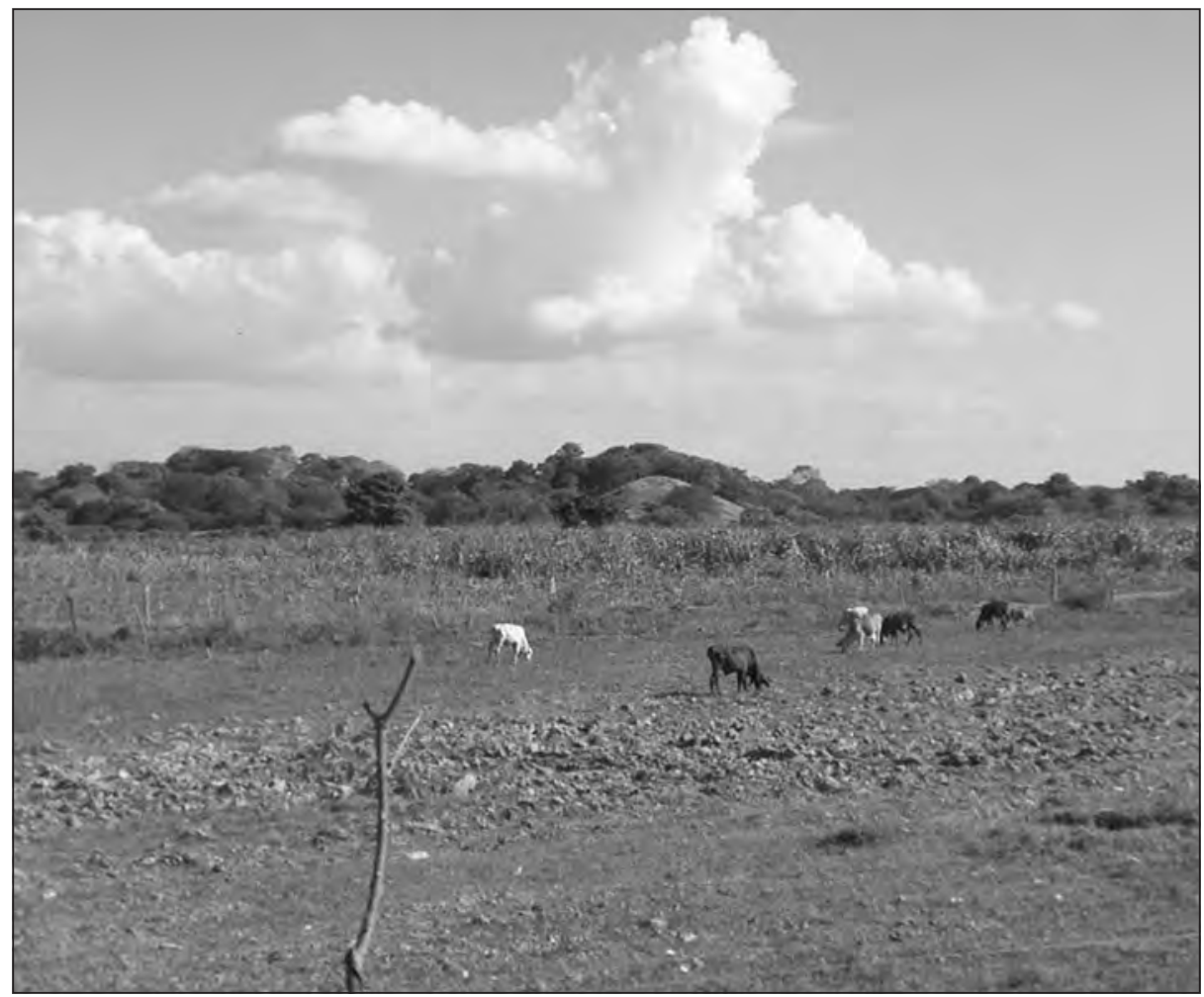

Fuente: Archivo Oraloteca (2017).

Ahora bien, con el auge de la economía algodonera que se imponía en esta subregión en la década de 1960-1970 se promovió un desarrollo económico a través de la consolidación de las grandes algodoneras del Cesar. Las haciendas que anteriormente se dedicaban a la ganadería se convirtieron en terrenos dedicados al cultivo del algodón y en espacios de trabajo para la población: "las algodoneras daban trabajo, todos trabajaban allí, desde niños, mujeres, jóvenes y adultos había trabajo todo el año, todos ganaban algo del algodón, sí señor" (D. Mercado, comunicación personal, 2 de enero del 2017).

Así, muchas personas del interior del país - específicamente del departamento del Tolima y los Santanderes- llegaron en busca de nuevos territorios y condiciones económicas 
porque ellos sabían trabajar la tierra. Ya en sus regiones se cultivaba algodón y cuando aquí se empezó a sembrar muchas de las familias que llegaron del interior del país empezaron a trabajar en la hacienda y [a] hacer sus casas y vivir en estas tierras que muchas fueron civilizadas por esas personas (D. Mercado, comunicación personal, 2 de enero del 2017).

Esto impulsó el poblamiento y la fundación de varios municipios.

Imagen 66. Campesino del Sur del Cesar

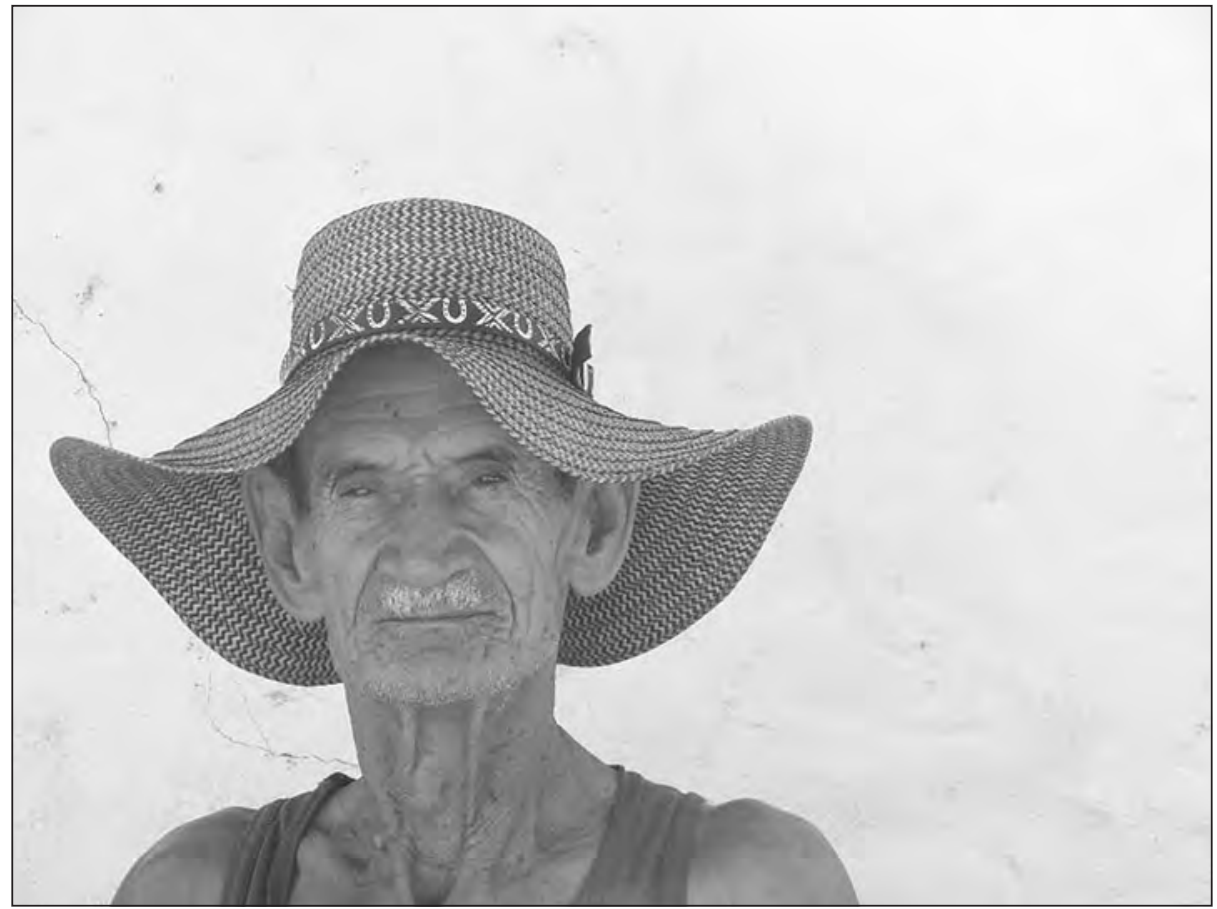

Fuente: Archivo Oraloteca (2017).

Con la bonanza algodonera se generaron un sinnúmero de diásporas de poblaciones campesinas de las regiones andinas hacia el departamento, consolidando colonias de santandereanos, tolimenses y boyacenses que fortalecieron la producción del algodón, además de procesos de construcción de identidad, de territorialidades e intercambios culturales debido a su presencia e influencia en las dinámicas de esta subregión. 
Vida campesina en el Magdalena Grande

Es valioso mencionar que los municipios de Agustín Codazzi, Becerril, la Jagua de Ibirico, Pailita y Aguachica fueron unas de las principales despensas algodoneras en el Cesar. Para el caso del municipio de Agustín Codazzi el algodón fue un elemento que potencializó los modos de producción económica de los habitantes del pueblo: fue un centro de producción, abastecimiento y distribución del algodón en el departamento y a nivel nacional. Muchos de los sectores rurales fueron dedicados fuertemente al cultivo, por lo que la mayoría de sus habitantes reconocen y recuerdan con nostalgia aquella producción de algodón que constituyó la principal fuente de la economía local y un elemento de reconocimiento identitario. Su influencia fue tan valiosa que el municipio fue denominado coloquialmente como "la ciudad blanca de Colombia", catalogación que da cuenta de la relación que existió entre el sujeto de Codazzi, el algodón y su historia:

El municipio de Codazzi fue un pueblo algodonero, por lo que muchos de sus corregimientos crecieron gracias al algodón, muchas personas comenzaron a llegar aquí a Casacara por el algodón. Antes de la bonanza esta fue una región donde se sembró mucho algodón. Los primeros que sembraron algodón fueron el señor Luis Giraldo, proveniente del Tolima, y así fue como se comenzó a poblar con más habitantes el corregimiento de Casacara en Codazzi, a través de la bonanza del algodón (J. Carlo, comunicación personal, diciembre del 2016).

Los cultivos de algodón se sembraron mayormente en las zonas rurales, en los corregimientos y en las veredas del municipio (entre los cuales destacamos Casacara y Llerasca como los principales centros agrícolas en Codazzi). Igualmente, estos poseen fuerte relación con la ganadería dado que su fundación y desarrollo económico fueron impulsados paulatinamente por la bonanza del algodón:

Los fundadores de estas tierras en Llerasca fueron los Terneras, fueron [ellos] quienes llegaron aquí y así fueron llegando más personas. Anteriormente, estos eran territorios baldíos y las personas que llegaron aquí se organizaron en sabanas comunales, cada habitante trabajaba un pedacito de tierra, todos se dedicaban a la agricultura y [a la] ganadería; 
Vida campesina en el Magdalena Grande

luego, se fueron armando las grandes haciendas que eran Hacienda Monte Carmelo y Hacienda Monte Isabel. Mucha gente de afuera vinieron a coger algodón acá: tolimenses, antioqueños, santandereanos y gente del sur que llegaron por las cosechas de algodón, ya que había mucha fuente de empleo que en otras partes no las había. Aquí en Llerasca, tanto en la parte baja como en las partes altas, se cultivaba el algodón. Las fincas llenitas de cultivos de algodón y por eso comenzaron a llegar mucha gente a buscar el sustento económico y les iba bien. Así se fueron formando familias en esta región, toda esta zona eran fincas algodoneras (Y. Castro, comunicación personal, 11 de diciembre de 2016).

Los procesos de poblamiento del municipio de Becerril fueron muy similares a los de Codazzi debido a la cercanía entre ambos municipios: el cultivo del algodón (más que la ganadería y la agricultura) se constituyó como un pilar socioeconómico que permitió la transformación de dicho territorio en un municipio. La extensión territorial del poblado fue escenario de los grandes y masivos cultivos de algodón y se dio la presencia de centros de acopios de algodón, haciendas y fincas algodoneras, que promovieron condiciones para que muchos grupos campesinos de regiones vecinas se asentaran en estos territorios a trabajar en la producción algodonera:

Cuando yo era nuevo, Becerril era un poco de casitas de paja, era pequeño, la gente vivía de la agricultura y el ganado. Antes se jarreaban hatos de ganado, una cuadrilla de hombres nos íbamos desde aquí hasta Valencia de Jesús, un pueblecito que está cerca de Valledupar, con cantos de vaquerías. Cuando se empezó a sembrar algodón por aquí todo esto se creció, esas fincas que tenían ganado cosechaban algodón por cantidad, todo el año se trabajaba con el algodón y mucha gente llegó de todas partes del Bolívar, Magdalena, Ocaña y el Tolima y se quedaron aquí trabajando (Juan, comunicación personal, 11 de diciembre del 2016).

Igualmente, la calidad de las tierras fue otro elemento que promovió el poblamiento de las partes más altas del municipio, dado que muchos de los territorios de la Serranía fueron ocupados por campesinos que en busca de tierras fértiles y lugares para habitar alzaron caseríos y veredas para cultivar en las partes más altas de la montaña. 
Imagen 67. Cultivo de yuca

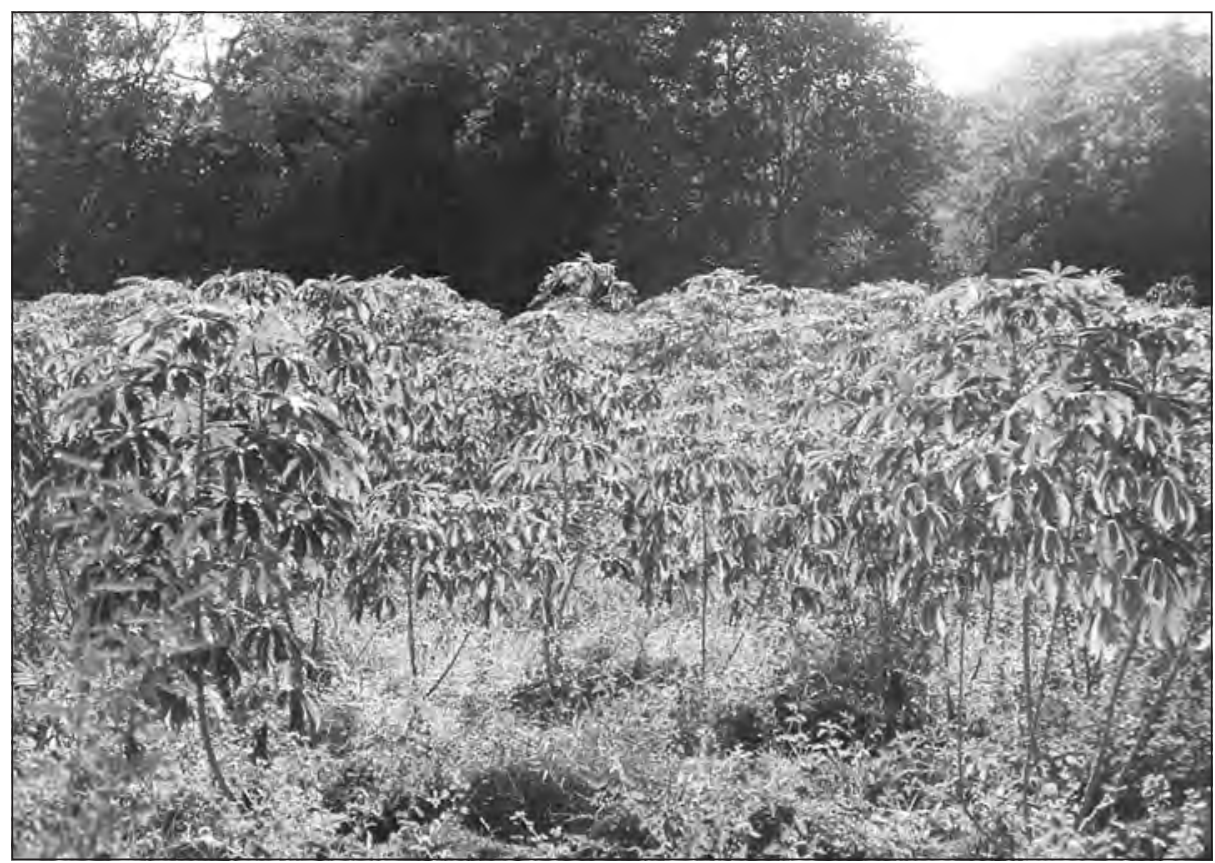

Fuente: Archivo Oraloteca (2017)

Aquí se poblaron estas tierras porque eran territorios baldíos. Mucha gente llegó por estas tierras por la bonanza del algodón y por la tala y venta de madera. [En] esta zona abundaba[n] los maderables caracolíes, [la] ceiba, entre otros. Cada persona cortaba un árbol y los vendía y los sacaban en camiones para el interior del país; también se sembró mucho maíz, yuca, ahuyama, fríjol. La agricultura, el algodón y la madera daban platica, no para ser ricos, pero sí para vivir bien. Por estos lugares llegó mucha gente del interior, sobre todo tolimenses que ya sabían cómo trabajar el algodón. Estos fueron trayendo más gente y estos territorios se poblaron impresionantemente; de allí nacieron caseríos y veredas (J. Vuelvas, comunicación personal, diciembre del 2016).

En el municipio de La Jagua de Ibirico el algodón no tuvo tanto auge como en los demás territorios, dado que allí principalmente se consolidó la industria arrocera. Según E. Castilla (diciembre del 2016), "la Jagua de 
Vida campesina en el Magdalena Grande

Ibirico fue el primer productor de arroz del Cesar; en este municipio tuvo presencia Fedearroz durante mucho tiempo, la producción de arroz fue el principal motor de la economía" (comunicación personal).

El cultivo de arroz, sorgo y, en algunos lugares, el algodón, impulsaron el crecimiento y desarrollo - tanto poblacional como económico- en los primeros años de fundación del municipio. Así mismo, la ganadería fue otra fuente de empleo para muchas personas que llegaban del interior del país en busca de trabajo, las cuales encontraron en la Jagua de Ibirico y sus corregimientos lugares propicios para asentarse.

Sin embargo, las prácticas agrícolas hoy se debaten por su permanencia debido a la fuerte incursión de la minería a partir de la década de 1980. Según E. Castilla (diciembre del 2016), "cuando llegó el sector minero llegó comprando a la buena y a la mala las tierras que anteriormente se cultivaban, lo que desplazó a las comunidades campesinas y la agricultura a lugares más reducidos" (comunicación personal), afectando fuertemente la agricultura y la vida social de las comunidades campesinas.

Imagen 68. Sembrado de maíz en Pailita, Cesar

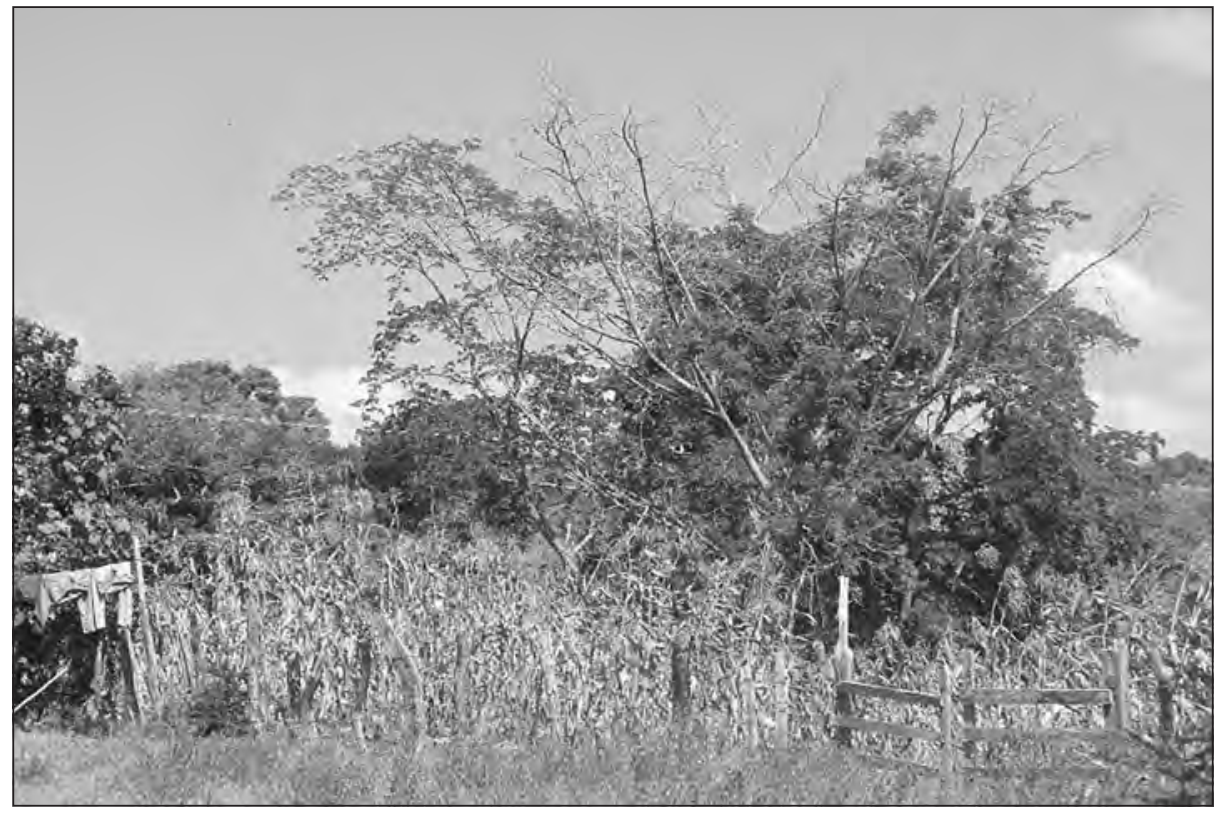

Fuente: Archivo Oraloteca (2017). 
Vida campesina en el Magdalena Grande

En el caso de Pailita los procesos de origen y poblamiento del municipio responden a las actividades agrícolas, ganaderas y pecuarias que se desarrollaron tempranamente en su diverso territorio:

Cuando llegué a esta región, porque yo vengo de Ocaña, la gente vivía de la agricultura, de sembrar la mata de maíz, yuca, plátano y ahuyama; también había ganado y se sembraba todo el año. Yo llegué porque había tierras buenas para trabajar y yo me amañé aquí (C. Pallares, comunicación personal, enero del 2017).

La agricultura fue el principal elemento que dinamizó la vida de las diferentes poblaciones asentadas. El arroz y el algodón fueron las fuentes de empleo de muchos habitantes de la zona. El trabajo en las haciendas arroceras y algodoneras fue consolidando familias de campesinos que aportaron al desarrollo socioeconómico del municipio, conformando redes de comercio entre las zonas rurales y el casco urbano.

Si bien es cierto que gran variedad de los municipios del sur del departamento del Cesar tienen relación directa con la bonanza algodonera de la década de 1960, se debe resaltar que existen otros municipios cuyo desarrollo económico y social no fue impulsado precisamente por la producción algodonera; esto, dado que su presencia en las dinámicas económicas y en zonas rurales jugó un papel secundario, por lo que otros productos agrícolas dinamizaron la economía, como el caso de la Jagua de Ibirico y Pailita con el cultivo y la producción del arroz.

En el municipio de Pelaya los procesos de conformación y poblamiento son similares a los de Pailita, pero cabe resaltar que el municipio cuenta con una ciénaga que conecta a dos corregimientos y diferentes municipios, la cual es zona de pesca tradicional de los diferentes pueblos pescadores que se encuentran asentados a sus orillas. Sin embargo, la presencia del maíz fue la que influenció el crecimiento poblacional del municipio: su cultivo en las grandes haciendas potencializó la economía local, promoviendo la oferta de empleo para el trabajo en las arroceras. Al igual que con la industria del algodón, el maíz fue el principal atractivo para que muchas familias campesinas llegaran a estas regiones a trabajar la tierra. El trabajo en las arroceras jugó un papel importante en la conformación de la identidad e historia de los habitantes de Pelaya. 
Vida campesina en el Magdalena Grande

Actualmente, en la vía principal que comunica al municipio con los demás entes territoriales reposa la estatua de una figura de tusa de maíz en honor a su importancia.

Imagen 69. Monumento al maíz en Pelaya, Cesar

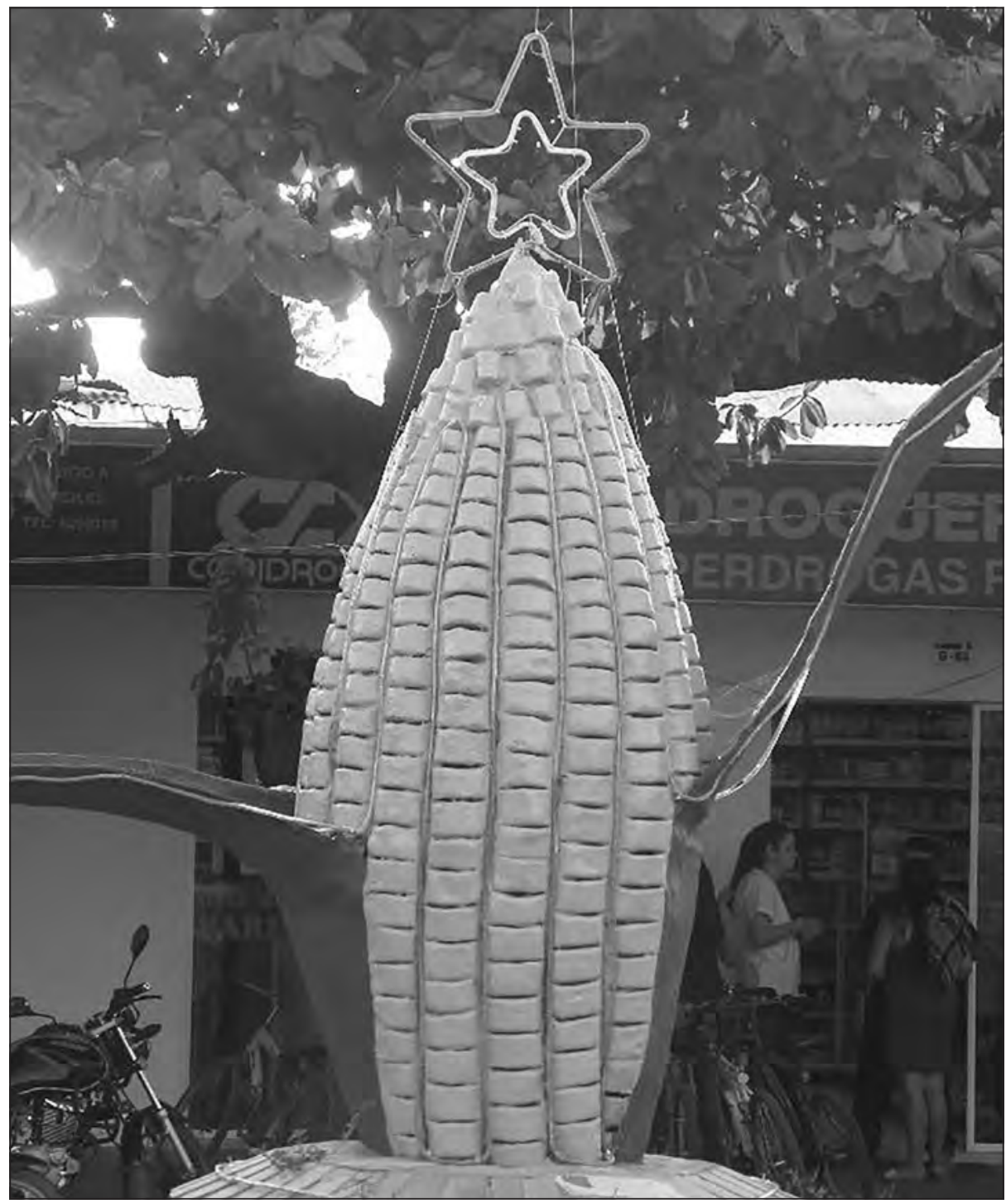

Fuente: Archivo Oraloteca (2017), 
Vida campesina en el Magdalena Grande

Yo muy niño recuerdo que mi papá nos sacó de las veredas esas donde nacimos, por la violencia. Eso le decían "la violencia" cuando los chulavitas, entre liberales y conservadores; en esa época era de un lado para el otro hasta que llegamos por esta región. Antes, la gente cultivaba maíz, yuca, plátano, ahuyama y, en las partes altas, café y ganado; de eso vivíamos antes. Pelaya fue un pueblo maicero porque era la parte donde más se producía maíz en esta región. Decían que era la despensa de maíz del Cesar, eso se cultivaba desde que Pelaya eran unas cuantas casitas. Llegó gente de todas partes: de Ocaña, de Aguachica, de Tolima, a trabajar con el cultivo de maíz, tanto en las partes medio altas [como] en las bajas, donde también se cultivaba arroz (Juan de Dios, comunicación personal, 6 de enero del 2017).

Actualmente, la presencia de la ganadería extensiva y de la palma de aceite ha desplazado paulatinamente las producciones agrícolas y pesqueras en el municipio. La cría de búfalos, principalmente, ha intensificado los impactos ambientales en los territorios que muchos agricultores utilizaban para realizar sus labores:

Hoy día muchas haciendas ganaderas tienen búfalos. [A] estos animales les gusta el agua; a diferencia de las vacas, a los búfalos les gusta estar metidos en el agua todo el día. Aquí en el corregimiento hay muchas fincas que han ampliados sus predios para los búfalos y nos han tomado playones de la ciénaga donde los animales esos se meten y la baba y la orina de ellos es malísima, eso daña la fauna, como si fuera ácido (J. Padilla, comunicación personal, enero del 2017).

En el municipio de Aguachica la bonanza algodonera fue un proceso que marcó el rumbo de la historia, además de ser la base fundamental de la economía del municipio y de sus corregimientos más cercanos:

Anteriormente, las personas en Aguachica vivían de la agricultura y de la cacería. Apenas eran unas cuantas casas en el municipio y unas cuantas veredas, pero en el año 1968 llegó la bonanza algodonera y llegaron muchos terratenientes a comprar las tierras y las fincas y empezaron a tumbar y talar las montañas y los bosques para cultivar el algodón. Así, la 
Vida campesina en el Magdalena Grande

industria del algodón se posicionó fuertemente en el municipio. Empresas como ColCesar, al igual que muchas procesadoras y comercializadoras, dotaron de fuente de empleo a los habitantes tanto del casco urbano como de las zonas rulares. Actualmente se encuentran edificaciones antiguas y deterioradas que evidencian la presencia de dicha industria en el municipio. La apertura del algodón fue precisamente el hecho que atrajo la presencia de pobladores del centro del país como en los demás municipios donde se desarrolló la actividad algodonera (D. Mercado, comunicación personal, enero del 2017).

Yo llegué al pueblo a la edad de once años. El pueblo era desde el parque de San Antonio para acá y después de la bonanza del algodón se comenzó a poblar más el pueblo. Eso del algodón sí dio trabajo; después de eso ya no había dónde trabajar. Anteriormente, existían oficinas de ferrocarril que se llevaba[n] el algodón para otras partes del país. Las personas que vivían aquí sembraban yuca, plátano y maíz; eso se acabó. Cuando la época del algodón todos trabajábamos y a todos nos pagaban. Cuando comenzaban las siembras del algodón en julio o agosto, donde eran las últimas siembras del año, llegaba gente de todos los lados para trabajar en las grandes algodoneras (CUALCESAR). En Buturama se cargaban los vagones de algodón desmotado para que se fuera para otros lugares y por la bonanza del algodón se vino mucha gente de afuera porque las tierras eran muy baratas y muchos compraron para sembrar el algodón. De allí se comenzó a poblar todo este pueblo: muchos se quedaron e hicieron sus familias aquí. Después del algodón, la cosa se puso mala (Eliodoro, comunicación personal, febrero del 2017).

Sin embargo, el desarrollo de la industria del algodón en el municipio fue truncado por la apertura económica propuesta por el expresidente Cesar Gaviria en 1990. Según D. Mercado:

Al momento que se dio la apertura económica en 1990 se decayó la agricultura en el país. Como el Gobierno nunca subsidió a los agricultores no se pudo competir con las demás industrias internacionales y [al] agricultor de algodón le afectó porque la fibra del algodón no compensaba con los gastos que dejaba (comunicación personal, enero del 2017). 
A partir de ese momento los agricultores de algodón no encontraron condiciones propicias para el cultivo, por lo que las prácticas agrícolas se fueron desmejorando. Actualmente, el comercio, la producción ganadera y los cultivos de palma africana dinamizan la economía del municipio. Por su parte, la agricultura se practica en pequeñas proporciones, sobre todo en las partes altas del municipio en las que diferentes familias de campesinos aún cultivan yuca, plátano y café, entre otros productos de pancoger.

Imagen 70. Antiguas bodegas de ColCesar en Aguachica

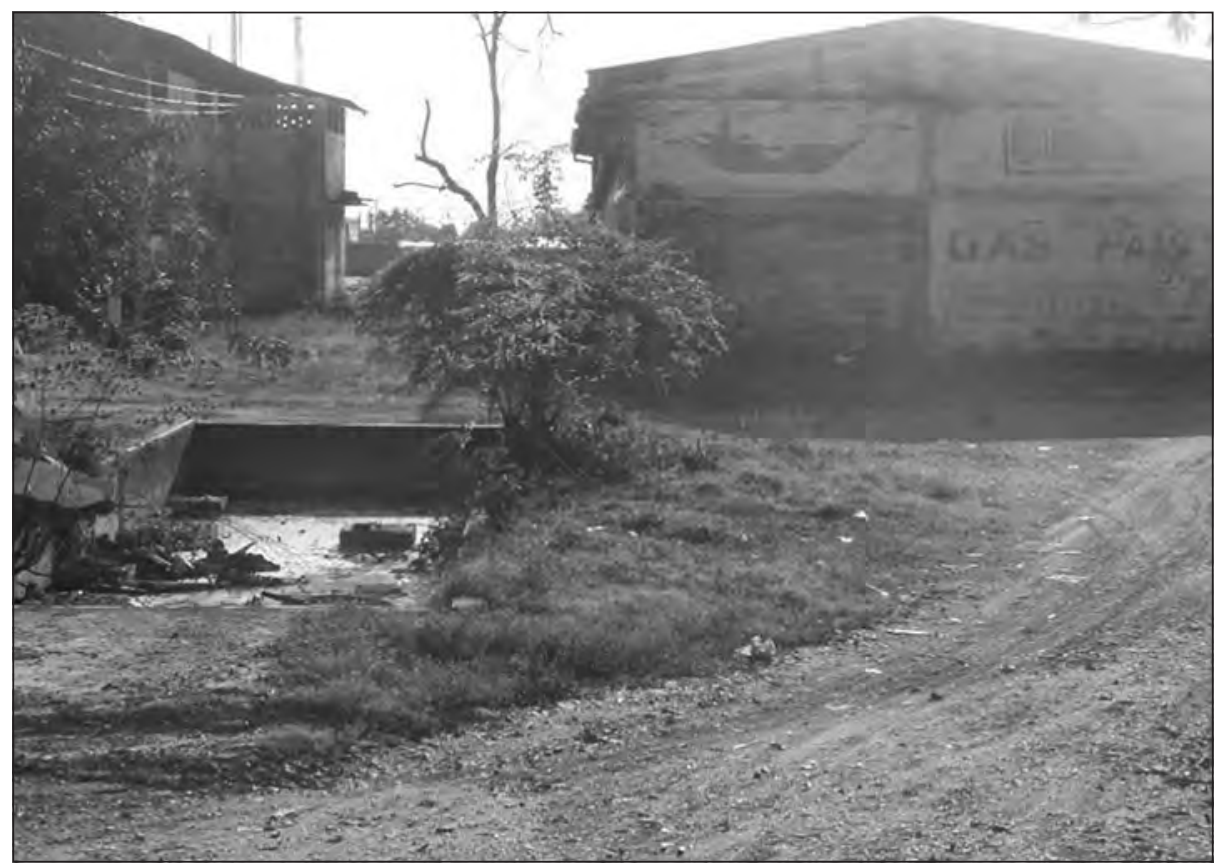

Fuente: Archivo Oraloteca (2017).

\section{Cotidianidad campesina: saberes locales y modos de vida en el sur de la Serranía del Perijá}

Los saberes locales son construcciones sociales y culturales que han permitido a los grupos humanos identificarse y diferenciarse unos a otros colectivamente (Aristizábal, 2002). Para el caso de las comunidades 
campesinas, sus saberes tradicionales son el producto de la conexión armónica o conflictiva que históricamente el sujeto campesino ha entablado con el entorno ambiental y geográfico para su subsistencia, generando así la construcción de conocimientos que dan sentido al territorio y a los modos de vida de las comunidades.

Es así que los modos de cultivar, el conocimiento sobre las propiedades curativas de la naturaleza, la interpretación de los ciclos naturales y lunares, las leyendas, los mitos, los versos, las músicas campesinas, las cocinas locales, sus formas organizativas, las arquitecturas populares, el conocimiento del territorio y el vínculo profundo con la tierra son elementos que dan cuenta de la diversidad cultural y de los procesos de cambio que colectivamente han vivido las comunidades campesinas.

Sin embargo, estos saberes campesinos han sido marginados y categorizados como folclor; es decir, como expresiones culturales estáticas en el tiempo y ajenas a las dinámicas sociales, económicas y políticas de las sociedades modernas y que se sustentan en la superstición, profundizando la brecha entre las zonas rurales y urbanas, agudizando el aislamiento, las crisis sociales, económicas y culturales que ha sufrido el campo colombiano.

En ese sentido es fundamental señalar que, para fines de la investigación, los saberes locales de las poblaciones campesinas son elementos y expresiones culturales cargados de significados, resistencias e historias que permiten entender y reflexionar sobre la filosofía y ontología del ser campesino en el Caribe colombiano. Por este motivo, a continuación se presentarán algunos elementos que dan cuenta del valor y significado que poseen las manifestaciones culturales dentro de los procesos sociales y comunitarios de las poblaciones campesinas.

Las comunidades campesinas de la subregión Sur del Cesar comparten elementos y manifestaciones de la cultura local que los asimila y diferencia entre sí como grupos sociales. Si bien es cierto que comparten a la Serranía del Perijá como escenario de producción agrícola, cada comunidad, pueblo, vereda o caserío ha desarrollado conocimientos, habilidades y modos de vida particulares que ritualizan y dan sentido a sus dinámicas cotidianas, económicas y culturales. 
Imagen 71. Campesino del Centro del Cesar

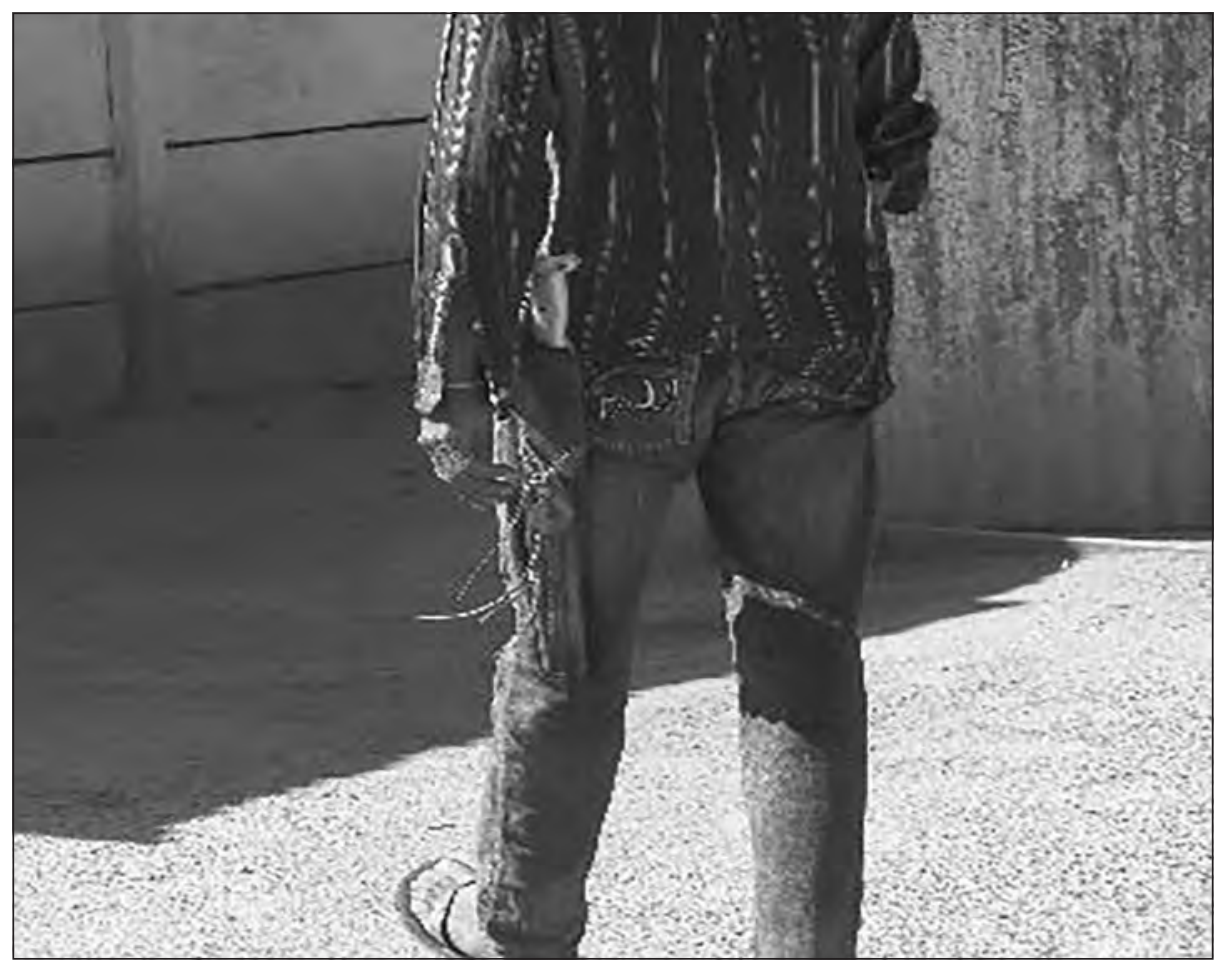

Fuente: Archivo Oraloteca (2017).

Es vital mencionar que los municipios de Llerasca (Codazzi), Estados Unidos (Becerril) y la Victoria de San Isidro (la Jagua de Ibirico) son las principales despensas agrícolas en la parte centro occidental del departamento del Cesar. Sus modos de vida están vinculados a los trabajos en el campo; es decir, muchos de los habitantes reconocen su herencia campesina como parte fundamental de su identidad.

Estos pueblos poseen calles sin pavimentar, las arquitecturas de las casas son diversas, se conservan las casas de bahareque, la organización de los territorios responde a los procesos de poblamientos desarrollados por los primeros pobladores, los patios de las viviendas suelen ser espacios para el descanso y el trabajo (algunos son pequeñas huertas mixtas), donde la cría de animales y cultivos como el plátano, la yuca, el limón y los mangos ayudan al sustento diario de las familias. 
Vida campesina en el Magdalena Grande

Imagen 72. Cultivo de plátano en Codazzi, Cesar

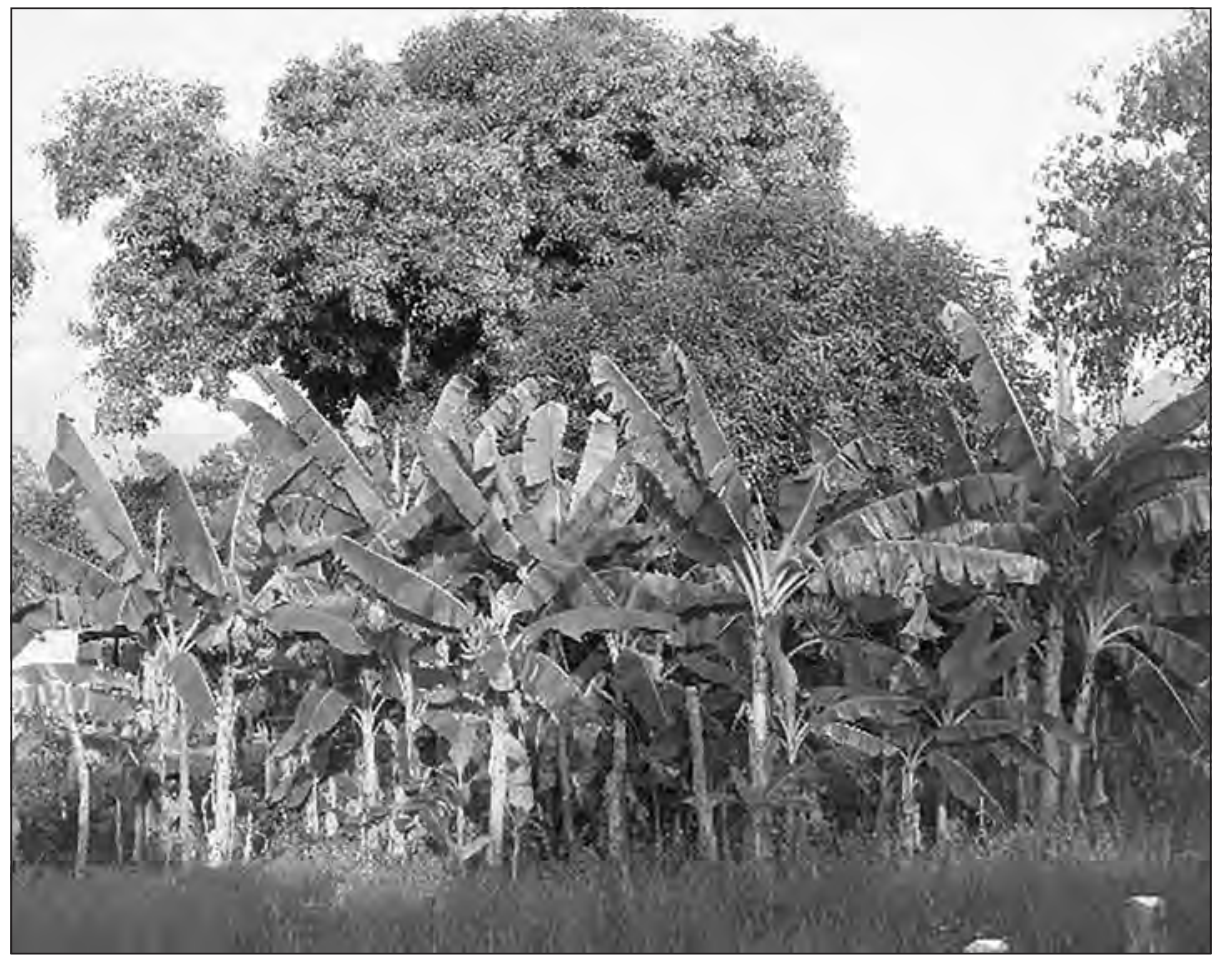

Fuente: Archivo Oraloteca (2017).

En el caso del municipio de Agustín Codazzi, la cultura y las tradiciones campesinas se caracterizan por su diversidad. Las prácticas agrícolas responden muchas veces a las condiciones medioambientales de los territorios, por lo que los cultivos de maíz, yuca, ahuyama, tomate, fríjol, malanga, plátano, limón y mango son sembrados en las partes bajas del pie de monte de la Serranía, mientras que en las partes más altas se cultiva café, aguacate y maíz en mayor proporción, especialmente en los corregimientos de Casacara y Llerasca.

El proceso de colonización de los territorios rurales de Codazzi logró consolidar generaciones de campesinos que, a través de lazos de apropiación y afectividad por el campo, reorganizaron el territorio, configuraron saberes y tradiciones que regulan las dinámicas sociocomunitarias, culturales, espirituales y económicas de los habitantes. 
En ese sentido, cultivar para los campesinos del corregimiento de Llerasca, según E. Torres (enero de 2016), es "una forma de trabajar muy linda, muy honesta, trabajar la tierra es hacer la vida de uno en el campo, cultivando y criando, es vivir la vida como pobre, trabajando para subsistir" (comunicación personal). En ese sentido, el "trabajo a pulmón", aquel realizado con azadón y machete en mano, es una de las prácticas cotidianas en las dinámicas campesinas.

Imagen 73. Eduardo Torres, campesino de Llerasca

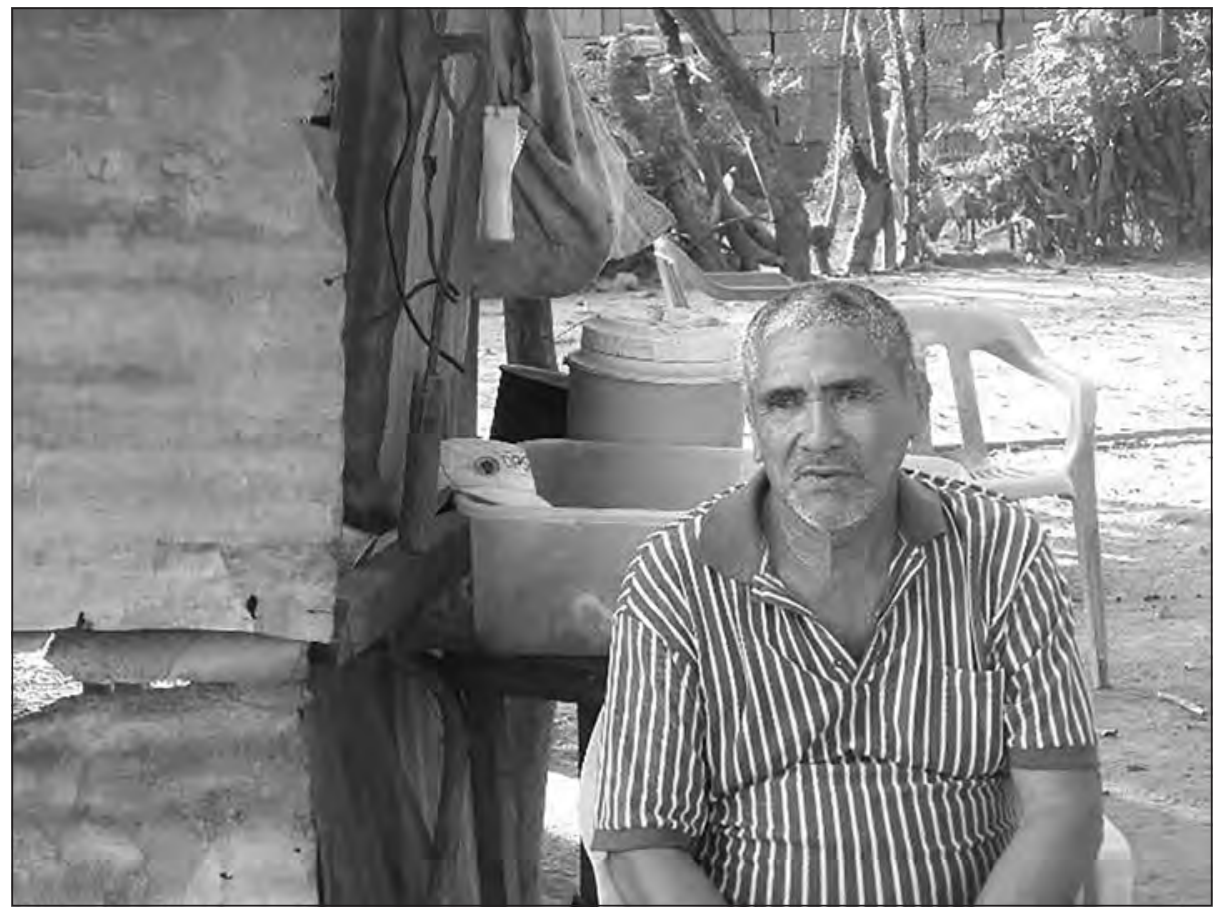

Fuente: Archivo Oraloteca (2017).

Es vital mencionar que la agricultura da sentido a la manera de habitar y trabajar en el campo. A través de las actividades de sembrado los campesinos desarrollaron saberes articulados a factores tanto ambientales como astronómicos, culturales y económicos que diversifican las formas de cultivar de acuerdo al tipo de cosecha que se quiere y a los insumos que posea el campesino. 
Vida campesina en el Magdalena Grande

Imagen 74. Sistema de riego, Cesar

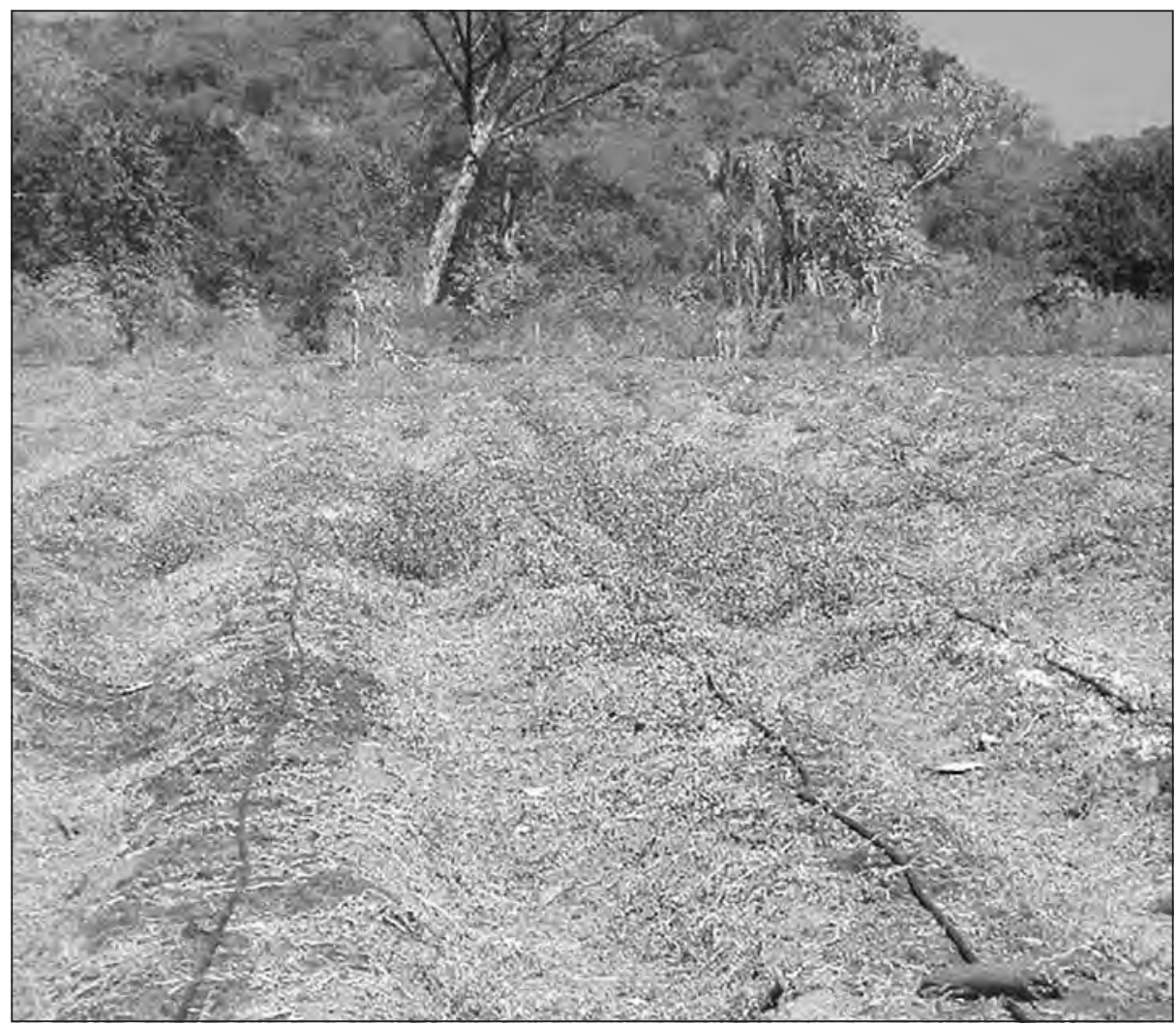

Fuente: Archivo Oraloteca (2017).

Actualmente, las prácticas agropecuarias se debaten entre la tradición y la tecnificación, generando transformaciones en las labores campesinas. En muchos casos, los modos de cosechar se articulan a las nuevas tecnologías que llegan al campo para tecnificar el trabajo agrícola, por lo que el uso de tractores, distritos de riego y otros tipos de equipos utilizados para moler el sorgo y obtener alimento para las vacas han fomentado que muchos campesinos y jornaleros mezclen sus conocimientos locales con las nuevas tecnologías en algunos sectores del campo.

Si bien es cierto que en muchos sectores rurales del corregimiento se ubican grandes haciendas Palmeras y Arroceras que poseen grandes equipos tecnológicos para potencializar su trabajo, existen campesinos y 
Vida campesina en el Magdalena Grande

parceleros que siguen articulados a las dinámicas tradicionales del sembrado, donde los ciclos ambientales y lunares son fundamentales para la realización de los cultivos y el florecimiento de las cosechas:

Yo llegué a cultiva[r] arroz, yuca, ñame, plátano, maíz, eso se siembra "palanqueao": uno coge el "efequeón", siembra y va midiendo uno con el pie, a eso le llamaban que uno va "tranqueando"; así sembrábamos. Después, sembrábamos maíz a la perdía; es decir, sembrábamos maíz más cerca uno del otro. Para la yuca hay que cavar la tierra hasta que se hacen unas zanjas hondas "liniao". Entonces, dejábamos que lloviera y ahí metíamos la semilla, ahí sí era que paría yuca: así sembrábamos en la parcela. Ahora toca buscar el agüita para sembrar, los tiempos ya no nos ayuda[n] con eso. Nos toca hacer pozos, hacer préstamos para un distrito de riego, gracias a Dios que nosotros en la vereda tenemos un distrito de riego que nos dio la Alcaldía y ahí nos ayudamos (M. Ferrero, comunicación personal, enero del 2017).

Cuando en el mes de febrero caen dos o tres aguaceros la gente dice que la cosecha de café va a estar buena porque eso pronuncia que la producción va [a] ser exquisita; es decir, [que] la mata va a empreña, porque así dice uno por aquí, así me enseñó mi papá: que agua lluvia empreña a la mata de café. Pero cuando florece una mata de café y le pegan tres soles calientes se daña la mata, empieza a marchitar y daña la vegetación. Si llueve hay prosperidad en el cultivo, también cuando el maíz está espigando, eso tiene un sistema que si le pegan quince días de verano se muere, porque la mata no tiene fortaleza y se marchita. Yo aprendí eso porque lo viví y todavía lo pongo en práctica (E. Torres, comunicación personal, febrero del 2017).

No todo cultivo es igual: el plátano tiene su forma de cultivar y tiene su época, por lo menos el plátano es un cultivo que se puede sembrar en marzo, uno lo siembra en estas fechas para aprovechar ciertos movimientos de la atmósfera. Para el cultivo de maíz se hacen las tierras en enero, febrero, y se cultiva en marzo para poder aprovechar las aguas para que no se pierdan. La segunda, en el mes de junio, julio se quema y agosto se siembra para cogerlo en diciembre. El café es un cultivo que uno lo 
Vida campesina en el Magdalena Grande

siembra este año, pero dura tres años para ver la cosecha a la mata. Después de tres años viene la purga, lo que uno llama castizamente "la purga": los primeros granitos de café. El fríjol es temporal: la siembra de fríjol es en septiembre para cogerlo en diciembre (E. Torres, comunicación personal, 5 de febrero del 2017).

En ese sentido, la relación del campesino con la naturaleza y el medio ambiente es fundamental en la labor agrícola: los ciclos de la luna, los veranillos, los tiempos de lluvia, son elementos que les permiten a los campesinos reconocer - de acuerdo a los ciclos naturales - los mejores momentos para realizar los sembrados. El acceso al agua, los inviernos y los grandes aguaceros potencializaban la agricultura. Actualmente, los fuertes veranos, las sequias y el cambio climático afectan radicalmente los modos de vida, los conocimientos y las prácticas de las comunidades campesinas, por lo que los distritos de riego o pozos son las principales alternativas para mitigar estas afectaciones:

Las cabañuelas son los primeros aguaceros del mes de diciembre, final de enero o primero de febrero. Son pequeñas lluvias que le avisan al campesino cuándo es bueno para sembrar, pero el cambio del clima ha afectado esas cabañuelas. Yo siempre [he] dicho que nosotros hemos acabado con la naturaleza, los campesinos deberíamos trabajar en las orillas de los ríos, sembrando árboles para cuidar el agua porque sin ella no se puede sembrar (D. Hernández, comunicación personal, 3 de febrero del 2017).

Los tiempos han cambiado mucho: anteriormente, uno sembraba yuca en el mes de abril, era preciso, lo esperaba uno para cultivar, pero ahora no, ahora está lloviendo en cualquier mes, ahora no tenemos seguridad con la lluvia, pero ahora hay mucha facilidad con los distritos de riego. Anteriormente, nos sosteníamos con la lluvia del cielo; hoy día no, hoy podemos cultivar en verano con los distritos de riego. Un mes de abril, un sábado de Gloria, le tenía mucha fe: por ser meses lluviosos, uno esperaba agua, esperaba uno la primera palanca; ahora no, ahora uno siembra en seco. En marzo, que no hay lluvia, ahí ya no da; en el mes de agosto, la segunda palanca de sembrar maíz; la yuca una sola siembra al año, pero con el distrito de riego ahora se puede cultivar la yuca dos veces al año. 
Mire, yo tengo uno y muchas veces cojo agua del arroyo y el pueblo me cae encima porque hecho un poquito de agua para los cultivos. Yo trabajo es en la noche. Nosotros ayudamos con la construcción del acueducto para el pueblo, pero la gente me cae cuando cojo un poquito de agua del arroyo (P. Castro, comunicación personal, 4 de febrero del 2017).

Los modos de vida de la población y la manera de habitar el territorio del Llerasquero poseen un vínculo estrecho con las actividades agropecuarias: la cría de animales, el cuidado de las huertas caseras, el trabajo en las parcelas, el trabajo de jornal y las diferentes labores de la ganadería dinamizan como primera medida el día a día de la comunidad. Aunque muchos se dedican a las labores campesinas, se encuentra un grupo extenso de personas dedicado a diferentes labores: albañiles, conductores de rutas intermunicipales, obreros, mototaxi, trabajadores de las palmeras y las minas, entre otros, que encuentran en las prácticas agrícolas un elemento secundario en sus dinámicas cotidianas, ocasionando que muchos campesinos puedan alternar sus conocimientos agrícolas con las dinámicas urbanas que se posicionan en sus territorios.

Imagen 75. Patio de casa en Llerasca, Cesar

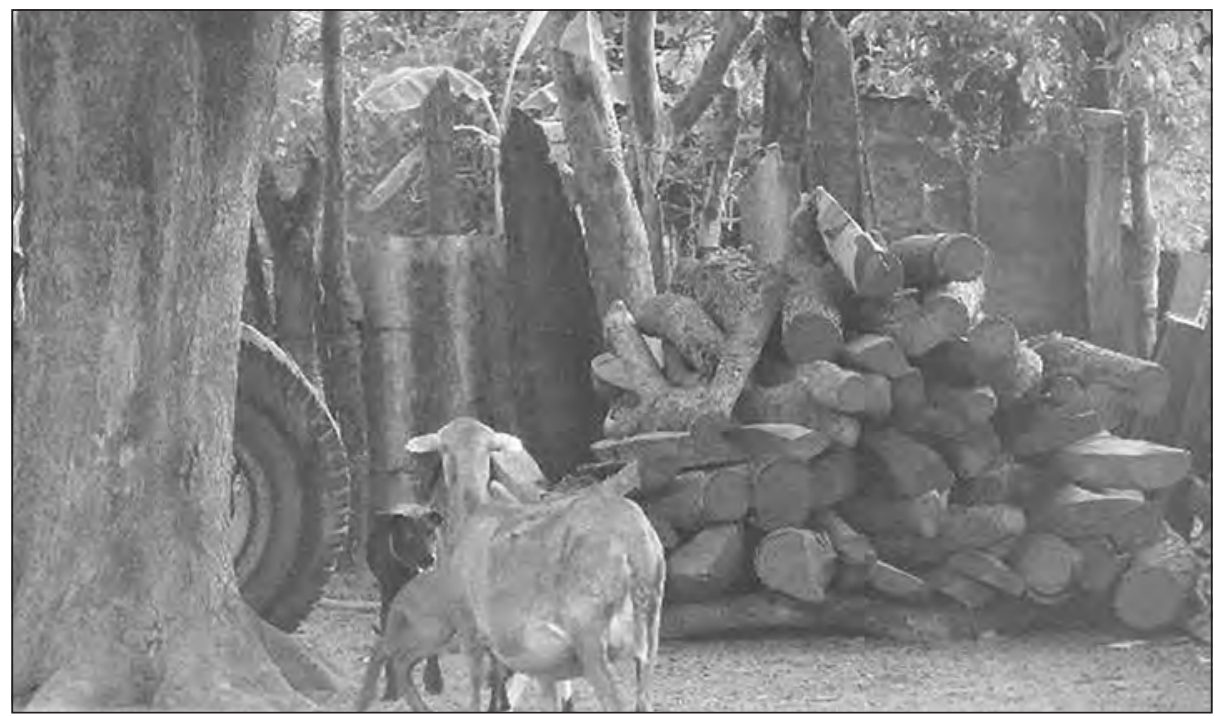

Fuente: Archivo Oraloteca (2017). 
Vida campesina en el Magdalena Grande

Mira, yo soy campesino, criao' en el monte. Todos mis hermanos y papá, todos saben de agricultura: sabemos sembrar, cuidar animales, de todo en el campo. Nosotros tenemos una parcela donde tenemos unos señores cuidando porque a mí no me da el tiempo para estar allá, entonces me toca buscar otras formas de trabajar porque muchas veces están malas las cosechas, la parcela no da y toca pagarle al trabajador, buscar para la comida, ayudar a mis hijas, entonces toca hacer de todo. Aquí en la casa tenemos esos animales para la venta, cerdo y gallinas criollas que criamos para la venta, eso nos ayuda. Yo quisiera vender mi parcela porque a veces la cosa se pone dura y fea, pero mi mujer no me deja, ella está metía' con el cuento de la parcela, entonces así estamos (Tito, comunicación personal, 3 de febrero del 2017).

En ese sentido, es el trabajo en el campo el primer centro de aprendizaje y transmisión de conocimiento de los diferentes miembros de la comunidad. Son muchos los niños, niñas, jóvenes y adolescentes que acompañan a sus padres y familiares en los procesos de siembra, fomentando la sostenibilidad y permanencia de los conocimientos asociados a la agricultura a través de la oralidad y la práctica, tanto en la cabecera del corregimiento como en sus zonas rurales.

Esto sucede tanto que muchos jóvenes asocian o encuentran en la agricultura una estrategia de emplearse y generar ingresos, por lo que terminar la escuela es un objetivo secundario. Si bien es cierto que muchos jóvenes van a la escuela, existen otros que no asisten y sus conocimientos son adquiridos a través de las prácticas agrícolas. 
Vida campesina en el Magdalena Grande

Imagen 76. Joven campesino caminando hacia su parcela

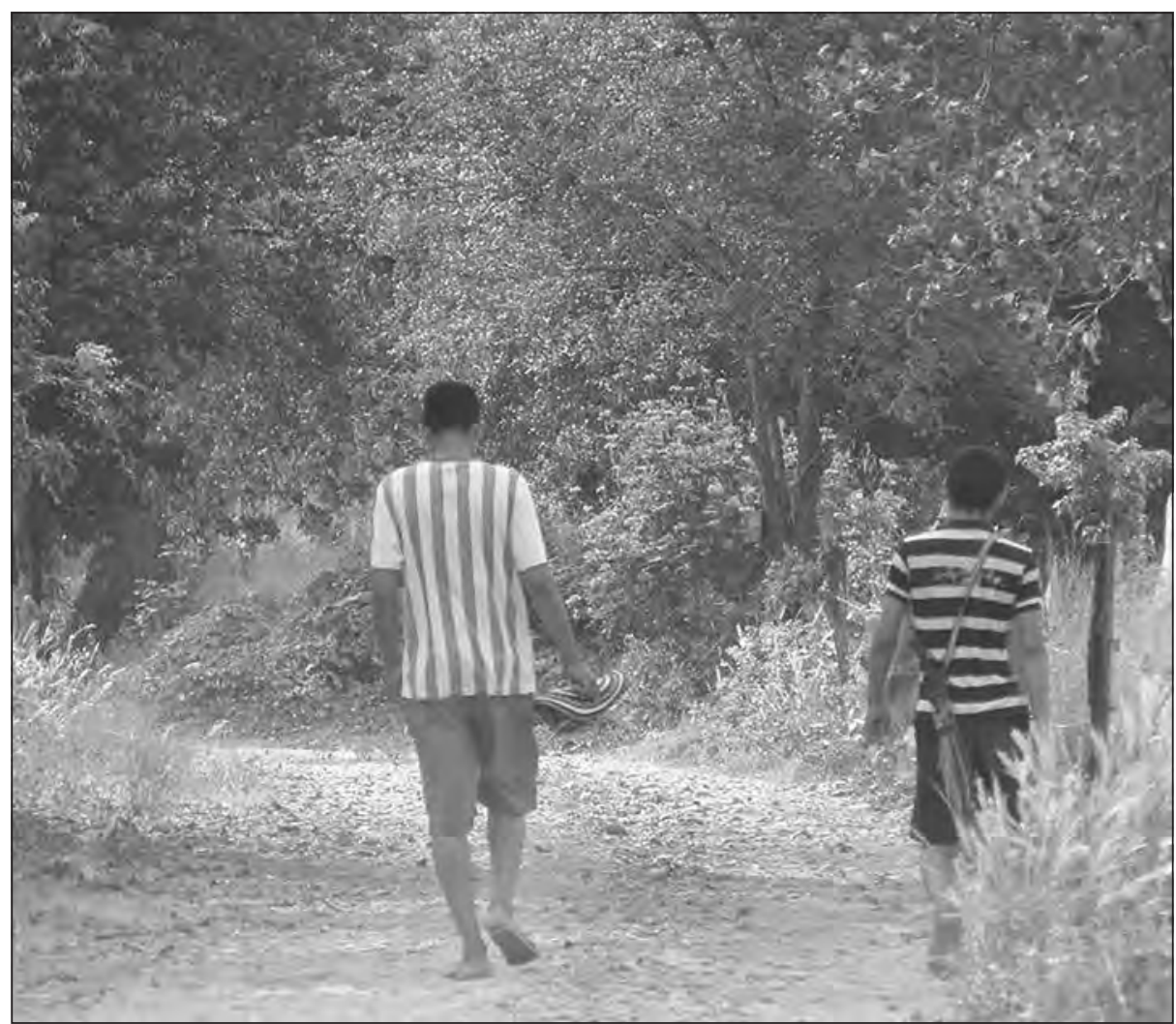

Fuente: Archivo Oraloteca (2017).

En Llerasca es usual observar a jóvenes, niños y niñas realizando limpiezas en los corrales de animales, cuidando los cultivos y cultivando en las parcelas como ejercicios cotidianos que dan vida y recrean las tradiciones campesinas. Así, D. Hernández (febrero del 2017) nos cuenta:

Yo aprendí la agricultura fue con mi papá, yo me levanté trabajando con mi papá y mis tíos, sembrando maíz. Desde pequeño él me llevaba a los cultivos y me enseñaba todo sobre cómo se debía cultivar, en qué momento del año, cómo sembrar las semillas, conocer las plantas, lidiar con los animales, recoger cosecha, todo eso, y así aprendí a trabajar en el campo (comunicación personal). 
Vida campesina en el Magdalena Grande

Otro elemento que alimenta y dinamiza los saberes locales de la población campesina en Llerasca son los conocimientos y usos asociados a las propiedades curativas de las plantas. En el corregimiento existen campesinos conocedores de las propiedades curativas de varias plantas: sus conocimientos han sido adquiridos a través de la experiencia, identificando y clasificando diferentes tipos de vegetación que ayudan al cuidado del cuerpo, la salud, y para la sanación de algún tipo de enfermedades, como es el caso del árbol de yarumo, particular en esta región; según Y. Castro (enero de 2017) "este árbol es muy utilizado para varias cosas por sus propiedades curativas para la gripa y la cortadura entro otros; también se utilizan las aromáticas para apaciguar dolores de cabeza, barriga y fiebres" (comunicación personal). Sin embargo, la tala masiva de los bosques nativos de la región para la ampliación de las grandes haciendas palmeras y las minas carboníferas ha disminuido la presencia de dicho árbol en la zona.

Ahora bien, dichos conocimientos representan una parte de la herencia cultural campesina de las comunidades; estos reflejan el valor que poseen las tradiciones campesinas en las dinámicas de vida de los "llerasqueros". La medicina tradicional es una manifestación cultural que revindica el vínculo de la población con el campo y sus memorias colectivas:

Por aquí mismo hay una planta que se llama "solita", yo las conozco; hay otra que se llama (que se parece un bejuco) "contracapitana", que sirve para la picada de la culebra; hay otras que es una batatilla amarilla... uno cuando va a trabajar lleva la contracapitana y uno en el monte encuentra la contramapana: uno le da esas tomas a las personas unos minutos después de la mordida y la persona no se muere. También hay matas como el guacaco, la chicoria, la manzanilla; esas plantas curan un mal de estómago, que en el monte es uno de esos males que afectan al campesino. Para una cortada en el monte uno busca yarumo, uno raspa la majagua del yarumo y, si hay una miguita de panela, lo revuele con la baba esa y se lo echa en la cortada y eso para la sangre y, después de unos cuatro días, esa corta[da] ya está sana y no hay necesidad de cogerse puntos; eso conoce uno como "campesino" (E. Torres, comunicación personal, febrero del 2017). 
Vida campesina en el Magdalena Grande

Otro aspecto fundamental en la vida de los campesinos es la alimentación. En Llerasca se caracteriza por el consumo principal del arroz, la yuca, el plátano y la ahuyama, pero en las zonas veredales el consumo de arroz es menos frecuente, al igual que el consumo de la carne; esto, dado que los cultivos de pancoger son las principales despensas alimentarias, mientras que el arroz y la carne son complementarios en la dieta cotidiana debido a que su consumo se articula a las dinámicas de comercialización de los productos agrícolas en la región:

Lo típico en el campo era la sal, las cinco libras de carne, los aliños, [la] cebolla [y el] cebollín porque siempre en la finca había bastimento. La liga era la carne: para el campesino, la liga eran cinco libras de carne. El que tenía dinero lleva sus libras de arroz para la noche, porque el sancocho es lo típico en el medio día y la arepa de maíz siempre al desayuno: esa era la alimentación del campesino (E. Torres, comunicación personal, febrero del 2017).

Cuando yo crecí en la vereda el 11 nosotros nos levantamos fue comiendo yuca, maíz, ahuyama y café de leche; la carne se comía a veces, cuando mi papá cazaba un animal o había plata para comprar la liga (lo que uno llama carne), porque antes ni el arroz se comía a diario... ahora esa está cambiando, nosotros nos alimentábamos era de puro cultivo de nosotros: solo arrancar la mata [de] yuca y cocinarla (U. Puentes, comunicación personal, febrero del 2017).

Las relaciones de compadrazgo, comunitarias y afectivas entre los campesinos se representan y reproducen en la medida en que muchos propietarios de cultivos comparten sus cosechas con los demás habitantes de las veredas y el pueblo. Si bien es cierto que los cultivos son comercializados en los mercados mayoristas, los campesinos conservan la tradición de ayudar a las familias de escasos recursos, obsequiándoles yucas, plátanos o cualquier cultivo que posean, ya sea en sus rozas, parcelas o huertas. 
Vida campesina en el Magdalena Grande

Imagen 77. Cultivo de plátano y yuca en Llerasca, Cesar

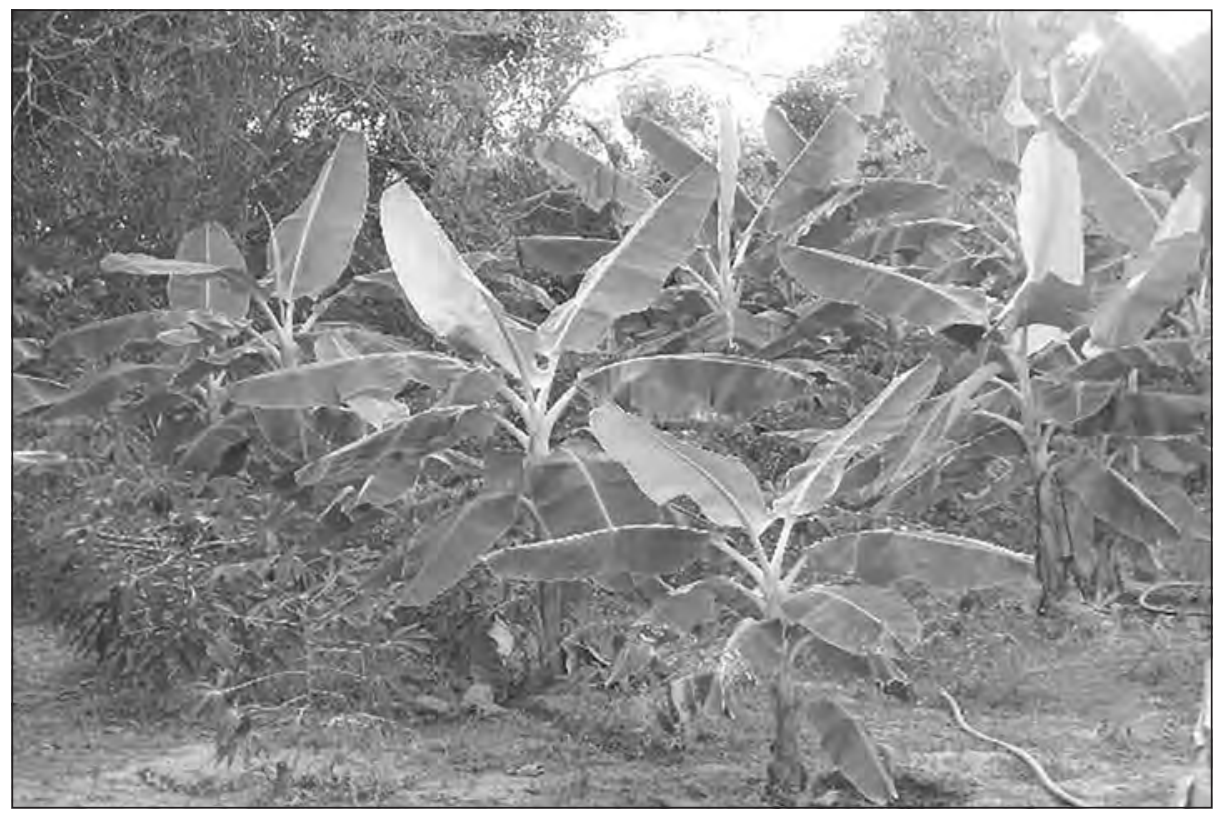

Fuente: Archivo Oraloteca (2017).

A nosotros nos enseñaron desde pequeños que cualquiera que llegue a la finca y necesita una mata de yuca o plátano se le regala, así nos enseñó mi papá desde pequeños, a compartir de la cosecha, porque así eran las cosas de antes: si el vecino necesitaba yuca para la comida nos pedía y se le daba la matica (J. Triana, comunicación personal, febrero del 2017).

Igualmente, las narrativas, mitos y leyendas son elementos culturales que dinamizan y representan la territorialidad, la memoria colectiva e identidad de la comunidad, tanto de las zonas rurales como de la cabecera del corregimiento. La presencia de copleros, cantores de vaquería y cuenteros da cuenta de la importancia de la oralidad en las dinámicas sociales, comunitarias y espirituales de la población, dado que a través de estas expresan su relación con el mundo, su visión del territorio, su identidad, sus historias colectivas, problemáticas y resistencia. Igualmente, las expresiones orales son elementos canalizadores y dinamizadores de las manifestaciones propias de la cultura campesina en la región: 
Vida campesina en el Magdalena Grande

De nacimiento, agricultor: herencia que me dejaron. No olvido mi profesión: labriego labra tu palo, labra tu palo labriego, destino que Dios te dio. Alzando este barretón, este cafetal sembró, este cafetal sembró, típico, tradicional, y como es de mala producción, lo tengo que renovar, lo tengo que renovar, y así buscaré el progreso. Con ayuda del Comité, vive esta industria de ingreso, lo tengo que renovar (y aquí mi mente se inspira): si me patrocina el Comité, me afilio en cooperativa, ya llegó la solución pa' todos los cafeteros. Voy [a] hablar con doctor, hágala el análisis al suelo. Programe café a las cinco, programe a los cafeteros. Saludos a Leda Rodríguez y Margarita Guerreo, que eran los dueños del programa Café a las 5 en Guatapurí (E. Torres, comunicación personal, enero del 2017).

Tanto las coplas como los cuentos e historias populares son expresiones culturales de la vida campesina que en el corregimiento de Llerasca reposan en la memoria colectiva de los adultos mayores; a través de ellas se transmiten valores, normas y conocimientos asociados a los usos, límites y cuidado de los territorios, en tanto que leyendas como "La lámpara maravillosa", "El gigante pata de barro" y "El brujo jalón" son narrativas que regulan las actividades sociales y reafirman los vínculos de la comunidad con su territorio. Actualmente, la transmisión de dichas expresiones culturales se encuentra en estado de alerta: la presencia de portadores de estos conocimientos es cada vez menor en el corregimiento y los niños desconocen muchas de estas historias. La ausencia de una estrategia pedagógica articulada a la escuela agudiza la situación de la sostenibilidad de las manifestaciones culturales. Actualmente, los saberes campesinos en Llerasca son elementos culturales que reafirman la identidad colectiva y dan cuenta de los vínculos sociales comunitarios; sin embargo, se debaten entre la tecnificación y lo rural.

Para el caso del municipio de Becerril las prácticas agrícolas se concentran principalmente en el corregimiento de Estados Unidos, siendo el maíz y el café los productos agrícolas con mayor presencia en el territorio. La comunidad de la vereda Estados Unidos se encuentra en el pie de monte de la Serranía del Perijá, el cual posee vías terciarias que conectan al pueblo directamente con la Serranía y las diferentes veredas que allí se encuentran. 
La configuración del corregimiento responde a procesos de civilización de territorios utilizados para la explotación maderera, lo que permitió que colonos se asentaran en dichos territorios y forjaran la consolidación de familias de campesinos que, además de cortar madera, encontraron tierras fértiles para el sembrado y cultivo de diferentes productos agrícolas como el maíz, la yuca y, especialmente, el café, entre otros. El proceso de apropiación de estos territorios se realizó desde las partes bajas hacia las partes altas, por lo que el corregimiento ofrece diferentes cultivos de acuerdo a la ubicación geográfica de sus diferentes parcelas, algunas ubicadas en el pie de monte y sobrepasando los $2.000 \mathrm{~m}$ sobre el nivel del mar, dotándolo de una agricultura compleja y diversificada.

Sin embargo, el café se consolida como el producto agrícola que dinamiza la economía local del corregimiento: muchas familias poseen relación directa con su producción dado que diversos habitantes trabajan en los procesos de siembra, recolección, distribución y comercialización de dicho producto. En el corregimiento existen centros de acopio de café en los que los diferentes cafeteros (que se estratifican de acuerdo a la cantidad de hectáreas cultivadas, dado que se encuentran parceleros y grandes hacendados) venden el café en bruto para que luego sea comercializado en la región. Vale mencionar que el maíz jugó un papel fundamental en la conformación del municipio; sin embargo, actualmente las cosechas no son tan productivas como en años anteriores debido a las fuertes sequías y a las desviaciones de arroyos y ríos que han afectado sus procesos de sembrado:

El señor Rogelio Borgues era de los más antiguos de por acá. A él le gustaba lidiar con sus mulas y acerrar y "jarriar" madera. Por aquí había la tolú, cedro, roble, madera fina; había en cantidad el carreto, había para sacar más de diez doble troque a la semana. Antes, se acerraba con serrucho, sierra de mano, el uno abajo y el otro arriba: se colocaban un palo a un serrucho, unos iban arriba y otros abajo, así sacaban la madera y amarraban esos bloques a esas mulas y las llevaban al pueblo, donde los montaban a unos carros gigantes que no recuerdo cómo se llama[n], donde montaban esa[s] maderas con guinches y esas trosas de madera eran llevadas a Becerril, Codazzi y el Valle. Mira, aquí vivíamos era de la madera. Quien tenía en sus parcelas uno, tenía veinte palos, y los cortaba para tener un billetico, la papita o el arroz, y uno cultivaba mucho el maíz, 
Vida campesina en el Magdalena Grande

maíz blanco, maíz amarillo, la yuca, la ahuyama. Yo salía con mi mamá cuando tenía nueve. En ese entonces eran nueve horas desde estas tierras hasta Becerril en mula. Llevábamos repollo, cilantro, cebollín, malanga, zanahoria, para traer la panelita a la casa... eso fue duro, nosotros pasamos necesidades (J. Vuelvas, comunicación personal, diciembre del 2016).

Por los años 70-80 conseguimos una tierrita con unos amigos y empezamos a sembrar maíz; esas tierras eran buenas, que se llaman el Descanso, donde se encuentran las minas esas. Nosotros llegamos a esas tierras a sembrar maíz. El maíz en ese entonces daba platica. No era plata para uno enriquecerse... uno se hacía 300, 400 mil pesos, que eran como 30 millones de pesos en ese entonces, pero la cosa se puso dura cuando llegó la violencia, la cosa fue más dura, lo perdí todo (J. Vuelvas, comunicación personal, diciembre del 2016).

Las tierras más altas de la Serranía del Perijá son los principales escenarios para la actividad cafetera, al igual que para los cultivos de lulo, mora y fresa, cuyas cosechas muchas veces se pierden por la falta de mejores condiciones en las vías que comunican al municipio con las parcelas de las partes altas de la Serranía. Por su parte, en las zonas del pie de monte en Becerril la agricultura ha disminuido paulatinamente debido a la transformación de la vocación de la tierra, siendo la ganadería extensiva una actividad constante en las dinámicas económicas de las familias de los campesinos: muchos agricultores poseen en sus parcelas crías de ganado como un recurso para fortalecer su economía familiar a través de la venta de la leche, por lo que muchas parcelas son mixtas (la agricultura se conjuga con la actividad ganadera sin restricciones).

Las dinámicas y prácticas agropecuarias en el corregimiento se caracterizan, principalmente, por las diferentes formas de cultivar el maíz y el café; sin embargo, las crisis ambientales y los diferentes conflictos armados desarrollados en este territorio han afectado y modificado radicalmente los saberes de los campesinos:

Anteriormente, la agricultura fue el motor de desarrollo del pueblo: así se conformó este caserío, trabajando la agricultura. Hoy día la cosa es muy diferente, son pocos los que tiene[n] la tierra y la trabajan bien para que 
Vida campesina en el Magdalena Grande

le[s] produzca. Ahora las cosas son diferentes: la poca agua, la falta de vías, el cambio en el clima, hacen que la agricultura no dé como antes. Las cosas han cambiado, ahora nos toca buscar otras cosas para poderse ayudar uno, porque uno como campesino es pobre y humilde (J. Vuelvas, comunicación personal, diciembre del 2016).

Tanto el café como el maíz poseen tiempos específicos para su sembrado, que depende de diferentes criterios para su realización. De acuerdo a los conocimientos tradicionales de los campesinos, cuando se avecinan los meses de lluvia se preparan las tierras y antes de que la lluvia empiece a caer de las nubes las semillas deben estar sembradas y distribuidas en las zonas próximas a cultivar:

De campesino como me enseñó el viejo, nosotros ahorita vamos a recoger el maíz que sembramos de traviesa. En el año hay dos sembradas: la de inicio del año y la de traviesa, que es la segunda, la última del año. Aquí rozamos lo que es marzo, junio y abril; enero y febrero comienza a tumbar los montes; los últimos meses de marzo quema el monte, y en la última semana de marzo o [en] las primeras de abril comienza a sembrar, porque son las semanas de lluvia. Las de traviesa comienzan [a] rozar en junio o julio y siembra[n] en las primeras semanas de agosto, que son las lluvias. Ahí la mata que no se le pegue haciendo buen invierno es porque la semilla sinceramente está mala. Estas tierras son ricas para cultivar.

Nosotros sembrábamos la yuca, bastimento común, el guineo, el plátano, la batata, el ñame, aquí hay mucha gente bajera que sabe del ñame, mi mamá era de San Jacinto, de la tierra del ñame, aquí hay gente de Guamal y el Banco, del Tolima, de todas partes, aquí se cultivó de todo y muchos de forma diferente (J. Vuelvas, comunicación personal, diciembre del 2016).

Igualmente, en el corregimiento son varios los agricultores que conjugan los ciclos lunares y las dinámicas medioambientales con sus actividades agropecuarias; es decir, de acuerdo al ciclo lunar los cultivos pueden ser prósperos o menos prósperos. Es así que la luna, más que un 
Vida campesina en el Magdalena Grande

astro natural, es un elemento que posee un vínculo fuerte con las territorialidades y tradiciones campesinas: a través de sus diferentes formas los campesinos pueden predecir el resultado de sus cosechas.

Mire, para cultivar con la luna yo la utilizo para resguardar semilla. Usted siembra en menguante porque si siembra en creciente le da, pero cuando lo va a recoger la semilla se le apolilla. Pero si lo siembra en menguante la semilla le perdura; o sea, si yo sembré ese maíz y lo sembré en menguante puedo utilizar la semilla para el año que viene, [la semilla] que él mismo me da para la próxima cosecha, pero si siembro en creciente sí le da, pero le cae el gorgojo, le cae la plaga, entonces tiene que vender la cosecha rápido porque la plaga se lo daña. Mire, yo sí sigo con mis costumbres si lo siembra en cosecha.

Mire, yo me emputé con un técnico de la Umata y la gente lo burló porque me vino a decir que nos iban a dar unas semillas de plátano pa' cuando ese plátano tuviera un año arrancar la mata (que ya el colino ésta listo para parir la mata), dijo que la mocháramos a "tarrejo" de tierra y les estampáramos y sacáramos colino. Ahí yo le dije: "Doctor, ¿usted quiere que los que armamos con las manos lo destruyamos con los pies?”. Me dijo: “¿Por qué?". ¿Usted cree que una mata de un año apenas va a dar racimo y yo voy a destruir mi mata cuando apenas nos va a dar frutos? Yo sigo con mis costumbres (J. Buelvas, comunicación personal, diciembre del 2016).

Aunque la reproducción de dichos conocimientos se ha mantenido en el tiempo, es en las zonas veredales donde mayor presencia y relevancia adquieren; esto, a diferencia de las cabeceras municipales, donde la presencia de portadores de estos saberes es cada vez menor.

La tecnificación de las prácticas agrícolas ha generado conflictos entre los campesinos. La presencia de tractores, sistemas de riego, electricidad, entre otros elementos, en haciendas, fincas y parcelas ha generado fuertes controversias en cuanto al ejercicio campesino. Por un lado, ha agudizado la desigualdad social en el campo dado que mientras unos cultivan con azadón, otros cultivan con tractores, lo que dificulta la producción y comercialización de las cosechas de los campesinos con bajos recursos $y$, por otro lado, ha fomentado nuevos usos y prácticas en relación a la 
vocación campesina, puesto que muchos campesinos y parceleros han articulado (no armónicamente) sus saberes tradicionales con los nuevos instrumentos, promoviendo nuevas formas de trabajar el campo y de entender el territorio.

Igualmente, muchos habitantes del corregimiento de Estados Unidos son fieles a sus tradiciones. Las fiestas del 11 de noviembre son un acontecimiento que posee un fuerte valor simbólico, moral y espiritual para muchas de las familias. La fiesta de San Martín de Porras es un elemento cultural a través del cual se ritualizan y recrean las costumbres de las antiguas generaciones, dado que se ofrecen oraciones y velaciones al santo patrono de los campesinos para que ayude en lo económico y nunca falten las cosechas:

Aquí celebran el 11 de noviembre, celebran la virgen del Carmen cuando no había tanto evangélico; ahora hay mitad católico y mitad cristiano y las fiestas han cambiado. Mira, en la casa mía yo compraba una caja de velas, una caja de ron, y destinaba un cerdo con tiempo para engordarlo para el 11 de noviembre [en las fiestas de] San Martin de Loba y yo hacía mis fiestas, estas eran mi tradición: yo le pedía a ese santico y [él] me daba el milagrito. Mira, muchos eran los que celebraban esas fiestas, todo el pueblo; había comida típica y bailes, todos disfrutábamos (J. Buelvas, comunicación personal, diciembre del 2016).

Otro elemento que da cuenta de la riqueza cultural de los campesinos del corregimiento son las comidas típicas. La alimentación conjuga las tradiciones enseñadas por las abuelas en el fogón. Actualmente, el consumo de yuca y plátano es fundamental en la dieta de los habitantes del corregimiento; sin embargo, las fuertes afectaciones ambientales a causa de la expansión de la mega minería y el desviamiento de arroyos para las grandes palmicultoras han promovido la pérdida acelerada de diferentes especies animales que servían de complemento nutricional en la dieta de los habitantes de Estados Unidos:

Nosotros aquí nos criamos con la comida de monte: conejo, la guartinaja, el saíno, el morrocoyo, el venado; esos son [mis] animales favoritos. El pescado usted iba a ese río y sacaba con dos "atarrayasos" una cantidad de 
Vida campesina en el Magdalena Grande

pescado, bocachico, besote, coroncoro... pero las minas nos han dañado el río, el río Tucuy. [Con] mi amá cultivamos ajonjolí y ella hacía unas bolas de ajonjolí, lo molía con sal y se comía con la yuca (eso nunca me agradó, pero ella lo hacía); también hacía chocolate de ajonjolí. El maíz cariaco es un maíz finito, suavecito, usted lo muele y hace chocolate, es un maíz amarillo, pero suavecito. Mi mamá no podía ver una bola de ajonjolí con yuca, eso era felicidad para ella; también nos los hacía con sal. Todas esas costumbres se han perdido, son pocas las personas que hacen esas comidas. A veces encuentra uno por la calle a estas negritas que vende[n] cocada[s], ellas todavía hacen bolas de ajonjolí, pero dulces, cuando compre uno se acuerda de mí mamá (J. Buelvas, comunicación personal, diciembre del 2016).

De acuerdo a lo expresado anteriormente, el corregimiento de Estados Unidos juega un papel fundamental en la sostenibilidad de la vocación agrícola en el municipio de Becerril, dado que se conservan tradiciones y saberes locales que expresan la historia, las resistencias, los cambios y la identidad de los sujetos campesinos que, desde hace más de medio siglo, han consolidado una comunidad que se ha mantenido en el tiempo en relación directa con el campo y la labor campesina: "nosotros los campesinos fuimos quienes armamos este caserío, los campesinos. Quienes fundaron estas tierras fueron los campesinos, quienes fundamos este pueblo fuimos nosotros los campesinos a punta de machete" (J. Vuelvas, comunicación personal, diciembre del 2016).

En el caso del municipio de La Jagua de Ibirico, el corregimiento de la Victoria de San Isidro es uno de sus principales centros agrícolas; esto, debido a su proximidad con la Serranía del Perijá, a su historia marcada por la agricultura y a su herencia campesina. Es vital mencionar que las prácticas de la agricultura se encuentran en conflicto con la minería a cielo abierto, dado que La Jagua de Ibirico es reconocida nacional y regionalmente por ser la capital minero energética del departamento del Cesar; en su extensión territorial se encuentran ubicadas estratégicamente tres empresas mineras Drummond y Prodeco, dedicadas a la explotación de carbón en la región. 
Imagen 78. Casa campesina en la Victoria de San Isidro

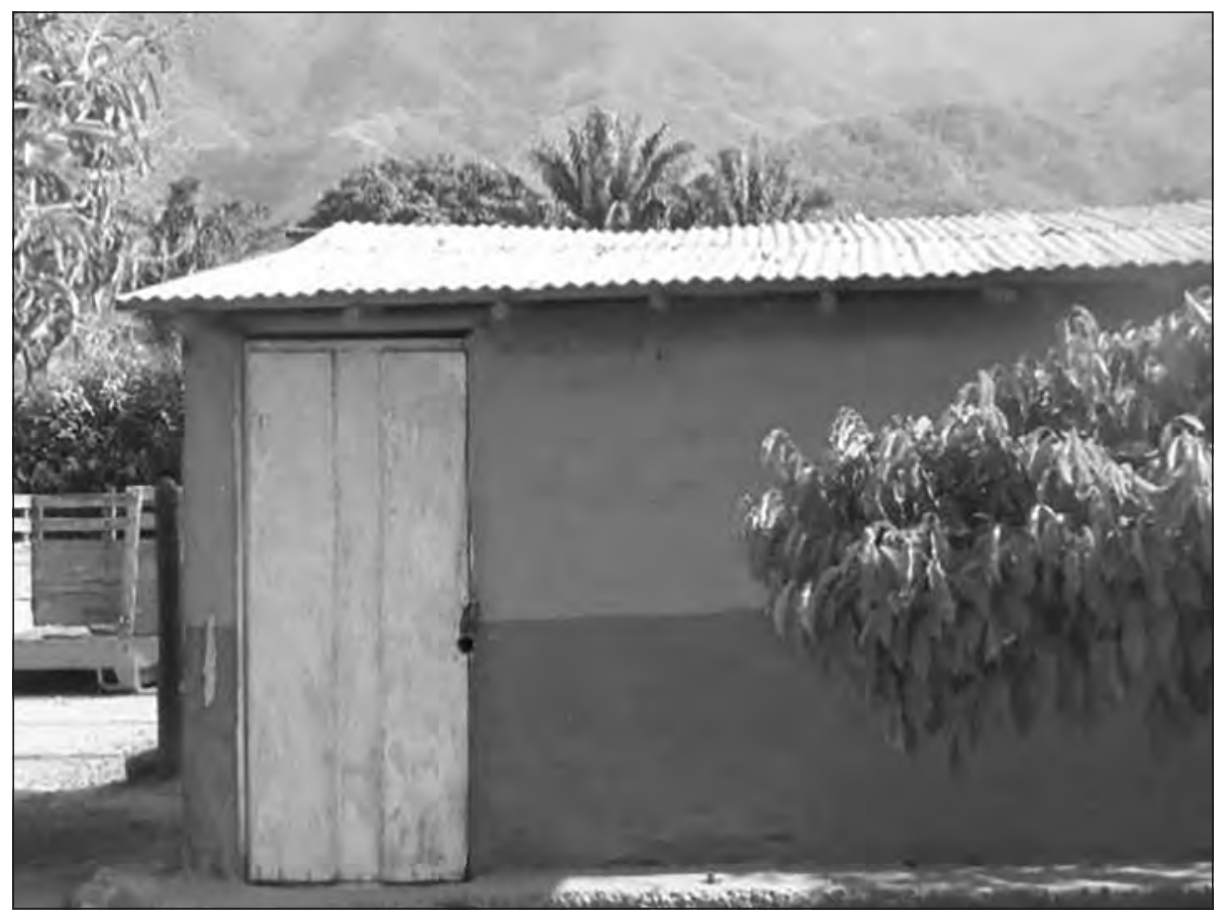

Fuente: Archivo Oraloteca (2017).

El municipio de la Jagua de Ibirico se encuentra aproximadamente a 20 minutos de distancia del municipio de Becerril por vía terrestre. Durante el recorrido es evidente la presencia de la infraestructura minera. Es usual encontrar en la carretera la presencia de la fuerza pública (soldados), camiones que transportan carbón, buses que transportan miembros de las diferentes compañías, diferentes distintivos de las empresas carboníferas y las entradas a las diferentes minas que se encuentran sobre la cabecera del municipio; es decir, todo el tramo de la carretera que conecta a los municipios de la Jagua de Ibirico, Becerril y la Loma es un corredor minero energético donde las producciones de carbón son distribuidas a los diferentes puntos de acopio en dicha región.

En ese sentido, la minería se ha posicionado como el principal motor de desarrollo económico del municipio y sus diferentes corregimientos, desplazando a la agricultura a un tercer plano, dado que la ganadería y 
los monocultivos de palma de aceite son actividades económicas que han adquirido gran relevancia en la comunidad. Sin embargo, la minería, la palma de aceite y la ganadería han generado impactos significativos en gran parte de la extensión territorial del municipio, lo que ha atentado contra la sostenibilidad de las prácticas, los saberes y modos de vida de las poblaciones campesinas. Vale mencionar que las problemáticas medioambientales se desarrollaran con mayor detalle en los apartados siguientes:

El sector minero-energético se posicionó desde hace más de treinta años en el municipio. Cuando la minería llegó, muchos campesinos empezaron a vender sus tierras para la expansión de la minería. Los que no quisieron vender fueron desplazados, despojados de sus territorios, afectando a muchos campesinos y las prácticas agrícolas (E. Castilla, comunicación personal, diciembre del 2016).

Ahora bien, en cuanto a los saberes locales y modos de vida de la población campesina en el municipio vale resaltar el papel que juega el corregimiento de la Victoria de San Isidro como despensa agrícola y en la sostenibilidad de las memorias y tradiciones campesinas. El corregimiento se encuentra a escasos veinte minutos de la cabecera municipal. Se caracteriza por ser un camino directo a la Serranía del Perijá. Posee aproximadamente nueve veredas, distribuidas sobre la Serranía en sus diferentes pisos térmicos.

Los campesinos de dicho corregimiento han cultivado históricamente café, aguacate, maíz, fríjol, yuca, sorgo y arroz (es vital mencionar que la Jagua de Ibirico fue el primer productor de arroz del Cesar); actualmente, es el café el producto con mayor comercialización en el corregimiento. Muchos campesinos manifiestan que son portadores de una cultura cafetera en la región:

El principal cultivo aquí es el café. Cuando llegó la violencia, el café que aquí se sembraba era el Caturra y, por el desplazamiento a los cultivos, los afectó una enfermedad que se llama "roya": esta enfermedad lo que hace es que deja la mata sin follaje y no hay producción. Tras la violencia, llegó la roya y se tuvo que resembrar el café; entonces, llegó la Federación 
Vida campesina en el Magdalena Grande

de Cafeteros con préstamos y resembró los cafetales con una variedad nueva: Castilla. Cafetales de cincuenta, sesenta años se cambiaron, se perdieron, se dañaron debido a la violencia. También éramos zonas productoras de aguacate, pero por una enfermedad llamada la "efitoctora" acabó con el aguacate criollo; las cosechas no son las mismas, ahora se trabajó con semillas injertas de aguacate (J. Hernández, comunicación personal, febrero del 2017).

La fuente más pudiente en el agro aquí es la caficultura: somos caficultores. Lastimosamente, los cambios climáticos han afectado las cosechas de café. Estas tierras se poblaron por el café y el pancoger. Desde el Quindío se trajo la semilla de café arábica y por la calidad de la tierra se dio el café. Muchas de las montañas se poblaron para los cultivos de café, muchas familias en las veredas se ayudan con el café (J. Quintero, comunicación personal, febrero del 2017).

Por su parte, la actividad ganadera se posicionó como una práctica económica dentro de las dinámicas cotidianas de los campesinos, dado que algunos parceleros - además de sus cultivos- poseen algunas cabezas de ganado que utilizan para obtener su leche y venderla a las lecheras de la cabecera municipal.

La Victoria de San Isidro es un corregimiento que posee una fuerte conexión con los modos de vida agrícola. Sus pobladores suelen utilizar los patios y terrazas de sus casas como huertas mixtas, donde la cría de animales como cerdos, gallinas, chivos, y los cultivos de plátano, yuca y ahuyama son prácticas que dan sentido a las dinámicas del hogar de las diferentes familias. Igualmente, posee varias calles sin pavimentar que se conectan entre sí, formando callejones donde se levantan las distintas casas que conforman el pueblo. Es importante resaltar que cada una de las casas se encuentra pintada con colores cálidos y vivos que dotan de una hermosa vista al pueblo. El corregimiento cuenta con un puesto de salud, un megacolegio agropecuario y un centro para la atención del adulto mayor; igualmente, posee servicio de luz, gas y agua, aunque el acueducto presenta problemas con la potabilidad del líquido.

Aunque la presencia de las minas de carbón en dicho corregimiento es muy próxima, las dinámicas campesinas se desarrollan con 
Vida campesina en el Magdalena Grande

mucha relevancia y poseen un fuerte vínculo colectivo con los miembros de la comunidad. Cotidianamente las labores domésticas inician para muchas personas con el trabajo en las parcelas; el cuidado de sus cultivos y animales de crías es una tarea fundamental para retomar labores agrícolas:

Nosotros venimos de familia de campesinos y vemos la agricultura desde siempre, desde niños. El pueblo es un pueblo campesino. En la Victoria hay veredas donde los campesinos cultivan y bajan sus productos y los comercializan en la Jagua: cultivan tomate, lulo, tomate de árbol y, más que todo, café; las parcelas son más que todo cafeteras. Hay muchas veredas donde también se cultiva yuca, maíz, plátano, tomate, también la gente tiene pollo de engorde, gallinas ponedoras y peces. Para el cultivo de café, septiembre, octubre, noviembre, diciembre y hasta enero, y de los demás productos se cultivan todo el año (Z. Sierra, comunicación personal, enero del 2017).

Soy agricultor desde niño. Nos enseñaron la agricultura artesanal, esa que no utiliza tecnología, antes no teníamos tecnología. A pesar [de] que se nos vende propaganda, que se está modernizando el campo, no es así; los programas sociales no han tenido impacto. Mira, desde niño veía a mi papá trabajar en los cultivos de pancoger, maíz, fríjol, hortalizas y caficultura (J. Quintero, comunicación personal, febrero del 2017).

Yo aprendí la agricultura de mi papá: él era agricultor, sembraba yuca, plátano, ajonjolí, duchama, todo lo que era del campo. Nosotros vimos eso, la cultura del campo, siempre lo acompañaba, las costumbres de sembrar... ahora hay mucho café para la parte de arriba. Para mí ser campesina es ser luchadora, que uno sabe del cultivo: uno ve las matas de las yucas, los plátanos, uno se enamora del campo. Antes se sembraba manual y tradicional, no había tecnología. El trabajo era a pulmón, a mano, por eso nosotras sabemos cultivar, preparar el maíz, desgranarlos, molerlo. El campo me gusta porque uno creció sobre eso, uno coge una mata de yuca, una mata de plátano y, como uno le tenía amor a eso, yo en mi casa tengo mis cultivos porque uno creció sobre esos racimos ( $\mathrm{J}$. Quintero, comunicación personal, febrero del 2017). 
Vida campesina en el Magdalena Grande

Es clave mencionar que la presencia de las minas se ha posicionado como una fuente de empleo para muchos jóvenes que se han distanciado de las labores agrícolas: "las minas han generado que muchas personas se alejen del campo, se olviden de dónde vienen" (E. Castilla, comunicación personal, diciembre del 2016). Sin embargo, muchas familias campesinas conservan, reproducen y transmiten sus conocimientos locales cotidianamente. La relación que poseen sus tradiciones con el territorio se representa en la medida en que para sembrar muchos tienen en cuenta diversos elementos y ciclos de la naturaleza como las nubes, vientos, lluvias y animales (libélulas y hormigas), los cuales son interpretados y dan cuenta de los mejores momentos para cultivar:

Nosotros los campesinos hemos aprendido a conocer al monte, a la naturaleza; anteriormente, los mayores decían que cuando veían muchas nubes y vientos fuertes se avecinaban los primeros aguaceros y entonces empezaban a preparar la tierra para sembrar. Igual pasaba con las hormigas y los caballitos voladores (libélulas): cuando los viejos veían que había mucha hormiga en la tierra era porque la tierra estaba buena para trabajarla y los caballitos, según mi abuelo, llamaban "lluvia" (E. Castilla, comunicación personal, diciembre del 2016).

Nosotros aprendimos a cultivar teniendo en cuenta los tiempos, la luna, los vientos: así cultivaban nuestros padres, sin la ayuda de la tecnología. Ahora los tiempos han cambiado y uno no sabe cuándo va a llover, cuándo son los mejores tiempos para cultivar (Y. Hernández, comunicación personal, diciembre del 2016).

Mira, los campesinos saben que las fechas más idóneas para cultivar es abril y mayo, porque viene el invierno y viene el veranillo de San Juan, que afecta las plantas en acomodarse al piso, en asentarse en los terrenos, $\mathrm{y}$ viene el invierno de fin de año que ayuda para que la planta ya se radique en el suelo y aguante el verano [en el] que estamos. Por lo general, los tiempos, cuando son normales, predecimos el invierno. Entre fines de marzo ya estarían empezando los inviernos, entonces son épocas que... en febrero la gente comienza a preparar la tierra para sembrar los cultivos de pancoger, para sembrar a fines de marzo-principios de abril la yuca y 
[el] maíz. También [se] tiene en cuenta la luna; sobre todo, muchas veces contradecimos a los ancestros, pero la luna es elemental: si van a cortar madera para el arreglo de sus casas cortan la madera en luna menguante y cortan la madera en menguante y se corta después de mediodía para que sea duradera (J. Quintero, comunicación personal, febrero del 2017).

Al igual que los modos de cultivar, la alimentación es un aspecto clave en sus dinámicas campesinas. Las comidas más típicas son el sancocho de gallina y la yuca con queso, platos de consumo constante en los diferentes hogares victorianos: sus proteínas y sustancia ayudan a los campesinos a recuperar fuerzas después de sus jornadas de trabajo. Igualmente, los dulces naturales son una de las recetas con un gran significado colectivo para los miembros de la comunidad debido a que los relacionan estrechamente con las memorias colectivas de los habitantes y con el desarrollo de la Semana Santa, momento del año en el que muchos campesinos católicos ritualizan las tradiciones aprendidas de sus mayores; entre estas, la preparación e intercambio de dulces entre los vecinos.

Imagen 79. Yuca

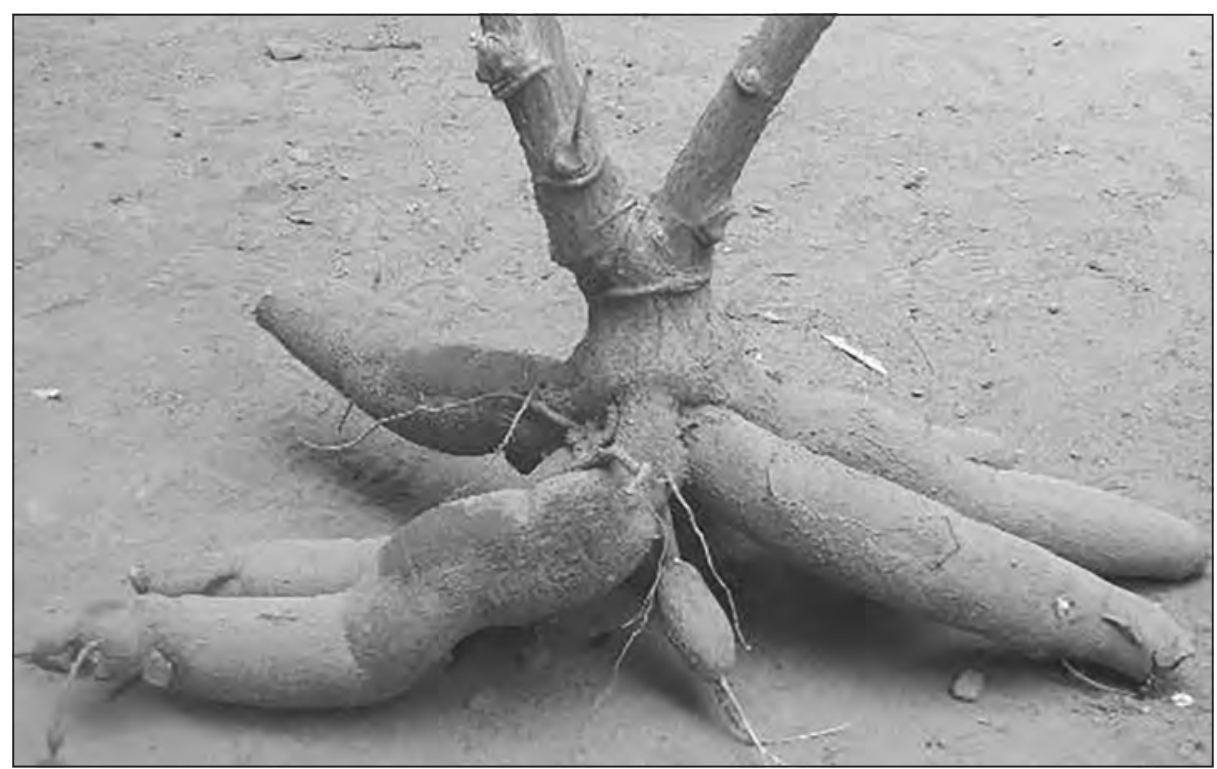

Fuente: Archivo Oraloteca (2017). 
Vida campesina en el Magdalena Grande

El advenimiento de las nuevas religiones cristianas, los desplazamientos y los impactos ambientales han truncado la sostenibilidad de dichos conocimientos. Si bien es cierto que el sancocho de gallina es un plato típico que dinamiza las tradiciones y los lazos colectivos entre los miembros de la comunidad, los procesos de urbanización cada día se posicionan en el corregimiento, generando cambios en las dinámicas de la comunidad:

En la Victoria de San Isidro existen comunidades campesinas, afrodescendientes y afrocampesinas. El corregimiento es un pueblo campesino donde hay varias culturas, tanto en el casco urbano como en las zonas veredales hay personas afrocampesinas. La violencia género que se perdieran muchas de nuestras tradiciones y costumbres afrodescendientes y campesinas. Antes comíamos mejor: carne de monte, buena yuca; hoy día no es igual, comíamos la yuca, el plátano día a día. Hemos vivido una temporada muy fuerte que fue la violencia que género que muchas de nuestras costumbres se perdieran (E. Mendoza, comunicación personal, febrero del 2017).

Lo que siempre cocinábamos eran los dulces de maíz, dulces de coco, de leche; esas comidas son deliciosas. Mi mamá las hacía y siempre mandaba dulce para los vecinos, la familia; esas culturas se están perdiendo. Yo sí sé preparar esas comidas, yo aprendí de mi mamá: ella para la Semana Santa siempre hacía sus dulces. Antes nada más era coger el maíz y hacer el dulce. El de papaya uno preparaba el maíz y después se cocinaba el dulce. También aquí se come la carne, el pescao, el sancocho de gallina, la viuda de pescado. Uno el pescado lo prepara, lo alinea y lo adoba y, si es frito, es frito o, si es guiso, es guisado; se acompaña con yuca. También los tamales con arroz, con carne de cerdo, pollo y vaca, yo los hago, son unos tamales deliciosos, la gente los come mucho. Pero pa' la Semana Santa se hacían más los dulces, esos dulces de papaya, de coco con papaya, de maíz y de leche. Se han perdido las costumbres, esas fiestas donde todos los vecinos se intercambiaban dulces se ha acabado (J. Quintero, comunicación personal, febrero del 2017). 
Igualmente, las narrativas orales, leyendas e historias son elementos culturales que se reproducen dentro de las dinámicas sociales de la comunidad. Muchas leyendas responden a los diferentes procesos migratorios que se desarrollaron durante la fundación del corregimiento: la Llorona, la Patasola, la Madre Monte y las creencias en las brujas son las narrativas más reconocidas dentro del imaginario colectivo de los miembros de la comunidad; sin embargo, en las zonas veredales estas expresiones culturales se reproducen y se transmiten con mayor intensidad. Debido a su leve acercamiento a las dinámicas urbanas, las leyendas juegan un papel clave en la regulación de la moral de las comunidades y en la relación con el territorio. Actualmente, en la cabecera del corregimiento muchos jóvenes han olvidado este tipo de narrativas, mientras que los ancianos y adultos aún las recuerdan.

Imagen 80. Mujer campesina

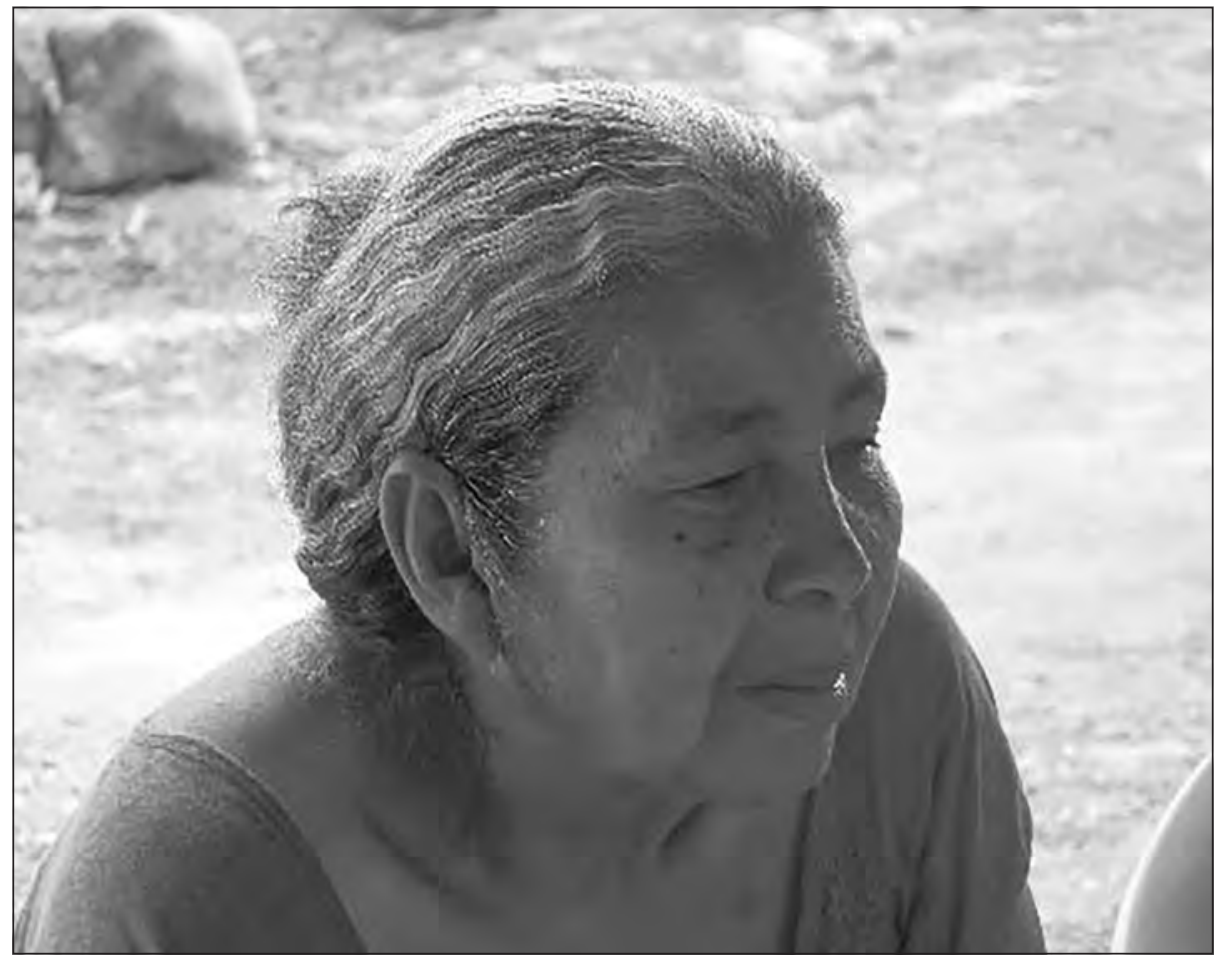

Fuente: Archivo Oraloteca (2017). 
Vida campesina en el Magdalena Grande

Yo crecí escuchando leyendas muy conocidas como la Llorona, nos las contaban nuestros abuelos, nos llamaban y se ponían a contar muchas historias que se daban en el campo. La Madre Monte, una señora que cuida el campo, la Patasola y las brujas; siempre crecimos escuchando esos cuentos que le salían a la gente por no hacer caso, por cosas que hacían mal. Nosotros tenemos muchas leyendas que se dan en el monte, que las conocimos de nuestro antepasado. En nuestra cultura creemos en las brujas, hacemos rituales, adoraciones, tenemos nuestra propia identidad religiosa y creencias (E. Mendoza, comunicación personal, febrero del 2017).

Mi papá me contaba que en el monte salían aparatos, que había lugares donde había espíritus, que la una luz, la Madre Monte, la Mano Pelua’: esos cuentos nos enseñaron a nosotros desde pequeños, eso ya no se ve ni se habla, los pelaos ya no creen en eso. Antes nos tocaba dormir temprano; ahora no, eso se ha perdido ya (Y. Hernández, comunicación personal, diciembre del 2017).

Con respecto a los conocimientos asociados a las propiedades curativas de las plantas, cabe resaltar la labor que realiza la Asociación de Mujeres Campesinas (ASOMAVIC) por la recuperación y sostenibilidad de los saberes locales de los campesinos en el corregimiento, dado que dichas mujeres poseen un vivero en la zona rural donde cultivan especies aromáticas, medicinales y ornamentales que favorecen al cuidado de la salud de la población. Igualmente, cultivan yuca, plátano, ají, entre otros. Se cultivan principalmente este tipo de plantas porque son de la región y son las más usuales al momento de atender algún tipo de enfermedad desde el hogar.

Ahora bien, la medicina tradicional está presente en la labor campesina en el corregimiento, dado que muchos campesinos utilizan y preparan remedios caseros para combatir la mordedura de las serpientes, las conocidas "contras", las cuales son de uso frecuente en las casas de los victorianos dado que también ayudan a aliviar los dolores de cabeza y las fiebres.

El reconocimiento de las plantas con propiedades curativas que poseen algunos campesinos les ha permitido consolidar todo un cuerpo de 
Vida campesina en el Magdalena Grande

saberes relacionados con prácticas de salud propias que han ayudado a las comunidades a sanar algún tipo de enfermedad mientras se recurren a los tratamientos médicos modernos.

Imagen 81. ASOMAVIC en la Victoria de San Isidro

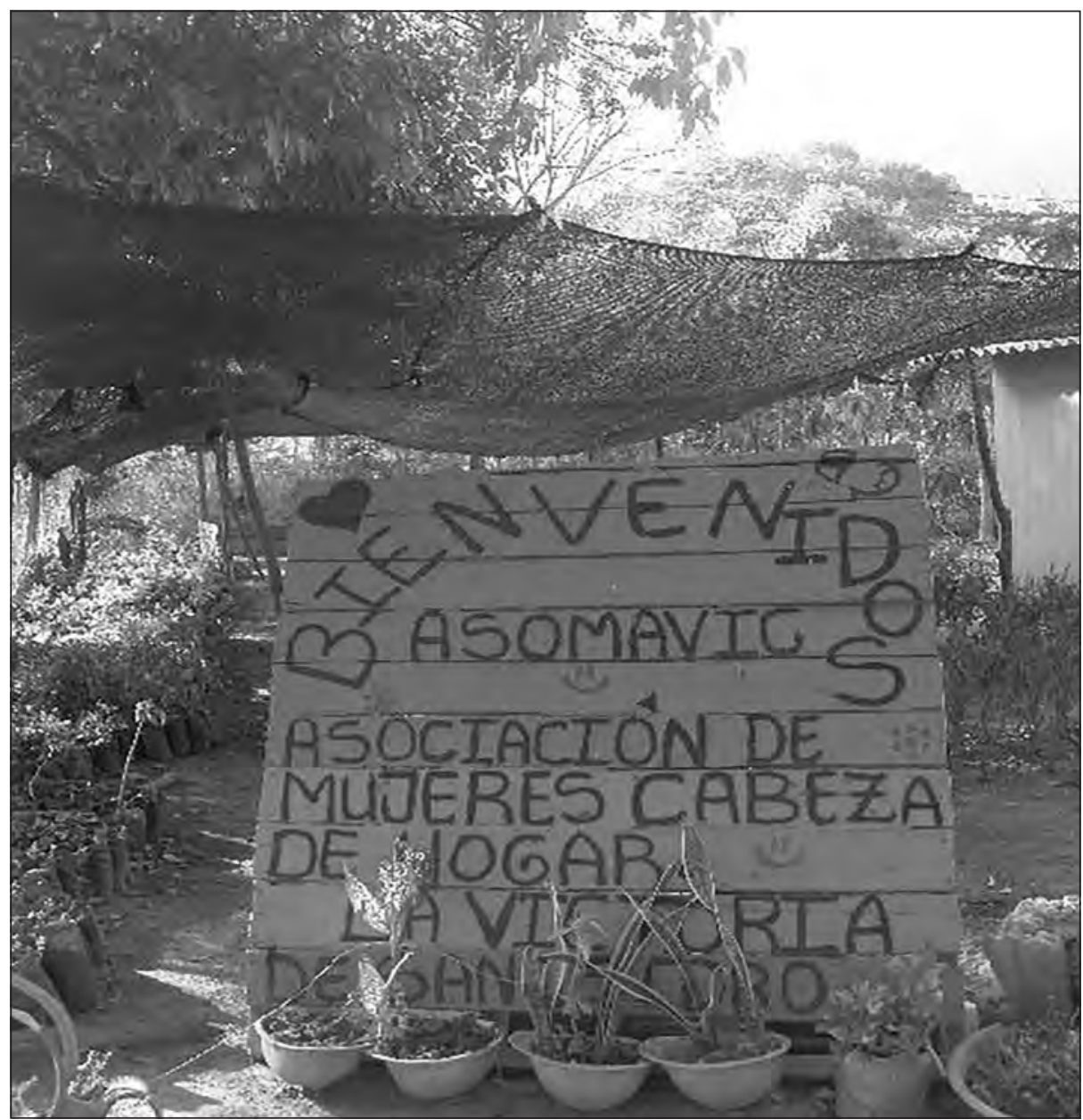

Fuente: Archivo Oraloteca (2017).

Aquí en la comunidad el uso de plantas medicinales sí se da. Se utilizan, por ejemplo, para infusiones, tomitas de la plantica que se llama ruda, la limonaria, yerbabuena, y para los dolores de cabeza y cuestiones así. Hay 
Vida campesina en el Magdalena Grande

otras para los dolores de estómago. Por aquí también se utiliza la contra para picadura de culebra: hay rezanderos que pueden ayudar a alguien que mordió una culebra si no es muy grave. Por aquí sí se ven las tradiciones de nuestros ancestros.

Nosotras con la Asociación nos hemos empoderado con nuestra unidad. Tenemos cultivos de aromáticas y plantas medicinales como el orégano, moringa, que no hemos concentrado en la recuperación de nuestras culturas y costumbres. Cuando teníamos dolores de cabezas, fiebres y [dolor de] barriga nos trataban con plantas, con aromáticas que buscaban en el monte, en los jardines, no con tanta pastilla como hoy, por eso cultivamos para que la gente que quiera (Y. Hernández, comunicación personal, diciembre del 2016).

Imagen 82. Cultivo de aromática

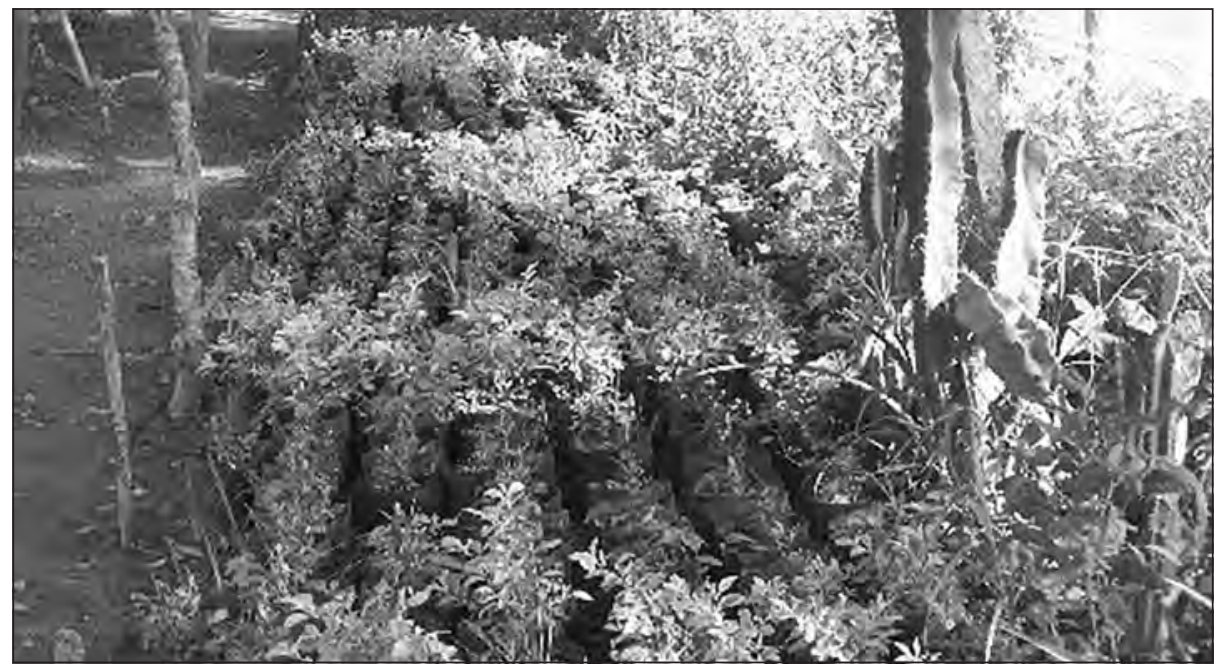

Fuente: Archivo Oraloteca (2017).

Igualmente, las fiestas tradicionales se siguen realizando en territorio victoriense. Las fiestas de San Isidro Labrador son las celebraciones patronales en la comunidad. Cada año, para los meses de mayo, los victorianos se visten de fiesta para conmemorar a su santo patrono, reconocido por ser el santo de los campesinos. En dichas fiestas la comunidad en general 
se reúne en la plaza central del corregimiento para disfrutar de muestras culturales como bailes típicos, presentaciones de versiadores y canciones inéditas. Tanto los campesinos de las diferentes parcelas como los que viven en la cabecera del municipio participan de estas celebraciones de manera espontánea, abierta y colectiva; igualmente, se realizan misas al santo en la iglesia central, procesiones y velaciones con el objetivo de purificarse y ser recompensados en sus labores agrícolas.

Las comidas típicas, los dulces, sancochos y los fríjoles con cerdos son platos que se degustan y se ofrecen en diferentes puntos del pueblo, representando la sazón de las comidas campesinas. Por su parte, muchos campesinos traen sus mejores productos y los ofrecen o intercambian con las personas de la comunidad. Se realizan pequeños mercados campesinos donde se comercializan todo tipo de frutas, hortalizas y verduras. Durante los días de fiesta, en el corregimiento se renuevan los lazos colectivos entre los miembros de la comunidad, se reafirman sus costumbres e identidad y se reproducen sus conocimientos constantemente:

Las fiestas patronales son fiestas donde todos compartimos en comunidad. Muchas familias (si no todas las de las veredas) bajan para disfrutar de las celebraciones. Los campesinos traen sus cultivos, los venden. Muchas veces traen yucas gigantes, ahuyamas, pepinos que uno por aquí no ve. Es un momento donde todos compartimos, disfrutamos, le rezamos a nuestro patrono para que nos ayude con las cosechas y nos vaya bien (J. Quintero, comunicación personal, febrero del 2017).

Si bien es cierto que la minería se posiciona cada vez con mayor fuerza en el municipio de la Jagua de Ibirico, los modos de vida campesinos resisten y se ajustan al contexto sociopolítico actual. El corregimiento de la Victoria de San Isidro es un pueblo que representa y sostiene la identidad campesina en el municipio: tanto el café como el aguacate son elementos que dinamizan las cotidianidades y economías de sus pobladores quienes, a través del trabajo directo con el campo y las montañas, han consolidado conocimientos y tradiciones que ratifican su historia y herencia campesina. Actualmente, muchos campesinos victorianos se han organizado para resistir y generar alternativas a los problemas medioambientales que la minería ha generado en su territorio y modos de vida: 
Vida campesina en el Magdalena Grande

Ser victoriano... [la Victoria de San Isidro] es el mejor pueblo del mundo y uno aspira [a] morir en su pueblo. Por el tema del posconflicto, el Estado nos han visitado mucho. Nosotros esperamos que se acuerden de los corregimientos. La Victoria es el principal pueblo del municipio y eso es un orgullo. El campesino que entró en la Victoria es un campesino serio, arraigados a sus costumbres, [a] su alimentación. El señor Luis Arena tiene 86 años y todavía viene de su finca a pie al pueblo que está como a 3 horas; todos los fines de semana viene y comercializa sus productos: esas son personas de admirar que transmiten sus costumbres a sus hijos y siguen en el pueblo (J. Hernández, comunicación personal, febrero del 2017).

Imagen 83. Líder campesina de la Victoria de San Isidro

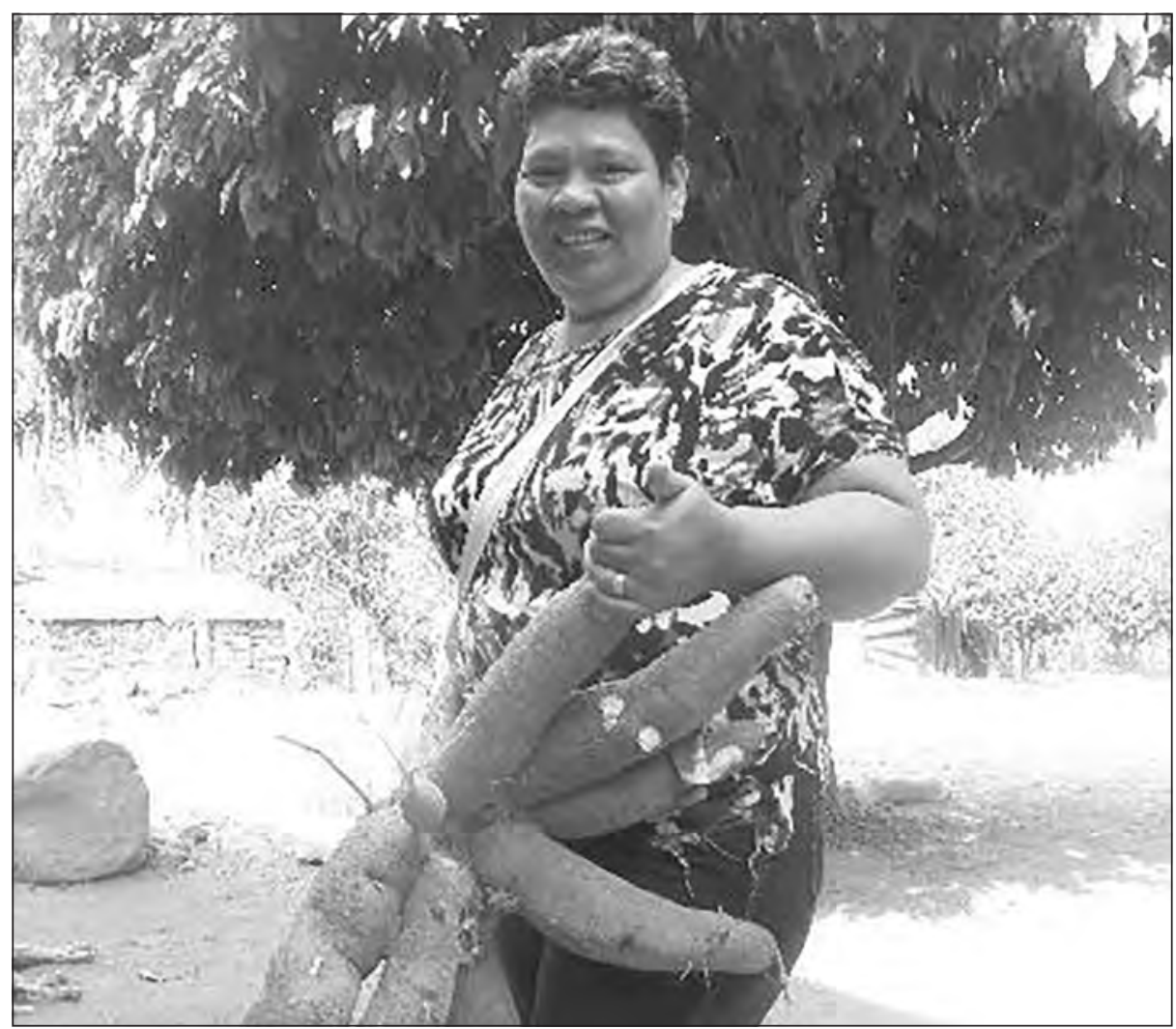

Fuente: Archivo Oraloteca (2017). 
Vida campesina en el Magdalena Grande

\section{Conflictos sociales y ambientales en el piedemonte de la Serranía del Perijá}

En este apartado se presentan elementos etnográficos relacionados con los diferentes conflictos sociales y ambientales desarrollados en los municipios de Codazzi, Becerril, la Jagua de Ibirico y Aguachica, que dan cuenta de las diferentes percepciones, denuncias, luchas y resistencias que los campesinos en dicha región han liderado para superar las afectaciones que tanto las bonanzas económicas como el conflicto armado interno han generado en sus estructuras sociales, en sus relaciones con el medio ambiente y en sus formas de vivir el territorio. En dicho sentido, las bonanzas algodoneras y palmeras, la minera extractivista y el conflicto armado interno son los elementos de análisis que permitieron el desarrollo de los siguientes enunciados.

\section{Del algodón a la minería de gran escala}

El departamento del Cesar ha vivido diferentes contextos socioeconómicos que han dado giros trascendentales a su historia, como es el caso de la bonanza algodonera y la bonanza minera. Específicamente los municipios de Codazzi, Becerril, la Jagua de Ibirico y Aguachica son referentes de estos procesos históricos. Actualmente, los tres municipios mencionados primeramente se caracterizan por ser una región con vocación económica minero-energética; tanto que estos tres entes territoriales se han denominado nacionalmente como "distrito minero del departamento". Por su lado, Aguachica es un municipio comercial que comparte una fuerte historia algodonera.

De acuerdo a su rentabilidad y producción, la producción de carbón en el Cesar es de las más significativas del país. Desde los años ochenta, con las primeras exploraciones de carbón en el municipio de la Jagua de Ibirico, se inició un megaproyecto que lleva más de 30 años de rentabilidad en la región. Con la llegada de la minería las prácticas agrícolas se fueron desplazando por el boom minero, hasta el punto de encontrarse en una crisis profunda.

Resultado de ello fue la caída de la producción del algodón en Codazzi y Aguachica a finales de los años ochenta. Si bien es cierto que para mediados de los años noventa la agricultura nacional se encontraba en alerta 
Vida campesina en el Magdalena Grande

por las constantes reformas agrarias, la apertura económica, el poco apoyo al sector agrario y el posicionamiento de la minería se potencializaron y agudizaron los problemas en el agro, lo que permitió que la extracción del mineral se estableciera en el primer eslabón de la producción económica en dichos municipios y en la región:

Aquí la minería empezó con el barbacheo en el municipio de la Jagua, labor que hacían los campesinos a puro pala y pico. En las partes altas se encontraban lugares con carbón; eso atrajo al inversionista y la minería empezó a desarrollarse aquí. Luego, llegaron las grandes empresas. Muchos campesinos vendieron tierra; otros, fueron desplazados. Con la mina muchas cosas cambiaron: ahora los jóvenes quieren ir a la mina y rechazan el trabajo en el campo. En la Jagua se celebra el festival minero-agrícola, apoyado por las compañías (E. Castilla, comunicación personal, diciembre del 2016).

Ahora en Becerril hay mucha gente que trabaja en la mina. Muchos pelaos estudian para entrar en las minas. Algunos trabajan como paleros, maquinistas, se joden bastante, pero ayudan en sus casas. Muchos no quieren el campo por estar pendiente[s] de conseguir un trabajo en las mineras de la Jagua (J. Vuelvas, comunicación personal, diciembre del 2016).

Para los casos de los municipios de Codazzi y Aguachica la caída del algodón significó un fuerte impacto a las prácticas campesinas dado que muchos de los habitantes de los corregimientos y pueblos vecinos se beneficiaban económicamente de las algodoneras del Cesar. Sin embargo, la crisis económica no solo impactó las prácticas laborales y agrícolas en la región; la utilización de fertilizantes y productos químicos para acelerar la producción del algodón afectó y deterioró de manera radical la riqueza mineral de los territorios, por lo que muchos campesinos dejaron de cultivar en lugares donde solían trabajar la tierra.

La caída del algodón no solo afectó la economía local y regional, dado que los modos de vida de las poblaciones campesinas sufrieron fuertes afectaciones. La baja productividad en las prácticas agrícolas, el desplazamiento de sus zonas de cultivos y la búsqueda de nuevas oportunidades 
Vida campesina en el Magdalena Grande

laborales fueron elementos que laceraron el tejido social y comunitario de las poblaciones localmente:

Las tierras quedaron cansadas porque el cultivo de algodón bajó volumen. "Venenos", que les decían en esos tiempos, para tumbarle la plaga, pues vuelven estéril la tierra y por mucho que una tierra se abone no va a ser lo mismo porque las tierras quedaron cansadas, más de 20 años recibiendo muchos venenos y no daba; sembraban una hectárea de yuca, ya no daba. La producción [de] yuca se quedaba muy pequeña, el plátano lo sembraban y no producía, se incrementó mucho el verano también. Los químicos generaron mucha destrucción en la capa orgánica de la tierra para sembrar el pancoger (D. Quintero, comunicación personal, enero del 2017).

Para esos tiempos se traían unas clases de algodón muy buenas, de mucha producción, ahora últimamente comenzaron a traer semillas de otros países y eso se fue derrumbando: trajeron semillas buenas para la empresa, pero para uno que le decían que si cogía 200, 300, 150 kilos con la anterior semilla, con la nueva uno eso que recogía no era sino más que 100 o 150 kilos, cogía uno menos. Uno con 7 lonas de algodón cogía hasta 300 kilos, ahora eran menos y después llegó al término que no cogía sino 40 kilos o 50 kilos. Yo fui uno de los que cogía en una producción 150, 180 kilos; con las nuevas semillas ya no cogía sino 70 u 80 porque la clase de algodón no servía... o bueno, servía para usted si era empresario. El algodón solamente lo sacábamos a las empacadoras o a empresas [de] la Diagonal que en Aguachica se llamaba SENAALGODON. Diagonal era la empresa comercializadora con las diferentes textiles del país, Diagonal era el que se encargaba de vender esas pacas que se producían acá en esta zona, desde aquí hasta donde comienza la ruta del sol. Eso era una cola grande de camiones y tractores de hasta dos y tres vagones, todo[s] eso[s] llenos de algodón para procesar, y hoy en día eso se acabó y ahora un montón de gente que tenía ya no tiene (D. Quintero, comunicación personal, enero del 2017).

La nostalgia por las algodoneras estuvo acompañada de un fuerte detrimento de las prácticas agrícolas. Regresar al campo significó un acto de resistencia de muchos campesinos que se negaron a ir a las ciudades 
y decidieron sembrar nuevamente. Sin embargo, después de 30 años de producción algodonera los suelos no se encontraban en condiciones óptimas para cultivar, por lo que muchos campesinos se vieron obligados a dejar sus antiguas tierras y cultivar en la Serranía, proceso que permitió la recuperación paulatina de la agricultura. Es vital mencionar que muchos campesinos que trabajaron en las algodoneras lograron adquirir predios y parcelas que ayudaron a la estabilización de las familias, tanto económica como alimentariamente, mientras que otros se dedicaron al trabajo del jornal en las diferentes parcelas y fincas ganaderas de la región.

Imagen 84. Antigua algodonera en Aguachica, Cesar

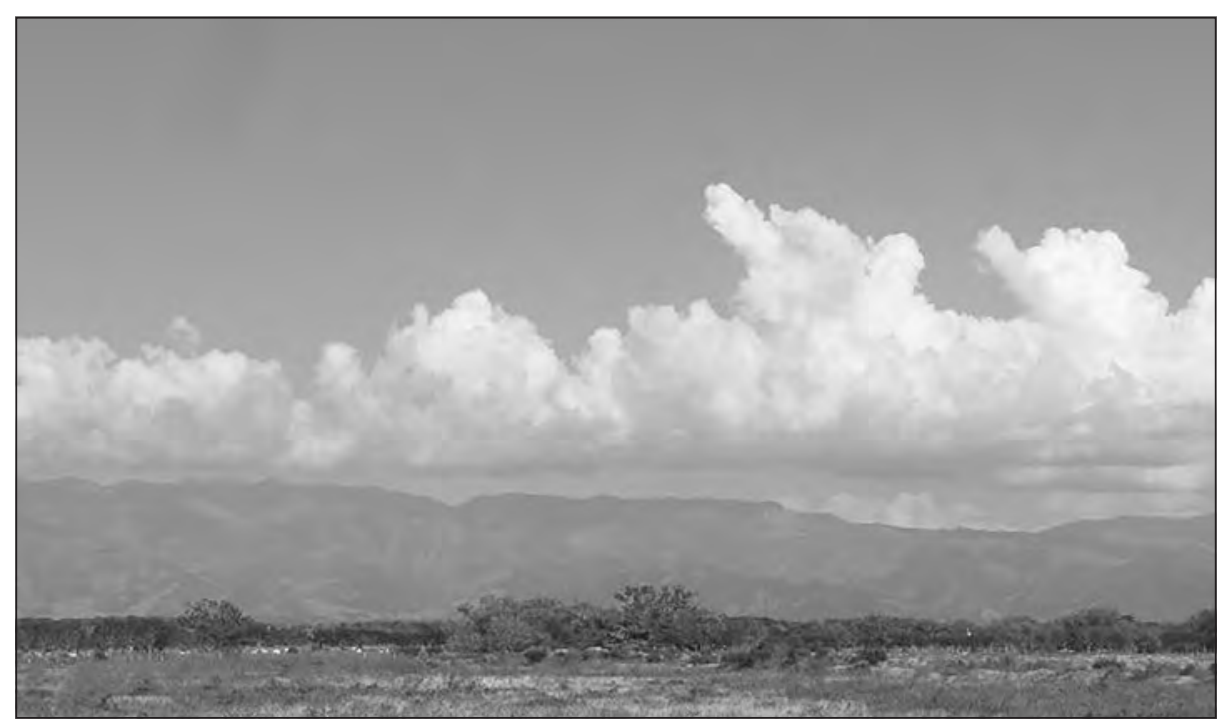

Fuente: Archivo Oraloteca (2017).

Lo que fue la finca el Piñón al dueño le tocó venderla y todo fue así. Ya la gente de antes sembró el algodón. Aquí era bien arada la tierra, bien utilizada, la trataban para que a la tierra no le fuera a nacer mucha maleza. Últimamente usted tenía un lote de tantas hectáreas y le salía mucho monte, usted venía y le zampaba la siembra y, después de la siembra, le pasaba con los aparatos a fumigar ese monte; entonces, así se acabó el cultivo del algodón. La apertura económica ayudó a la caída del algodón. Íbamos a competir con los países desarrollados, con países donde 
Vida campesina en el Magdalena Grande

la agricultura es subsidiada. Aquí en Colombia la agricultura no es subsidiada y, por eso, al abrir esa apertura económica [se] acabó con [el] agricultor en el país, [este] se vio afectado porque los costos de la producción eran muy altos: a lo que ya se podía vender la fibra del algodón no compensaba con los costos que se daban, había mucha incidencia de plagas y el cultivo de algodón era un cultivo que generaba, en esos tiempos, muchas plagas como el "alabama", como el "trichoplusia", entonces había que estarlo fumigando y eso incrementó el costo por hectárea del cultivo de algodón. Entonces, muchas veces, no daba lo que me pagaba el Estado y, con eso, el agricultor se endeudó mucho en los bancos. Así fueron perdiendo las tierras, rematando las tierras, los bancos y otros terratenientes que llegaron en la forma ganadera, que ahora [es] la forma de explotación de la tierra... bueno, los ganaderos llegaron y se fueron quedando; eso, y la palma de aceite que es el otro cultivo que hay (D. Quintero, comunicación personal, enero del 2017).

La caída del algodón y la baja productividad de la agricultura facilitaron, de una u otra manera, que las economías como la palma de aceite y la ganadería intensiva y extensiva se posicionarán como elementos dinamizadores de las economías locales, agudizando la crisis que atraviesa las prácticas agrícolas en la región. La sobrefertilización de los suelos solo permitió que creciera pasto, lo que conllevó a que la ganadería se fundamentara como una fuente principal de subsistencia: muchos campesinos adquirieron ganado a través de préstamos con los bancos; otros, se dedicaron a criar "ganado ajeno" para fortalecer sus economías.

La llegada de la palma de aceite y la potencialización de la ganadería dieron un giro a la vocación productiva de los territorios en dicha región; con ello, nuevas formas de trabajo y afectaciones ambientales que atentan contra los modos de vida de las poblaciones campesinas:

Mire, después del algodón ya esto se compone solamente de fincas ganaderas: de aquí para allá son fincas ganaderas. Qué día que fui yo por allá a un culto con los hermanos evangélicos a la loma, tenía tiempo que no iba a la loma del corredor, ahí compré pescado... bueno, todo eso son fincas ganaderas. La gente no cultiva; ahora tiene[n] ganado y otros tiene[n] pura palma (D. Quintero, comunicación personal, enero del 2017). 
Vida campesina en el Magdalena Grande

Si bien es cierto que las palmeras son fuentes de empleo y profesan el progreso en la región, su discurso no es proporcional a las realidades de muchas poblaciones campesinas. Para el caso del corregimiento de Llerasca, las palmeras han desviado el río y han creado arroyos para suministrar agua a las grandes extensiones de sus cultivos; de esta manera, se han apoderado arbitrariamente de los bienes comunes de la población, como es el caso del río Casacara. El acceso al líquido vital se ha convertido en una de las principales problemáticas en la comunidad:

Cuando se fue el algodón llegaron las empresas palmeras comprando tierras. Muchos campesinos vendieron; otros, fueron desplazados. Desde hace como 20 años se cultiva palma de aceite y hay muchos lugares donde no se puede cultivar. Estas empresas tienen reservorios de agua solo para ellos y para el pueblo no hay la misma cantidad de agua. También la ampliación de las fincas ha deforestado bosques y eso afecta a los ríos [...]. Esa sequía que ve usted en el pueblo la hizo las palmeras Monte Carmelo. Ella viene de la parte alta y pasa por la mitad del pueblo y termina en los cultivos. Nosotros utilizamos esa agua, nos toca limpiarla y hay una campaña de las empresas que vienen y la limpian [...]. Nosotros los campesinos padecemos de agua, lo que da los cultivos es el agua y ahora es difícil conseguirla. Los tiempos han cambiado: uno ya no puede predecir cuándo son tiempos de agua. Las minas y las palmeras han deforestado muchos bosques y desvían ríos para su beneficio y los campesinos cada vez es más duro. (Y. Castro, comunicación personal, diciembre del 2016).

Si bien es cierto que la bonanza algodonera afectó la riqueza ambiental de los territorios del Centro del Cesar, las empresas palmeras no dan tregua: su posicionamiento como dinamizador de la economía local ha promovido constantes cambios en el territorio, tanto en sus límites y usos para las diferentes comunidades como en la privatización de zonas, las desviaciones de ríos y las masivas talas de árboles para la ampliación de los cultivos; todas estas son acciones que influyen en las dinámicas sociales y territoriales de los campesinos de manera negativa. La disminución de los caudales de los ríos, la deforestación de bosques nativos y el calentamiento acelerado del medio ambiente han propiciado que las prácticas 
Vida campesina en el Magdalena Grande

agrícolas desmejoren notablemente, generando que muchos agricultores busquen otras formas de emplearse fuera de las zonas rurales con tal de conseguir el sustento de sus familias:

La llegada de la palma no solo trajo trabajo porque también vino con ella la deforestación: muchos bosques nativos fueron talados para que se sembrara la palma, sobre todo los que estaban a la orilla de los ríos. Muchos trabajan en las palmeras, pero esas empresas han dañado el medio. Nosotros nos hemos quejado, pero no nos escuchan, nadie dice nada (J. Vuelvas, comunicación personal, diciembre del 2016).

Con la palma se intensificaron la deforestación: en nuestra región se han perdido muchos árboles, como el caracolí y el roble, árboles que cuando yo nací los vi en cantidad por todos lados a la orilla del río, por las calles, ahora son pocos los que encuentras. La ampliación de las palmeras también trajo al ejército, por eso a la entrada del pueblo tú encuentras a un grupo de soldados siempre ahí, ellos son los [que] cuidan los cultivos (Y. Castro, comunicación personal, diciembre del 2016).

En ese orden de ideas, tanto el algodón como la palma africana han sido elementos que han generado afectaciones medioambientales y socio comunitarias profundas en las diferentes comunidades campesinas $-\mathrm{y}$ en diferentes momentos históricos- de los municipios de Codazzi, Becerril y Aguachica, pero igualmente han promovido procesos de resistencia y denuncias de las comunidades por mantener su territorio. Sin embargo, actualmente las relaciones entre institucionalidad, empresarios y comunidad es débil y muchas de las denuncias e iniciativas de las comunidades por mitigar dichos impactos quedan en el papel, por lo que las crisis ambientales y el acceso al agua son problemáticas constantes que agudizan y atentan contra la sostenibilidad de las poblaciones campesinas.

Ahora bien, en cuanto al municipio de la Jagua de Ibirico es contundente afirmar que la minería a gran escala es la principal problemática ambiental, social y económica que afecta y deteriora tanto el medio ambiente como al campesinado local. Con la minería no solo llegó la economía y la modernización, puesto que con ellos se posicionaron otros fenómenos sociales que cambiarían la dinámica de la población como 
Vida campesina en el Magdalena Grande

son el conflicto armado interno, la prostitución y la intensificación de la delincuencia común.

La minería estalló como un hecho que modificaría la relación de las poblaciones con su territorio y sus tradiciones, específicamente de los pueblos campesinos, que se vieron obligados a desplazarse forzadamente del campo debido a la compra de sus territorios - con vocación histórica agrícola-, por parte de los empresarios mineros, para ser explotados por las compañías mineras extranjeras:

Muchos campesinos aquí en La Jagua fueron desplazados de sus tierras por las exploraciones de carbón. Muchos de las partes altas y medias fueron sacados de sus fincas por la[s] empresas. Antes de la minería la Jagua era cielo roto: eso llovía casi todos los días, los días eran mucho más frescos, pero con la minería se deforestó y se empezó a joder el pueblo, el clima cambió, los ríos se empezaron a secar y el campesino se le hizo más duro la agricultura. Esas explotaciones han afectado mucho al municipio y a la Serranía; nosotros nos hemos organizado, pero las empresas pueden más, las escuchan más (J. Vuelvas, comunicación personal, diciembre de 2016).

La actualidad ambiental en el municipio de La Jagua de Ibirico es drástica: las constantes exploraciones para la búsqueda de yacimientos de carbón, las cotidianas explosiones para la obtención del mineral y la ampliación de las zonas de explotación mineras son factores que han afectado el desarrollo de la actividad agropecuaria y han reducido la frontera agrícola cada vez más. Igualmente, la figura de las minas como una empresa rentable con sueldos generosos, en contraste con las ganancias obtenidas en la labor agrícola, ha estimulado que muchos jóvenes campesinos se distancien del campo. Por estos motivos, la minería ha afectado tanto el medio ambiente como los modos de vida de las poblaciones campesinas, acelerando procesos de cambio y desarraigo de las tradiciones locales.

En dicho sentido, es evidente mencionar que la minería extractivista ha sido el principal obstáculo para el desarrollo y fortalecimiento de las prácticas y tradiciones campesinas en el municipio, dado que ha trascendido los aspectos económicos y ha tenido mucha incidencia en los procesos sociales, políticos y comunitarios de las poblaciones. No obstante, 
las fuertes afectaciones ambientales generadas al aire, al agua y a la naturaleza son indicadores que complejizan las problemáticas en los sectores agropecuarios del corregimiento y el municipio.

La expansión cada vez mayor de los predios de las minas ha fomentado que las fronteras entre dichas empresas con los diferentes corregimientos y veredas en el municipio sean cada vez más estrechas y reducidas. En el caso de la Victoria de San Isidro, las empresas mineras se encuentran a escasos kilómetros de distancia. En diferentes puntos del corregimiento se pueden observar infraestructuras que se alzan sobre los cerros cada vez más deforestados del municipio, la presencia de polvillo de carbón es constante y muchos líderes se han manifestado; sin embargo, la problemática persiste.

Imagen 85. Mina de carbón en la Victoria de San Isidro

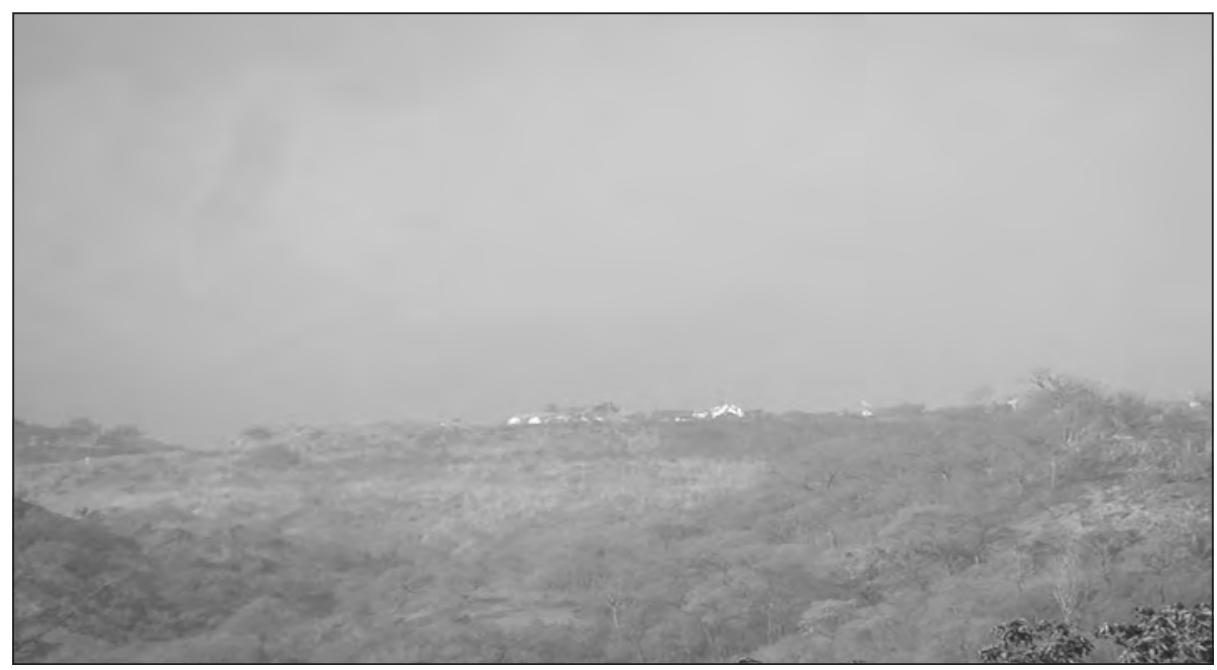

Fuente: Archivo Oraloteca (2017).

Los impactos que ha generado la mina se evidencian en la salud de las personas y los campesinos. Muchos habitantes denuncian públicamente que desde la aparición de la minería se ha formado una nube de smoke sobre la población; así mismo, el polvillo y los residuos de carbón sobre los ríos han fomentado la aparición de enfermedades en los diferentes habitantes: 
Vida campesina en el Magdalena Grande

La actividad minera ha fomentado la contaminación. Aquí están los botaderos de los materiales inertes de la explotación minera en el río. Se han desviado río[s], se han detectado enfermedades en los niños... al medio día, cuando se hacen explotaciones de carbón, se nota en el cielo una mancha amarilla y, si uno está en la parte de arriba -a $2.000 \mathrm{~m}$ sobre el nivel del mar- puedes ver una mancha de carbonilla que cubre la Victoria; si llueve, usted recoge de los techos de las casas aguas con carbonilla: las minas nos han afectado fuertemente, la explotación ha generado desplazamientos y enfermedades (E. Mendoza, comunicación personal, febrero del 2016).

Igualmente, la situación que se presenta sobre el estado ambiental del río Sororia, principal afluente del municipio, es dramática. Este río baja desde las partes altas de la Serranía y baña al municipio con sus aguas. Históricamente ha proporcionado el recurso hídrico a las diferentes poblaciones asentadas en toda la extensión territorial del municipio. Actualmente, su caudal se ha reducido en casi un $80 \%$ de su forma originaria. Dicho lugar dejó de ser un escenario tradicional de esparcimiento, diversión e integración familiar, para convertirse en un riachuelo contaminado y utilizado por las empresas mineras de acuerdo a sus intereses y objetivos.

Imagen 86. Río Sororia en La Jagua de Ibirico, Cesar

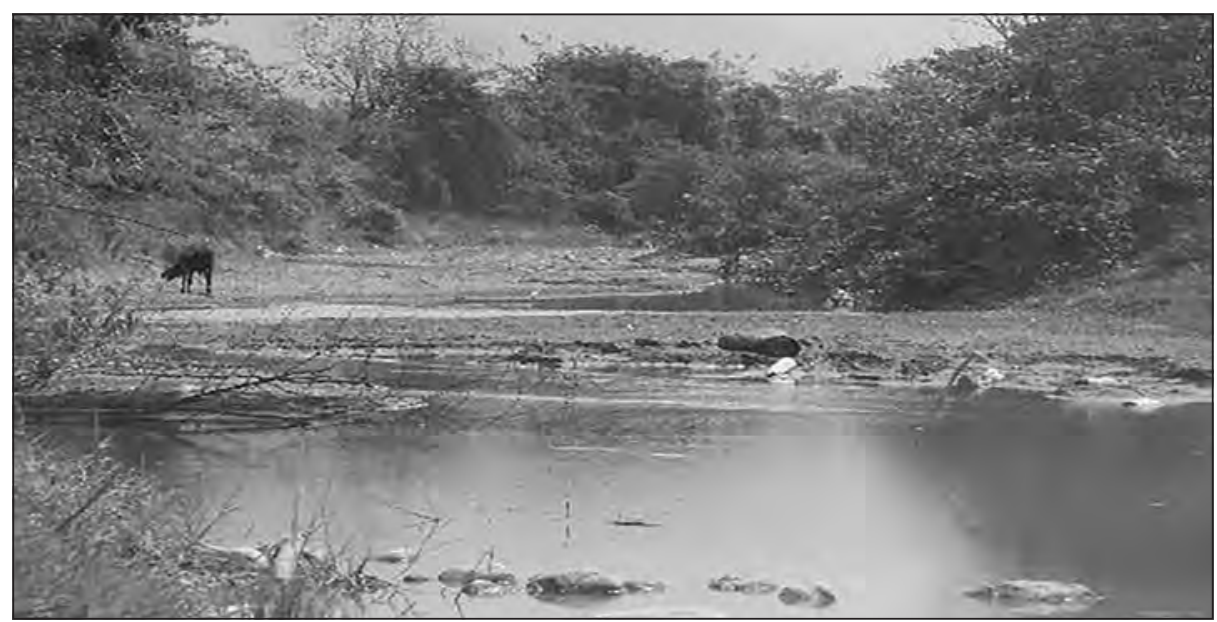

Fuente: Archivo Oraloteca (2017). 
La desviación de los ríos, la deforestación masiva de bosques y el fortalecimiento del modelo económico extractivista son acciones que generan profundas afectaciones medioambientales y sociales de acuerdo al contexto en el que se desarrollen. En ese orden de ideas, es claro que las economías extractivistas son depredadoras de la naturaleza y de las tradiciones locales de los pueblos. En el caso del departamento del Cesar, los municipios con vocación minera han sido sus principales dolientes, principalmente los campesinos que, tanto de manera colectiva como individual, han tomado medidas autónomas como las vías de hechos, denuncias, demandas y negociaciones que no son cumplidas a cabalidad por las empresas mineras, las cuales aún siguen en deuda con el país por las graves afectaciones que han ocasionado en los modos de vida de las poblaciones humanas y a las reservas de agua, flora y fauna en las diferentes regiones que han sido explotadas masivamente:

Nosotros como campesinos, como labradores de la tierra que vivimos del campo, nos hemos organizado y agremiado para así poder defender nuestros derechos que tenemos. La propiedad por la tierra es una pelea que venimos gestando desde hace tiempo con la organización campesina: es la formalización de la tierra. Muchos agricultores no tienen títulos de las tierras y eso es una desventaja para nosotros, así nos pueden quitar de cualquier lado y no pasa nada. El campesino y la tierra se complementan, por eso nosotros queremos conseguir que se nos den las zonas de reservas campesinas, donde nosotros conservemos la naturaleza y podamos trabajar con autonomía y tranquilidad (E. Castilla, comunicación personal, diciembre del 2016).

\section{Conflicto armado interno en el piedemonte de la Serranía del Perijá: memorias y voces sobre la violencia.}

El conflicto armado interno colombiano se ha consolidado como uno de los fenómenos sociales más significativos en la historia del país. Su desarrollo y periodicidad en el tiempo han desangrado al territorio nacional drásticamente: las masacres sistemáticas, torturas, desapariciones, mutilaciones, secuestros, enfrentamientos y desplazamientos forzados han fomentado la desestabilización social, cultural, económica, emocional y psicológica de los diferentes habitantes colombianos. 
En ese sentido, el presente apartado presenta una mirada sobre las afectaciones que el conflicto armado interno ha generado en las diferentes comunidades campesinas de la subregión de estudio. Si bien es cierto que el desarrollo y la intensidad de la violencia se vivieron con mayor presencia en las zonas rurales del país, cada comunidad o pueblo campesino sufrió, observó y resistió la presencia de la guerra de manera particular, por lo que las voces de los campesinos víctimas y no víctimas es fundamental para entender las complejidades y dinámicas del conflicto armado interno en el piedemonte de la Serranía del Perijá.

Por este motivo, a continuación se presentan diferentes relatos de campesinos y campesinas de los municipios, corregimientos y veredas del área de estudio, con el fin de resaltar, en primer lugar, la dinámica e impacto del conflicto armado interno en dicha subregión y dignificar, en segundo lugar, a los diferentes campesinos y campesinas víctimas del conflicto interno armado en el centro del departamento del Cesar:

El corregimiento fue muy golpeado por la violencia. Tanto guerrilleros y paramilitares golpearon fuerte al corregimiento. Este pueblo quedó solo. Después del acuerdo entre los paramilitares muchos campesinos retornaron a las diferentes parcelas a trabajar la tierra nuevamente. La violencia fue un impacto irreversible (E. Castilla, comunicación personal, diciembre del 2016).

Aquí la[s] FARC-EP y el ELN bajaban y coordinaban. Aquí hacían retenes y subían gente hacia allá arriba. Las FARC nos reunían en el pueblo y nos hablaban. Después, la gente se intimidó y siempre hemos vivido en conflicto. Después de que se desmovilizaron, las cosas apenas fueron mejorando. Por el miedo, la gente dejó [de] cultivar en el campo. El miedo, el temor, el miedo fue un factor para que le gente se alejara: el miedo de un enfrentamiento en el monte, que pasara algo en el monte, muchos salieron de las zonas rurales, el temor de los enfrentamientos, que los fueran a matar. Yo me fui para Codazzi y allí también estaban, pero con el tiempo tocó retornar porque en la ciudad la cosa es más dura... el recurso económico, el arriendo, [los] servicios; en el campo hay más solidaridad con la gente: "dame un pedacito de yuca, plátano" y se dan (Y. Castro, comunicación personal, diciembre del 2016). 
Vida campesina en el Magdalena Grande

Cuando venía caminando de la parcela me encontré dos manes y en la cuesta me les pegué y les pregunté que de dónde venían. Y los vi y tenían armas y [uno de ellos] me comenzó a decir que ellos venían de lejos, que no tenían parcelas, y me di de cuenta [de] que eran guerrilleros. En esta región la que mandaba era la guerrilla: aquí en las cantinas bebían públicamente y por eso fue que los paramilitares nos dieron tan fuertes, porque esto era zona roja (D. Quintero, comunicación personal, enero del 2017).

La relación de la guerrilla era, mira, ellos les pintaban pajaritos en el aire, mira: si era una mujer bonita le tiraban al muchacho más bonito y si era un hombre [a] la mujer. Los jóvenes fueron los principales que se aprovechan de su inocencia y así les pintaban pajaritos de oro y cuando estaban allá dentro era otro cuento; así muchos se fueron para la guerra (J. Vuelvas, comunicación personal, diciembre del 2016).

La Serranía del Perijá, como frontera natural estratégica y corredor de grupos al margen de la ley, utilizada para el aprovisionamiento y la distribución de diferentes productos, fue un factor fundamental para el establecimiento y la dinámica del conflicto en la región desde mediados del siglo XX. Tanto la presencia guerrillera como la presencia paramilitar y del Ejército Nacional ejercieron e impusieron relaciones de poder en las zonas rurales; estas influenciaron determinantemente las relaciones de los campesinos con su medio ambiente y sus modos de vida. La incursión de la violencia en dicha región fue totalmente visceral: las muertes selectivas y las constantes humillaciones llevaron al desplazamiento masivo de los campesinos. Desde Codazzi hasta Aguachica la población campesina que habita la Serranía del Perijá fue víctima de los estragos del conflicto. 
Vida campesina en el Magdalena Grande

Imagen 87. Casa abandonada en Llerasca, Cesar

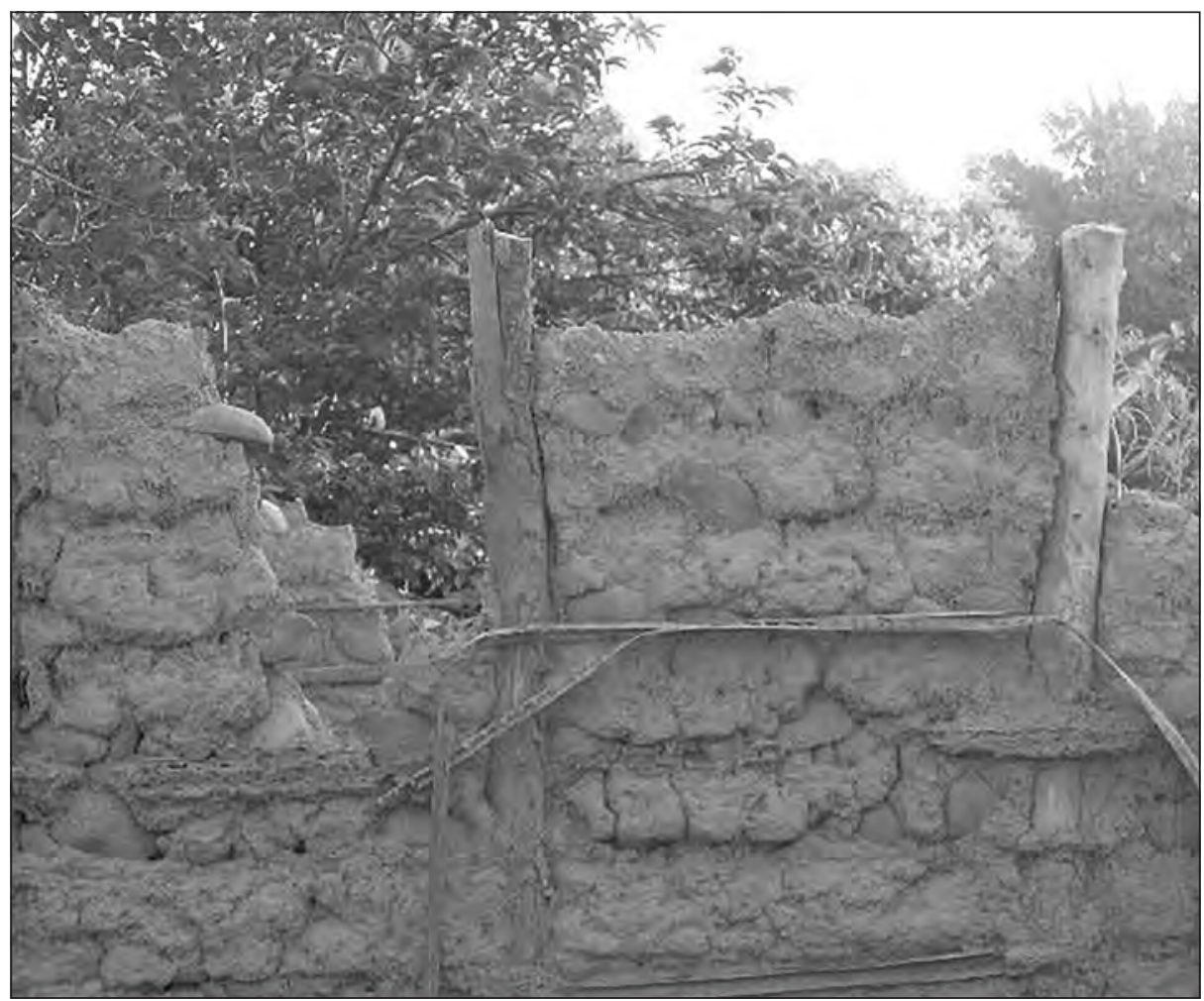

Fuente: Archivo Oraloteca (2017).

El conflicto armado nos afectó enormemente, por grupos alzados en armas como las FARC, el ELN y los paramilitares [quienes], en últimas, generaron mucha violencia en nuestros municipios, tanto en la zona alta como en la baja. A muchos afincados les tocó irse porque la guerrilla los extorsionaba, los secuestraban y prefieren vender a grandes terratenientes las fincas $y$, en eso, se forma[ro]n muchos grupos paramilitares que tuvieron incidencia en Aguachica (D. Quintero, comunicación personal, enero del 2017).

Nosotros salimos más que todo por el conflicto que tuvieron los paracos y la guerrilla. Los paracos no querían que estuvieran allá porque entonces decían que uno era guerrillero porque vivía en el monte (así uno no lo 
Vida campesina en el Magdalena Grande

fuera). Entonces, cuando nos dijeron que cuántos años teníamos de vivir aquí, nosotros respondimos que 4 , y nos decían que nosotros éramos guerrilleros y nos dijeron que los más viejos nos teníamos que ir de aquí o no respondían. Entonces, ¿qué más tenía que hacer uno aquí? Salir y dejar todo esto botado para salvar la vida. Entonces, ese fue el problema, que con el tiempo vendí mi tierra, pero a menor precio del que es porque esa finca son 125 hectáreas, diga usted: ¿cuánto puede valer? Yo la vendí en 30 millones y la gente me decía: "Juancho, te ganaste una lotería”. Vender en esos tiempos... pero, ¿qué hacía uno si le tocaba? Esa finca vale hoy en día como mil millones de pesos... pero, bueno, gracias a Dios que estamos aquí y conseguimos esto y aquí estamos (J. De Dios, comunicación personal, enero del 2017).

Aquí sufrimos verracamente cuando esa gente llegó por aquí en el 1992, por las haciendas arroceras, y se asentaron aquí. Había días donde ellos cerraban el pueblo y decían que no se trabajaba y nos tocaba quedarnos aquí. La cosa se puso dura y empezaron las muertes y los desplazamientos. Muchos nos fuimos, pero usted sabe que la vida fuera del pueblo es dura, no es la misma (J. Padilla, comunicación personal, enero del 2017).

Cuando vino la vaina de la violencia nos afectó los paramilitares. Aquí cogieron esta parcela para una base paramilitar, por eso me fui de aquí. Ellos empezaron entrando, buscando la guerrilla, y como decían que esta zona era guerrillera aquí llegaron como perros por su casa y dijeron que "nosotros nos quedábamos" y así fue que se quedaron y siguieron aquí y tomaron esto como un hospital: aquí llegaban heridos y mochos, una mochera. La última vez que me fui fue una vez que trajeron un herido y lo tiraron a mi cama y eso llena de sangre, y por eso me fui con mi mujer. Mucha gente de la región se fue desplazada por esas guerras y muertes (C. Pallares, comunicación personal, enero del 2017).

Tanto las bonanzas de la marihuana y la cocaína como la presencia de las empresas privadas de carácter extractivista fomentaron que el conflicto en dicha subregión aumentara: las disputas por el territorio, por las rutas de comunicación estratégicas y por el control de las economías locales por parte de los grupos armados ilegales permearon -durante 
más de una década de enfrentamientos y combates, de llanto, sangre y tristeza- las miles de vidas campesinas que vivieron en sus diferentes niveles y facetas las atrocidades del conflicto.

Actualmente, el departamento del Cesar — según la Unidad para la Atención de las Víctimas- cuenta con un total de 435.085 víctimas registradas, de las cuales muchas comunidades retornaron a sus territorios de origen paulatinamente, con el objetivo de reconstruir sus vidas, recuperar y fortalecer los vínculos con sus tradiciones y la tierra. Es indudable que el departamento del Cesar y sus pueblos campesinos son víctimas del conflicto interno armado; sin embargo, son pueblos que han resistido y han aportado a la consolidación, renovación y construcción de una nueva nación:

Nosotros retornarnos porque en la ciudad éramos como extraños, no sentíamos lo mismo que cuando uno está en su tierra, respirar el aire de su tierra, se siente a gusto en su pueblo, así sea pasando necesidades, pero en su pueblo todos nos ayudamos; en la ciudad no, por eso regresé, porque mi pueblo es mi todo: aquí tengo todo, mis hijos, mis viejitos, nosotros retornamos porque teníamos las ganas de cambiar nuevamente la vida al pueblo (Y. Hernández, comunicación personal, diciembre del 2017).

Para mí el campo significa un sustento diario, de ahí es donde uno está labrando la tierra, sacando para la comida y para una cosa y la otra, entonces para mí el campo es lo mejor. Ser agricultor significa algo muy bueno, porque yo soy muy feliz en el campo, soy muy feliz en el campo trabajando y haciendo labores de campo, para mí significa eso (J. De Dios, comunicación personal, enero del 2017). 


\section{Vida campesina en el Centro y Sur del Magdalena}

Esta subregión hace parte del departamento del Magdalena, el cual se encuentra ubicado al norte de Colombia, limitando al oriente con los municipios del Cesar y la Guajira, al sur y occidente con el río Magdalena y al norte con el mar Caribe. Está conformada por las poblaciones que habitan los valles y sabanas del centro del departamento y aquellas poblaciones ubicadas en la ribera del río Magdalena. La gran diversidad de ecosistemas permite a la población desarrollar actividades económicas ligadas al aprovechamiento de los recursos de su entorno, desatacándose de esta forma la agricultura, la ganadería, la pesca y, más recientemente, los monocultivos de palma y maderables.

En esa medida, podríamos decir que esta subregión se divide en dos grandes zonas: las poblaciones ribereñas y las poblaciones del centro del departamento. Para el caso de las poblaciones ribereñas tenemos que son comunidades que se dedican a la agricultura y a la pesca artesanales como principales medios de subsistencia, alternando entre una y otra según las condiciones ambientales y los ciclos del río (que, en gran medida, determina la cotidianidad de los habitantes). Existen algunos campesinos que tienen ganado, pero en pequeñas cantidades en comparación con las grandes extensiones de ganadería presentes en el territorio.

Por otro lado, en las poblaciones del Centro del Magdalena la cercanía de sabanas y las aguas de los ríos que bajan de la Sierra Nevada proporcionan a los campesinos los medios necesarios para el desarrollo de sus cultivos, aunque diferentes factores como el 
conflicto, el cambio climático y el abandono estatal están obligando a la población a migrar hacia otras actividades económicas, abandonando las labores del campo y, por ende, todo el acumulado de conocimientos que han pasado de generación en generación.

\section{El campesino ribereño}

Mapa 6. Recorrido realizado para la realización de este capítulo

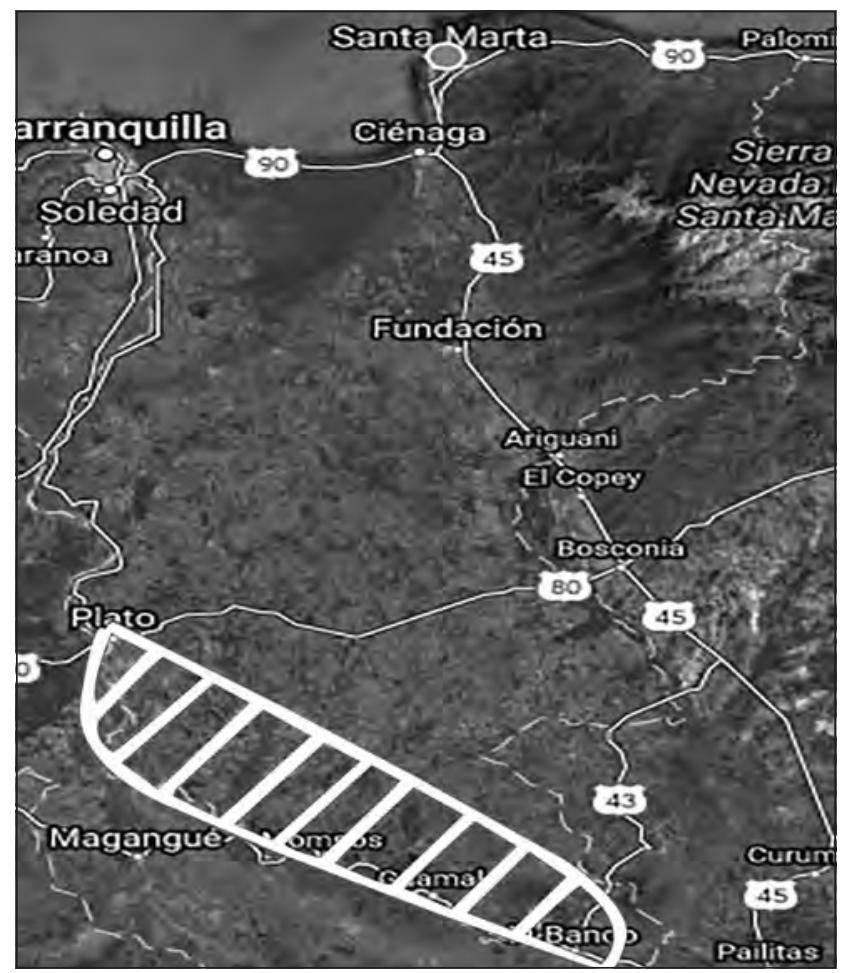

Fuente: Google Maps (2017).

El río Magdalena bordea el departamento en una extensión aproximada de $428 \mathrm{~km}$ (CORMAGDALENA, 2013), en la cual se encuentran municipios como el Banco, Guamal, San Zenón, San Sebastián de Buenavista, Santa Ana, Santa Bárbara de Pinto y Plato; escenarios de nuestra aproximación etnográfica sobre las formas de vida campesina que les presentamos a continuación. 
Al ser parte de la depresión Momposina, esta subregión se caracteriza por estar rodeada de ríos, caños y humedales que le imprimen un clima estacional cálido con dos temporadas secas y dos temporadas de lluvias que le otorgan a este territorio características especiales para el desarrollo de actividades como la agricultura, la pesca y la ganadería.

\section{Poblamiento y colonización de la Ribera del Río}

Mapa 7. Sitios y misiones fundados en el siglo XVIII

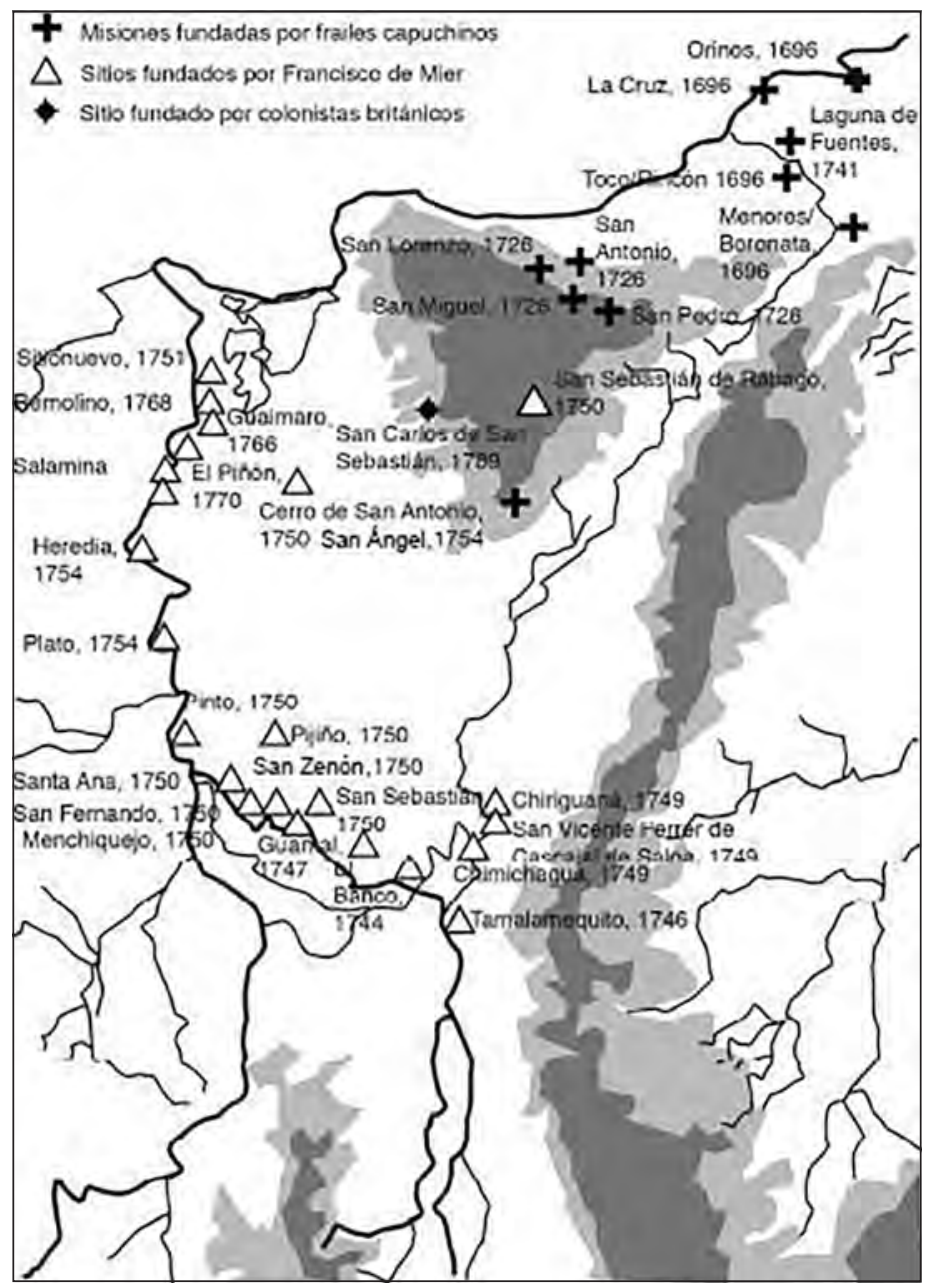

Fuente: Saether (2012). 
Vida campesina en el Magdalena Grande

Para hablar del proceso de poblamiento y conformación de las poblaciones que hoy se ubican en la ribera del río Magdalena en el departamento debemos remontarnos a los tiempos de la conquista y la colonia, cuando los españoles realizaban excursiones en busca de tierra y oro, colonizando y fundando ciudades a su paso (como el caso de Tenerife, convertida formalmente en ciudad española en 1541 [Saether, 2012]); de esta forma, fueron apareciendo nuevas poblaciones en la ribera del río Magdalena. Sin embargo, si hubo un hecho que realmente dinamizó la colonización y fundación de ciudades en estos territorios se dio en medio de la guerra que España libraba con Inglaterra durante el siglo XVIII:

Esta situación se tornó especialmente difícil cuando Inglaterra y España entraron en guerra en 1739. En 1741 los británicos sitiaron Cartagena de Indias y la ciudad tenía que ser aprovisionada de alimentos por tierra. Se confió esta tarea a Joseph Fernando de Mier y Guerra, peninsular, quien se había establecido en Mompox en 1740. Nombrado maestre de campo por el virrey en 1740, su acometido consistía en transportar ganado de la provincia de Santa Marta y, en particular, del valle del Cesar a Cartagena. Con el fin de cumplir con este cometido era necesario asegurar los caminos y ríos contra los ataques de los chimilas. También existía el temor de que los británicos proporcionaran armas a estos para fomentar la rebelión. Uno de los objetivos al fundar los pueblos a lo largo de los ríos Magdalena y Cesar era, por tanto, contener a estos indios y asegurar el transporte (Saether, 2012, pp. 45-46).

Así mismo, dinámicas políticas como la violencia bipartidista o el conflicto guerrilla- paramilitares han sido generadores de una diáspora campesina por todos los territorios del país. Procesos de abandono, colonización y repoblamiento hacen de cada territorio una historia llena de historias.

El conocimiento sobre el poblamiento de los asentamientos rurales del campesino ribereño reposa en la oralidad de personajes conocedores del territorio y su historia. Reconocidos por parte de las comunidades visitadas, estos tienen en cuenta las historias vividas en el territorio y, así mismo, enfatizan sobre el legado de sus ancestros como abuelos y padres. 
Vida campesina en el Magdalena Grande

La herencia cultural de las generaciones pasadas aún pervive en la memoria de los pobladores actuales, lo cual se evidencia en los relatos sobre el poblamiento del territorio; por ello, hablar del territorio es rememorar los hechos, impresiones o testimonios que generaron la migración hacia nuevas tierras y el enlace con la historia de los asentamientos.

En el extremo sur de esta subregión encontramos el municipio del Banco, ubicado en la margen derecha del río Magdalena, en medio del ecosistema formado por el brazo de Mompós y las zonas cenagosas donde se encuentran poblaciones de vocación campesina y pesquera, territorio que es conocido por sus habitantes como la "despensa agrícola del sur".

Recorriendo su zona rural al noreste de la cabecera municipal, a una distancia de ocho kilómetros de la cabecera por la vía que conduce al municipio de Guamal, encontramos pueblos ribereños como Tamalamequito. Al ingresar a la zona encontramos una vía destapada que nos lleva a una población que, como muchas otras del Caribe, ha visto cómo su desarrollo se da a través de las diásporas campesinas generadas por los conflictos armados en nuestro país. Es así como el señor Teobaldo nos cuenta cómo llegaron él y su familia a este territorio:

Vengo de la Pacha (Bolívar), un pueblo donde me levanté con mis padres, que nos levantó de una pobreza tremenda y le doy gracias a Dios porque ella levantó a cuatro hijos y con el compañero pasando trabajo, porque ese pueblo no es solidario, sino que pasó momentos difíciles [...]. Mi mamá vivía de lavar ropa, lavandera, de ahí que cayó grave debiendo un dinero. Ella se comprometió con el padrastro de nosotros y de ahí se fue al monte, entonces ahí vivían del cultivo de arroz, maíz y la yuca, esos eran los tres cultivos que se manejaban ahí después [de] que ya el pueblo fue creciendo con la otra mata que fue dañino. Mi mamá lavando ropa y mi papá cultivando, los momentos difíciles hicieron que nos fuéramos por el golpe de la violencia [...]. Mi papá se salió del monte y se fue para el pueblo, entonces levantaron una cría de gallina. Mi papá se ganaba el jornal, vivía del jornal, hacía sus maticas, pero no tenía cómo sobrevivir, entonces vivía limpiando cultivos de Marihuana y ahí en esos cultivos se puso tremendo porque había pelea diaria y borrachos... de ahí, pues, se cambió a la cocaína, pero mi mamá nunca quiso que nos metiéramos en eso, nosotros trabajábamos ganando el día. Luego, mi mamá se apartó 
Vida campesina en el Magdalena Grande

del marido y quedamos solo[s] sin él. Luego, mi padrastro murió y me trasladé a un monte y me comprometí; después, llegué al pueblo de la Pacha y me vine para Tamalamequito, donde murió mi mamá (T. Rivera, comunicación personal, diciembre del 2016).

Sumado a estas condiciones históricas y políticas, la riqueza de estas tierras también fue otro de los motivos por los cuales muchas familias, al pasar por estas tierras, decidían quedarse. Es así como encontramos poblaciones como la de los Negritos o asentamientos como Malpica, el Salto, la Sabana de Hatillo, Algarrobal, San Roque y San Felipe: aunque son distantes en el tiempo sus procesos de colonización, coinciden en que todos sus habitantes entraron parcelando, abriendo linderos y caminos en baldíos del Estado para construir casas de bahareque y palma habitadas por familias que buscaban tierras para ejercer actividades como el cultivo de maíz, yuca, plátano o "mafufo" y fríjol, alternando esta actividad con la pesca artesanal en ciénagas como la de Chilloa, Zapatosa y Palomeque y, en menor cantidad, con la tala de árboles y cría de animales:

[Los Negritos], fundado [hace] como alrededor de 200 años por unos colonizadores que vinieron por otros lados, eran preparadores del carbón y lo comercializaban por este puerto a los barcos y también vendían alimentos y peces... Se le decía "los Negritos" porque [sus colonizadores] eran de raza negra (N. Quintero, comunicación personal, diciembre del 2016).

[Malpica]: nuestra comunidad nace de familias que emigraron de otras regiones, atraídos por las fuentes de agua (la que tenemos detrás, como la Ciénaga de Chilloa, y otra que es la Ciénaga de Palomeque). Entonces, eran dos espejos de agua muy ricos en peces y ese fue el motivo por el que las familias fueron asentándose en la región [...]. El reglón de la pesca apareció en toda la región y, como ellos no se preocuparon por la tierra porque toda esta franja de tierras eran baldías, vinieron gente de todas partes del interior que no miraron o no eran pescadores, pero sí le[s] interesaba la tierra (W. Díaz, comunicación personal, diciembre del 2016). 
Imagen 88. Calle de San Felipe

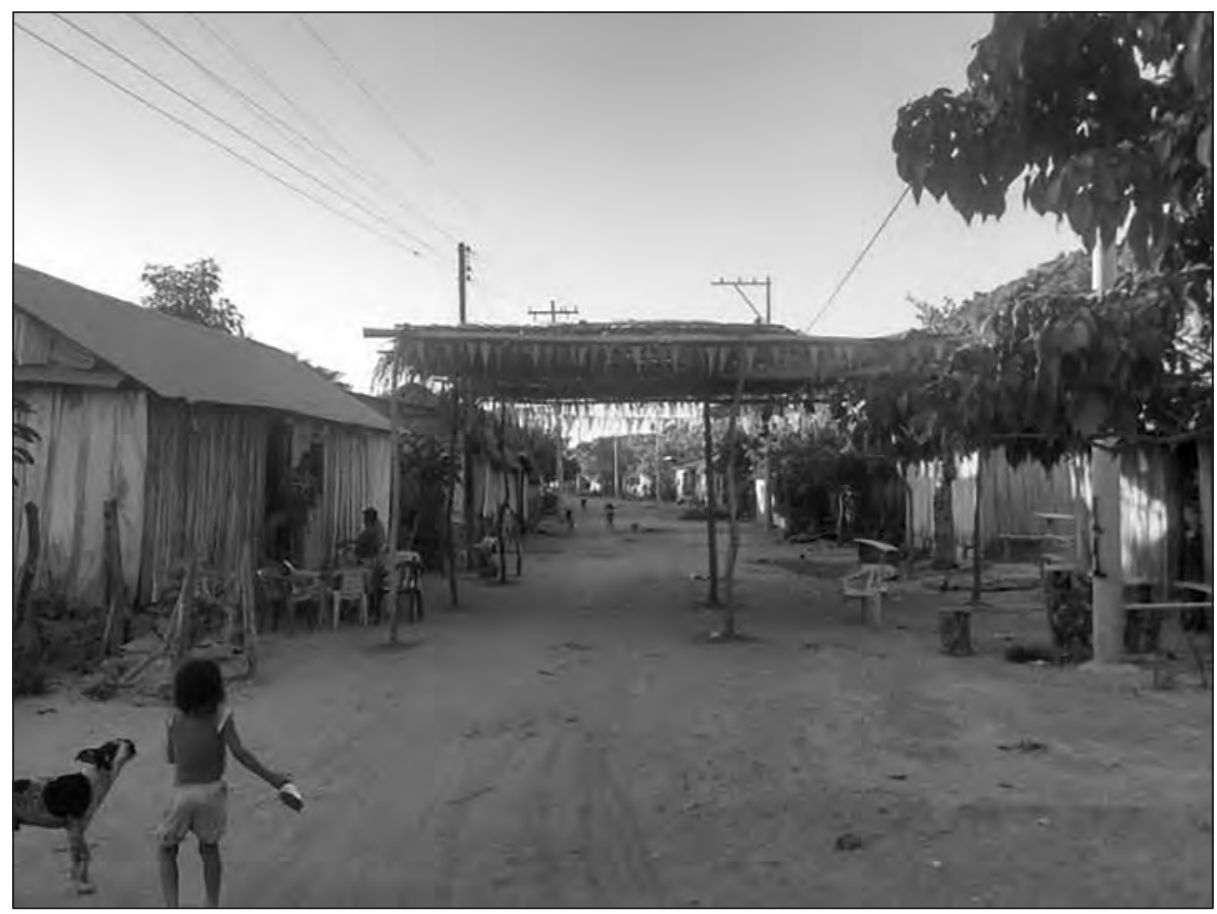

Fuente: Archivo Oraloteca (2017).

[San Felipe] existe desde el año 1940, porque mi papa nació en el 45. Anteriormente, eran tres casitas y esto era San Roque y había un almacén en la plaza de San Roque. Poco a poco se va poblando y se independizó San Roque y San Felipe, ya hace más de 50 años [...]. Yo digo que se llama San Felipe porque la señora que fundó se llamaba Felipa y, así, hay una poza que se llama la Vieja Felipa [...]. Anteriormente no había tanto admiración al cultivo porque uno sembraba el maíz para pilarlo y hacer chicha y bollo limpio (W. Quiñonez, comunicación personal, diciembre del 2016).

Siguiendo por la misma vía encontramos la población de Guamal, distinguida por ser de "tierra colorada". Su recorrido se puede realizar en motocicleta desde la cabecera municipal, teniendo como característica que en el transcurso es recurrente pasar por zonas inundadas en invierno 
Vida campesina en el Magdalena Grande

que comprometen las vías de comunicación entre veredas y trochas (donde el transporte de los habitantes es en bicicleta, burro o motocicletas). Estos asentamientos tienen su origen en las zonas del sur de Bolívar y el Magdalena, pueblos que se declaran descendientes de la etnia Chimila por la tradición oral y los hallazgos de cultura material o piezas arqueológicas en las zonas rurales:

Para mí era puro indio, porque aquí consiguieron enterrados, estaban explorando oro y consiguieron indios. Hemos tratado [de] conseguir la historia de este pueblo, pero no, los últimos viejos en el año 2002 hicimos la investigación, cada pueblo tiene sus fundadores. Pero cuando, según dicen los viejos, era una gente que vivía por el Guaimaro, de la ciénaga del Piñal. Aquí en el pueblo hay dos familias: los Florián y Martínez y otros como Pedroso, Ruidíaz, Pérez, pero toda esta tierra es de indios. Pensábamos [que] íbamos a encontrar explicación de esta tierra, pero nadie sabe, había gente de 120 años y no sabía sobre el pueblo (E. Pedroso, comunicación personal, diciembre del 2016).

Si seguimos descendiendo por el río, llegamos al municipio de Plato, cuya población es considerada la segunda más importante del río Magdalena. Por ser centro de acopio de mercancías y productos agropecuarios, concentró a una gran cantidad de pobladores nativos y provenientes de Tenerife y Montes de María, cimentando asentamientos que, en muchos casos, se ubicaron en las periferias del centro poblado (como es el caso del corregimiento Apure, con características de sabanas, ubicado sobre la Transversal del Caribe o Transversal de los Contenedores, en zona limítrofe con el municipio de Nueva Granada):

[Apure]: mi papá era del lado de Bolívar y se vino pelaito y nos tuvo por acá. Él era de Chalán, Sucre, era campesino [...]. Esa época era bonita porque llovía bastante, lo que sembrabas producía. Ahora hay mucha pérdida del producto: se perdió el maíz porque se secó (mucho verano), la yuca también se perdió (M. Contreras, comunicación personal, enero del 2017). 
Imagen 89. Casa de bahareque

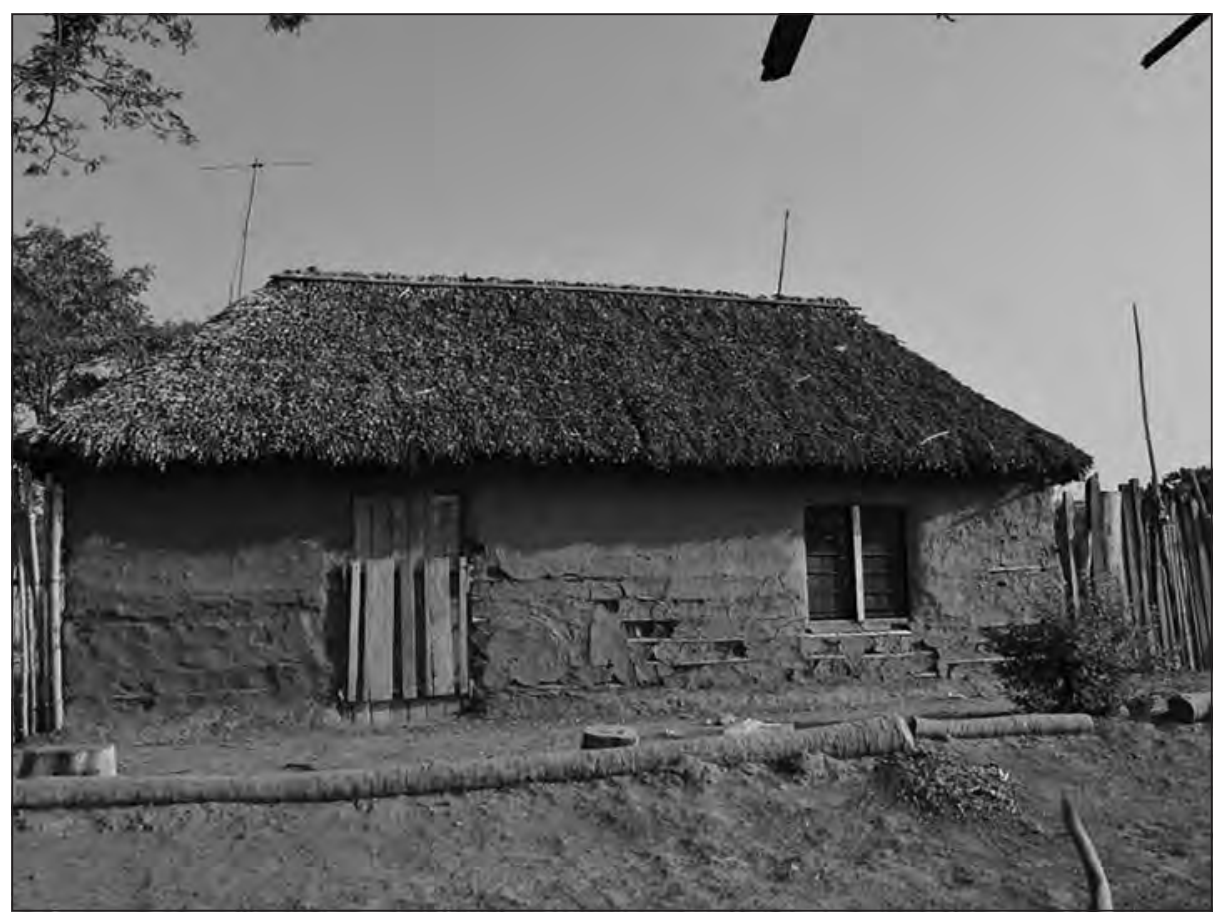

Fuente: Archivo Oraloteca (2017).

Por otro lado, encontramos la singularidad del área rural municipal, pues tiene el segundo complejo cenagoso más grande del país, a una hora de camino por vías de herradura hechas por los pobladores de la Ciénaga de Zarate, Cerro Grande y pueblos de la Ciénaga y el río Magdalena, con la particularidad de ser caminos temporales en verano e inaccesibles en invierno; por esta razón, una de las alternativas para poder realizar estos recorridos es la navegabilidad de la Ciénaga:

[Zarate]: esto, según cuentan por aquí, era de indígenas. Se llama Zarate porque el indio se llamaba Zarate. Este pueblo es más viejo que Plato... y quedaba en otra orilla del playón, llamada Plato Viejo [...]. Pero aquí papá, abuelo y abuela tenían descendencia de Bolívar y mi abuelo era de aquí por parte de mamá y papá. Uno aquí sale, pero otra vez viene (D. Torres, comunicación personal, enero del 2017). 
Vida campesina en el Magdalena Grande

Los pueblos de la Ciénaga de Zarate poseen tradición en la pesca y la agricultura. Las tierras para cultivar son en "tierra firme", en suelos de baja humedad en las comunidades de Zarate y Buenavista, donde se siembra yuca y maíz; no obstante, Cerro Grande (que tuvo actividad agraria en pequeña cantidad) hoy sólo subsiste de la pesca:

[Cerro Grande]: los antiguos dicen que Cerro Grande es otro caserío de los grandes ganaderos, que son los que tienen grandes extensiones de tierra para el lado de Pinto, Chibolo, Granada. Cuando era época de verano se secaban los pozos de la ganadería y ellos se trasladaban aquí porque la Ciénaga de Zárate quedaba con agua. Aquí venían a buscar el agua y hacían las cañadas para que el ganado bebiera agua; entonces, había puro corral y se volvió el punto bueno y se fueron quedando. Aquí la mayoría de los antiguos [eran] como mi papá, que es de Manatí (Atlántico), pero había personas de Cerro de San Antonio, Purgatorio, Zapayán, pueblos del río Magdalena, Bolívar y Cesar. Se dedicaban a pescar en laderas de ríos y trabajar en fincas. Los que se dedicaban a la agricultura venían de tierra alta como Chibolo, Granada... aquí los descendientes son pescadores de Bolívar [...]. El antiguo poblado era Zarate, pero ellos vinieron a poblar acá porque no tienen agua y nosotros sí (E. Cantillo, comunicación personal, enero del 2017).

Otra dinámica recurrente en algunas poblaciones ribereñas que dinamizaron en cierta medida los procesos de poblamiento de estos territorios tiene que ver con la necesidad que tienen los campesinos de establecer sus rozas o parcelas en otros municipios debido a la condición árida de sus tierras y a la utilización de las mismas para la ganadería extensiva, aunque esto implique tener que desplazarse grandes distancias desde sus casas. Tal es el caso de los campesinos de Pijiño del Carmen, cuyas zonas agrícolas se encuentran en su mayoría en el municipio de San Zenón, como el caso de la Montaña o en el municipio de Santa Ana, como el caso de San Fernando, donde laboran campesinos provenientes de Pijiño del Carmen. Estos campesinos laboran lejos del municipio buscando tierras óptimas para el cultivo debido a que las tierras nativas son áridas y las de sabana están destinadas a la ganadería extensiva: 
El agricultor de nuestra región es diferente al de San Fernando (Santa Ana), porque esa es para venderla para negocio, pero aquí en Pijiño solo se produce ahí para arrancarla y para sostenimiento de la familia; el del Horno (San Zenón) igual, ellos abastecen la región (M. Díaz, comunicación personal, diciembre del 2016).

\section{Los tiempos de cultivo y las tierras de la ribera del río Magdalena}

Imagen 90. Ribera del río Magdalena

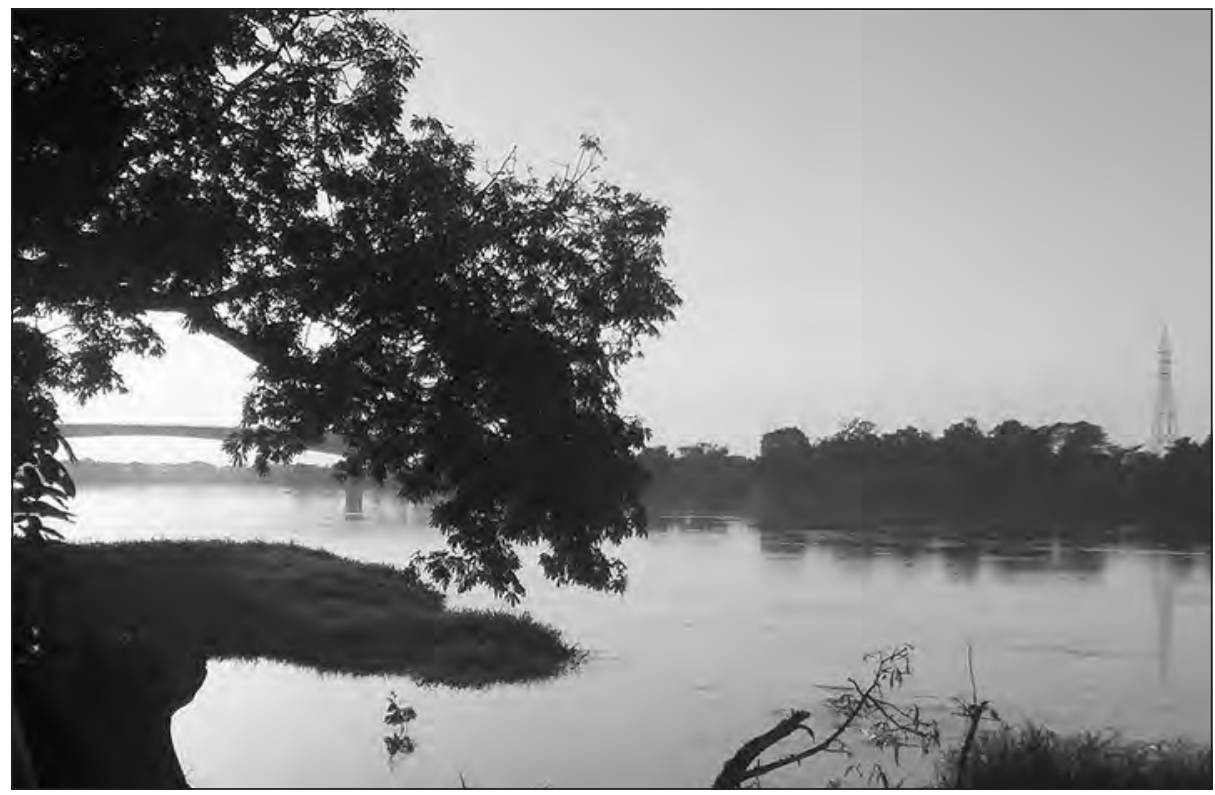

Fuente: Archivo Oraloteca (2017).

La región del Sur del Magdalena es un territorio con características climáticas muy singulares para el trabajo de la tierra. Esta zona está atravesada por el río Magdalena, conformando a su paso playones, ciénagas y caños que circulan alrededor de pequeñas ondulaciones sobre el territorio. Posee un clima y fenómenos naturales que determinan la relación e interacción del campesino con la naturaleza, generando un conocimiento sobre la periodicidad y sobre las manifestaciones que tiene el medio ambiente con relación a los asentamientos. 
Vida campesina en el Magdalena Grande

La noción de tiempo en estos territorios ribereños está directamente relacionada con las condiciones del ambiente; específicamente, con los fenómenos de creciente y sequía que presenta el río Magdalena como parte de sus ciclos naturales, pues son estos ciclos los que determinan las actividades económicas que se desarrollan: alternando entre la agricultura durante las temporadas de caudal bajo y la pesca artesanal durante las crecientes. Así mismo, este conocimiento le permite al campesino ribereño establecer una relación entre el tipo de tierra para sembrar, las condiciones propicias para cada tipo de tierra y el cultivo apropiado, siendo los playones el escenario ideal para la siembra de cultivos como la yuca (el cual presenta una cosecha de mejor calidad en estas tierras, según manifiestan los campesinos, pero solo puede ser sembrado justo después de que pasa la creciente y la tierra está fresca):

Cuando llega la época [en la] que el río se desborda esa zona queda muy fresca para el cultivo. Ahora que se creció el río y cuando el río busca su nivel el campesino le queda la tierra favorable para el cultivo (N. Quintero, comunicación personal, diciembre del 2016).

De lo contrario, pueden sembrar en tierra firme: aquellas extensiones de tierra no inundables, pero las cuales dependen de las temporadas de lluvia para el desarrollo de los cultivos, siendo estas "la primera" (que comprende las lluvias del mes de abril) y "la segunda" (que hace referencia a las lluvias de los meses de septiembre y/u octubre):

En la finca es a mitad de año cuando empieza a llover porque es tierra firme. En las islas la tierra produce desde enero en adelante, la tierra es en barro y todo queda mojado y el agua queda a nivel. En tierra firme hay que esperar que llueva para sembrar: la siembra en tierra firme es en marzo que comienza a llover y en tierra de barro en enero (tierra de isla) (P. Martínez, comunicación personal, diciembre del 2016).

Con la yuca en tierra firme estamos de cosecha porque uno siembra en abril-mayo y recoge de noviembre para acá. Ahora hay yuca, pero es de veranillo, porque a comienzo de año no se pegaron los palos de yuca porque estaba muy seca, entonces pasa de que en tierra firme la yuca no 
Vida campesina en el Magdalena Grande

vale porque la gente prefiere la yuca de isla, la isla siempre es la mejor yuca, pero este año hubo problema por la creciente y quedó poquita y el que había tenido yuca por acá, porque además venimos de cuatro años de verano. Después del 2010 no hubo creciente un poco grande y la gente estaba dando el batazo porque había hecho plata la gente. Pero ya ahora el tiempo cambió y estamos en la antesala de todo lo que están pronosticando como una creciente grande, pero si te digo vale la pena probar con un cultivo grande en esta tierra es con la yuca, porque yo sé que la yuca es lo que mejor se da y que no falta en los platos de la familia que es consumible (W. Díaz, comunicación personal, diciembre del 2016).

En marzo, por lo menos, hay de los que siembran en marzo las primeras yucas; las otras, en abril, en mayo, y las otras en junio: tres temporadas. Lo que se siembra en marzo, se recoge en septiembre o agosto, según el tiempo, porque si el tiempo es bueno [en] agosto, pero si es malo [en] septiembre. Te digo algo... si la yuca sale buena, se levantan juntas los otros meses. Según el tiempo, los primeros aguaceros son en marzo o febrero. Uno la tiene arreglada para los primeros aguaceros, por lo menos nosotros sembramos en abril o mayo, entonces la gente la tiene lista y en el aguacero se siembra[n] las primeras yucas y de ahí va. En mayo son lluvias normales día y noche y no hay problema, cuando llueve es época buena (E. Pedroso, comunicación personal, diciembre del 2016).

El conocimiento de estos aspectos climáticos le permite al campesino ribereño conocer el estado de la tierra durante cada época del año y predecir en el ambiente si las condiciones son favorables o no para el cultivo, aunque, como muchos cuentan, con el cambio climático es cada vez más difícil saber cómo va a estar el clima cada año. Los fenómenos climáticos ocasionan cambios en el volumen del caudal del río Magdalena que se ven en dos periodos: una creciente mínima durante el primer semestre del año y las crecientes de octubre y noviembre. 
Imagen 91. Caño en el corregimiento de los Negritos

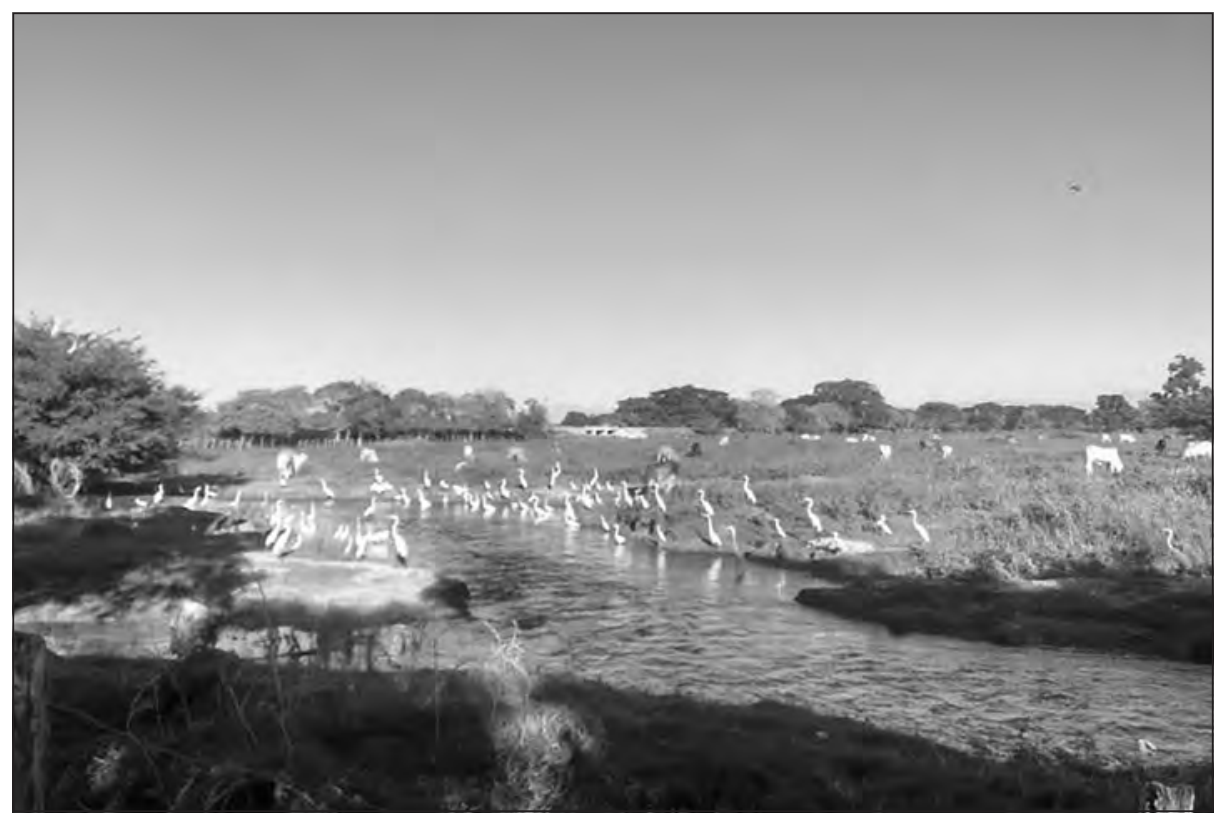

Fuente: Archivo Oraloteca (2017).

La creciente se presenta en octubre y en mayo otra, pero la de mayo no crece tanto: en octubre cuando es creciente grande inunda el pueblo, en mi casa llegó el agua donde ve la raya negra. Aquí pasamos, pasa uno, mucha necesidad, no hay ni pescado... Porque hay pescado, uno más que otro, pero no es abundante. Ahora mismo no hay pescado, ve los estanques y no se ve [...]. Cuando llega el verano la gente no cultiva, se va para la tierra de barro; ahora, en este momento, estamos en verano hasta abril, hemos tenido seis años de resequedad, ahora fue que llovió más como en el mes de octubre que cayó un agua buena (V. Villegas, comunicación personal, diciembre del 2016).

Cabe resaltar que estas inundaciones no son nuevas y, de hecho, hacen parte del ciclo natural del río que bien supieron interpretar las comunidades indígenas de antaño, construyendo un sistema de caños que les permitía amortiguar las inundaciones y redirigir esas aguas hacia tierras cultivables. El taponamiento de estos caños, sumado a las afectaciones 
por el cambio climático, hace cada vez menos predecibles los ciclos naturales del río, lo que ha conllevado a desastres en los cultivos que finalizan en la pérdida de la producción y en calamidades públicas - generadas por la creciente - en corregimientos, veredas y caseríos:

Hay una cantidad de yuca que se perdió en la creciente, se perdió el cuatro filos, la yuca, todo se ahoga por aquí. En el 2010 y 2011 nos azotó a la agricultura de yuca. Los señores que tiene[n] su pedazo, siembran la yuca para el sostenimiento de ellos y sus trabajadores. Después de eso nos azotó un verano donde el campesino hizo todo para cosechar, pero el verano no dejó [...]. Todos cultivamos lo mismo y esperamos un milagro de Dios. Estamos esperando que baje la creciente para poder sembrar. Este año la cosecha no tuvieron valor como otras veces que hay salida, este año se estancó todo con la creciente porque no la esperábamos [...]. Este año iba a haber buena producción, había mucho maíz en la isla, pero llegó la creciente y todo lo arrasó, el agua no lo aguanta nadie, solo el creador (M. Díaz, A. Gómez y P. Martínez, comunicación personal, diciembre del 2016).

Ahora bien, en relación a la capacidad que tienen los campesinos de esta subregión para identificar las características de cada terreno en proporción a los ciclos del río y las lluvias, podemos identificar dos tipos de suelos que son denominados de diferentes maneras según la relación de cada campesino con cada uno de ellos. Encontramos, por un lado, los suelos denominados por la gente como "tierra firme" (también llamada "tierra de arena" o "tierra de piedra"), que hace referencia a los suelos que se encuentran un poco más adentro de la ribera del río o en las pequeñas elevaciones del territorio. Esta tierra se caracteriza por ser un poco más árida y depender de los ciclos de lluvias para su cultivo:

La tierra baja es para toda clase de cultivo, el maíz da rápido, en cambio acá en el pueblo la tierra es de arena, caliente y, si no llueve, siembras y se te muere la semilla, tienes que buscarla porque cuando no tienes semilla se compra y cuesta la carga a 20 mil pesos, entonces uno busca la semilla y se le muere; en cambio, allá la semilla crece y va enseguida, cuando menos piensas está grande. El maíz da bastante. En tierra firme la yuca 
dura más en cosechar que en la tierra baja: la tierra baja a los 3 o 4 meses hay yuca; en cambio, en tierra firme hay que esperar 6 meses o 7 meses (E. Pedroso, comunicación personal, diciembre del 2016).

La tierra es difícil porque es tierra firme. Malpica es zona de tierra firme, pero en tiempo de lluvia se vuelve barrosa porque como son sabanas se encharcan mucho y el agua lo vuelve blandita (W. Díaz, comunicación personal, diciembre del 2016).

Las plantas que sean de cultivo cálido se da[n] en el Cerro: a pesar de que es de piedra es fresca, todo es piedra. Aparentemente ve pedazos de solo piedra y se da buena, entre más piedra hay sale fresca la yuca. Sale uno a las seis de la mañana para allá y a las ocho está acá con dos sacos de yuca para comer, echarles a los marranos (L. Martínez, comunicación personal, diciembre del 2016).

A la zona de [la] ladera del río le conviene el verano, pero nosotros llevamos del bulto. En la ola invernal que hubo ahorita último, fue el 8 de diciembre que cayó el aguacero, ¡uy! Eso hacía pastos en un dos por tres y se secaba, las tierras botaban agua por todas partes y ya con diez días de sol parece que no hubiera habido nada. Esa[s] tierra[s] de las riberas del río son rápidas para cosechar porque la tierra es húmeda, pero acá a lo que entre el verano aquí, ¿quién va a sembrar? Porque aquí no hay riego y uno está a lo que dé la naturaleza, lo que Dios quiera cuando lleguen los tiempos de invierno para poder sembrar (F. Díaz, comunicación personal, diciembre del 2016).

Pues uno en [el] Cerro cultiva y es muy buena, pero con un sistema de riego sería una bendición. No estamos enseñados a [la] fumigación, todo lo hacemos a uña: no usamos fumigación porque daña la tierra, entonces arrancamos la maleza. Los trabajos lo[s] hacemos en la mañanita hasta las once, como no son cantidades (como una hectárea o dos hectáreas que tiene[n] posibilidades de hacer maíz, porque por aquí son muy pocos los que venden cultivos), cuando hay lo sacamos al Banco en carromula. Acá no hay carro; nos tienen en un abandono total (E. Martínez, comunicación personal, diciembre del 2016). 
Mientras los campesinos que habitan en las zonas de tierra firme esperan con ansias las lluvias cada año, los campesinos de la "tierra baja", "tierra de ladera" o "tierra barro", como son conocidos los suelos inundables o que están en la ribera del río, aprovechan cada verano para establecer sus cultivos en aquellos terrenos que la creciente deja húmedos y abonados para la siembra. Así como para los campesinos de tierra firme los intensos veranos se vuelven su principal enemigo en las cosechas, para los campesinos de tierra barro las crecientes amenazan constantemente sus cultivos:

Cuando ya sale la creciente uno se preocupa por sembrar, eso pega enseguida porque es fresca. Nosotros le decimos "tierra de barro", que son las pegadas al río; hay tierra firme y de barro. La de barro produce más, pero [en] la tierra firme tiene que llover constante para que produzca (mientras no llueva se pierde todo), pero la de barro tiene todo el tiempo y si se hunde mucho mejor todavía. Un cultivo para sembrarlo en una tierra firme de estas se pierde si no hay riego por lo que viene el verano (V. Villegas, comunicación personal, diciembre del 2016).

Mi tierra está cerca de la Ribona (Bolívar), cerca al río. Voy todos los días y después, en temporada, se recogen los bastimentos. Es muy buena: todo lo que siembra eso produce con ganas. El plátano también se da bastante: por ejemplo, corté gajos de mafufo y todavía estoy cortando. A ese todavía no le hace y, como medio se inundó el cultivo, se corta gajo de mafufo de ciento y pico (J. Torres, comunicación personal, diciembre del 2017).

Hay agricultores playeros que son los de la orilla del río, por lo menos la gente en San Luis cultiva en playa. La de San Luis, San Antonio, Barbúl, Purgatorio, esa gente por lo menos ahora no tienen nada porque el río les creció (D. Torres, comunicación personal, enero del 2017).

Así mismo, dentro de esos terrenos de "tierra barro", usados por los campesinos para la producción agrícola, es importante señalar la existencia de una franja de tierra inundable ubicada en la mitad del cauce del río Magdalena, conocida por la gente como "la Isla". Estas son tierras inundables que forman parte del cauce del río, pero que en verano emergen a la superficie y son aprovechadas por los campesinos para cultivar: 
Vida campesina en el Magdalena Grande

Es que cultivar por aquí es una cosa y cultivar en la Isla es otra cosa, porque la Isla no es igual acá, porque en Hatillo cultivamos es en el Cerro, pero en otras partes ya para la orilla del río es Isla. En la Isla la tierra es más fértil; en el Cerro hay que ayudarla con abono y esas cosas, porque la tierra de río viene con mucho abono porque viene arrancando tierra, arrancando, entonces va aumentando en unas partes y eso se hunde y ayuda para eso. Entonces, aquí nosotros cultivamos en el Cerro yuca y maíz, casi fríjol no cultivamos y ahuyama sembramos las maticas para tener 2 o 3 ahuyamas para comer y hay unos que cultivan, siembran $50 \mathrm{o}$ 100 matas de fríjol, pero no es como en la Isla que siembran por hectárea y de ahuyama en la isla es por hectárea (E. Palomino, comunicación personal, diciembre del 2016).

Las tierras de la Isla nos ayudan mucho. A esa tierra le llueve dos aguaceros y se mantiene dos meses, mientras tanto aquí tiene que llover cada dos días para que produzca. Ahora no, porque quién se va a meter a sembrar... se pierde el trabajo y la plata. Es mejor la tierra fresca que reproduce en un momentico todo lo que le siembren (V. Villegas, comunicación personal, diciembre del 2016).

La tierra es otra clase, aquí [en la Isla] no se le hace nada: se limpia y no se ayuda con nada. Hay partes [en] donde la aran y le dan abonos; anteriormente se fumigaba, pero salía rucha la yuca por el veneno. Aquí en cinco meses sale buena o sino sale rucha (E. Pedroso, comunicación personal, diciembre del 2016).

Teniendo en cuenta esta realidad, muchos campesinos y campesinas de esta zona alternan sus actividades económicas, teniendo el caso, por ejemplo, de los campesinos de tierra barro quienes, por las crecientes, se ven obligados a buscar suelos en tierra firme para sembrar; algunos se dedican a la pesca artesanal durante estas épocas. Así mismo, durante los intensos veranos los campesinos de tierra firme se ven obligados a trasladarse a las zonas de tierra barro para buscar suelos para sembrar.

En algunas de estas comunidades es normal encontrar extensiones de tierra sin ningún tipo de explotación agrícola o pecuaria; por el contrario, constituyen reservas forestales que las mismas comunidades han dejado 
Vida campesina en el Magdalena Grande

para la preservación de los reservorios de agua y la calidad de los suelos. Un ejemplo de esto es la comunidad de la vereda de Hatillo, en el Banco, cuyos habitantes poseen una reserva forestal; sin embargo, según denuncian los habitantes, estas reservas se han visto afectadas últimamente por las quemas indiscriminadas y la tala del bosque nativo:

La reserva queda detrás, donde hay una selva, y la protegemos hace mucho tiempo. Llevo 50 años y eso era reserva; este pueblo tiene como 80 años de fundado. Aquí la protegen las veredas del Cinco, Botillero y Hatillo. [A] la montaña la ha destruido la candela, la gente ha echado mucha candela y ha acabado la madera, y ya para que vuelva a nacer es difícil porque nace la hierba mala, entonces se forma un matorral. La guadua se ha acabado porque se ha quemado y es silvestre, porque cuando se le[s] da mal uso a las cosas se acaba[n]. El profesor de la escuela ha recogido palo de guamarillo y madera de toda clase para sembrar: limpian el pedazo y siembran. Además, lo que pasa es que entra mucho ganado y el palo pequeño lo daña el ganado, no hay encerrado. El Gobierno no le ha dado fuerza a este pueblo, tanto político que hay aquí, pero mire en la montaña de Bello: hay unos playones y la montaña sola esperando ayuda, pero también la gente encierra los playones y mete ganado en los playones, la comunidad debería recoger fondo para proteger la montaña. A la montaña le podemos hacer un sembrado y va a producir hasta cuando ya el palo esté grande, pero aquí el Gobierno no apoya a la comunidad (E. Palomino, comunicación personal, diciembre del 2016).

\section{"Somos el espejo de nuestros padres": el aprendizaje y conocimiento sobre la tierra}

Mientras en las escuelas del país es habitual aprender sobre el entorno natural a través de asignaturas como Biología, Ciencias Naturales o Ciencias Agropecuarias, en algunos casos el proceso de conocimiento acerca de la naturaleza y el trabajo de la tierra en los campesinos es empírico y es heredado a partir de técnicas y métodos singulares que cada miembro de la familia aprende desde la niñez con el acompañamiento de su padre. 
Imagen 92. Campesino ribereño

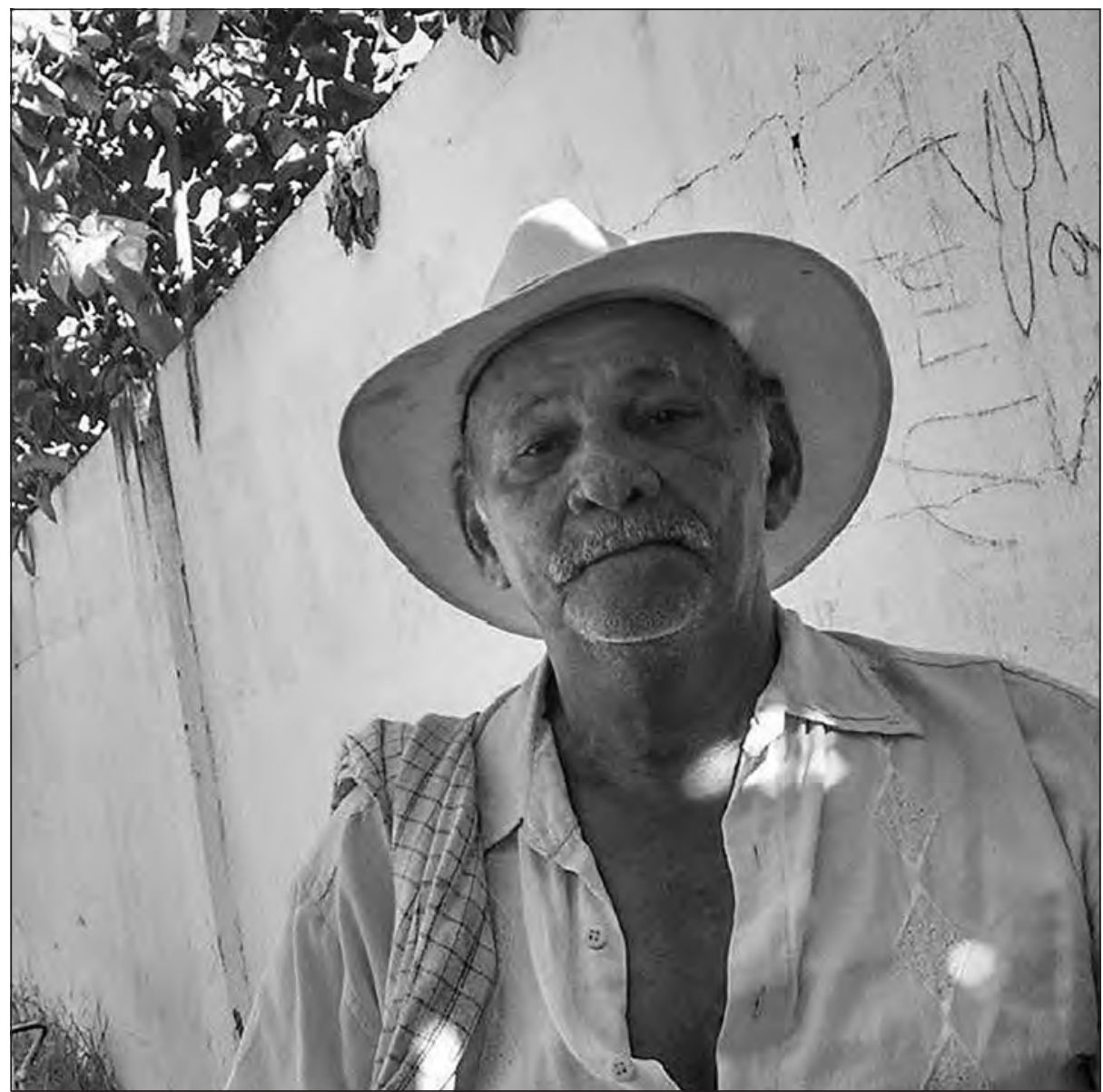

Fuente: Archivo Oraloteca (2017).

Aprendí con mi papá y mi abuelo y uno trabajando sabe cómo se siembra la mata, cuándo se recoge, qué tiempo se demora para dar el fruto [...]. Tú sabes que la tradición es de los ancestros, ellos son los espejos de uno y nosotros somos lo[s] espejos de los hijos si ellos cogen la cultura de uno de salir adelante y trabajar con empeño [...]. Sabes que todo el que tenga el hijo, si está en el colegio, se lo lleva todos los sábados para que vaya aprendiendo a tirar pala (E. Palomino, J. Torres y Felipe Díaz, comunicación personal, diciembre del 2016). 
Vida campesina en el Magdalena Grande

Desde la edad de 14 años que yo me crie con mi papá y le ayudé en el trabajo porque era agricultor, entonces tuve los 20 años y me obligué a casarme para cubrir mis obligaciones, a trabajar el machete: todo era machete porque escuela nada más llegué a tercero [...]. Tengo 25 años de estar cultivando. Uno se dedica a aprender porque [a] uno le nace, viendo al papá cómo trabajaba va aprendiendo, después uno se defiende solo y entonces va aprendiendo muchas cosas (J. De Dios y V. Villegas, comunicación personal, diciembre del 2016).

En ese ejercicio de aprendizajes de las labores del campo los jóvenes campesinos y campesinas van identificando las actividades de acuerdo a sus roles de género y se van especializando en una u otra especialidad. Así, mientras los hombres generalmente salen a sembrar o a pescar, las mujeres se quedan en la casa realizando las actividades propias de la economía del cuidado y, en la mayoría de las ocasiones, son las encargadas del procesamiento y la comercialización de los productos como los bollos, mazamorras, enyucados y el pescado (en el caso de las mujeres de los pescadores). Ahora bien, esto no quiere decir que no existan mujeres que vayan a pescar o sembrar, pero en la mayoría de las ocasiones estas actividades son desarrolladas por lo hombres, pues así lo han aprendido de generación en generación:

El hombre es el que cultiva y la mujer se queda en la casa; por allá algunas mujeres va[n] a trabajar, pero son dos. Mi actividad es construcción, pero aparezco como agricultor porque ese es mi actividad principal, pero dado el caso de que se presente la oportunidad toca buscar otra alternativa. Entonces, trabajo en compañía con el cuñado y toca buscar el trabajo de obrero para tener la plata (W. Díaz, comunicación personal, diciembre del 2016).

Yo los he criado así toda la vida: sembrando, vendiendo y pescando; a todos los pongo a vender yuca. Yo como mamá y tengo 13 hijos luchando, vendiendo yuca, pescado y bollo, es que yo los he criado a ellos, ahora los pongo a vender yuca. Nosotros compramos para distribuir aquí y sembramos, pero cuando está la cosecha vendemos. En Santa Helena distribuimos (A. Martínez, comunicación personal, diciembre del 2016). 
Vida campesina en el Magdalena Grande

Hacer bollos para vender en el Banco, bollo de mazorca, muchos se dedican a comprar el maíz, lo muelen y lo llevan al Banco en carro o en cicla y así por lo regular. Lo hacen utilizando el mismo maíz biche: cuando está biche lo repellan y lo muelen para hacer bollo (V. Villegas, comunicación personal, diciembre del 2016).

Otro elemento fundamental para el trabajo en el campo son las herramientas, las cuales, al igual que las costumbres, son heredadas de los mayores a los jóvenes. Junto a las herramientas se transmite un sistema de conocimiento alrededor de su uso y manejo, como por ejemplo en qué situación usar una u otra herramienta y cómo debe usarse en cada momento:

En el trabajo usamos el sable, machetilla o rula (son diferentes calibres), la pala, palines, azadón. El sable es más alto, la rula un poco más pequeña y la peinilla es la que se carga en el cinto [...]. Usamos el machete, como ahora también es la guadaña, y ahora el palín que se está usando bastante [...]. Aquí se cultiva a mano, se hace el trabajo a machete o se hace el tractor, pero arrendado: el que mejor opción tenga o facilidad entre ellos porque no hay maquinaria para el campesino (J. Torres, E. Pedroso y M. Díaz, comunicación personal, diciembre del 2016).

Desde chiquitos, comencé la agricultura a la edad de ocho años. Mi papá me decía: esto se siembra así, lo otro así, él nos explicaba todo, [hasta] cómo agarrar el palín, [la] paladraga, [el] machete, [el] martillo, [la] grapa, [la] pinza, para cualquier cosa; por ejemplo, que [si] el ganado está metiendo la cabeza, se compone la cerca. Se iba uno y lleva la vástiga para uno picarla y sembrar el maíz (S. Benítez, comunicación personal, diciembre del 2016).

Trabajamos con rula, cuando toca de monte pequeño o gramalote solo rula. El gramalote es una paja, eso bota varios ganchos, pero la matona le pega abajo y la voltea y la tierra queda, pero esa mata cuando tiene hormiga te pica, te hincha el cuero, te toca es sacudirte y tratar de apartarte de ahí y buscar otro lado, porque muchas veces hasta el pantalón te hace quitar. Cuando toca tumbar la madera alta es con el hacha; cuando toca arrancar, 
Vida campesina en el Magdalena Grande

toca trabajar con barretón o palines diferentes al pico porque el barretón ya no tiene el hueco del palo; el palín es para meterlo y voltear la raíz; el azadón es para voltear la tierra y, más que todo, usamos unas botas largas, con eso la hormiga no pica ni se monta, pero zapato pequeño te comen las hormigas (T. Rivera, comunicación personal, diciembre del 2016).

Con respecto a los horarios de trabajos, estos varían según las actividades realizadas por cada familia. En ocasiones, el día se distribuye entre el cultivo de la tierra y cualesquiera que sean las otras actividades que puedan alternar con la siembra y generar algunos ingresos extras para la casa; por ejemplo, jornalear, ordeñar o pescar. En el caso de las mujeres, su dedicación a las actividades del cuidado del hogar, el procesamiento y la comercialización de los productos es de tiempo completo:

Aquí ahorita mismo eso no vale nada: el jornal de trabajo está en 10 mil pesos hasta medio día, 20 mil pesos todo el día manteniéndose en el campo. Cuando llegué por acá me ganaba 3 mil pesos el día trabajando, vendiendo bollos me ganaba mil quinientos, llegué a ganarme 14 mil pesos vendiendo dos baldes de bollos en el día. En la madrugada yo me iba tipo 4:30 de la mañana hasta las 11:30 de la mañana y, después, 2:00 p.m. a 11:00 p.m. que llegaba a la casa, eso era muy trabajado. Esto se puso bastante fuerte cuando estaba muy malo por la violencia, pero yo vendía bollo y nunca tuve problema (T. Rivera, comunicación personal, diciembre del 2016).

A veces nos contratan los ricos para ganarnos el día de trabajo ordeñando el ratico y, cuando termino de ordeñar, se va uno para la casa, se baña y se va para el cultivo (A. Gómez, comunicación personal, diciembre del 2016).

Trabaja uno pescando: se va uno a pescar después del trabajo. Por ejemplo, yo me voy a las cinco en punto al Cerro en ayunas a trabajar hasta las nueve y diez; me vengo, me desayuno y si es coger la atarraya o el trasmallo en la tarde o tirar el chinchorrito para coger pincho, me voy a la Ciénaga, tiro, me vengo a descansar y mañana otra vez a trabajar, y así mantiene uno la familia (E. Palomino, comunicación personal, diciembre del 2016). 


\section{El fruto de la tierra: el proceso de la siembra y cosecha}

El proceso de preparación de la tierra y el mantenimiento de los cultivos es otro de los escenarios importantes en el que se reproducen los conocimientos que han sido transmitidos de generación en generación. Aunque el avance tecnológico ha reemplazado muchas tradiciones, en las labores campesinas de la ribera del río Magdalena se mantienen formas artesanales de preparar la tierra y mantener los cultivos, ya sea por decisión propia o por falta de apoyo institucional para la tecnificación de las labores agrícolas. Por una u otra razón, el campesino siempre expone con orgullo el conocimiento adquirido sobre las formas y momentos de desarrollar sus cultivos:

Si las aguas vienen en abril se siembran en abril. El 20 de abril es quema, de ahí para adelante se espera el agua para sembrar la yuca, el maíz y, de veranillo en junio y julio, se hace el monte y se pica para cuando lleguen las aguas otra vez, pero a veces el año pasado se pasó la siembra y no sembramos y el maíz que yo sembré se murió, me cosechó fue la yuca apenas porque la yuca aguanta más que el maíz en la tierra alta, pero en la tierra baja cultivaron bastante (E. Palomino, comunicación personal, diciembre del 2016).

Los cultivos se siembran de la siguiente manera: lo primero es desmontar y echar veneno con la bomba en la espalda y quemar y sembrar. Si es machete, apenas seco el monte se siembra. Eso si usted va a hacer un cuadro o media hectárea se lo alista a los dos o tres días, baja rápido el monte verde en tres o cuatro días lo termina o lo quema. Antes había personas que usaban la magia negra; por ejemplo, este cultivo tenía algo, le echan un secreto. Ya han dejado eso, solo le echan el líquido o tamaron y es bastante fuerte, esos venenos son de cultivos de guayaba, también [los] usaron [en] los cultivos de melón (H. Jiménez, comunicación personal, diciembre del 2016).

Aquí uno siembra si el monte está bajito, pero hay montes que están grandes, entonces le meten guadaña y lo rebajan, lo dejan bajito, fumigan y siembra[n]; a veces, muchos limpian a machete, ponen la tierra a 
Vida campesina en el Magdalena Grande

machete, pero así por lo regular, pero uno la compone con el veneno y queda lista para sembrar (V. Villegas, comunicación personal, diciembre del 2016).

El cultivo predominante en la región de los campesinos ribereños es la yuca, el cual se caracteriza por resistir en tierras con bajo volumen de agua; en un segundo plano, está el cultivo de maíz; además, también se presentan en menor cantidad cultivos de naranja, patilla, fríjol, ajonjolí, sorgo:

Es una tierra de barro fresca. Ahora en el verano uno siembra y se produce yuca, maíz, patilla, ajonjolí, habichuela, melón, papaya, ahuyama, batata... Todo eso se cultiva en el terreno. El maíz dura dos meses, pero hay uno que se está sembrando que es de 45 días; la habichuela al mes se recoge; la ahuyama es demorada; la batata también es el año, y la yuca seis o siete meses [...]. Aquí se cultiva en ese tiempo el fríjol cabeza negra y, de vez en cuando, el fríjol (pero el cuarentano, ese es más rápido, pero al "cabeza negra" le cae plaga y se deja de cultivar), se cultiva yuca, maíz (F. Díaz y Álvaro Gómez. Santa Ana. Diciembre del 2016).

La tierra de por aquí es buena para la agricultura, lo que tú siembres porque el maíz pare bastante: tú siembra[s] batata, yuca. No por una comparación, uno siembra la yuca y la batata ella se extiende para crecer. La yuca la sembramos de metro y medio, pero la batata de seis metros; cuando se extiende, se encuentra una tras otra. El maíz lo sembramos de a dos granos o tres granos y así una mata a otra, porque si uno le echa de [a] cuatro granos se crece y no pare, en una hectárea uno está cogiendo un poco de maíz (M. Contreras, comunicación personal, diciembre del 2016).

Se vive del tomate, ají, guineo, aquí lo único que no se da es la papa, pero con asesoramiento las tierras son buenas. Un gajo de mafufo de por acá uno no puede con él. La gente ve otros cultivos que son más rápidos, pero se quedan admirados por los cultivos ordinarios de mafufo, se parten por la mitad (J. Torres, comunicación personal diciembre del 2016). 
Vida campesina en el Magdalena Grande

Ahora se siembra, [en] enero comienzan a sembrar. Cuando baja la creciente y la tierra está fresca, va bajando el agua y la gente va sembrando. Se siembra mafufo y ahora se siembra ahuyama, pero a la vez yuca y maíz para que no sea solo ese cultivo. La yuca demora seis meses (la usamos para comer) [y] el maíz cinco meses: aquí la gente solo vive de la yuca (A. Rodríguez, comunicación personal, diciembre del 2016).

En lo referente al mantenimiento de las tierras y los cultivos hay una constante en todos los territorios ribereños y [que está] presente en todas las entrevistas realizadas: la falta de asesoramiento en la tecnificación de los cultivos. Las labores de mantenimiento de la tierra y los cultivos siempre se han realizado artesanalmente. Aunque algunos campesinos manifiestan la posibilidad de sembrar otros productos que potencien la producción agrícola de sus territorios, aseguran no tener, no obstante, los conocimientos sobre las formas de atender estos cultivos; por este motivo, las veces que lo han intentado no han obtenido buenos resultados:

Aquí se cultiva la yuca, [el] maíz, [el] mafufo o plátano, [el] fríjol, [el] ajonjolí... tenemos [una] tierra muy fértil, lo que falta es tecnificarla ya que aquí se cultiva a la voluntad de Dios, no hay tecnificación, pero cuando llega el verano ya hasta ahí queda el cultivo; cuando llueve se reactiva, pero tecnificada sería una gran tierra (E. Martínez, comunicación personal, diciembre del 2016).

Ha habido ocasiones en las que se ha[n] querido emplear cultivos de otros sitios como el melón, que se metió en una ocasión, pero fueron otras personas de otros lados. El campesino de aquí le tocó enfrentarse al tipo de manejo de esa planta. Uno busca lo más fácil, donde no invierta tanto, pero imagínate la patilla, que necesita mucho insumo, pero como un campesino no tiene plata ni insumo se va a lo más práctico (N. Quintero, comunicación personal, diciembre del 2016).

El ajonjolí, por ejemplo, no se puede mecanizar mucho, aquí no se mecaniza la tierra: una vez lo sembraron bastante y lo dejaron. Es que el ajonjolí aprieta la tierra y es de bastante raíz y ningún animal se la come, ni la vaca, [el] burro o [el] chivo, eso no se lo comen porque es babosa; los 
Vida campesina en el Magdalena Grande

pájaros sí o las cotorras, pero toca pajarearlo con bola de barro, curumuta o troja y ahuyentarlo. Una troja son tres palos y [se] coloca una arriba con una honda de mano arriba de un árbol; son tejidas de pita larga, en nylon, y después se le pega los perreros y dele barro o curumuta. Se la saca, uno la pone a secar, y la levanta uno (si es barro melcochado mucho mejor, porque se encalicha). El plátano se siembra normal; hay unos que fertilizan y le echan urea a la mata porque hay tierras buenas para eso. Aquí [lo] hicieron con los naturales cuando nos hicieron una charla, el señor Braulio. Por ejemplo, con el tabaco, la semilla del ni, la mariposa que le cae a la naranja le colocan trampas. El plátano le ataca más al choncho y se va amarillando; unos se mueren y no produce[n] y, si alcanza a echar el gajo, eso no sirve (H. Jiménez, comunicación personal, diciembre del 2016).

Es que por aquí la mayoría nunca, pues yo que he nacido aquí, la gente por aquí no siembra o no se dedica al ajonjolí y es un cultivo que da, es que a veces no hay quién nos oriente para hacer este cultivo. La Umata del Banco aquí no ayuda a nadie. Crearán un programa para sembrar una hectárea de esto, no hay asesoría técnica que es lo principal para el campesino (V. Villegas, comunicación personal, diciembre del 2016).

Una de las principales problemáticas que afecta a los campesinos de estas zonas tiene que ver con las vías de comunicación, pues como mencionamos inicialmente la entrada a las zonas agrícolas se encuentra en condiciones deplorables. Las vías terrestres están destapadas y son de tierra y barro, lo que hace que en épocas de invierno sean intransitables, mientras que las vías fluviales resultan, en muchas ocasiones, más ágiles para la extracción de los productos hacia puertos donde pueden sacar los productos por carretera. Un ejemplo de esto nos lo da el señor Nelson Quintero (diciembre del 2016), quien nos cuenta que, para sacar sus productos, "es por vía de agua, los desembarcan aquí en el puerto artesanal y los camiones llegan y cargan, traen los bultos en la canoa y llegan hasta aquí los negritos para sacarlo por carretera" (comunicación personal). Sin embargo, en época de verano - que los caños y ciénagas se secan-el transporte debe hacerse por las vías en mal estado ya que las administraciones municipales no realizan la inversión adecuada en infraestructura 
Vida campesina en el Magdalena Grande

en las zonas rurales. Así, frente a este panorama, los habitantes siguen realizando sus recorridos por estas vías en motos, burros, bicicletas y canoas. La ausencia de vías de comunicación óptimas para la extracción del producido de la cosecha se vuelve una pesadilla para el desplazamiento de los campesinos y para la calidad del producto.

Imagen 93. Transporte de productos en canoa

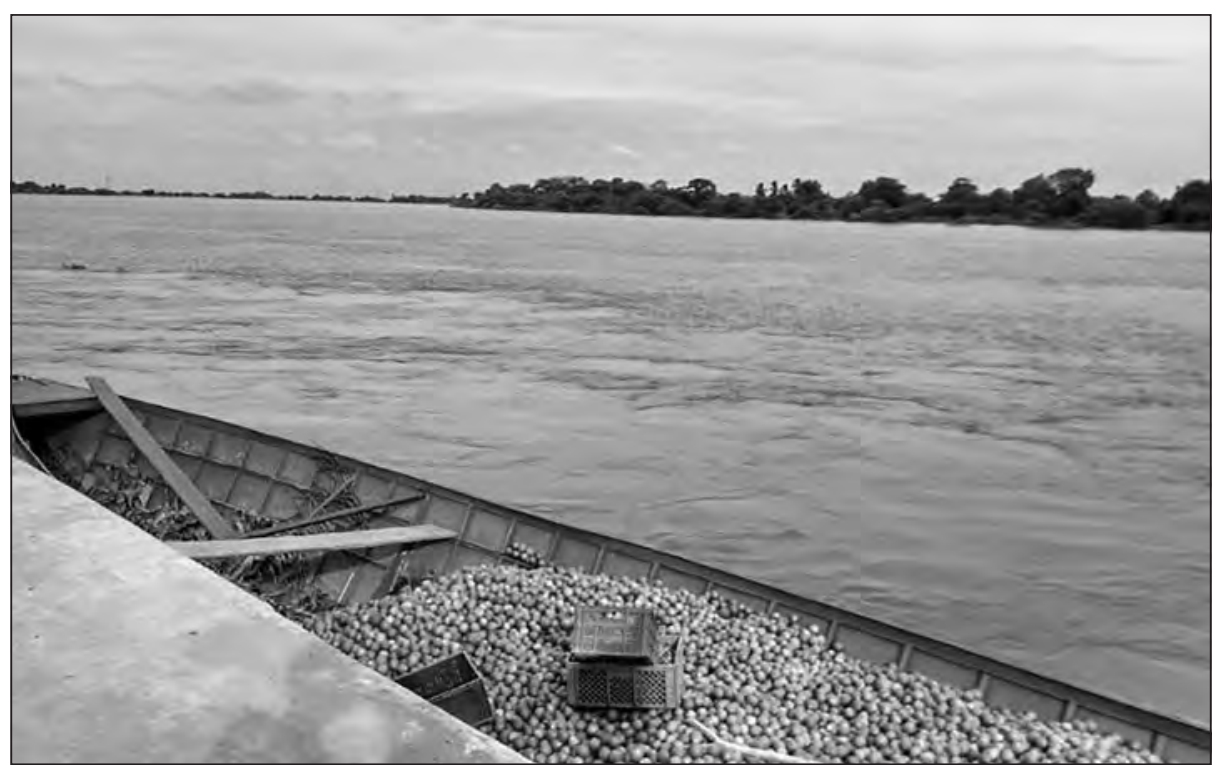

Fuente: Archivo Oraloteca (2017).

Hay muchos que se van en burro porque está lejos, el que tiene moto se va en moto, el que tiene cicla, el que se va a pie. Yo antes me iba a pie y tenía que echarme la carga en el hombro para acá, así hasta cuando compré una cicla (E. Palomino, comunicación personal, diciembre del 2016).

Mira cómo están las vías. Ahorita tan siquiera pasa transporte porque ahora que llovía ese camino era una sola ciénaga y uno tenía que irse bajando de las motos para poder pasar. Si había un terrón, te lleva... porque no hay una vía [...]. Aquí tenemos que cruzar un puente, pero ahora se hundió y no podemos pasar. Queremos un puente, el dueño de los terrenos es el que nos colabora con los vehículos y nos da la madera 
Vida campesina en el Magdalena Grande

para nosotros hacer el puente de nuevo [...]. Los políticos de turno nos tienen huérfanos: no tenemos carretera, solo hay trocha, ahora que estuvo la gobernadora cepillaron la carretera por encima (F. Díaz, A. Gómez y E. Martínez, comunicación personal, diciembre del 2016).

La comercialización de las cosechas se da por medio de la visita de camiones provenientes de grandes centros de abastos como Valledupar, Santa Marta, Barranquilla, o de algunos mercados municipales que recorren toda el área subregional recogiendo los frutos de la temporada de cosecha, fijando los costos de las cargas recogidas en cada uno de los corregimientos y veredas.

Imagen 94. Medio de transporte en los pueblos ribereños

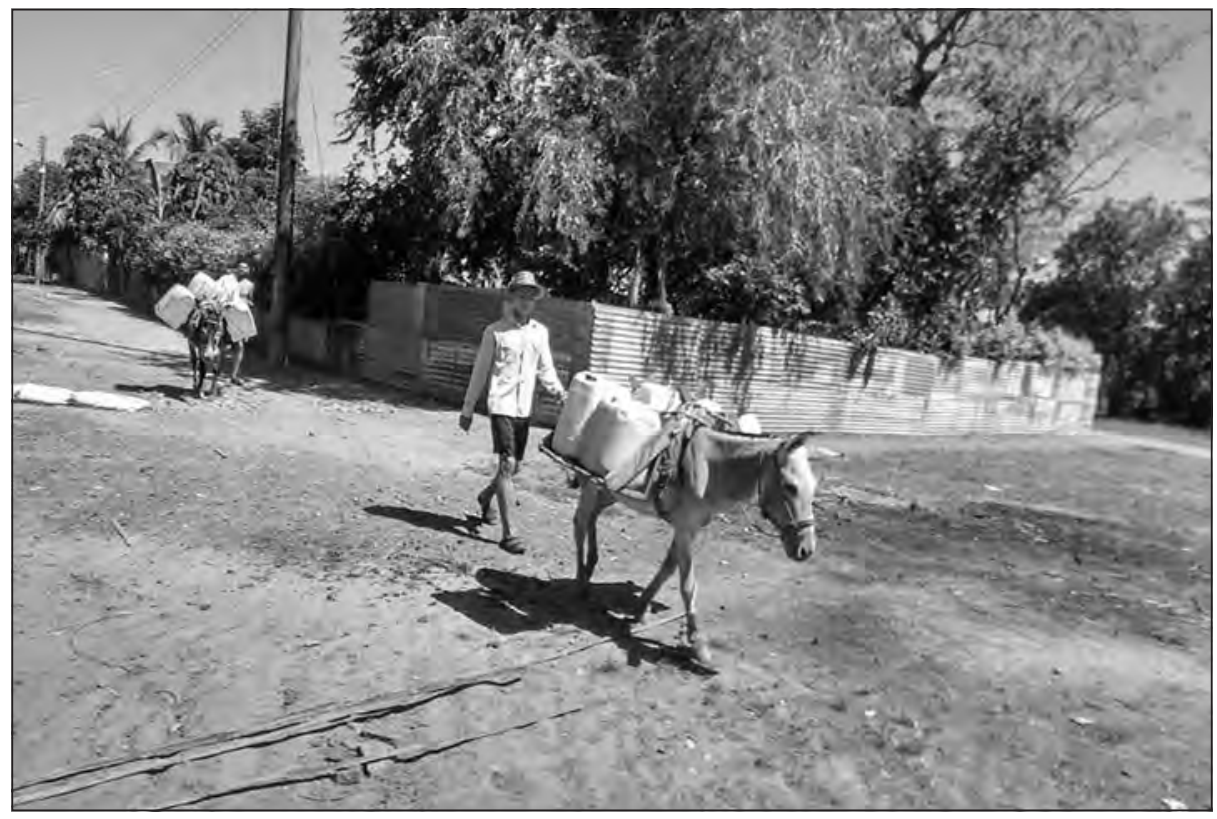

Fuente: Archivo Oraloteca (2017).

A nosotros nos alimenta la Montaña, San Fernando, Peñonsito, el Horno, donde hay agricultura. La yuca pasa[n] una o cinco motos diarias sacando yuca en bulto para venderla. Por ejemplo, la venden a Cabrera o [a] un pueblo que está cerca que se llama Filadelfia y le dicen Pita. Toda la yuca 
la sacan de esta región [...]. Aquí no hay quien compre una libra de yuca; es decir, [en] este pueblo lo más caro que está la libra de yuca es 300 pesos. Aquí la venden [en] 3 o 4 en mil pesos, sino le dan 10 mafufos en mil pesos, está guapo porque todo el mundo cultiva. Esto es de los pueblos donde encuentra más barato (M. Díaz y L. Martínez, comunicación personal, diciembre del 2016).

Anteriormente, la gente se metía por la carretera y llegaba a San Roque, San Felipe, San Eduardo. Eso compraban por bultos de fríjol, la ahuyama, y se metía camión: ellos mismos cogían y le vendían al camión, no tenían necesidad de comprar en el Banco. El comercio del Banco acapara todo: usted compra una carga de maíz y vale 70 mil pesos y a los cinco días vale 100 y pico de mil de pesos y le toca traerlo para acá (E. Palomino, comunicación personal, diciembre del 2016).

Ahora siembra uno en enero el fríjol, la patilla, son los productos más caros que se venden: la patilla por unidad se vende a 4 mil pesos, si uno cosecha mil o 2 mil patillas... El fríjol, [la] patilla y [el] maíz, pero el maíz de 120 mil pesos no sube, pero en cambio el fríjol [que] siembre lleva 30 mil o 40 mil pesos la arroba, cuando la producción está escasa y comenzando (W. Quiñonez, comunicación personal, diciembre del 2016).

De Plato vienen compradores de yuca en carro. Le[s] vendemos por bolsa o hectáreas de yuca; lo que le vayan a comprar, eso lo pagan barato. Este año me antojé de sembrar ahuyama y allá la tengo, no he podido venderla porque no hay quién la compre. Ahora la voy a regalar porque dicen que hay bastante ahuyama, entonces me encarté (M. Contreras, comunicación personal, diciembre del 2016).

Estamos en un sector [en el] que estamos escaso[s] de empresa, donde se articule el personal y lo que pueda lo entregue a buen precio, porque el problema es que el campesino produce, pero le toca enfrentarse a la plaza del acaparador que es el que pone el precio. Son comercializadores por fuera, intermediarios para Barranquilla y otras ciudades de la costa, le compran al precio que ellos consideren (N. Quintero, comunicación personal, diciembre del 2016). 
Vida campesina en el Magdalena Grande

El corregimiento de los Negritos es uno de los puertos artesanales hacia donde muchos campesinos de la zona sacan los productos, debido a que es una de las comunidades más cercanas a la que llegan camiones de otras ciudades a comprar sus productos. A diferencia de muchas otras comunidades, los Negritos cuenta con una infraestructura mínima heredada de la época en la que se encontraba en su territorio la Petrolera Andian, que influyó en el pasado del corregimiento y cuyas actividades extractivas y la residencia de empleados foráneos demandaban abastecimiento de alimentos, lo que conllevó a la bonanza campesina en el territorio:

Estaba pelado y trabajaba, había junta campesina, ellos trajeron una caseta cuando existió la compañía Andian, petrolera, estuvieron hasta el 84 y ahora funciona el colegio de bachillerato. Trajeron una caseta tubular al hombro y ellos hicieron, por medio de Rodrigo López, el Gimnasio Rangel. Vinieron primero en Aguas Frías, en Sabanas, y Algarrobal no solo cultivó porque para allá tenían galpón en Aguas Frías; la pastoral apoyó también panadería y cultivo. Había más movimiento porque allá consumían arroz, compraban pescado y había fincas con más trabajadores. [Ahora] hay hectáreas y solo para dos trabajadores y de 800 hectáreas, cuando eso habían 8 o 10 personas trabajando, había mucho más empleo; hoy hay poco empleo (H. Jiménez, comunicación personal, diciembre del 2016).

Sin embargo, la actividad de trabajar la tierra no es la única vocación que tiene el campesino de la zona del río; esto se debe a que las ganancias económicas que deja la producción de la tierra no alcanzan para la manutención de las familias. Por ese motivo es frecuente encontrar campesinos que alternan la actividad agrícola con la pesca, la albañilería, la fabricación de ladrillos, la fabricación de carbón, el corte de madera y oficios informales como el moto-taxismo u otras actividades que se encuentran extintas como las balsas:

Se trabaja el carbón, que ha destruido mucha madera por aquí: eso cogen un palo y lo repican por trozos y entonces hacen el fogón y le colocan leña y más leña y hacen algo así como por decir un cuadro, lo hacen redondo y [lo] reducen tapándolo con hierba y, después, con tierra, y le echan candela hasta quemarse todo. Tiene[n] que estar pendiente[s] porque si se 
Vida campesina en el Magdalena Grande

llega a romper se daña el carbón, entonces toca taparlo. Cuando el horno que hasta arriba y abajo, hasta que saca la candela, se apaga, y lo abren, y sale el carbón para cocinar, fritar. Acá también se trabaja el ladrillo y van colocando una hilera por aquí, una en el medio; de ahí se va alzando y se va sellando arriba; de ahí lo sellan con barro y le dan candela abajo y eso comienza a arder con una cantidad de leña hasta quemar toda la ladrillera para sacar ladrillos de las casa[s]. Se trabajó en las balsas: cortaban las maderas o bigas, podía[n] ser de cinco metros o seis metros - un palo lo podían cortar de diez metros-; entonces, ponían el de diez metros así y otro de cinco, amarraban y tiraban la balsa de barrancas hasta Barranquilla, llevándola por todo el río. Ahí iban montados por toda la balsa, esas eran las balsas para navegar el río, la madera se vendía en Barranquilla y ahí en remolcadores hasta Barrancabermeja. Ese es el trabajo que hace el campesino: el cultivo, carbón, ladrillo y, ahora, la madera; anteriormente, la madera la sacaban con sierras. Las sierras eran unas cosas largas de metal donde se colocaba uno arriba para sacar tabla y todo tipo; antes se trabajaba mejor porque ahora es con motosierra, que es más fácil, pero ya no trabajan lo que antes trabajaban, antes había grandes vigas, mi papá trabajó en eso (T. Rivera, comunicación personal, diciembre del 2016).

\section{El campesino y la pesca: un acercamiento a la actividad pesquera}

Aunque ya lo habíamos mencionado con anterioridad, es importante recalcar la importancia que tiene la pesca artesanal para las comunidades ribereñas del Magdalena, pues es una actividad que siempre ha estado presente en el territorio y que se alterna con la producción agrícola según los ciclos del clima. El señor Eliodoro Palomino (diciembre del 2016) nos dice que "el que no tiene el pedacito de monte solo se dedica a la mera pesca, de ahí compra la yuca, el café, la panela, al que le gusta beber, le gusta fumar y ahí" (comunicación personal):

Es la cultura del pescador artesanal, porque hay cuatro variedades de pescadores: los que estamos en la región somos artesanales, porque no hay ni por deporte, ni industrial, ni ocasional; la mayoría es artesanal. Entonces, 
Vida campesina en el Magdalena Grande

ellos se dedicaron a la pesca y no se preocuparon por la tierra; estoy hablando de los primeros pobladores de esta zona, las familias de 120 años o 130 años atrás (W. Díaz, comunicación personal, diciembre del 2016).

Se pesca desde temprana edad, todos saben tirar atarraya, el que no sepa tirar atarraya no es sitionuevero o no aprendió, pero aquí todo el mundo pesca, pero había rato que no había pesca por las crecientes, porque tú sabes que el verano, cuando hay sequía, pues... nosotros tenemos un caño aquí que se llama Caño Grande, es un caño grandísimo y hondo, de todo pescamos: pescado, bagre, y tenemos la Ciénaga de Chilloa o Chimila, queda aquí mismo; también tenemos la Rinconada, que es una ciénaga grande. Le decimos la Rinconada porque ahí entra[n] la Ceiba, Pedregosa, Playa Blanca, Santa Teresa y es una sola entrada donde se llega a los pueblos, cada una por su brazo (E. Pedroso, comunicación personal, diciembre del 2016).

De cultivar tengo 20 años que no cultivo porque me empeñé en comprar pescado, vivir de la pesca y vender pescado al por mayor. Tengo años que no cultivo porque es muy duro, por eso decidí vivir de la pesca. Legalmente, ahora mismo había más pescadores que agricultores porque las cosechas no estaban dando por el mal tiempo. Entonces, la gente se ponía a pescar, porque anteriormente en estos cinco años uno sembraba y se perdía, entonces la gente prefería pescar que cultivar porque perdía el tiempo cultivando. Hubieron cultivadores que, para tener la mata de yuca, tuvieron que sembrar hasta tres veces porque sembraba[n] y se moría; entonces, como no había acompañamiento del Estado se ponían a pescar. De tres años para acá la que nos estaba dando de comer a nosotros es la pesca; además, el pescado estaba perdido. Yo creo que ahora es que estoy pescando. Es que el producto se ve y se agarra, entonces hay pescado; pero si van y dicen "nada, no hay ninguna", entonces sí uno dice que la vaina anda mala. Por ejemplo, la Ciénaga de Chilloa es muy grande y la mojarra hay bastante cantidad ahora; si usted se mete a Caimanera (porque yo estuve ayer allá y todo el mundo anda es cazando para coger mojarra), usted va y ve los patios, calles, carreteras como la del Burro y la vereda Caimanera donde ahora se ve la mojarra porque es lo que hay y agarran en cantidad (V. Mozo, comunicación personal, diciembre del 2016). 
Vida campesina en el Magdalena Grande

En las comunidades ribereñas, como el caso de la Ciénaga de Zarate, las faenas de pesca despiertan una nostalgia de la abundante producción de antaño, que contrasta con el recuerdo de la intensa sequía que se extendió por más de cuatro años hasta finales del 2016, fecha en la que realizamos las salidas de campo para esta investigación:

Aquí el pescado era en cantidad. Antes el pescado no era comercial, la gente pescaba para la comida. Recuerdo que en el 1983 empezaron a comercializar el pescado en camiones. A esta ciénaga llegaban más de mil pescadores porque venía gente de la Raya por Magdalena - casi los límites de Antioquia- y de Barranquilla llegaban aquí a pescar. Eso venía un seiscientos en la mañana y en la tarde otro cargado con pescado enhielado: se echaba una capa de pescado, una capa de hielo picado en bloque y así. Cuando era creciente llegaban los Jhonson de Barranquilla y le metían 2 mil pescados o 4 mil pescados a un aparato; arrancaba en la mañana y la tarde salía otro en cantidades. Este pueblo, el año pasado la Ciénaga, que es el sustento, se secó, sequesita, y eso que usted ve ahí como ciénaga era pasto; entonces [a] la gente le tocó migrar, se fueron del pueblo más de cuarenta familias, usted sabe que en año veranoso no hay agricultura y, si no hay pesca, este pueblo vive de la agricultura y la pesca. Ahora volvieron para fin de año y se están yendo. Estos pueblos han pasado crisis económicas. Al comienzo era visitado por Corpamag, pero solo era tomar fotos. Nosotros quedamos entusiasmados por organizarnos para ver qué íbamos a conseguir todo[s] estos pueblos. En esa sequia se sufrió y el sufrimiento sigue por el año de verano y la agricultura es muy poca que queda y aquí es para que tuviera la tierra donde cultivar (D. Torres, comunicación personal, enero del 2016).

Con la atarraya no le digo que hace años atrás uno iba de día o noche [y] en poquito traía un ciento de pescado, lo que uno quisiera, pero hoy se muere tirando atarraya. El año pasado llegaron a coger de 50 a 80 loras de libra y media o de a libra, pero después se perdió por el trasmallo; ahora no cogen nada. La otra cosa que dicen es que el Gobierno va a ayudar para limpiar la Ciénaga, pero, ¿cuándo? Ahí quedó el proyecto que solo le dijeron para sacar el carnet y nada (F. Díaz, comunicación personal, diciembre del 2016). 
Vida campesina en el Magdalena Grande

Con la pesca se bebía, se vestía y compraban el bastimento, no se preocupaban, pero cuando desaparece el renglón de la pesca sí se preocupan porque ya no hay cómo usted comprar, tiene que verse en la obligación de producir. Tenemos que pedirle al que está en la tierra y la tiene que la preste por dos años, pero después le sembramos la paja, es el compromiso. Aquí todavía se vive de manera antigua (W. Díaz, comunicación personal, diciembre del 2016).

Esta relación campesinos/pescadores evoca aquella idea del "hombre anfibio", tan difundida por el profesor Orlando Fals Borda en su trabajo sobre el campesinado en el Caribe colombiano: una relación construida desde antaño y que les permite la supervivencia en estas comunidades en los territorios. Sin embargo, vale la pena mencionar que, a pesar de ser actividades que los campesinos alternan en relación a las condiciones ambientales de cada momento, muchos de ellos también se especializan en una u otra actividad. Es así como, en ocasiones, encontramos campesinos que saben pescar, pescadores que no saben sembrar, pescadores que no tienen el suficiente conocimiento sobre los ciclos de la tierra y los productos que se siembran o campesinos que no conocen los ciclos del río y las especies de pescado que se pueden encontrar en $\mathrm{X}$ o Y sitio. A pesar de esto, el compañerismo y la solidaridad entre habitantes hace que estas pequeñas problemáticas desaparezcan, pues el que no sabe pescar aprende con el pescador y el que no sabe sembrar aprende con el agricultor. El trabajo en equipo y el compartir forman parte de los valores campesinos que están presentes en esta subregión del departamento:

Hay dos clases de problemas: si usted pesca y no tiene bastimento es malo, pero si usted tiene bastimento y tiene pesca está bien. Esta zona para acá se perece mucho cuando el bastimento se pone rucho y en época que no hay creciente se pone mal y tenemos que ir a Guamal; allá todo es comprado, todo el tiempo que hemos estado sin pesca estamos en Guamal porque además hay que ir por bastimento y comida allá. Con pesca y con Rosa fuese distinto. Este pueblo que si usted no tiene nadie le niega nada a usted por ese lado. La gente le da la yuca y el pescado, somos un pueblo unido y colaborador (E. Pedroso, comunicación personal, diciembre del 2016). 
En la pesca, las temporadas de bonanza o de escasez están determinadas por los ciclos del río, de manera similar a la actividad agrícola, aunque con la diferencia de que en la pesca el ciclo llamado "la creciente" no es nefasto ni representa pérdida a su economía sino que, por el contrario, produce prosperidad y abundancia durante las faenas: "la época buena [para] pescar es octubre, noviembre y diciembre, porque son épocas de subienda; entonces, estas son las épocas buenas, se pone barato el pescado, en esta temporada tiende a bajar" (V. Mozo, comunicación personal, diciembre del 2016).

La abundancia de pescado la hubo en el 2010 por la creciente: tiraba el trasmallo y salía fuleteado. Estas eran las épocas. Después, cuando bajó, no había a quién venderle. Para esta zona no había bocachico porque las ciénagas se secaron de cinco y seis varas de agua (E. Pedroso, comunicación personal, diciembre del 2016).

Durante las faenas de pesca la colaboración grupal es fundamental para la recolección de los peces, que se lleva a cabo en grandes y pequeñas embarcaciones elaboradas con madera en las que los pescadores llevan consigo las artes de pesca como el trasmallo, el chinchorro, la lanza (elementos que son elaborados artesanalmente en los asentamientos o son obtenidos sintéticos en los centros urbanos más cercanos, como el caso del trasmallo). Los pobladores son conscientes de que estos nuevos materiales - si bien han facilitado en algún modo la actividad de la pescahan deteriorado el medio donde se reproducen los peces, lo que a largo plazo ha generado la desaparición del recurso pesquero de sus territorios, obligándolos a desplazarse cada día a zonas más lejanas para realizar sus faenes o, en su defecto, a comenzar a capturar aquellos peces que están por debajo de la talla mínima estipulada por la ley:

Mi papá era pescador y uno aprende de los viejos. Mi papá era un pescador de río con chinchorro. Entonces cogía bagre, porque anteriormente mi mamá decía que el pescado [bocachico] no lo cogían, solo agarraban el bagre y el pescado, cuando ya veían que venía la subienda de pescado, le alzaban el chinchorro, pero no lo cogían porque no tenía precio el pescado, nadie lo valoraba y ahora el pescado es lo más caro que hay, el 
mejor producto, ahora todo el mundo pregunta es por el pescado, dicen que está en vía de extinción, que no lo había. Está ahora pequeño. Antes, el pescado era de libra y de dos libras; ahora está de media libra y tres para una libra, pero este año por la creciente lo hemos conocido, porque teníamos tiempo que no conocíamos el pescado. Ahora las empresas nos ha[n] facilitado las cosas porque antes había que tejerlo a pulmón, porque ahora [el que] tiene la plata va al Banco y lo compra y mañana mismo ya está pescando. Anteriormente, duraba hasta un mes para hacer el trasmallo; ahora ya viene listo. Porque usted no sabe lo difícil que es tejer ese nylon...había gente que duraba hasta un mes para tejer un kilo. Ya al otro día está pescando porque ya está hecho, hay más facilidad. Hay diferentes tipos: hay un chinchorro que cuando la Ciénaga está limpia lo tira y lo arrastra, no lo pesca como tirar el trasmallo aquí y dejar que ella misma caiga, sino que uno lo arrastra a la orilla a la fuerza, ya ese es chinchorro. Hay un trasmallo que usted lo tira y si camina pues se agarra, esa es la pesca de aquí. Ahora mismo están utilizando para esa mojarra 3.60 o 3.50 de calibre de malla y para pescado el 3.18 , pero aquí todo el municipio es con $3.50,3.30$ y 3.40 calibre de malla y llegan unas mojarras bonitas (V. Mozo, comunicación personal, diciembre del 2016).

Imagen 95. Ciénaga de Zarate

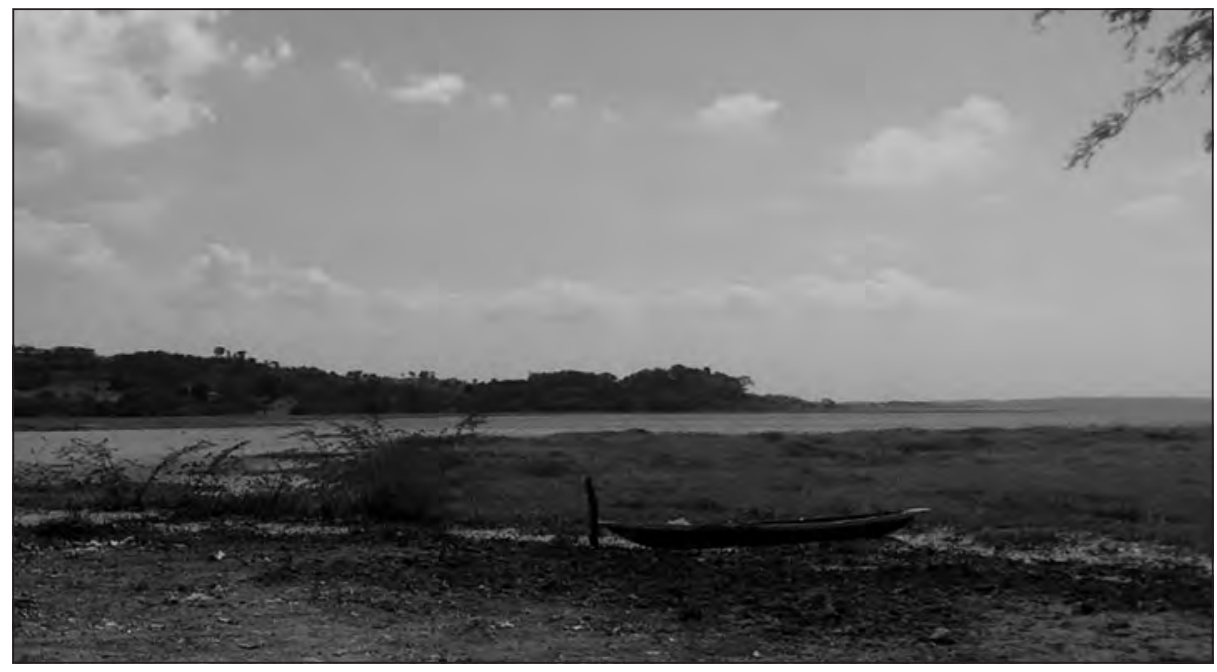

Fuente: Archivo Oraloteca (2017). 
Entonces había comida. El pescado uno lo veía en cantidad e iba al puente, y tiraba tres lanzas, y traía un poco de pescados, ipero eran pescados! Como el bagre, entre otras cosas, pero aquí lo [que] abundaba más era el pescado "bocachico". Hoy en día no se ve, en ese tiempo lo comíamos, pero ahora no porque no lo hay; hay, pero pequeñitos, lo pescan por allá por Algarrobal, que es una zona de pesca, porque esa es la Ciénaga de Chilloa y eso habilita a varios pueblos y [a] toda la región. Y [también hay] una que está por la vía de Belén: son dos ciénagas grandes y todos estos pueblos viven es de la ciénaga porque por allá no cultivan, se dedican es a la pesca (V. Villegas, comunicación personal, diciembre del 2016).

Cuando había bocachico en el río era con la atarraya. El chinchorro ha acabado las especies: uno coge pequeñito. Anteriormente, se convidaba a un tío y [a] un compañero para ir al puerto de la Sierra y, al día siguiente, saladito se vendía a los pueblos de Bolívar por carretera. Entonces, ahora se le vende a un camión y se lo lleva todo (W. Quiñonez, comunicación personal, diciembre del 2016).

Ante[s] íbamos a pescar y cogíamos un ciento de bocachico. Desde que llegó el trasmallo destruyó todo. Entonces, hay personas que se aferran a cuidar la Ciénaga y hay hasta muertos. De aquí fueron hasta San Roque y echaron 10 mil pescados pequeños $y$, cuando aquí colocaron como un millón, los pescadores tiraron trasmallo y acabaron la Ciénaga: así, cuando va a haber producción, el mismo hombre acaba con la naturaleza. Aquí anteriormente era el bocachico que era el original, ahora ha quedado la lora estilo mojarra (es el que más abunda), pero ahorita que se creció, aunque esta es más pequeña, pero la gente se ha escondido y meten el trasmallo y lo ahuyentan (F. Díaz, comunicación personal, diciembre del 2016).

Ese es un animal que se reproduce mucho más que otros pescados, por eso está abundando más que el pescado, porque el pescado se reproduce cada 6 meses; en cambio, la lora cada 45 días, entonces se reproduce muy rápido. Además, el pescado lleva otra cosa: que si no hay creciente no hay pescado porque el pescado en las crecientes desova, entonces empieza a 
Vida campesina en el Magdalena Grande

poner y preñarse; en cambio, si no hay corriente, nada (V. Mozo, comunicación personal, diciembre del 2016).

En términos organizativos debemos decir que existen más organizaciones de pescadores que de campesinos, aunque sus capacidades de gestión en el territorio muchas veces son limitadas. Estas tienen como objetivo gestionar recursos para mejorar las técnicas de producción y, por ende, las condiciones de vida de sus familias, la comercialización a precios justos en los mercados locales o con los intermediarios y la coordinación de actividades comunitarias. Sin embargo, frente a estos procesos se presentan voces críticas sobre los procesos desarrollados y reflexiones de la pesca artesanal:

Hay asociación de pescadores, pero no funcionan. Porque la gente es negativa y no cree. Por lo menos hace como dos semanas nos mandaron de la Alcaldía para los que fueron afectados por la ola invernal del 2016, pero nos piden documentos y más documentos [...]. Existe una organización de piscicultura y tiene personería jurídica. La personería jurídica no se les vence, pero eso es de la comunidad. Hubo para cambiar el comité, pero dicen que "el que traga más saliva es el que traga más harina". La gente se queda quieta. Una vez para la Ciénaga se limpió para amontar y abrir los puertos por la salida, eso lo hizo Corpamag, y no se informó a la comunidad, solo a un grupo de personas sin consultar (S. García y E. Palomino, comunicación personal, diciembre del 2016).

Con respecto a la comercialización del pescado, al igual que con los productos agrícolas, la intermediación entre productor y consumidor es la que genera mayor ganancia, quitando poder adquisitivo - que les permitiría fortalecer sus procesos organizativos- a las organizaciones de pescadores:

Lo que pasa es que la comercialización hacia afuera ha acabado todo eso porque anteriormente de aquí del Banco no [se] exportaba hacia afuera y ahora no, porque hay mucha comercialización hacia afuera, todo lo que uno pesca aquí lo lleva uno hacia afuera. Yo compro y mando hacia afuera, mando para el Valle porque tengo unos contactos allá. Yo compro 
Vida campesina en el Magdalena Grande

aquí o allá, donde vea el producto allá voy a recogerlo. No quedarme parado porque viviendo de la Ciénaga esta... mejor dicho (V. Mozo, comunicación personal, diciembre del 2016).

Aquí mismo, vienen de Plato compradores, lo reciben en las canoas y ellos se los llevan y venden allá para repartirlo. Cuando hay época de subienda lo llevan a Barranquilla, Valledupar (Emilse, comunicación personal, diciembre del 2016).

Finalmente, otro elemento a resaltar es la fabricación artesanal de las casas, pues estas hacen parte del acumulado de conocimientos transmitidos de padres a hijos. La mayoría de las zonas donde habitan estas comunidades son invasiones o tomas de tierra que se presentaron hace más de cincuenta años. Las casas fueron elaboradas con los recursos que encontraban en su entorno $y$, aunque actualmente existen casas que ya han sido construidas de material, se mantiene la tradición de aquellas casas que son fabricadas con bahareque, ladrillo artesanal, madera o material reciclable:

Vivimos en Santa Ana y en el barrio la Paz, allá hay como 30 casas. En el barrio la Paz llevamos 12 años. Esa zona eran unos naranjales como una granja, ahí comía el ganado de los campesinos. Cuando estaba solo con mi papá a él se la cedieron para sembrar y nosotros sembramos toda la tierra y, a los 4 años de estar cultivando, se metieron los invasores, pero no se metieron con el cultivo, sino que por la misma línea de la yuca tiraban la cerca y esperaron que la yuca cosechara y nosotros la arrancamos para ellos proceder a parar los ranchitos. Las casas eran de palma y de plástico: hacíamos una "curranchita" y le colocamos plástico (A. Gómez, comunicación personal, diciembre del 2016). 
Imagen 96. Construcción de casa de bahareque

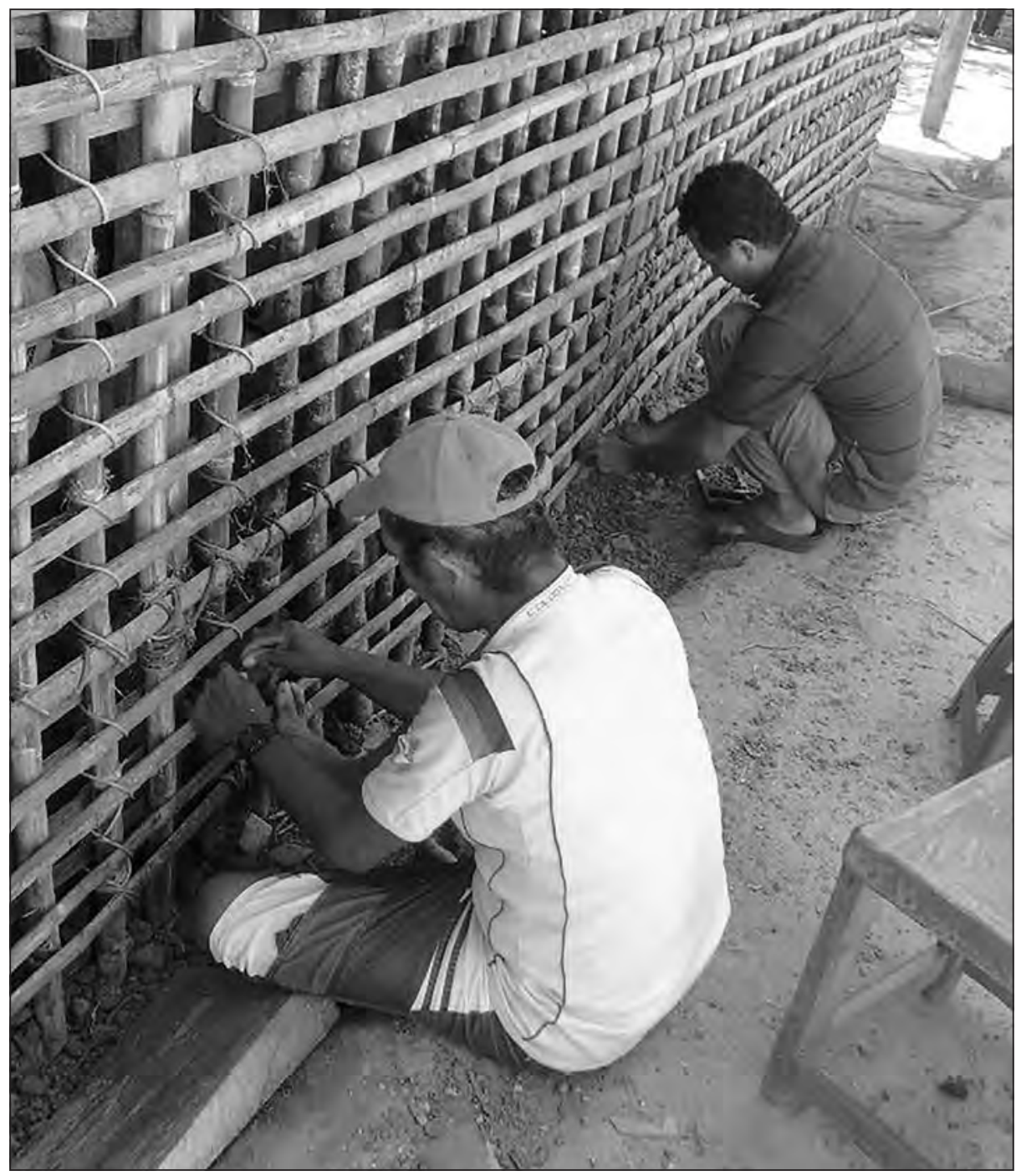

Fuente: Archivo Oraloteca (2017)

Se aprende a hacer las casas de bahareque con los papás y siguiendo las tradiciones. Si tiene el barro recién echado es más fresco. Posteriormente, se corta palo, se amarra y se le mete el barrito, la boñiga y se va echando. El palo es la guadua y es silvestre. Entre más haya personal... lo que más 
Vida campesina en el Magdalena Grande

demora es trozar los pedazos y después les echa el barro y la boñiga a las casas de bahareque. Se necesita una arena que no se cuarte tanto; entre más arcilloso mejor (E. Martínez, comunicación personal, diciembre del 2016).

\section{“El problema es que la tierra no es de quien la trabaja": el problema de la tierra en los pueblos ribereños}

La discusión acerca de la tenencia de la tierra ha sido, por más de cincuenta años, una de las principales discusiones en la nación. Este es uno de los principales hechos que desencadenó el conflicto social y armado que vive el país. Es por ello que factores como la ocupación, distribución y el uso del territorio han llevado a discusiones constantes entre los campesinos, el Estado y los grandes terratenientes; sin embargo, esta situación no ha sido un obstáculo para el trabajo de la tierra y su producción. Por esta razón, reclamaciones e invasiones de tierras se presentan cada día en las zonas baldías de la región: "todos tienen rosas, pero las rosas se hicieron fuera del playón, son tierras del Estado, por lo que esas tierras no tienen dueño, pero usted coge, asegura media hectárea o una hectárea y, después, suelta la tierra" (E. Pedroso, comunicación personal, diciembre del 2016):

Se presenta en todos lados y en todo el país: la falta de tierra para cultivar, digamos que el 70\% de los campesinos no tiene para cultivar, entonces tiene que usar un terrateniente que tenga un terreno que no esté apto. Como tiene monte, entonces el terrateniente dice que lo laboren y trabaje, aproveche el espacio y, luego de talar el árbol, le dé limpieza para poner a tono el terreno. Cumplido cierto tiempo, le toca entregar la tierra, una especie de contraprestación o canje; la cede, pero tiene que entregársela en pasto (N. Quintero, comunicación personal, diciembre del 2016).

Casi todos estamos en tierra prestada. Unos al cultivo y, otros, a la pesca: es la única forma de sobrevivir en la Ciénaga de Chilloa. Por medio de ella sobrevivimos y, en la mañana, se van a trabajar la tierra casi todos los campesinos para cultivar el maíz, la yuca. Se dedican a cultivar (la yuca, el maíz), pero no todos tienen el terreno y se lo prestan para que cultiven 
Vida campesina en el Magdalena Grande

(pero no todos): los ganaderos tienen la tierra y le ceden un pedazo para que cultiven, y todo el tiempo ha sido así (S. García, comunicación personal, diciembre del 2016).

Esa tierra era de un cuñado mío y me dio para trabajar. No tengo tierra para trabajar, así le[s] sucede a muchos por acá. El amigo que tiene le da para que haga la matica, pero no sé qué pasa por aquí porque el Banco -a pesar de que tiene bastante gente en la política en Bogotá y Magdalenatiene mucha gente en la política, pero esa gente no miran a la pobreza, sino que miran los bolsillos de ellos y el pobre lo dejan botado. Ahora poco trajeron unos bultos de abonos, unos muchachos de no sé dónde, y llegaron donde mí y regalaron unos bultos de abono triple 15 para que le echara a las matas. A mí me regalaron un bulto y yo he ido a echarle a la yuca y el maíz y me regalaban las libras (E. Palomino, comunicación personal, diciembre del 2016).

En el caso mío, ahí tengo una cosecha de maíz, pero uno la utiliza para alimentar la gallina y pensando en los animales, porque uno tiene la gallina y uno tiene un desayuno porque ella comiendo le va a producir huevo y eso está seguro... Y, bueno, complementa uno con lo otro. Entonces ahorita le comentaba que hay necesidad o una debilidad que es la tierra, que no tenemos y es del Estado. Cuando viene la creciente el agua llega a nuestras casas, es por eso que estamos en una zona de alto riesgo, pero hay unas franjas de tierra que están buenas y está[n] en mano[s] de otra gente que no las va a prestar porque la[s] necesitan para utilidad ganadera: los ganaderos (W. Díaz, comunicación personal, diciembre del 2016).

La tierra es de los ricos y uno les pide un pedazo de tierra para uno cultivar. Algunos hacemos el pasto para pagar o sino nos meten en problema. A uno le dan una hectárea o dos hectáreas, pues lo que uno alcance a sembrar, esa es la vida de por aquí. Eso decían de que iban a repartir una tierra para los pobres, pero qué va... eso quedó en "veremos". Por ahí vino un man del Incoder, hacían monte y cada vez que nos reunía nos quitaba plata; entonces, se perdió (M. Contreras, comunicación personal, enero del 2017). 
Vida campesina en el Magdalena Grande

El problema de la tierra ha tenido como mediador al Estado colombiano; por ello, instituciones como las Unidades Municipales de Asistencia Técnica Agropecuaria (UMATA) son las más cercanas a los procesos agrícolas del campesinado. Sin embargo, según relatan los campesinos, esta intermediación estatal a través de sus instituciones solo ha dejado malas experiencias y sinsabores en las comunidades, pues se sienten usadas y no ven ningún resultado en el mejoramiento de sus condiciones de vida:

El campesino lo hace a punta de uña porque el Estado y el municipio no $\mathrm{da}[\mathrm{n}]$. De pronto una entidad que esté dispuesta a la comunidad para dar desarrollo, por lo menos los de las huertas caseras nos dieron una semillita y bomba de mano (que no sirve para nada), pero nos tocó conseguir otras semillas porque no se dieron; entonces, obligan al campesino que desarrolle el trabajo que quiere por falta de ayuda. Si tuviéramos personal para desarrollar un proyecto sin necesidad de acudir al Estado sería mejor, porque es trabajo de su propia cuenta, pero no podemos porque no tenemos...entonces, ahí estamos achantado[s] por falta de apoyo (A. Pérez, comunicación personal, diciembre del 2016).

Hicimos préstamo para los agricultores y campesinado para, supuestamente, beneficiar [a] los campesinos y [a la] clase media, pero fue para los de cuello blanco. El banco de los pobres lleva 14 años de estar funcionando; la plata se la dieron a gente rica. El año pasado hubo plata como puño de arroz, pero en Guamal. Para la gente pobre no funcionó el banco de los pobres (E. Pedroso, comunicación personal, diciembre del 2016).

A los damnificados cuando perdieron los cultivos para la creciente en el 2009 - que fueron tres años de crecientes-, la yuca y todo lo sembrado se perdió. Entonces el Gobierno mandó partida para pagarle los cultivos a los damnificados, pero se comió la plata el alcalde [...]. Nosotros perdimos todos los animalitos, puercos, y vinieron con un abogado a decirnos que eran millón quinientos... y ni millón doscientos. Nos hizo firmar el personero y dijo: "no vino la plata"; ese fue el alcalde que salió [...]. Los campesinos de esta región se sienten rezagados por la política del Estado, que no favorece al campesino. Eso ellos resienten mucho por 
Vida campesina en el Magdalena Grande

esta parte, le reconozca su identidad, cosa [que] hemos reclamado por mucho tiempo (F. Díaz, A. Gómez y N. Quintero, comunicación personal, diciembre del 2016).

Esta condición generalizada entre los campesinos y campesinas de la ribera del río Magdalena ha sido el principal detonante para la toma e invasiones de tierras en esta zona. Generalmente, estas invasiones se realizan sobre terrenos de grandes terratenientes de la región, pero también cabe resaltar que algunas tomas se realizan sobre predios que son del Estado (como playones y humedales) y que no pueden ser titulados; sin embargo, muchos hacendados tiran sus cercas sobre estos predios, privatizando el acceso o tránsito sobre estas porciones de tierra. La necesidad por la tierra y la gestión de apoyo financiero para el desarrollo de proyectos productivos motivaron la creación de organizaciones campesinas que tienen como principal objetivo la consecución de tierras para el campesinado y el apoyo en el desarrollo de sus proyectos de vida, desde la gestión de créditos, el asesoramiento y la tecnificación de los modos de producción y el acompañamiento institucional:

El Estado no dice nada porque la gente invadió. Eso fue un caño que lo dividió, se fue expandiendo y aislando para terminar como una isla. Entonces, cuando la gente vio que estaba aislado, la gente se metió y comenzó a hacer rosas, pero no pueden porque la escritura es una sola, pero como es de un hombre rico la gente invadió para cosechar ahí, como no había tierra baldía. En la sabana la gente no dejan agarrar para trabajar: agarra un pedazo para hacer cultivo y de una la acción comunal se reúne, ni trabajan ni dejan trabajar. Tenemos mucha gana de trabajar, pero no sé (A. Martínez, comunicación personal, diciembre del 2016).

Hace aproximadamente 30 años se organizó un grupo y se metieron como grupo asociado a hacer cosecha, tumbar monte y a sembrar. Cuando cosecharon partieron de dos hectáreas a cada uno y fueron parcelando entre todos con linderos. Ya pues a mí papá le tocó una de dos hectáreas; entonces, seguí comprando a los vecinos. Ya eso está con lindero, porque nosotros estamos en una sola parcela que los viejos le quitaron a una finca porque el señor no la necesitaba porque tenía demasiada tierra. Ellos se 
metieron y le ganaron la tierra, entonces ahí estamos. Los viejos dejaron a sus familias, lo de mi papá lo compré yo porque la tierra debe quedar para nosotros mismos, entonces hemos seguido comprando (J. Torres, comunicación personal, diciembre del 2016).

Una vez, de cuenta propia, los trabajadores formalizamos una organización campesina [y] la bautizamos "organización campesina". El presidente era Abelardo Meche, era el presidente, y yo el vicepresidente. Sacamos tres grupos y salíamos a trabajar a levantar monte y lo labrábamos. Si quería que la junta se la sembrara, con gusto; sino, por su cuenta. Así hicimos buenos trabajos, pero nunca falta el maleante. Cuando vieron que estaba bien entraron y robaron la plata del fondo, nunca la devolvieron y salió derrotada, no la apoyó el Gobierno porque no alcanzamos a tener personería jurídica. De ahí más nunca salió una junta...eso fue del 75 o 70, quedó derrotada. Siempre he sido muy inquieto con el pueblo. Presidente reelegido cuando no existía la junta de acción, fui y trabajé la política a un grupo llamado Concordia, en Santa Ana, porque empecé a pedidos. Cuando el Frente Nacional me tocó batallar la cuestión política. Le trabajé a ese grupo e hicimos obras: Barroblanco de ahí para acá se superó en vías, luz, puertos. Resultó que se derrotó a la noche a la mañana: el grupo, con unos políticos corruptos, terminaron con el grupo Concordia... las cosas se deshacen de la noche a la mañana (S. Benítez, comunicación personal, diciembre del 2016). 


\section{Imagen 97. Asociación Campesina y Pescadores de Zarate}

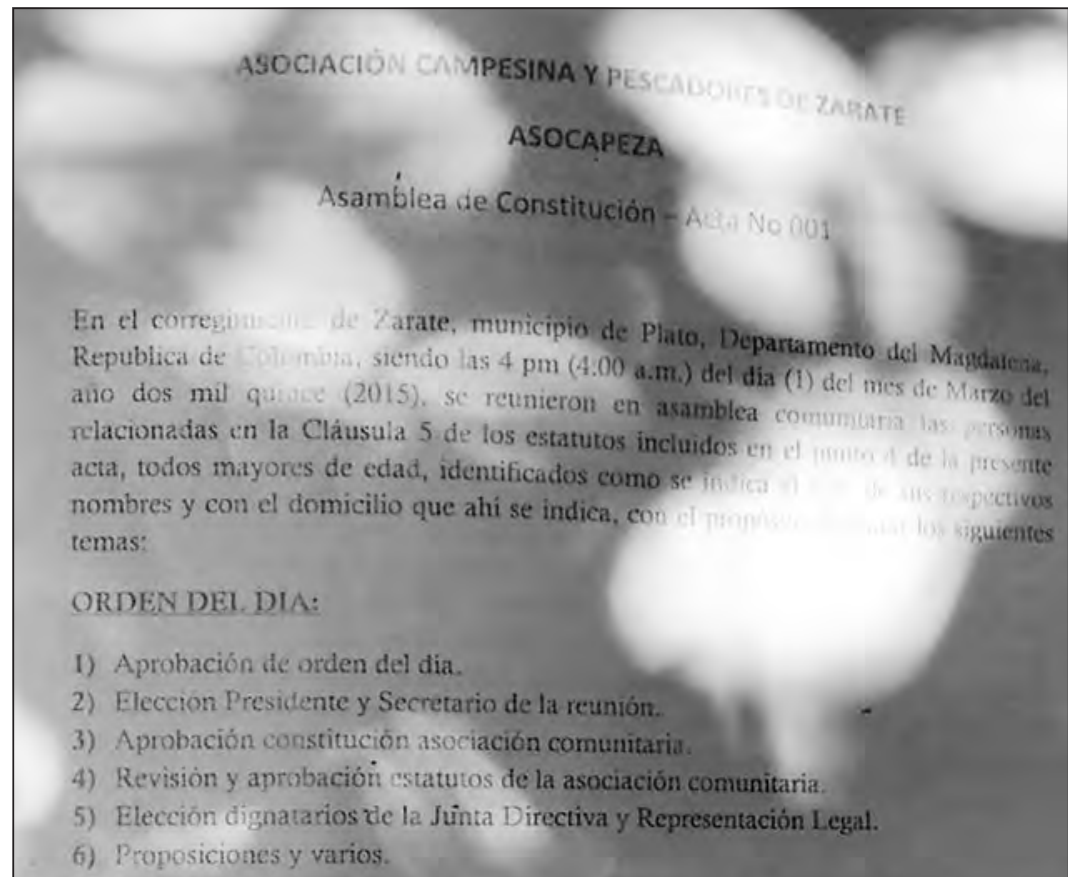

Una vez reunidos los convocados aqui indicados, el señor DARLING ANTONIO TORRES DEL TORO propuso dar inicio a la rèunión, la cual se desarrolló como se indica a continuación:

1. APROBACION DEL ORDEN DEL DIA: La asamblea aprobó por unanimidad el orden del dia propuesto en la convocatoria, incluido el primer párrafo cie a presente acta.

2. BLECCION PRESIDENTE Y SECREIARIO DE LA REUNION: L asamblea nombro por unanimidad a los stñores DARLING TORRES DEI TORO y DEMOSTENES TORRES CARDOSO como presidente y secretari de la reumión respectivamente. Las personas nombradas, presentes en reunibun, aceptaron los cargos para los que fueron nombrados.

3. APRCIBACION CONSITTUCION ASOCIACION COMUNTTARLA: presidente sometio il consideración de la asamblea la constitución de ur asociación comumitura que tenga como finalidud u objeto social principal: desartollo de proceses, programas, proyectos o actividades que propendan p el mejoraniento de las condiciones de vida de fa membresia v en generai familias duecta o indirectamente vinculadas al sector agropecuario y pesquex

Fuente: Archivo Oraloteca (2017). 
Vida campesina en el Magdalena Grande

Hace diez años hubo una organización, por parte del INCORA, que entregó terrenos y salieron beneficiados con ese proyecto. Después, vino otra entidad y montó a familias para [la] cría de carneros y salió bueno; a la final, eso se acabó y quedamos sin nada... Dios permita que más adelante alguna entidad que esté dispuesta de trabajar con la comunidad y sea productiva (A. Pérez, comunicación personal, diciembre del 2016).

Aquí estuvo la Pastoral Social con el cura Barón. Se trabajó con Lanceros de Boyacá, que hizo un aporte. Los Lanceros es una asociación y ese es su nombre con la pastoral, y se fundó un colectivo. Lo que faltó fue darle la complementación de las cosas, no[s] informaron la forma de trabajo cómo era, pero [a] la gente no se le hizo pedagogía. Cuando hubo producción, dio plata de grandes utilidades del solo fríjol que se vendió y ahuyama. Cuando estaba la pastoral, con el mero fríjol se cubrió y se repartió entre la gente. La pastoral tenía visita de curas brasileros. Aquí venían y se hacían reuniones con ellos en los cultivos. Cogían el machete y limpiaban, hablaban con uno; además, se produjo bastante fríjol, por lo que ellos aportaron con la pastoral una plata. Se metió semilla y auxilio por persona, los que estuvieron en el proyecto, aportes personales $(\mathrm{H}$. Jiménez, comunicación personal, diciembre del 2016).

A pesar de todas estas dificultades, los campesinos y campesinas siguen dispuestos a la organización para poder ser parte de los proyectos y programas que se desarrollan en sus territorios. Podríamos decir que la organización es una condición innata para los campesinos y pescadores de la ribera del río Magdalena; sin embargo, siguen solicitando apoyo y asesoramientos en el fortalecimiento de sus procesos. 
Imagen 98. Ejercicios organizativos del campesino ribereño

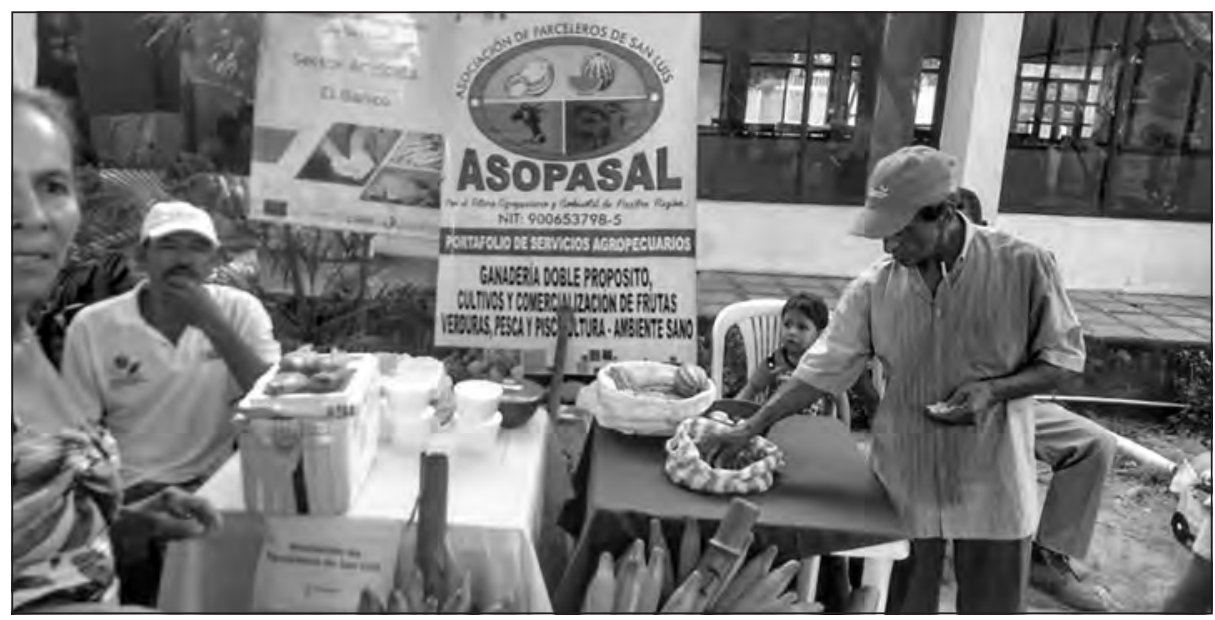

Fuente: Archivo Oraloteca (2017).

Estamos buscando la manera de consolidar una asociación para buscar proyectos, pero ni las legalmente constituidas hemos podido acceder, entonces la gente desistió de la idea, pero está bien hacer la organización campesina [...]. Si no estamos asociados no hay ayuda. Necesitamos un proyecto que jale y asocie porque no puedes exigir asociación si no vas a crear nada. Hay una organización, pero hay desconfianza, por eso no hemos organizado. Hemos intentado dos veces con cuotas, la primera se recogió bastante y la segunda quedó la gente "sicosiada" [...]. La gente dice que hacemos una de campesinos, pescadores o agricultores porque el Gobierno nos vería mejor porque estamos unidos. Pero cada quien está por su lado y tiene apego a las cosas que uno produce (N. Quintero, H. Jiménez y W. Quiñonez, comunicación personal, diciembre del 2016).

CISP es una entidad o un operador que contrata el Estado, pero que según [dicen] es italiana y hace presencia en 130 países (Comité Internacional para el Desarrollo de los Pueblos). [La crearon] para que manejaran unos recursos y fueran llegando a varias regiones y de eso montaron en la región 860 huertas familiares y 4 fincas agroecológicas. El municipio del Banco salió beneficiado con una finca agroecológica. De las 116 para la comunidad, nos trajimos 40 porque fuimos uno de los grupos más 
Vida campesina en el Magdalena Grande

organizados y seguimos el proceso, porque la confianza que teníamos para que continuara el proceso era que en el plebiscito ganara el "sí", para seguir y trabajando con recursos de la Unión Europea (W. Díaz, comunicación personal, diciembre del 2016).

Una de las principales consecuencias de la desarticulación en el ejercicio organizativo de las comunidades es la pérdida de los espacios en los cuales se transmitían los valores y costumbres del ser campesino. La desaparición de fechas conmemorativas como el Día del Campesino o el abandono del campo por parte de la población campesina pueden interpretarse como resultado de la desarticulación de las organizaciones.

Imagen 99. Recuerdos del Día del Campesino

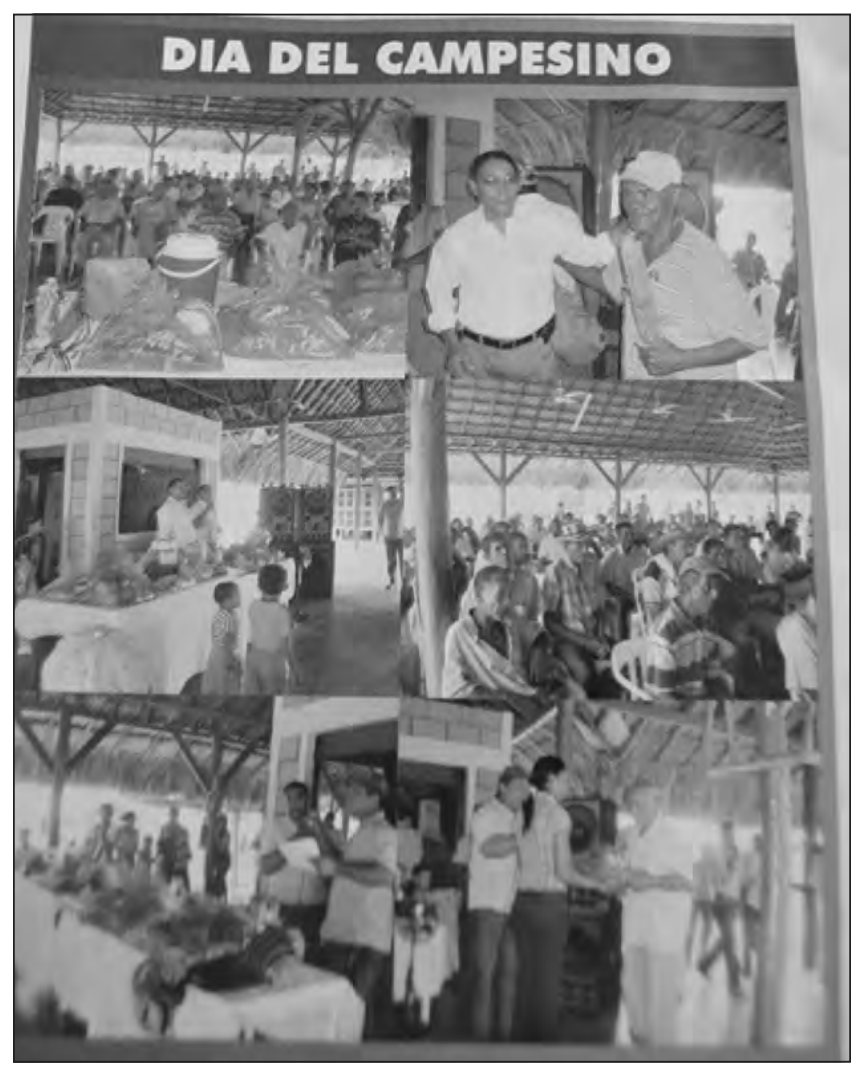

Fuente: Archivo Oraloteca (2017). 
Vida campesina en el Magdalena Grande

Estamos buscando que se celebre de nuevo el Día del Campesino; hace 25 años se celebraba. Se perdió la tradición por falta de organización. El Gobierno dejó que dejaran esa celebración. Ese día se hacía una integración en un sitio específico y se invitaba a todos los campesinos del corregimiento. Entonces, se hacía un asado y actividades donde ellos se sentían propios. Vamos a tratar para este año tener más impulso por el municipio (N. Quintero, comunicación personal, diciembre del 2016).

La agricultura se ha acabado porque los hombres agricultores se han muerto y los hijos no jalan a eso, no hay asociación de agricultor. Aquí el Banco Agrario, en épocas atrás, les prestaba a agricultores; eso ahora no se ve, ni de un amigo que le preste tierra o para la cosecha (M. Díaz, comunicación personal, diciembre del 2016).

Finalmente, hay que mencionar que, al igual que en muchas otras comunidades de la región Caribe, la presencia de los grupos armados ilegales en el territorio configuró muchas de las relaciones sociales; sin embargo, según manifiestan sus pobladores, sus territorios solo fueron sitios de tránsito, pues nunca se instalaron en sus comunidades:

Cuando la cuestión de los paras se metieron varias veces, hacían reuniones y había presión con la gente. Una vez llegaron al colegio. Yo siempre trabajaba en preescolar con niños pequeños y hubo unos muchachos paras que vinieron buscando una profesora, y yo les dije: "hombe, date cuenta [de] que estamos en un salón de clases y si hay algún problema soluciónalo, pero no vengas a maltratar los niños". Bueno, el muchacho salió y dijo que perdonáramos y eso. Entonces, llamaron a la mayoría del pueblo e hicieron una reunión, pero, ¿qué le comentó? No te puedo decir porque yo no asistí y me quedé en el colegio. Se oyó después que era una plata que le debía un señor y de pronto el señor trajo uno de ellos para presionar que le pagaran (Emilse, comunicación personal, enero del 2017). 
Vida campesina en el Magdalena Grande

\section{El campesinado del Centro del Magdalena}

Mapa 8. Zona Centro del Magdalena

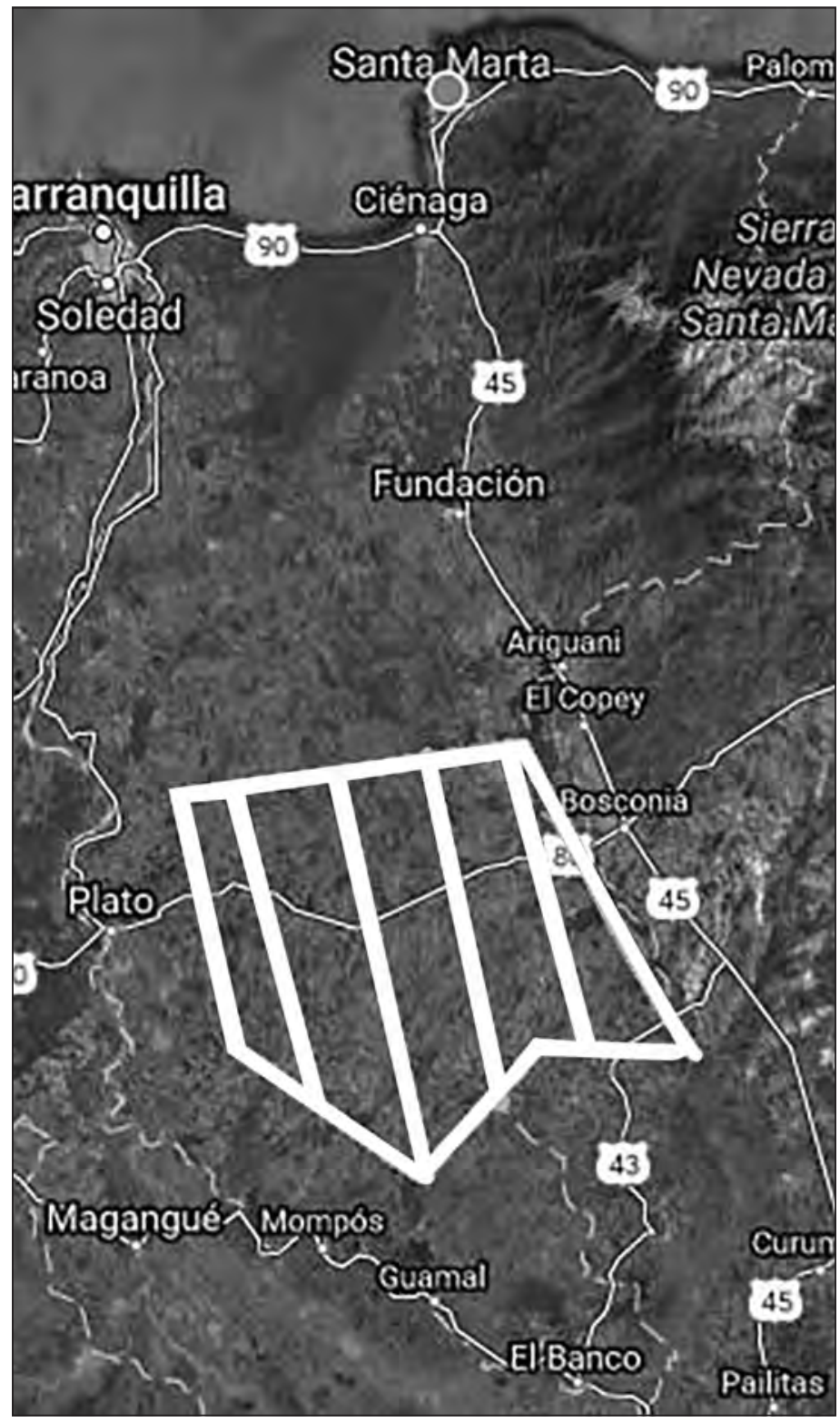

Fuente: Google. Archivo Oraloteca (2017). 
Vida campesina en el Magdalena Grande

Esta subregión comprende a los municipios de Algarrobo, Ariguaní, Sabanas de San Ángel, Nueva Granada y Chibolo. Se caracteriza por conformar el área del centro del departamento del Magdalena, desde el río Ariguaní hasta el área municipal de Chibolo. Su paisaje está conformado fundamentalmente por sabanas, a excepción de pequeñas elevaciones en el municipio de Ariguaní. Sus tierras son áridas, con escasas fuentes hidrográficas, y se encuentran habitadas, en la zona rural, por campesinos con alta vocación ganadera que se dedican a cultivos transitorios como la yuca y el maíz, pero que participan de una sobresaliente economía en la ganadería.

\section{Poblamiento y colonización de campesinos hacia el Centro del Magdalena}

Imagen 100. Campesino de Sabanas de San Ángel

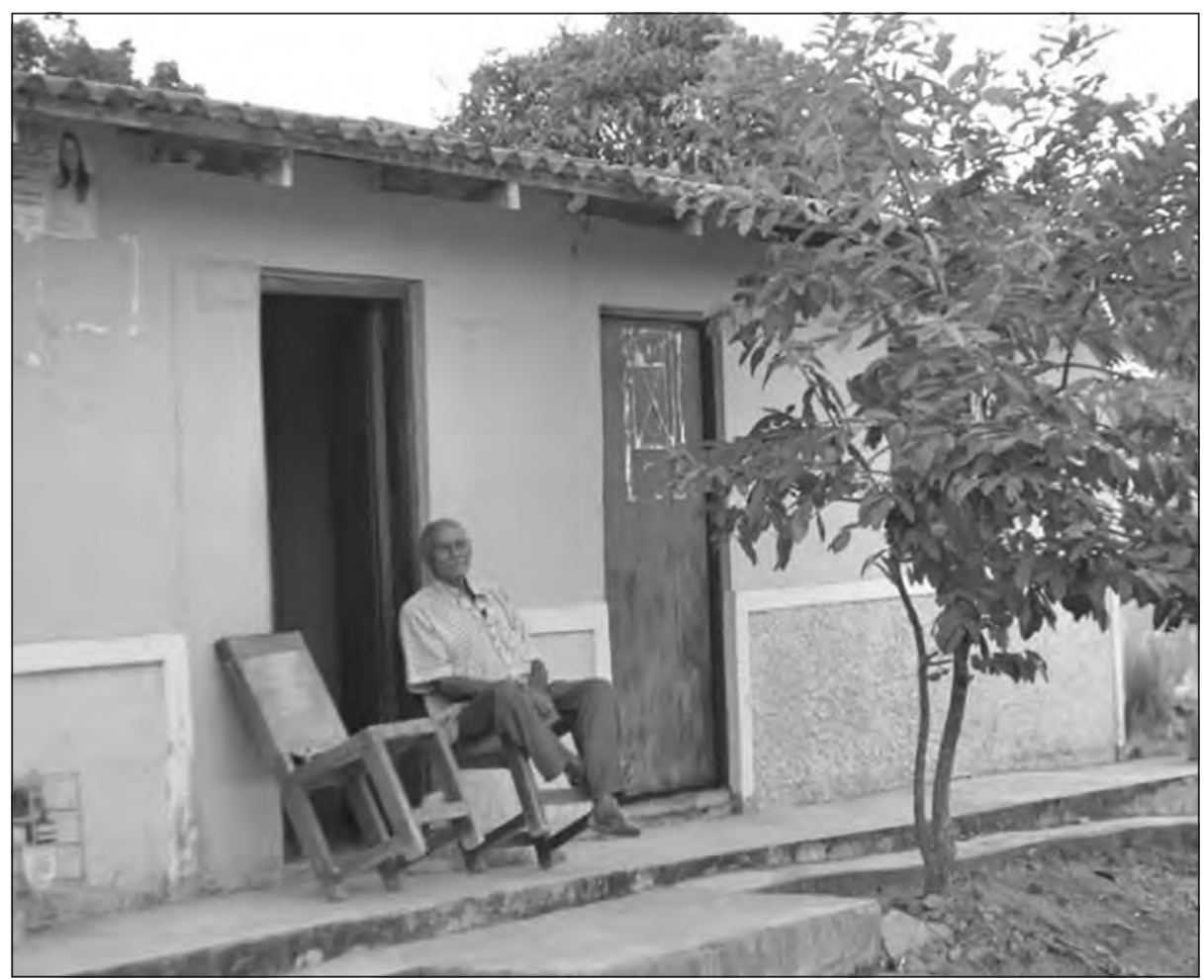

Fuente: Archivo Oraloteca (2017). 
El proceso de poblamiento de estos territorios puede explicarse como la continuación del proceso de poblamiento de la ribera del río Magdalena. Una vez pobladas las laderas del río, la población indígena se internó en las selvas y sabanas del departamento. Con la intención de seguir asegurando estos territorios y de poder realizar sus actividades económicas sin ser atacados constantemente por los indígenas, se comienzan a realizar expediciones a estas tierras para capturar indígenas y fundar poblados que rindieran tributos a la provincia y sirvieran de puestos de avanzada para sus incursiones contra los indígenas:

Aquí hay un hecho y es el famoso Tapón de los Chimilas, por eso es que Fernando de Mier y Guerra empieza a refundar pueblos, [a] crear pueblos en ciertos sitios con el fin de aguantar el embate a los chimilas, porque actuaban como guerrillas: picaban, hacían daño y huían, por eso le[s] tenían miedo. Esta subregión del Valle del Río de Ariguaní la usaba Fernando de Mier y Guerra para llevar su ganado hacia Barranquilla, para exportarlo, pero tenía que tirarlo por el río, por pueblos como Mompós, Plato, Tenerife, Cerro de San Antonio, y buscar llegada a Bocas de Ceniza, pero como que tenía que pagar los famosos "barrancos", porque estaban las aduanas o alcabalas. En esos barrancos tenía que pagar en Mompós; luego, en Plato había otro; [en] Tenerife... pero para evitar eso, y dándose cuenta [de] que por aquí podía salir de la tierra del Paso, Cesar, tirar hacia acá y hacer un corte hasta Tenerife y Sitio Nuevo (y es la famosa carretera a pueblo nuevo, antiquísima, que uno llamaba la "carretera al Banco" que no cogía por allá por Cuatro Vientos, sino por Pueblo Nuevo), salía para Arjona y de ahí a Chimichagua. Ese famoso Tapón de los Chimilas era [a] lo que le tenían miedo cuando traían esos grandes hatos de ganado, de 200 o 400 reses, para sacarlas hacia afuera, y esos chimilas los hacían derrotar, y ese ganado se perdía por aquí, ese ganado quedó cimarrón. La gente le tenía miedo a meterse aquí porque eso estaba infectado de chimilas, que son los famosos ette-ennaka, que tienen la lengua ette, que aún conservan esa lengua porque nosotros estamos metidos en ellos, aquí en Isawu Itssuna y Etta Uteriya, las dos fincas que se les ha dado aquí en San Ángel, pero antes pertenecían a Ariguaní (A. Pacheco, comunicación personal, enero del 2017). 
Posteriormente, se presenta la bonanza del Bálsamo de Tolú, que generó la migración desde Tenerife (Magdalena) en dirección al centro del departamento, en búsqueda de tierras para extraer la savia — apetecida por el componente medicinal-, que generaría un nuevo renglón económico y daría una dinámica social a las comunidades del Magdalena. De esta forma, surgieron poblados como Chibolo, que no posee señalización en el ingreso al área municipal: para acceder a su cabecera municipal hay que tomar un transporte en motocicleta desde Plato, cruzando la troncal, y encontrar, por medio del conocimiento de los plateños y chiboleros, el camino destapado o de tierra.

\section{Imagen 101. Vía Chibolo}

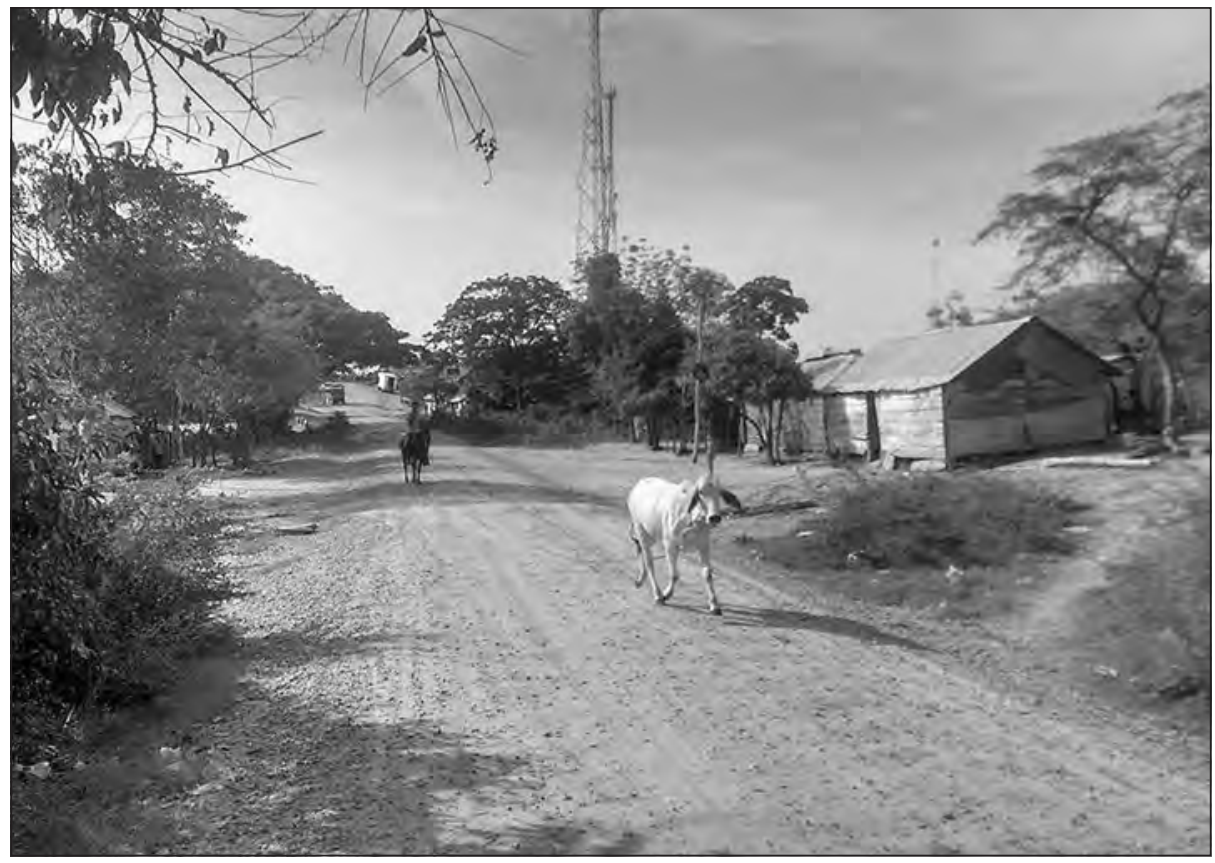

Fuente: Archivo Oraloteca (2017).

La fundación de Chibolo, eso se dice que fue[ron] Agustín Anaya y Manuel Pujo los que fundaron el municipio. Venían buscando madera, entonces se situaron primero por allá en una zona que es de tierra que brota, que son manantiales que son superficiales, entonces se sentaban 
Vida campesina en el Magdalena Grande

ahí mirando el agua y aprovechando la madera. Cuando ellos llegaron [...] se quedaron buscando y sacando Bálsamo y así se fue poblando el pueblo. De aquí fuimos trabajando hasta el Difícil, [que] fue fundado por nosotros los chiboleros. Este es un pueblo balsamero que hacía trochas buscando el agua salada, pero allá fue muy difícil, pero la conseguimos; por eso se llama "el Difícil" (O. Carranza y E. Obredor, comunicación personal, enero del 2016).

La zona del Ariguaní se caracteriza por tener relieve de montañas, donde las casas se encuentran en pendientes muy pronunciadas; así también, esta área enuncia - desde los portadores de su memoria- la historia que dinamiza el territorio en su poblamiento, como en el caso de la Guerra:

La ocupación del Difícil fue en la Guerra de los Mil Días. Las personas vinieron huyendo de la violencia y eran montañas altísimas impenetrables donde había escasas fuentes y las aguas eran salobres o salinas. Cuando empezó la guerra, en Chibolo era una carnicería por la batalla entre liberales y conservadores. La gente empezó a huir y les tocó llegar al Tapón de los Chimilas. El Difícil era un caserío, pero rodeado de pura montaña. En el centro de la montaña los chimilas hacían la casa, en el centro del boscaje, cosa que no tenían ni caminos, pero buscaban la forma para estar escondidos. Por ese hecho empezó a venir gente plateña, chibolera y pinteños, encontrando que era la región más rica en [el] bálsamo de Tolú, resina que utilizaban anteriormente para hacer toda la medicina que estaba patentada. Empezaron a sacarle y [a] llevarla a los centros para empezar a vivir; de esta manera, se forma el campesinado en la subregión de Ariguaní (que era el Difícil, San Ángel y Nueva Granada). Así nace la agricultura en el territorio, pero además encontraron que los chimilas sembraban el maíz y la yuca llamada "bituaya" (A. Pacheco, comunicación personal, enero del 2017).

La agricultura fue renglón fundamental en la colonización de baldíos en el territorio Magdalenense, presentándose en las zonas rurales la parcelación y la apropiación de la tierra a la que llamaban "ranchito", "roza" y "puesto": 
Vida campesina en el Magdalena Grande

Las personas llegaban y decían que iban a hacer la casa y un ranchito. Lo que él fuera desmontando para hacer rosa, era para él; el espacio era para él, porque el espacio era cercado para él: era cogerse el espacio que estaba cultivando. No es como ahora que ahora tiran la cerca y la coge por allá. Cuando iban a vender a otro, porque no tenían derechos legales de posesión — que era de hecho para amigo—, vendían el famoso puesto (A. Pacheco, comunicación personal, enero del 2017).

Y, por último, la bonanza tabacalera, a mediados del siglo XX en los Montes de María, llevó a la proliferación del cultivo por parte de campesinos del Carmen y Ovejas, que migraron hacia la zona de Ariguaní; esto, por la similitud en el terreno donde se desarrolla la actividad tabacalera y por la creación de industria tabacalera de importancia económica regional y nacional: "el tabaco no se conocía, el tabaco viene después del Carmen de Bolívar, que era la zona tabacalera. Entonces, la gente empieza a colonizar y a hacer los famosos puestos o parcelas" (A. Pacheco, comunicación personal, enero del 2017):

Mis abuelos eran de Plato [...], pertenecían a Bolívar. Se vinieron de Plato y [...] hasta el Difícil. Los que son de aquí era mi papá, pero los abuelos de afuera, más que todo de Bolívar, por eso la tradición de hacer rosa y tabaco, eso es de Bolívar. Los descendientes de nosotros vienen también de Plato y Pinto y Barroblanco (L. Pérez, comunicación personal, enero del 2017).

Mi familia viene de Barroblanco, Santa Ana, zona de cultivo de arroz, tabaco, ajonjolí, yuca... entonces, de ahí dependen las tradiciones del cultivo. Aquí cultivaban tabaco, pero por motivos de ser considerado ilegal se fue dejando de cultivar porque no había compradores. [Antes] había bodega de compradores de la Compañía, era un medio para muchas personas [que] de ahí sacaban su sustento, como subsidios. Todo se acabó cuando se fueron en los años 80, la empresa (A. Romero, comunicación personal, enero del 2017).

Colindando con el municipio del Difícil se encuentra Sabanas de San Ángel, municipio reconocido por tener dentro de su jurisdicción la comunidad ette-ennaka o chimila y por ser la tierra de Alicia Dorada. 
Imagen 102. Juan Evangelista Sabayé

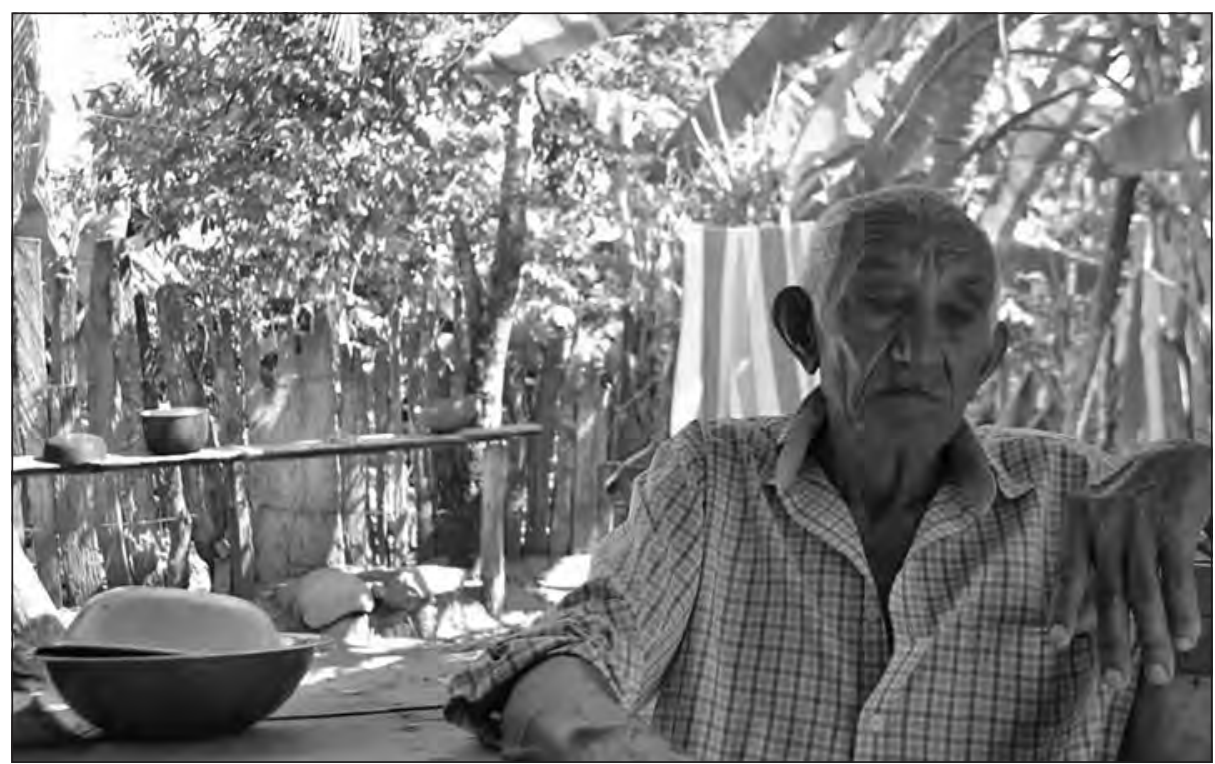

Fuente: Archivo Oraloteca (2017).

Esto era un pueblo que duró por aquí encerrado, lo que pasa es que ha vivido encerrado. Aquí vivieron unos españoles en una época y fueron los que inventaron hacer el pueblo en el monte, hasta ahí había unos mulos que dejaron cuando eso, esto es un pueblo que tiene años (J. Sabayé, comunicación personal, febrero del 2017).

Los orígenes de la población campesina se sitúan alrededor del río Ariguaní que, en la actualidad, posee un escaso caudal. La llegada de habitantes de diferentes lugares del Magdalena se dio por la búsqueda de tierra para cultivar, por la extracción del bálsamo de Tolú y, además, por la cría de ganado de grandes terratenientes:

Esto se formó cuando yo nací. Era un pueblo regular. Cuando abrí los ojos, en el 45 o 46, el pueblo era más o menos regular: no era grande, pero era un pueblecito. Yo tuve un conocimiento de una historia, que San Ángel no era aquí sino en el cementerio y allá se llamaba San Antoñito, por una enfermedad de niño y lepra que a la gente se le presentó: a los 
Vida campesina en el Magdalena Grande

niños que se le[s] caían las orejas entonces aquí le[s] decían "los mochos". Entonces de allá abandonaron el pueblo y se hicieron acá, entonces le pusieron San Ángel, así era la historia (E. Gamarra, comunicación personal, febrero del 2017).

Reflejos de la cotidianidad de los pueblos rurales magdalenenses los podemos encontrar en juglares vallenatos como Juancho Polo Valencia y sus composiciones inspiradas en los trayectos realizados a lomo de burro y en parrandas donde las costumbres y sentimientos encierran relatos del pasado:

Los abuelos míos de parte de mamá cuentan que llegaron de la vía de Plato Magdalena y se estacionaron en un pueblo que se llama las Mulas (pero el propio nombre es San Roque, pero es conocido como las Mulas), que era como [a] 1 hora o 2 horas en motos de aquí. Y ellos de allá vinieron hasta que se asentaron en Sabanas de San Ángel... ya la mamá mía y los tíos míos sí son nativos netos asentados y, de parte de papá, el abuelo mío cuenta que él llegó a los 15 años de Remolino y se sentó en un pueblecito que se llama Flores de María, el cual tiene mucha historia porque fue donde nació Alicia Dorada y Juancho Polo Valencia, que llegó de Caimán, e, inclusive, que llegaron juntos. Mi abuelo mío dice que llegó con Juancho Polo Valencia, porque Juancho es Caimanero y mi abuelo era de Remolino. Llegaron a la edad de 15 años y Juancho Polo tenía 12; llegaron a Flores de María. A Juancho Polo le gustaba el arte de la música. Ojalá conociera el pueblo de donde es Alicia Dorada: un pueblo que da lástima a pesar de la historia que tiene y ha sido reconocida Alicia Dorada y se llama Flores de María y mi abuelo me cuenta que allá tuvo los hijos, en Flores, entonces ellos descendieron a San Ángel (G. Sabayé, comunicación personal, febrero del 2017).

Los constantes flujos migratorios en el poblamiento de la zona céntrica del Magdalena, en donde la ausencia de fuentes hidrográficas es una constante, se dieron a partir de la necesidad de buscar tierras para trabajar de jornalero ante las dificultades de poseer tierra; por ese motivo, esta zona aparece como la opción para laborar en la actividad extractiva del bálsamo de Tolú: 
Vida campesina en el Magdalena Grande

Nací en un punto llamado las Mulas, que es un caserío que hay para allá. Vine a la edad de 18 años con la señora porque como acá era el movimiento. Le voy a decir la verdad: desde niño anduve andariego por todas partes porque mi papá murió y, al principio, cuando estaba a edad de 10 años vi que en las Mulas se hacían cargo de llevarme a Fundación, que desde entonces viajaban ganado a Fundación, y a mí me daban un burro para llevarlo con todo lo que había en el burro, con comida y todo. Mejor dicho: era el que llevaba la mercancía al personal que iba y así varias veces hasta que me hice hombre para allá. Cuando me hice hombre seguí trabajando y, poco a poco, me he quedado, y tengo años de estar acá. De aquí se llevaba, cuando eso había negocio de engordar puerco para llevar la manteca y eso. Las balsameras que había y todo ese transporte eran en burro: el bálsamo que llevaban para afuera y para Plato, todos los productos (J. Sabayé, comunicación personal, enero del 2017).

La extracción del bálsamo se realizaba en cuadrillas de hombres que salían a explorar la zona de monte en la madrugada en búsqueda de la apetecida savia:

El bálsamo venía, que el palo se cogía y se hacían trochas de balsameras donde se iban haciendo caminos para llegar. Así, iba por todo eso. Cuadraban el lugar y, si estaba harto, le colocaban troja, y eran con coca de totumo y se ponían a cada ocho días quitaban bálsamo y ponían las cocas y todo eso según el tiempo. También, si estaba un poco seco, le daban más, y así eso quedó un tiempo y había plata. Lo que nos daba plata era el bálsamo y se cogía, después se covaba y quedaba eso ahí, venían por ratos, pero daba plata; a mí me tocó todo eso (J. Sabayé, comunicación personal, febrero del 2017).

La constante explotación del recurso natural de manera intensiva en el centro del Magdalena, el descontrol y la ausencia de sostenibilidad de la actividad en la relación trabajo-medio ambiente causó efecto de reflexión en el señor Juan Evangelista de San Ángel sobre el suceso histórico generado a mediados del siglo $\mathrm{XX}$ : 
Vida campesina en el Magdalena Grande

Todo eso se ha acabado como la madera y han quedado en arreglar toda la madera, pero cuando era montaña sí porque por todas partes lo había, pero a las montañas se fueron de derribada y derribada, fueron acabando todo eso y, por aquí, las maderas. Eso era una exageración, para que vea: esos eran palos altísimos, como decir uno un palo de tolú. Hay una parte por aquí donde se ve una montaña de tolú y eso cogían a tumbar ese palo y hacían cajones para cuajar leche, batea y todo lo que hubiera. Hacían una artesanía como "plantosito", era el palo que más se utilizaba, y los demás sí tenían valor, esos eran altísimos, palos que los tumbaban y estaban como a dos metros, de ahí sacaban madera (J. Sabayé, comunicación personal, febrero del 2017).

Por otra parte, un hecho trascendental en la conformación de los territorios a nivel nacional ha sido la delimitación política de las jurisdicciones gubernamentales. Esta ha sido presentada por efectos políticos de las administraciones de turno, que determinan el curso de poblados - en este caso, del departamento del Magdalena- con nuevos ordenamientos territoriales accionados en la década de 1990 (teniendo en cuenta que en el transcurrir del siglo XX se presentaron múltiples reformas y creaciones de municipios y situando como ejemplo la creación del área municipal de Sabanas de San Ángel, que pertenecía anteriormente a la jurisdicción de Plato):

Decidimos separarnos de Plato por la sencilla razón de que Plato está lejísimos y las comunicaciones eran malas y todo era malo y nos tenían en un abandono y, por eso, nos decidimos. El promotor de ese movimiento fue el señor Salvador Meza Camargo, [a quien] le decían el Momo Meza. [Él] y yo (pelado) apoyamos esa causa por el abandono y decidimos crear el municipio y no teníamos nada, en el abandono total, nos valimos por nuestros propios medios. Cuando eso estaban los paracos y los problemas. Nosotros sorteamos eso y metimos un tipo para que nos hiciera una investigación y nos encerramos en el bachillerato con ese tipo una semana enterita dándole punto por punto lo que habíamos recogido y gastado y preguntó: ¿por qué ustedes tienen más gastos que entradas? Por la sencilla razón de que el señor tesorero tiene un padre que es colaborador y se llama Andrés Meza: cuando nosotros necesitamos para trasladarnos a Santa Marta él va y nos presta plata y cuando nosotros 
Vida campesina en el Magdalena Grande

podemos y recogemos... pero se luchó y se consiguió. Nosotros pertenecíamos a Plato, de Plato [se] pasó a Ariguaní y ya nosotros perteneciendo a Ariguaní hubo un líder muy famoso llamado José Mesa Batista; estaba Juan Carlos Vives Menoti de gobernador y Patricia la secretaria. Vino el gobernador un 20 de septiembre y donde está el hospital había un puesto de salud y entró el gobernador y llegó José Mesa y le leyó una carta en petición pidiéndole el apoyo para ver si era posible llevar esto a cabecera y él contestó: ¡sigan trabajando que de parte mía yo los ayudo! Entonces conformamos, entonces conformamos el Comité Municipal, de los cuales fui miembro de ese comité, y luchamos y creamos el municipio Sabanas de San Ángel (E. Gamarra, comunicación personal, enero del 2017).

\section{A la espera de las lluvias y el milagro de la cosecha: el trabajo de la tierra en el Centro del Magdalena}

La subregión del Centro del Magdalena es singular por poseer un clima de largos periodos de verano y prevalencia de tierras áridas o suelos de arena que dificulta el trabajo agrícola; sin embargo, encontramos zonas de altas montañas como el Difícil, en Ariguaní, o grandes extensiones planas en Sabanas de San Ángel o Chibolo, donde encontrar tierras aptas para el cultivo (como las de barro) se vuelve una odisea:

La mejor tierra es la de barro y la ventaja que tiene es que usted siembra una mata de yuca en el barro y le va a demorar más que una que arranca en la arena. Lo que pasa es que arrancando en la arena se tiende a secarse más rápido porque el agua se la chupa más rápido, eso lo vemos cuando se arranca una mata de yuca de arena que está caliente y prácticamente mañana ya está jorra, como le dice uno; en cambio, en el barro se pone como verde y tenemos yuca hasta de veinte raíces y, si la amontona bien, le dura hasta un mes por[que] dicen que el barro mantiene más la humedad (G. Gutiérrez, comunicación personal, enero del 2017).

Hay tierra de iguana (que es pura capa), tierra de peña (no tiene capa fértil), arcilloso como amarillo o rojo y esta tierra morena. Hay arenosa, morena (que es como si le fueran echado abono) y la arcillosa que es buena (A. Romero, comunicación personal, enero del 2017). 
Vida campesina en el Magdalena Grande

Lo que ve alrededor es seca. Aquí las temporadas de sequía son largas y cuando llueve duro hace daño porque se desbordan las cañadas, [los] arroyos, se lleva los tapecitos y aquí la tierra depende mucho de que le llueva y, como no tenemos la asistencia técnica y tecnología para que nuestros cultivos no se pierdan -o sea, no tenemos un pozo profundo o un jagüey grande- entonces es una situación difícil, y aquí el campesino es campesino y de ahí no evoluciona para más porque no le da lo que produce para más (G. Orozco, comunicación personal, enero del 2017).

Estas tierras sirven, pero tenemos que voltearla[s] para poder tener sal, porque esta tierra es maltratada tanto como nosotros los campesinos, el ganado, el ovejo, cerdo, entonces estas son tierras que no tienen "retrojunto"; si no tienen "retrojunto" no nos dará[n] savia [...]. El ajonjolí no se da porque son tierras cansadas del cerdo, [del] carnero, el ganado la tiene cansada. Entonces tenemos que buscar partes donde haya maleza para que haya savia, porque aquí hay maleza, pero esa maleza no nos va a sostener a nosotros. Por ejemplo, ese es una montaña y tiene una tierra descansada. Esos árboles todos los podan y los tiran al suelo a quemar la tierra y se limpia. En el abono todavía es precario, no utilizamos fertilizantes; entonces, el fertilizante que se usa es que quema la maleza, entonces la ceniza es el fertilizante para las cosechas y eso es malo porque mata los microorganismos de la tierra, pero como no hay otra forma y eso es herencia de antaño... [En] muchas partes le[s] falta es la capacitación para usar la tierra y repartirla para cada cultivo. ¿Qué terreno te sirve? No tenemos estudios de suelo para decirle a la tierra qué necesita para echarle. ¿Qué nutrientes hacen falta? No usamos. Las cosechas dan menos porque la cosecha ya acabó los nutrientes, entonces es un factor de que el Estado no tiene en cuenta para el campesino entre comillas, porque para ellos el campesino es el hacendado, el del ganado que tiene cultivo de arroz extensivo (A. Romero, comunicación personal, enero del 2017).

El periodo para cultivar está determinado por los ciclos climáticos: inicia cuando culmina el verano, en marzo, fundamentalmente por la aparición de las primeras lluvias y su prolongación; sin embargo, actualmente el campesinado no puede predecir o determinar el día, hora o mes 
Vida campesina en el Magdalena Grande

en el que ocurrirán las precipitaciones debido a que el cambio climático y los últimos periodos de sequía — sufridos desde el 2011 con las pocas lluvias - han generado la pérdida de cosechas y el abandono de la actividad agropecuaria.

Imagen 103. Parcela de Giovanni Gutiérrez

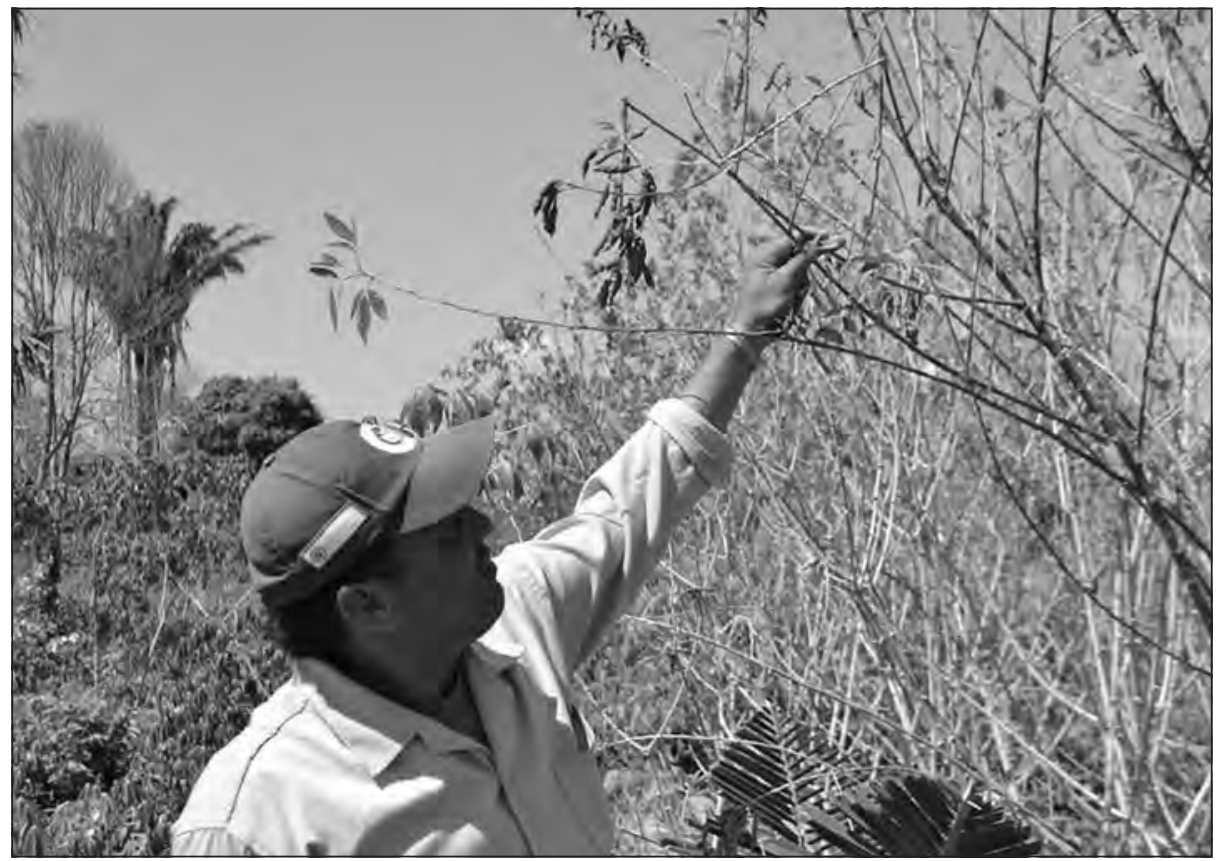

Fuente: Archivo Oraloteca (2017).

Hasta ahora se hacían dos cosechas: la primera y la segunda en el mes de marzo y, después, ya empezaba uno a quemar a final de marzo para empezar a sembrar; pero como los tiempos están cambiando, a veces no llueve en marzo y uno no puede quemar en marzo porque está lloviendo mucho y así [...]. Se comienza a preparar el terreno desde enero, en marzo se comienza la siembra y se saca[n] por ahí en septiembre, octubre, noviembre y diciembre las cosechas. En junio se saca la segunda, que siembran en septiembre y octubre, y desde mayo comienza la cosecha de yuca. Aquí el fuerte es la yuca y, después, el maíz (E. Obredor y K. Silva, comunicación personal, enero del 2017). 
Vida campesina en el Magdalena Grande

Octubre es el primer mes de verano hasta diciembre, marzo es el primer mes de invierno y [el] último mes de verano. Ya uno en marzo debe tener la rosa quemadita y lista para esperar la siembra, a lo que llueve se siembra [...]. En verano el que no está preparado pasa necesidad. Ya el pueblo es nativo y, por instinto, sabe que hay que dejar los árboles nativos: el que deja árboles nativos se combate en el verano; también llega el plátano para la comida y vender. Cuando la cosa estaba buena le decía el marido a la mujer: "hoy no hay nada de comer, mátate siquiera una gallina para comer". Imagínate, cómo que no estaba sabrosa... tan siquiera una gallina y no había nada que comer para venir al pueblo a comprar y tenía el cerdo, pavo, gallina para sobrevivir (J. Lozano, comunicación personal, enero del 2017).

Imagen 104. Preparando la tierra para cultivar

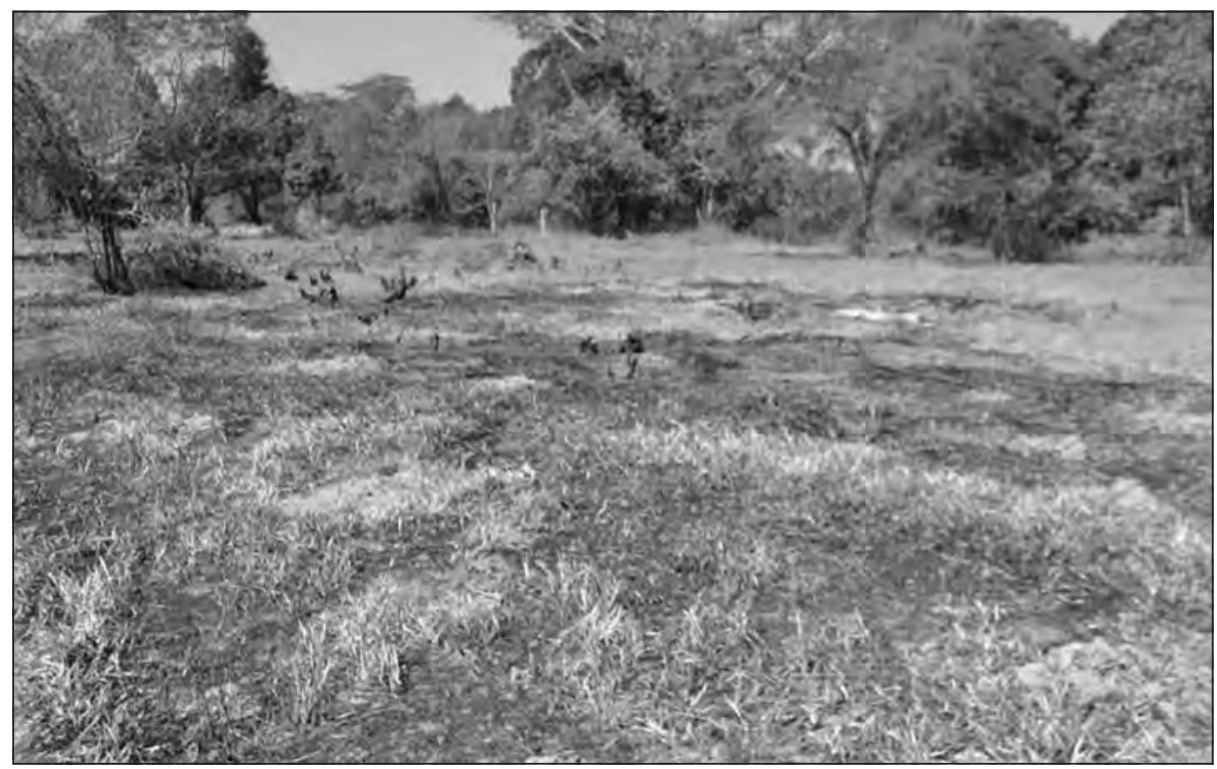

Fuente: Archivo Oraloteca (2017).

Este ya es tiempo cuando nosotros los campesinos estamos picando monte hasta el mes de marzo que se quema. Entonces, en marzo vamos a comenzar Sábado de Gloria y ahí se siembra el maíz, la yuca (que esos son mitos que tenemos acá: para estos tiempos da la yuca). Entonces 
Vida campesina en el Magdalena Grande

uno tiene la fecha estipulada [sobre] en qué época se puede dar más y en cuándo [es] más chiquita: ese es otro factor que nosotros tenemos [y] es que el medio ambiente no es lo mismo, porque antes nosotros esperábamos las lluvias que eran precisas, pero con los fenómenos que hay - con [el] calentamiento global - las lluvias no son a tiempo, como lo esperaban los abuelos de uno. Ese es otro problema que nosotros tenemos y la tecnificación es la que nos va a ayudar con el sistema de riego. Antes había ahuyama de burro y eso desapareció. La ahuyama era más grande y había una yuca que le decían "harta perra": ese era una yuca alta, gruesa, que cuando usted la cocinaba salía el bien, pero aquí no le prestan atención, entonces si es de perro es la misma. La ahuyama de burro la sembraban para los animales que teníamos como el burro, ganado, cerdo, pero ya ahora hay que darle viaje a todo (A. Romero, comunicación personal, enero del 2017).

El conocimiento de la tierra es heredado de los ancestros y, en efecto, el aprendizaje de la agricultura se da desde la niñez, en compañía del padre, en los desplazamientos en burro, bicicleta o motos hacia las fincas a realizar labores como la limpieza de las tierras, la preparación de la tierra y la elaboración de las cercas; en este caso, el campesino va acompañado de herramientas para realizar estas actividades como el palín, azadón, machete o herramientas echas artesanalmente como la palanca:

Cuando el papá de uno sabe un arte uno lo aprende con él: de campesino a hacer roza y cerca, de coger la rula y de sembrar el palo de yuca. Uno ve con el papá de uno y aprende con la rula. Me iba a las cuatro de la mañana y [a] las once de la mañana estaba haciendo la carga para venirme. Venía a desayunar a esta hora o, sino, me iba a desayunar para allá, pero yo a las tres de la tarde ya estaba en casa. Pero [hay] de los que pasan todo el día ahí, a sol y agua, y ahí están sufridos (E. Obredor, comunicación personal, enero del 2017).

Ahora mismo estamos en verano y esperamos el agua del 20 de marzo para adelante. Ahora, por ahora prácticamente [lo que están] haciendo los pequeños campesinos es picando monte y haciendo socola para cuando del 10 de marzo en adelante ponerse a quemar. Queman el pedazo del 
Vida campesina en el Magdalena Grande

terreno y recogen lo que queda, entonces el terreno queda apto para la yuca. Apenas comienza a llover enseguida empiezan a coger la tierra y la hollan. Como no tiene arado ni nada, entonces la hollan con palanca (un pedazo de palo que cortan de pronto de guayacán) y empiezan, pero ahora como la tecnología ha avanzado ya usan es palín y mueven todo el pedazo de tierra (aquí lo llamamos "pata de gallina”). Prácticamente un campesino aquí a una hectárea le mete mil palos porque son $10 \mathrm{mil}$ metros cuadrados que tiene una hectárea, entonces del 20 o 25 empieza a llover y esa yuca en septiembre u octubre ya esa yuca está de comer y por ahí en noviembre la están explotando para venderla en bolsas o en libras (G. Gutiérrez, comunicación personal, enero del 2017).

Los campesinos que están por aquí no están tecnificados, no tienen maquinaria ninguna, todo lo hacen a machete, azadón, pico, paladrague, pero tecnificado muy poco. La fuente de empleo de la zona es el campesinado porque la mayoría es un sustento de pancoger. Lo poco económico que tienen es la yuca, [el] maíz, [el] plátano es escaso, pero se cultiva (A. Romero, comunicación personal, enero del 2017).

El proceso de cultivo se desarrolla con estas herramientas artesanales que determinan la cantidad y calidad de sus cultivos; en cambio, el proceso de producción por medio de la tecnificación genera otra relación entre el tiempo de manutención y la cantidad en la cosecha:

Nosotros sembramos así porque nos enseñaron así. Hay unos que siembran a un metro de mata a mata con un metro y medio; hay otros que no y dicen "yo siembro al paso" (es decir, de aquí a allá dan un paso y siembran ahí, no la siembran en [la] calle y es más difícil para las limpias y todo). Entonces, hay unos que siembran así; otros, son más tecnificados en sus distancias en siembra, pero tecnificados en el sentido [de] que no tienen un sistema de riego para regar la yuca, pero ellos mandan a hacer los arados y su lugar. Hay unos que mandan a arar, pero hay otros que cogen $y$ pican el monte, hacen quema y, después, hacen... hollan y, después, siembran. Esa es la forma tradicional y la forma tecnificada es el arado, que le meten cincel y siembra, pero los campesinos no tienen sistema de riego ni cultivos para vender (K. Silva, comunicación personal, enero del 2017). 
Vida campesina en el Magdalena Grande

Por aquí pica uno la tierra, tumba uno los árboles, deja que se seque y le echa candela para que la tierra quede limpia para sembrar. Aquí no le dan a ayuda con una máquina para limpiar. Aquí si usted tiene la finca le da a cinco o cuatro personas que le cultiven, pero aquí no hay recurso como, por ejemplo, [en] Pivijay, donde van los campesinos a cultivar (E. Obredor, comunicación personal, enero del 2017).

Anteriormente, en la región se presentaban cultivos como el tabaco, impulsado por empresas agroindustriales cuyo recuerdo genera nostalgia en la comunidad campesina debido a los altos recursos económicos que dejaban para el municipio y a las distinguidas áreas de grandes plantaciones, como las del Difícil y el Plato, que fueron desapareciendo por ser consideradas como cultivo de contrabando:

El tabaco se destruyó por la situación de que [con] el tabaco pasó como [con] la marihuana, que es considerada contrabando. Aquí lo ven con un tabaco y va preso, entonces empezaron a destruir el tabaco. Ahora le consiguen tabaco por aquí y ya usted tiene que sacarlo al Carmen de Bolívar porque aquí ya no hay compradores de tabaco, aquí hicieron hasta bodega y las ventas eran inmensas, ¿qué pasó aquí? La mayor parte salía del Magdalena, entonces tuvieron el mejor perfume y comenzó la marihuana, la coca y el contrabando del tabaco, entonces dejaron de cultivar por eso. Era un medio de vida para muchas personas. Hubo hasta una empresa tabaquera donde trabajaban más de ciento y pico de personas y sacaban su sustento. Como toda empresa, daban liquidación, daban sus primas, subsidios familiar[es] para niños... y fue decayendo a medida que no cultivaban y los dueños se la llevaron para otros lugares y quedó gran número de personas sin empleo; para el año 1989 se acabó. A la salida de acá hacia Plato [están] las bodegas conocidas como "la espinosa", [que son] grandísimas [y] fueron construidas por gringos. Aún existen las bodegas; ellas las han utilizado para, primero, guardar las maquinarias [y], después, para la fabricación de adoquines para el municipio... ya eso es monumento histórico (L. Pérez, comunicación personal, enero del 2017). 
En la actualidad, los cultivos que se dan en la región son, principalmente, la yuca; luego, el maíz y, después de este, muchos otros productos que se siembran para el consumo del hogar, como la batata, el ñame, el pato, entre otros:

Más que todo yuca y, de segundo, maíz. Antiguamente, el campesino sembraba ajonjolí en la zona, pero es poco, más que todo es la yuca y el maíz porque tanto la yuca como el maíz sirve[n] para alimentar animales; en cambio, los otros cultivos no [...]. Ahora como hace 15 días arranqué una yuca que tenía 2,20 m y mi papá está por el monte y trajo una yuca de 1,80 m y una batata de 17 libras. Entonces son cosas en las que tomamos fotos; en la Alcaldía está la foto de la yuca (A. Pacheco y A. Romero, comunicación personal, enero el 2017).

Imagen 105. Transportando productos en burro

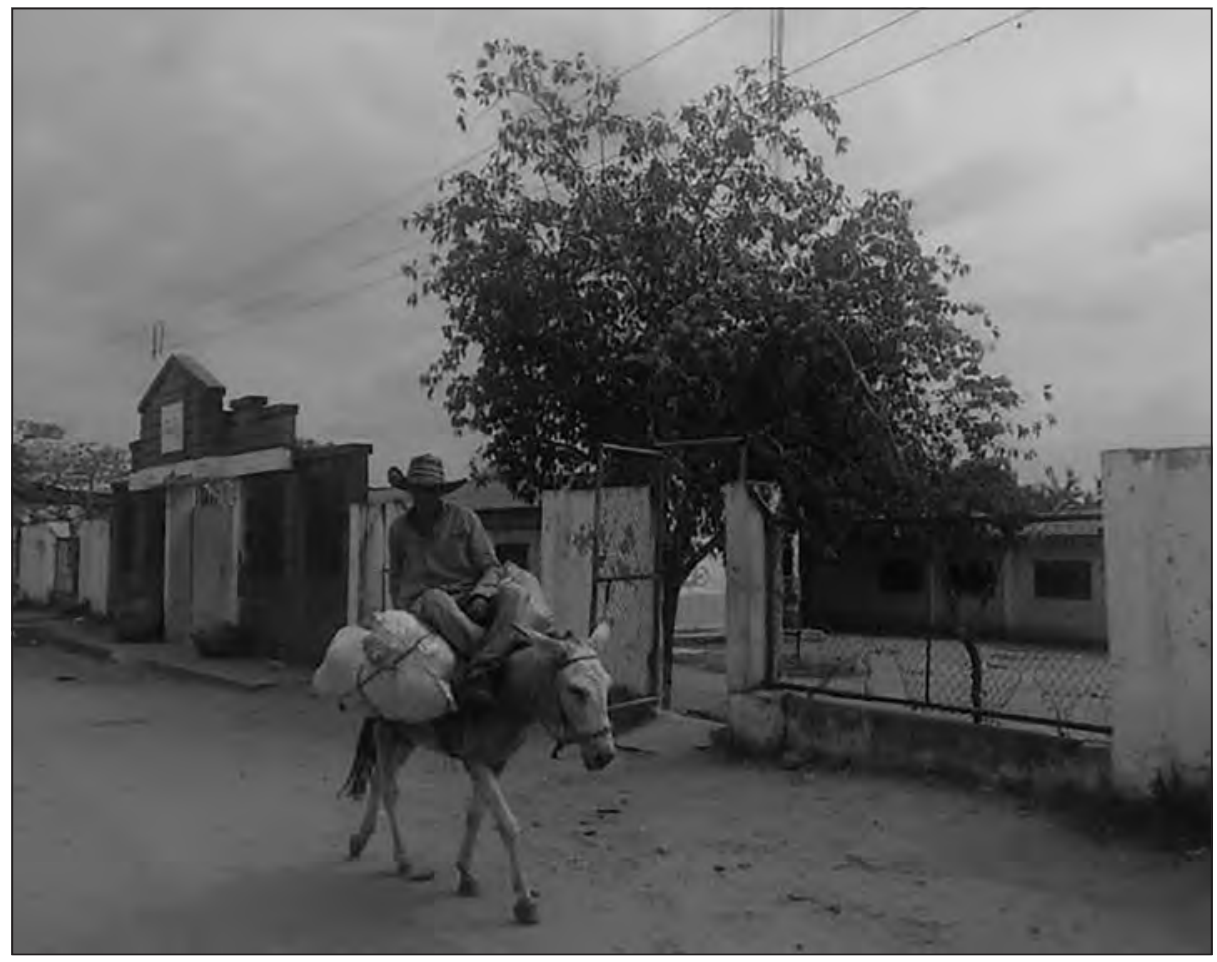

Fuente: Archivo Oraloteca (2017). 
Vida campesina en el Magdalena Grande

Para llegar a los cultivos o sacar sus cosechas se desplazan en burros, bicicletas o motocicletas. Prevalecen los caminos destapados en arena que en temporada de invierno se vuelven intransitables, lo que dificulta la movilidad de las cosechas hacia los centros poblados para su comercialización. Ese es uno de los principales reclamos de los pobladores a las administraciones locales de estos municipios, la necesidad de una mayor inversión en las zonas rurales:

La vida del campesino es difícil porque las vías de acceso son malas. Entonces, para sacar sus productos y venderlas es mala. Gastan más en un transporte para sacar un bulto de yuca porque [de] donde tenemos las parcelas hasta acá cobran 15 mil pesos y el bulto lo pagan a 14 mil pesos. No compensa de ir a buscar un bulto de yuca y pagarlo a 14 mil pesos, vas perdiendo mil pesos. Entonces, [esto pasa] por[que] la calidad de las vías es mala. Además, no hay electrificación en las parcelas: algunos tienen sus plantas solares, otros sus mechones (K. Silva, comunicación personal, enero del 2017).

Las vías son pesadas. Usted mira desde Apure para acá y nos dicen que la vía está buena y no lo está. Hay un problema de que Apure pertenece a tres municipios y la arregla nada más Chibolo, entonces la plata que invierte es de Chibolo porque los otros nada más es para cobrar impuestos. Ahora, con un grupo de promotores ambientales comunitarios, estamos proponiendo un encuentro intermunicipal para mirar los verdaderos límites con los municipios vecinos. En eso va a participar el alcalde de turno, [la] secretaria de Planeación, [el] Concejo y los representantes de Planeación, Secretaría y Asamblea para solucionar nuestra vía (J. Lozano, comunicación personal, enero del 2017).

Por esta razón, la mayoría de los productos se comercializan en los mercados locales de las cabeceras municipales, en tiendas de abastos e intermediarios que recorren la zona rural en camiones comprando los diferentes productos. En pocas ocasiones los productos se llevan a centros urbanos como Valledupar, Santa Marta o Barranquilla: 
Vida campesina en el Magdalena Grande

Antes el cultivo no valía nada, uno vendía una libra de yuca en 20 centavos o 10 centavos. Ya después llegó a 1 peso y 3 pesos y fue aumentando. En el maíz, uno cogía un ciento de maíz en 2 mil o en mil pesos, pero eran 100 pesos en ese entonces o 2 mil y 3 mil, ahora vale 50 mil el ciento de maíz [...]. Se vende a la plaza de mercado de Valledupar, la de este sector y vía de Bucaramanga. A Barranquilla muy poco y de Santa Marta porque ellos exigen una calidad de yuca que por aquí no se da, ellos la traen de la vía a Montería y sale para Bosconia (E. Obredor y Karen Silva, comunicación personal, enero del 2017)

Imagen 106. Camiones recolectores de productos campesinos

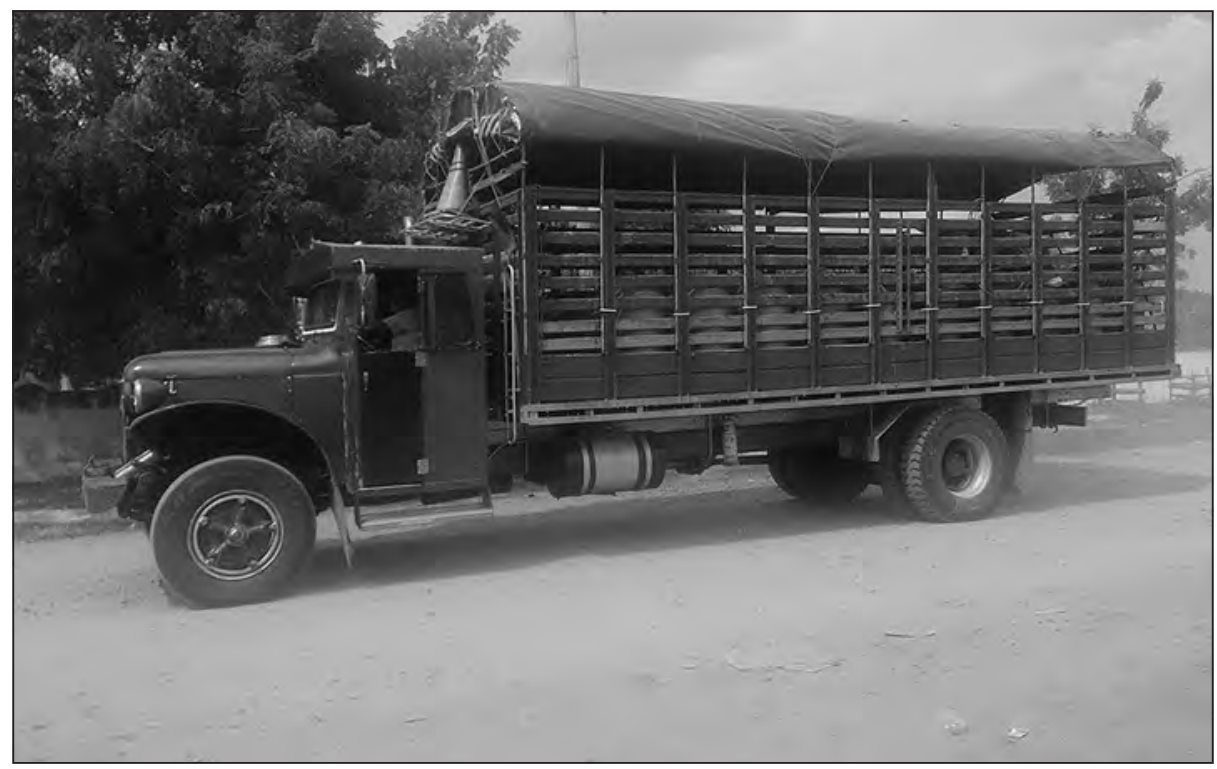

Fuente: Archivo Oraloteca (2017).

La cosecha de los cultivos es usada de diferentes formas, como en el caso del maíz. Este, además de ser comercializado, es destinado a la preparación de un alimento profundamente arraigado y apetecido en las mesas magdalenenses: "el bollo", que encontramos en Sabanas de San Ángel, elaborado artesanalmente a base de yuca o maíz en los patios de las casas, diariamente, y vendido en las casas, calles, plazas y tiendas de barrio como parte fundamental de la gastronomía. 
Vida campesina en el Magdalena Grande

Imagen 107. Preparación del bollo de yuca
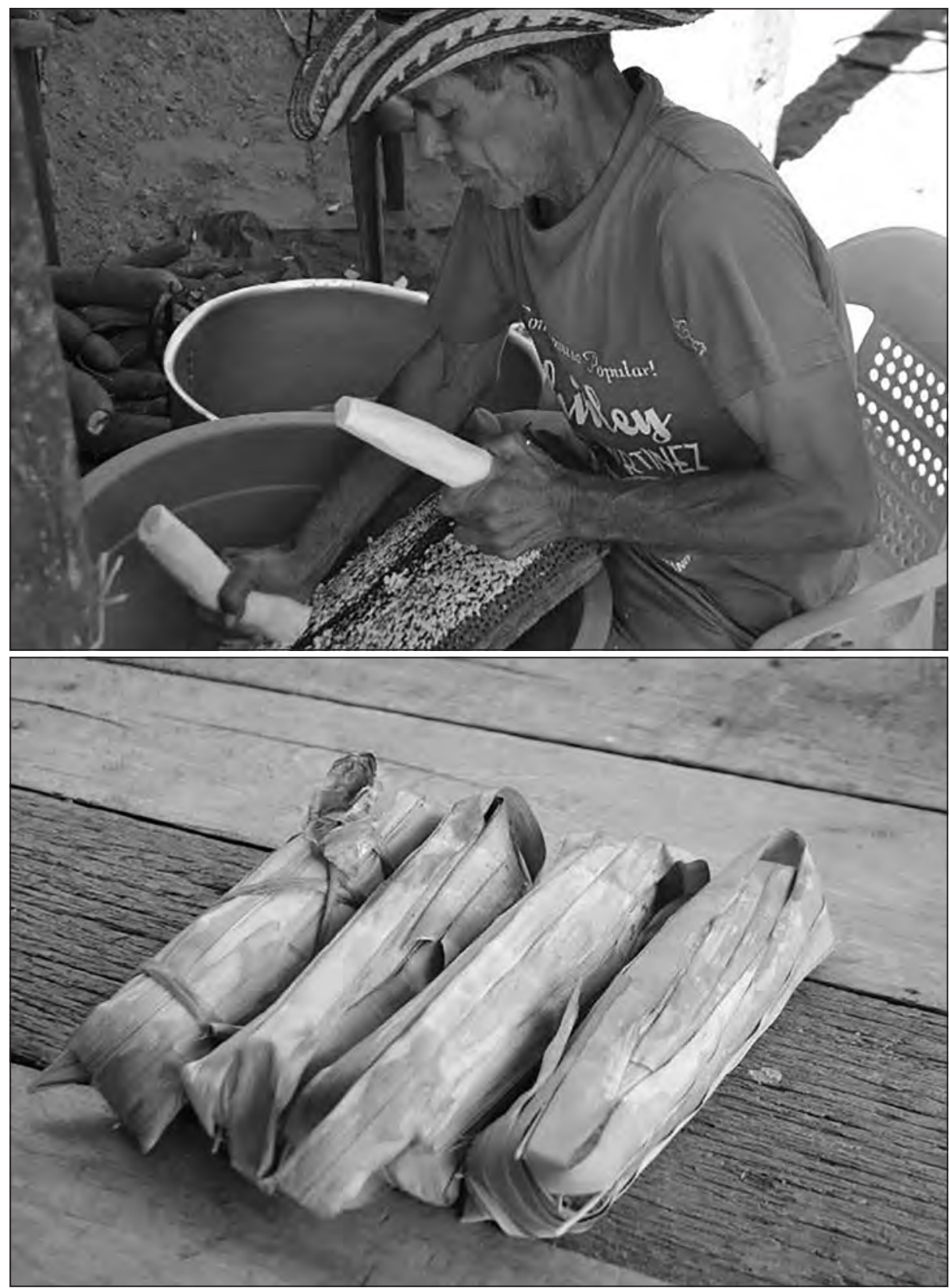

Fuente: Archivo Oraloteca (2017) 
Vida campesina en el Magdalena Grande

Aquí, que es un pueblo agricultor. [Antes] vendimos la yuca a mil pesos y ahora está a 500 pesos [...]. Tenemos todo lo del maíz que siembran en marzo y, si es bueno el tiempo, en julio o junio estamos cogiendo maíz, pero ahora estamos cogiendo maíz seco [...]. Prácticamente, los campesinos vamos a vender lo verde que secó, porque seco no les vale nada y verde el ciento de maíz lo venden a 20 mil, 30 mil pesos, entonces les beneficia más. Al papá mío hace bollo de maíz verde y de un ciento de maíz le están sacando 40 o 45 bollos, de eso lo venden a mil pesos y de 45 mil del bulto le están quedando para ponerle al azúcar o para el poquito de leche y [le] están quedando unos 15 mil de rentabilidad para el bollo de yuca. El papá mío hace 100 bollos o 70 bollos y hace de dulce o simple; aquí es de yuca con cogollo de palma de vino y lo vendemos a mil pesos (G. Gutiérrez, comunicación personal, febrero del 2017).

\section{El campesino y la ganadería}

Desde sus orígenes, el campesinado ha tenido como actividad alterna a las labores agrícolas la estrecha relación con la ganadería; esto, debido a que es una de las actividades económicas con mayor uso de las extensiones de tierra en esta subregión y a que es en estas fincas ganaderas donde muchos campesinos jornalean en labores del cuidado. También hay algunas familias que tienen algunas cabezas de ganado, pero son pocas en comparación con los emporios ganaderos del departamento:

El municipio de Ariguaní es agricultor y ganadero. Aquí los que tienen ganadería extensiva son los medianos y grandes productores y los pequeños se tienen en pequeña escala. Además, tienen su cultivo de pancoger para vender; es decir, aquí el productor que menos cultiva yuca son tres o cuatro hectáreas y el que cultiva menos es para comer, y las comidas como el ñame, ají, patilla, melón, papaya y el fríjol, antes de que venga la cosecha de la yuca. Sembrando la yuca y todo eso, ellos recogen todo y, después, para solventarse mientras que sale el cultivo de la yuca trabajan de jornal en las fincas ganaderas (K. Silva, comunicación personal, enero del 2017). 
Vida campesina en el Magdalena Grande

La ausencia de fuentes de trabajo ha desplazado la actividad agrícola por el riesgo que en los últimos años ha implicado para los cultivos el cambio climático, las extensas sequías sin temporada invernal y la escasez de fuentes hídricas. Por esta razón, muchos campesinos han optado por la ganadería como actividad alterna:

El campesinado de esta región es ganadero y agricultor. Aquí todos o la mayoría de mi familia somos campesinos: en mi familia somos campesinos por naturaleza. Carecemos de recursos, pero aquí nosotros nos hemos mantenido con la agricultura de la yuca, [el] maíz y todo lo que tiene que ver con las fincas y [los] ricos trabajando de jornalero[s]. Por aquí llaman al que trabaja en temporada [de] la ganadería que "está atrás del ganado"; esto se lo dicen porque se dedica a trabajar de por meses, ordeñando y haciendo todo lo que tiene que ver con eso. Se dedica a la ganadería el campesino y es una de las grandes diferencias en el del Centro del Magdalena, porque la ganadería hace que la persona piense diferente al agricultor. El campesino ganadero piensa diferente al agricultor aunque todos vienen de la misma raíz, pero más que todo es ganadero y tiene dos, tres, cuatro o cinco vaquitas, también sus animalitos en su pedacito de tierra, entonces los pone a pensar totalmente diferente al campesinado, cosa que no pasaba hace veinte años atrás o más, en que el campesino era agricultor, pero los problemas de los veranos fuertes se han ido retirando de la agricultura y llegando a la ganadería (A. Pacheco, comunicación personal, enero el 2017).

De pronto nos vamos por la parte animal porque se necesita menos agua que el cultivo de planta, porque a nosotros nos gusta el cultivo de planta, pero el agua es imposible en estos municipios. Mira que aún en el casco urbano no es potable para consumir y, mucho menos, para regar y montar un cultivo de cualquier pancoger con el que uno pueda vivir. No tenemos agua apta, entonces estamos maniatado[s], amarrado[s], y necesitamos ayuda del Estado (V. Aragón, comunicación personal, enero del 2017).

El campesino vive también de la leche, [d]el suero para tener complemento porque se da cada quince días y están recibiendo; en cambio, en la agricultura es algo incierto porque el factor climático ha influido debido a 
Vida campesina en el Magdalena Grande

que el año antes pasado no hubo cosecha, pero el año pasado sí. [aunque solo] en sectores porque no en todos hay lluvia (K. Silva, comunicación personal, enero del 2017).

\section{"Haga paja y no cultive": el problema de tierra en el Centro del Magdalena}

Las comunidades rurales agrícolas del Centro del Magdalena han padecido históricamente por el acceso a la tierra, desde la colonización ocurrida a principios del siglo XX. En primer lugar, el dueño del ganado, concentrando extensas fincas, $y$, en segundo lugar, las pequeñas parcelas campesinas, invadidas a tierras del Estado:

Aquí, al contrario, dicen: "haga paja y no cultive". Por allá en una finca donde estábamos cultivando hay ciento setenta y pico hectáreas de tierra. Se mete el patrón y decía: “¡ya me desocupan la tierra!”. Eso era lo que ocurría en Chibolo: el patrón le decía a uno "denme la tierra" o le metía el ganado al cultivo, entonces se jodía uno y, pues, para demandar al patrón no se podía porque como era de plata... Entonces yo le dije a los compañeros que estábamos ahí que teníamos que salir porque el municipio tenía más preferencia con la ganadería. Después, nosotros nos reunimos todos y dijimos que íbamos a pelear con los patrones o, si no, tendríamos que llamar al ministro de Agricultura que venga a arreglarse con él. Yo digo que eso es lo que tenemos que hacer porque la agricultura está por sobre todo y no tenemos que escuchar siempre lo que dicen: "desocupen ahora mismo", y no podemos dejarnos porque siempre a uno lo desocupan para meter el ganado (E. Obredor, comunicación personal, enero del 2017).

Es recurrente encontrar media, una, dos o tres hectáreas de tierra en posesión del campesino, pero son muy pocas las ocasiones en las que encontramos al campesino trabajando en tierras de su propiedad; esto se debe a que el acceso a la tierra es una problemática generalizada en los campesinos de la región y gran parte del país:

Solo se puede coger para hacer la roza nada más porque por ese lado estamos fregados. Nos hemos cansado con los alcaldes y [con] todos los políticos que vienen, que miran que no tenemos para trabajar; no dicen: 
Vida campesina en el Magdalena Grande

"en tal parte hay un pedazo tierra para el campesinado o agricultor". Aquí un tipo tiró la idea de una tierra por aquí para cultivar, pero se la echaron para atrás porque el tipo que alquiló la tierra se la propuso a cuatro millones y, después, nos dijo que aceptó una oferta para comprar cien hectáreas; entonces dijo: "para dársela tienen que pagar a seis millones", entonces dejé eso así (E. Obredor, comunicación personal, enero el 2017).

Desde niño nací en el campo y aún no estamos en los programas del Gobierno, por eso no podemos acceder a un pedazo de tierra y no es por falta de organizarnos, sino que es difícil acceder a la tierra, y no sé cómo vendrá este año con el proceso de paz porque tenemos expectativas, porque se dice que el primer punto es sobre tierras y, como la tierra es para el campesino, tenemos esperanza a acceder a un pedazo de tierra o parcela donde podamos desarrollar nuestro proyecto de vida allí y potencializar a nuestros hijos para que vayan a la universidad; ese es nuestro anhelo (G. Orozco, comunicación personal, enero del 2017).

Imagen 108. La casa del campesino en Chibolo

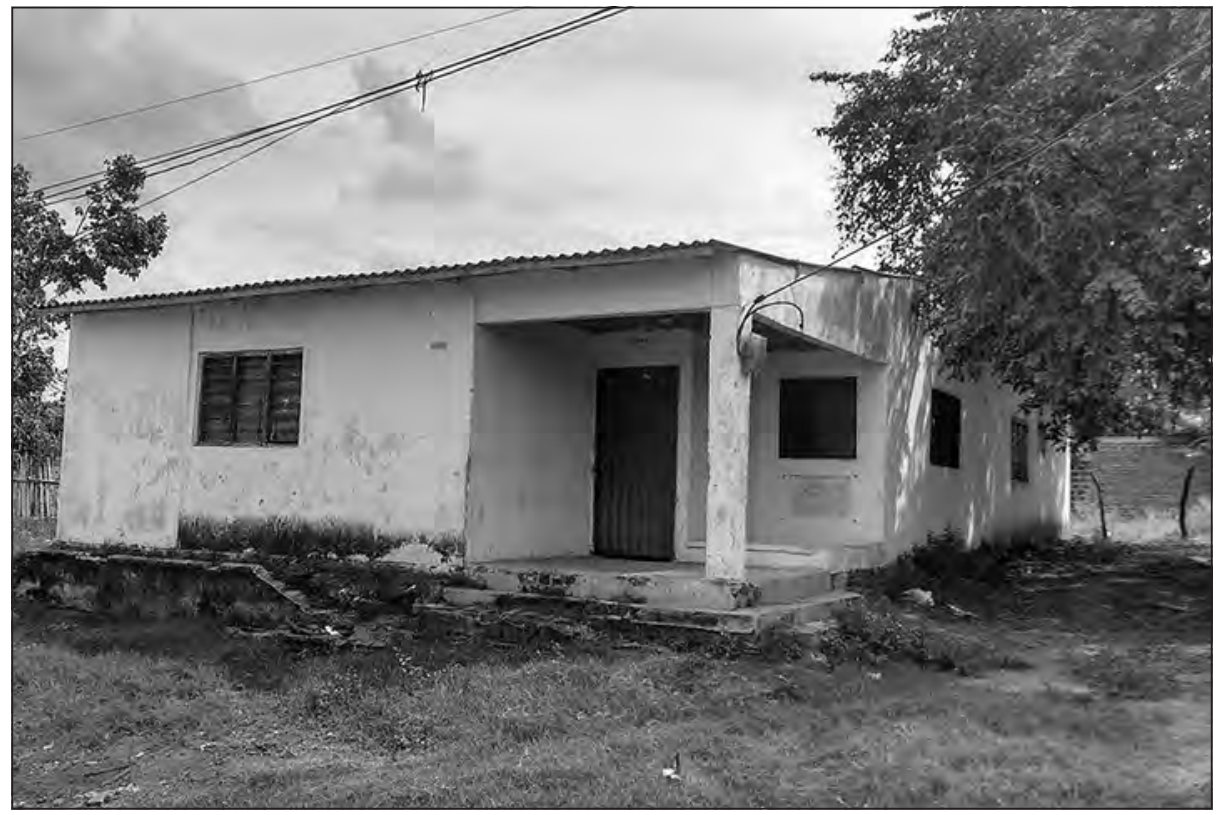

Fuente: Archivo Oraloteca (2017). 
Vida campesina en el Magdalena Grande

Este anhelo de paz y la esperanza de acceder a la tierra es el resultado de años de conflicto que han vivido las comunidades del departamento del Magdalena, ya que por estos territorios han pasado todos los grupos armados: FARC, ELN, AUC, Ejercito Nacional y ejércitos privados; cada uno, a su manera, ha dejado su huella social en el territorio. El conflicto armado ha sido un factor transversal en la actividad agropecuaria, teniendo en cuenta que, por muchos años, la ley y residencia de altos mandos, como "Jorge 40" (jefe del bloque norte de las autodefensas), se encontraba en el municipio de Chibolo y Sabanas de San Ángel; además de que también hacían presencia otros grupos al margen de la ley, como guerrillas y bandas delincuenciales:

La mayoría nacemos en el campo y nos hemos desplazado al casco urbano porque nos ha dado miedo la forma o soledad del campo. Entonces, cuando el tiempo de los paramilitares, la mayoría de los campesinos nos desplazamos a la ciudad y nos dedicamos a mototaxista; otros, a pintar; otros, a pegar bloque; otros, a vivir en la urbe o en el pueblo; pero en sí, en el fondo de nosotros, es trabajar como campesino, trabajar lo que trabaja el campesino (lo que es criar gallina, pollo, cerdo, peces) y nos sentimos mal trabajando lo que trabajamos porque nos han sacado o nos hemos salido del hábitat de trabajo y nos hemos quedado comiendo migajas (V. Aragón, comunicación personal, enero del 2017).

Ellos llegaron y se metieron y se adueñaron de todo. Estuvimos aquí en el pueblo, acá hubo masacre... La gente que los paracos judicializaron era que tenían problemas, entonces los amedrentaron y así ellos tenían un punto donde se repartían y tenían en 3 mil, 4 mil, hasta 5 mil personas... y así amanecía. Después, en la noche, no había ninguno. Quedaron de que iba[n] y venían, y en sí andaba uno con temor porque no sabía qué iba a suceder (E. Gamarra, comunicación personal, febrero del 2017). 
Vida campesina en el Magdalena Grande

Imagen 109. Campesino vendiendo helado

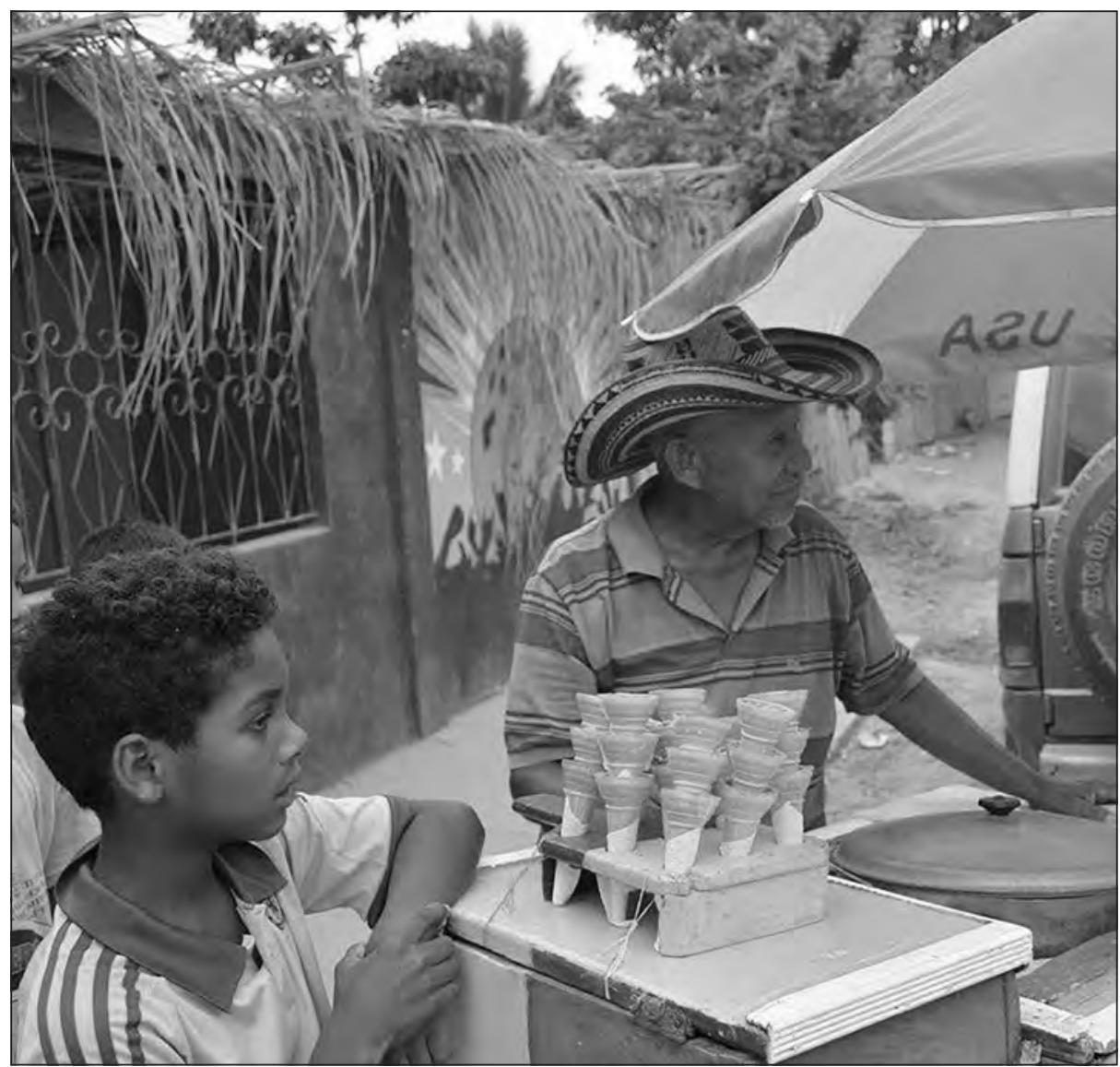

Fuente: Archivo Oraloteca (2017).

Uno no se atrevía a trabajar porque si uno iba por aquí a trabajar a la una, dos o tres de la madrugada o a las tres de la tarde encontraba el poco de gente. No se metían con uno, pero lo molestaban. Nos decían que anduviéramos con cuidado; a veces se metían para la roza y cogían lo que querían y se iban. No teníamos a dónde quejarnos, uno tenía que agachar el hombro, pero el que cogieran que estuviera robando y se enteraban le caían y lo desaparecían. Por ese lado estábamos bien porque no [se] tenía miedo de que le iban a coger el cultivo, pero ya después de que se acabó el conflicto [se] le tenía miedo era al mismo personal que nos robaba (yuca, 
Vida campesina en el Magdalena Grande

patilla, ñame) porque si uno iba a poner la queja al policía e inspector tenía que tener prueba o testigos y uno dónde conseguía esas pruebas. Todos los días aparecían treinta y pico de palo[s] de yuca arrancados, entonces le pedí una escopeta a un sobrino y me metí hasta la una de la madrugada porque la idea mía era barrerlo, no que partirle las patas, y yo decía que era la cabeza partirle. Y yo digo: "el enemigo es mejor matarlo que dejarlo vivo". Bueno, después le puse la queja a los paracos y me dijeron: “¡No seas marica!, quiébralo y entiérralo ahí mismo. No te vayas a poner a sacarlo y decir que lo mataste. Quiébralo y enciérralo ahí mismo", esa era la ley. Esto aquí sufrimos duro matando gente. Por aquí mataron a uno, después al frente mataron cuatro... por allá otro y otro; mejor dicho, le dieron la vuelta a esto a tiros... pero mi tesis es no meterme con nadie (E. Obredor, comunicación personal, enero del 2017).

Actualmente, el Estado colombiano, al observar la crisis en la que se encuentra el campesinado, ha optado por programas productivos en el Centro del Magdalena, concentrados en la actividad piscícola. Este es otro factor que ha generado el distanciamiento con el cultivo de la tierra, optando por nuevas alternativas para solventar económicamente la situación; por ello, [el] acceder a este tipo de proyectos:

Yo venía comentando a mis compañeros lo del proyecto piscícola con el Ministerio de Agricultura y le dije a cada uno de nosotros sobre su labor diferente: unos cultivaban, otros hacían, y esto se ha vuelto una alternativa de trabajo porque no solo del campo se puede vivir, porque se sufre mucho. Necesitamos alternativas de trabajo (A. Romero, comunicación personal, enero del 2017).

Fuimos favorecidos con un proyecto piscícola a través del Ministerio de Agricultura y el programa Colombia Siembra. En eso estamos y esperamos que podamos plasmar lo que el Gobierno proyectó o, digamos, que su acompañamiento en esto sea una realidad y no vaya a fracasar, porque los recursos que vienen destinados para el proyecto realmente se ejecuten. Entonces, también le[s] decimos que apuesten en este proyecto para que no se vaya a convertir en un elefante más (G. Orozco, comunicación personal, enero del 2017). 



\title{
Vida campesina en el Norte del Magdalena
}

\author{
Mapa 9. Mapa subregión CGSM
}

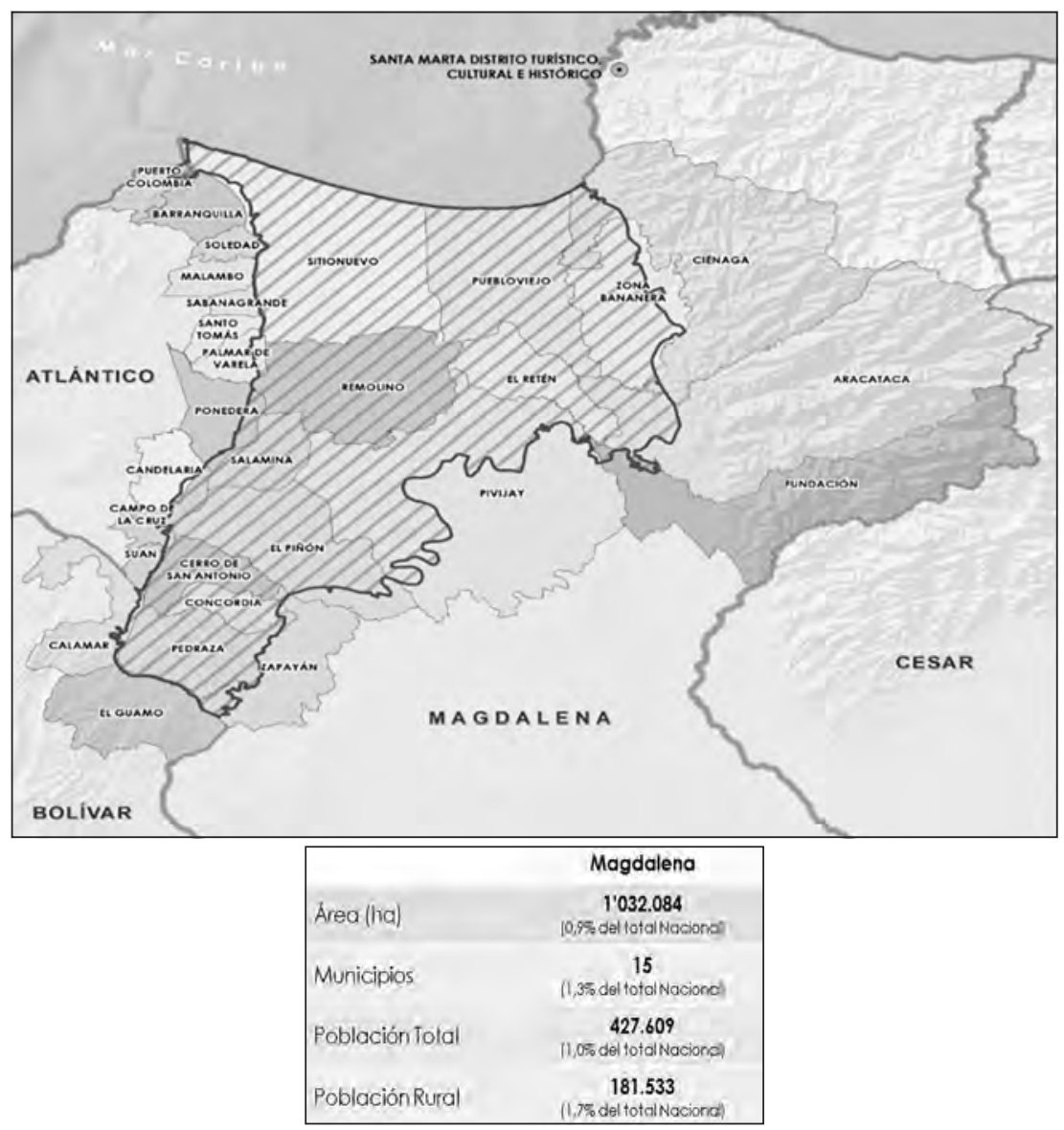

Fuente: UPRA (2014). 
La vida cotidiana es "el espejo de la historia", así la definía Agnes Heller (1985), quien la entendía "como el conjunto de actividades que caracterizan la reproducción de los hombres particulares, los cuales crean la posibilidad de reproducción social... es la forma en que se viven los valores, las creencias, aspiraciones y necesidades" (p. 232). Así, en la vida cotidiana son las vivencias diarias las que permiten, con el paso del tiempo, construir estrategias para enfrentar el diario vivir. Con la acumulación de estas experiencias es que los individuos dan sentido a sus vidas.

En este capítulo nos interesa observar la vida cotidiana actual de los campesinos de la subregión Ciénaga Grande de Santa Marta (en adelante, CGSM), ubicada en el departamento del Magdalena, para establecer cómo se producen y reproducen sus particularidades y cómo estas se transforman en el tiempo, respondiendo a las dinámicas sociales y económicas que ha vivido el país y la región Caribe en la que se enmarca. Adentrarse en la vida cotidiana de los campesinos de la Ciénaga implica observar aspectos como la relación que establecen estos con sus familias, con el territorio, con el trabajo, la política y con el poder, la moral, la religión y los elementos de la identidad que se expresan en la cultura.

Describir estos aspectos fue nuestro objetivo primario. El trabajo de observación e indagación por el presente, realizado en las salidas de campo, se complementa y cobra sentido cuando se enlaza con el pasado. Por lo tanto, para aportar a la comprensión de estos aspectos de la cotidianidad - es decir, para comprender cuál es la historia que se refleja en ella- se hace menester delinear algunos de los aspectos centrales de dicha historia reflejada.

En este sentido, es absolutamente necesario reconocer que el momento presente de la subregión CGSM fue determinado, en gran parte, por las particulares dinámicas de poblamiento y ordenamiento del territorio (agenciadas por el modelo agroempresarial bananero), por las significativas experiencias de organización social de campesinos y asalariados (generadas por y a pesar de dicho modelo agroempresarial) y por la reciente experiencia, vivida colectivamente como subregión entera, de los repertorios de acción violenta que se usaron por diferentes tipos de actores armados y no armados, ligados a los dos aspectos anteriores. 
Vida campesina en el Magdalena Grande

Durante los años comprendidos entre 1996 y 2006 el éxito social, político, económico y cultural que alcanzó a desarrollar el proyecto de región y de nación de las Autodefensas Unidas de Colombia (AUC) fue tan contundente que para realizar un análisis etnográfico de las comunidades campesinas en la actualidad se hace inevitable remitirse a la descripción de los principales aspectos, sucesos, actores y estrategias que se desplegaron en aquella época para su cristalización. Dichos aspectos delinearon los actuales rasgos de las formas de ser y estar de los campesinos de la CGSM.

Por otra parte, a pesar de que el territorio comprendido por la Ciénaga Grande de Santa Marta puede considerarse una subregión claramente delimitada geográfica y socialmente, ya que en torno a ella se dieron las dinámicas de poblamiento y estructuración del particular modo de vida campesino-pescador, durante la investigación se advirtieron tajantes diferencias y particularidades históricas y sociales entre las poblaciones campesinas asentadas en el último tramo del río Magdalena y las asentadas a lo largo del ferrocarril de la Zona Bananera. A estas dos zonas las llamamos Bajo Magdalena y Zona Bananera Histórica, respectivamente.

En este orden de ideas, en el presente capítulo se abordan separadamente las dos zonas de la CGSM: primero, la Zona Bananera Histórica y, posteriormente, la zona del Bajo Magdalena. Repasamos las particularidades geográficas y de poblamiento de cada una de ellas, de tal manera que se tengan elementos históricos para el análisis de la etnografía presentada a continuación (esta es: la exposición ordenada de acuerdo a las dimensiones de estructuración de la vida cotidiana de acuerdo a los ejercicios etnográficos realizados en campo). Esta exposición está acompañada con material fotográfico y abundantes extractos de las entrevistas realizadas a los campesinos y campesinas habitantes de este territorio. 


\section{Zona Bananera Histórica}

Mapa 10. Zona Bananera Histórica

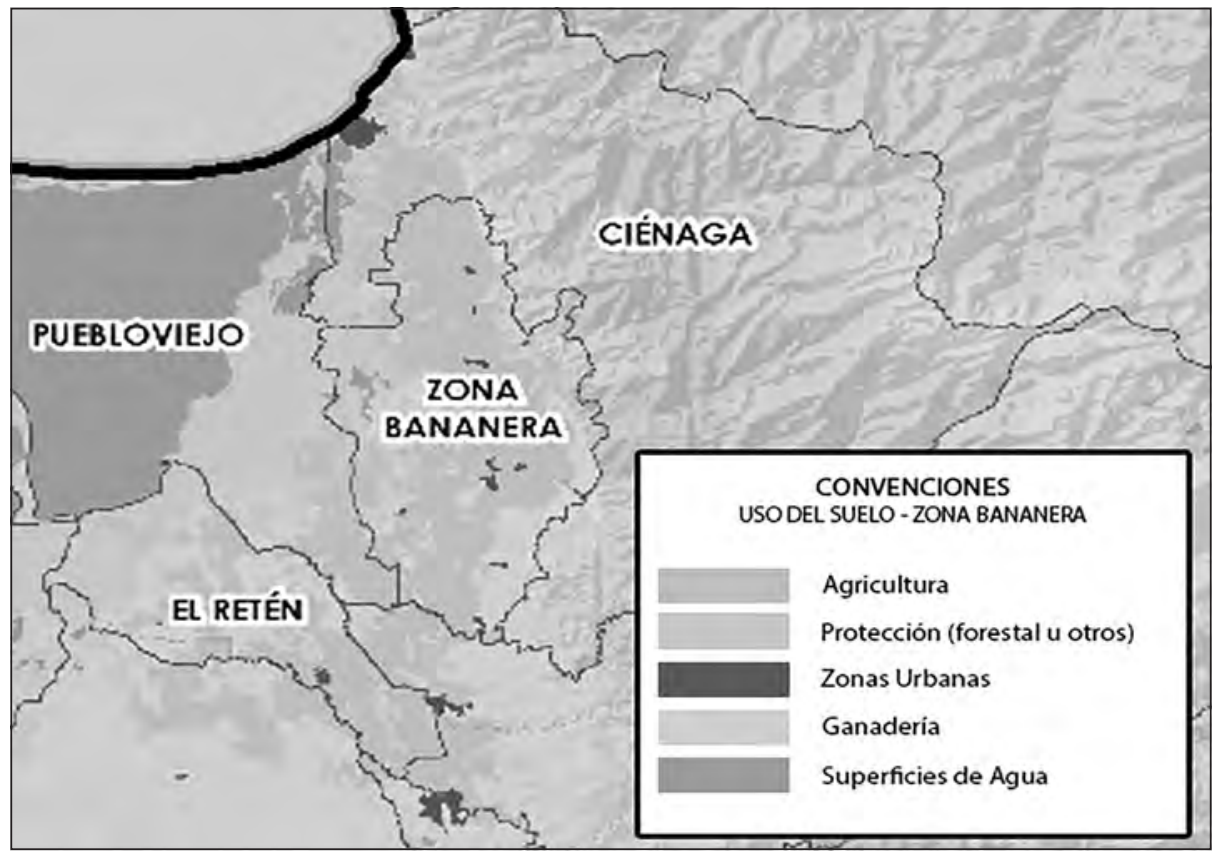

Fuente: UPRA (2014).

\section{Dinámicas de poblamiento y ordenamiento del territorio}

La historia del poblamiento campesino del territorio que en la actualidad se conoce como la Zona Bananera del Magdalena está estrechamente relacionada con la historia de las diferentes bonanzas económicas que han impulsado el desarrollo de la región. Las bonanzas del banano, de la palma aceitera, de la "marimbera" y de la coca, entrelazadamente, fueron conduciendo el sentido de las dinámicas de poblamiento (y despoblamiento), así como de los procesos sociales de ordenamiento de la tierra y del territorio.

La primera bonanza se remonta a finales del siglo XIX y principios del XX, cuando simultáneamente con la llegada de la United Fruit Company (UFC), familias como los Díaz-Granados, Dávila, Zúñiga, Campo-Serrano, Noguera, Alzamora, Abello, Vengoechea, Manjarrés, Durán, Robles, 
Vida campesina en el Magdalena Grande

Riascos, Vives, Pumarejo y Castro - que para entonces ya eran consideradas las "familias tradicionales" - , junto a veteranos militares de la Guerra de los Mil Días, fueron beneficiados en diferentes gobiernos liberales con la cesión de generosos bonos territoriales como incentivo para la expansión de la frontera agrícola y el estímulo a la producción destinada a la exportación, aprovechando el creciente interés nacional e internacional en la producción de banano y como estrategia de consolidación de clientelas políticas de los gobiernos de turno (Viloria, 2009).

Esta política de fomento al banano contribuyó a la formación de los primeros grandes predios privados sobre las abundantemente irrigadas tierras, ubicadas entre la Sierra Nevada de Santa Marta (SNSM) y la Ciénaga Grande de Santa Marta (CGSM) ${ }^{2}$. Posteriormente, las mencionadas familias y portentosas multinacionales bananeras entablaron relaciones de mutuo beneficio. La familia Dávila, por ejemplo, usó su influencia política en el Gobierno, orientada hacia la disminución de los aranceles para la exportación del fruto a favor de las multinacionales. A cambio de esto, recibió préstamos, contactos comerciales y asistencia técnica por parte de multinacionales como la inglesa Colombia Land y la norteamericana United Fruit Company (UFC) (Viloria, 2009).

Durante las siguientes tres décadas (1900 a 1929), esta asociación entre familias terratenientes y las multinacionales hizo de las planicies ubicadas entre la SNSM y la CGSM, comprendiendo lo que entonces era el extenso territorio de los municipios de Ciénaga, Aracataca y Fundación (subregión a la que nos referimos como la Zona Bananera Histórica), el epicentro de un creciente efecto de apropiación y concentración de tierras destinadas para el cultivo de banano ${ }^{3}$ (Viloria, 2009).

Según LeGrand (1983), la UFC consolidó, en esas primeras tres décadas, un total de 60 mil hectáreas de propiedades privadas; esto lo hizo en gran parte por medio de la adquisición de títulos sin linderos definidos,

2. Para examinar en detalle la historia de la disputa por el agua en la subregión ver el extenso estudio de Olga Fabiola Cabeza Meza en Agua y Conflictos en la Zona Bananera del Caribe Colombiano en la Primera Mitad del Siglo XX. Universidad Nacional de Colombia, Facultad de Ciencias Económicas, Instituto de Estudios Ambientales, Bogotá, Colombia, 2014.

3. Actualmente, esta subregión comprende: Sur de los municipios de Pueblo Viejo y Ciénaga, todo el municipio de Zona Bananera y el del Retén y las planicies de los municipios de Aracataca, Fundación y Algarrobo. 
el otorgamiento por parte del Gobierno de más bonos sobre la tierra a las familias tradicionales y la demostración de derechos de herencia de parte de estas mismas familias que esgrimieron títulos de antepasados. Por su parte, Viloria señala que "un informe del Departamento de Baldíos del Magdalena detectó que en 1924 había en la Zona Bananera 35.400 hectáreas de baldíos pertenecientes a la Nación, de las cuales 32.900 habían sido adquiridas irregularmente por la UFC" (Viloria, 2009, p. 18).

Constituido como un verdadero enclave agrícola de la mano de la UFC, la Zona Bananera Histórica fue convertida en el más productivo campo de actividad agrícola de Colombia (Viloria de la Hoz, 2009). Las familias Campo Serrano, Díaz-Granados, Dávila, Goenaga, Riascos, Salcedo Ramón, Noguera, Vengoechea y A. Correa eran las beneficiarias directas de los créditos de la UFC. Algunos miembros de estas familias pagaban arriendos en las tierras de la UFC y, además, ocupaban altos cargos administrativos dentro de esta misma compañía (Meisel, 2004).

Para 1928, empresarios nacionales y extranjeros tenían cultivadas más de 31 mil hectáreas de banano, distribuidas en unas 380 haciendas (Viloria, 2009); esto significaba que la UFC había desplegado con evidente éxito un modelo monopólico de producción y exportación que determinó, igualmente, el ordenamiento territorial de la subregión: adecuó vías terrestres, amplió el ferrocarril desde Santa Marta hasta Fundación, amplió los puertos de embarque en Santa Marta y Ciénaga, distribuyó a su antojo los sistemas de irrigación de cultivos usando los ríos, acequias y canales provenientes de la SNSM, concentró la producción y comercialización del fruto usando su Gran Flota Blanca y llegó a administrar el uso del telégrafo, el matadero municipal y la fabricación de cemento y de hielo (Viloria, 2009).

Este modelo de producción y ordenamiento atrajo a campesinos de distintos lugares del Caribe, que llegaron a asentarse en la cabecera municipal de Ciénaga de tal manera que, durante este periodo, Ciénaga relegó a Santa Marta como la ciudad más importante del departamento. De esa manera, se fueron instalando comunidades campesinas no asalariadas alrededor de las plantaciones de banano que, a su vez, aprovechaban la cercanía del ferrocarril, extendiéndose a lo largo de su recorrido hasta Fundación. Dichas comunidades iniciaron vidas colectivas independientes, estableciendo caseríos y pueblos a lo largo de toda la Zona 
Vida campesina en el Magdalena Grande

Bananera Histórica y el piedemonte de la SNSM y desarrollando cultivos de yuca, plátano, maíz, arroz, caña de azúcar y tabaco. Según Viloria (2009), durante estos años la producción de estos campesinos llegó a abastecer a la subregión y a las ciudades más cercanas como Barranquilla y Santa Marta.

Es importante entender que, también desde esta época, este modelo agenciado desde la UFC generó sendos conflictos territoriales que ocasionaron migraciones internas de campesinos asalariados y campesinos sembradores. No solo las precarias condiciones laborales al interior de las plantaciones, sino además el restringido acceso al agua y la disputa por la posesión de la tierra llevaron a los campesinos cultivadores a la disyuntiva entre desplazarse hacia el interior del departamento o someterse definitivamente al modelo de contratación en las plantaciones bananeras (LeGrand, 1983). Como se sabe, este modelo ocasionó la profundización de las contradicciones sociales y la elevación de los niveles de miseria, descontento y desigualdad, tanto de trabajadores como de campesinos sembradores; a su vez, este modelo provocó la maduración de los repertorios de acción colectiva de los afectados hasta el desenvolvimiento de la denominada "gran huelga de las bananeras"4, que culminó con la ampliamente conocida masacre de las bananeras ${ }^{5}$.

Sin embargo, los siguientes años fueron de crisis para la economía bananera. La crisis de 1929 y el cierre de algunos corredores de transporte en el Caribe, a causa de la Segunda Guerra Mundial, contribuyeron a que la UFC redujera al mínimo la producción de banano, despidiera una ingente cantidad de trabajadores y recortara sus salarios y contratos (LeGrand, 1988). Consecuentemente, un gran número de campesinos sin tierra - que se encontraban además sin salario o con sus salarios recortados- invadió nuevamente las tierras que estaban en desuso, generando un fenómeno social de connotaciones regionales (Viloria, 2009).

4. Viloria (2009) señala que durante el período de huelga los trabajadores incendiaron 40 plantaciones de banano, 9 comisariatos, 2 oficinas de ferrocarril, y derribaron 35 mil metros del telégrafo. El autor estima que las pérdidas materiales ascendieron a US\$1.250 millones, distribuidos entre la UFC, la empresa del ferrocarril y los agricultores nacionales.

5. Le Grand, (1983) calcula que participaron en la huelga unos 25 mil individuos que, durante 3 semanas, detuvieron las operaciones de la United Fruit Company hasta la masacre de trabajadores, ejecutada por el Ejército Nacional el 6 de diciembre de 1928. 
Vida campesina en el Magdalena Grande

Solo hasta 1947, con la terminación de la Segunda Guerra Mundial y el desarrollo de una alianza entre las familias Dávila y Vives, se conformó la Federación de Productores de Banano del Magdalena y la UFC reactivó su producción en la zona, usando el nombre de Frutera de Sevilla. Sin embargo, nuevamente diversos fenómenos meteorológicos adversos y la propagación de la sigatoka afectaron sensiblemente la producción de banano en el Magdalena y la Frutera de Sevilla decidió desplazar su área de producción hasta el Urabá Antioqueño, generando una nueva crisis en la economía regional (Viloria, 2014) y repercutiendo en nuevas dinámicas de desempleo, migraciones internas y subutilización del suelo (Buchelli, 2005).

En consecuencia, durante las siguientes dos décadas la producción de banano del Magdalena fue relegada por la de Urabá en Antioquia. Durante este periodo, algunas familias tradicionales magdalenenses entablaron relaciones sentimentales y matrimonios con inmigrantes franceses como los Lacouture, quienes se habían mantenido como exportadores de banano en el departamento (Buchelli, 2005). Solo hasta la década de los 60 los empresarios locales se asociaron entre ellos para lograr competir con los precios internacionales. Así, se crearon las principales asociaciones de productores y comercializadores de banano a nivel regional y nacional ${ }^{6}$.

Simultáneamente al crecimiento de la industria bananera nacional y a la implementación de modelos obreros patronales — basados en la explotación laboral y la represión de las dinámicas organizativas, y heredados de la experiencia caribeña de la UFC-, las agremiaciones sindicales también se fueron desenvolviendo. También con epicentro en Urabá, el gremio obrero había creado desde 1964 el Sindicato de Trabajadores del Banano (SINTRABANANO). Posteriormente, surgió el Sindicato de los Trabajadores del Agro (SINTRAGRO), en 1972, en la empresa holandesa COLDESA. Finalmente, en 1988, tras la fusión de SINTRABANANO y

\footnotetext{
6. La Asociación de Bananeros de Colombia (AUGURA), en 1963, y la Asociación de Bananeros de Urabá (UNIBAN), en 1966; además de estas, entraron en funcionamiento las comercializadoras Turbana Banana Corporation, en 1970, y Técnicas Baltime de Colombia (TECBACO), subsidiaria de Standard Fruit Company, en 1976. Posteriormente, surgieron CI BANACOL S.A., en 1980, y PROBAN, en 1983; esta última se creó cuando la Frutera de Sevilla cerró operaciones en Urabá y retomó su renaciente enclave en el Magdalena (Buchelli, 1991).
} 
Vida campesina en el Magdalena Grande

SINTRAGRO, se fundó SINTRAINAGRO, la mayor organización sindical de los trabajadores del agro hasta ese momento ${ }^{7}$.

Al mismo tiempo, según la prensa de la época, el interés y los precios de la tierra se incrementaron (El Tiempo, 1991). Finalmente, desde 1996, año en el cual ingresan las Autodefensas Campesinas de Córdoba y Urabá - ACCU - al Magdalena, se inició un nuevo periodo de reducción de las exportaciones de banano de la zona que solo hasta el 2003 recuperó un nivel solo comparable con el de los años sesenta.

En el año 2000, en la Zona Bananera del Magdalena:

El 94,8\% [1.044] de las fincas pertenecían a productores independientes, y acumulaban 8.981 hectáreas, es decir el 69,5\% de las hectáreas totales del cultivo. Asimismo, el 77,7\% de estas fincas tenían un tamaño de 10 o menos hectáreas, es decir pequeños productores, mientras un $22,2 \%$ corresponde a productores medianos con tamaños promedios de sus fincas de entre 10 y 40 hectáreas. Sólo un 1,3\%, es decir 20 fincas, son explotaciones de más de 150 ha [...]. En poder de las comercializadoras (Grupo Dole, Uniban-Expocaribe, Proban, Grupo Chiquita, Grupo Banamar) en el año 2000 estaban el 30,5\% de las hectáreas totales de la región, correspondiente al 5,18\% del total de fincas (Observatorio Agrocadenas Colombia, 2005, p. 76).

En la actualidad, las empresas multinacionales como las norteamericanas Chiquita, Dole (Standard Fruit Company) y Del Monte, las británicas Fyffes y Geest, y la jamaiquina Producers, así como las comercializadoras nacionales Banacol, Uniban y Proban, no participan directamente de la producción, pues compran la fruta bajo contrato a las cooperativas o corporaciones que agrupan a los productores (Observatorio Agrocadenas Colombia, 2005).

Hacia 1958, por iniciativa del Gobierno Nacional, se propuso un plan de fomento al cultivo de la palma en la región de la Zona Bananera, el cual fue elaborado por Maurice Ferrand, quien resaltó las condiciones

7. Sea preciso señalar la importancia de este sindicato tanto para las estrategias de defensa de derechos laborales de las poblaciones "zoneras" como a nivel nacional, en el marco de los procesos de participación política resultantes de los acuerdos de paz durante el gobierno de Betancourt. 
Vida campesina en el Magdalena Grande

favorables existentes para el cultivo de la palma en la zona, con lo cual inició el apoyo a las actividades palmíferas en la región (FEDEPALMA, 1998). Estas actividades se enmarcaron en la política de sustitución de importación, desarrollada por el Gobierno Nacional en los años cincuenta y sesenta "ante la creciente demanda de aceites vegetales y materias grasas que registraba el mercado interno y el descenso de las reservas internacionales" (Aguilera, 2000, p. 54).

En la Zona Bananera la empresa precursora del cultivo de palma fue Palmares de Andalucía, propiedad del español José Martínez, quien realizó en 1965 su primer cultivo de palma en la finca Gato Bravo, propiedad de Joaquín Campo, en una extensión de 600 hectáreas.

Mapa 11. Vocación y conflicto de uso del suelo en Zona Bananera

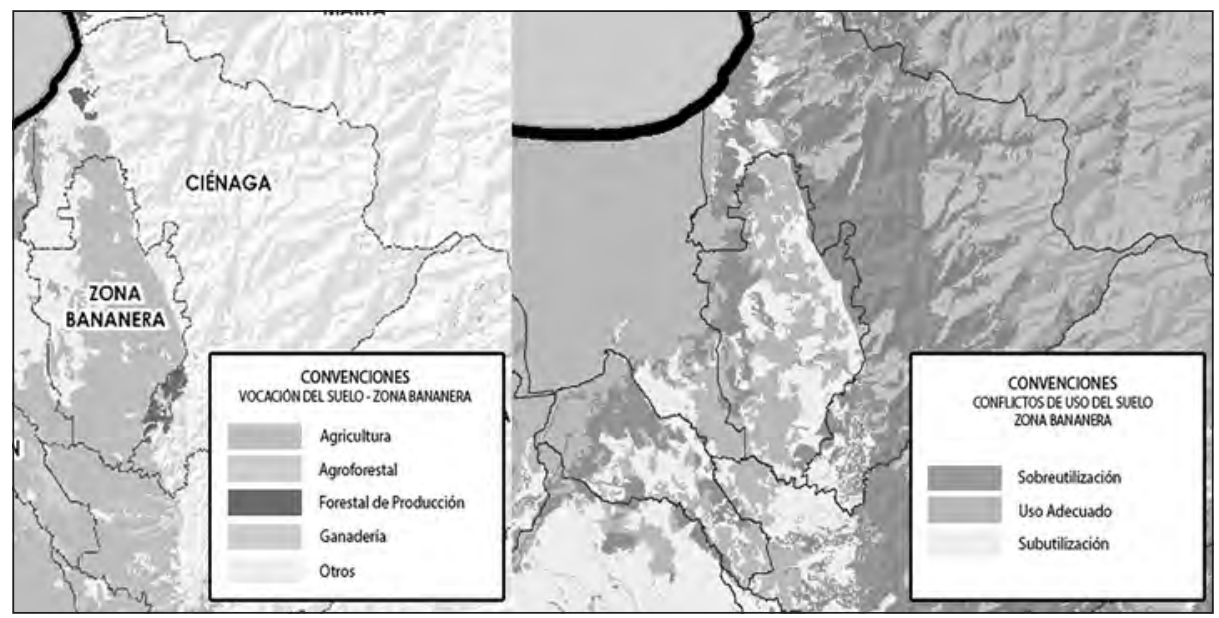

Fuente: UPRA (2014).

A partir de allí, y aprovechando los estímulos de los gobiernos de turno, los palmicultores iniciaron su actividad en la región. De esta manera, entre los años sesenta y setenta empezaron los cultivos en las fincas Patuca, el Carro, la Fe, Sierra Morena y Bella Vista, propiedad del Grupo Vives, y la Cabaña, el Roble y la Gabriela, propiedad de los hermanos Hernando, Alfredo y Carlos Lacouture, quienes además poseían fábricas de extracción de aceite en las cuales ofrecían sus servicios a pequeños productores. 
Vida campesina en el Magdalena Grande

Si bien se dio, por parte del Gobierno Nacional, estímulo para la aparición de pequeños cultivadores de palma en la región, una de las características más relevantes del cultivo de la palma en la CGSM es que la propiedad de las unidades palmeras "mantiene la preeminencia de los nativos de la Costa Atlántica, en la forma de sociedades familiares" (FEDEPALMA, 1998).

Se resaltan cuatro familias, las cuales han tendido desde el inicio una participación significativa en los cultivos de palma africana en la región: "los Lacouture, los Dangond, los Vives y los Dávila, todos oriundos de las que fueran provincias del Magdalena o de Santa Marta, la capital del departamento" (FEDEPALMA, 1998).

El auge de la palma en las últimas décadas se encuentra directamente relacionado con las dificultades de la industria bananera en los años noventa y la creciente demanda de aceites y de sus subproductos:

en el momento en [el] que las grandes compañías comenzaron a irse y que se abandonaron grandes áreas de banano, la gente comenzó a mirar qué hacía [...]. La palma llegó como una posibilidad de un cultivo alterno frente a una crisis que se empezaba a dar en el sector bananero (Goebertus, 2008, p. 47).

Respecto a la crisis bananera, el historiador Elías Caro señala que

en los albores del siglo XXI, la Zona Bananera contaba con más de 32 mil hectáreas [de área cultivada de banano], sin embargo, para 2013 parece ser [que] hay menos de 10 mil, con tendencia cada vez más a disminuir esos indicadores fruto de ese cambio productivo (Elías, 2013, p. 75).

La Zona Bananera es, quizá, uno de los municipios en los que se puede observar de mejor manera lo que Consuelo Corredor denominó "modernización sin modernidad"(Corredor, 1992, p. 20), un periodo en el que se produce una sensación de vivir en dos mundos: por un lado, el que resulta de los cambios en el sistema económico, buscando modernizar el país a través de la imposición de las transformaciones del modelo de producción; por otro, el que se queda anquilosado, sin posibilidad de asimilar los cambios y construir valores modernos. Al respecto, 
Vida campesina en el Magdalena Grande

Corredor (1992) anota: "la sensación simultánea de estar viviendo entre dos mundos, proviene de las profundas mutaciones experimentadas por la sociedad colombiana a lo largo del proceso de modernización económica que 'desde arriba' han promovido las élites económicas y políticas dominantes" (p. 23). Así, las élites económicas y políticas de esta región han sabido adaptarse a los procesos de modernización económica para mantener un oligopolio sobre el banano, mientras que hacia el interior de las plantaciones y en la relación con el municipio mantienen lógicas propias previas a la modernidad.

Este argumento se refuerza con el relato que hace el señor Vladimir Carranza, pequeño productor de banano de Orihueca, líder social durante toda su vida, desplazado y actual reclamante de tierra del predio Chimborazo, sobre la manera en cómo los terratenientes han monopolizado todos los ámbitos de la vida social en la Zona Bananera:

Bueno, aquí se dan yo no digo que fenómenos, sino una cuestión que se ha desarrollado es que, por ejemplo, los grupos económicos son los mismos terratenientes, esos mismos, son los mismos dirigentes políticos del municipio. Entonces, hay una monopolización total del agua, de la tierra, de la política: ellos son los dueños de la actividad económica que, inclusive, ellos tienen alianzas con las multinacionales del banano y son ellos mismos dirigente[s] políticos [...]. Estos terratenientes han generado un sistema cerrado en el cual los campesinos que han entrado a disputar la tierra y sus derechos han tenido que pagar con su vida tener que enfrentarse a estos (V. Carranza, comunicación personal, diciembre del 2016).

Esta situación se evidencia en las condiciones de vida de los campesinos de la Zona Bananera que ven cómo, generación tras generación, trabajan arduamente en las plantaciones de banano $-\mathrm{y}$, más recientemente, de palma - sin que sus condiciones de vida mejoren. En el siguiente aparte se abordarán las generalidades en materia de acceso a derechos fundamentales y, posteriormente, abordaremos la descripción de la manera en cómo los pobladores de esta zona enfrentan el día a día, bajo estas condiciones estructurales, de acuerdo a las dimensiones ya expuestas. 
Respecto al acceso al agua, en algunas cabeceras municipales, como la de Sevilla, cuentan con servicio de acueducto (que se alimenta del río Sevilla). En el resto del municipio, que es en su totalidad rural, a pesar de que está bañado por tres ríos (Frío, Sevilla y Tucurinca) el acceso al agua se está dando a través de pozos subterráneos porque los terratenientes han monopolizado el acceso al agua.

Según Rubén Urueta, campesino jornalero habitante de toda la vida de Varela, diez años después de haber iniciado las obras de instalación de acueducto y alcantarillado aún hay zonas que no cuentan con este servicio en la Zona Bananera:

De antes y de ahora porque es que antes también era lo mismo, antes no había acueducto aquí, antes nos tocaba sacar dos canecas con un palo en una mula y arrearla. Ese problema del agua viene constantemente. Vea ahora lo que están haciendo ahora: un tanque elevado, ya la tubería está enterrada y rogándole a Dios que organicen eso rápido antes [de] que se vaya [a] acabar el presupuesto porque el colegio también está parado por eso, porque no hay plata (R. Urueta, comunicación personal, diciembre del 2016).

Esta situación implica que los campesinos en la actualidad tengan que tomar el agua de un pozo o del río directamente, sin ningún tipo de tratamiento para su potabilización: "porque uno tiene que salir de su casa y traerla de allá de esa sequía, que cuando eso estaba seca. A donde había que irla a buscar allá al río de Río Frío en bicicleta o en moto" (R. Urueta, comunicación personal, diciembre del 2016).

El señor Carranza advierte que esta agua de pozo no es adecuada para el consumo humano y que los terratenientes están violentando el derecho que tienen los pobladores a acceder al agua:

Ellos quieren obligarnos a que la comunidad consuma agua de pozo y ya no se la echan a las plantaciones de banano porque les hace mal, pero nosotros los seres humanos sí nos tenemos que consumir esa agua porque el agua de los ríos es para ellos y la de pozo para el ser humano, sabiendo todas las afectaciones que está generando la cuña marina (V. Carranza, comunicación personal, diciembre del 2016). 
Vida campesina en el Magdalena Grande

Imagen 110. Pozo artesanal para la extracción de agua
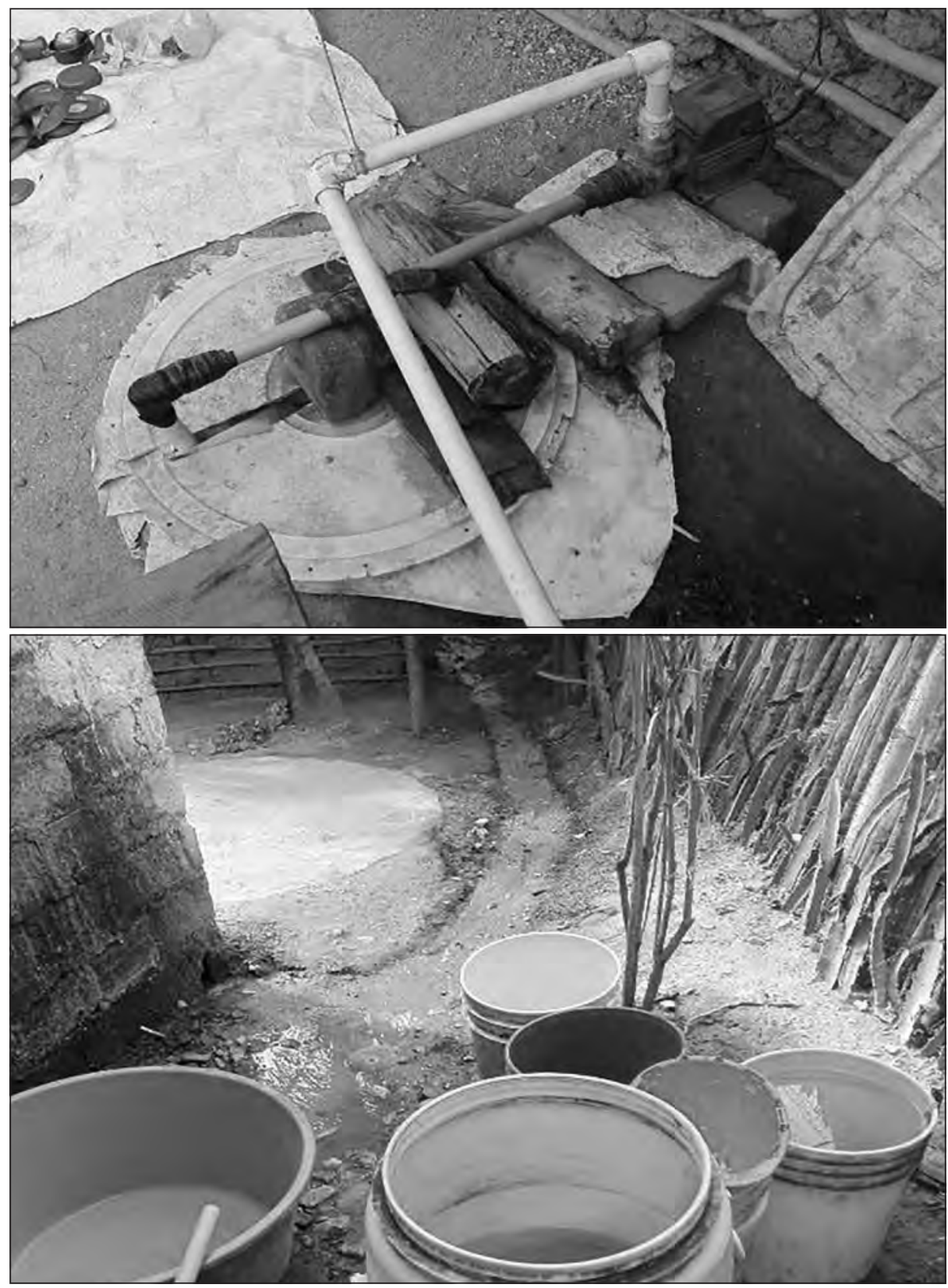

Fuente: Archivo Oraloteca (2017). 
Vida campesina en el Magdalena Grande

La problemática de acceso al agua para el consumo humano está vinculada al tema de salud, pues además de no contar con un adecuado servicio de acueducto proliferan las enfermedades que no pueden ser tratadas de manera adecuada por las deficiencias en la prestación del servicio de salud. Por ejemplo, en el corregimiento de Varela el señor Rubén Urueta manifiesta que hay un puesto de salud, pero que carece de personal médico para brindar la atención:

El agua, el acueducto para las viviendas, es que como le digo el agua viene de la salud, es el mejor puesto de salud que hay en el municipio de la Zona Bananera, pero ahí no hay médicos sino 2 días a la semana... El médico, el único problema de salud, está bien bonito el puesto de salud, pero lo único que falta es un médico. Así como le digo, que viene médico a veces hasta 2 días a la semana, un puesto que está capacitado para citar un médico todas las 24 horas, como yo se lo dije al carnero: “¿usted sí cree que un puesto de salud con toda su maquinaria que tiene, porque ahí le trajeron maquinaria pa' todo, es para que tenga médico cada 2 días semanal[mente]?". Es lo que hace un médico 24 horas, permanente con ambulancia, pero esas son cuestiones que uno está manejándose como a punta de uña, viejo (R. Urueta, comunicación personal, diciembre del 2016).

Las viviendas han sido, en gran parte, producto de la autogestión y del conocimiento heredado sobre cómo debe ser una vivienda de acuerdo a las condiciones climáticas, a los usos que se les asigne a los espacios según la composición familiar y, por supuesto, a los recursos de las familias. No se cuenta con programas de vivienda por parte del Gobierno ni de los grupos económicos. V. Carranza (diciembre del 2016) señala: "uno no ve que esas empresas hagan un programa de vivienda para el mejoramiento de la calidad de vida del trabajador" (comunicación personal).

Según el relato del señor Carranza, el municipio de Zona Bananera aporta un porcentaje importante al PIB del departamento, pero esto no se ve reflejado en planes sociales. En el caso de la educación, comenta:

Hay una desidia institucional, tanto de la empresa privada como del sector público. No existe un programa interinstitucional donde diga "bueno, listo, este muchacho terminó, vamos [a] hacerle un proceso de 
Vida campesina en el Magdalena Grande

orientación hacia la técnica, tecnológica o superior"; no existe. Yo siempre le hago la observación a los grupos económicos, que si uno hace una evaluación acá tú preguntas cuántos muchachos hay en el Sena, en la universidad, al medio de ese canal y no hay, prácticamente no hay... no buscan soluciones a la parte de educación y estamos bastante quedados. Ahí observamos que, por ejemplo, la Zona Bananera en el departamento representa el 50\% del PIB y es el $4 \%$ a nivel nacional y el 10\% de las exportaciones nacionales y todo lo que genera la Zona (V. Carranza, comunicación personal, diciembre del 2016).

Imagen 111. Vivienda campesina en Varela, Zona Bananera

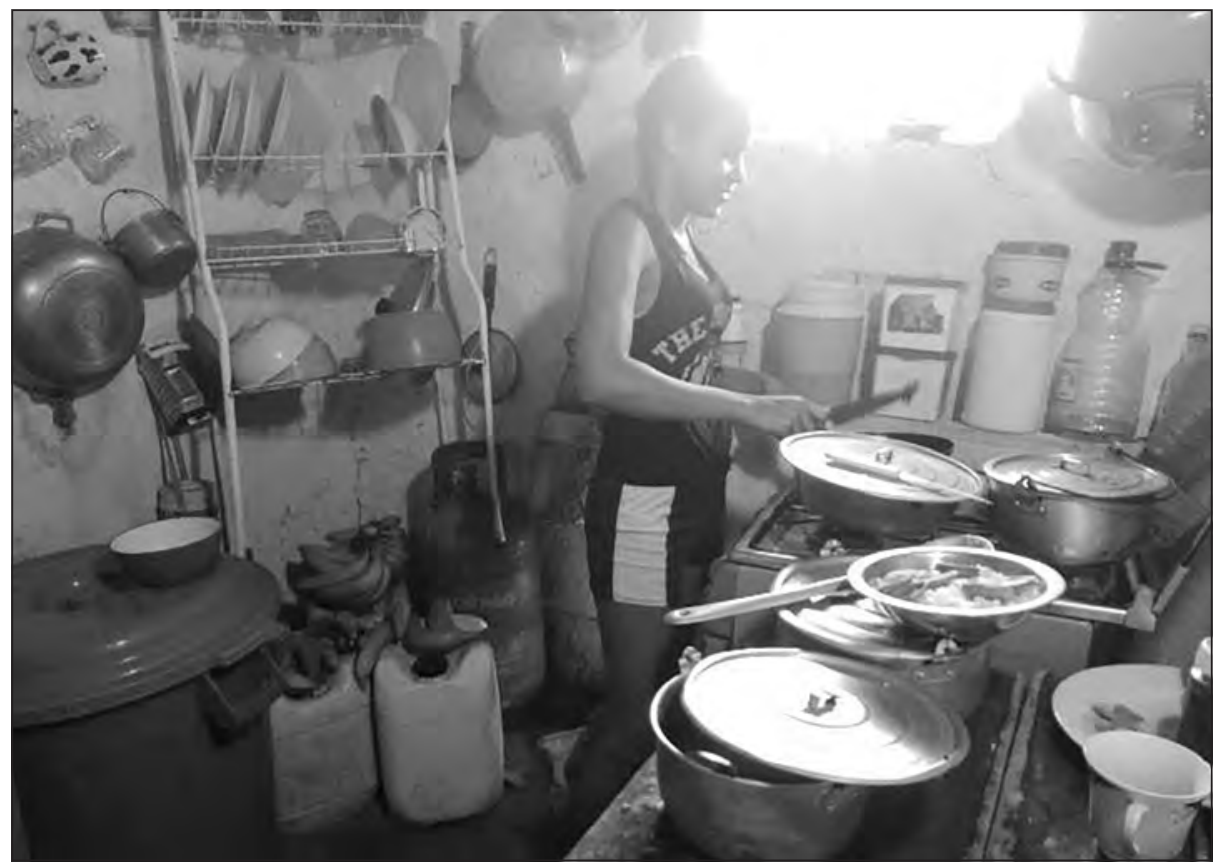

Fuente: Archivo Oraloteca (2017).

Los pobladores de la zona ven que para los jóvenes no hay una opción de futuro que mejore sus condiciones de vida. A la ausencia de programas de formación académica y técnica se le suma el aumento de prácticas como el consumo de alcohol y drogas, que conducen al aumento de la violencia y el mantenimiento de la pobreza: 
Vida campesina en el Magdalena Grande

No hay un programa [...] donde orienten al hijo del trabajador hacia unos procesos de formación. Acá los muchachos terminan el bachillerato y a los papás les da miedo hablarle[s] de universidad porque no está la condición, no está el medio, pero yo digo que es por falta de conocimiento porque del trabajo para la casa y el fin de semana a consumir alcohol, y no hay la cultura para que el hijo entre a la Universidad o el Sena donde ahora hay opciones con el ICETEX, el Sena con canales como que desplazado... entonces falta un poquito de información y a la gente no le interesa (V. Carranza, comunicación personal, diciembre del 2016).

\section{Dimensión socioeconómica}

En cuanto a lo productivo, en la Zona Bananera encontramos la persistencia de las dos formas históricas de relacionamiento con la tierra en cuanto medio de producción: los campesinos que se dedican al trabajo asalariado en las grandes plantaciones de banano y palma, como los que tienen sus parcelas o los que, de alguna manera, procuran mantener su independencia frente a estas mismas plantaciones y funcionan a través de cooperativas de trabajo, tratando de combinar en sus parcelas cultivos transitorios y banano.

Como hemos visto a través de la historia, las dos formas reflejan por igual la desventaja económica del campesinado, pues el esfuerzo que implican ambas formas de acceso al medio de producción no se satisface con la remuneración obtenida. Las pésimas condiciones de trabajo que tienen que enfrentar, las largas jornadas de trabajo y las casi nulas garantías sociales y de agremiación para exigir sus derechos hacen que su condición de pobreza se mantenga y no gocen de una vida digna.

Los ingresos obtenidos de manera independiente o resultantes del trabajo asalariado en las plantaciones no logran cubrir las necesidades básicas de los campesinos de esta zona. Por ejemplo, el señor R. Urueta (diciembre del 2016), quien trabaja en una plantación de banano, tiene ingresos variables, pero no alcanzan nunca el salario mínimo mensual: “[¿Cuánto se puede estar ganando usted al mes?]. Hay épocas [en las] que como 400 y pico, 500 y pico, como hay épocas que puede coger uno los 600 ; depende del terreno en el que uno está trabajando al mes" (comunicación personal). 
Vida campesina en el Magdalena Grande

Estos escasos recursos tienen que ser distribuidos en la manutención de la familia (alimentación, servicios públicos, educación y salud), pero como dice el señor Rubén, son más los egresos que los ingresos. Según su testimonio, en alimentos gasta un promedio de 200 mil pesos quincenales que paga a un tendero en río Frío que le vende al fiado, tiene que pagar servicios públicos, dónde el más costoso es el de gas por un crédito que solicitó para adquirir un computador. Así, según él los gastos son mayores que su nivel de ingresos, no importa cuánto trabaje al mes.

En el siguiente aparte observaremos las dos formas en las que los campesinos de esta zona obtienen ingresos. En primer lugar, observaremos la lógica de producción parcelera ${ }^{8}$, donde encontramos a los campesinos que tienen tierra y [a] los que no la tienen, pero que prefieren arrendar tierras para cultivar que trabajar en las plantaciones; en segundo lugar, veremos la lógica de producción que implantó la agroindustria del banano, donde el campesino asalariado está enajenado de lo que produce.

\section{La producción parcelera}

Como se sabe, la economía campesina en Colombia está profundamente determinada por la estructura de tenencia de la tierra. Como hemos visto, el modelo de producción agroindustrial de banano y palma, en la subregión CGSM, está soportado sobre la dinámica histórica de concentración de enormes extensiones de tierra y agua que, después de más de un siglo de desarrollo, ha dejado escasos retazos de tierra (y los de menor calidad para otros usos). Por lo tanto, las formas de vida campesina con producción parcelera se han adaptado a las condiciones ambientales, sociales y económicas que implican habitar estos retazos.

En primer lugar, los campesinos que no tienen tierra y que quieren mantener su independencia tienen como opción pagar un arriendo a un pequeño o mediano propietario, corriendo un doble riesgo, pues así el cultivo llegue a feliz término o no tienen que pagar a la persona que les arrienda.

8. Hemos denominado "lógica de producción parcelera" a la que se acerca a las tradiciones de los campesinos, donde ellos trabajan de manera independiente, sean dueños o no de la tierra, y alternan el cultivo de banano y otros frutales con cultivos transitorios para el consumo propio. 
Vida campesina en el Magdalena Grande

Un ejemplo de una relación colaborativa no formalizada que les permite lidiar con estos problemas de acceso a tierra y evitar las plantaciones es el de los señores Javier Ruiz y Guillermo Polo, en Candelaria, el último de los pueblos de la Zona Bananera antes de encontrarse con las aguas de la CGSM.

El señor Javier cultiva en pequeños predios alquilados, cuyos propietarios no los están trabajando y le permiten trabajarlos y cuidarlos temporalmente. Algunos de estos arrendadores le exigen como canon, además, entre un $10 \%$ y un $20 \%$ de las ganancias de la cosecha, dependiendo de cómo le resulte. Por lo tanto, sus ingresos son muy variables y por temporadas. Mientras no tiene cosechas o cuando las pierde recibe la ayuda de Guillermo, el cual es propietario. Guillermo le presta dinero para los gastos de abono, plaguicidas u otros necesarios para cultivar, o para los gastos domésticos mientras sale la cosecha. Javier calcula que ha llegado a deberle cinco millones de pesos. En los últimos diez años ha utilizado, junto a otros predios prestados o arrendados temporalmente, nueve hectáreas y media de tierras inundables junto a la Ciénaga, con el riesgo de perder los cultivos en invierno, como le ocurrió el año pasado con un cultivo de ahuyama. Con todo, el señor Ruiz prefiere vivir de esta forma que aceptar las condiciones de las plantaciones de banano:

[¿Pero usted nunca ha trabajado en una plantación de banano?]. O sea, en una ocasión. Una vez trabajé ocasional, trabajé como 15 días y me di cuenta de las cosas y nombe', no. Ey, una persona sale a las 6 de la mañana de aquí, a las 5, salen, a las 5 o 4 de la mañana, regresan a veces a las 6,7 de la noche... o sea, como para irse a ganar por decir algo 25, 30 mil pesos, $y$ sale la mujer diciendo: "no, que no hay pa' hacer... no alcanza para hacer las compras", entonces trae lo que es manteca, arroz y sal. Como estaba diciendo, el hombre [el anterior entrevistado, que trabaja en una plantación de banano], que él come carne, por eso yo digo: “joda, de verdá lo que es la vida, la gente no se da cuenta los demás". Yo me he dado cuenta [se refiere a que no todos los trabajadores de plantación de banano ganan lo suficiente como para comer carne a diario] [...]. [Y cuándo trabajabas en la finca, ¿qué labor desempeñabas?]. Trabajé en caciqueo, haciéndole mantenimiento al guineo pequeño; por ahí una vez hice un solo corte, me acuerdo, y no fui más porque... desde las 5 de la mañana y eran las 8 de 
Vida campesina en el Magdalena Grande

la noche y todavía estábamos en corte, y yo "no, yo no voy más", le dije al coordinador. Y me dijo “¿usted se va?” y yo "sí", [a lo que respondió:] "no, no te pago", y yo "isi no me va a pagar no me pague, pero yo no vengo más aquí!” (J. Ruíz, comunicación personal, diciembre del 2016).

Siendo uno de los pueblos más tradicionales, Orihueca le sigue en importancia a Prado Sevilla, que es la cabecera urbana del municipio de Zona Bananera. Allí vive Eusebio Hernández, un campesino desplazado y reclamante de tierra de la finca El Tiempo. Desde hace 12 años posee 401 hectáreas de tierras de playón junto al tramo final del río Frío. Durante la temporada de lluvias estas tierras permanecen inundadas, por lo que solo puede trabajarlas 6 meses al año, con 2 o 3 de las 6 personas que sostiene en su núcleo familiar.

El señor Eusebio Hernández (diciembre del 2016) también cultiva en arriendo una hectárea de tierra no inundable. El arriendo es por cosecha de banano: "cada corte que uno embarca son 200 mil pesos que tienen que dar por hectárea" (comunicación personal). Recientemente, adquirió 5 ha que comenzó a cultivar junto a otros 5 campesinos, apoyándose en el programa gubernamental Colombia Siembra, que les permitió adquirir las semillas e instrumentos que, a su vez, utilizan para las tierras inundables propias.

Imagen 112. Parcela de banano en Orihueca

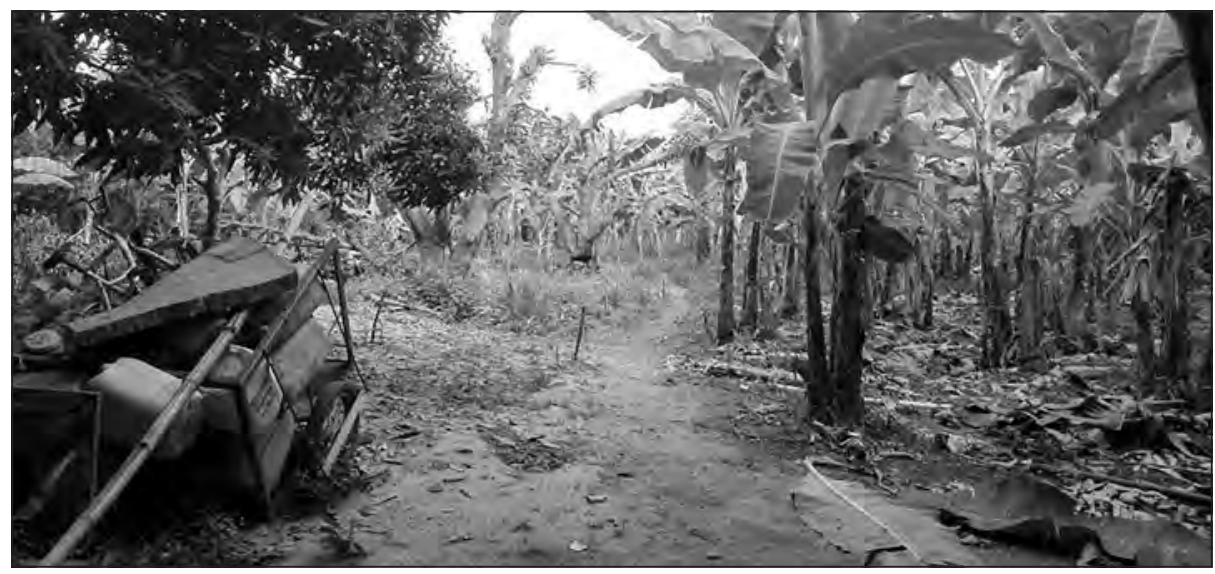

Fuente: Archivo Oraloteca (2017). 
Vida campesina en el Magdalena Grande

Además de las dificultades para acceder a la tierra, como se dijo anteriormente, otro elemento que dificulta el proceso productivo es que no se cuenta con sistemas de riego apropiados; esto, debido a la apropiación indebida de los caños y a la desviación de ríos. Los campesinos que habitan esta zona se han adaptado a este tipo de lógica en la que están en una condición de desventaja: poseen las tierras ubicadas en zonas que presentan las mayores deficiencias ambientales y no poseen los recursos para adecuar sistemas de riego. Al respecto, comenta el señor Vladimir:

En los últimos tiempos se ha dado la cuestión del agua, en donde los terratenientes acumulan el agua en reservorios y le anulan el acceso del agua que, por tradición, lo tenían los pequeños. Entonces, ya no tienen ese acceso. Entonces, a la gente se le deteriora el cultivo y ellos compran todos los alrededores de la parcela y el pequeño ese que está en el medio les tiene que vender porque ellos lo ahogan (V. Carranza, comunicación personal, diciembre del 2016).

Por su parte, en la Mira, sector cercano a la periferia urbana de Ciénaga, la señora Aura Rodríguez vive y cultiva tierras propias con su esposo y sus tres hijos. Poseen hectárea y media que dedican a una gran variedad de cultivos, tales como cañandonga, coco, mango, zapote, guayaba, guanábana, plátano, guineo cachaco, torombolo, etc. Su hijo menor va al colegio en la mañana mientras los otros miembros de la familia realizan las actividades del campo, como tirar guadaña o tirar pala. Ella, particularmente, tiene a su cargo una huerta recién creada de plantas medicinales a cuyo cuidado se dedica, aunque ocasionalmente también asume actividades de fuerza como tirar pala.

Se levanta a las 4:30 a.m., un poco antes que los demás, para ir preparando el tinto y el desayuno. Junto a su hija, que estudia en la tarde (como su hijo mayor), asume la preparación del almuerzo y de la cena, por lo cual o termina la jornada de trabajo de la mañana antes que todos o su hija termina a las 3:00 p.m. cuando no tiene clases. El hijo menor colabora en la tarde durante, máximo, una hora.

En este contexto, la apropiación indebida del recurso hídrico ha empujado a las poblaciones a buscar otras fuentes de agua que implican mayor dificultad para su acceso y menor potabilidad: 
Vida campesina en el Magdalena Grande

En la época de verano nosotros pasamos bastantes necesidades. ¿Por qué? Por el agua, sobre todo el agua porque a nosotros como pequeños productores nos ha tocado hacer pozos subterráneos para poder regar nuestros productos, nuestros cultivos, ¿por qué? Porque no teníamos otra alternativa y debido a que Socio Riofrío [se refiere a ASORIOFRÍO'], pues los canales de riego, los sistemas de riego los había quitado de acá de... o sea, nos habían quitado el agua que nos daban... pues, a través de los ríos nos daban el agua por desnivel (A. Rodríguez, comunicación personal, diciembre del 2016).

De igual forma, en sus predios inundables, ubicados en el corregimiento de Sevilla, Eusebio Hernández se debate entre la escasez de agua y las inundaciones, fenómeno que se agrava debido a las dificultades para organizarse gremialmente y superar "el acaparamiento" o la proliferación de intermediarios comerciales del producto:

[¿Por qué a pesar de estar asociados no han superado el tema del acaparamiento?]. Por las inundaciones, porque nosotros para hacer eso tenemos que tener un terreno adecuado para trabajar invierno-verano, para poder tener un mercado donde uno exportar, porque así uno si sembró hace un cultivo y ahí mismo coge y uno viene la creciente, y se mete, ya uno tiene que venderlo como sea, ahí se estanca. Entonces, tiene uno que salir a buscar trabajito por ahí en otra parte [...], en el invierno sufre uno eso y en el verano la sequía por parte de acá arriba que le digo, que esa agüita debe de permanecer abajo para uno sostenerse [...]. Entonces, eso no lo encuentra uno por aquí porque los ricos estos, los Cadavid y toda esa vaina, atrancan esa agua acá arriba y esa vaina es de ellos (E. Hernández, comunicación personal, diciembre del 2016).

9. Sobre la vertiente occidental de la SNSM el Estado concedió a los usuarios de los ríos que desembocan en la CGSM la creación de figuras de derecho de carácter corporativo de objeto especial y sin ánimo de lucro, conformadas por quienes reúnen las condiciones para ser tenidos en cuenta como usuarios de un determinado distrito de riego. Es así que existen AsoAracataca, AsoTucurinca, AsoSevilla y AsoRiofrío. A cada uno de estos distritos de riego le corresponde la administración y el buen uso del recurso hídrico del que se proveen. Ver. Plan de Manejo Santuario de Fauna y Flora de la Ciénaga Grande de Santa Marta, PNN, 2005, p. 115 
También en la Mira vive y trabaja Guillermo Polo, quien hace parte de la Cooperativa Integral de Fruticultores del Magdalena (COFRUMAG). Junto a un compañero, Polo trabaja en una parcela - de 2 hectáreas cultivadas y 1 y media todavía sin cultivar- en comodato por 5 años. Los cultivos principales son limón y mango, seguidos por zapote, níspero, guayaba, torombolo y marañón, a los que le siguen los cultivos secundarios.

Polo se levanta diariamente a las 4:00 a.m. y llega a los predios a las 5:00 o 5:30 a.m., aprovechando las motos de los trabajadores de las fincas cercanas. Comienza a trabajar poco antes de las 6:00 a.m. y a las 8:00 u 8:30 a.m. hace un pare para desayunar. Tras el almuerzo, a medio día, la jornada de la tarde termina dependiendo de qué tan atrasada esté la labor que realicen. Lo más tarde que han terminado es a las 6:00 p.m. Actualmente, están podando e injertando el limón, labor que han comenzado después de una limpia de yerbas que terminaron hace poco.

Adicionalmente a la usura por parte de los intermediarios, en la regulación del precio de los productos entra a jugar la oferta del mismo producto en otras regiones del país, que disputan el mercado interno. Un ejemplo de esto lo brinda la explicación de Guillermo Polo sobre el caso del precio del limón en Ciénaga:

Ahora [el limón] está bajo, bastante bajo, y uno baja cada 8, cada 10 días, pero ahora está el limón barato, no ha querido subir, no se sabe por qué, aun cuando hay. Bueno, sí sabemos cuál es el motivo, pero no ha podido coger precio porque los compradores están trayendo limón de otras parte[s] (del Tolima, del Cauca), lo están trayendo pa’ acá pa’ Barranquilla. Ese limón no es un limón uno A, como le dice uno aquí, pero le baja el precio al de aquí [...]. El vendedor es muy hábil, entonces dice: "no, hay tenemos pucha [el otro limón de menor calidad], regala, barata"; entonces, por lógico le bajan el precio al de aquí, por eso es que no pasa de 50 , cuando más caro se ha vendido es a 60 mil pesos el bulto [que contiene entre 86 y 90 kilos de limón] (G. Polo, comunicación, diciembre del 2016).

Cuando la cooperativa COFRUMAG intercede y les compra trata de pagarles un poco mejor que los intermediarios. En cuanto a estos últimos, Polo profundizó luego en las razones de los bajos precios, precisando que no se deben solamente al limón traído de otras regiones: 
Vida campesina en el Magdalena Grande

Aquí hay una cuestión en la zona y es que a nosotros, el grupo de personas que compran el limón, ¿qué hacen? Se ponen de acuerdo, cuestiones jocosas de nuestra comunidad, que dicen... que cuando los ven tomando dicen "se nos va el limón porque ahora la plata que se gastan nos la cobran a nosotros". ¿Qué hacen? "El limón hoy está a 80 mil”. Y vienen mañana: "se pasó la compra del limón". ¿Por qué? "Porque el limón está barato", y no es ningún barato, [es] pa' bajarle el precio (G. Polo, comunicación personal, diciembre del 2016).

Imagen 113. Vivero de COFRUMAG, en Ciénaga

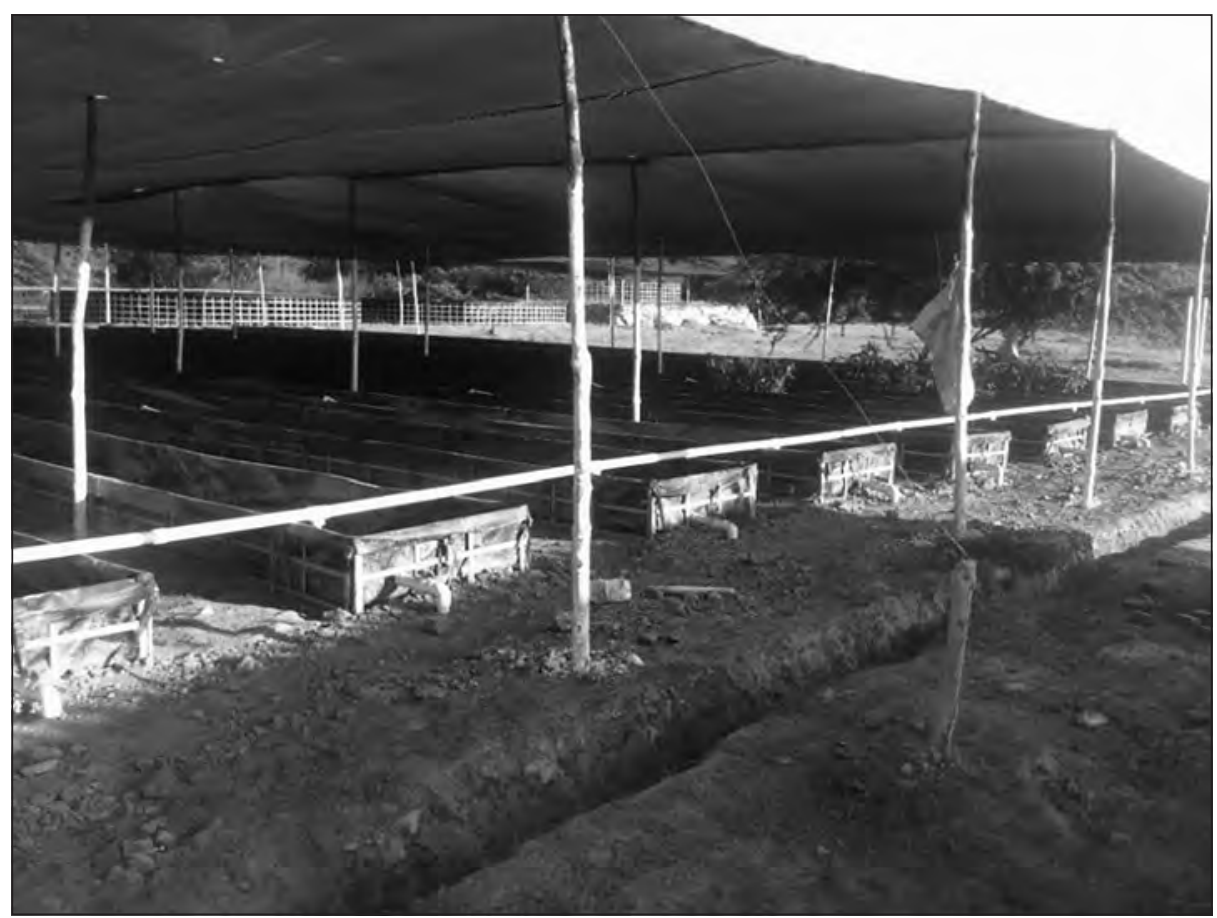

Fuente: Archivo Oraloteca (2017).

El precio del maíz que vende Eusebio Hernández, del municipio de Zona Bananera - pero que cultiva en tierras inundables propias y también en tierras no inundables, pero alquiladas, en Sevilla, Ciénaga-, parece estar sujeto también a la disponibilidad del producto en otras regiones y a los convenios de intermediarios: 
Vida campesina en el Magdalena Grande

[¿En cuánto se vende el maíz?]. Eso, francamente, ahora mismo eso está por el suelo, porque ese maíz ocañero, que lo traen de Ocaña, una mazorca muy bonita, lo traen más bien regalado aquí a Ciénaga, Santa Marta, Barranquilla, eso lo inunda esa gente de allá, barato, y uno siembra el maíz aquí, que es el maíz de plaza, que es el maíz híbrido, eso vale 28 mil pesos un bulto. Uno lo que viene sacando son unos 17, 18 bultos, pa' venirlo a regalar ahí a 20 mil pesos el bulto no paga. Entonces, ¿quién es el que gana aquí? Los acaparadores, esos que acaparan todo el producto allá en la plaza, Santa Marta, Ciénaga, Barranquilla, esos son los que se llenan (E. Hernández, comunicación personal, diciembre del 2016).

La señora Aura Rodríguez también señala la problemática de la excesiva intermediación y el comportamiento usurero que afecta la economía familiar:

Nosotros queremos transformar nuestros productos para hacerle ese seguimiento para que nuestros productos tengan un valor agregado, porque es que realmente al campesino... a nosotros nos tienen totalmente abandonados en ese sentido. ¿Por qué? Porque los productos, por ejemplo: una canastilla de torombolo aquí nos la quieren comprar en 3 mil pesos y eso... ¿sabe lo que uno trabaja, lucha, para que esos productos, o sea, lleguen al mercado y nos vengan a pagar $30 \mathrm{mil}$ pesos por una canastilla de limón, un bulto de limón? Ahora porque está en 50 mil pesos, pero 30 mil, 40 mil pesos no se justifican; o sea, no es el valor que realmente le deben de dar a esos frutos (A. Rodríguez, comunicación personal, diciembre del 2016),

Otro de los factores que impide a los pequeños productores participar con precios competitivos en la fase de comercialización y venta es la carencia y el estado deficiente de las vías terciarias que conectan sus alejados poblados con la carretera principal. Rafael Elías (diciembre del 2016), en Ciénaga, lo denuncia:

Hay otro flagelo que son las vías terciarias, que son las áreas rurales, no hay vías de acceso donde ellos [los campesinos] bajen sus productos para comercializarlos ni hay un mercado preestablecido donde ellos vengan a 
Vida campesina en el Magdalena Grande

traer sus productos para tratar de negociarlos. [Además], Ciénaga carece en este momento de un "corabasto" (comunicación personal).

Tras las exigentes jornadas de trabajo en tierras poco irrigadas que tienen que pasar estos campesinos para lograr producir lo necesario, la fase de comercialización está determinada por el comportamiento oligopólico del mercado de la fruta, en el que prima la especulación del precio en detrimento de los ingresos de los productores. La especulación está determinada por las condiciones impuestas por los intermediarios que, a su vez, dependen de los requerimientos de las grandes comercializadoras internacionales y de las grandes plataformas comerciales o de supermercados. Como el campesino no tiene participación en la comercialización de sus productos, está obligado a venderle al costo a unos intermediarios que pueden presionar a su antojo en la negociación de la mercancía; esto, debido a la sobreoferta de banano y a la "batalla del centavo" entre los mismos pequeños productores.

Finalmente, destacamos la percepción que los campesinos parceleros o pequeños productores tienen del fenómeno de concentración de tierra, puesto que ellos han observado durante años de relacionamiento con las grandes haciendas y las familias tradicionales una dinámica que no es visible fácilmente en los procedimientos jurídicos o administrativos, pero que sí se conoce en la cotidianidad de la vida en el territorio.

Es así que, desde la percepción campesina, la tierra en la Zona Bananera está concentrada principalmente en manos de siete familias: los Cadavid, los Vives, los Fernández de Castro, los Lacouture, los Díaz-Granados, los Dávila y los Serrano. Solamente en el sector de Orihueca, los Cadavid son propietarios de las fincas Lolita, Playita, Merecer, Don Juan I y Don Juan II, el Enano, la Vega; la familia Díaz-Granados de las fincas la Ceiba, Naranjitos, Porvenir, Playa, la Esmeralda, Circacia y la Bomba, y la familia Vives de las fincas Dilia, Catalina, la Teresa, la Eufemia, la Esperanza y Sacramento. También existen fincas en sociedad entre estas familias; por ejemplo, entre las familias Vives y Díaz-Granados los campesinos incluyen las fincas Ángeles Vijagual, Buenavista, Arenal, Martes, Franciscas y Yisel Beatriz, mientras que las familias Cadavid, Lacouture y Vives poseen las fincas la Olga, la Teresa, Eufemia, Llano y Polonia. Aunque, como es lógico, los campesinos no conocen la extensión total 
Vida campesina en el Magdalena Grande

de dichas fincas, según sus apreciaciones las más pequeñas se encuentran cerca de las $200 \mathrm{Ha}$.

En contraste, los campesinos comparan estas extensas y equipadas fincas con la precariedad de sus parcelas y viviendas. Siempre se refieren a la época de mediados de los 90 cuando algunos de ellos lograron ser adjudicados con tierras. Al respecto, Vladimir Carranza afirma:

Hoy en día eso es lo que queda de las cooperativas [se refiere a las otrora exitosas cooperativas de banano]; ellos están conformados por pequeños productores de banano de tres, dos hectáreas y media hectárea. Ellos, en esa época, accedieron a ese proceso de acceso a la tierra mediante el INCORA y fueron propietarios. Eso aquí había una gran porción de tierra en manos de pequeños productores, pero a causa del fenómeno paramilitar, por ejemplo, eso [el paramilitarismo] influyó para que eso disminuyera. Antes de eso había más campesinos dueños de tierra, pequeños propietarios; después del fenómeno paramilitar eso se redujo porque mucha gente abandonó los campos, mucha gente se retiró y el terrateniente aprovechaba y se posesionaba. Entonces, le compraba al pequeño. Por ejemplo, acá hay una extensión de tierra que lo llaman la Santa Marta, eso eran sesenta hectáreas de tierra que fue del INCORA. Hoy en día, a causa del fenómeno paramilitar, los Díaz-Granados creo que tienen como el $60 \%$ de lo que era de pequeños, hoy está en manos de los Díaz-Granados, esos grupos económicos (V. Carranza, comunicación personal, diciembre del 2016).

De igual manera, la gran mayoría de los entrevistados señala cómo, después de la época de la violencia, no solo se concentró tierra, sino que se acaparó el agua:

Antes había sectores aquí donde la gente cultivaba pancoger, piedemonte de la Sierra y aquí un sector, los humedales de la Ciénaga Grande, en los playones, donde el campesino por épocas pescaba y por otras cultivaba pancoger; ese ciclo se perdió a causa de que el mismo fenómeno de la monopolización del agua que se va para los reservorios. Ya las aguas de los ríos no llegan a los humedales, a esas tierras bajas de la Ciénaga Grande y ya, como no llega el agua dulce, ya no se puede cultivar porque 
Vida campesina en el Magdalena Grande

el agua dulce en épocas de estos veranos que nos han obstruido. En los últimos tiempos ya las aguas de los ríos se pasan para los reservorios, pero no llegan allá los humedales y las aguas de la Ciénaga invadieron todo ese sector a donde hubo grandes pérdidas, inclusive de fauna, flora, y de gente que ya no pudo cultivar más en ese sector. Entonces, nos hemos visto afectados [...] por fenómenos como el paramilitar, que eso le dio pie para la monopolización del agua de la tierra y cada día los terratenientes son más y los pequeños productores son menos. Entonces, nosotros estamos invadidos por terratenientes y grandes multinacionales de banano (V. Carranza, comunicación personal, diciembre del 2016).

Imagen 114. Plantación de banano en Candelaria

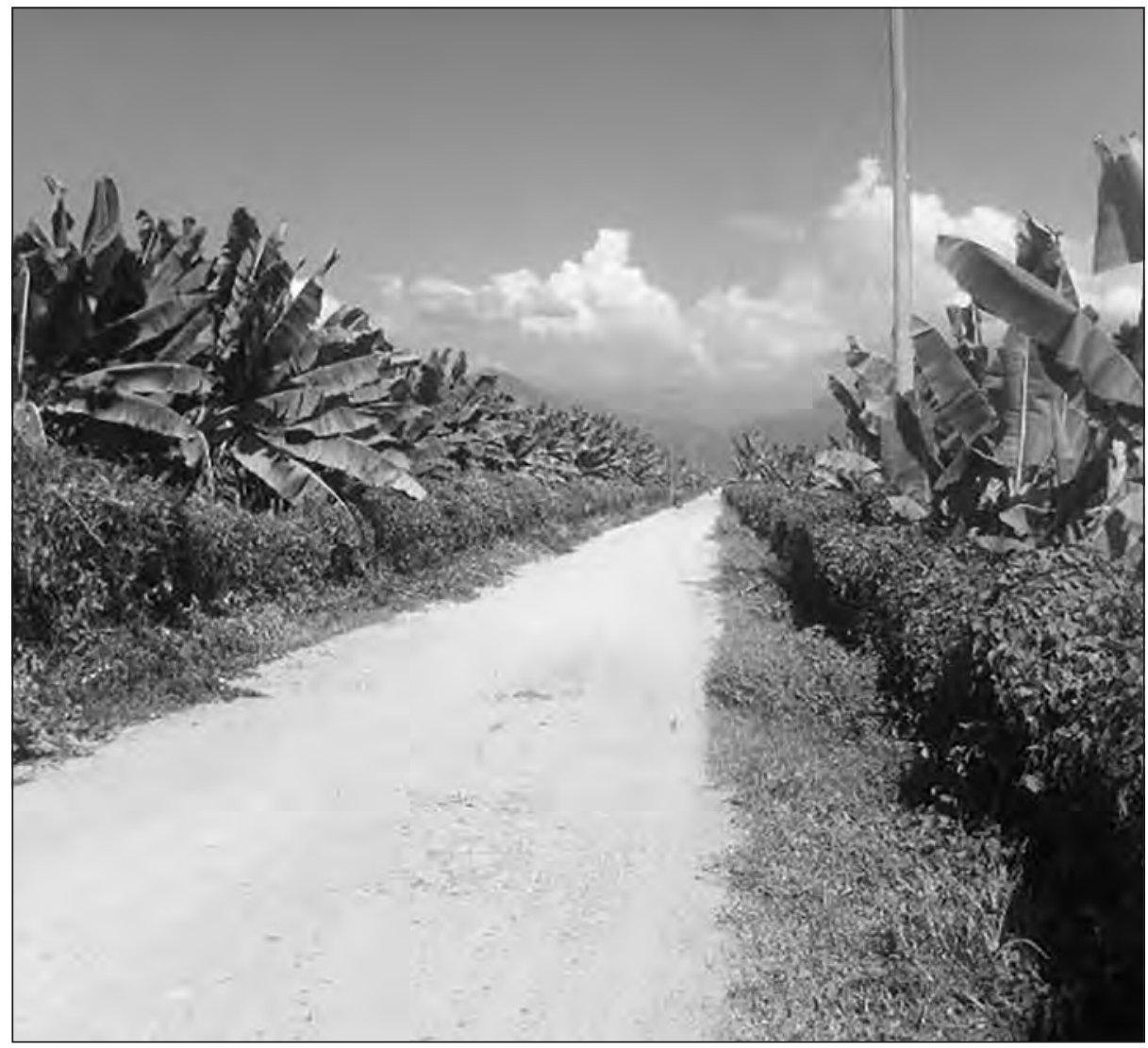

Fuente: Archivo Oraloteca (2017). 
Vida campesina en el Magdalena Grande

\section{La producción y el trabajo en la plantación bananera}

Buena parte del trabajo campesino en la Zona Bananera Histórica transcurre precisamente en las plantaciones de banano. Incluso muchas de las familias que tienen tierra propia, arrendada o en comodato también le aportan fuerza de trabajo a dichas plantaciones como forma adicional de obtener ingresos. Esto ocurre no solo en el municipio Zona Bananera, sino también en la vereda la Mira, en Sevillano y en Aracataca. El hermano de Guillermo Polo participó en la entrevista para decir que: "la gente de por aquí, casi toda, la mayoría, aunque tenga parcela, trabaja en la Zona Bananera porque esto [la tierra propia] no solventa y todo el que saca al hijo termina el bachillerato y pa' la Zona Bananera" (H. Polo, comunicación personal, diciembre del 2016).

Aunque generalmente el campesino está acostumbrado a levantarse en la madrugada, los habitantes de este municipio tienen que levantarse a las cuatro o cinco de la mañana todos los días para poder iniciar sus labores en las plantaciones a las seis de la mañana y así cumplir una jornada de casi doce horas.

Sobre la producción y el trabajo en las plantaciones de banano, Armando Mendoza, quien actualmente se desempeña haciendo botaderos, nos ilustra:

[Cuéntenos a grandes rasgos cuáles son las fases, los pasos que se dan para un cultivo de guineo $\left.{ }^{10}\right]$. Inicialmente, se laboran las tierras con maquinaria: desmontar la tierra, se ara, se rastrilla; bueno, se hace todo. Después llegan, la abonan. Entonces, entramos a la parte de siembra de guineo, que ya hacen [los] viveros. Del vivero trae uno la plantica para sembrarla a la tierra, ya en el cultivo. Eso es en cuanto al manejo de guineo. Ya de ahí se pasa a sembrar el guineo, se pasa... cuando ya viene la hora de cultivarlo, que ya comienza a producir, entonces una va deshijando la mata [quitándole los retoños para sembrarlos], ubicando la mata en los puntos, y todo cultivo debe tener su delimitación... y yo así fue que empecé, que yo sé ubicar la mata, la piden, déjemelo abajo [el retoño], déjemelo arriba, el barrigón que uno llama, el barrigón es el

10. Guineo es el nombre que se le da al banano en la región, especialmente cuando está verde. 
Vida campesina en el Magdalena Grande

que deja uno [...]. Entonces, uno ubica el puyón para que siempre salga lateral, buscando la parte en que dé el sol (A. Mendoza, comunicación personal, diciembre del 2016).

Isidro González, experto seleccionador de guineo y trabajador durante toda su vida en las plantaciones de banano de la zona, explica el proceso secuencial del cultivo y la cosecha así:

[¿Cada planta de banano solamente bota un puyón o bota varios?]. El corno de ellos o la corona tiene tres secuencias, tres emisiones. En la primera corona, [contando] de abajo hacia arriba, da dos hijos; en la segunda corona, que queda en medio, da tres, y en la primera corona, [contando] de arriba hacia abajo, ya tira dos. O sea que ella tiraría siete hijos en su vida productiva, pero de los siete solamente se va a escoger uno, que es el primero que emite, que es el que tiene mayor edad y que tiene más posibilidades de tener una producción más rápido, que es lo que se busca en el banano [...]. [ ${ }_{i} \mathrm{O}$ sea que no puede haber dos puyones que tengan la misma edad?]. Sí puede haber, manejando los espacios... Aquí se manejan 2,40 [metros] por 2,30 de una planta a otra, por lo menos esa planta se pierde, ya ese espacio queda ahí, y habiendo un hijo acá, teniendo el espacio, estando parejos los dos, pueden trabajar. Cuando se deseche la mamá y se descomponga el tronco que le va a servir de reserva, de alimento a ellos, ya ellos se separan y quedan siendo unidades de producción diferentes. [Entonces, si tuviéramos otro de este lado - igual a este-, cuando ya la abuela, digamos, se pierda, el que está de este lado o este, cualquiera de los dos, ¿lo pondrían en otra parte o los dejarían ahí?]. No, ellos quedan ahí, ellos quedan ahí trabajando el espacio que queda libre (I. Gonzales, comunicación personal, diciembre del 2016).

La planta de guineo tarda entre siete y nueve meses para producir. A partir de ese momento, un cultivador de banano empieza a sacar tres cosechas al año. Los meses de cosecha entre un año y otro no necesariamente se repiten. Entre cosecha y cosecha, se llevan a cabo diferentes tareas de mantenimiento: 
Imagen 115. Planta de banano y sus retoños

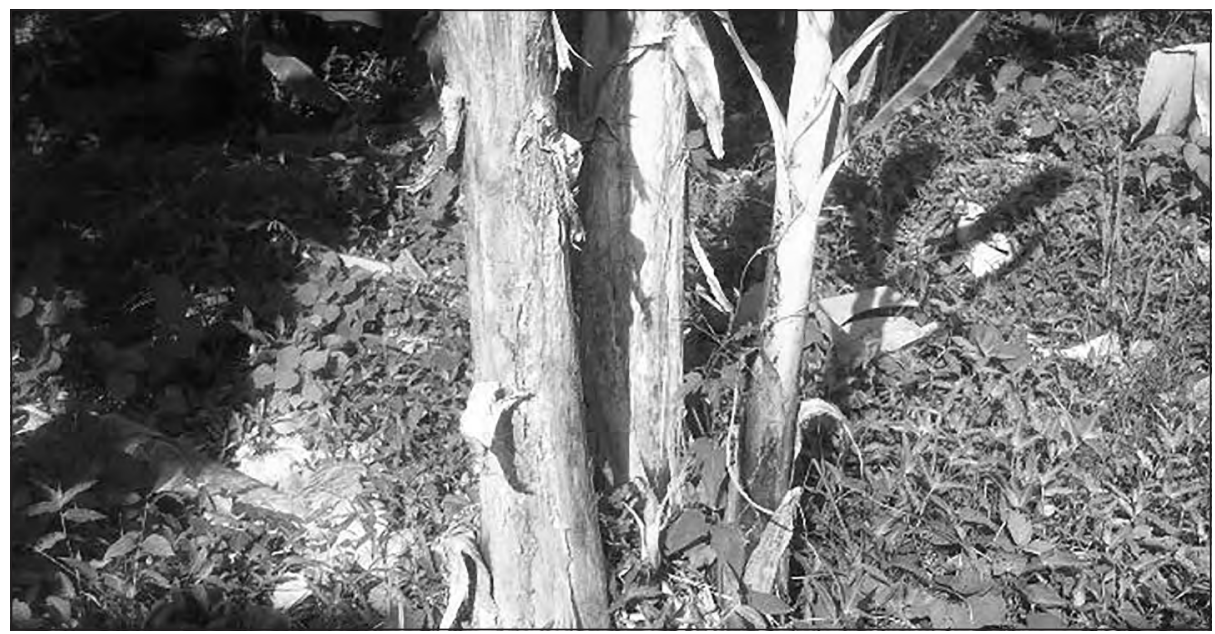

Archivo Oraloteca (2017).

[Al banano] hay que estarlo abonando, hay que estarlo puliendo, buscándole puyones, hay que desmancharle la matica, quitarle las hojas, hay que proteger el racimo cuando nace: se le pone una bolsa [...] para protegerlo del sol, $[\ldots]$ entonces ahí entramos al drenaje [...]. El capataz nos dice: "señor Armando, yo necesito que usted me ubique un botadero en tal lote" (por decirle, en el lote 5), [...] bueno, yo me voy allá, le ubico un botadero, tengo que sacarlo de dos metros de ancho para que muera abajo con $150 \mathrm{~cm}$ o $80 \mathrm{~cm}[\ldots]$, ese trabajo es cúbico. “¿A cómo me va a pagar usted el cubo?" [le pregunto], él me dice: "bueno, el cubo se está pagando a 3 mil pesos". Bueno, yo contrato mi gente y hago el trabajo (A. Mendoza, comunicación personal, diciembre del 2016).

Cuando las plantas están produciendo, toda la finca se dispone para sacar la cosecha:

[¿Cómo se organizan para sacar el cultivo?]. Ya la finca implementa una cablería aérea, cables de transporte que llaman [...]. Van 20 garruchas $^{11}$

11. La garrucha es una polea que está inserta en un sistema de cableado por el que se transporta el banano. La garrucha tiene un gancho donde se cuelga el racimo para ser transportado. 
Vida campesina en el Magdalena Grande

[en un cable] y 20 garruchas las jala un hombre hacia allá, al sitio de procesamiento, donde está la empacadora [...]. Esas 20 garruchas deben de darle al productor entre 20 y 25 cajas de banano producido, ese es el estimativo que tiene un dueño de finca para una bananera [...]. En el día, pongamos, 6 cuadrillas de 5 personas; bueno, ustedes van a procesarme 2 mil cajas (A. Mendoza, comunicación personal, diciembre del 2016).

Cada garrucha transporta un racimo de guineo que equivale a una caja cuyo peso promedio es de 20 kilos. En un día se pueden sacar las 2 mil cajas de guineo de toda una finca incorporando todos sus lotes en la operación, los cuales no necesariamente tienen la misma extensión. Armando calcula que se requieren, al menos, unas 20 hectáreas para producir esas 2 mil cajas en un día:

Que serían... póngale dos lotes de 10 hectáreas por cabuya cuando la producción es buena, porque si la producción es mala usted va a sacar 2 mil cajas con 50 hectáreas, pero en un lote de 5 cabuyas usted está sacando 5 mil cajas. Las fincas siempre cortan 5 días a la semana, casi todas [...]. Entonces, el último día de corte ya todas las puyas se encuentran en un solo sitio (A. Mendoza, comunicación personal, diciembre del 2016).

Imagen 116. Transporte de banano en las plantaciones

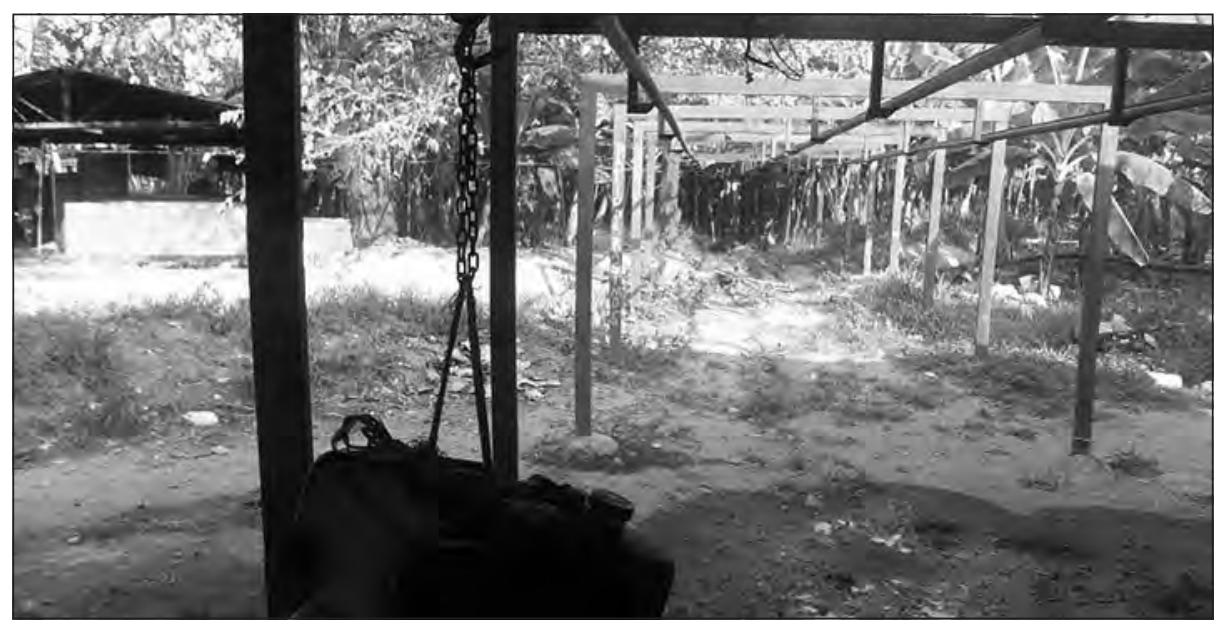

Fuente: Archivo Oraloteca (2017). 
Vida campesina en el Magdalena Grande

La cuadrilla tiene una estructura definida, donde cada quien cumple una función:

[¿Cómo se organiza una cuadrilla?]. Se organiza con cinco personas [...]. La primera que sale es la puya [el que va cortando], con los coleros [los que van atrás]; segundo, salen los garrucheros, que es el que lo va a llevar a la empacadora (son dos garrucheros que ponen por cuadrilla, a la puya le ponen dos colas). ¿Ahora no ponen fijador? [Interviene Guillermo Olivera]. Sí, ahora ponen fijador. El fijador es el que espera el gajo, la garrucha la arma en todo el cable, con unas ruedecitas (A. Mendoza, comunicación personal, diciembre del 2016).

[¿Qué diferencias hay entre oficios?]. Son distintos porque el parcelero tiene que dedicarse al desflore, al embolse, al amarre. Viene otro trabajador que se dedica al desmanche, el deshoje... son distintas labores (I. Prado, comunicación personal, diciembre del 2016).

Los trabajadores que se vinculan a la plantación van definiendo el tipo de trabajo en el que se van especializar. No existe una tecnificación en las labores que van a desempeñar; como dice el señor Idelfonso, aprenden haciendo:

[¿La gente cómo aprende a hacer esos oficios?]. Pues dedicándose a aprender porque hay unos que no se dedican sino a hacer colero: ese es el que lleva el racimo y lo saca para el cable vía. Ese pasa verano e invierno y tiene que hacerlo porque no sabe. [¿Cómo así?]. No, los otros no porque son distintas labores y pues el que sabe colear sabe eso y nada más; entonces, ese tiene que hacerlo porque [a] un colero si no sabe coger una burbia para ir a sanear no lo dejan en la empacadora. Son distintas labores y hay muchos que no saben (I. Prado, comunicación personal, diciembre del 2016).

Precisamente, la labor de puya es una de las especialidades de Armando Mendoza e implica la responsabilidad de pegarle a cada racimo que corta una cinta de color definido. Estos colores son usados para controlar la cantidad de racimos: 
Vida campesina en el Magdalena Grande

Yo soy puyero porque ya yo tengo estipulado la medida, el calibre de la fruta. A mí me dan en la empacadora el día que salgo, el primer día de corte me dan, me estipulan un[a] cinta: "usted va a barrerme la cinta roja [dicen los jefes] y me va a calibrar la blanca", eso lo hacen durante tres semanas, una cinta. [De] una cinta a la otra se lleva tres semanas, porque si usted comienza con la cinta roja hoy, por decirle lunes comienza con la cinta roja, usted el lunes que viene de hoy en ocho días debe estar haciendo el segundo pase a la cinta roja. Para el último día que ya es la tercera semana, ya usted cuando llegue a la cinta roja el capataz le dice: "oiga, señor Armando, en toda la finca hay doscientos racimos rojos, ¿por qué aquí me han llegado cien racimos no más? (A. Mendoza, comunicación personal, diciembre del 2016).

Cada una de estas funciones requiere un nivel de especialización del trabajador que no es desaprovechado por los administradores de finca para controlar el rendimiento de cada trabajador. Como comentó el señor Idelfonso, el empacador -último en la cadena de producción del banano - es el de mayor responsabilidad porque es el filtro del corte del banano: del trabajo que este realice depende que se exporte o no el producto. Esto no se ve reflejado en el pago de los trabajadores; es decir, así desempeñen distintas labores en la plantación y cada una con un nivel distinto de responsabilidades, el pago para todos oscila entre el salario mínimo y un valor inferior. Al respecto, Idelfonso comenta:

Yo conozco todas las labores del banano, pero a donde más me he dedicado es al empaque. Por eso yo te digo que debería ganar un poquito más, por la responsabilidad: que la caja vaya bien empacada, que no lleve ningún defecto, la caja lleva un número porque ahí ese... por decir esa caja... yo empaco con el número siete, ellos llevan un control con una planilla... en el puerto tiene que llevar el nombre mío, el número de la caja... si esa caja sale mala ya saben quién es, quién la empacó [...], vienen derechito donde Idelfonso (I. Prado, comunicación personal, diciembre del 2016). 
Vida campesina en el Magdalena Grande

\section{Condiciones laborales en las plantaciones}

Según los relatos de las personas entrevistadas, las empresas bananeras mantienen condiciones de explotación de los trabajadores a pesar de que la legislación les exija contratar personal de acuerdo a los requisitos exigidos por el Ministerio del Trabajo. Las largas jornadas de trabajo no se ven reflejadas en los pagos de los salarios y, en la mayoría de los casos, los contratos no contemplan los aportes a seguridad social, prestaciones sociales y demás garantías laborales.

En este contexto, Sintrainagro (Sindicato de Trabajadores de la Industria Agropecuaria) continúa funcionando luego de tantas décadas de persecución, desempeñando un papel importante en materia de monitoreo y regulación de un régimen laboral abiertamente desconocedor de los derechos humanos y de la legislación laboral colombiana.

Henry Guerrero, campesino desplazado en 2001 y actual reclamante de tierra del predio la Isla, cerca de Orihueca, en cuyo desplazamiento estuvo implicado un miembro de las familias tradicionales a las que, paradójicamente, hoy está vinculado (pues trabaja en una de sus fincas bananeras), explica cómo funciona en la actualidad el mayor sindicato de trabajadores de la Zona Bananera:

En cada finca que uno trabaja hay dos obreros principales que regulan las relaciones y [los] conflictos entre trabajadores y coordinadores o administradores de fincas. Ellos deben llevar las quejas de los trabajadores hasta los directivos de Sintrainagro. También, cada cierto tiempo, son los encargados de arreglar las convenciones o acuerdos con los empleadores de los precios de las labores desempeñadas durante un periodo de contratación. Por ejemplo, en este momento nos rige una convención que empezó en 2015 y termina en 2018, pero desde ya se están preparando para la convención de 2018 a 2021 (H. Guerrero, comunicación personal, diciembre del 2016).

Henry goza de unas condiciones laborales favorables comparativamente, debido a su extensa trayectoria sindical que le ha permitido esta privilegiada situación: él trabaja durante 10 horas todos los días de lunes a jueves, entrando a la plantación a las 6 a.m. y saliendo a las 4 p.m. Los 
Vida campesina en el Magdalena Grande

viernes solo se trabaja hasta las 2 p.m., completando 48 horas de trabajo a la semana. Su sueldo, denominado "catorcena" (14 días laborales) ronda los 400 mil pesos, lo que le permite igualar un salario mínimo mensual vigente. Sin embargo, no hay subsidio de transporte ni subsidio de alimentación. Los "contratos" son planillas que relacionan las horas de trabajo de cada obrero durante un tiempo determinado; aunque estos no cumplen con los requisitos legales para considerarse contratos reales y válidos, los firman. Después de un periodo de 3 meses, dependiendo de la cantidad de trabajo y la convivencia con los administradores o coordinadores de finca, les son renovados hasta por otros 3 meses más. Además, a Henry le descuentan en todas las catorcenas: 19 mil pesos de salud, 19 mil pesos de pensión, 8 mil pesos de seguro de vida y 8 mil pesos de un seguro especial en la clínica la Milagrosa, en Santa Marta, a la que jocosamente se refiere como "la peligrosa", haciendo alusión irónica a la reputación de la calidad en la prestación de sus servicios. Henry, además, acepta que los sábados de catorcena gasta hasta 50 mil pesos en la ingesta de alcohol "que es la única entretención aqui", pero que le deja los restantes 350 mil pesos a su mujer.

El señor R. Urueta (diciembre del 2016) recuerda las únicas dos veces que, en 46 años de vida productiva consagrada al banano, su contrato duró más de tres meses:

Mi primera vez trabajando fue cuando llegué aquí. Tenía 10 años. En la finca del patrón José Vives de Andreis duré 6 años. Me pagaban 14 pesos el día y la catorcena me salía a 60 pesos. La otra vez fue en la finca Josefina, en 1975, cuando tenía 15 años. Allí duré 11 años trabajando, tenía seguro y cotizaba a pensión (comunicación personal).

Sin embargo, se puede apreciar un avance reciente de las condiciones laborales en cuanto a contratación formal y prestaciones. De acuerdo con I. Prado (diciembre del 2016):

Eso ahora sí más o menos ha tenido su control porque anterior[mente] no se veía eso de que contrato, de que a nadie le pagaban sus prestaciones, que le pagaban su seguro; ahora sí ya varias fincas han venido asumiendo la responsabilidad que tienen con el trabajador (comunicación personal). 
Vida campesina en el Magdalena Grande

Al lado de estos avances recientes persiste la cuestión de los bajos salarios que condicionan a los trabajadores, por ejemplo, a llevar preparado su propio desayuno y almuerzo para no tener que comprar el de los casinos de la propia plantación:

[¿QQué almuerzan?]. Se toma la sopa en el casino. [¿Compran la sopa en el casino?]. Sí. [¿Y qué más, además de la sopa?]. Arrocito y la gaseosita, pero es que uno no se puede exceder porque un corte, por decir, le vale 30 mil, y un almuerzo todos los días le sale por 5 mil, ¿cuánto queda? Y si mete desayuno, 10 mil... ¿qué viene quedando? Entonces, uno trata de controlar eso (I. Prado, comunicación personal, diciembre del 2016).

En cuanto a las relaciones laborales en las plantaciones de banano hay distintas apreciaciones. A algunos les parece que las relaciones entre administradores y trabajadores son armónicas, mientras que otros consideran que están en una condición de explotación y que eso se traduce en el trato que reciben como trabajadores.

$\mathrm{Al}$ respecto tenemos el caso del señor Armando Mendoza, quien percibe que la relación entre directivas y trabajadores es positiva:

[¿Cómo son las relaciones laborales entre los trabajadores y con los jefes?]. Armonía total, todos somos amigos, si fuéramos enemigos no estaríamos en el mismo grupo, ahí el enemigo se va pasando enseguida, todo el que entra a una finca va a hacer es amistad, hacer amigos, eso es como un deporte, como un juego, hay gente que tiene su, sus problemitas, pero eso es interno (A. Mendoza, comunicación personal, diciembre del 2016).

Como vimos anteriormente, el señor Javier Ruiz no opina lo mismo y considera que el trabajo en las plantaciones requiere mucho esfuerzo que no se ve compensado. De igual manera, Vladimir Carranza afirma que no solo se da la explotación en términos de los salarios, sino que también el trato es discriminatorio por parte de los administrativos hacia el trabajador raso:

[¿Qué sabe usted de las condiciones laborales de las personas que trabajan en las plantaciones?]. 20:00. O sea, normalmente aquí pagan las 
Vida campesina en el Magdalena Grande

prestaciones, pero los salarios son el salario mínimo y el trabajo es pesado, y a veces hay una máxima exigencia del trabajador [...]. Lo que tengo entendido y por información de compañeros que están vinculados a las empresas esas, la gente se queja mucho es del trato a veces que tienen personas a cargo de ellos, como son los capataz o los administradores; que tienen el problema del trato, o sea la forma como se dirigen a ellos es muy discriminada, discriminan mucho lo que es el trabajador raso con el de la oficina (V. Carranza, comunicación personal, diciembre del 2016).

\section{Dimensión socioambiental}

El monopolio sobre las fuentes hídricas, el desvío de caños y la construcción de reservorios privados ha dejado graves consecuencias para el territorio y para las comunidades que lo habitan. Los campesinos han venido estudiando la situación y observan la manera como los terratenientes han diseñado un sistema hídrico propio para abastecer las plantaciones:

Si esos grupos económicos han hecho su propia, como yo les digo, su propia ronda hídrica donde, por ejemplo: esta es la Sierra Nevada, el agua baja y ellos se van posesionando en los tres ríos [Frío, Sevilla, Tucurinca] estratégicamente, van comprando entonces ahí donde están, ellos desvían los ríos. Inclusive ahorita están posesionados a lo largo y ancho del río y lo desvían y nadie se da cuenta porque les pasa por la finca de ellos, entonces han tenido la estrategia de ubicarse estratégicamente en... inclusive, está la muestra como tal y eso está documentado, el material audiovisual donde se demuestra cómo los ríos se desvían a los reservorios y cómo la Ciénaga Grande invadió el río Frío 12 kilómetros adentro, porque el agua dulce no llegaba y la salada se vino... En una evaluación hidrológica y de contaminación de los acuíferos, que se llama "evaluación hidrológica y de contaminación de los acuíferos de la Ciénaga Grande de Santa Marta" (ese fue un estudio que hizo la CGZ, CORPAMAG e Ingeominas), [se] habla sobre la sobresaturación de pozos profundos aquí en la zona y la explotación del acuífero, [de] las aguas subterráneas. Entonces, hay una sobreexplotación y una sobresaturación: eso genera un vacío en las aguas internas y eso se está llenando de aguas marinas; entonces, hay una carga de hierro impresionante (V. Carranza, comunicación personal, diciembre del 2016). 
Vida campesina en el Magdalena Grande

Imagen 117. Represa y reservorio en predios de los Cadavid

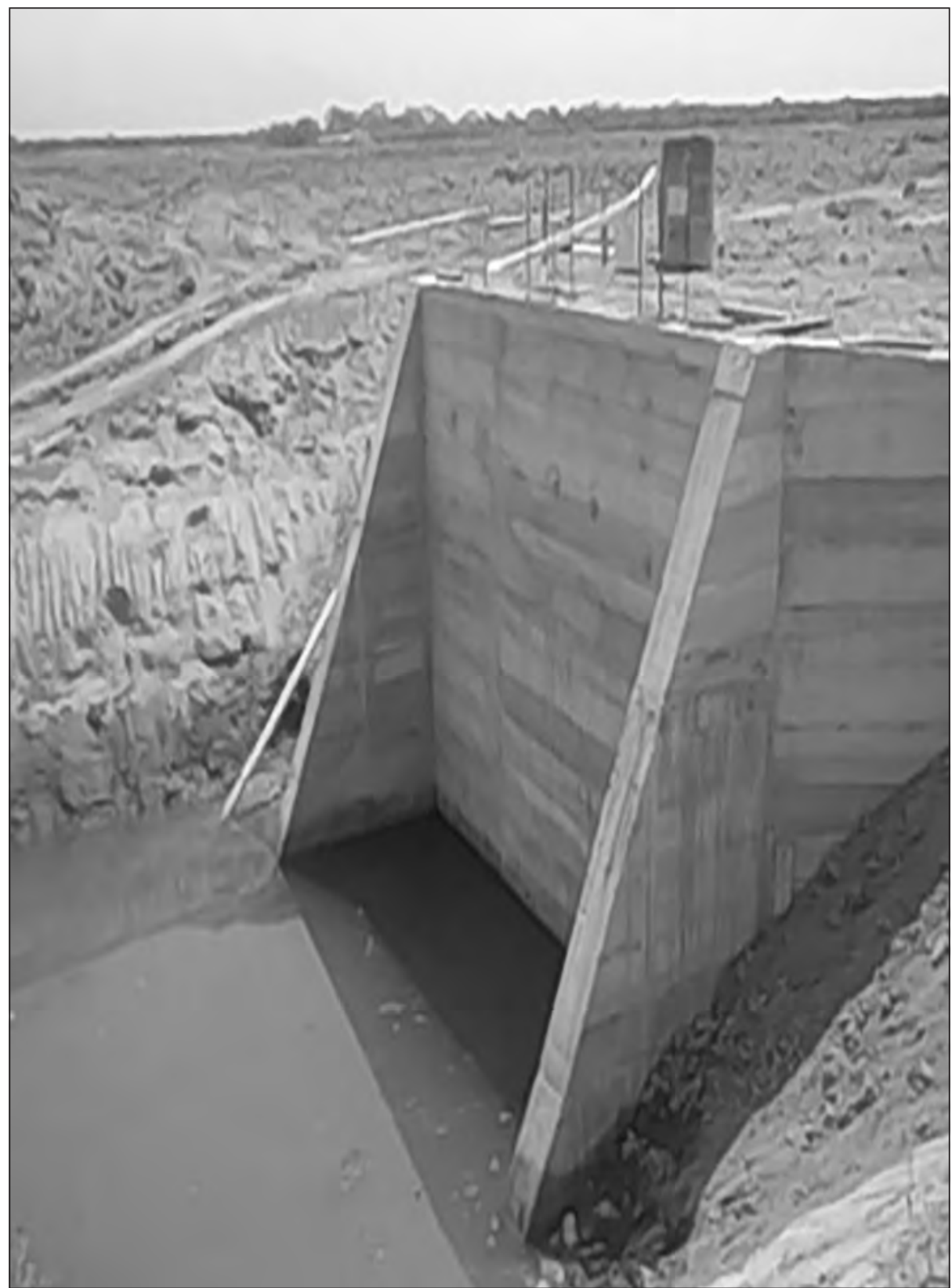

Fuente: Archivo Oraloteca (2017). 
Vida campesina en el Magdalena Grande

Esta monopolización del agua en los reservorios ha generado graves consecuencias en el ambiente y en la vida de los campesinos, pues algunos de ellos ya no pueden cultivar:

El monopolio del agua que se va para los reservorios, ya las aguas de los ríos no llegan a los humedales, a esas tierras bajas de la Ciénaga Grande, y ya como no llega el agua dulce ya no se puede cultivar porque el agua dulce, en épocas de estos veranos que nos han obstruido en los últimos tiempos, ya las aguas de los ríos se pasan para los reservorios, pero no llegan allá [a] los humedales, y las aguas de la Ciénaga invadieron todo ese sector a donde hubo grandes pérdidas, inclusive de fauna flora y de gente que ya no pudo cultivar (V. Carranza, comunicación personal, diciembre del 2016).

El agua de estos pozos subterráneos también la utilizan para sus necesidades domésticas. Aunque esta familia lleva aproximadamente siete años sin que su pozo se haya salinizado o secado, tal cosa sí ha ocurrido con los de otras familias. Lo que resulta paradójico es que cuando no hay escasez, hay exceso de agua:

[¿Y han tenido problemas con las inundaciones?]. ¡Uy! Sí, para qué decirle. Yo soy una de las más afectadas de eso. Aquí hay un dragado [al] que le dicen "el Sajón", que pasa por allá, y ese dragado cuando se llena, que hay demasiada agua lluvia, él se devuelve, coge hacia acá y el agua aquí me llega casi cerquita de la casa [...]. Estoy pidiéndole a Dios que nos ayude porque tenemos pensado hacer nuestra casita, porque prácticamente ahí no se puede ya tener, hay que hacerla en una parte ya más alta. [¿¿Ese dragado sale de río Frío?]. Sí, viene de allá directamente, del río Frío, y va recorriendo, o sea, lo que son las fincas bananeras, los que son por aquí los pequeños productores, y atraviesa allá otra finca de banano y atraviesa una ganadería; o sea, eso va a caer a la laguna y hay veces que, por ejemplo, el verano los grandes terratenientes lo tapan para que el agua no pase hacia la... o sea, que ellos son los dueños del agua prácticamente (A. Rodríguez, comunicación personal, diciembre del 2016). 
Imagen 118. Agua de la CGSM entrando al río Frío

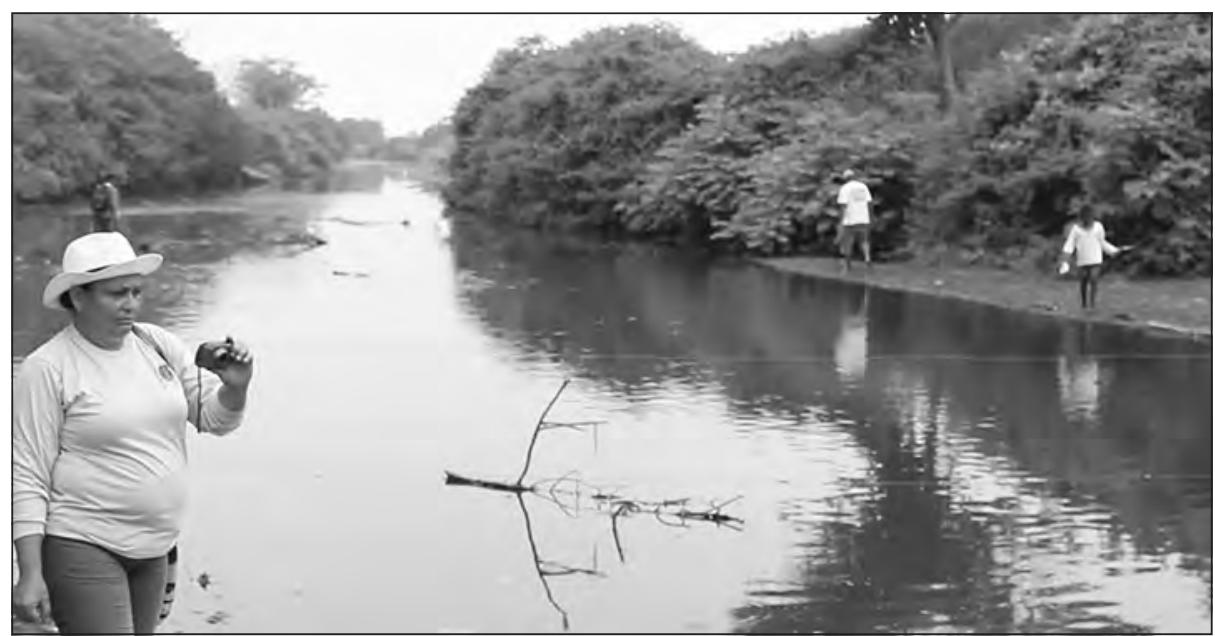

Fuente: Archivo Oraloteca (2017).

La misma paradoja fue expuesta por Guillermo Olivera, en la vereda Candelaria, del municipio Zona Bananera, cuyos predios están más cerca de la desembocadura de río Frío:

Imagen 119. Extracción de agua de pozo artesanal

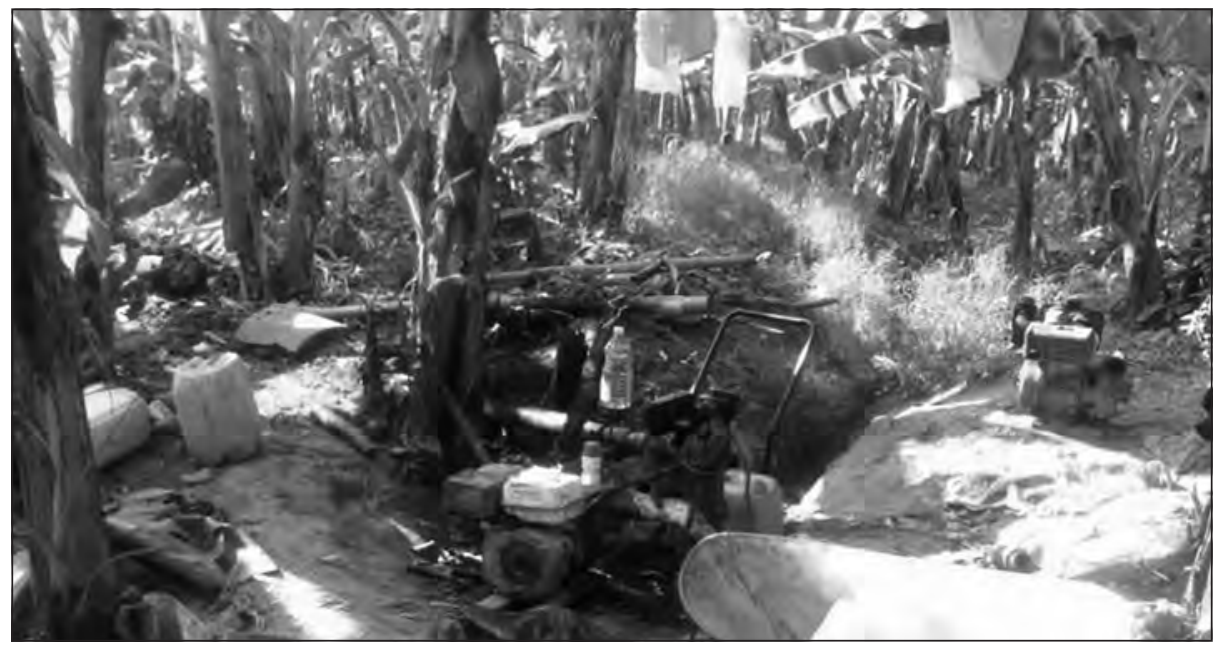

Fuente: Archivo Oraloteca (2017). 
Vida campesina en el Magdalena Grande

Nosotros teníamos una bocatoma que tenía agua ilegal y, en ese orden, había un poco de finqueros grandes que tenían las maquinarias del mundo. Entonces, como estaban arriba, ellos cogían el agua primero y una asociación que tiene un distrito de riego (ASORIOFRÍO), que tomaba el agua de allá arriba, y cuando llegaban las inundaciones nos la sueltan. En el invierno pasamos inundado[s] y en el verano morimos por sequedad $\mathrm{y}$, en ese orden de ideas, hemos estado trabajando; de hecho, ya conseguimos la concesión de agua [...]. El Estado no le da prelaciones a uno porque "no, que mira, que se presentó el fenómeno del Niño, la Niña, esa vaina está mal, no le vamos a cobrar este año, le vamos a hacer cualquier cosa”... no, tenemos que pagar, "pague o pague", y entonces eso ha agravado el conflicto entre nosotros mismos porque la gente cuando va a cobrar no le queda plata, porque los costos no alcanzan, son más baratos los ingresos que los egresos (G. Olivera, comunicación personal, diciembre del 2016).

Otra entidad que tiene que ver con la regulación ambiental es COR$\mathrm{PAMAG}^{12}$, a la que los habitantes de esta zona han presentado las denuncias sobre los malos manejos que se hacen de las fuentes hídricas y las consecuencias no solo ambientales, sino también humanas que esto acarrea; sin embargo, no se ha obtenido respuesta debido a los intereses privados que están en la dirigencia de la institución. Al respecto, el señor Carranza explica:

Se han hecho videos en las redes sociales, denuncias en las emisoras se han hecho, pero no pasa nada porque como el director de CORPAMAG, que es el que tiene que mirar las concesiones del agua, pero entonces como el director de CORPAMAG, que es la supervisora de la cuestión de manejo del agua acá, forma parte de las familias de los grupos económicos, entonces nadie supervisa a nadie (V. Carranza, comunicación personal, diciembre del 2016).

12. Corporación Autónoma Regional del Magdalena (CORPAMAG): "es un ente corporativo de carácter público encargado de administrar el medio ambiente y propender por el desarrollo sostenible del Magdalena. Es un ente del orden nacional, que como su nombre lo indica, cuenta con autonomía administrativa y financiera, así como patrimonio propio y personería jurídica. Fue creada por la ley 28 de 1988 y modificada en su jurisdicción y denominación por la ley 99 de 1993, tiene jurisdicción en los 29 municipios que conforman el departamento del Magdalena, así como en el área rural de Distrito de Santa Marta" (CORPAMAG, 2017, párrafo 1). 
Vida campesina en el Magdalena Grande

Frente a la ausencia de respuestas de las entidades encargadas de preservar el medio ambiente y regular los conflictos, los pequeños productores han buscado solucionar por su cuenta la monopolización del agua que los está afectando; al respecto, se comenta:

En la zona ya hay pequeños productores que quieren ir a darse a pelar los machetes porque los terratenientes ya ponen dónde lo tienen, en sus propias rondas hídricas, ponen a indios a celarle, a cuidarle, gente armada. El pequeño productor que va allá a pelear tiene que ir con un machete. Ya hay conflicto de esa índole. A medida que se incremente el verano, se va dando la confrontación entre el pequeño productor y los grandes terratenientes. Eso pasa en toda la zona; pasa, por ejemplo, en Orihueca, en Quebrada Linda, con los parceleros de la Virginia: por ejemplo, eso está rodeado de los Cadavid, de los Díaz-Granados, y ellos se reparten esos canales y al pequeño tratan de sacarlo. Todavía hay pequeños que riegan por inundación, acá en lo que llaman abajo de río Frío. En Candelaria también los pequeños productores tienen que ir a tumbar las barreras que ponen los grupos económicos, los Cadavid, para desviar los ríos los campesinos tienen que ir con machete y armados a tumbar esas barreras que les ponen (V. Carranza, comunicación personal, diciembre del 2016).

Imagen 120. Campesinos desmontando talanquera en Caño Mocho

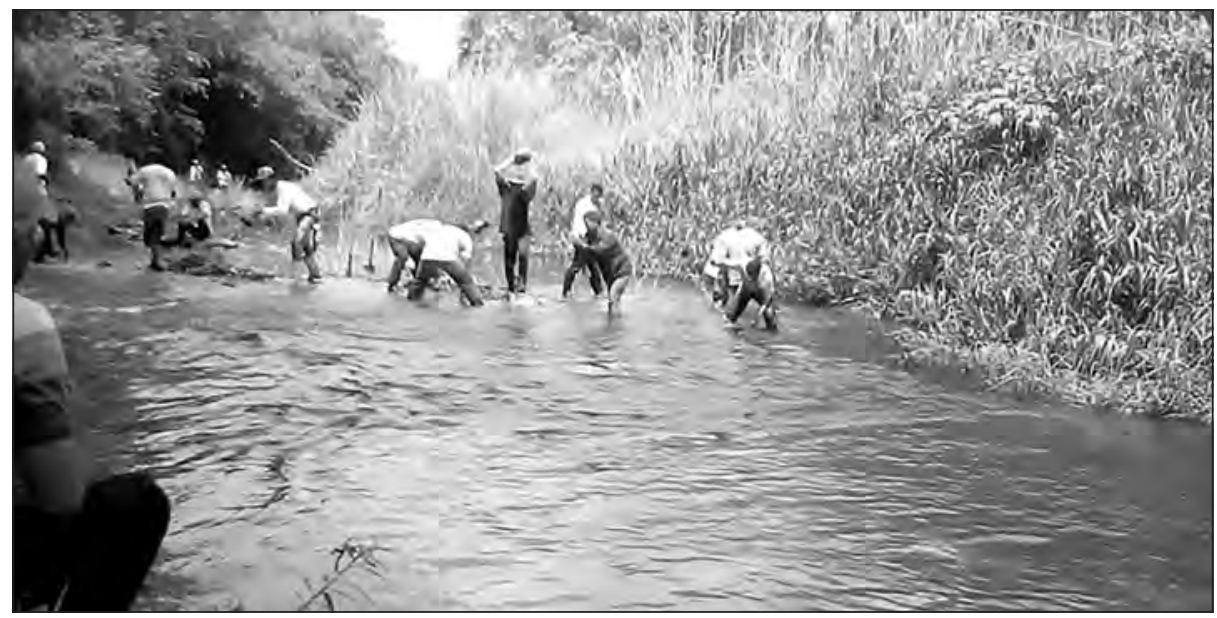

Fuente: Archivo Oraloteca (2017). 
Vida campesina en el Magdalena Grande

\section{Dimensión sociopolítica}

En el ámbito político se pueden observar varios hechos que responden a la dificultad del Estado para ejercer soberanía sobre todo el territorio y democratizar la política. Esto se ve reflejado en distintos fenómenos, como la histórica tendencia al exterminio de los escasos procesos organizativos campesinos y sindicales; la emergencia de una cultura política "post paramilitar", caracterizada por el clientelismo, las mafias del asistencialismo y los liderazgos que hicieron de su rol un "rebusque" económico, y una institucionalidad totalmente funcional al mantenimiento de las condiciones sociales necesarias para la protección de los intereses de las economías legales e ilegales, en la CGSM y la SNSM.

Como expusimos anteriormente, el proceso de crecimiento cualitativo y cuantitativo de los procesos de organización campesino y sindical se vio interrumpido, desde 1996, con la violenta irrupción de las Autodefensas Campesinas de Córdoba y Urabá (ACCU) en el departamento del Magdalena. Esta estructura se encargó de escalar el ataque que ya venían adelantando grupos de autodefensa y narcotraficantes del departamento contra las asociaciones campesinas, los sindicatos y otras formas de organización social.

Durante casi dos décadas, cada desplazamiento forzado individual y colectivo supuso una serie de otras violaciones a los derechos humanos - como el abandono o despojo de tierras o territorios, amenazas, tortura, violencia sexual, homicidios, masacres, desapariciones forzadas de familiares vecinos o amigos- que implantaron el terror en los intersticios de la subregión y la cotidianidad de las comunidades. Se rompieron las relaciones con la vida pasada, separando vínculos familiares y comunitarios, y truncando proyectos de vida.

Ilustrativa de miles de situaciones similares es la historia de vida de Pastor Ayala, un campesino de 77 años que vive con su esposa y un hijo en una de las pequeñas parcelas que trabaja a las afueras de Aracataca. Tiene un brazo casi sin movilidad. Con su brazo derecho cultiva banano, ají y yerba santa, entre otros cultivos secundarios. Sufrió la pérdida de tres de sus hijos durante los años más intensos del conflicto armado: 
Vida campesina en el Magdalena Grande

[Ustedes, su señora y usted, son desplazados, ¿cierto?]. Sí, señor. [¿De dónde los desplazaron? ¿Cómo fue la historia de su desplazamiento?]. Nosotros... la historia ha sido un poco... un poco larga, por el hecho de que nosotros, cuando nos mataron los hijos nosotros no sabíamos ni para dónde coger. Fueron tres hijos que nos mataron seguidos: a uno lo mataron en el 97, y el otro lo mataron en el 99, y el otro en 2001. El último que mataron era profesional, estaba en la profesional, y a nosotros nos dieron el seguro prácticamente y no nos dieron más nada. Y pusimos un abogado para ver y el abogado "no, que ya casi va a salir el proceso suyo, ya les va a tocar la pensión; no se afane, viejo", y yo "hombre, yo todavía ando mal, yo quiero hacerme una operación y toda esa cosa, pero no puedo porque no tengo cómo hacerme una operación" [...]. Pero nada, nunca (P. Ayala, comunicación personal, diciembre del 2016).

Las ACCU y luego las AUC trazaron una estrategia de arrasamiento contra los liderazgos de las comunidades que quedaron dentro de los territorios que controlaron. El Bloque Norte cometió, en su área de influencia, más de trescientas masacres, en las cuales fue sistemático el asesinato a los líderes importantes de las comunidades y organizaciones sociales. Presidentes/as de JAC, inspectores/as de policías comunitarios, profesores/as, madres comunitarias, sindicalistas y líderes juveniles fueron objetivo militar y sus asesinatos se convirtieron en una acción sistemática de las estructuras paramilitares.

Durante este largo periodo, el sentido de la organización social simplemente se extinguió o debió conferirse a la lucha por el reconocimiento de su condición de víctimas del conflicto armado y el restablecimiento de los derechos que les fueron vulnerados, tanto individual como colectivamente.

Una generación de líderes fue exterminada en toda la región. Los sobrevivientes y los nuevos líderes comunitarios debieron aprender de manera autodidacta cómo sobrevivir a tragedias posteriores, derivadas del hecho victimizante, en medio de contextos no campesinos y ciudades que avanzaban en sus proyectos de modernización y globalización, alejados de las realidades de la guerra. Por muchos años, el Estado no contó con leyes especializadas para la particular condición de afectación, daño e impactos dejados por el conflicto armado; ni siquiera estuvo en la agenda entender la clase de daño que sufrieron las comunidades: 
Vida campesina en el Magdalena Grande

[¿Ustedes no se afiliaron a Sintrainagro cuando estaba eso?]. Claro. Eso fue hace rato cuando fue que comenzó la masacre, que fue que comenzó todo el mundo a abrirse, tantos compañeros pusieron por nosotros el pecho también. [De esa época de los de Sintrainagro, digamos que eran los que tenían que reunirse en otras ciudades los que eran como los de la directiva, ¿queda alguien?]. Sí, señor. Por ejemplo, de la sede salían dos, tres, cuatro, para Urabá; donde estaba el sindicato de lo mejor, era lo pujante del sindicato, [era en] Urabá (R. Urueta, comunicación personal, diciembre del 2016).

Yo recuerdo el caso de Camilo y Mauricio Tapias [sindicalistas asesinados]. Los sacaron de la sede de Ciénaga. Las fincas sindicalizadas hacían marchas de protestas y paros para que dijeran dónde estaban los cuerpos, hasta que aparecieron. La violencia que vivieron los compañeros de Sintrainagro nosotros también la vivimos. Yo me sindicalicé en 1991 porque tenía 6 meses de estar ahí en la finca y apenas tenía como 19 años. Llegaron a mi casa, yo tenía mi primera hija, cuando eso la finca estaba metida en el sindicato, [y me dijeron] que firmara aquí la ficha de inscripción para mejorar el salario y la vida. Yo les dije: "pero si así estamos bien”, pero sin embargo yo les firmé. Lo[s] de Sintrainagro servían de mediadores en casos de despidos o de deudas. Hacían marchas, protestas y tomas de carreteras. Yo me acuerdo es la de las protestas por los muertos. Ellos convocaban a todas las fincas en un punto, pacíficamente, para que llegaran los del Gobierno (H. Guerrero, comunicación personal, diciembre del 2016).

Los líderes comunitarios que vivieron la época de relativa paz en sus montañas y ciénagas, y que luego sobrevivieron a la década entre 1996 y 2006 en el Magdalena, coinciden en que la capacidad de adaptación a la reconfiguración de las relaciones de poder en sus contextos locales y subregionales, además del establecimiento de políticas de blindaje social y político de los procesos y sus familias, se dio a partir de técnicas de liderazgo comunitario, aprendidas de antaño, claves para la sobrevivencia, la resistencia y la conservación de su ser campesino y sus proyectos de vida.

En este sentido, por ejemplo, la reducción o neutralización de las relaciones con los grupos armados de cualquier tipo, pasando por prácticas 
Vida campesina en el Magdalena Grande

y discursos aislacionistas que implicaban la desatención a las actividades típicas de los diferentes grupos armados hasta la tolerancia a niveles bajos o moderados de uso y abuso de fuerza en situaciones de control policivo dentro de los territorios, así como la interpelación y desarrollo de acercamientos directos con los grupos armados y sus comandantes locales y regionales para prevenir desinformaciones acerca de alguna persona $\mathrm{o}$ actividad que pudiera generar intranquilidad en sus filas.

Todas estas estrategias de coexistencia y modulación del conflicto con los actores armados estaban diseñadas para la mera sobrevivencia de las personas y la protección preventiva de los procesos organizativos que se habían interrumpido, desactivado o desacelerado. Estas estrategias has permanecido hasta el día de hoy en los liderazgos sociales y la cultura organizativa de la Zona Bananera Histórica.

Fue en medio del desenvolvimiento de semejante escenario que se crearon los planes y programas de atención a víctimas originales desde el interior de la misma infraestructura institucional inexperta, burocratizada y clientelista del Estado que había generado las condiciones que dieron lugar al surgimiento del conflicto armado en las regiones y que, además, estaban cooptadas por el paramilitarismo.

El Estado improvisó un enfoque humanitario y cortoplacista para atajar la problemática: programas para la reubicación, asistencia, atención en crisis, brigadas de salud, subsidios, indemnizaciones, talleres de caracterización y reconstrucción de los hechos victimizantes, recopilación de denuncias, investigaciones individualizadas y exhumaciones en zonas de presencia armada, levantamiento de censos y diagnósticos de diversa índole y desde diferentes instituciones. Su agregado configuró un entramado de ofertas institucionales que sería el moldeador de una segunda generación de liderazgos comunitarios. 
Imagen 121. Sede SINTRAINAGRO, en Ciénaga, Magdalena

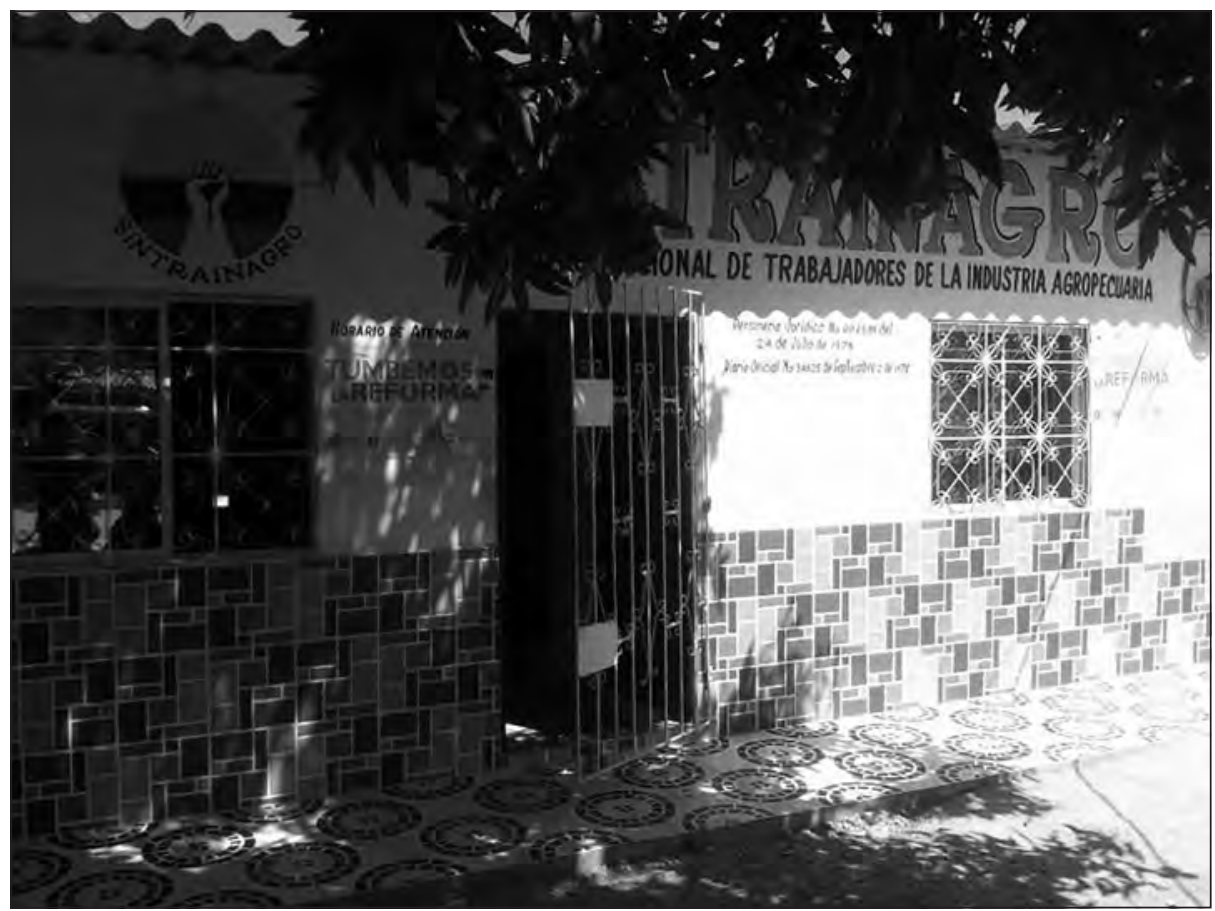

Fuente: Archivo Oraloteca (2017).

Las formas organizativas campesinas anteriores al desplazamiento y las políticas de blindaje de estas mismas durante la consolidación paramilitar en la CGSM fueron desplazadas por criterios asistencialistas, dependientes y clientelistas de relacionamiento con la comunidad y construcción de liderazgos:

Hay muchos líderes que sí tienen un ego, pero al mismo tiempo no aportan nada en los procesos [en] que tiene derecho el colectivo, sino que tienden a individualizarlo y, como tienden a individualizarlo (y por el solo hecho de ser líderes), cuando se matricula con un alcalde de turno entonces a dedillo le dicen: "venga, hecha tú para acá que yo necesito que estés aquí en este butacón para yo dirigirte como cualquier muñequito"; o sea, se constituye en un subalterno más de la administración (R. Elías, comunicación personal, diciembre del 2016). 
Vida campesina en el Magdalena Grande

Es frecuente escuchar a los líderes comunitarios de mayor edad señalando el nacimiento de la figura del tramitador a partir de estas políticas de reparación a víctimas. Los líderes sociales fueron criándose en medio de la necesidad de sobrevivir y convirtieron su función social en un servicio por el cual se merecía sacar alguna ventaja o ingreso extra. Por lo tanto, los líderes de hoy son especialistas en el manejo de los procedimientos, las normas y los trámites necesarios para acceder a cualquier tipo de oferta institucional, además de ir apropiándose de una jerga institucional propia de las autoridades competentes para la atención y reparación a víctimas.

Finalmente, tal vez este es el municipio en el que más claramente se evidencia el fenómeno de históricas familias tradicionales que mantienen un abierto ejercicio de control sobre el sistema político y administrativo a nivel municipal, departamental y nacional. Esto implica que las instituciones que ejercen el papel del Estado en el territorio definan su accionar sobre intereses de las familias económicamente poderosas, dejando de lado la garantía de derechos fundamentales para la mayoría de la población. Los pobladores de la zona tienen claridad sobre la manera en cómo funciona y cuáles son los intereses que se mueven en estas elecciones:

Los políticos, ellos son los dueños de la actividad económica, que inclusive ellos tienen alianzas con las multinacionales del banano y son los mismos dirigentes políticos. Hoy en día vemos posesionados a la familia Díaz-Granados en una columna vertebral impresionante en el Estado; por ejemplo, Sergio Díaz-Granados, que todos sabemos que es ministro del Comercio Exterior, pero sigue formando parte de la cúpula del Gobierno. Si vamos más abajo, está... no sé a quién poner primero, si al viceministro de Agricultura, Juan Pablo Díaz-Granados, exalcalde de Santa Marta... en ese orden, sigue Eduardo Díaz-Granados, representante a la Cámara, y, [después de él], sigue Carlos Francisco Díaz-Granados, exdirector del INCODER, hoy en día director de CORPAMAG, que es la entidad ambiental, ¿sí me entiende? O sea, los grupos económicos tienen la entidad que maneja las directrices ambientales del departamento (V. Carranza, comunicación personal, diciembre del 2016). 
Vida campesina en el Magdalena Grande

\section{Dimensión sociocultural}

En general, lo que se pudo observar es una tendencia a la pérdida de la cultura anfibia, que se basa en la relación que se tiene con la tierra y con el agua. El monopolio sobre las fuentes de agua y la tierra, la violencia política y la falta de inversión social hacen que las prácticas propias de los campesinos de esta zona se vayan erosionando:

Con la enajenación del trabajo viene también la pérdida de las tradiciones campesinas. Los espacios de esparcimiento están asociados al consumo de alcohol y, entre los más jóvenes, al consumo de drogas:

Aquí los más que uno ve que la gente trabaja bastante. El trabajo de campo es fuerza, es de alta temperaturas, es pesado. La gente se maltrata bastante y no les da dolor después del fin de semana tomarse eso en cerveza y hay una disciplina muy jodida del consumo de licor, que la gente trabaja es para consumir licor, ni siquiera para educar a los hijos, a la gente no le alcanza, pero los fines de semana tú ves esos billares (aquí son los últimos sitios de diversión), pero aquí se divierten los machos. Entonces, hay una cultura del derroche y del consumo de alcohol y ahí están encasillados, no hay un plan de fortalecimiento de la familia con los hijos y lo que uno observa es que los grandes grupo[s] económicos generan bastante empleo, uno ve que el grupo Cadavid es uno de los que más genera empleo acá porque son los que más tierra tienen, pero tú ves que viven de su salario mínimo y la condición de vida es limitada (V. Carranza, comunicación personal, diciembre del 2016).

Los más jóvenes están sufriendo las consecuencias del cambio de valores tradicionales a la inserción de prácticas consumistas, en un ambiente donde los recursos son muy escasos y donde las ofertas de opciones diferentes que contribuyan a un buen vivir no existen. Al respecto, el señor Vladimir observa que, a pesar de los talentos que puedan tener los jóvenes, no existen programas de formación que redunden en un mejor futuro:

Por ejemplo, necesitamos una sede Sena aquí en la Zona Bananera. A pesar de todo lo económico que representa, aquí no existen programas de formación en donde se identifique y se potencie lo que son las capacidades y el talento del joven para el deporte, para el arte, la música 
Vida campesina en el Magdalena Grande

(que hay bastantes valores acá en eso), no hay programas institucionales que ayuden a la identificación y el fortalecimiento y el desarrollo de esas capacidades de esos jóvenes y esos niños (V. Carranza, comunicación personal, diciembre del 2016).

Ante este panorama, algunas comunidades se resisten no solo a perder sus tierras, sino que, de manera especial, se niegan a perder sus tradiciones y valores ganados generaciones atrás. En algunas comunidades persisten dinámicas de ayuda mutua; principalmente, entre quienes tienen tierra propia y están organizados. En cuanto al arraigo en el territorio, la percepción de los campesinos es ambivalente. Por ejemplo, Aura Rodríguez reconoce la persistencia de patrones de colaboración e integración entre las familias campesinas de la Mira:

Acá nosotros hacemos lo que es el sancocho criollo, que entre familias formamos, por decir, un grupo. Por decir algo: hoy nos vamos a reunir en tal, X, Y familia, hoy vamos a hacer un sancocho porque vamos a hacer una actividad. Hacemos actividades de trabajo, realizamos actividades por ejemplo a... somos 30 familias, o 26 familias, vamos a la casa de la señora Sol Marina Rivera, por decir algo, vamos a realizar un trabajo de limpia, le ayudamos siempre, siempre estamos en contacto, siempre de ayudar a esa familia que necesita, por ejemplo, el apoyo para realizar su trabajo en la parcela porque a veces uno campesino, como somos familias a veces pequeñas, no tienen como que la ayuda suficiente, entonces nosotros les damos trabajo a esas familias, las ayudamos para que salgan adelante, para que surjan esas familias (A. Rodríguez, comunicación personal, diciembre del 2016). 
Vida campesina en el Magdalena Grande

Imagen 122. Espacios de socialización en el Bajo Magdalena
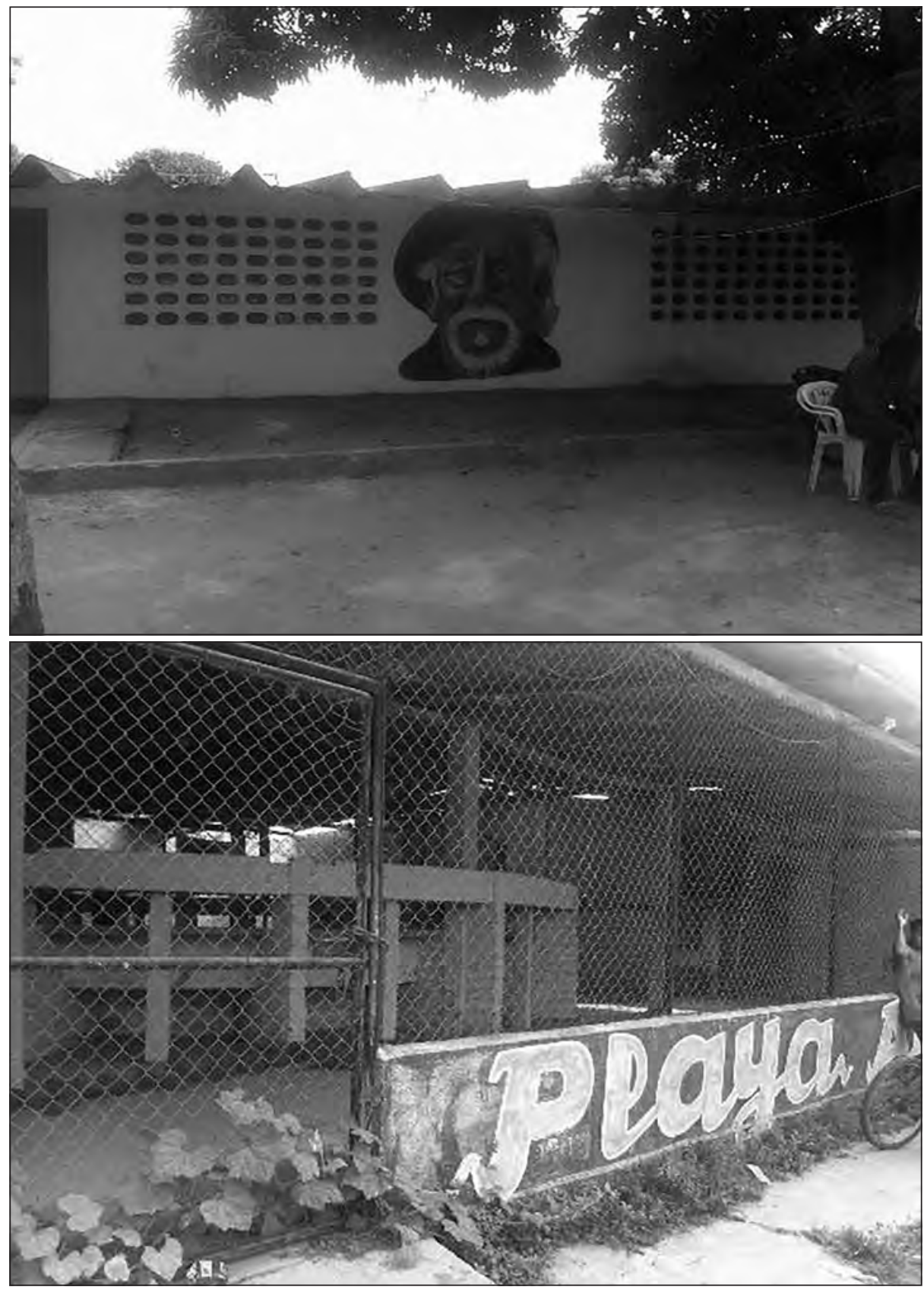
Vida campesina en el Magdalena Grande
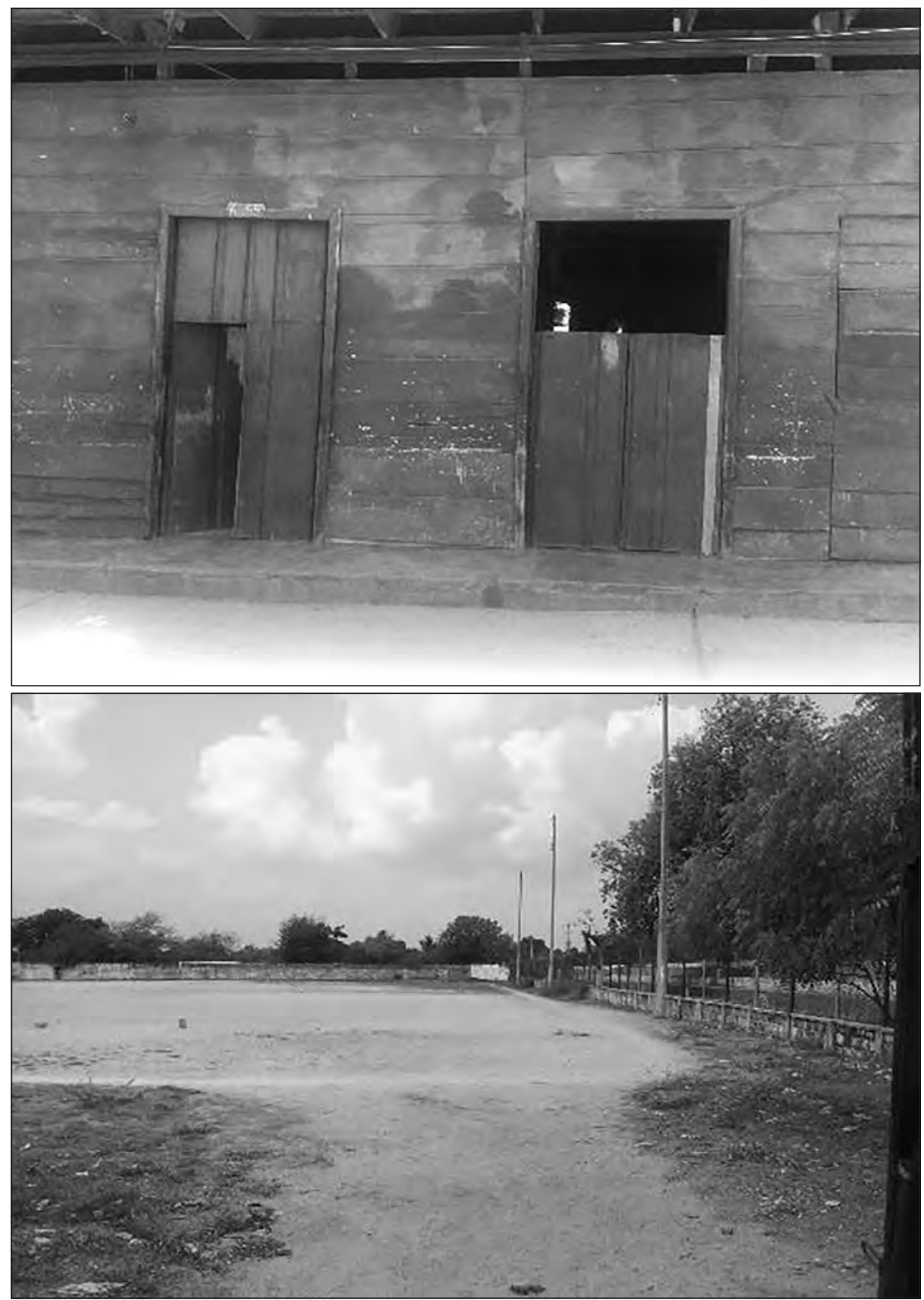

Fuente: Archivo Oraloteca (2017). 
Vida campesina en el Magdalena Grande

Guillermo Olivera habla de Candelaria como un pueblo "amañador":

Este es un pueblo que es amañador. Aquí ha venido gente a pasear una Semana Santa y, de repente, se salen viniendo pa' acá. Los moradores de este pueblo la mayoría son [de] Atlántico, Bolívar, de allá son la mayoría de los moradores de aquí. Tú preguntas a los ancestros: “¿usted de dónde?” [y responden:] "Mi papá era del Carmen de Bolívar, mi papá era de Barranquilla, de Sitio Nuevo, de Palmar de Varela...”, y así [...]. Como esto fue un epicentro, era el boom en todas partes, las bananeras colombianas, venía gente de todas partes, y se fueron quedando. Por aquí había muchos campamentos de la compañía, donde había gente en los montes, que eran las fincas, y la gente se fue quedando (G. Olivera, comunicación personal, diciembre del 2016).

Para estos campesinos la forma de vida de un parcelero es una forma de resistencia ante los terratenientes porque garantiza no solo una mejor calidad de vida para el campesino, sino también que los elementos de su cultura se transmitan de una generación a otra:

Tú ves la diferencia entre la forma de vida entre un pequeño productor y la forma de vida de la gente que trabaja en donde los terratenientes $\mathrm{y}$ es totalmente diferente. Vive mejor el que tiene su parcela porque es que aquí se daba algo que en tres hectáreas de tierra de un pequeño propietario vivían el señor, la esposa y los tres hijos y resulta que esos tres hijos ya tienen mujer e hijos y todavía siguen viviendo de las mismas tres hectáreas; con eso viven hasta tres familias. Metían a trabajar todo en el mismo núcleo de la parcela y ellos se sostenían, inclusive (V. Carranza, comunicación personal, diciembre del 2016). 


\section{Zona del Bajo Magdalena}

Mapa 12. Subregión Bajo Magdalena de la CGSM

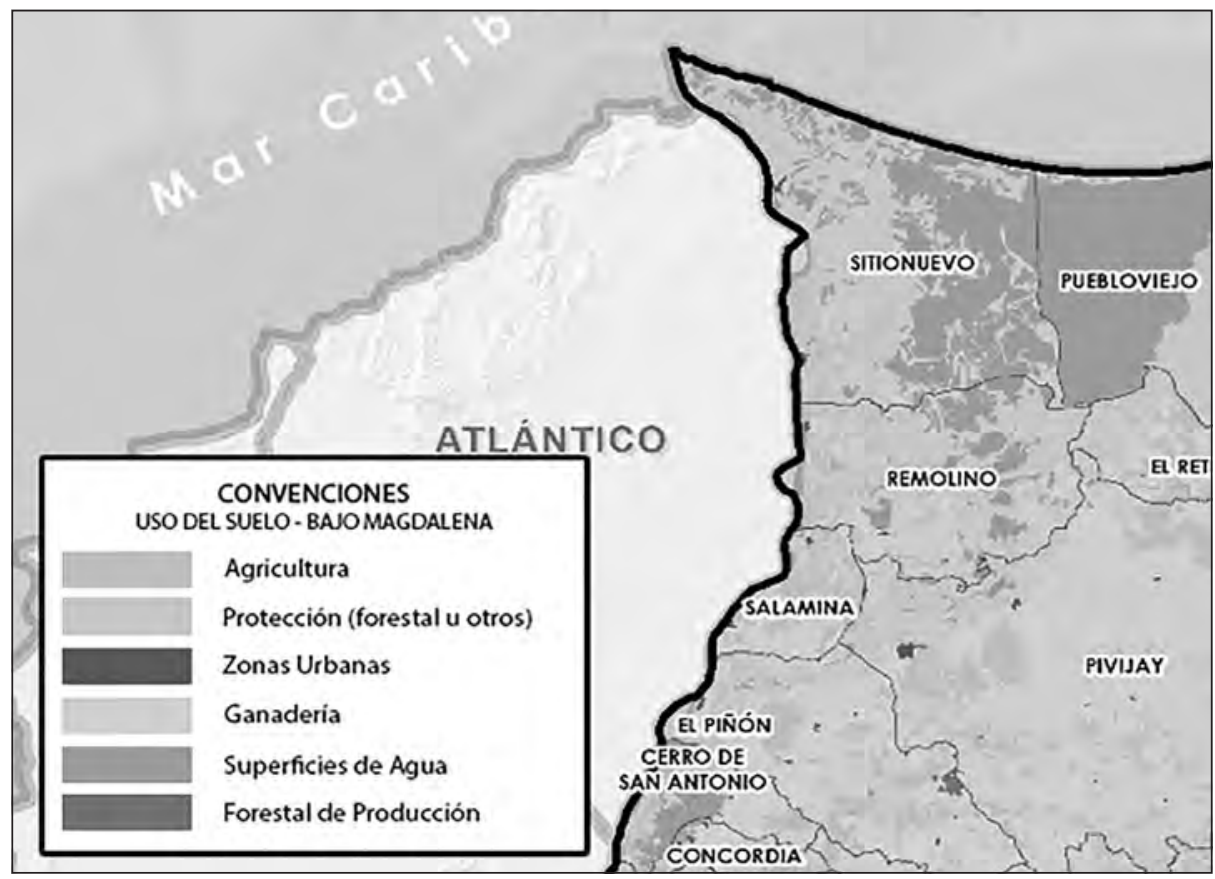

Fuente: UPRA (2014).

\section{Caracterización de la subregión}

La subregión Bajo Magdalena de la CGSM abarca los municipios ubicados entre el margen izquierdo del último tramo del río Magdalena ${ }^{13} \mathrm{y}$ el sistema de ciénagas, caños, quebradas y ojos de agua que abastecen de agua dulce a la Ciénaga Grande de Santa Marta desde este mismo río. La zona corresponde al delta final del río Magdalena, el cual conforma, junto con la laguna costera, el complejo delta-estuario Ciénaga Grande de Santa Marta. Básicamente, se trata de una subregión, entre el río Magdalena y la laguna costera, que puede considerarse como una enorme estrella hídrica.

13. Estos municipios son: Sitio Nuevo, Remolino, Salamina, Pivijay, el Piñón, Concordia, Cerro de San Antonio y Pedraza. 
Esta zona es rica en acuíferos y tierras cenagosas. Por el costado occidental, como ya vimos, la CGSM se alimenta de los ríos que bajan de la Sierra Nevada de Santa Marta, entre los cuales están: Fundación, Aracataca, Sevilla, Tucurinca, Frío y Orihueca. Por el costado oriental, es decir, el Bajo Magdalena, la CGSM se abastece mediante los caños: Salado, Renegado, Aguas Negras y Clarín, cuyo afluente se sustenta en las aguas del río Magdalena.

De la misma manera que en todas las zonas de llanuras de pastoreo de la costa norte, y como extensión de las grandes llanuras del centro del Magdalena, los usos de suelo que históricamente se han desarrollado son la ganadería extensiva, con una mayor preponderancia, seguida marginalmente de la agricultura y la pesca artesanal (Ministerio de Ambiente, Vivienda y Desarrollo Territorial, 2004).

Especialmente en Pivijay, Piñón y Salamina la producción de leche y la venta de ganado a los mataderos de Santa Marta y Barranquilla representan la mayor parte de sus ingresos, siendo este el negocio predilecto de las familias tradicionales. En Salamina, Remolino y Sitio Nuevo predomina también la ganadería; sin embargo, se mantiene una discreta tradición de producción campesina, principalmente de maíz, yuca, millo, tomate y melón.

Debido a la alta concentración de tierras, el deterioro ambiental de la CGSM y el nulo control sobre la distribución del recurso hídrico la economía agropecuaria difícilmente satisface el sustento diario de las familias campesinas. En la misma situación se encuentra el oficio de la pesca artesanal, que exige al pescador ir cada vez más lejos de su hogar, a donde existan bancos no explorados, en largas faenas de pesca que exigen más de tres noches en busca del recurso.

Al igual que en la Zona Bananera, es el gremio ganadero el que desvía y se apropia indebidamente del recurso hídrico, especialmente durante la temporada de sequías, represando el bajo caudal que llega para el ganando y la conservación de los pastos.

Al tratarse de ganado criado en zonas inundables, la manera menos costosa que han encontrado los ganaderos de la subregión ha sido el aprovechamiento de la mayor extensión de tierra posible y con acceso a cuerpos de agua que permitan mejor calidad de tierras, así como soportar las largas sequías (Viloria, 2003). Por ende, al igual que en la Zona 
Bananera, la estructura de tenencia de las tierras ha sido tradicionalmente latifundista, mientras que las tierras de menor calidad y con menor acceso al agua han sido ocupadas por el pequeño agricultor.

Además, desde la época de la colonia el río Magdalena ha sido una ruta privilegiada para la salida de mercancías hacia el exterior, ruta que a su vez fue históricamente reemplazada por la construcción de carreteras paralelas a ella que van hacia el Puerto de Barranquilla y el Puerto de Palermo perteneciente al Magdalena. Por este motivo, la subregión es estratégica tanto para la producción agrícola y ganadera, como para el transporte y salida de mercancías.

Imagen 123. Vocación y conflictos de uso del suelo en el Bajo Magdalena

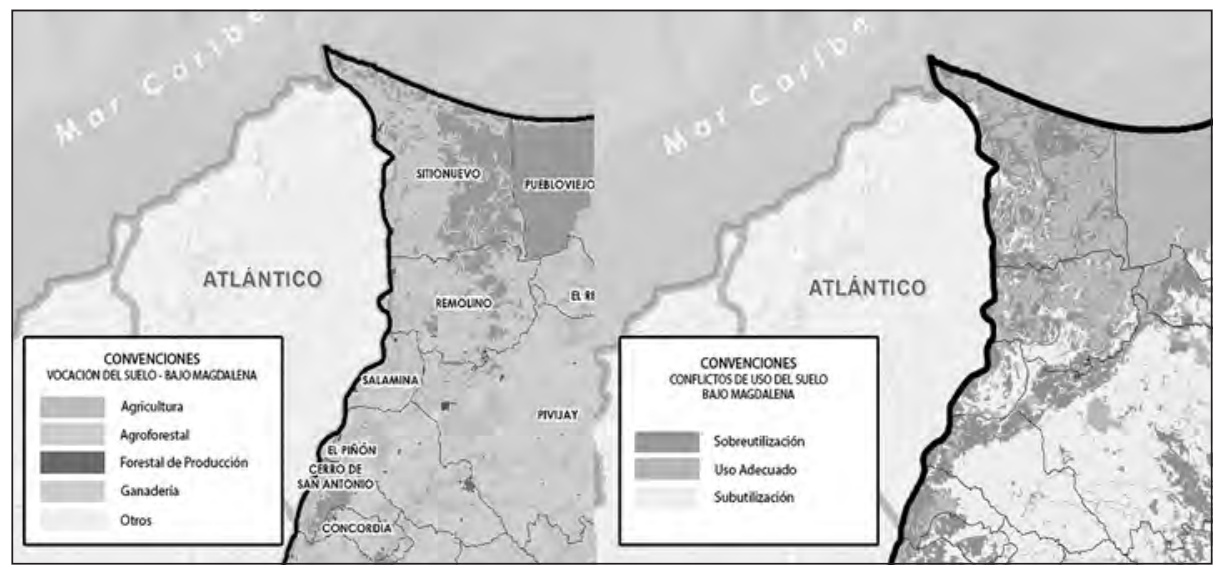

Fuente: UPRA (2014).

La escasa producción agrícola de la región se basa en la pesca y el cultivo de berenjena, maíz, yuca, tomate, fríjol y frutales como el mango. Los terratenientes han venido impulsando la ganadería extensiva y las plantaciones de palma aceitera. En menor escala está la producción de ladrillos, que se hace de manera artesanal en las zonas de chircal. También se explota la madera para la producción de carbón.

De la misma manera que en la Zona Bananera, pero con un capital político y económico menor, existen familias tradicionales terratenientes en torno a las cuales se generaron dinámicas gamonalistas y clientelares. 
Vida campesina en el Magdalena Grande

Dichas familias datan de la época colonial, como fundadores o primeros colonos de las campañas "civilizatorias" de los españoles y de los criollos realistas de Santa Marta y Barranquilla. Otras provienen de la migración turco-libanesa que se asentó a finales del siglo XIX en Barranquilla; los Caballero, Pérez, Zambrano, Matera y Salah son algunas de ellas.

A una escala menor que en la Zona Bananera Histórica, que posee los suelos más fértiles y más costosos del departamento, el Bajo Magdalena se convirtió con los años en un territorio igualmente disputado por diferentes intereses sobre la tierra y sus ventajas geoestratégicas.

Debido a los proyectos de canalización artificial del caño Renegado y Aguas Negras, y a la construcción de sus respectivas compuertas, realizadas en el marco del megaproyecto para la recuperación de la Ciénaga Grande, desde 1994 los caños perdieron su caudal gradualmente, se ensancharon y sedimentaron al punto de que hay épocas del año en las que el agua no llega hasta la Ciénaga, las tierras quedan completamente secas y el ciclo vital de los peces no se completa, haciendo que se devuelvan a las ciénagas sin desovar.

El impacto ecológico que han generado las intervenciones antrópicas sobre el sistema cenagoso se debe, principalmente, a las carreteras y a las desviaciones de agua para las extensas fincas ganaderas, a la sobreexplotación de ganado (que causa erosión por compactación) y a las posteriores obras de recuperación hidráulica de la Ciénaga Grande, entre 1994 y 1998, sobre el sistema de caños y ciénagas, que la comunican con el río Magdalena; todo esto ha ido reduciendo el acceso al agua de estas comunidades, así como deteriorando la calidad de este mismo recurso, afectando, particularmente, el caño Renegado, del cual se han abastecido históricamente.

$\mathrm{El}$ acceso a agua potable es deficiente y, en algunos casos, solo en las cabeceras municipales se garantiza el servicio gracias a la reciente política del Ministerio de Vivienda, Ciudad y Territorio, que ha dotado a los municipios que no contaban con uno de un sistema de potabilización del agua y redes de abastecimiento. El sistema de acueducto, en todos estos municipios, se abastece del río Magdalena, cuyas aguas son tratadas para el consumo humano. Estos municipios no tienen cobertura en la parte rural, que se abastece de los caños y ciénagas que transportan aguas del Magdalena para alimentar la ciénaga. En estas zonas, además, 
Vida campesina en el Magdalena Grande

las comunidades no hacen una debida protección a sus fuentes de agua y su consumo y distribución se hacen de manera artesanal.

En cuanto al manejo de aguas servidas en las cabeceras municipales no se cuenta con una planta de tratamiento de residuos líquidos. Las aguas servidas del perímetro urbano son arrojadas, generalmente, a campo abierto, generando contaminación en todo su recorrido. No existen planes maestros de alcantarillado que canalicen las aguas servidas producidas. Las áreas rurales no cuentan con programas de disposición adecuada de excretas.

En la parte rural no existe un estudio detallado de alcantarillado. El sistema de los pozos sépticos y sumideros es usado en el 10\% de la población rural; el resto, está creando indirectamente un problema de contaminación al quedar los residuos al aire libre ya que, cuando llueve, son arrastrados al río Magdalena, deteriorando la calidad del agua. Al respecto, comenta el señor Alejandro Montero:

Todos los pueblos que están a orillas del río vienen a dar a los sistemas de alcantarillado del río porque son pocos los pueblos que tienen la planta de tratamiento para transformar y contabilizar el agua servida, el único es el Piñón, los únicos con tratamiento de las aguas servidas a través de la decantación. Prácticamente el agua cuando se manda al río por la laguna de oxidación ya ha perdido un poco la cantidad de infestación que tiene (A. Montero, comunicación personal, enero del 2017).

En cuanto al acceso al servicio público de salud, este es deficiente, tanto por las condiciones propias del sistema subsidiado del país como por la falta de infraestructura de los municipios que, por un lado, no cuentan con hospitales o centros de salud equipados y, por otro, no cuentan con las vías de comunicación adecuadas y en buen estado para el tránsito de los enfermos, además de que en ocasiones no se cuenta con ambulancias. $\mathrm{Al}$ respecto, comentan los habitantes del Piñón que, de haber un enfermo, tendrían que trasladarlo hasta dicha cabecera para luego llevarlo a Pivijay o Barranquilla.

La nutrición de las familias no alcanza los niveles necesarios de buena nutrición; esto se debe a varios factores: 1) No hay oferta de productos variados y nutritivos y a precios razonables para una buena nutrición, pues 
las tierras productivas aún se encuentran inundadas. Como no se están produciendo los alimentos en el municipio, tienen que traerlos de Barranquilla, lo que implica un aumento de los precios; 2) el bajo nivel de ingresos económicos de las familias restringe la demanda de alimentos que garanticen una alimentación balanceada; 3 ) por cuestiones culturales, las familias están acostumbradas a consumir alimentos con un alto contenido en grasas y carbohidratos y hay poco consumo de vitaminas y minerales.

Las condiciones de habitabilidad de las viviendas en las zonas urbanas son precarias. Las zonas rurales se caracterizan, en su mayoría, por tener viviendas temporales, de materiales blandos o de materiales duros, pero con condiciones de ventilación, iluminación y saneamiento básico de baja calidad.

No hay oferta de vivienda y la demanda está aumentando, pues los hijos constituyen familias a temprana edad y se quedan a vivir con sus padres. Estas viviendas se caracterizan porque tienen entre una y dos habitaciones, una cocina, un patio, un baño y una sala en el mejor de los casos; en cada una de estas habitaciones convive una familia en hacinamiento. Esto recae en problemas sociales, como el maltrato intrafamiliar y el abuso sexual a menores de edad.

Imagen 124. Cotidianidad en Santa Rita, Magdalena

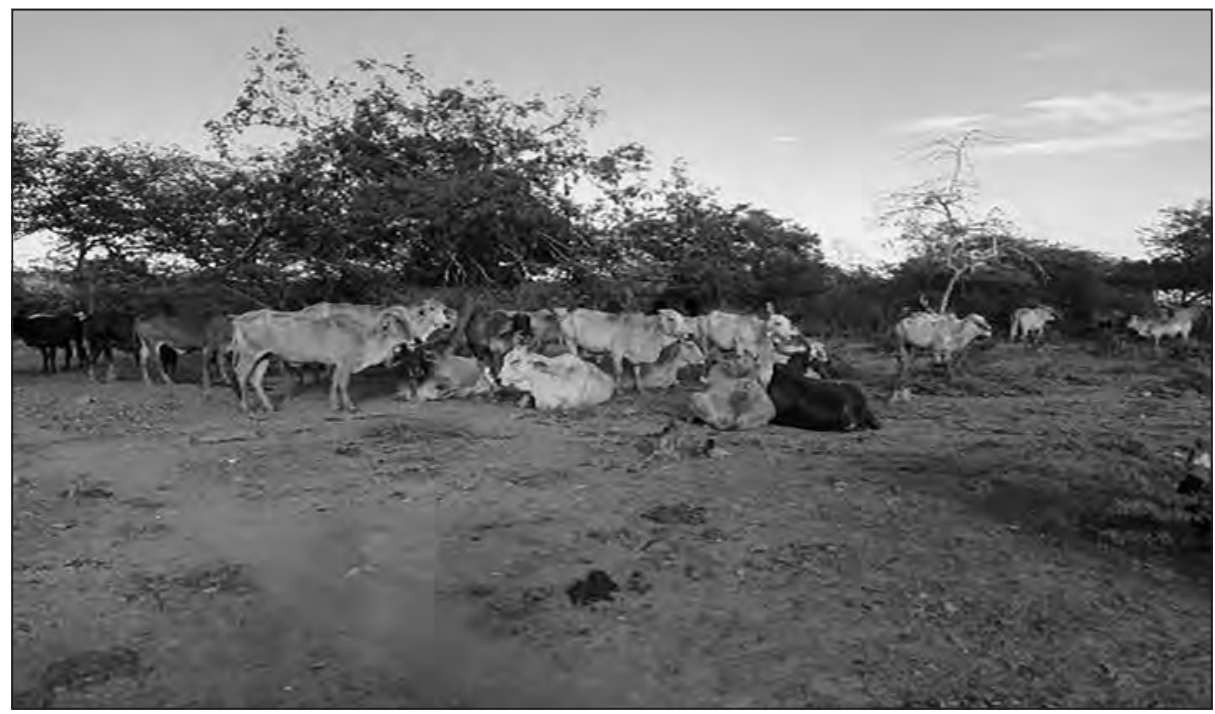



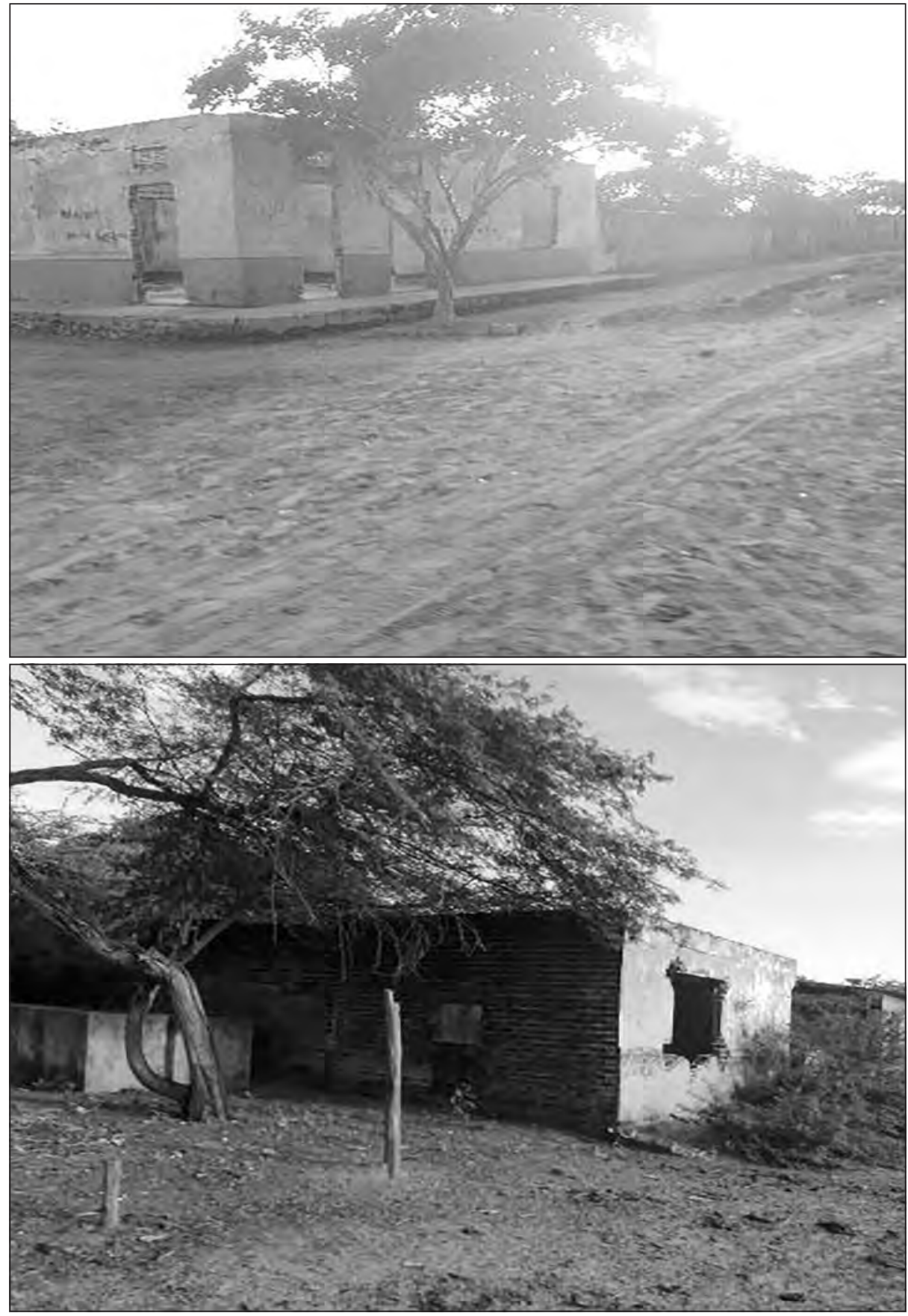


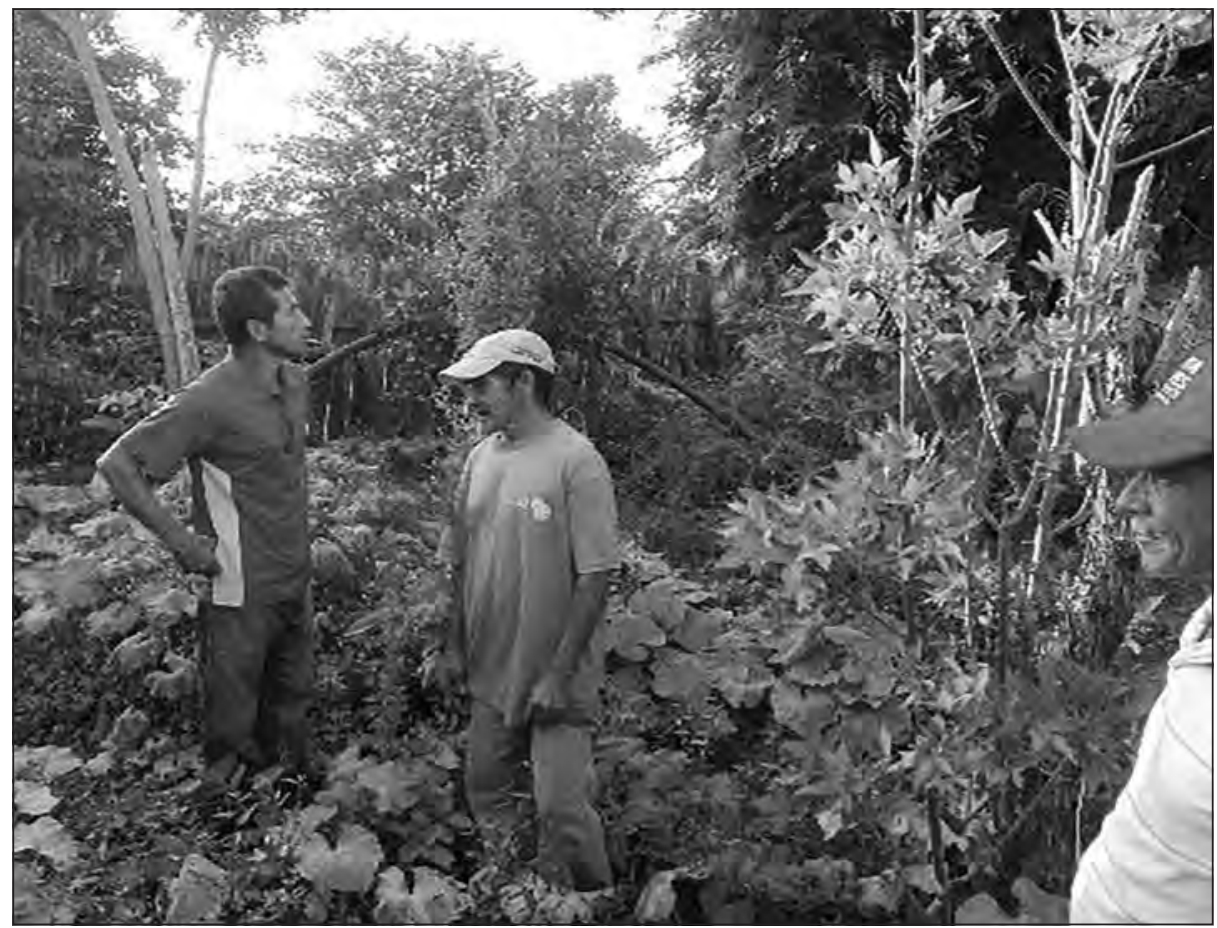

Fuente: Archivo Oraloteca (2017)

En la mayoría de los municipios visitados se evidenció el servicio de recolección de basuras por medio de un vehículo recolector; las basuras son dispuestas a cielo abierto en lotes alejados del perímetro urbano. Aunque se han venido adelantando campañas educativas referentes al manejo de basuras para evitar la contaminación del medio ambiente, se da la presencia de aves de rapiña, roedores, etcétera.

Los niveles de alfabetización son básicos. Tanto campesinos agricultores como pescadores tienen escasos niveles de alfabetización. Podría decirse que la generación de los abuelos no asistió a la escuela; hay una segunda generación, la de los padres, que alcanzó la primaria, y una tercera y cuarta generación, la de los hijos y nietos, en la que se empieza a observar un aumento en el nivel de escolaridad, encontrando algunos miembros de estas familias que estudian el bachillerato completo y que, incluso, se han venido especializando en profesiones técnicas o que están estudiando actualmente. 


\section{Dimensión socioeconómica}

En esta zona del BM es donde se expresa mejor la cultura ribereña o anfibia que, según Fals Borda, se caracteriza por el dominio de unas técnicas acuáticas para el caso de la pesca y agrícolas y de caza para el caso de la tierra. Los habitantes de esta zona son expertos en la caza, en la agricultura y en la pesca. Esta forma de vida la observamos en la relación que establecen los habitantes de esta zona con su territorio.

La actividad productiva de los campesinos de la zona ribereña, agricultores y pescadores, está marcada por fenómenos estructurales como el cambio climático, las transformaciones en el modelo económico hacia el neoliberalismo, los tratados de libre comercio, las lógicas locales de tenencia de la tierra y la adaptación de los terratenientes a las lógicas de mercado actual. Ante estas transformaciones, la única opción que han tenido los campesinos es la de la adaptación y mantenimiento de sus condiciones precarias de vida. Como afirman todos los entrevistados, su opinión nunca ha sido tenida en cuenta por parte de los gobiernos y los poderosos de la región en la toma de decisiones que busquen beneficiar a todos. A continuación, veremos la manera en cómo se han venido dando estas adaptaciones al modelo; dadas las particularidades de los campesinos de esta zona, el análisis se dividirá entre la observación de las dinámicas productivas de los agricultores y las dinámicas productivas de los pescadores.

\section{La producción agrícola}

Las dinámicas de producción agrícola de esta zona están determinadas por una serie de situaciones que podemos observar en otras zonas, pero con las particularidades de las condiciones geográficas de estas zonas ribereñas, donde la relación con la Ciénaga, el río Magdalena, el puerto de Barranquilla y, en general, con los municipios del Atlántico, marca dinámicas distintas en la producción agrícola. Para analizar estas particularidades veremos los siguientes elementos claves en la producción agrícola: propiedad sobre la tierra, cultivo (tipos de cultivos, periodos de siembra), incidencia del neoliberalismo y el cambio climático en los tipos de productos y periodos de siembra y la comercialización. 
Vida campesina en el Magdalena Grande

En cuanto a la propiedad sobre la tierra, los campesinos manifestaron que está concentrada en manos de las familias poderosas de cada municipio. Al respecto, el señor Montero comenta la situación en el Piñón:

esta [es] una tierra rica y, a la vez, sus habitantes son pobres, porque el $80 \%$ de la tierra de este pueblo está en manos de 4 o 5 familias, las podemos contar con los dedos, las familias que tienen casi el $80 \%$ de la tierra... Aquí son 4 familias y están cruzados entre sí mismos: son los Caballero, Zambrano, Pérez, Caballero con Pérez, Zambrano con Caballero y, ahorita mismo, pues los Pérez se cruzaron con los Martelo de Cartagena que tienen plata (A. Montero, comunicación personal, enero del 2017).

Las tierras aptas para el cultivo y la tenencia de animales de pastoreo y ganado están concentradas en manos de los terratenientes, obligando a los campesinos a ubicarse en los playones y zonas inundables para explotarlas en las temporadas de lluvias bajas. Al respecto, el señor Montero comenta que la forma de acceso a la tierra por parte de los campesinos bajo la figura de aparcería ha venido desapareciendo, reforzando el argumento anterior:

Antes había la oportunidad de que los grandes ganaderos para hacer hierba a sus potreros le[s] daba[n] las tierras a los campesinos 2 años, o sea que el que quiere monte tiene 2 años para trabajarla. Al menos esos campesinos podían tener hasta 2 hectáreas, eso en producción de yuca es bueno porque le estaría dando casi 400 toneladas, en maíz igual, sin ahuyama; o sea, una persona con 2 hectáreas en esta zona en la ribera del río puede sostener una familia porque aquí se da diversidad de cultivos y son tierras al lado del río que tienen mucha fertilidad y mucha humedad (A. Montero, comunicación personal, enero del 2017).

En el ejercicio de la producción agrícola los habitantes de esta zona han tenido que enfrentarse a la lógica del jornalero, que implica una ruptura con un estilo de vida basado en la autonomía en el trabajo, pues esta implica no solo cumplir con horarios de trabajo fijos (que dependen de la jornada impuesta por el que posee la tierra), sino también una ruptura en la relación que establecen con la tierra, elemento central en la identidad campesina. 
En una situación diferente está el jornalero, que no posee tierra ni los insumos básicos para producir un cultivo. El modo de explotación de la tierra cambia por las lógicas que impone la producción que busca la rentabilidad del cultivo: por tanto, el jornalero se ve obligado a trabajarle a otro cumpliendo una jornada de ocho a doce horas y con un pago por día de trabajo sin reconocimiento de prestaciones sociales, alimentación ni transporte.

Imagen 125. Rancho para sombrear durante el jornal

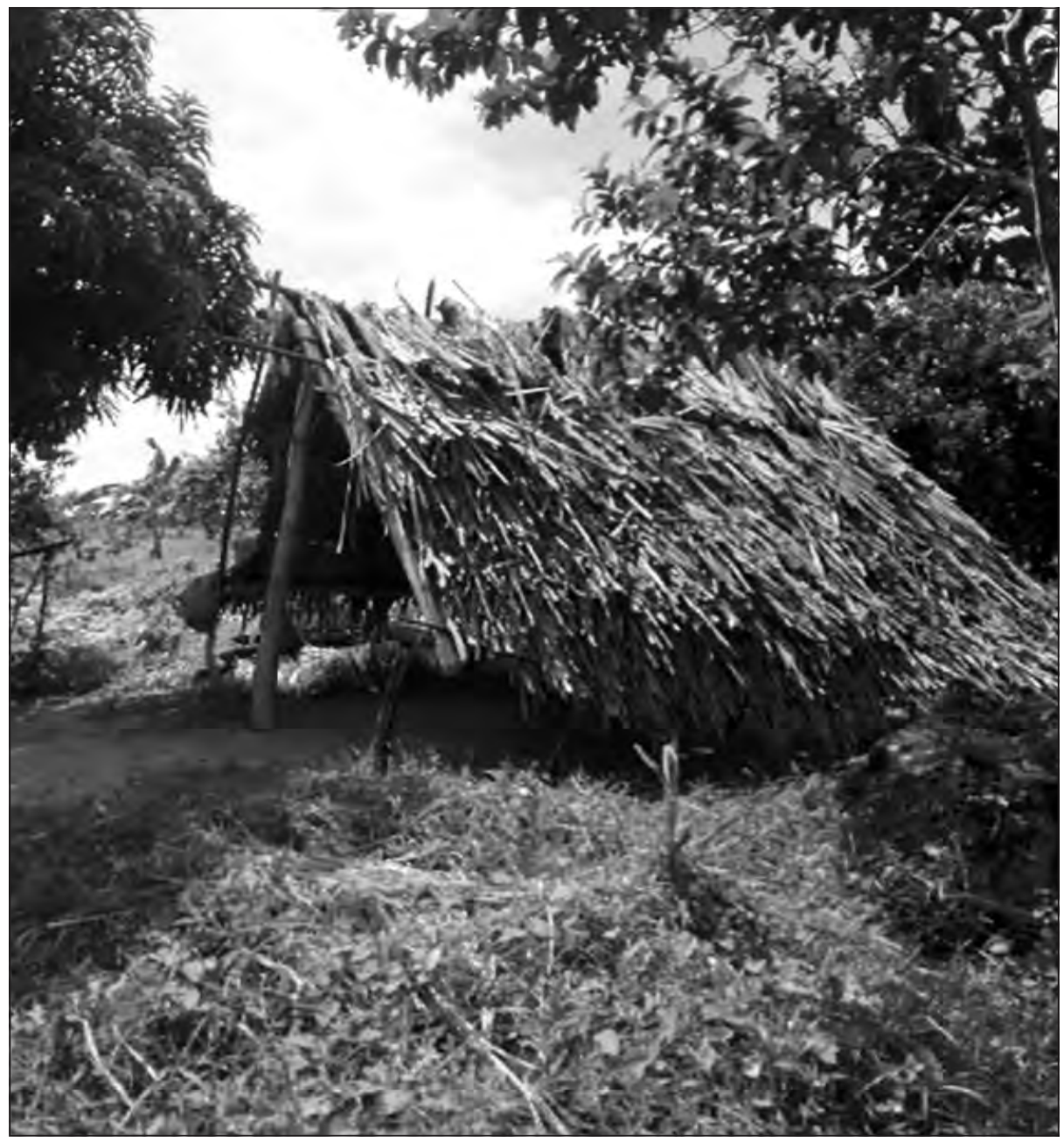




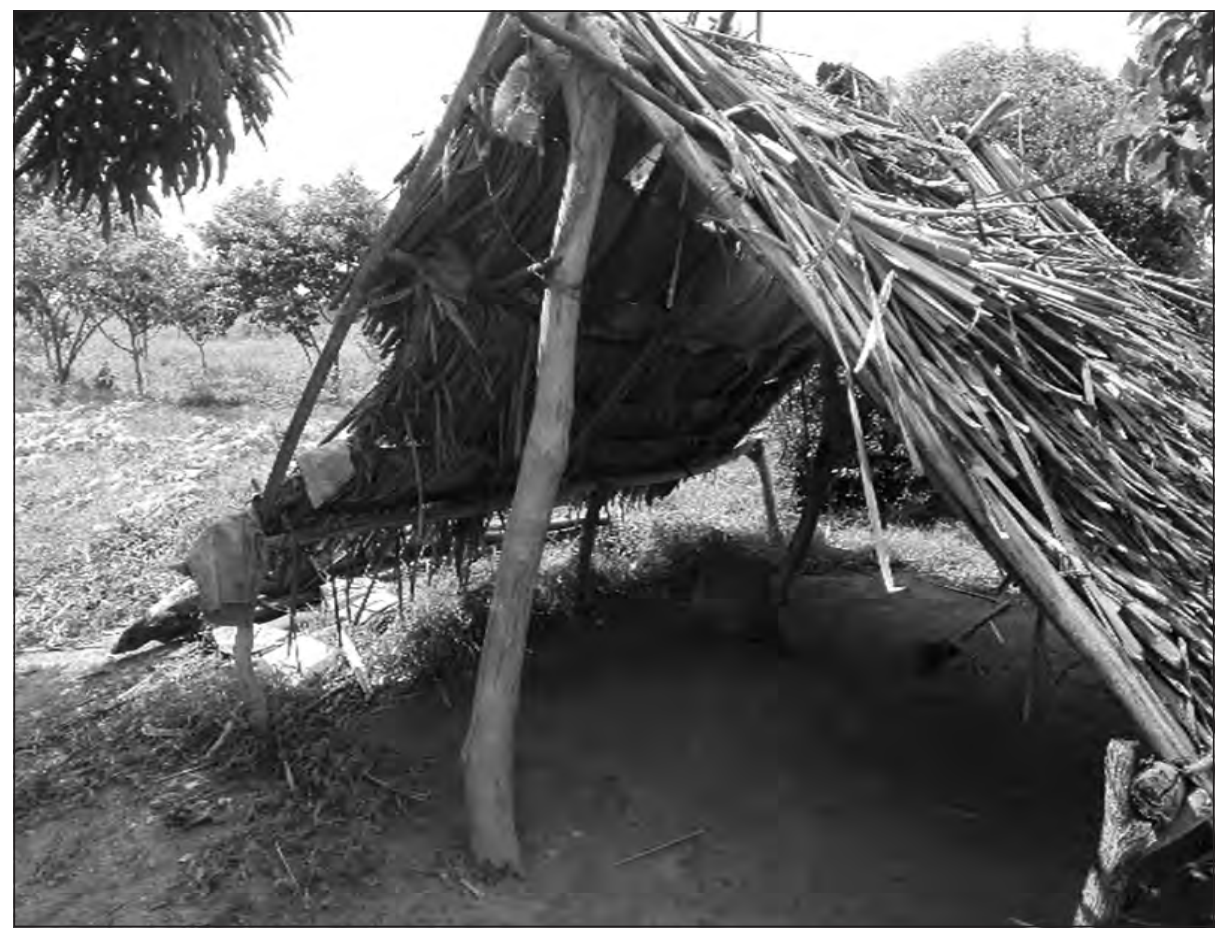

Fuente: Archivo Oraloteca (2017).

Para el caso de los campesinos que poseen tierra, como dijimos anteriormente, la rutina diaria de trabajo la definen ellos mismos según las actividades que tengan que hacer. En general, los campesinos de la zona recorrida suelen despertarse a las cuatro de la mañana, almorzar a medio día en sus parcelas y continuar la jornada de trabajo hasta las seis de la tarde. Sin embargo, esto es variable de acuerdo al tipo de actividad productiva que realizan en sus parcelas. Por ejemplo, en Santa Rita generalmente trabajan el jornal solamente hasta medio día. En cambio, en el corregimiento de Carreto, Carlos Cervantes trabaja la tierra principalmente en la tarde: tras levantarse a las cuatro y treinta de la mañana emprende un viaje de hora y media en burro hacia sus predios, donde ordeña las vacas, con cuya leche regresa para el desayuno en su casa, así como para vender en el casco urbano. Después de desayunar, comienza su tercer viaje de hora y media en burro, llevando el almuerzo ya preparado. En ese sentido explica que: 
Vida campesina en el Magdalena Grande

No puedo jardear [separar a los terneros de la vaca] en la mañana enseguida porque ya así maltrato los terneros. Aquí la costumbre es [que] uno ordeña en la mañana y suelta los animales en la tarde. De doce a una uno jardea, aparte los terneros de las vacas, y entonces yo, para no quedarme allá, o sea: porque lo uno es que tengo que traer la leche que la vendo acá en Carreto y lo otro es qué tengo que hacer allá mientras se llega la hora de venirme y [en] eso yo me puedo poner a componer un portillo, puedo dar vueltas y los animales, es lo que hago (C. Cervantes, comunicación personal, enero del 2017).

Con relación al tipo de cultivos, estos son variados y dependen del para qué; es decir, hay una producción local para abastecer la canasta familiar diaria de la familia propia y de vecinos y hay otro tipo de cultivos que son para la comercialización (que van desde la yuca hasta la palma aceitera, implementada por los terratenientes):

De aquí hasta Plato hay una cultura y de Plato hacia San Sebastián, San Zenón, hay otra cultura. Aquí te siembran maíz, yuca, fríjol y guineo, $y$, cuando hay producciones, tomate. Allá te siembran, desde Plato para adelante, te siembran tabaco, te siembran la yuca, el maíz, ñame, cambian totalmente el cultivo. Ya el tomate lo han ido reduciendo; quien siembra tomate es para, de pronto, surtir las tiendas... La otra cultura es tabaco, maíz, ñame, y el otro cultivo que ellos siembran -y lógicamente siembran la yuca también-, pero debo decir que [en] el caso de Plato hay muchos campesinos, porque esas tierras son muy buenas allá, las playas están sembradas es de tabaco: usted sabe que esa vaina es rentable porque las fábricas son pocas. Las zonas donde se está cultivando tabaco: la gente de Tamalameque, de la Gloria, Gamarra, los pueblos que están ahí cerquita de Pelaya, de Aguachica, bajando para acá, Curumaní, Pailitas, Tamalameque, son tierras que tienen parte del Magdalena y tienen parte de tierra alta (A. Montero, comunicación personal, enero del 2017).

Las mejores zonas para cultivar son las playas que están sobre la ribera del río Magdalena. Por esto las lógicas del cultivo dependen de la condición climática del país, pues como se sabe el Magdalena atraviesa todo el país y cuando llueve en exceso en el interior del país estas zonas se 
Vida campesina en el Magdalena Grande

inundan porque el río Magdalena arrastra todas estas aguas. Los agricultores ribereños, a partir de la observación de la manera en cómo ha venido cambiando el clima, se han ido especializando en los cultivos transitorios y han definido nuevas temporalidades tanto para la siembra como para la recolección. Al respecto, el señor Montero nos explica:

Los periodos del río son periodos que van con las estaciones en Colombia. Usted sabe que el verano aquí comienza en diciembre, el verano comienza desde final de noviembre a principios de diciembre y, luego, comienza en el mes de mayo, el invierno aquí comienza en abril. Aquí las fiestas terminan a finales de abril, que es el 29 de abril, que comienza la época de lluvia, y el mes de mayo. Entonces, mayo, junio, julio, agosto, septiembre, octubre, noviembre y diciembre: tenemos 8 meses de lluvia. Entonces, sucede que uno siembra y ahorita la tierra está hundida, ya el río comenzó a bajar, ponle tú que a más tardar el 20 de enero ya la gente está sembrando. Entonces llega[n] febrero, marzo, abril, en mayo comienza la lluvia en el interior del país y, si es fuerte, se viene el río y las partes bajas te las hunde, por eso nosotros usamos cultivos transitorios de 3 meses como el maíz, el tomate, el caso del ají, que son cosechas rápidas y de ahí el problema porque el Banco Agrario no nos presta a nosotros porque esos son de alto riesgo; te presta para yuca, que son 8 meses. Si tú puedes conseguir que el banco te preste para sembrar maíz te da 6 meses para que tú alcances a hacer 2 cosechas porque el maíz se da a los 3 meses (A. Montero, comunicación personal, enero del 2017).

Un elemento central para garantizar el cultivo es el acceso a fuentes hídricas para el riego de los cultivos. A pesar de ser una zona rica en agua, los campesinos no cuentan con sistemas de riego adecuados ni con la capacitación técnica para llevar de manera adecuada el proceso de producción agrícola.

Sobre la Trinidad ${ }^{14}$, Manuel Altamar (enero del 2017), uno de los reclamantes de tierras que fue desplazado de dicho predio, refiere la falta de canales de riego, aclarando que "la sentencia no dice nada de riego, la

14. La Trinidad es un predio restituido recientemente, en el marco de la Ley de Víctimas y Restitución de Tierras, ubicado en el municipio de Sitio Nuevo, a diez minutos del casco urbano. 
solución es que entre la mayoría de los 70 [después corrigió a 96] que habemos para ver a quién nombramos para que le exija al alcalde" (comunicación personal). Actualmente, se abastecen con el agua del río Magdalena, que transportan en dos timbos a lomo de mulo por un camino que toma media hora. Sin embargo, existen canales que pueden ser utilizados para abastecer las tierras de los campesinos de la Trinidad, pero requieren convenios con propietarios privados debido a que pasan por unas tierras con dueño:

Allá hay un canal que llaman el "canal del burro"; por aquí mismo también hay otro que es el que también baña a la Trinidad. Pa' ve' cuál de los dos se arregla para que nos pase esa agua allá a nosotros (M. Altamar, comunicación personal, enero del 2017).

En Guaimaro, ubicado en el municipio de Salamina, Gregorio Escorcia (enero del 2017) señaló como problemática la falta de acceso al río Magdalena: "no tenemos por dónde meter el agua [del río Magdalena] por la sequía. [Eso] se resuelve con tubería y turbina" (comunicación personal). Esto lo ratifica Cesar Payares (enero del 2017): "Si se pudiera meter el agua habría cultivo estable, falta una turbina” (comunicación personal).

Sobre el corregimiento de Carreto, C. Cervantes (enero del 2017) afirma que "la agricultura es pésima, trabajamos con las uñas a la esperanza de que nos caiga un aguacerito porque no tenemos ayuda técnica para el cultivo" (comunicación personal). Al ser interrogado sobre la principal problemática que afrontan los campesinos del corregimiento, respondió que:

Principalmente el agua, como le dije ahorita. Por aquí no tenemos sistema de regadío, está uno es esperanzado es a que le llueva. A veces uno prepara la tierra $[y]$ no llueve para sembrar, o hay veces de que ya llovió, viene uno, prepara, sembró y está la cosecha, [pero] ahí al tiempo de producir se le paró el agua y uno no tiene cómo salvar esa cosecha: le toca perder porque no tenemos un sistema de regadío por aquí ni hay el agua disponible como en muchos pueblos que hay ciénegas, hay cachos, hay ríos... por aquí no pasa nada (C. Cervantes, comunicación personal, enero del 2017). 
En cuanto a los predios inundados tras la ruptura de la zanja, Elías Díaz calcula que perdió unas 200 matas de plátano, su principal cultivo, cada una con unos 10 "pichones" (gajos) de plátano en crecimiento, que se venderían en 6 mil pesos cada uno. O sea, unos 12 millones por todo el tiempo que tarda el plátano en dar cosecha.

En los cultivos subsidiarios calcula que le queda poco menos de una hectárea de berenjena y que tendrá que venderla a $10 \mathrm{mil}$ el bulto. Con la yuca la situación es similar:

Es que nosotros estamos arrancando es para medio salvar lo poquito que hay. Es que la yuca tiene un tiempo límite: usted la deja que ella llegue a los ocho meses y es una yuca que usted va a arrancar completa, es una yuca que usted la puede mandar para donde sea, pero cuando ya falta tiempo por cuestión de emergencia ya usted lo que va a tener es pérdida, porque se va a escoger es la más grande, todo ese "raberío"... pa" comer o pa' los animales (E. Díaz, comunicación personal, enero del 2017).

Esta situación conduce a que la bolsa de yuca la estén vendiendo a precios mucho más bajos:

La yuca hoy en día estamos... por cuestión de emergencia, porque la estamos sacando antes [de] que ya el agua se la acabe de ahogar, porque ha habido cantidad de pérdida aquí, entonces yo por lo menos estoy sacando una yuca que la están escogiendo aquí, la más buena. Una bolsa de las grandes, 20 mil pesos aquí, la están pagando en 14, 18, 15. Esta bolsa, llenita, vale 20 mil pesos aquí, compare. A mí me la están pagando a 20, el amigo que se las va a pagar ahí se la están pagando a 14 mil pesos, y esto pesa más de 100 libras... ¿ ¿y por qué esta uno vendiendo así? Por... antes de que se pierda, eso es lo que le queda a uno; antes de que se pierda, que se lleven eso (E. Díaz, comunicación personal, enero del 2017).

Las situaciones anteriormente descritas se relacionan directamente, desde la década del noventa, con la profundización del modelo neoliberal de desarrollo. Con la implementación de las políticas de "apertura económica" de César Gaviria varias de las plantas de procesamiento agrícola que funcionaban en Barranquilla y que compraban la producción a 
Vida campesina en el Magdalena Grande

los campesinos de todas estas zonas tuvieron que cerrar, pues el modelo implementado puso a competir a la industria local — sin garantías para esta-contra el mercado internacional. Así, ingresaron al país productos de la agroindustria producidos a precios más bajos de los que se producían aquí:

Sucedió en el lapso de dos años. Al tercer año, las empresas importaron la fruta de Chile, tomate refrigerado puesto en la zona franca de Barranquilla más barato que el que se producía en Ponedera, que estaba a $70 \mathrm{~km}$ de Barranquilla. Entonces, la zona franca nos afectó a nosotros. Eso fue a finales del 99, comenzando el año 2000, ellos importaban directamente la fruta y la siguen importando. California te está recibiendo aquí tomate de Chile; ahora Frucosta la está recibiendo por el puerto de Buenaventura porque la fábrica de Frucosta está en Cali: eso nos acabó a nosotros... o sea, que el tomate puesto en la zona franca, traído de Chile (porque es más barato el de Chile, porque el de Chile es subsidiado por el Estado chileno y, como aquí no pagan aranceles, lógicamente toda la producción se la traen para acá, afectándonos a nosotros, empezando por Ponedera, que es el municipio más cerca que tiene Barranquilla que producía tomate porque lo que es Ponedera, Santo Tomás, Sabana Grande, a ellos también los afectó (A. Montero, comunicación personal, enero del 2017).

Imagen 126. Cultivos ahogados en Sitio Nuevo y Piñón

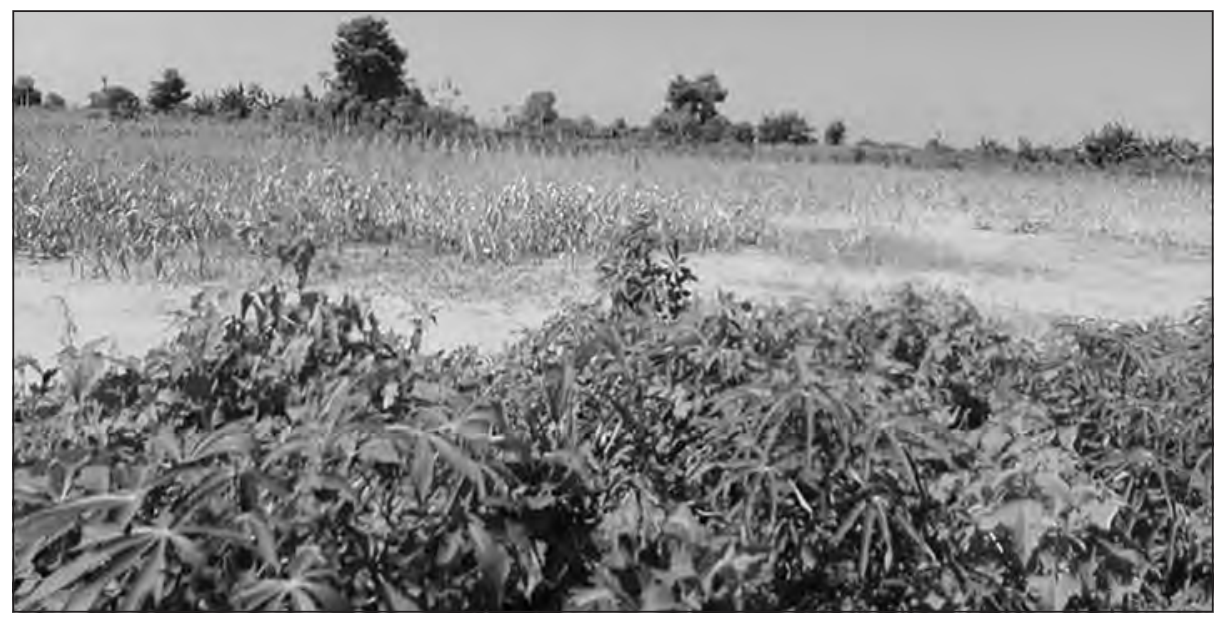




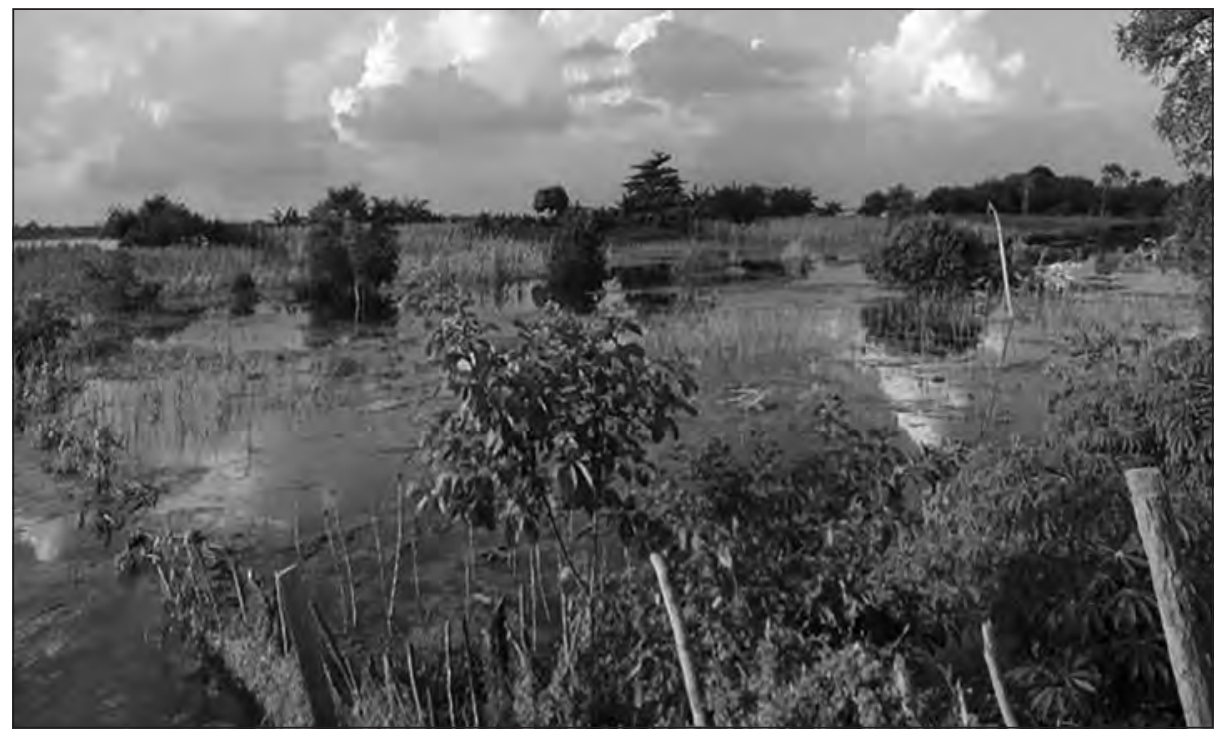

Fuente: Archivo Oraloteca (2017).

Con respecto al naciente modelo neoliberal en Colombia y a las políticas que se implementaron, en los que el pequeño productor o los que no tenían tierra fueron los más afectados, el señor Montero comenta su percepción sobre las afectaciones negativas que tuvo dicho modelo sobre el agro en el Bajo Magdalena:

La otra parte que sí nos afecto fue la apertura económica de Gaviria porque nosotros teníamos la alta producción de yuca. Tanto es así que las plantas más grande[s] de secamiento de yuca estaban aquí en esta zona en Media Luna. Usted sabe que la planta de Media Luna fue financiada por el Pastoral Social a través de los proyectos que presentamos con el Ministerio; era la planta más grande, que tiene una capacidad de 2 mil metros de largo de secado de yuca, y estaba la de Pivijay, que era más pequeña, y teníamos la de aquí... o sea que cuando se dio la apertura económica, al permitir las importaciones de sorgo, que era el sustituto de la yuca seca, se nos metió el sorgo del Ecuador. Entonces, ¿cuál era la diferencia del sorgo con la yuca? Que la yuca le da mayor calidad al producto de concentrado de alimentos, pero el comercializador o el transformador del producto no le interesa mucho la calidad, sino la cantidad. 
Vida campesina en el Magdalena Grande

Entonces, nos importaron el sorgo, que era el sustituto de la yuca, y eso acabó prácticamente con las plantas. ¿Qué sucedía últimamente? Las cooperativas le[s] decían a los campesinos: "Bueno, el que quiera sembrar yuca ahí tiene la planta de procesamiento" ... y aparte de esa vaina el mayor comprador que nosotros teníamos era Soya, de Bucaramanga. Y resulta que a nosotros nos llevaba aquí el transporte porque transportar 10 toneladas de yuca seca significaba contratar una mula con capacidad de 15 a 18 toneladas (porque la yuca seca hace volumen) y una vez se nos voltió, llegando casi a Bucaramanga se nos volteó una mula, y no nos habíamos asegurado y perdimos esa cosecha; entonces, ahí sí nos afectó la apertura económica de Gaviria (A. Montero, comunicación personal, enero del 2017).

El señor Montero puso de manifiesto otra situación y es que la inversión en el agro, de acuerdo con el modelo de desarrollo rural que se implementa en el país, está orientada a la "bancarización" del agro. En esta lógica, claramente a un campesino que no tiene buenas tierras, buen flujo de capital, difícilmente le prestarán para el mejoramiento de sus cultivos. La situación que tienen que enfrentar es de continua inestabilidad.

En el caso de la comercialización y rentabilidad de la producción, se corrobora que la situación de desventaja - por los elementos anteriormente descritos, sumados a la intermediación en la comercialización de su producción - hace que el campesino se mantenga en una situación de pobreza por generaciones. En una evaluación sobre las ganancias obtenidas después de una temporada de producción se establece que todo el esfuerzo empleado para sacar adelante el cultivo no se compensa, pues el pago es mucho menor y son los intermediarios, que nadie regula, los que determinan los precios de las mercancías, no los productores. En la conversación con el señor Alejandro Montero, nos comentaba:

Se lo digo con toda realidad, el campesino de aquí no cuenta. Yo de aquí les he mostrado y nosotros hemos vuelto a lo que se hacía a los años cuarenta o cincuenta. [Esto ha sucedido], primero, porque la cantidad de tierra que tiene la gente no es grande: el que más tiene puede tener una hectárea y, sobre todo, el cuello de botella es la comercialización, y aquí al campesino le llega la parcela como se deba, de Campo de la Cruz, de 
Vida campesina en el Magdalena Grande

Santa Lucía y de Bohórquez le van a comprar el cultivo a como sea y los poquitos que hay aquí lo venden a los comerciantes de aquí.... el gran problema que tenemos aquí es que quien pone el precio son los intermediarios y, aparte de esa vaina, hay unos que les avanzan o prestan plata para que le paguen la cosecha. ¿Cómo hace el campesino? Eso hemos tratado con las organizaciones, eso es lo que más me preocupa, y hemos hablado con los alcaldes de buscar una forma. Ahora estamos con una propuesta de alianzas productivas. El año pasado hicimos con una cooperativa de Córdoba [que] tampoco dio resultado precisamente por no saber del programa de Colombia Siembra... yo, que tengo rato ya que lo hablo con Pedro y ya me cansé de esa vaina. Uno no ve resultados, la misma gente no deja y es paternalista, que todo lo quiere resuelto, es la gran realidad (A. Montero, comunicación personal, enero del 2017)

En el mismo sentido, los entrevistados en Santa Rita, manifestaron que "todavía no hay apoyo del Estado en esta zona [...]. Los caminos no ayudan mucho para la agricultura ahora, [a diferencia de la cabecera municipal], porque está seco [...]. El problema más importante es mejorar la vía. [Así mismo, el problema de la montaña de lodo en el caño Renegado se resolvería con una intervención estatal:] Falta una canalización más profunda que conecte la limpieza que ya hay con la compuerta del caño" (J. Herrera, comunicación personal, enero del 2017).

Por tanto, se evidenció como característica universal la pauperización de sus modos de vida y un permanente "rebusque"15, debido a que la actividad agrícola o pesquera no es, por sí sola, suficiente para garantizar unas condiciones de vida dignas.

La fuente de generación de empleo depende, generalmente, de los terratenientes: son ellos quienes poseen las tierras y quienes pueden invertir en producciones a grandes escalas, como la palma de aceite. Para el señor Montero, la inestabilidad laboral y la falta de inversión en el agro representan el ocaso de la cultura campesina, pues los más viejos están

15. El "rebusque" es la palabra como comúnmente se conoce al ejercicio de cualquier oficio que le genere alguna ganancia para garantizar los medios de vida propios y de la familia en caso de que exista. Es la respuesta a la inestabilidad en el trabajo, que se agudiza con el modelo neoliberal impuesto en los noventa. En el "rebusque" no hay salario fijo, no se obtienen prestaciones, y la seguridad social es inestable o se cubre por el régimen subsidiado por el Estado. 
Vida campesina en el Magdalena Grande

cansados y los jóvenes no ven posibilidades de mejorar sus condiciones de vida si se quedan en el campo; por ese motivo, emigran a las ciudades. $\mathrm{Al}$ respecto, comenta:

En estos momentos ha sido negativo porque resulta que la generación de mano de obra es poca y es mal paga. Prefieren mejor que se pierda la misma cosecha porque no quieren pagar los transportadores y, aparte, se les paga una miseria. Aquí la mano de obra es bastante; entonces, cambian. Cuando demoran entonces les pagan retrasado, buscan otro grupo y ya los cambia. El de aquí al lado es administrador de una finca de palma; al menos este es más consciente, pero de Caballero no, todas las semanas está cambiando de personal. En Aracataca les cobraban por producción y no aguantaron sino un mes. Tuvieron que irse $y$, aparte, esa vaina, la ganadería, que era la que generaba mano de obra, la han sustituido por la palma. La palma es con maquinaria: ellos tienen los tractores y hacen la limpieza con tractor. Solamente usted sabe que la palma [es] un poco incómoda cuando está pequeña, pero ya grande usted puede pasar cerquita, lo único que gastan en la mano de obra es en el plateo y en la fertilización.... pero no es así "rentable" que digamos (A. Montero, comunicación personal, enero del 2017).

La progresiva pauperización de los modos de vida de agricultores y pescadores se evidencia en todas las entrevistas, tanto en las alusiones o explicaciones de condiciones anteriores más favorables, como en las respuestas relacionadas con la situación actual y sus dificultades.

Los pescadores entrevistados afirmaron que hay agricultores y pescadores que se ven obligados a trabajar en las fincas ganaderas [a] 70 mil la semana sin comida incluida. Otro rebusque es ir a hacer ladrillos en el Cesar. En Guáimaro, las condiciones de trabajo en las fincas de los "copetudos" (grandes propietarios) han llevado a que la mayoría ya no quiera trabajar en ellas, como lo afirma Beris Alminta (enero del 2017), precisando que "los que viven en las fincas [jornaleros] no hacen otras cosas. Ganan 20 mil por día. La prueba son 2 meses" (comunicación personal). Víctor de la Hoz afirma que en Playón de Orozco quienes optan por el rebusque de jornalero, desmontando las fincas, no ganan más de 20 mil diarios. 
Vida campesina en el Magdalena Grande

Imagen 127. Campesinos en el "rebusque"
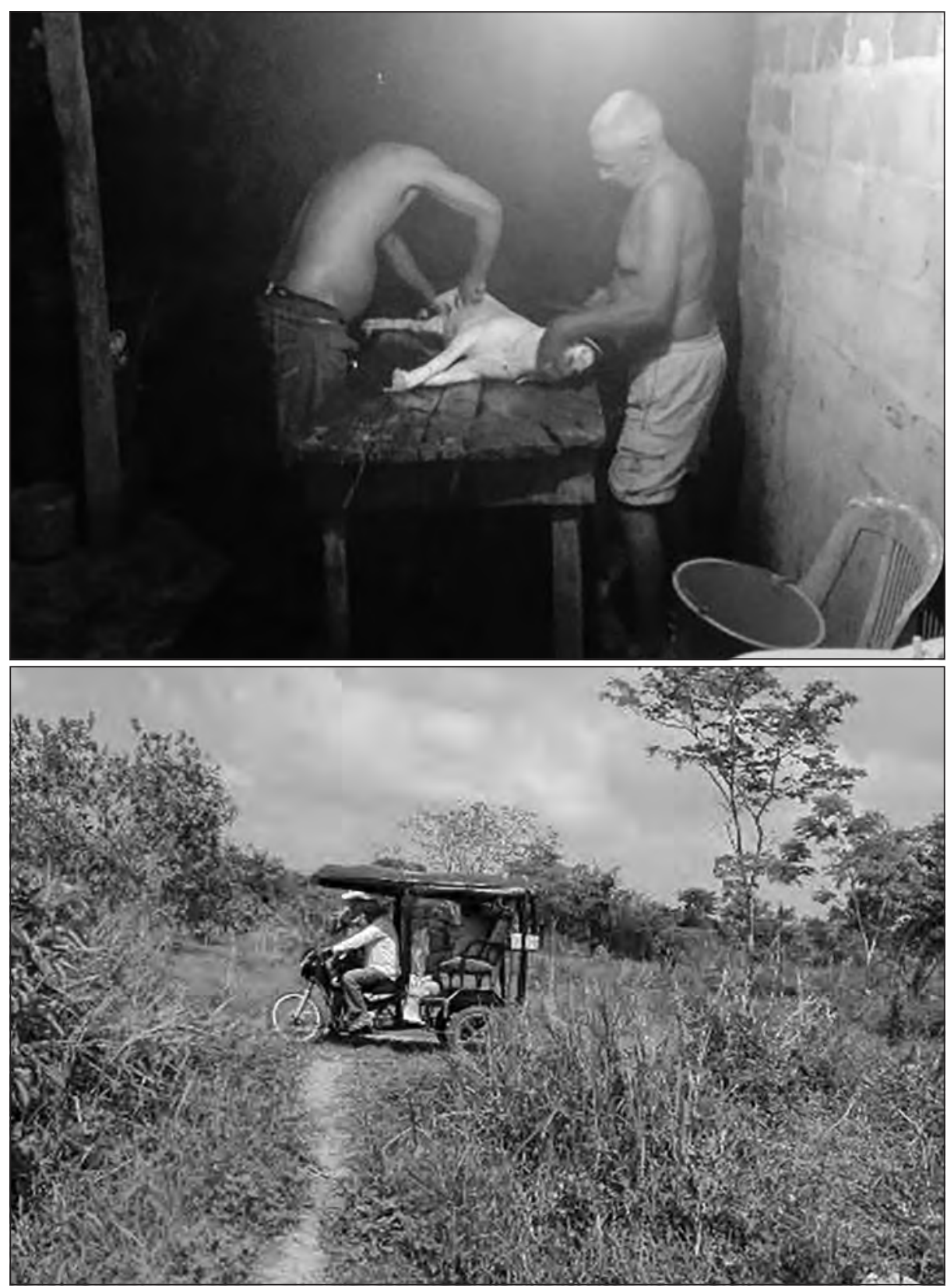

Fuente: Archivo Oraloteca (2017). 
Vida campesina en el Magdalena Grande

Para este corregimiento del Piñón también describió otras formas de trabajo en las fincas: el "piguero", quien ordeña las vacas y realiza otras tareas desde las 4:00 a.m. y cuyo ingreso no es mayor a un salario mínimo y el "estrero", ayudante del "piguero", quien gana entre 5 y 8 mil pesos diarios, trabajando hasta las 8:00 a.m.

Otro rebusque en Playón de Orozco es la elaboración de las esterillas que se utilizan debajo de las sillas para montar; o sea, entre esta y el pelaje de la bestia montada. Se elabora con un bejuco llamado "junco". Tras 5 días cortando en las orillas de caños y lagunas, este es puesto al sol para luego amarrarlo, formando las esterillas. Luego, las venden a 2 mil pesos a intermediarios que las revenden entre 3 y 4 mil pesos.

Esta suma de factores ha hecho que se reduzcan al mínimo las opciones laborales para los campesinos, convirtiéndola en una de las subregiones históricamente más pobres del departamento, en clara contraposición a la Zona Bananera, ubicada justo en el extremo opuesto de la Ciénaga Grande.

\section{La pesca artesanal}

La pesca artesanal hace referencia a la actividad pesquera que utiliza técnicas tradicionales con poco desarrollo tecnológico. El pescador determina su día de acuerdo a las faenas de pesca. Los pescadores forman grupos de entre cuatro y seis para realizar "faenas" de pesca, que corresponden al trabajo realizado desde que salen de sus casas en la mañana hacia los cuerpos de agua hasta su regreso a la mañana del día siguiente. Los peces obtenidos son contados para venderlos al distribuidor y repartir las ganancias. 
Vida campesina en el Magdalena Grande

Imagen 128. Contando el pescado

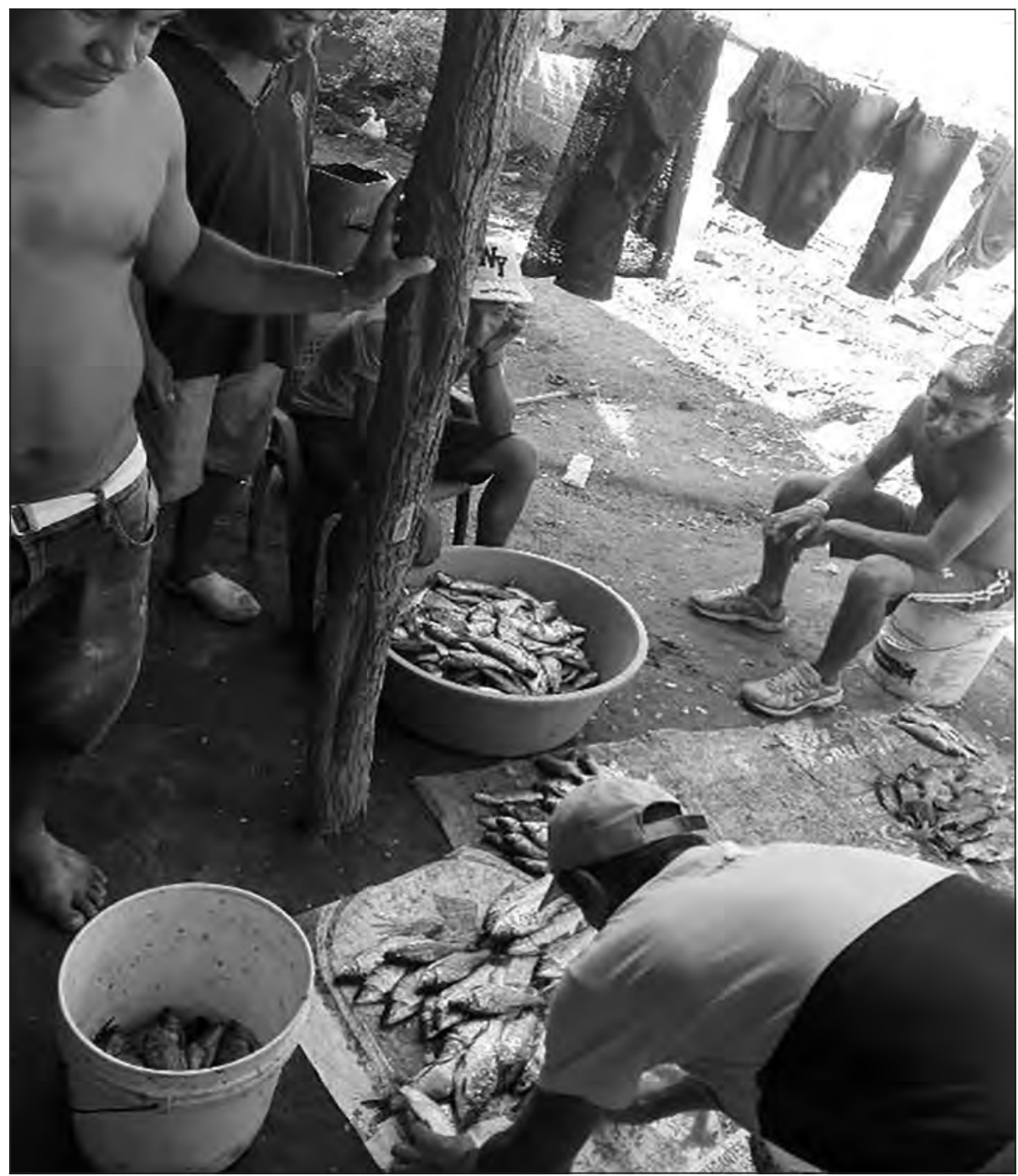

Fuente: Archivo Oraloteca (2017).

Para establecer cómo es una faena de pesca le preguntamos a los pescadores entrevistados, quienes nos la describieron. En el caso del grupo entrevistado, los pescadores habían salido el día anterior desde las ocho de la mañana a la ciénaga donde pescaron. Se llevaron el arroz y, a medio 
Vida campesina en el Magdalena Grande

día, brincaron a tierra para cocinar. Tiraron la manta desde las tres de la tarde y comenzaron a revisar desde las diez de la noche hasta la una de la mañana: "Brincamos otra vez, y en la mañana principiamos otra vez a revisar, a requisar, y ya cuando viene amaneciendo vamos sacando la manta" (A. Mendoza, comunicación personal, enero del 2017). Eso implica que están todo un día en el ejercicio de la pesca. No duermen durante la noche porque son esas las horas en las que atrapan a los peces en los trasmallos o mantas: estos últimos pueden ser dañados por una babilla o un búfalo - además del riesgo de ser robados-, ante lo cual deben estar atentos. Descansan día de por medio, por lo cual hacen en promedio quince faenas al mes.

La regularidad y la manera en cómo se dan estas faenas no siempre son iguales; estas dependen de la afluencia de pescado, lo que hace que la jornada se extienda a más días, llevando a pérdidas al grupo de pescadores. Este grupo, por ejemplo (y por razones que veremos más adelante), solo desde hace tres meses hace estas faenas de un día; antes, tenía que ir a otra zona, con mayores dificultades:

Así como se iban duraban 6 días, 5 días, no alcanzaba ni pa' pagar lo que es el transporte. Se llevaban 100 mil pesos en avío, canoa, carro e mula, y el tiempo de ellos na'. En verdad que así como se iban venían y no se ganaba simplemente ni pa' pagar lo que ellos se consumían, lo que uno llevaba para el monte (A. Mendoza, comunicación personal, enero del 2017).

La pesca artesanal se ha visto significativamente reducida como opción productiva y han emergido grandes porciones de tierra desecada que son cercadas por los propietarios latifundistas.

Los pescadores que regresaban de su faena contabilizaron con el distribuidor 56 manos de bocachico, que equivalen a 100 mil pesos, o sea $25 \mathrm{mil}$ pesos por pescador/faena, $375 \mathrm{mil}$ pesos por pescador/mes (15 faenas). Esta es una faena mala, teniendo en cuenta que para ellos una buena generaría entre 35 y 40 mil por persona, pero el panorama es incluso peor teniendo en cuenta que ese resultado fue producto de una leve mejoría tras la ruptura de la zanja: "hace 3 años no se veía agua sino hasta Retén, no se ganaba casi, ahora es que está entrando agua de una zanja en 
Vida campesina en el Magdalena Grande

[el caño, a la altura de] la carretera, y porque creció el río Magdalena” (A. Mendoza, comunicación personal, enero del 2017).

En caso de concretarse el interés de los capataces de la finca de volver a cerrar la zanja, la afectación del pescado los obligaría a ir hasta Palermo por carretera y, después, en canoa, trayecto que de por sí solo requiere de 3 días, por una ganancia que equivaldría a 15 mil pesos, con el riesgo de que los atraquen ladrones que vienen de Barranquilla:

Ahora en la asociación [en] que están ellos, ellos están pescando en una tierra que es ajena, es como una finca, y ahí es donde están cogiendo el pescao, y por eso es [que] ellos ahora, que ahora el dueño de eso [...], los capataces, los trabajadores quieren cerrar lo que es la zanja, cierran la zanja y se jodió el pescao de por aquí, ya no pueden pescar porque no puede entrar agua y no hay de dónde cogerlos tampoco. Ya duran un rato y tienen que buscar otra forma de vivir más, de buscar pescaos más lejos... que si pueden pagar transporte allá a Palermo, de ahí coger una canoa y atravesar no sé cuántos kilómetros por agua, tirando palanca [estimaría luego que durante 12 horas], para poder llegar, pa' poder pescar. [¿Tirando para dónde?]. Para... buscando la ciénaga, el kilómetro 13, la Aguja, el Morro (A. Mendoza, comunicación personal, enero del 2017).

El riesgo de que los trasmallos y mantas queden destruidos ha aumentado con la introducción de búfalos en las ciénagas por parte de las fincas cercanas. Esto implica pérdidas económicas: un trasmallo cuesta 60 mil pesos y una manta 120 mil pesos. Por su parte, el distribuidor José Martínez manifestó que el pescado se vende a 6 mil y que siempre es incierto qué tanto se le va a ganar.

\section{Dimensión socioambiental}

Los campesinos de esta región han sido testigos de las grandes transformaciones que han sufrido las condiciones físicas y ambientales de esta zona. Las actividades de agricultura y pesca que desarrollaban estos pobladores desde generaciones atrás llevaron a adquirir unos aprendizajes sobre cómo mantener el equilibrio con la tierra y las aguas para garantizar su sustento y perdurabilidad en el territorio. 
Vida campesina en el Magdalena Grande

Sin embargo, este equilibrio se ha visto trastocado por tres situaciones que se conectan entre sí: las transformaciones en el modelo de explotación agrícola que ha tenido el país, el mal manejo institucional de todo el complejo de la CGSM y la contaminación del río Magdalena, la deforestación y consecuente erosión de sus márgenes.

El modelo de explotación agrícola se ha concentrado en la implementación de programas de explotación extensiva de ganado - especialmente de búfalo- y la agroindustria con el monocultivo de Palma y otros. Estas actividades han sido adelantadas por los terratenientes, quienes han aprovechado sus condiciones económicas y de poder para apropiarse de las tierras y el agua.

La desviación indebida de los caños es una constante que se evidenció durante todo el recorrido. Los campesinos ubicados más cerca de la CGSM plantearon la dificultad que tienen para cultivar, pues la tierra se ha vuelto muy salitrosa debido las intervenciones que se han hecho sobre los caños. Al respecto, Luís Altamar (enero del 2017) afirma: "con el agua salada no se puede producir [...]. El agua salada viene de la Ciénaga del Pajaral y sus otros puntos de ciénagas pequeñas" (comunicación personal). Esta situación tiene que ver con el caño Aguas Negras, uno de los que conecta al río Magdalena con la Ciénaga: actualmente, Pajarales está dulce por Aguas Negras, pero desde marzo se va a secar y se mete el agua salada. Aunque el verano implica por sí solo la reducción del nivel de agua de este caño, en el fenómeno es determinante la intervención humana; por eso, L. Altamar resalta como causa "el mal manejo que se le da a los canales de riego, como la compuerta del Aguas Negras" (comunicación personal, enero del 2017).

El agua salada de la Ciénaga, que a su vez proviene del mar, también afecta los predios de Manuel Altamar (enero del 2017):

Si al mar se le da por crecer si tan siquiera tres metros allá, justo lo baña a uno, toda esa agua llega aquí. Ahora poquitico se puso el agua salada del mar [...], se nos vino por arriba de la Ciénaga Grande, más del nivel del río [...]. El río estaba crecido y eso compensó, pero en todo caso quedó el agua "salobrona", y a algunos animales les cuesta adaptarse a ella (comunicación personal). 
Respecto al caño Aguas Negras, los pescadores entrevistados dijeron haberle abierto un agujero a la talanquera, el cual fue creciendo hasta permitirles un mayor flujo de agua y el consecuente aumento en la cantidad de peces; esto mejoró levemente su situación: "Ahora se están viendo unos pescaitos porque nosotros propusimos de romper los caños esos, rompimos una zanja y por eso fue que se metió el poquito pescao que hay" (A. Mendoza, comunicación personal, enero del 2017).

Ellos identifican estos taponamientos con intereses particulares, direccionados al acaparamiento del agua que fluye por los caños:

Los dueños de las ciénagas tapan las alcantarillas [los caños] por donde entran las aguas pa' que lleguen a todas estas ciénagas, pero están tapadas, tienen unas trincheras de tierra que eso tiene más como de tres metros, que en una creciente así como viene ahora en estos tiempos pa' allá donde pescaban ellos no entra, pero por la parte de atrás - como por allá más allá de Santa Rita, Remolino-, pero por aquí por el frente del río Magdalena sí no puede entrar porque lo tienen tapado (A. Mendoza, comunicación personal, enero del 2017).

Infieren que los capataces de la finca cercanas quieren cerrar la zanja. Sin embargo, su apertura también produjo que se inundaran algunos predios de pequeños campesinos ubicados a las orillas de un retorno que tenía el caño, generando tensiones entre ambos sectores.

En Santa Rita los entrevistados señalaron que "el caño Renegado viene del río Magdalena. Cuando abren la compuerta esto se inunda, como [ocurre con] Corral Viejo, porque la montaña de lodo hace que [el agua] se dispersa por las tierras planas" (J. Herrera et al., comunicación personal, enero del 2017).

En el casco urbano del Piñón, "debido a la alta creciente del río, casi el $70 \%$ de las tierras están bajo las aguas y, con ello, lógicamente que los cultivos están totalmente destruidos" (A. Mendoza, comunicación personal, enero del 2017). Por este motivo los campesinos están pasando una situación bastante crítica, intentando generar ingresos con otro tipo de actividades como la cacería o la pesca. Sin embargo, no se trata solamente del río, sino también del caño que cruza por el oriente: 
Resulta que este pueblo es una batea, agua aquí [del lado del río Magdalena] y agua acá atrás [del lado del caño], ¿por qué? Porque tú vez [que] el caño del cerro no tiene control, no tiene compuertas, eso en la medida de que el río sube el agua entra y, ¿a dónde descarga? A la Ciénaga Grande (A. Mendoza, comunicación personal, enero del 2017).

Imagen 129. Plantación de palma de aceite en el Piñón
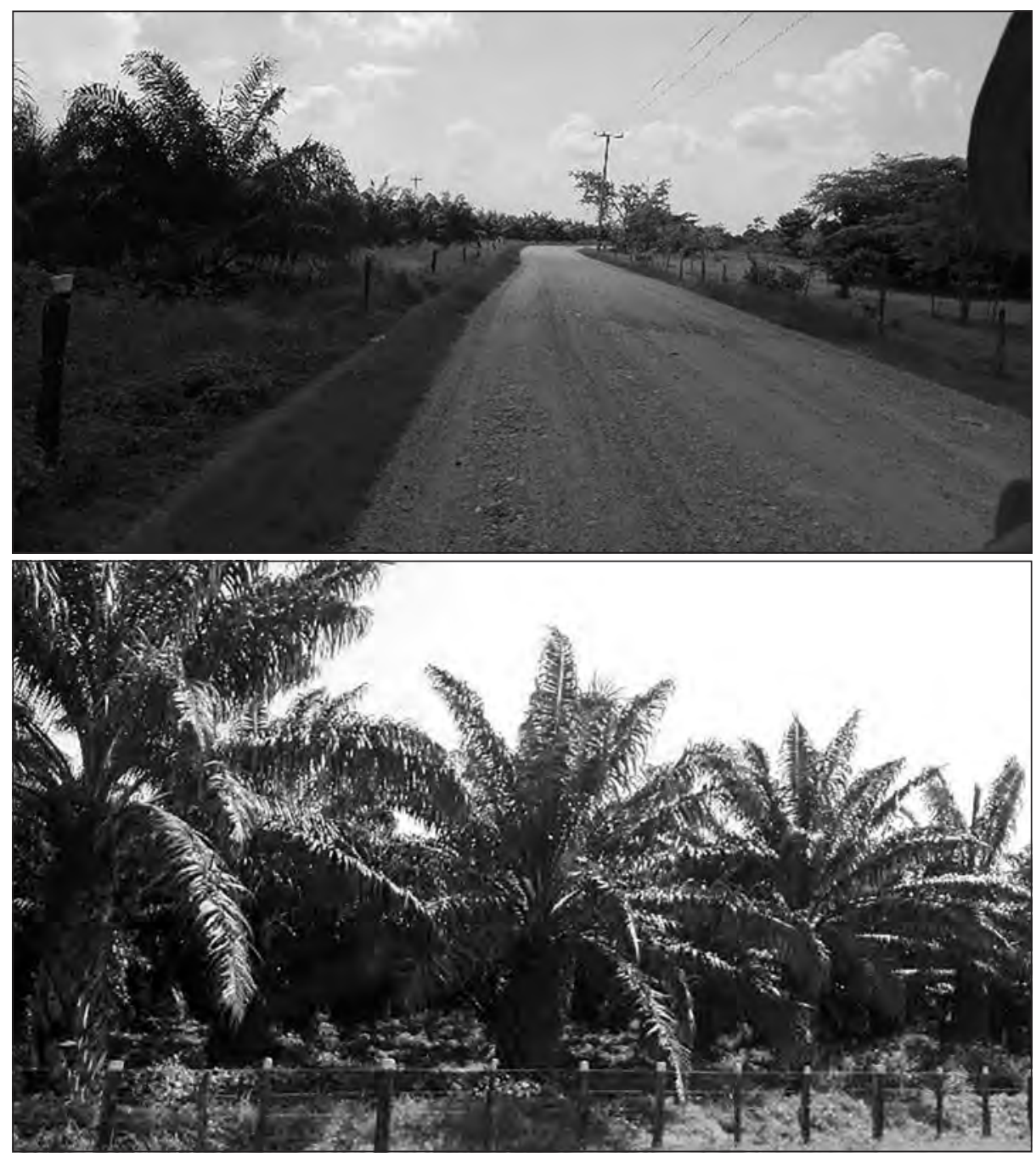

Fuente: Archivo Oraloteca (2017). 
Vida campesina en el Magdalena Grande

Todas las comunidades que habitan esta zona se surten del agua del río Magdalena para su consumo diario. Aunque el río Magdalena es uno de los más contaminados del país, las administraciones municipales cuentan con plantas de tratamiento para la potabilización del agua. Sin embargo, esto no es suficiente, sumándole la deforestación del borde del río que erosiona y hace que se generen emergencias ambientales como inundaciones.

El problema de la contaminación y erosión del río, así como la deforestación de sus márgenes en Guaimaro, fue señalado por la señora Beris:

Sí, existe bastante deforestación y contaminación. El agua del río Magdalena supuestamente viene tratada, pero tiene asiento en los baldes. La Alcaldía no pone atención [...]. En ambas partes están cortando mucha madera... hacia Pivijay, Salamina y Sitio Nuevo. [Por la erosión] el río se quiere llevar el jarillón, hay un comelín frente a la iglesia.

El señor Armando Cruz complementó diciendo que "el problema del medio ambiente es la basura que queman, aunque ahora se la llevan para Salamina [se refiere a la cabecera municipal] y la entierran" (A. De la Cruz et al., comunicación personal, enero del 2017).

Otro elemento a resaltar son los tiempos del clima y el agua. Elías Díaz identifica dos momentos en los que se crece el río Magdalena:

[¿Para qué época del año esperan ustedes que vuelva y se tape acá?]. Mire, aquí si la creciente es tempranera nos podemos hundir como en el mes de julio por ahí, junio, julio, que si ya se pasa, se pasó esa, el río baja, en esa época también baja el río, ¿ya? Porque en esa época sí está el río bien crecido, entonces él hace un baje y comienza a crecer de septiembre pa' delante. De pronto nos hundimos en octubre o noviembre, o posiblemente hasta en el mes de diciembre nos hemos hundido, ¿ya? Pero cuando el río tiene una marea demasiado baja hay veces que nos mantenemos aquí, pero cuando esto se hunde, compae', mejor dicho pasamos necesidad, más de la que estamos pasando (E. Díaz, comunicación personal, enero del 2017). 
Vida campesina en el Magdalena Grande

Elías Díaz tiene sus predios junto al retorno del caño Aguas Negras. En las tierras de Playón, junto al río Magdalena, como vimos, los cultivos pueden hundirse desde comienzos del mes de mayo, justo cuando comienza el "invierno" (temporada de lluvias) y, aunque el "verano" comienza desde finales de noviembre o principios de diciembre, los cultivos empiezan a destaparse desde finales de enero. Esto limita el tipo de cultivos que se pueden sembrar en el Piñón o amenaza constantemente con perderlos en el retorno del caño.

Para quienes no están tan cerca a los cuerpos de agua o para quienes estando cerca tienen poco o ningún acceso a ella (como en Guaimaro), el principal problema no es de inundación, sino de sequía; esto, debido a que dependen de las lluvias de la subregión - que han perdido la regularidad de antaño-, mientras que las crecientes del río Magdalena dependen de las lluvias en el centro del país. En todo caso, sus mejores meses de cultivo son los contrarios a quienes se inundan. Ya vimos que Carlos Cervantes afirma que en Carreto están esperanzados en la llegada lluvia, que cuando se va los hace perder los cultivos, pero además en Santa Rita los pobladores afirman:

Nos mantenemos de acuerdo a la ola de invierno, a la temporada invernal - es como si fuera la aventura-. Si la temporada invernal es mala, perdemos todo, no tenemos manera de salvar ninguna clase de cultivo de lo que estamos haciendo, el producto todo se pierde. Los fenómenos [climáticos] estos están variando y nosotros no tenemos ninguna clase de tecnología para contrarrestar esos cambios que se producen. Por ejemplo, cuando se meten los veranos no hay manera de que nosotros podamos ayudarnos con un motor para echarle agua a lo que uno siembra, y se nos pierde todo... antes las lluvias estaban más constantes y las tierras estaban mejor (J. Herrera et al., comunicación personal, enero del 2017).

También hemos visto que pescadores como los de Sitio Nuevo necesitan que el caudal aumente, incluso ayudan a que así ocurra. De no haber roto la zanja la Unión durante este verano, habrían tenido que moverse al sector de los palafitos, con los costos y riesgos ya mencionados, como habían estado haciendo hasta el tercer mes anterior a la entrevista. Quienes también necesitan un buen caudal en los caños que 
Vida campesina en el Magdalena Grande

conectan al río Magdalena con la Ciénaga son los campesinos que cultivan cerca de ella, como Manuel Altamar, ya que de otro modo se les mete el agua salada.

\section{Dimensión sociopolítica}

En la lógica institucional de la región del Bajo Magdalena se logró observar el clientelismo y la corrupción como el "deber ser" en la forma de ejercicio del poder local, mientras que en la lógica comunitaria se lograron encontrar sedimentos de los procesos organizativos históricos que resistieron a la violencia paramilitar. En esta dimensión observaremos la manera en cómo se perciben las instituciones del Estado y su accionar, el ejercicio de la democracia y lo público, y los procesos de ejercicio de poder autónomos de los campesinos.

\section{Cultura política instrumental}

En la memoria de los adultos se conserva vívidamente cómo, a causa de la violencia, los diferentes intentos de liderazgos comunitarios, proyectos colectivos y expresiones de organización social frente a las necesidades históricas más sentidas (agua y vivienda) fueron sistemáticamente aniquilados al pasar por las armas a líderes comunitarios que se enfrentaron a las élites regionales y a los proyectos que deterioraban cada vez más la Ciénaga y la vida de sus habitantes.

Actualmente, estos mismos adultos construyen su sobrevivencia entre temporada y temporada, preparándose cada año para las inundaciones y las sequías, resignados al monopolio del poder político por parte de los mismos apellidos, reticentes a una participación más activa en la resolución colectiva de las necesidades comunes, reproduciendo al interior de las familias una actitud de resignación, oportunismo, asistencialismo y despreocupación por el futuro, constreñidos a un ciclo de producción mínima-consumo precario, que reparte sus imprevistas ganancias entre el mínimo vital de las familias, y "la parranda" como un mecanismo fácil y barato de entretenimiento y de olvido.

Las prácticas políticas en esta zona están determinadas por la imposición de reglas por fuera de la ley en detrimento de los intereses de la mayoría de la población. Los funcionarios, como representantes del 
Vida campesina en el Magdalena Grande

Estado, ejecutan acciones en beneficio propio o de los privados, perjudicando al conjunto de los pobladores. Por ejemplo, la razón que da Elías Díaz para su poca disposición inicial a conceder la entrevista tiene que ver con que integrantes de una institución de apoyo agropecuario habían ido varias veces a su parcela a realizarle un "censo" que permitiría una mejor caracterización para intervenir en pro de los campesinos; sin embargo, la ayuda nunca llegó y a él más bien le resultó sospechoso el procedimiento:

A ellos les da pena porque un día los cogí aquí y los insulté, porque, ¿sabe qué hacían? Le tomaban a uno los datos y uno: "vea, aquí yo tengo berenjena, tengo maíz, tengo el poquito de vaina". Entonces abajo traían un formato: "fírmeme aquí". Caímos como dos veces. Yo dije "estos maricas me los cojo yo”. Resulta que a las tres veces llegué aquí y ya yo: “¡Partida de sinvergüenzas, bandidos, ¿ustedes creen que nosotros vamos a volver a caer?! Ustedes nos ponen a firmar aquí es pa' llenar el formulario allá o pa' hacer papel donde nosotros ya recibimos maíz, recibimos urea, recibimos... y viene una investigación y aparecemos firmando que ya recibimos porque ninguna persona que le vayan a hacer un censo tiene derecho a firmar”, ¿sí o no? (E. Díaz, comunicación personal, enero del 2017).

En ese aspecto, B. Alminta (enero del 2017) señalaba que hay mucha corrupción por la política sucia que se maneja, por la mala costumbre que nos dejó la violencia de que nos muevan un [bulto de] maíz y ahí estamos [...]. Pocos campesinos se preocupan por estar en los escenarios [de participación], varios están es por lo que pueden sacar a cambio (comunicación personal).

Se hace un señalamiento similar por parte de José María (enero del 2017), quien afirmó que "en las capacitaciones se legalizan más recursos de los que se invierten” (comunicación personal). 
Imagen 130. Salón comunal en Playón de Orozco, Magdalena

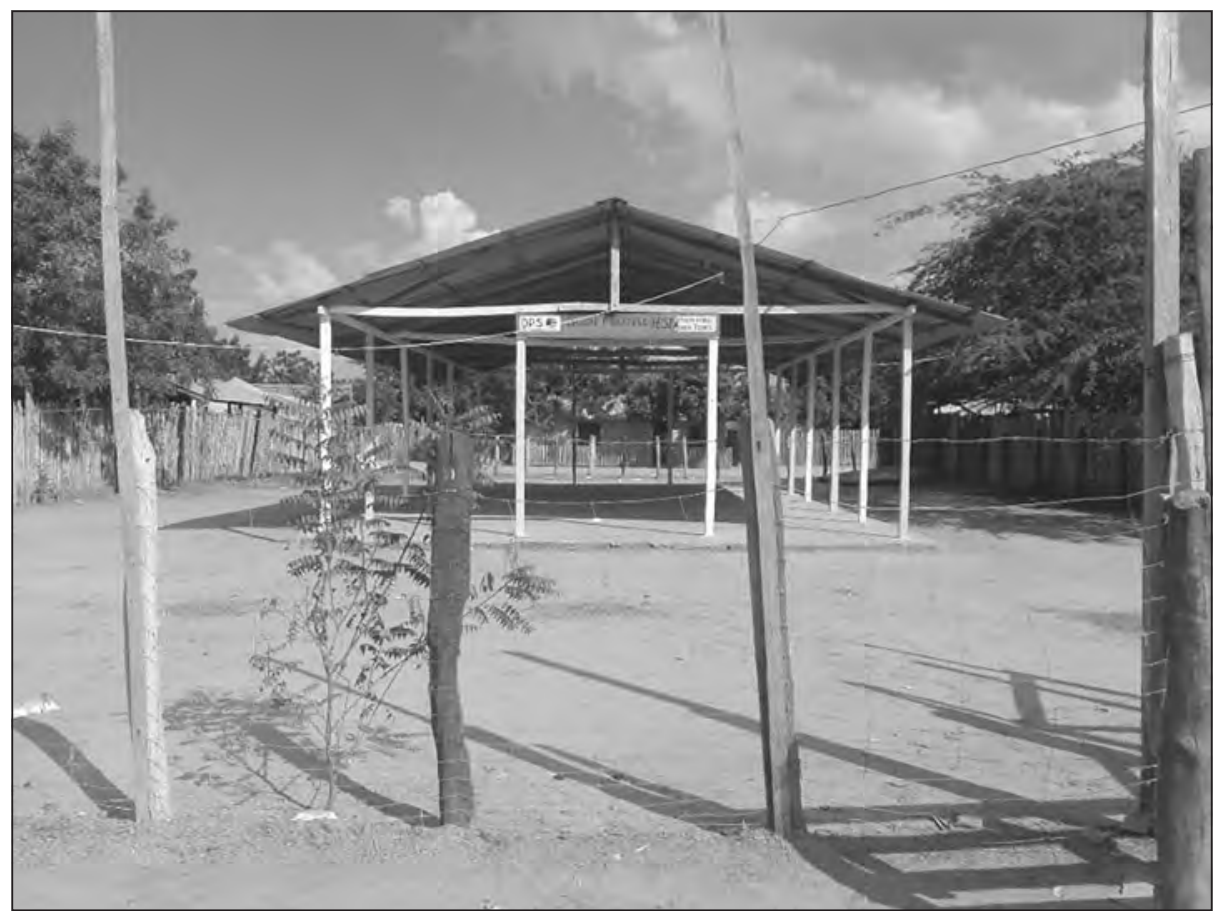

Fuente: Archivo Oraloteca (2017).

En Carreto, la falta de ayuda técnica aparece igualmente asociada a la corrupción:

No sé por qué, si es que hay una apatía acá contra el pueblo o qué pasa, porque es que ahí en el Piñón [cabecera municipal] existe una institución $\left(\right.$ UMATA $\left.^{16}\right)$ que debería ser la encargada de ayudar acá para uno meter proyectos allá y ayudar al campesino, y eso, y uno lo hace y nada, uno no recibe muchas veces respuesta $y$, si vienen proyectos que son convenientes para el campesinado, se viene a saber cuando ya eso ha pasado, que ya no hay opción a reclamar ni a nada (C. Cervantes, comunicación personal, enero del 2017).

16. La UMATA es la Unidad Municipal de Asistencia Técnica, que es una entidad que se crea en el año 1992 con el fin de brindar asistencia técnica a los campesinos en los municipios. 
El ejercicio de la democracia está restringido al sentido utilitarista que le dan los poderes económicos. En tales condiciones, la garantía de los derechos para estas poblaciones está mediada por los "favores políticos"; es decir, el acceso a derechos fundamentales como agua, vivienda, educación y trabajo está mediado por el hecho de garantizar el voto a determinado sector político en época de elecciones, sin que esto garantice el cumplimiento de las promesas hechas por parte del político.

Esto hace que el sentido de lo público se desdibuje y que la legitimidad de las instituciones del Estado sea nula, al punto de que los líderes no quieran hacer parte de la institucionalidad por miedo a perder la legitimidad que han ganado en el proceso organizativo. Esta es la posición del señor Montero, quien por su trabajo ha sido llamado varias veces a hacer parte de la administración municipal del Piñón, pero quien, a sabiendas de la manera en cómo se concibe la política y la gestión de las instituciones locales, prefiere mantenerse alejado de estos escenarios:

¿Por qué me había negado a ser concejal? Por dos razones: primero, cuando uno es concejal y no se alía con la mayoría todos los proyectos no pasan para que te aprueben, un proyecto tiene que estar con la mayoría y ser cómplice de la sinvergüenzura, y, segundo, pierde uno la personalidad con la gente: cuando tú haces unos compromisos con la comunidad y no le cumples, tú pierdes el respeto, ya la gente te señala. Tú sabes que el político es sinónimo de sinvergüenzura, de falsedad, entonces pierdes el respeto, ya todos te van señalando y la gente tiene una mentalidad del que la hace se la imagina, el que es sinvergüenza piensa que uno es sinvergüenza también, entonces no piensa que uno lo hace por amor a la comunidad y sino porque tiene algún interés. Entonces no: yo tengo que estar de gratis ahí, yo les he demostrado a ellos que he sacado plata de mi bolsillo para hacerles todas las vueltas porque he dado alimentos, plata para proyectos, todo, y hasta a mi familia, abandoné a mi esposa, a mis hijos (A. Montero, comunicación personal, enero del 2017).

\section{Organización comunitaria}

Por otra parte, los procesos de organización campesina en esta zona datan de la década del ochenta y están asociados a la Asociación Nacional de usuarios Campesinos (ANUC). 
Vida campesina en el Magdalena Grande

El proceso en la región Caribe funcionaba de manera federada y consistía en la conformación de cooperativas autónomas que se articulaban a nivel regional para garantizar procesos de comercialización justos, sin intermediarios. El señor Alejandro Montero es un testimonio vivo de este proceso:

Las organizaciones de la costa, o sea, nosotros teníamos una federación, teníamos FAGROCOL, teníamos 22 cooperativas de la costa, tanto de Bolívar, de Córdoba, de Sucre: Federación de Productores Agropecuarios de la Colombia. Fuimos los que le dimos inicio a gran abasto en Barranquilla. Teníamos también la planta procesadora de tomate aquí en Ponedera. Mi hermano... a nosotros nos dieron la infraestructura y la maquinaria. La otra está en Pivijay, la planta procesadora de ajonjolí que está en Pivijay, eso era otro de los cultivos sustitutos de la yuca, el ajonjolí... hace poquito creo que la reactivaron en Pivijay. Ahí está y la otra es la planta procesadora de pulpa de fruta, eso era en la zona de San Sebastián, pero resulta que teníamos el problema de que San Sebastián es Magdalena y la atravesada del río nos jodía, entonces se hizo fue en Margarita, Bolívar, que está al frente. Esa planta se hizo en Margarita, Bolívar, porque en Magdalena nos jodía atravesar la producción, entonces se llegó al acuerdo de que se hiciera en Margarita, además [de] que allá hay una variedad de naranjas muy dulces porque desde que tú coges la zona del Banco hacia arriba ya te cambia totalmente la cultura de cultivos: allá te siembran ñame, te siembran ajonjolí y tabaco, naranja (A. Montero, comunicación personal, enero del 2017).

Con la articulación de los campesinos de esta zona al proceso de la ANUC, los líderes no solo lograron una cualificación política, sino que también las luchas que venían dando, especialmente de acceso a la tierra, se vieron respaldadas y materializadas con este proceso. El señor Alejandro Montero nos cuenta sobre la vinculación a este proceso y la manera como se obtuvieron las tierras en los playones del Piñón:

Yo formaba parte de la ANUC departamental, yo formaba parte del consejo consultivo del INCORA, fue cuando me doy cuenta que aquí en el 
Vida campesina en el Magdalena Grande

Piñón había 5 playones que no veíamos. Yo investigué, saqué la documentación... el plano de los playones lo solicité yo con los vecinos y alcancé a quitarle 120 hectáreas peleando con ellos. Yo tenía una organización fuerte, esos playones estaban baldíos, nosotros los ocupamos, 120 hectáreas (A. Montero, comunicación personal, enero del 2017).

El señor Montero resalta que la incidencia del proceso de la ANUC en la vida de los campesinos de esta zona logró dignificar la vida de los campesinos. Para él la gestión de recursos y proyectos para los campesinos fue un elemento importante para el fortalecimiento organizativo porque demostró que era posible que los campesinos, a través de la cualificación política y la inversión de capital en proyectos productivos, tomaran las riendas del proceso organizativo e incidieran en la política local. Al respecto, comenta:

Aquí se miraba al campesino por debajo del hombro porque era el campesino aquel con sombrero roto y lo miraban como persona que no valía. Yo comencé una lucha con ellos. Lo primero que hice fue reactivar la Asociación de Usuarios Campesinos que estaba caída, asumí esa responsabilidad. En el 85, a mediados, se presentó el programa de Padre Barón, de Pastoral Social, y comenzamos un trabajo. Aparte de eso logré comenzar a hacer mis trabajos en el departamento del Magdalena con las asociaciones y vino el PNA (Plan Nacional de Alimentos) de las Naciones Unidas, unos programas de alimentos por trabajo; ese programa lo manejaba el Estado colombiano, pero lo politizaron y las Naciones Unidas le quitaron el manejo y se lo dieron a las comunidades (A. Montero, comunicación personal, enero del 2017).

El proceso que se venía adelantando por parte de la ANUC se vio golpeado por el paramilitarismo, que empezó a tener presencia a mediados de los noventa.

Después de iniciada la apertura económica, "nos llegó la otra plaga, del 97 adelante, prácticamente del 95 comenzaron a llegar los primeros grupos paramilitares" (A. Montero, comunicación personal, enero del 2017). Esta otra plaga que llegó desde el 97 afectó la cotidianidad, la institucionalidad y las formas organizativas del campesinado: 
Vida campesina en el Magdalena Grande

[¿Cómo influyó el paramilitarismo en la vida campesina?]. Aquí influyó mucho, primero que todo porque ellos limitaron las salidas del campesino aquí: no te podía salir el campesino sino a las 6 de la mañana y ya a las 3 de la tarde todo el mundo estaba en la casa [...]. Y, aparte de eso, el temor, el temor y, [en] el caso mío (que yo tenía la organización), me dijeron que no podía seguir haciendo reuniones y, sobre todo, pues que... es que hasta el mismo pescador. O sea, aquí estuvieron carnetizando a la gente, aquí se reunía doña Sonia, que era la cacica aquí, y aquí reunía a todo el pueblo, todo mundo, nadie se quedaba en casa [...]. ¿Qué hacía? A decir de que el sinvergüenza que tal, tal, que las casas había que arreglarlas, que las cercas había que arreglarlas. Entonces ellos decían: "El que no tiene para pintura de la casa nosotros se la regalamos, eso sí, pero lo vamos a investigar. Si constatamos de que realmente es por sinvergüencería, ya saben lo que les pasa”. Esto aquí se convirtió en un matadero. Resulta que la... aquí donde está la planta de tratamiento de aquí del Piñón pa' los corregimientos, que llamamos "mataburro", ahí era donde mataban a toda la gente y la tiraban al río. Al principio, la tiraban a la carretera, [pero] nosotros nos quejamos con ellos, con el alcalde nos reunimos con ellos: "ombe' que no nos tiren los muertos en la carretera". Entonces, ¿qué hacían ellos últimamente? Que los tiraban a la orilla del río, los mataban, los degollaban, los abrían, para que no bollaran, para que no hubieran; o sea, ellos tenían hasta el egoísmo de que el cuerpo no apareciera para que las autoridades no te determinaran que fue muerto por paramilitares, para luego lógicamente hacer el trámite para la consecución de las ayudas, las indemnizaciones, ¿ya? Aquí [...] viernes, sábado y domingo me tocaba hasta cargar un muerto y meterlo a la camioneta de la policía, porque yo salía aquí a las 5 de la mañana a ordeñar las vaquitas y cuando venía de regreso ya encontraba a la policía con 3 y 4 muertos (A. Montero, comunicación personal, enero del 2017).

Aunque esta historia está contada desde el Piñón, en realidad podríamos dar cuenta de muchas más historias en cada uno de los pueblos del Bajo Magdalena. El punto es que el fenómeno paramilitar debilitó a las organizaciones campesinas e instituciones del Estado.

El interés de debilitar el proceso organizativo por parte de los paramilitares, especialmente a la ANUC, fue evidente no solo en el control 
Vida campesina en el Magdalena Grande

territorial, como se describió anteriormente, sino también en el asesinato de los dirigentes políticos de la ANUC a nivel nacional, regional y local:

En lo departamental, precisamente, había un compañero que lo mataron en la lucha de las tierras en Ariguaní, un compañero que era presidente de la ANUC porque a la ANUC sí nos dieron duro, mataron hasta al presidente nacional, a William Jaime, y al vicepresidente, que nos lo mataron aquí, en el Magdalena... y en Zona Bananera hicieron también desastres (A. Montero, comunicación personal, enero del 2017).

La incursión paramilitar fue el motor del aumento en los índices de corrupción. La escaza participación ciudadana en materia de política agraria (a la que se refirieron todos los entrevistados) contribuyó considerablemente a producir la situación actual, junto con la apertura económica, articuladas ambas con el acaparamiento del agua por parte de grandes terratenientes: infraestructura pública y privada que contribuye al taponamiento de los flujos de agua.

\section{Resistencia campesina}

En la actualidad, existen en algunos municipios procesos de retorno, reconstrucción del tejido social y asociativo que han permitido la construcción de agendas de trabajo, junto a algunas instituciones, para la rehabilitación del agro. El señor Montero nos contó cómo se viene adelantando este proceso en el Piñón:

Nosotros tenemos una estructura organizativa bastante fuerte. Aquí en la cabecera tenemos al rededor - casi- de seis organizaciones y en los corregimientos tenemos organizaciones que... precisamente ahí tenemos a Pedro Rivera que cuando salió egresado de la Universidad del Magdalena (yo fui su profesor aquí) y ahorita mismo lo tenemos como director de la UMATA [refiriéndose a las organizaciones del Piñón]... sí, seis: está ASPAGROPIN (Asociación de Pequeños Productores Agropecuarios), está la Enzo de la Alcaldía, está AGROSAN, está la asociación de pescadores, y está otra que se creó, está mi organización, está la organización de mujeres... la mía es la ANUC, la de mujeres... (A. Montero, comunicación personal, enero del 2017). 
Vida campesina en el Magdalena Grande

En municipios como Salamina y el Piñón, donde los procesos organizativos de los campesinos se mantienen a pesar de las amenazas y la presión de los terratenientes, han logrado cualificar sus liderazgos; estos se ven reflejados en la capacidad de gestión e incidencia en los escenarios de decisión política, donde han logrado desplazar a los terratenientes y han empezado a ser administradores en sus municipios. El señor Montero cuenta cómo estos procesos se han convertido en ganancia para los campesinos de estos municipios:

Tanto Salamina con el Piñón nos respetan y ahorita mismo las organizaciones campesinas participan del Consejo de Gestión de Riesgo, del Consejo Municipal de Planeación. Nosotros tenemos participación y constantemente nos están llamando, o sea que la participación política aquí sí se ha visto y está reflejada tanto aquí como en los corregimientos. Entonces, ahorita mismo tenemos compañeros que son concejales, que son campesinos, inclusive la alcaldesa es campesina, el personero, que es mi hermano, es hijo de campesinos; o sea, la mayoría de puestos que se están... o cuando la mayoría son hijos de campesinos... Entonces, mira que aquí la parte política, el campesino sí tiene representación y aceptación, ya no lo miran como menos (A. Montero, comunicación personal, enero del 2017).

Un elemento importante en la incidencia política que han logrado las organizaciones en esta zona tiene que ver con la cualificación (no solo en términos políticos, sino también académicos). Como relata el señor Montero en el párrafo anterior, los campesinos o los hijos de campesinos que conocen el trabajo del campo, pero que además se capacitan técnicamente, tienen una doble experiencia que los lleva a trabajar de la mano con los campesinos y que, a su vez, los hace ser reconocidos por estos como aliados en la garantía de sus derechos y en la dignificación de sus vidas.

\section{Dimensión sociocultural}

Por generaciones, la Ciénaga Grande de Santa Marta ha sido escenario de eventos, de inundaciones, de desbordamiento de ríos, mar de leva, etc., y sus pobladores han aprendido a vivir en esta contingencia. 
Sin embargo, a causa de los desplazamiento forzados - bien sea por violencia o por dificultades económicas-, han tenido la oportunidad de vivir en contextos urbanos o semiurbanos donde hay más facilidad de acceso a la electricidad (y, por lo tanto, a electrodomésticos), transitando largas distancias en transporte público a otros centros urbanos como Ciénaga, Santa Marta y Barranquilla, teniendo otras oportunidades de empleo, accediendo a derechos y servicios que no conocían antes y teniendo contacto con el entretenimiento propio de la ciudad y el pueblo grande (tabernas, estancos y billares). El clásico mecanismo de la modernización se observa claramente en las generaciones más jóvenes de campesinos que manifiestan no tener la motivación para volver al campo ni a la Ciénaga. Dos indicadores de este fenómeno son: por un lado, el crecimiento de los centros poblados de los municipios y el abandono de las viviendas, ubicadas en la profundidad del territorio; por otro lado, la creciente tendencia de adultos y jóvenes a ejercer algún oficio y vivir en Barranquilla, pero trasladándose, cada vez que hay dinero, a su pueblo natal.

\section{Roles de género}

En las familias cuyo sustento se genera de la pesca y la agricultura la actividad productiva primordial recae en el hombre, quien es el proveedor de la familia. En el procesamiento del pescado o los cultivos las mujeres desempeñan labores domésticas y se dedican al cuidado de los niños. Solo cuando las familias atraviesan condiciones económicas difíciles las mujeres son impulsadas a salir a trabajar, desempeñando oficios de poca rentabilidad, pero que requieren un gran esfuerzo. En las familias que residen en los centros urbanos hay más flexibilidad frente a las posibilidades de trabajo de las mujeres para aportar al hogar.

Por otra parte, las mujeres jóvenes deben lidiar con la tensión entre el fuerte control vecinal de su comportamiento en público, acorde a los estándares morales y religiosos de sus coterráneos, y el constante acecho de hombres de distintas edades sobre sus cuerpos y espacios cotidianos. Sus expectativas de vida suelen estar acorde a los intereses de sus familias y en sintonía con el rol social que se les adjudica: acompañantes del hombre, dispuestas y responsables de la crianza. Los métodos anticonceptivos son 
Vida campesina en el Magdalena Grande

considerados, por las comunidades cristianas, contrarios a sus principios de defensa de la vida, calificándolos de "microabortivos". El maltrato conyugal es socialmente aceptado y pocas veces denunciado.

Los jóvenes, por su parte, al carecer de opciones de continuación de estudios secundarios o superiores, tras una niñez de privaciones y resignación, se han blindado con una actitud que oscila entre una resentimiento social que los impele a vencer en la competencia por la consecución de los ideales de "progreso", inculcados por los mass media, y la complacencia que ofrece el sobrevivir día a día, apenas con lo necesario, alejados de la ciudad y cobijados por la sensación de aislamiento de la Ciénaga y el pueblo. Por tanto, la percepción de los entrevistados es que se ha incrementado la delincuencia, la drogadicción y el alcoholismo.

\section{Ritualidad}

En la zona ribereña, al igual que en las otras zonas observadas, la religión es un elemento importante para hacer frente a las dificultades. Se pudo observar que antes de la incursión paramilitar la mayoría de sus habitantes eran católicos; esto, especialmente por el trabajo que realizó el padre Barón, de la diócesis de Santa Marta, en toda esta región, combinando aspectos organizativos con las comunidades eclesiales de base y proyectos productivos que se fueron implementando a través de las cooperativas.

$\mathrm{Al}$ respecto, el señor Montero nos comenta:

Bueno, ahí es donde realmente Pastoral Social sirvió, porque yo le decía al padre Barón: "usted tiene la parte religiosa y moral y yo la organizativa", y precisamente lo que hace el campesino desde que abre los ojos es dar gracias a Dios por estar vivo y estar bien de salud y encomendarle los cultivos al Señor. Con la gente de aquí, prácticamente casi toda la comunidad del Piñón - tanto mujeres como hombres - formaron parte de Pastoral Social (A. Montero, comunicación personal, enero del 2017).

Sin embargo, esta situación tuvo un drástico cambio a raíz de la incursión paramilitar en toda esta zona. La iglesia católica, cuando no fue 
Vida campesina en el Magdalena Grande

perseguida, abandonó a las comunidades que se encontraban amenazadas. Adicionalmente, los paramilitares emplearon en varias ocasiones los templos religiosos para encerrar a las comunidades mientras masacraban a sus compañeros; esto tuvo una carga simbólica bastante fuerte entre los creyentes, quienes se sintieron desamparados doblemente: ni el Estado ni Dios los pudo salvar, afirman los habitantes de esta zona. Posteriormente, este espacio fue aprovechado por las iglesias evangélicas.

\section{Sociabilidad}

Al ser interrogados sobre la relación con los pescadores de los palafitos, el grupo entrevistado en Sitio Nuevo concordó con la respuesta de Luis Altamar (enero del 2017) en el sentido de que "en la Ciénaga todo el que entre es bienvenido" (comunicación personal), así como la respuesta de José Martínez (enero del 2017):

Yo digo que eso es como una familia unida. Los pescadores cuando no se encuentran por ahí o están lejos de aquí del pueblo, unos [a otros] se ayudan. Si el otro, no joda, necesita un poquito de azúcar, llegan en un bote: "vea, compañero, regáleme un poquito de azúcar" [y le responden:] "cómo no, aquí está" (comunicación personal).

En similar sentido, Víctor de la Hoz (enero del 2017) respondió que "el espíritu colaborador del playonero no se ha perdido [...]: el playonero se identifica por la ayuda" (comunicación personal). Sin embargo, pese a esa persistencia del espíritu colaborador, reconoce que la masacre produjo una ruptura del tejido social que apenas se está recuperando:

Antes, las fiestas con banda y pico eran más emotivas. Hubo una pérdida de fe que afectó, pero se han venido recuperando las fiestas patronales, los bailes, las bandas, con ayuda de la Unidad de Víctimas, específicamente el programa Tejiendo (V. De la hoz, comunicación personal, enero del 2017).

En Santa Rita, los entrevistados recordaron que antes del desplazamiento se hacían "chaguas": 
El campesinado antes tenía como costumbre ayudarse el uno con el otro. A ese grupo de personas que se convocaban le llamaban "chagua" (una "chagua", en esas "chaguas"), bien sea para hacer rosas, hacer cultivos o adecuar las tierras para cultivos, bien sea para construir una casa... depende del trabajo que necesitaba la persona, entonces convocaba una "chagua" y llegaban 20, 30 personas, y se trabajaba; eso, por ejemplo, está perdido (J. Herrera et al., comunicación personal, enero del 2017).

En la cabecera municipal del Piñón, Alejandro Montero cuenta seis organizaciones campesinas. A pesar de ello, también considera que se han perdido las dinámicas de ayuda mutua entre campesinos porque la política los ha permeado.

Imagen 131. Comida campesina del Bajo Magdalena en la CGSM

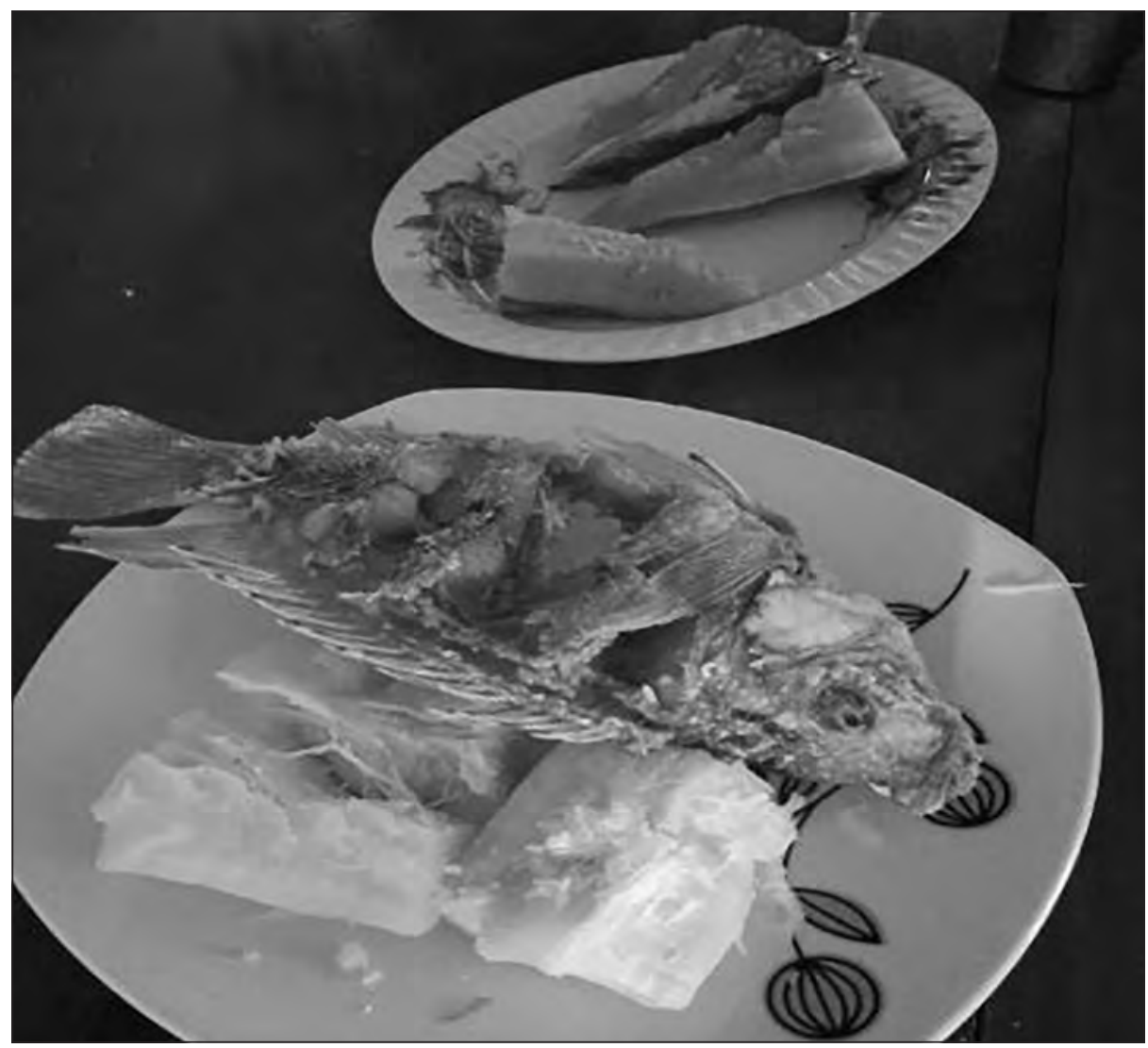




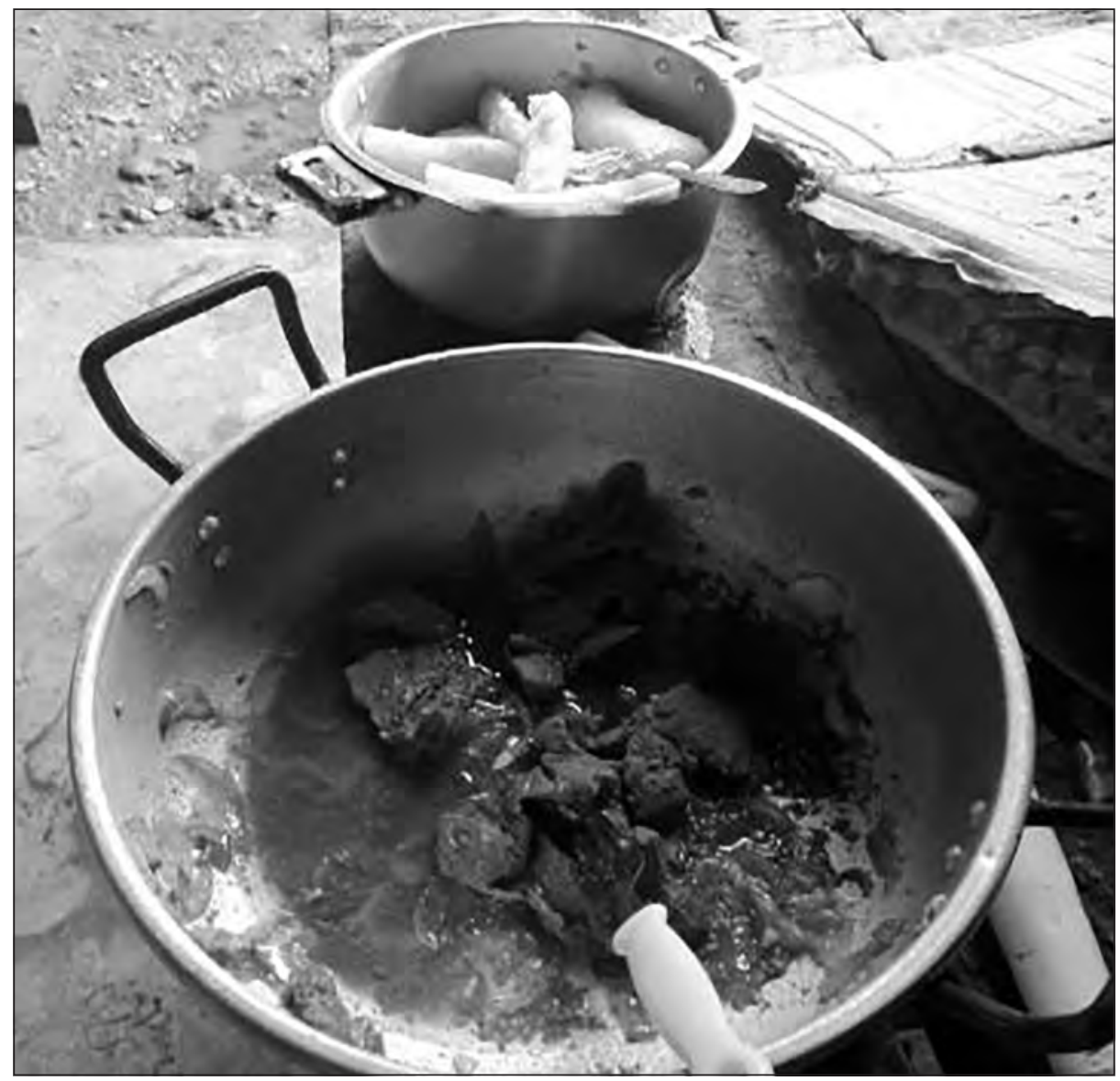

Fuente: Archivo Oraloteca (2017).

También fue identificado en las entrevistas el sentido de pertenencia con el territorio. Refiriéndose, por ejemplo, a las ventajas de mantenerse allí, los pescadores resaltaron que, a pesar de las dificultades, al menos había alimento y seguridad en el pueblo:

Lo más bonito de vivir en el pueblo de aquí es que toda la cosa es barata, se consigue a buen precio, los servicios [son] un poquito más baratos, tenemos el río Magdalena que es una mina de agua que tenemos. Pasamos necesidad en el agua, bueno, porque está lejos a veces pasamos necesidad, pero tenemos sí el burrito, sí, en el hombro traemos el poquito de agua 
Vida campesina en el Magdalena Grande

para la casa, y aquí en la forma, en la cosa las comidas se consigue[n]... lo que tenemos: el pescao, la yuca, el maíz, todo (A. Mendoza, comunicación personal, enero del 2017).

El relato anterior es la expresión de lo que para Fals Borda simboliza la hicotea para la cultura ribereña:

Implica no solamente ser sentí-pensante sino ser algo más, ser aguantador, el que aguanta los reveses de la vida y sabe superarlos. Porque sabe esperar su momento de alegría. Se sufre mucho, pero también se goza y en suma va ganando la alegría (Moncayo, 2009, p. 43).

\section{Expresiones culturales: fiestas patronales}

Aunque antes tenían festividades como el día de Santa Rosa, de Angelitos, los carnavales de Barranquilla, reconocen que algunas de esas festividades se están recuperando:

Las fiestas patronales se han venido realizando ya los últimos años que hemos estado acá: los 20 de julio se han vuelto a sacar banderas, los faroles, la de los muertos esa sí no se perdió, desplazados veníamos aquí a velar, y carnavales sí. Todavía nos hace falta, por ejemplo, los bailes de son de negros que antes se hacían en todo el periodo ese de carnaval, de precarnaval, pero que pues no, ya no tenemos instrumentos (J. Herrera et al., comunicación personal, enero del 2017).

\section{Elementos que generan rupturas en la vida comunitaria}

Junto a esa ambivalencia, entre la recuperación y la pérdida de tradiciones o de cooperación comunitaria, aparecen en los contextos locales de campesinos y pescadores problemas sociales que antes solo eran de las ciudades, o algunos que ya estaban adquieren una dimensión preocupante. En Guáimaro, Beris Alminta (enero del 2017) afirma que "alcohol siempre ha habido, pero ahora los jóvenes son más desordenados [...]. Antes, no se veían violaciones ni violencia contra animales, ni irrespeto juvenil" (correspondencia personal). Con respecto a la drogadicción identifica una relación causal con el conflicto: "el desplazamiento 
Vida campesina en el Magdalena Grande

también ayudó al vicio porque muchos de los que se fueron no volvieron igual" (Alminta, enero del 2017, correspondencia personal).

Aunque en Playón de Orozco Víctor de la Hoz no identifica drogadicción, sí hace un reconocimiento similar del efecto de la violencia en los jóvenes que en aquel momento eran niños o, incluso, no habían nacido, afirmando que el trauma de la masacre es heredado.

La permanencia generacional de la identidad campesina también presenta diferencias considerables. Por ejemplo, en el Piñón, Alejandro Montero advierte que los jóvenes ya no quieren ser campesinos; sin embargo, en Playón de Orozco, Víctor de la Hoz resalta que se ha mantenido el interés de los jóvenes por el cultivo.

En Sitio Nuevo, la ruptura de la zanja la Unión y la consecuente inundación de los predios contiguos al retorno del caño Aguas Negras han generado molestia en los campesinos de dichos predios, lo que parece ser el embrión de un conflicto social entre campesinos y pescadores. De hecho, el problema de la zanja viene de, al menos, un año atrás. Elías Díaz reseñó el episodio anterior:

Los señores del Morro, pretenciosos, querían la vía [se refiere a la vía fluvial] y no dejaban tapar el boquerón. Tenían las máquinas amenazadas: que las iban a quemar, eso me lo dijo él... con el que yo estaba hablando. [¿El del Morro de los Palafitos?]. Sí. Entonces él me pidió el favor, que si yo le ponía un personal en la mañana y uno en la tarde ellos ponían la máquina para tapar el boquerón, y yo le dije "bueno, yo se los prometo y les cumplo, compadre". Bueno, así fue: nos turnamos un personal en la mañana y otro en la tarde, y ellos comenzaron a trabajar, pero entonces nosotros nos aburrimos porque, eche', todos los días lo mismo, ¿ya? Habíamos dos grupos ahí, ¿los mismos?, no vamos más. Bueno, eso siguió corriendo. Entonces, hicimos otra reunión y nos los cogimos allá en la Alcaldía de Sitio Nuevo, y allá hablamos con él y también, bueno, ya al día siguiente llegaron a palabras fuertes: que si ellos no tapaban eso entonces nosotros llegábamos a quemarle las máquinas entonces a ellos. Bueno, ellos hicieron el esfuerzo y taparon... ya hasta ahí no tuvimos más problemas con CORPAMAG; CORPAMAG ya sabía los problemas que habían aquí (E. Díaz, comunicación personal, enero del 2017). 
Vida campesina en el Magdalena Grande

Con este antecedente, José María culpa concretamente a los pescadores del Morro por la situación actual, asociándolos con la Alcaldía del municipio:

Ahorita el que abrió el boquerón ese, ¿por qué lo abriría? Mire... hay tantas versiones que hay, pero la excusa que hay es porque al Morro se le está muriendo el pescao y para darle agua al morro abrieron el boquerón. Yo tuve una pelea con el alcalde porque nosotros somos conocedores de eso: cuando estos cultivos se nos pierden nosotros salimos con la atarrayita por ahí a rebuscarnos la comida de los pelaos, ¿ya?, y ya nosotros conocemos la problemática. Entonces, ellos vinieron donde el señor alcalde y le pidieron que abrieran un boquerón para la vía porque ellos lo que quieren es la vía... y métaselo en la cabeza y dígalo en Santa Marta, que los señores del Morro lo que quieren es la vía porque la compuerta la tienen después del boquerón a 50 metros, ¿no la vio ahí? A 50 metros y si ellos quieren agua la compuerta tenían que abrirla. Los señores del Morro quieren es la vía, ellos se han puesto tan pretenciosos porque el Gobierno los tiene pechichón. A ellos no se les puede[n] morir unos 4 pescados porque ya camionadas de compra y de cuanta vaina, cuanta atención les prestan a ellos. [A] nosotros aquí el verano nos está matando entre veces y nosotros aquí no recibimos nada, compae' (E. Díaz, comunicación personal, enero del 2017).

Otro elemento que genera conflicto es la incrustación de clientelismo en la vida cotidiana; esto lleva a que se generen desconfianzas entre los habitantes de una misma comunidad. Al respecto, el señor Montero nos cuenta cómo ha visto estas transformaciones en la vida comunitaria:

Cuando yo empecé con la organización, precisamente compañeros que estaban enfermos nosotros íbamos 10 o 15 y le[s] ayudábamos en la parcela; de igual forma, cuando yo salía, que estaba 4 o 5 días por fuera en congreso o [en] reuniones que hacía, los compañeros me ayudaban: iban los domingos, me ayudaban a limpiar la parcela... pero eso ya aquí han sucedido casos que la misma política ha penetrado (A. Montero, comunicación personal, enero del 2017). 


\section{Campesinos urbanos en la ciudad de Santa Marta}

En el distrito de Santa Marta existen muchas comunas, barrios y veredas que nacen a partir del desplazamiento interno que vive el país a raíz del conflicto social y armado que lo aqueja hace más de 50 años. Esto ha influido en la creación de zonas urbanas en las que la mayoría de la población proviene de círculos rurales de la región y el país, estableciendo, de esa manera, sistemas de producción agrícola alrededor o al interior de la ciudad.

Es por esto que para el distrito de Santa Marta se hace necesario un análisis del campesinado articulado a una dinámica de ciudad, urbana que, en efecto, evidencie y analice las transformaciones de los modos de vida campesinos asumidas en relación con un nuevo territorio alejado de la ruralidad, con nuevos conjuntos de saberes, espacios de organización y distribución de las territorialidades.

Para esta oportunidad se realizó un acercamiento a dos importantes veredas que expresan estas formas de análisis antes expuestas: la vereda el Mosquito, que limita en la urbanidad con el barrio Gaira, y la vereda Altos de Don Jaca, que se encuentra a las afueras de la ciudad, posterior al barrio Cristo Rey y mucho más cerca al puerto de carga Drummond Ltda. Abarcamos una población de más de treinta campesinos distribuidos entre las dos veredas, haciendo énfasis en las diferentes formas de vida campesina: desde el desplazamiento de su lugar de origen, el poblamiento de estos nuevos lugares, la transformación del trabajo, las nuevas formas de economía, los canales de comercialización, los problemas 
medioambientales, el conflicto armado, los saberes locales y la percepción del futuro de los campesinos enfrentados a la ciudad.

Cabe resaltar que en Santa Marta, al igual que en muchas otras capitales de los departamentos que conforman el Caribe colombiano, hay más de dos veredas cuyos habitantes son, en su gran mayoría, campesinos desplazados; por esto, proponemos este ejercicio como un acercamiento que servirá de insumo tanto para el abordaje de otras veredas en la ciudad, como para entender las diferentes formas en que el campesino se ha tenido que ver enfrentado, como un panorama más inteligible a las consecuencias del conflicto armado y el desarrollo económico nacional.

\section{Vida campesina en la vereda el Mosquito, de Santa Marta}

Mapa 13. Mapa de la vereda el Mosquito

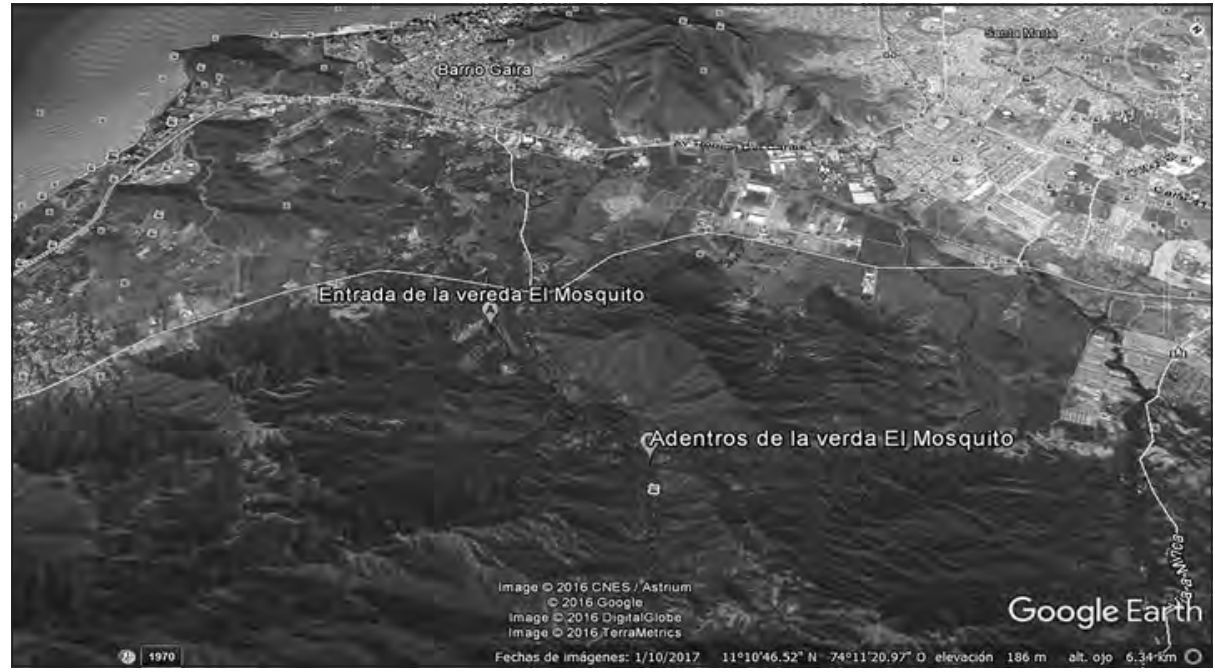

Fuente: Google Earth (2017).

Limitando con el antiguo corregimiento de Gaira, hoy barrio de la ciudad de Santa Marta, se encuentra la vereda el Mosquito, una zona rural que bordea el perímetro urbano del distrito hacia las estribaciones de la Sierra Nevada de Santa Marta. Esta vereda se caracteriza por tener como afluente el río Gaira, que suministra, a través de un sistema de canales y tuberías, el agua potable a las zonas turísticas del noroccidente de 
la ciudad, principalmente el Rodadero y el sector de Pozos Colorados; de hecho, es en la vereda en donde se sitúa la planta de tratamiento de agua potable para la ciudad. Otro de los elementos que distinguen geográficamente a esta vereda es el posicionamiento cercano del Servicio Nacional de Aprendizaje (SENA) de enfoque agropecuario, que cuenta con porciones de tierras planas que inician en los límites con la Troncal del Caribe y que sirve como institución de educación para algunos habitantes de la vereda.

Dentro del reconocimiento del territorio por los mismos habitantes se logran identificar algunas referencias territoriales que permiten a los pobladores entender, organizar y distribuir su territorio a través de representaciones de memoria y significación de los espacios, mostrando así algunos referentes de nombres como la vereda el Mosquito, Paso del Rosario, la Planta y la vereda el Canal, que no se encuentran delimitados físicamente, sino a través de su relación con los senderos, el río y las diferentes multinacionales que han creado sistemas de explotación en el territorio, como hidroeléctricas o plantas de tratamiento hídrico en relación con los nombres el Canal y la Planta. Sin embargo, algunos solo optan por reconocer y ordenar su territorio como, únicamente, la vereda el Mosquito:

Mosquito es hasta esta finca. De aquí para allá paso del Rosario y, después, [está la] vereda el Canal. Toda esa gente para allá es nueva, [llevan] menos de 10 años invadiendo. Mi papá dejó esas tierras, por ahí 200 hectáreas, hace 58 años; esas tierras costaron 500 pesos cuando eso (W. Zúñiga, comunicación personal, diciembre del 2016).

Su población se dedica a diversos quehaceres. Como principal actividad económica se encuentra la siembra de pancoger y algunos frutos de gran comercialización como el mango, la yuca, el aguacate y el ají, que generan ventas dentro de la vereda y en la ciudad, haciendo parte de los mecanismos de sustento de sus habitantes. No obstante, también hay otras formas de trabajo, como lo son el mototaxismo, la extracción de arena, hornos artesanales para sacar carbón vegetal y estaderos de servicios turísticos que, por su cercanía al brazo del río Gaira, se han convertido en un atractivo turístico para los habitantes de la ciudad de 
Santa Marta que visitan el lugar los fines de semana para sus paseos de olla. En estas actividades se ven involucrados los campesinos, dado que se convierten en nuevos mecanismos de subsistencia en relación con la dinámica de la ciudad, alternando de esta manera actividades agrícolas, turísticas y de transporte.

Aunque su población es agrícola, la tierra es, en su gran mayoría, propiedad de dueños que no cultivan, ni viven, ni mantienen la parcela: son habitantes de la ciudad que prestan sus fincas para el cultivo de algunas familias y solo exigen el cuidado del terreno y alguna porción de la cosecha que realicen los campesinos. En efecto, la gran mayoría de los campesinos de la zona no tiene tierras propias: solo son de su propiedad los cultivos y las cosechas que obtienen, pero hay algunas familias de más antigüedad en la vereda que han logrado adquirir, a través de los años, porciones de tierras, iniciando su actividad agrícola en tierras propias; sin embargo, sigue siendo una pequeña población la que se encuentra en esta condición. Otras familias también han logrado fragmentar partes de la montaña para la creación de casas tipo "lugar recreacional" a la orilla del río para generar nuevas fuentes de ingresos económicos. Esto otorga nuevos significados a la categoría de "campesino". Los sucesos sociales, políticos y económicos del país han replegado nuevas identidades alrededor del ejercicio agrícola, de manera que el campesino ya no es solamente quien crea una estrecha relación con la tierra y su cultivo, sino que también lo determinan las nuevas realidades que vive: un campesino desplazado que ha tenido que dejar su territorio por el continuo recrudecimiento del conflicto y las nuevas economías que han llevado a los distintos sectores a crear formas se subsistencias por las faltas de garantías, como por ejemplo los campesinos de Mosquito, quienes actualmente se dedican al mototaxismo y a la creación de estaderos, que es lo que mayormente devenga la relación con la ciudad.

Adentrándonos más hacia la organización territorial de la vereda, actualmente sus calles se encuentran sin pavimentar: desde su entrada, situada en la Troncal del Caribe, hasta el sistema de canalización del agua del río; esta calle recorre todo el brazo del río y las plantaciones se realizan al lado y lado del afluente. Algunos habitantes recuerdan que la carretera estuvo alguna vez asfaltada en los inicios del poblamiento, obra realizada por algunas empresas de origen norteamericano que se encontraban en 
la zona. Sin embargo ahora, con el crecimiento del turismo y la continua entrada de vehículos a la vereda, ha desaparecido totalmente el asfalto y los mismos campesinos han asumido la tarea de hacerle mantenimiento a la vía que les permite sacar sus cultivos a la venta, recalcando que lleva más de tres años sin ser arreglada ni por parte de la comunidad ni por los organismos estatales; esto, debido a que en relación con las figuras de agremiación campesina y comunitaria existe una desarticulación causada por diferencias interpersonales y territoriales que no han permitido la organización formal de un junta de acción comunal.

Imagen 132. Calle principal de la vereda el Mosquito

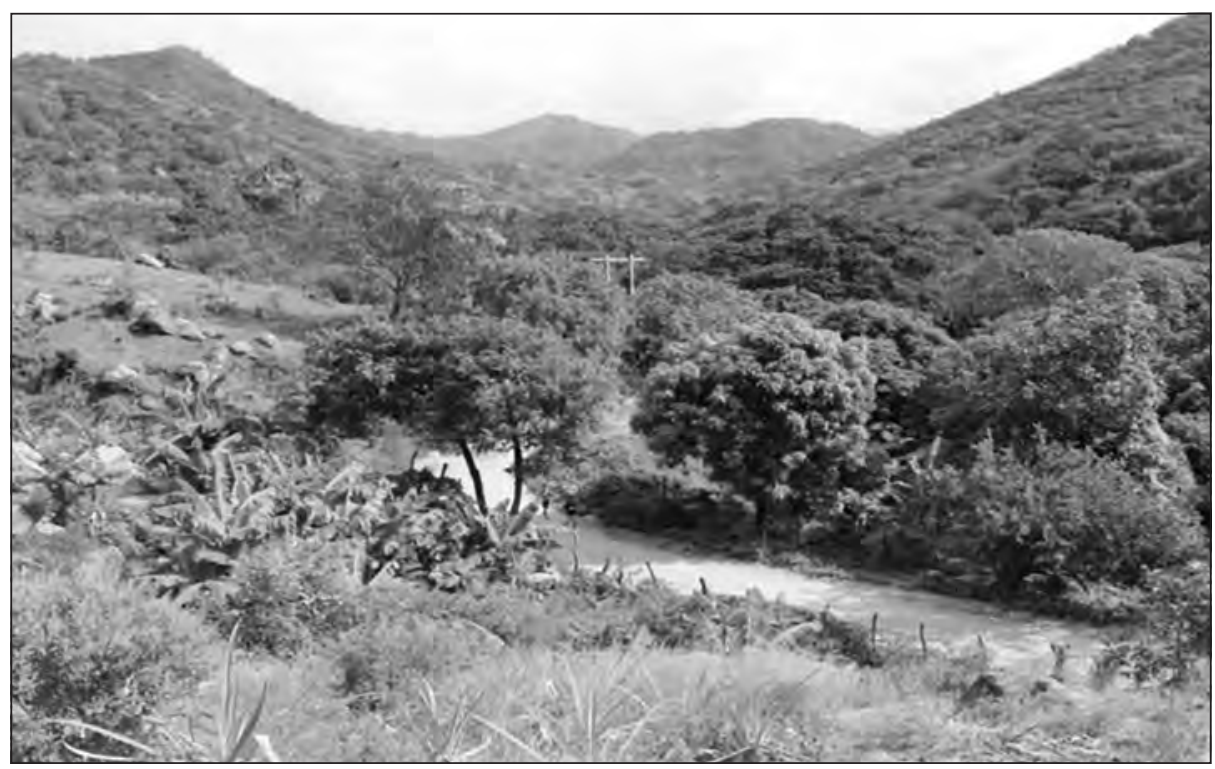

Fuente: Archivo Oraloteca (2017).

La desigualdad y la falta de inversión pública no son una novedad en la vereda. A pesar de su cercanía con la ciudad, los servicios públicos de gas, de luz eléctrica y, en algunas ocasiones, de agua, no son óptimos. La luz eléctrica es adquirida por los campesinos en consensos previos con la empresa de acueducto que tiene los sistemas de cableado eléctrico para el funcionamiento de su planta de tratamiento hace más de treinta años. Los campesinos deben comprar sus transformadores eléctricos 
Vida campesina en el Magdalena Grande

para poder obtener el servicio de energía eléctrica. El costo de estos transformadores supera los 5 millones de pesos y solo algunos pueden tener acceso al servicio. En su mayoría, los campesinos no son dueños de las tierras y les toca ceñirse a la inversión que haga el propietario dado que la cosecha esporádica no les permite tener el alumbrado por las noches en las parcelas, entendiéndose así que en la vereda no hay servicio de energía eléctrica.

Las viviendas, en gran proporción, son de material y, algunas, de guadua, aunque en general hay pocas viviendas. La vereda se extiende, en su mayoría, a porciones de macizo montañoso, fincas y cultivos. Grandes extensiones de tierra hacen parte de la Reserva Natural Iguana Verde, que hace control ambiental en cierta proporción del río y la montaña, donde evita la fragmentación de algunas zonas montañosas para la construcción de estaderos para el servicio turístico, asumiendo un discurso de conservación en la dinámica de la relación ambiental con el río Gaira y generando así estrategias de ecoturismo en el río:

Acá tenemos esta reserva natural que se llama Iguana Verde, entonces es un proyecto de vida. Acá no cobramos entrada; simplemente, [a] la gente que entra le marcamos unas pautas para que ellos cuiden la reserva: no fumar, no quemar... en conservación nos hemos dedicado, tenemos una batalla campal con Metroagua porque ellos quieren captar toda el agua del río (E. Díaz, comunicación personal, diciembre del 2016).

Uno de los quehaceres de los campesinos es la construcción de hornos artesanales para la extracción de carbón. En el proceso de mantener apta la tierra para el sembrado se realiza el talado de algunos árboles que impiden el "ollamiento" de la tierra para la siembra y de esta deforestación resulta una alternativa económica mientras los cultivos logran cosecharse. La quema de madera y posterior generación de carbón para la venta es una forma de subsistir, según manifiestan algunos, mientras transcurren los casi ocho meses que se tardan en cosechar lo que siembran. Sin embargo, algunos de los sectores que ejercen control territorial, como la Reserva Natural Iguana Verde, han restringido esta práctica y, en ocasiones, se han presentado decomisos de carbón, generando desacuerdos entre los campesinos y la reserva. 
Vida campesina en el Magdalena Grande

Imagen 133. Horno artesanal para la extracción de carbón

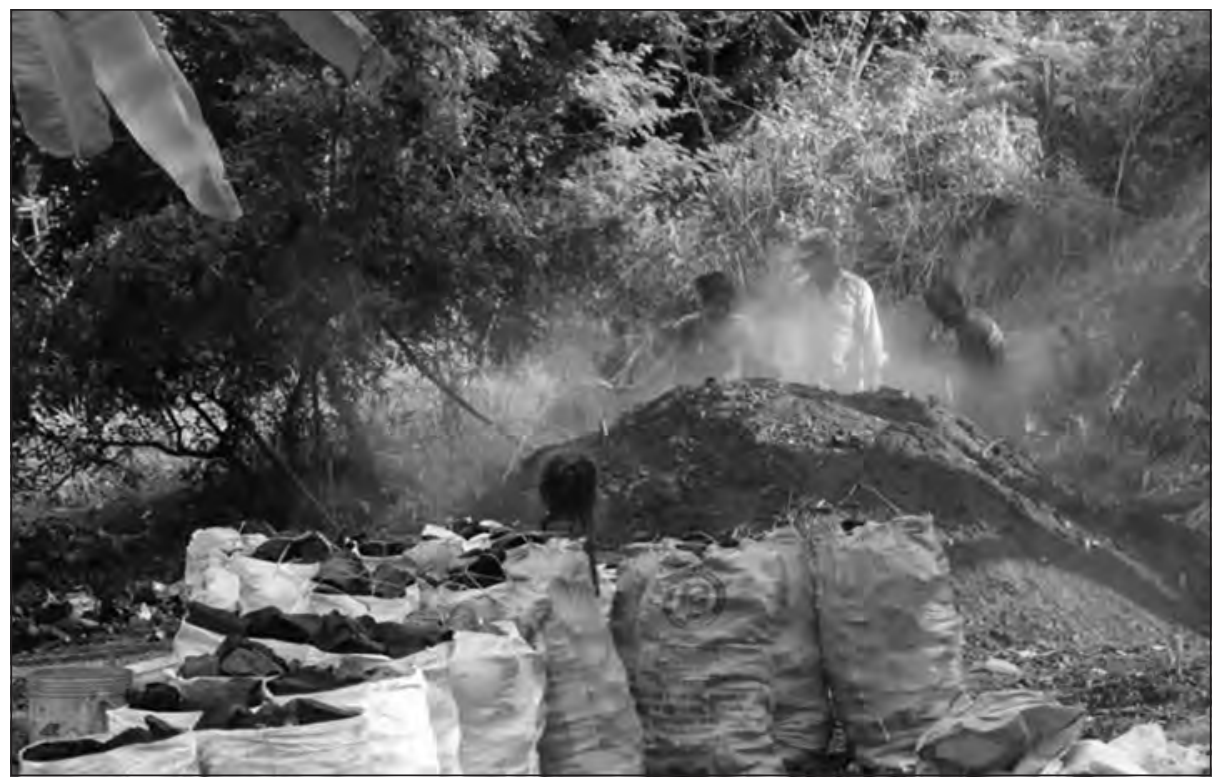

Fuente: Archivo Oraloteca (2017).

\section{Poblamiento de la vereda el Mosquito: realidad del conflicto social y armado del país}

El nacimiento de la vereda el Mosquito, como le dicen algunos campesinos, se remonta a hace más de setenta años, cuando estaba conformada por tierras baldías en las que funcionaban plantas hidroeléctricas (dada la cercanía del río). Estas empresas, dedicadas a vender como servicio público la luz eléctrica a lugares como Minca y Santa Marta, eran de nacionalidad norteamericana, siendo esta actividad necesaria para las nuevas formas económicas que incursionaban en el país a finales del siglo XIX y principios del XX, con la bonanzas bananeras y los enclaves en el departamento del Magdalena, específicamente en los municipios de Ciénaga, y la creación de pueblos en esa zona, potencializando la economía de exportación a través del banano, lo que significó la construcción de líneas ferroviarias y puertos marítimos para el ejercicio comercial que se consolidaba. Sin embargo, eso no era todo: era el inicio de las importaciones por parte de las mismas transnacionales, que traían cargamentos de mercancías 
Vida campesina en el Magdalena Grande

para ser comercializados en Colombia y generar rentabilidad para las nacientes empresas. Así, por ejemplo, se dio la construcción de plantas hidroeléctricas que se alimentaban del río Gaira y proveían la energía necesaria para el funcionamiento de la naciente industria del banano:

PRODELCA, esa gente puso a producir eso al máximo. Después, la Gobernación del Magdalena mal vendió esa vaina, lo desarmaron y lo vendieron por chatarra, necesitando muchos municipios [porque] ahí estaba todo: el canal, la tubería... PRODELCA trabajaba, producía energía y, al mismo tiempo, dejaba el agua (J. Rodríguez, comunicación personal, diciembre del 2016).

Para entonces, la población de la vereda el Mosquito era muy poca. La vereda estaba conformada por tierras baldías que luego fueron invadidas y apropiadas por terratenientes de grandes familias de la ciudad que prestaban sus fincas para el cultivo; a partir de ahí, los mismos campesinos comenzaron a generar utilidades y a comprar grandes hectáreas de tierra:

Cuando yo venía por aquí no había nada: unos campesinos viejos, había un señor que se llamaba Cristo Río Arroyo, tenía como 76 años... no existía ni Inderena, ni Incoder, antes todo esto no era de nadie y la gente llegaba, hacía un cultivo de maíz, se aburría y se iba, dejaba esa vaina ahí... Así [fue] como llegué yo: yo tenía una finca por allá, por donde Viviana Salamanca (ella era una representante de medio ambiente y esa vaina), sembrábamos árboles, por donde Cartagena yo sembré 70 árboles de maderable, yo tengo aquí 500 metros y los tengo protegidos... todo esto es mango... no se puede quitar una cantidad de árboles para sembrar maíz a la orilla del río; yo sembré mango, un árbol de mango dura lo mismo que un caracolí, dura como 200 años (J. Rodríguez, comunicación personal, diciembre del 2016).

El agua no iba de aquí para Gaira. Allá en Gaira había un rebombeo que era lo que llenaba los tanques al frente de la licorera. Ya después vino Metroagua... ese acueducto lo hicieron en el 85, después se metió Metroagua y dañó todo. Desde el 85 para acá eso cambió (R. Hincapié, comunicación personal, diciembre del 2016). 
Vida campesina en el Magdalena Grande

Luego, se comenzaron a identificar familias que se dedicaban en conjunto al trabajo de la agricultura. Eran las familias de apellidos Zúñiga, Serrano, Muñoz, Ríos y Rodríguez, que comenzaron a poblar la vereda; algunas eran familias campesinas de los Santanderes que venían desplazadas por la guerra bipartidista y algunas eran familias de la región Caribe. Para entonces, el ejercicio agrícola se juntaba en la cotidianidad con el trabajo familiar. Estas familias lograron transmitir a sus generaciones el trabajo de la tierra por más de cincuenta años, prevaleciendo en la actualidad las últimas generaciones que se dedicaron al campo:

Por aquí habíamos pocas familias en ese tiempo. En ese tiempo cuando se comenzó estaban era los trabajadores que cuidaban la planta de Gaira; eran unos 3 celadores. Aquí subía un jeep todos los días en la mañana, era el único transporte que había, esto era solo. La gente que está por aquí es nueva: los indígenas tienen como 10 o 12 años, todo esto que esta por aquí eso es ya nuevo, pero gente vieja por ejemplo mi marido, los Zúñiga, Bolívar Zúñiga era de los viejos, él vivía allá abajo donde estaban los aguacates. Todas esas familias se dedicaban al campo. El Seguro Social compraba por aquí frutas, le compraban a Bolívar, mi esposo trabajó con él, porque el único que tenía por aquí el contrato era Bolívar. Por acá se sembraba guayaba, papaya, pancoger: plátano, yuca, en ese tiempo no estaba el mango... es que ni la guayaba, porque es que el mango se perdía, es ahora que se está comprando... hace como 20 años para acá, para esa época la población no era muy amante a el mango como ahora, ni las frutas, antes nadie compraba frutas, nadie, nadie... el trabajo que había era campesino o albañil (R. Hincapié, comunicación personal diciembre del 2016).

Mi mamá tenía una tienda, una colmena. Llegamos a la agricultura porque mi tío Dima le regaló unas tierras y, después, mi papá compró unas tierras propias allá abajo, y se las compró a un señor que se llama Heladio Rodríguez. En esa época estaba la familia Río, los Serranos, los Muñoz, y otra familia Río, dos familias Ríos que no tenían que ver una con la otra (J. Zúñiga, comunicación personal, diciembre del 2016). 
Vida campesina en el Magdalena Grande

La familia Zúñiga tenía grandes extensiones de tierras distribuidas entre lo más cercano de la ciudad hasta los adentros de las estribaciones de las montañas de la zona. Para entonces, esta familia logró consolidar contratos de comercialización con unas compañías norteamericanas que se dedicaban a la elaboración de aderezos líquidos, generando nuevos empleos para las familias que dependían de los trabajos que les brindaban los Zúñiga en sus cultivos. Grandes extensiones de tierras comenzaron a ser compradas por esta familia que logró consolidar un conglomerado de territorio propio y de carácter familiar. Así, se convirtió en una opción económica de las nuevas generaciones que llegaban a la familia, mostrando que la actividad agrícola tenía una estrecha relación con la tierra y sus ciclos, y que este conocimiento - con grandes valores- debía prevalecer.

Además de ofrecer una opción económica a la comunidad, los Zúñiga trajeron consigo un conjunto de representaciones culturales expresadas en la creación de festividades alusivas al patrono del departamento de Bolívar (de donde venían): San Martín de Loba, al que se le realizaba una procesión anual por la calle principal de la vereda, congregando feligreses devotos y no devotos en un espacio que no solo reunía el objetivo religioso, sino que también permitía la integración de varias familias en el ejercicio compartido de lo agrícola; una integración que permitió que se tejieran prácticas, devociones y añoranzas en la esperanza de una mejor relación con los cultivos y de prosperidad a la hora de la cosecha. Sin embargo, estas fiestas solo fueron representativas hasta la fecha del fallecimiento de Bolívar Zúñiga, que era quien realizaba estas continuas y masivas congregaciones; después de su fallecimiento, las nuevas generaciones - que una vez hicieron parte de esas festividades- no continuaron la tradición en la vereda y, finalmente, se perdió por completo su realización. Hoy en día estas festividades solo hacen parte de la memoria de los más antiguos pobladores:

Mi papá toda la vida fue devoto a San Martín. Él viajaba a Cartagena donde Loba, él iba allá con mi mamá cuando ya tenía platica. Para el año 60 hubo un ciclón: todo el día lloviendo y una semana lloviendo en Minca... el río iba a pasar por la casa y mi papá sacó a San Martín y le dijo: "tú verá si te dejas matar", y el río se abrió. Eso no se me olvida nunca (W. Zúñiga, comunicación personal diciembre del 2016). 
Imagen 134. Altar de San Martín de Loba

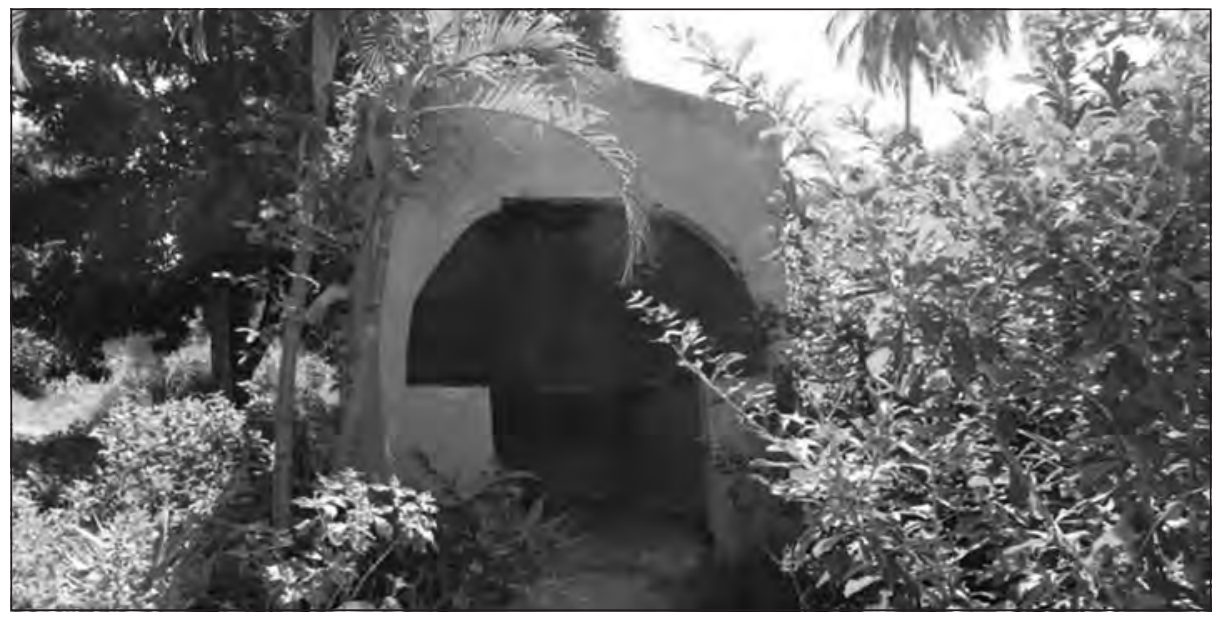

Fuente: Archivo Oraloteca (2017).

Antes eso era una fiesta buena. Antes, mi papá compraba cajas de ron y mi mamá pasteles y juguetes para los pelaos, para regalar. Ya ahora después de que murió mi papá ya eso dio pena (J. Zúñiga, comunicación personal, diciembre del 2016).

Y cuando no lo paseaban lo que era, no entraba, por aquí salió y no entraba después, no podían con él. La gente decía “está pesado" y cuando fueron a entrarlo no entró... duraron como hora y pico y no entró. Y cuando lo paseaban bien, entraba sin problema. Aquí venía gente hasta de Gaira, eso era una fiesta grande; ahora sí no, ahora es muy poca gente. Es como la Virgen de Gaira, que cuando no le da la gana de salir, no sale (W. Zúñiga, comunicación personal, diciembre del 2016).

En la vereda el Mosquito la relación entre familias, actualmente, es muy poca; sin embargo, las familias aún perviven y también han evidenciado una serie de leyendas que se tejen alrededor del territorio, pero que, lamentablemente, no hacen parte de la memoria colectiva del mismo. Algunas de estas leyendas han sido traídas de los lugares de donde algunos campesinos provienen. Si bien se escucha muy poco hablar de leyendas, muchas se relacionan con la falta de energía eléctrica y las oscuridades 
Vida campesina en el Magdalena Grande

en la vereda, y algunas de ellas han funcionado para controlar a las nuevas generaciones que han crecido en la zona, evitando que se encuentren hasta altas horas de la noche en el río y en ciertos lugares:

Me han dicho que han visto un perro negro que bota fuego por la boca y también [a] la Llorona. Una vez en Bureche veníamos en bicicleta y vimos un caballo grande negro. Hay una historia en ese mismo pedazo: salía una señora que la mataron ahí, ahí decían que salía, cerca de la troncal. La muchacha salía ahí, en la noche, paraba un taxi y la señora cuando se bajaba decía: "ya le traigo la plata", pero se encontraba con que estaba muerta (W. Zúñiga, comunicación personal, diciembre. 2016).

\section{El conflicto armado y la seguridad en el territorio}

Desde su poblamiento, la vereda el Mosquito comenzó a sentir épocas de conflictos, asesinatos y temor colectivo en la comunidad. El conflicto que recuerdan sus habitantes como uno de los primeros en surgir fue la guerra entre familias que se habían convertido en las adineradas de la ciudad y la región, como las familias Valdeblánquez y Cárdenas. Además de hacer control territorial en la ciudad y en algunas zonas rurales, por ser hacendadas y dueñas de grandes extensiones de tierras, estas familias iniciaron una confrontación que duró alrededor de 19 años. Hay varias versiones sobre las razones de este conflicto, entre las que se cuentan una trasgresión al "honor" y por otro lado, se cuenta que la renta de actividades como el contrabando de marihuana agudizó, en gran medida, los conflictos entre estas dos familias, porque se disputaban los corredores comerciales de estos cultivos ilícitos que les generaban grandes riquezas y, a partir de ahí, su accionar —-tanto territorial, como político-, acentuándose en las principales ciudades de la región como Santa Marta, Barranquilla y Riohacha. Pero los conflictos entre grandes familias en toda la región Caribe se venían dando con regularidad en las distintas bonanzas, entendiéndose estos como sucesos de control y seguridad articulados a actividades económicas y destacándose conflictos como el de las familias Gómez y Daza, que se remontan a unos años antes que el de los Valdeblánquez y las Cárdenas, pero que se concentraron hacia el departamento del Atlántico, en Barranquilla. 
Vida campesina en el Magdalena Grande

En la vereda el Mosquito la gente recuerda de manera significativa y funesta cómo se dio el proceso de poblamiento en medio de estos conflictos, ya que estos no solo se dieron en la ciudad de Santa Marta, sino que también se extendieron hasta la vereda el Mosquito. Algunos eran dueños de tierras por estas zonas y, como al ser una zona rural el lugar estaba desolado la mayoría del tiempo, había pocos campesinos, lo que permitía que fuera un lugar crudamente factible para la desaparición física de personas:

Eso era allá en el "palo", en la "bonga" o la "curva de la muerte" que le dicen. Esos eran dos familias, los Cárdenas [era una de las dos]. Cuando se estaban matando, ellos los tiraban ahí y eso se pudrían ahí. Ellos se acabaron una familia con otra, [por] una discordia allá y por eso los mataban unos con otros; no era por robar ni por nada, sino por venganza personal [...]. No, no hubo miedo; ellos los tiraban ahí y más abajo se sentaban a tomar tinto, donde Santa. Después [de] que los mataban aquí, allá se sentaban a tomar tinto, la asesinaban ahí en la Bonga (J. Rodríguez y W. Zuñiga, comunicación personal, diciembre del 2016).

Eso fue para la época del 65, eso eran los Cárdenas. Dos familias, porque en los Cárdenas había un sicario que mataba a todo el mundo. Los Cárdenas era una familia, lo que llamaba uno antes los "traqueteos", que eran los que transportaban la marihuana (J. Zúñiga, comunicación personal, diciembre del 2016).

Uno de los elementos que resulta un detonante para la memoria que de la época tienen los habitantes sobre estos conflictos en la vereda entre estas dos familias es el frondoso árbol al que llaman "la bonga": en ese sitio, según cuentan algunos testimonios, se realizaban los actos de asesinato que identifican y atribuyen los habitantes como actos realizados por estas familias. Algunos recuerdan que asesinaban a las personas a las orillas de la cascada que conduce al brazo del río; sin embargo, actualmente la reserva natural Iguana Verde ha utilizado como opción económica la memoria de este conflicto como recorrido turístico para los que visitan la zona: 
Vida campesina en el Magdalena Grande

Claro, precisamente en la reserva hay un lugar que hoy tenemos ecoturístico. [A] la gente que no conoce yo les doy ese tour y les digo qué pasaba en la curva del muerto en la época marimbera. Y los viejos de antes todavía recuerdan: en la bonga hay un brazo donde colgaban a la gente; la bonga todavía está y puedes tomarle fotos. Esa bonga iba a ser talada, pero mi esposa embarazada luchaba, y yo con ella; esperemos que las nuevas generaciones no lo hagan (E. Díaz, comunicación personal, diciembre del 2016).

Imagen 135. Árbol de bonga en la vereda el Mosquito

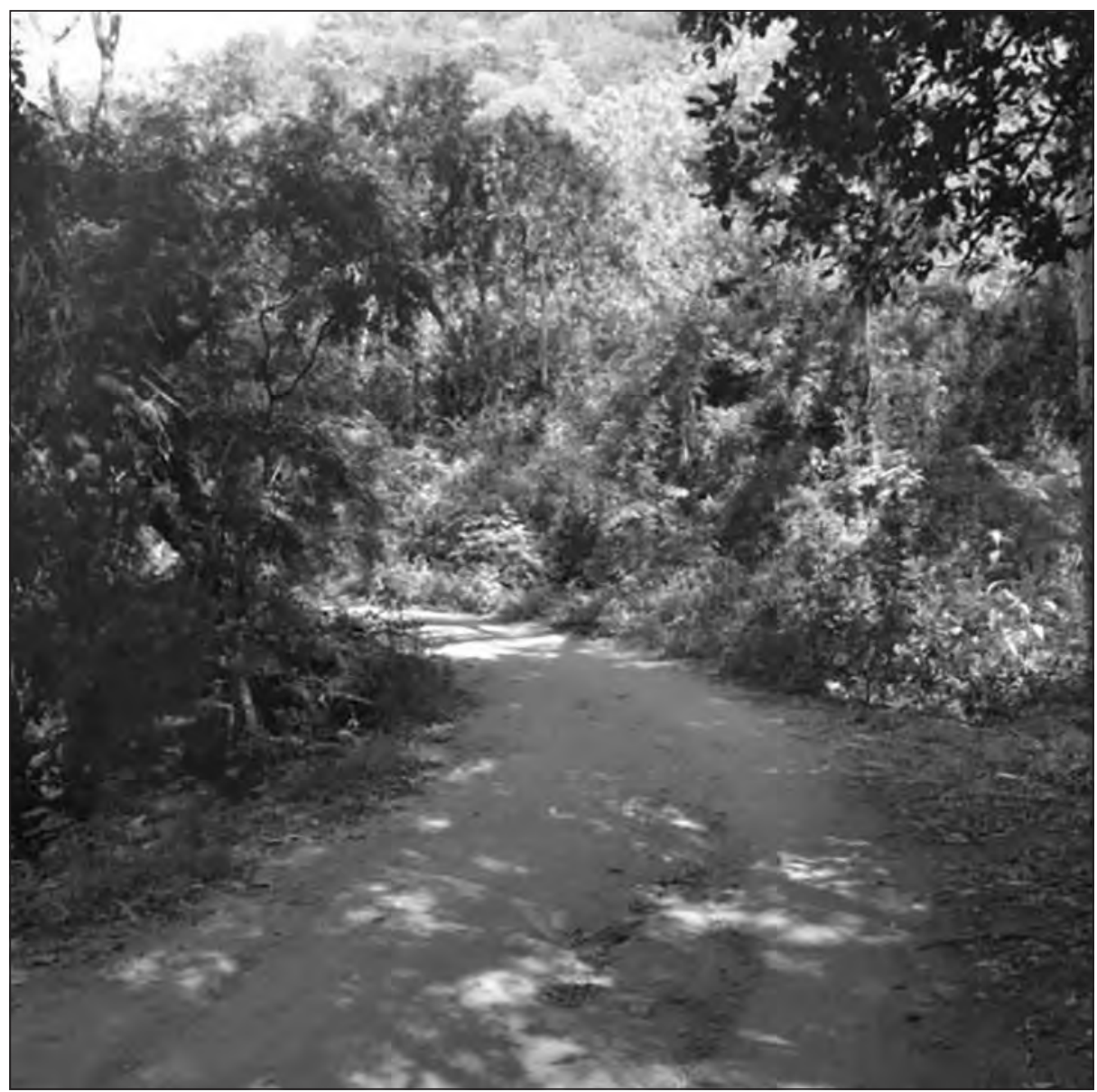

Fuente: Archivo Oraloteca (2017). 
Vida campesina en el Magdalena Grande

Sin embargo, estos no fueron los únicos hechos de violencia que recuerdan que ocurrían en la zona; identificaron también grupos paramilitares que atemorizaron a parceleros en busca de algunos alimentos. La mayoría de los testimonios que se refieren a esto se dirigen más hacia el hecho de que pasaban constantemente grupos con botas pantaneras y camuflados. Los asesinatos en ese momento se cometían contra personas que se escondían como campesinos en la zona, pero que en realidad eran delincuentes en la ciudad: estas eran las llamadas "limpiezas sociales" que hacían los grupos paramilitares. No obstante, los campesinos trabajaban bajo intimidaciones constantes:

Esto era sólido, sólido, yo le puedo decir que por aquí mataron muchas gentes aquí, que yo los veía tirado[s] por ahí. Entonces, como yo tenía necesidades de trabajo y pasando necesidad en la ciudad (porque vuelvo y le digo: fui a tocar las puertas en una empresa y no pude), me coloqué aquí en esta finca, allí. Entonces nos íbamos y nos veníamos el señor Clemente, Jaime Rodríguez - que viven allí- y mi persona. Por aquí habían dos finquitas, más que nada más las estaban viviendo; o sea, podía decir que habíamos como por aquí como unas diez personitas nada más. Entonces estos muchachos se regresaban con temor y yo duré regresándome con ellos y después dije: "bueno, la verdad es que Dios solo sabe lo que puede hacer conmigo" y yo vivo confiado de Dios porque yo soy una persona que no me meto con nadie. Me quedé y ellos me decían: "no te quedes, Rafa, porque te pueden matar". Si estoy pa' morirme me muero, y si Dios me tiene para otro largo tiempo no hay una persona que me mate y yo me voy a quedar aquí (J. Rafael, comunicación personal, diciembre del 2016).

Los grupos al margen de la ley comenzaron cuando comenzó a venir la vaina de la marihuana. Mataron mucha gente en esos cerros pa' quitarle la marihuana. En esos cerros hay gente enterrá que da miedo, por la vaina de la droga. Ya después vino la vaina de la vacuna y el Gobierno no intervenía. Por aquí sacaron una vez a siete personas y las asesinaron, a siete en una vaina tan chiquita, imagínate tú, y eran campesinos. Ahí mataron un amigo mío, un tipo "camellador" que le dio la mano a toda esta gente por aquí. Esa camioneta roja que está allá, esa camioneta me 
Vida campesina en el Magdalena Grande

la regaló él, y yo le daba aguacate, yuca, mango, guayaba... él exportaba y yo con eso le pagué la camioneta. Y lo mataron porque lo confundieron con otro tipo; él era un tipo sano (J. Rodríguez, comunicación personal, diciembre, 2016).

Los habitantes de la vereda el Mosquito se encontraban atemorizados, lo que en efecto ocasionó un desplazamiento continuo de familias hacia la ciudad, quebrando así el tejido social de la comunidad, las cooperativas, las juntas de acción comunal y el compadrazgo entre familias antiguamente congregadas y sumando, además, temor y desconfianza frente a las familias que pretendían asentarse en este lugar. Comenzó a haber presencia continua de grupos con mensajes amenazantes sobre la población por tener indicios de colaboración con grupos guerrilleros. Según puntualizan algunos habitantes, a muchos les quitaban enseres y animales que tenían para su alimentación y que hacían parte de la vida parcelera:

Claro que uno no ha dicho nada. La hija mía no puso el denuncio pa' no está enculebrá, pero una vez yo no bajé donde la hija mía - porque yo todos los días bajaba a comer y ese día no se me dio de bajá - y entonces al día siguiente yo vine acá en la mañana donde los pelaos porque la hija mía estaba sola. Los pelaos fue [los] que me dijeron: "abuela, aquí ayer como a las cuatro de la tarde vinieron un poco de hombres disfrazados como de soldado, fusil, machete, puñal, cabuya y una hacha". La hija mía venía a comprar desayuno y se los encontró, se la llevaron pa' la casita y allá, mejor dicho, le registraron la casita, le buscaron en el escaparate, se la llevaron pa' Metroagua y entonces llegaron a Metroagua, ahí la sentaron a ella y los pelaos asustaos, porque se querían como llevar a los pelaitos. Ahí cogieron a dos de Metroagua, los amarraron, le[s] quitaron celular y le[s] quitaron el radio de comunicación, se llevaron todo. Después fue que los soltaron, pintaron ahí en una pared, todavía se ven una[s] letras, que dice y que: "fuera AUC".

Bueno, ya después otro día que subieron otra vez, pero no hicieron nada. Pasaron por allá por mi casa; yo no estaba ahí, estaba la yerna mía, que era familiar. Yo estaba cuidando ahí en la finca porque yo cuidaba de noche, 
Vida campesina en el Magdalena Grande

yo sola, y entonces yo miré así pa' arriba que fui que los vi que venían tres cruzando de aquel lado del río pa' acá. Yo miré de lejos, ¿cierto?, y yo decía: "el ejército no carga botas de caucho". Yo dije: "¿quién saben quién serán?, ¿serán unos bandidos?, y yo me puse a barrer. Pasaron por allá: "seño... buenos días; no, buenas tardes, buenas tardes", yo estaba nerviosa, pero bueno, y yo pidiéndole a Dios que se fueran rápido. Llegaron: "regáleme un poquito de agua". Yo le[s] regalé el agua para que se fueran rápido porque yo sabía que no era el ejército. Así como ellos llegaron, así arrancaron pa' allá y yo me escondí. Como yo paraba sola ahí de noche, yo me les escondí pa' arriba del cerro... pueda ser que cuando vuelvan me vayan a reventar la puerta. Me trepé arriba del cerro... a las siete de la noche se iban trotando (C. Ortiz, comunicación personal, diciembre del 2016).

Muchas de las zonas rurales en la ciudad, que hacen parte de los poblados reconocidos por su creciente dedicación a la agricultura debido a la cercanía con la Sierra Nevada, se han construido a raíz del desplazamiento interno a los que se han visto obligados los habitantes de este país como producto del recrudecimiento del conflicto social y armado en gran parte del territorio nacional. Esto no fue una excepción para el caso del departamento del Magdalena; en este caso, la vereda el Mosquito ha tenido, desde hace más de 30 años, una creciente actividad poblacional. A sus adentros hay nuevas familias que han empezado a asentarse y se han dedicado a la agricultura. La mayoría de esta población ha sido desplazada por el conflicto armado en el departamento del Magdalena, registrándose procedencias de Fundación, Algarrobo, la Zona Bananera, el Banco y Pivijay, que claramente contienen una memoria funesta sobre su desplazamiento y la presencia continua de grupos armados en sus territorios de origen.

De esta manera, el análisis de un campesino urbano que se ha gestado a partir del desplazamiento de los municipios cercanos implica detenerse un momento a mirar los diferentes momentos de conflicto que vivieron las comunidades antes de situarse en esta parte del departamento, como un elemento importante para entender la transformación de los modos de vida campesina. Este análisis va dirigido específicamente a las personas que son más recientes en el territorio porque, como vimos atrás, las 
Vida campesina en el Magdalena Grande

familias que poblaron la vereda el Mosquito son familias que precisaron vivir en el territorio durante el conflicto entre guerrilla y paramilitares, pero que resistieron ante todos los casos presentados. Sin embargo, la misma razón de esa creciente actividad migratoria hacia la vereda genera gran preocupación a los campesinos más antiguos de la zona, quienes perciben con desconfianza el aumento poblacional y temen que pueda haber nuevos momentos de violencias en la zona por la incierta procedencia de los nuevos habitantes:

Sí, esa época hace para mí hace 20 años más o menos, 22 años estoy yo por acá dando trampolines porque yo llegué primero por acá. Por allá en esa época sí recogíamos muertos, tirábamos muerto[s] a los cementerios, eh... asustaos ya, pero asustado y confiao' en Dios de que nosotros no andábamos en cosas malas ya, entonces por eso andábamos un poco confiao' y que a uno a veces le arrebataban compañeros de las manos de uno, le decían: “vamos a llevárnoslos pa' que nos arregle el carro que se nos quedó varado allá" y nosotros, en vista de la demora del compañero, íbamos a buscarlo y lo encontrábamos era muerto. Entonces ese era el temor de nosotros, que de pronto sacaran a uno de nosotros porque nosotros somos 9 y todos 9 andábamos en carro ya. Entonces, nos daba miedo eso, entonces fue cuando decidimos abrirnos a regarnos, estamos todos regados: hay unos en Barranquilla trabajando en una empresa, aquí nada más hay una sola hembra, ella es costurera, tiene una cuestión que ella misma [ha] montado ahí y nosotros todos nos regamos, así aquí somos 2 nada más. Había unos grupos que recuerdo, ahí en ese grupo participaba el marido de una prima hermana mía que creo que por eso nos salvamos también, porque precisamente yo estaba en lista para matarme y mi sobrina me ayudó a saca[r] de la lista. ¿Por qué ellos me colocaron a mí en una lista? Porque yo supuestamente participaba con la guerrilla, porque yo manejaba de Fundación a Sacramento, cosa que jamás he tenido un fusil en la mano, no sé disparar una arma, ¿oyó?, y estaba colocado en lista porque ellos dicen que nosotros éramos colaboradores. No, a uno se le monta el policía, se le monta el soldado, se [le] monta el del grupo tal, porque uno no le pide ninguna identificación a la persona, entonces por eso mataron a los compañeros de nosotros (J. De la Cruz, comunicación personal, diciembre del 2016). 
Vida campesina en el Magdalena Grande

Nosotros nos vinimos porque allá hubo muchas balas, mucha violencia: la guerrilla, los paramilitares estaban molestando. $\mathrm{O}$ sea, yo me quedé allá porque como yo me casé con el papá de los hijos míos... mi mamá sí se vino con la niña mía y después, ya al poco rato, se metieron los paracos allá a molestar, a hacer de las suyas. Ahí en eso, en el 2005 mataron al papá de los hijos míos. Allá se formaba la guerrilla, cogía, una vez le metió una bomba a la estación de Minca y por aquí y que también se metieron. Los hermanos míos sí deben contarlo bien, porque por aquí sacaron varias personas y los mataron.

A mi esposo lo mataron en el 2005, el 26 de julio del 2005, yendo del corregimiento de Tigrera para Minca. A él lo mataron ahí y yo la verdad, yo hice las vueltas, busqué unos papeles y los metí allá en Acción Social en la Justicia y Paz, y eso tuve hasta audiencia con el que lo mandó a matar a él, conjunto con otro. Sí, yo tuve audiencia con una de las personas estas, con ellos pues, pero dijeron que son varios involucrados ( $\mathrm{N}$. Pimienta, comunicación personal, diciembre del 2016).

Bueno, el pueblo era un pueblo sano, un pueblo sano, también un pueblo de agricultura, pero la violencia lo cogió y lo azotó mucho y eso se acabó por allá, la mayoría del pueblo fuimos desplazados y allá quedamos todos regados. Ya no hay gente como [de] la edad mía, ya son los que están llegando nuevos y que están volviendo a retornar al pueblo, que son ya de los nuevos, la mayoría. Y muchos compañeros [a los] que los mataron, los desaparecieron, entonces los que quedamos fue poco[s] y estamos ahí regados ya. Ya uno va al pueblo y es desconocido, ya hay gente nueva trabajando. Unos quedaron en Santa Marta, otros en Barranquilla; el pueblo se acabó. Uno pierde todo, perdimos todo, dejamos la casa y todo se quedó, todo, todo, salimos nada más con lo que teníamos y volver a empezar de nuevo, pero gracias a Dios aquí estamos y ya nos volvimos a recuperar (J. De la Cruz, comunicación personal, diciembre del 2016). 


\section{Ser campesino en la vereda Mosquito: memoria oral y realidades concretas}

Imagen 136. Papaya en manos campesinas

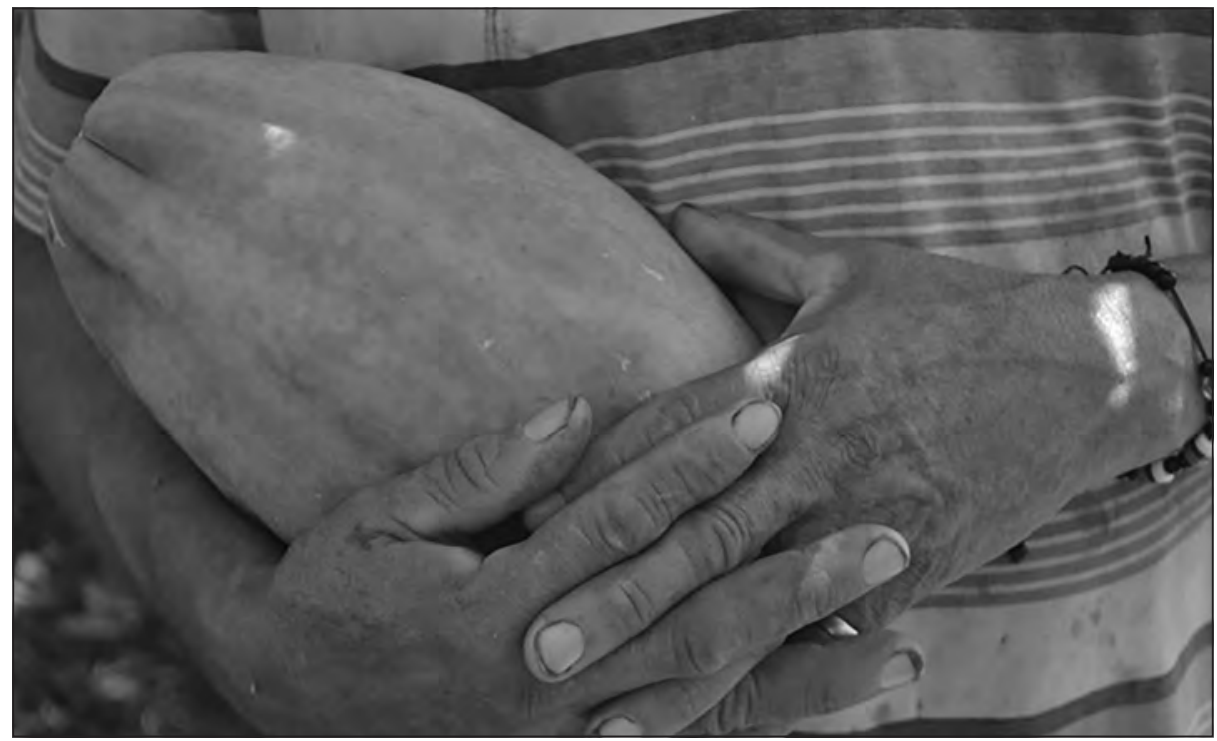

Fuente: Archivo Oraloteca (2017).

Las campesinas y campesinos de la vereda el Mosquito, Paso del Rosario, la Planta y el Canal se mueven en ciertas dinámicas sociales y culturales no muy diferentes a las que se dan en los demás corregimientos del Magdalena Grande; sin embargo, estas lógicas tienen particularidades que se van construyendo a través de las narrativas orales, la memoria, la llegada de nuevas personas de otros lugares del país y hechos como el conflicto armado. Estas vicisitudes de la vida del campesino en estas tres veredas se expresan en sus propios conocimientos sobre la naturaleza, en las dinámicas de subsistencia y en las relaciones sociales. Llegado a este punto es necesario empezar a encajar diferentes preguntas sobre lo que es "ser un campesino" en una zona no muy lejana al distrito de Santa Marta, pero, más que eso, es necesario observar esas complejidades que a ellos los hacen sentirse campesinos - además de sus conocimientos y de las luchas que han tenido que asumir desde la población del lugar- y, a partir de ahí, las construcciones culturales que se han establecido: 
Vida campesina en el Magdalena Grande

Ah... porque... cómo diría. Ah, cuando yo sembraba, ah, bueno, a mí me llenaba de orgullo porque cuando yo estaba sembrando decían "fíjate, mira ella cómo limpia, cómo siembra", y yo le decía "bueno, yo quiero que así lo hagan ustedes mis hijos, que sean unos hombres, hombres de pantalones", se reían. Ah... y mis hijos, mis hijos, ellos son campesinos. Este que está aquí desde los cinco años, él dice que para irse para el pueblo es que tenga la casa de él, pero así que para ir a pagar casa tan chévere que él está por acá, entonces no se va (C. Ortiz, comunicación personal, diciembre del 2016).

La transmisión de los conocimientos de generación en generación en la vida de los campesinos es evidente. La gran mayoría de ellos afirma haber adquirido las sapiencias de sus abuelos o de sus padres, en el caso de los más jóvenes. Es necesario recalcar que coexisten muchas formas de enseñanza; sin embargo, varias de estas tienen que ver con la práctica directa de la relación con la naturaleza y, en gran medida, con la observación que se asuma por parte del que quiera aprender:

Sí, claro, mi papá nos enseñó mucho a trabajar y a la agricultura. Mi papá tuvo varias fincas; entonces uno se adaptó al monte y entonces cuando la vaina de la violencia, que salimos, ya nos sabíamos defender, ya sabíamos cómo era sembrar unos palo[s] e’ yuca, una mata de plátano. Mis padres nos enseñaron desde muy pequeños a la agricultura y a todo. Nos llevaba desde muy pequeños, nos ponía a limpiar, nos ponía a sembrar la matica y él... o sea: "esto se siembra así, la matica, y esto así"... ahí nos explicaba y ahí aprendimos. Entonces, ya cuando la violencia, como nosotros éramos transportadores en unos carros de pasajeros, cuando se azotó ya la gente no, ni viajaba, entonces nos vinimos para el monte y nos defendimos porque ya sabíamos a la agricultura y eso (J. De la Cruz, comunicación personal, diciembre del 2016).

La relación con la tierra es de suma importancia en el proceso de adquisición de conocimientos para los campesinos, como es perceptible en la cita anterior y como fue evidente en otras conversaciones orales con campesinos de la zona. Para ser campesino se necesita cierto tipo de sabidurías sobre su entorno y, para alcanzar esos conocimientos, se 
Vida campesina en el Magdalena Grande

necesita tener una relación con el lugar - que muchas veces pertenece a otros propietarios- a partir del cual surgen compromisos con la vida del campo:

Eso más o menos se aprendió ahí, pero yo estudié en el Sena Agropecuario, fuimos de los primeros egresados. Hace cincuenta años yo estudié Industrias Menores y William, Ganadería. Nosotros comenzamos a sembrar, por tradición de mi papá, desde niños. Esa granja la hacíamos nosotros, mi papá hacía hornos y yo lo cuidaba, me tocaba cuidarlo a los cinco años, seis años, y de allá caminaba cinco kilómetros a buscar los burros... y ahora los nietos míos no quieren caminar, ahora hay que llevarlos y traerlo[s] (J. Zúñiga, comunicación personal, diciembre del 2016).

Además de los saberes tradicionales que adquirían los campesinos por medio de sus padres y abuelos, y por medio de metodologías diferentes a las que se dan en entornos académicos — pues aquí son más participativas y con vínculos familiares más directos-, algunos de los campesinos de esta zona tuvieron oportunidades de estudiar en el Sena por su cercanía a la vereda.

Imagen 137. El campesino y su parcela

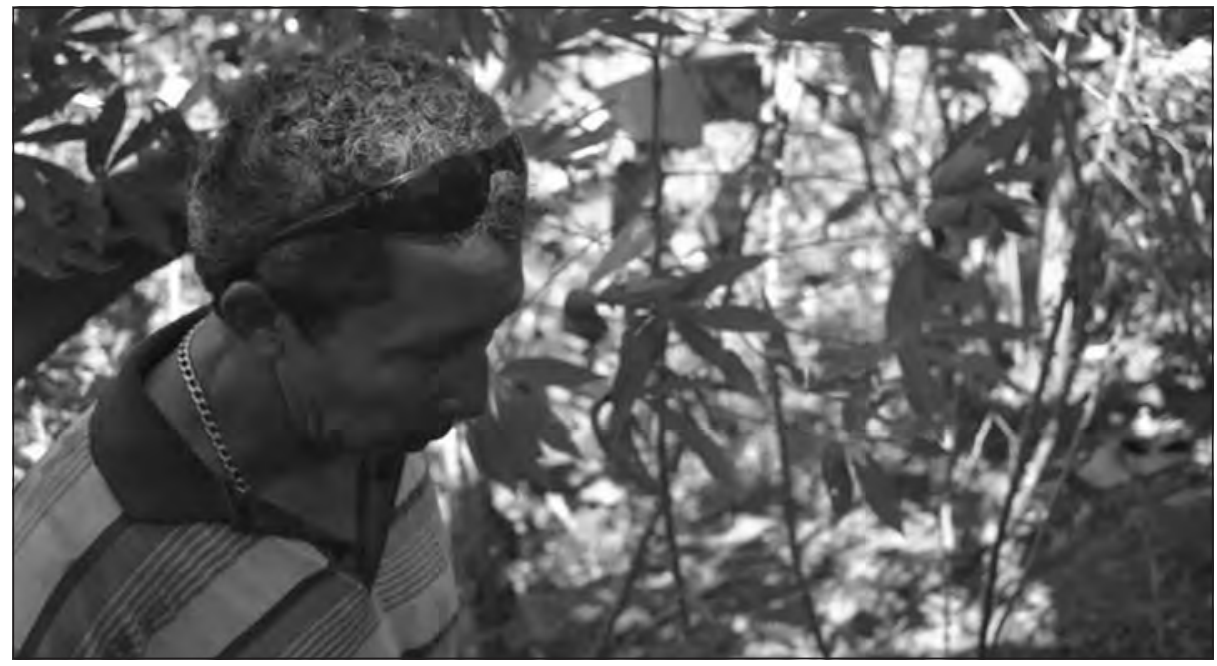

Fuente: Archivo Oraloteca (2017). 


\section{Saberes locales y dinámicas de subsistencia}

Los campesinos de la vereda el Mosquito se encuentran en una preocupación constante por la pérdida de los conocimientos tradicionales del campo y por el desinterés cada vez más notable de los jóvenes hacia la agricultura; por este motivo, tratan de involucrar, en la mayor medida posible, a los más pequeños en las tareas del campo. Sin embargo, muchos campesinos tienen una idea clara de que los menores deben ir a estudiar pues, aunque reconocen que las tareas del campo son de vital importancia para el ser humano, también afirman que hoy el campesino está abandonado por el Gobierno, no tiene garantías y, poco a poco, se irá acabando.

Imagen 138. Adaptación para el sistema de riego

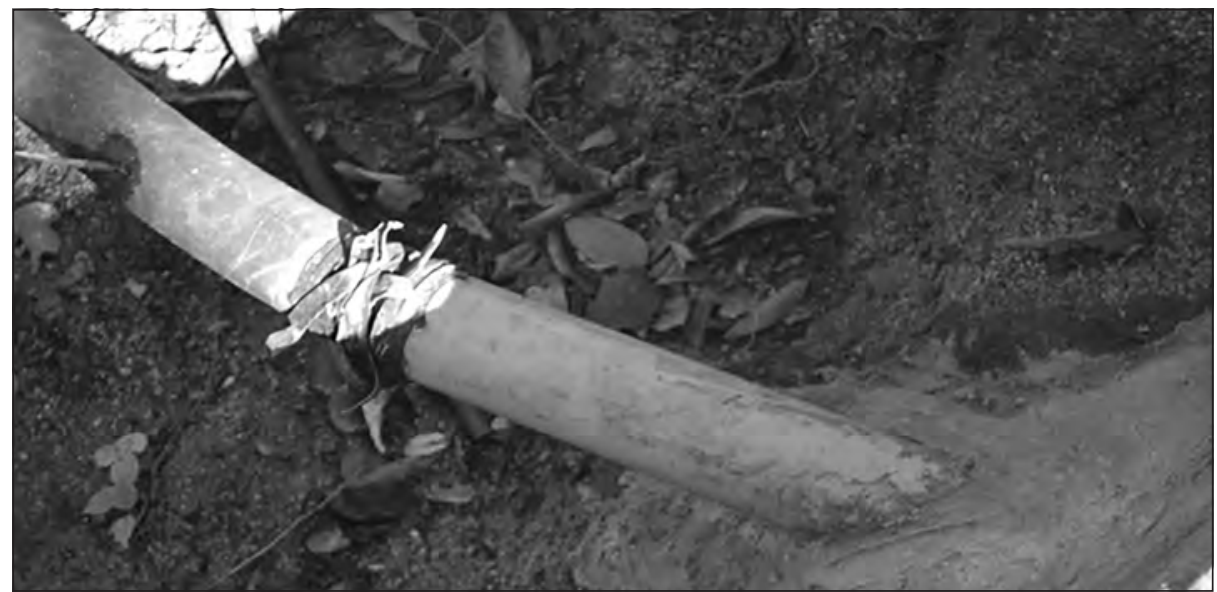

Fuente: Archivo Oraloteca (2017).

Las principales actividades económicas en las veredas el Mosquito, Paso del Rosario, la Planta y el Canal son la agricultura y avicultura, por lo cual el río es un elemento de suma importancia para los habitantes de la zona; sin embargo, el acceso al afluente de agua se presenta como una dificultad para los pobladores de estas veredas, pues muchos de ellos no cuentan con el servicio de acueducto domiciliario, lo que obedece a una segregación por parte de la empresa prestadora de este servicio (más aún estando ubicada a pocos kilómetros del centro de abastecimiento). No 
obstante, la comunidad crea tecnologías propias para un sistema de riego con el cual solventar el abandono estatal y poder cultivar sus tierras. Una de ellas consiste en utilizar las obras abandonadas por la Electrificadora del Magdalena, mediante la introducción de mangueras en un canal que trae y estanca el agua de la Montaña y la deposita en el centro de abastecimiento conocido como la Planta:

Allá arriba hay unas tomas que eso saca[n] el agua para la vía de Minca y un poco de finca[s] que empiezan de allá para acá. Aquí hay sesenta fincas y son sesenta mangueras de esas de a pulgada, de a dos pulgadas, que le jalan. Y el río se puso poquito y tuvimos una crisis de agua el año pasado. Aquí se perdió la mitad del cultivo porque el "reguío" era poquitico, el río le sacan mucha agua y le han sacado mucha tierra arriba. Por aquí tumbaron, allá había un manantial que le daba agua a uno por aquí el año antes pasado y ahora está seco porque el dueño de la finca le sacó toda la madera y se secó, y ese canal salía de ahí chorro de agua. Entonces, de aquí para arriba también hay quebradita... le han tumbado la madera y todo eso se ha secado y eso le afecta el río porque ya no le colaboran las quebraditas porque se han secado (J. De La Cruz, comunicación personal, diciembre del 2016).

Imagen 139. Manguera del sistema de riego de la vereda Mosquito

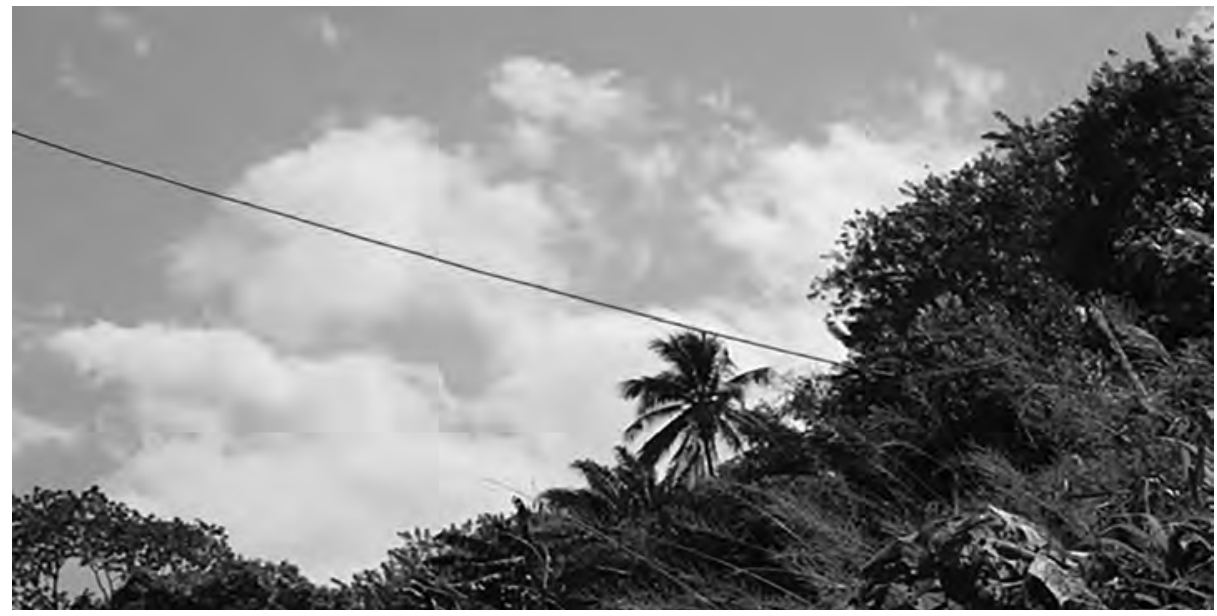

Fuente: Archivo Oraloteca (2017). 
Vida campesina en el Magdalena Grande

Este sistema de adaptación a las ruinas de un proyecto que tuvo su momento importante en la historia del pueblo es lo que les permite hoy a los campesinos y campesinas de la vereda el Canal mantener sus cultivos con un sistema de riego necesario para el sostenimiento de las plantas y árboles; sin embargo, al mismo tiempo, las aguas naturales del río a pocos metros están siendo absorbidas por dos tubos de veinticinco pulgadas cada uno, agua que poco después llegará a los principales destinos turísticos de la zona como el Rodadero y Pozos Colorados. Uno de los problemas que sufren hoy los campesinos y campesinas del lugar es la adquisición de metros y metros de mangueras, pues el Canal está relativamente alejado de las parcelas de los pobladores, lo que al mismo tiempo los limita a sembrar, pues no tienen la cantidad suficiente de tubos con los cuales acceder a todas las hectáreas de tierra, ocasionando que un gran porcentaje de las tierras siga sin ser intervenida por los habitantes.

\section{La agricultura y su relación con la naturaleza}

Los conocimientos y prácticas relacionadas con la agricultura se realizan todo el año. La yuca, el plátano, la guayaba, son los cultivos que más producen mensualmente, siendo usados por campesinas y campesinos para el abastecimiento propio. Son muy pocas las familias que comercializan estos productos; sin embargo, el conocimiento acumulado alrededor de la siembra, el mantenimiento y la cosecha de estos productos se transmite a través de la práctica en la parcela:

Para sembrar la yuca primero hay que "ollala", "ollala", y después ya uno le pone el agua y "reguío", que la tierra esté ya lista y pone el palito. Eso hay que esperar el tiempo: cuando la luna esté nueva no sirve porque la plantica no produce, sale mala, y entonces uno espera el tiempo de la luna y siembra. Yo ya sabía porque mi papá decía "no, vamos a esperar que la luna esté buena para sembrar"... entonces ya uno fue cogiendo y uno fue aprendiendo, ya uno sabe cuándo la luna pasa, ya no la ve delgadita, ya la luna pasa hoy o mañana, cuando ya a los tres días ya uno no la ve, ya sabe que pasó... a los cuatro días, dura uno[s] cuatro días oscuro, a los cuatro días ve uno la luna liviana ya. Ya de ocho días en adelante ya la luna esta gruesecita; entonces, uno puede sembrar (J. De La Cruz, comunicación personal, diciembre del 2016). 
Vida campesina en el Magdalena Grande

Hay una ahuyama que no tiene sabor, es fea y le dicen "ahuyama de burro". Por ejemplo, yo cuando voy a sembrar voy a mercado y le veo el color, la compro, primero hago el sancocho, la pruebo y, después, la siembro: por el color, el color de la ahuyama es como la flor, que tenga buen canto [comida lo que se come], que no sea tan tripuda, hay una que es muy tripuda. Esa casa que está ahí en la Planta, donde estaban los celadores, yo dormía allá con ellos y en un cuarto yo puse como 3 mil ahuyamas. Ahora no, la contaminación de la ciudad hace que sufra mucho el campesino, toda esa ahuyama se enferma por la ciudad. Ponte tú ahorita en la mañana y pasa la mano por la hoja de un palo de mango, te queda como un aceite, y el árbol sufre, el árbol es un ser viviente como nosotros.

Aquí en Santa Marta hay un deterioro del ser humano que a mí me da tristeza. A veces no quisiera ni hablar de esa vaina, ya la gente no le tiene amor a la vida. Imagínate: si el querer del ser humano es el que uno mismo se tiene, el que tú te das para seguir viviendo, y uno se quiere respetando la vida, respetando a los demás, todo eso son las cosas que lo hacen a uno ser buena gente y cumpliendo esas cosas llegas más allá de la naturaleza. Compadre, un ejemplo, si tus padres no te dan educación, no te enseñan nada de la vida real y llegas a los 20, pasas necesidad; por eso yo converso con mi señora y le digo: "mija, a mí me enseñaron a trabajar, no como ahora que no se puede, el trabajo lo enseña a uno a ser mejor persona, hay que conducirlo al trabajo". Si mi señora y yo estamos enfermos, y tenga un pelao' de 14 años que no esté haciendo nada: "mijo, vende estas arepas que eso es para tu comida". El trabajo no mata a nadie porque si no yo ya estuviera muerto, toda la vida he trabajado y trabajo duro (J. Rodríguez, comunicación personal, diciembre del 2016).

Como parte de ese acumulado de conocimientos transmitidos de generación en generación se encuentran las formas de atender los cultivos durante su desarrollo, de manera que puedan enfrentar las adversidades del clima, el terreno, la contaminación y una que otra plaga y maleza que los ataca. Estos conocimientos han sido adquiridos por los padres y abuelos, o por medio de cartillas que han leído o cursos cortos que ha dictado alguna fundación o el Sena, además de sapiencias que se van divulgando entre los campesinos nuevos que llegan a la zona: 
Vida campesina en el Magdalena Grande

Yo hago un preparativo con azufre y cal, entonces metes todo, pero que quede todo sumergido en agua, ahí los dejas veinte minutos, a los veinte minutos eso te sale negrito, todo eso se cura y el hongo se muere, la mata de guineo te sale limpia de Sicatoca. Si buscas para arriba, donde están esos cafetales, en los cafetales donde están los arroyitos hay guineos grandes, y yo allá me puse a ver el sistema y, ¡tan!, una mata doblada para el arroyo. Y dije: "mirá esa mata de guineo, mire como tiene la Sicatoca, y esa mata está sobre el arroyo, las hojas en el agua, y ese arroyo va a templar al río y después se la metemos a los cultivos". Cuando se va a curar, tú coges una hoja de guineo, ella tiene un polvillo, y pega la brisa y se riega; eso se produce por humedad (J. Rodríguez, comunicación personal, diciembre del 2016).

Entre las problemáticas que enfrenta el campesino hoy en todo el Caribe colombiano el abandono del Gobierno es la más evidente: la falta de políticas públicas hace que hoy el campesinado esté pasando una de las etapas más difíciles después del conflicto armado. Sin embargo, los procesos de resistencia y el amor al trabajo han hecho que no solo se mantengan los conocimientos populares a través de las oralidades - que ayudan a transmitir los saberes nuevos, creados como respuesta a los cambios del clima y el territorio-, sino que también las campesinas y los campesinos se hayan adaptado al espacio, conociendo la tierra y transformando la territorialidad, teniendo en cuenta que las tres veredas son montañas altamente inclinadas. Hoy el campesinado crea tecnologías que usa para transformar el espacio y adaptarlo de tal manera que le sea posible sembrar su cultivo, además de esparcir la labranza con cierto orden que le permita, al regar, humedecer todos los árboles con el agua; a esta forma artesanal de garantizar el riego de todos los cultivos le llaman "surco", herramienta que puede ser utilizada para cualquier tipo de cultivo como la yuca, el mango y plátano.

\section{La economía campesina en contextos urbanos}

Además del conocimiento que tienen las campesinas y los campesinos sobre la agricultura, muchos de estos ciudadanos también tienen otros quehaceres que pocas veces ejercen debido al tiempo y al esfuerzo 
Vida campesina en el Magdalena Grande

que le dedican a la agricultura, que les impide generar recursos económicos a través de otros medios de producción como la ebanistería, albañilería y mecánica:

[A] algunos les toca solo ese conocimiento de ser campesino, con el solo conocimiento de sembrar la matica porque no tienen, no han tenido otra oportunidad de aprender, pero todo lo que usted aprenda en esta vida es necesario porque usted no sabe en qué momento queda varado con su buen empleo que tiene, por muy buen empleo que tenga la persona se le llega el momento que queda desempleado, entonces usted se defiende con otra actividad que ya usted se sabe, entonces es muy importante aprender de todo en esta vida (J. De La Cruz, comunicación personal, diciembre del 2016).

Hoy también se ve reflejada, en los modos de vida de los campesinos de la vereda el Mosquito, la articulación de estas nuevas formas de trabajo entre las que se encuentra el jornal, la extracción artesanal de carbón a la que hoy se dedican algunos campesinos para el sustento diario; aunque esto ha conllevado a diferentes discusiones medioambientales entre habitantes de la zona, la limitación de oportunidades laborales, la falta de tierras para sembrar y la falta de acompañamiento estatal conlleva a que las poblaciones se vean obligadas a usar estos mecanismos de subsistencia.

\section{Imagen 140. Extracción artesanal de carbón}

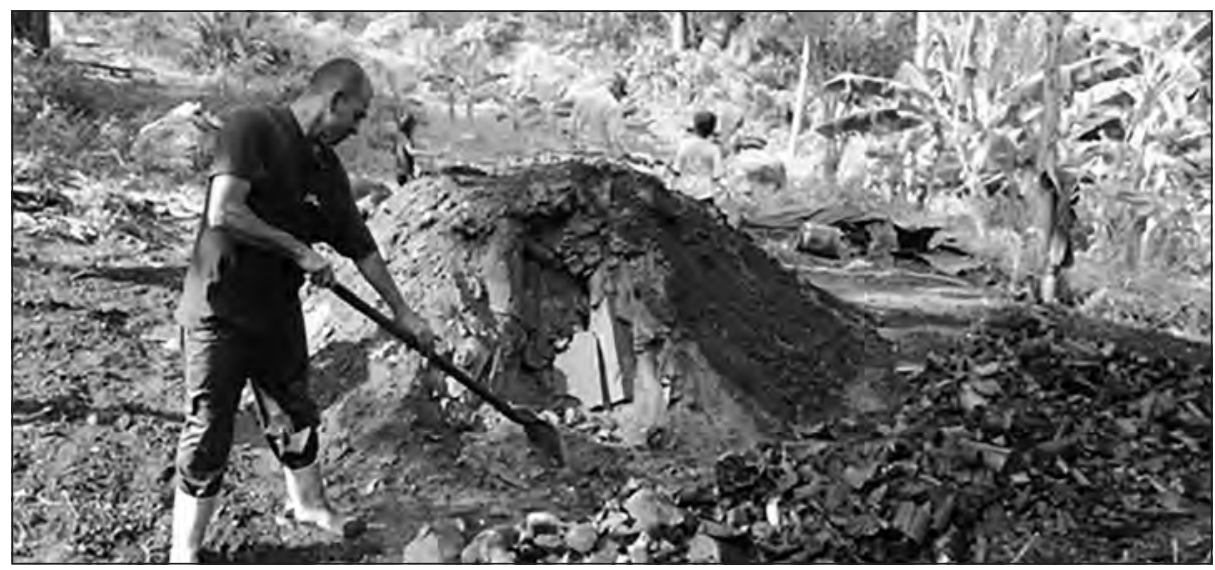

Fuente: Archivo Oraloteca (2017). 
Vida campesina en el Magdalena Grande

Yo comencé en el carbón con mis tíos, ellos me enseñaron, cuando tumbábamos me enseñaron. Ellos decían que para uno no metele candela se queme, uno lo coge mejor para otra cosa. La policía pone problema. Aquí no nos dicen nada, el problema es que cuando uno lo saca para la venta nos lo quitan. Entonces uno pierde trabajo, pierde todo, uno va con ánimo de venir a traer un poquito de comida para la casa y en el camino queda uno con las manos vacías (A. Orozco, comunicación personal, diciembre del 2016).

A pesar del daño ecológico que produce la extracción de carbón artesanal, observado en la tala de árboles, es notorio que los demás campesinos del lugar no se muestran muy en desacuerdo con esta actividad; incluso algunos campesinos prestan sus tierras para que laboren y puedan conseguir para "la comida de los hijos", como dicen algunos campesinos del lugar. Sin embargo, en la reserva natural Iguana Verde hay una notable oposición a la práctica, manifestada por uno de sus administradores, también Campesino, el señor Elías Díaz, de la Vereda Paso del Rosario o la Planta:

Lo que está intervenido lo reforestamos con frutales nativos, pues eso ha ayudado a que las especies vengan siempre y coman, estén comiendo ahí y se mantengan en el lugar. El bosque nativo lo hemos dejado recuperar, pues no dejamos que nadie queme la ronda hidráulica izquierda y derecha que hemos estado protegiendo por tanto tiempo y lo hemos declarado reserva. El mismo Ministerio del Medio Ambiente de Bogotá vino acá e hizo la caracterización y dijo: "esto hay que protegerlo", porque se encontraron estas especies que están en vías de extinción y accedieron a declararlo reserva natural y hoy en día [es] la Reserva Natural Iguana Verde; ya por lo menos la gente la respeta. Antes había mucho conflicto con muchos de aquí de la misma región porque yo no los dejaba pescar, yo les decía: "oye, pero pesca en la entrada o en la salida, esta reserva la permitimos para que ellos se reproduzcan, ellos no se van a aquedar aquí, ellos salen, entones aprovechas y los coges, así siempre va a haber", pero hoy en día ya vemos que no siempre va a haber así, eso se está acabando (E. Díaz, comunicación personal, diciembre del 2016). 
Vida campesina en el Magdalena Grande

Como en la mayoría de los pueblos del Caribe colombiano, en las tres veredas también nace el mototaxismo como una dinámica de subsistencia diaria, sobre todo en los jóvenes de la región quienes, al terminar su secundaria, consiguen una moto y se dedican a transportar el personal de la localidad, desde la entrada del SENA hasta la vereda:

Pregúntale a uno de esos para ver si ellos quieren venir a tirar machete [risas]... ese mototaxismo, eche'. Mira, cuando un niño está pequeño todo lo quiere fácil y le gusta investigar. Yo tenía una hermana y el niño Dios le puso a una hermana mía, en aquellos tiempos que no había modernismo, le regalaron una muñeca que lloraba, y un hermano mío la cortó y le sacó para ver qué era lo que lloraba y le metieron una limpia... el ser humano es así: si a ti te dan tus estudios, te dan plata todos los sábados, te tomas tus traguitos. Los padre[s] tienen que educar a sus hijos. Yo estudiaba de día y de tarde, pero los domingos tenía que ir a misa; ahora nada de esa vaina, en los colegios no enseñan nada. Tú le preguntas a un niño qué es un quintal métrico, no sabe; un kilogramo, no sabe; entonces, ¿qué es lo que educan? Yo no entiendo. En los colegios había que hacer fila y nos ponían a cantar el himno nacional. A este país [...le] falta educación, educación de los padres y educación del Estado (J. Rodríguez, comunicación personal, diciembre del 2016).

Sin embargo, no hay que dejar de lado que muchas personas de la comunidad, sobre todo de las veredas más lejanas, aprovechan en gran manera el mototaxismo pues es el único medio de transporte. Aunque hoy los hijos de los campesinos estén optando por comprar una moto, ante la falta de oportunidades - no solo educativas, sino también dentro del agro-, de igual modo el mototaxismo es ahora un elemento de transporte de gran importancia para la comunidad ya que es el mejor medio para transportar los productos ante la falta de vías adecuadas para el ingreso carros:

Antes del mototaximo, eran bicicletas. El mototaxismo tiene ahora como ocho años y la mercancía en carro. Y los que no tenían carro, en burro. Acá subía un carro todos los viernes que era el que la gente usaba como transporte (J. Zúñiga, comunicación personal, diciembre del 2016). 
Vida campesina en el Magdalena Grande

\section{El campesino y el turismo}

Entre esas dinámicas de subsistencia también se encuentra el turismo. Para muchos de los campesinos el paseo de olla no es una amenaza pues dicen que son los mismos nativos los que tienen los negocios y las comidas que preparan las hacen con los mismos productos que siembran; sin embargo, la contaminación ambiental es evidente y, para algunos, es un problema grave que hay que solucionar. Así mismo, terratenientes se están involucrando en el negocio, apostándole a la venta de bebidas alcohólicas:

Ha sido bueno porque esa es la idea, que esto va a ser una zona turística, entonces entra mucha gente turista a bañarse y a beber, los sábado[s] y domingo[s] el turismo entra bastante. Entonces, la idea es ir organizando los negocios porque esto va a ser una vereda prácticamente casi como el Rodadero: turística bastante, llega bastante gente, carro, de cuanta vaina (J. De La Cruz, comunicación personal, diciembre del 2016).

Ahora la gente de la ciudad mira el problema de la temperatura, la gente se viene para acá, la misma necesidad produce el turismo. Entonces vienen acá y es una ayuda al campesino. Lo que pasa es que esto aquí hace falta asfaltarlo, esto sería una belleza, de acá la gente no sale. Me estuvieras entrevistando en Santa Marta, estuviera secándome el sudor. Esto por aquí falta es organizarlo, aquí esto es para explotarlo e invertirle más al río porque donde tú pises para Bahía Concha o Taganga tienes que pagar. Nosotros no[s] la pasamos por ahí haciendo aseo, entonces hay gente que quiere venir a hacer sancocho y se va, entonces después tengo que yo limpiar lo que hay ahí; entonces debería ser que pagaran y uno colocara la leña y todo. ¿ Si no estuviera el campesino quién va a cuidar? Y acá no es caro la sopa (J. Rodríguez, comunicación personal, diciembre del 2016).

\section{Elmango}

Es vital mencionar que la práctica de recolección de mango en las tres veredas cumple un papel de mayor importancia en relación a otros cultivos, acompañado de frutales como el aguacate en la vereda el Canal, donde el clima disminuye y es más rentable para los terratenientes del lugar. 
Vida campesina en el Magdalena Grande

La producción del mango se da cada dos meses y los cultivos están en la zona desde sus inicios; sin embargo, la recolección del mango para la venta se da hace unos cuarenta años. Los campesinos y terratenientes no tienen una organización conformada que les garantice mejores condiciones de comercialización; es por eso que ellos mismos dicen que terminan "vendiendo al mejor postor" que, muchas veces, es la misma persona que tiene los contactos con las empresas y el interior del país:

El mango, si tú lo compras en un vivero ya de dos metros de alto, a los dos años ya hay mangos; si metes la pepita, ahí sí cinco años. Los hijos míos recogen el mango, dos hijos varones que tengo yo... tengo tres, pero hay uno que no viene, y a veces los indígenas, yo meto como a seis personas a recoger mango (J. Rodríguez, comunicación personal, diciembre del 2016).

Igualmente, el proceso de recolección de mango es importante para los pobladores de la región no solo por las oportunidades de trabajo que este genera, tanto para mujeres como para hombres, sino también para los jóvenes indígenas con los que los campesinos mantienen buenas relaciones.

Imagen 141. Campesino recolector de mango

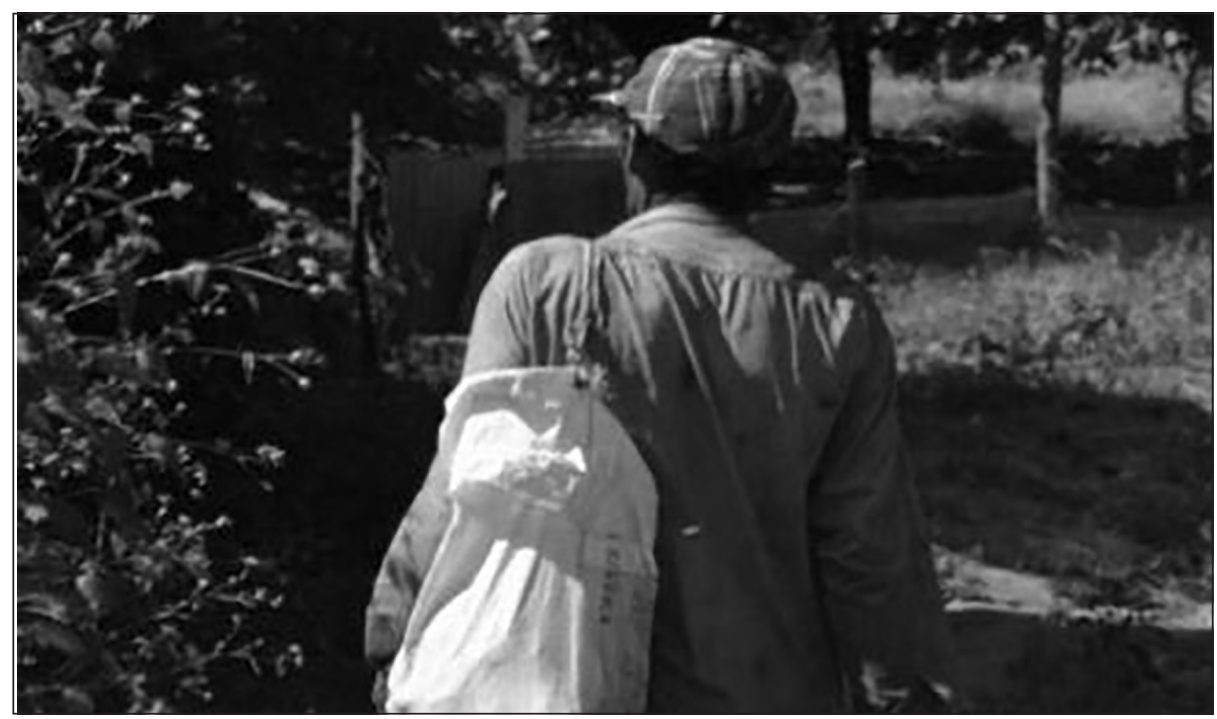

Fuente: Archivo Oraloteca (2017). 
Vida campesina en el Magdalena Grande

\section{La tierra}

Otra de las mayores afectaciones que tienen hoy las comunidades campesinas del sector es el problema de la posesión de la tierra. Muchos de estos campesinos hoy viven cuidando parcelas, trabajo del que muchas veces no reciben ninguna garantía económica: solamente el préstamo de la tierra; en la mayoría de los casos, incluso, el campesino o campesina debe repartir las ganancias del sembrado con el que tiene la posesión del terreno, además de tener que atender a toda su familia los fines de semana y festivos. Por esta razón, una de las discusiones que nos pareció importante tratar es cómo afecta al campesinado la posesión de la tierra, no solo en niveles económicos, sino también simbólicos: ¿se puede ser un campesino sin tierra?

Se le da la oportunidad a otros de que también trabajen porque esas personas son propietarios, pero tienen otras actividades. Abajo son profesores, otros son albañiles y acá le dan empleo, trabajo, a familias campesinas que no tienen trabajo en la ciudad, pues dejan a la gente trabajar. Lo que yo siempre he criticado es la parte ambiental, que ellos por sembrar una yuca cortan un árbol nativo. En esa parte ya estamos mal por ese lado, pero eso ya han venido muchos proyectos en esta zona donde se les está explicando eso; ahora hay un proyecto que "Mango Maíz", donde se les da a los campesinos para que reforesten con árboles nativos. Entonces se coge una zona en la que se siembra el pancoger como para el consumo, no tanto para la venta, pero lo que más se está sembrando son arbolitos frutales (E. Díaz, comunicación personal, diciembre del 2016).

\section{Ser campesino: orgullo, resistencia y esperanza}

Establecer un significado para la palabra "campesino" y, más que para la palabra, construir una reseña sobre lo que es un campesino en los alrededores del barrio Gaira, en Santa Marta, no es lo que se busca en este texto. Hoy en Colombia los campesinos y las campesinas están inmersos en una serie de problemáticas que crecen cada día: los problemas de agua, la falta de oportunidades económicas, las malas vías de acceso, la apropiación de la tierra y muchos más que son el diario vivir de los agricultores en la vereda el Mosquito. 
Vida campesina en el Magdalena Grande

Por eso, nuestra mayor intensión fue observar y reconocer las resistencias y acciones tecnológicas, sociales y culturales que crean los campesinos para socavar un abandono evidente por parte del Estado, además de reconocer las tradiciones y sus formas de vida cotidiana (contada por ellos mismos, donde el investigador y el investigado comparten conocimientos y experiencias, dejando de lado la jerarquización de los análisis etnográficos).

Una de las preguntas de nuestras entrevistas orales fue: ¿Qué es para usted ser campesino? A la que ellos y ellas mismas nos respondieron teniendo en cuenta sus realidades. "Orgullo" y "alegría" fueron de las palabras más mencionadas en las respuestas. A pesar de los problemas que deben afrontar, hoy la palabra "campesino", para los pobladores del Mosquito, es sinónimo de fe y esperanza en un país que no piensa en los trabajadores del campo:

Para mí ser campesino es valorar la tierra, me siento orgulloso porque la tierra da para hacer todo, tener tu casa. Una tierra es como una mina. Yo me pongo orgulloso cuando veo un fruto. La primera fruta se las doy a mis nietos, a los hijos o para mi mamá; por la felicidad, nunca me lo comía yo (W. Zúñiga, comunicación personal, diciembre del 2016).

Por lo menos en el caso de nosotros, el campesino entre más turista entra, para él es mejor porque la gente compra más el producto. [A] la gente de abajo, [a] los turistas, le gusta las cosas, cómo te diría, como menos contaminado. Compraban la yuca que la acaban de arranca', el plátano, la papaya, toda la fruta el turista la compra. Y nosotros aquí cuando antes del vendaval sacábamos una canasta de papaya aquí y lo vendíamos a los carritos que van pasando a 2 mil pesos, a 3 mil pesos la compran; es mejor, no es como usted saca un producto y lo almacena allá en el mercado y usted [ve] que están a veces podridas y así, a veces lo mismo. Entonces parece que es mejor, es mejor (J. De La Cruz, comunicación personal, diciembre del 2016).

Cuando tú siembras una tomatera, la agricultura tiene eso, cuando tú lo siembras, siembras hoy mil matas de tomates, la siembras hoy, le hechas el agua y, al día siguiente, ves ese tomate dónde está al medio día: $U y$, 
Vida campesina en el Magdalena Grande

qué bonito. De pronto ya a los 5, 10 días: no joda, está la vaina buena, ya está pegado, ahí lo que va a haber es tomate... y que si tiene plaga, que el agua, el cuido. Yo antes sembrara una tomatera, una ajicera, y yo iba con el canasto. Mira, aquí todo el tiempo hay guineo, plátano, se rajan de lo grueso; el cuatro filo se madura en las matas y los pajaritos comiendo guineo, eso es elegante. Yo tengo casi 40 años de estar aquí y, ¿tú crees que alguna vez he traído yuca de Gaira para comer aquí? El campesino es algo que si tú tienes tierra, lo tienes todo. Yo duro un mes sin ir a Gaira y yo tengo comida aquí, pero en la ciudad si no trabajas la cosa es pelua'. [Acá] no pago agua, tengo el río aquí cerca, te comes un guineo bien bacano, una papaya, un jugo de torombolo; en la ciudad uno lo que como es puro químico: el melón lo maduran con líquido, el aguacate con líquido, con carburo (y el carburo es un veneno), y tú te comes esa vaina. Cuando vayas a mercado y veas una pila de papaya y toda está amarrilla es madurada con carburo, pero si ves una que está verde, otra amarrilla, otra más o menos, esa es natural; lo mismo con el melón, el aguacate. Lo que uno cultiva es natural porque aquí no se echan los químicos para madurarlo (J. Rodríguez, comunicación personal, diciembre del 2016).

Una de las discusiones que se plantearon al inicio y largo del texto tienen que ver con la categoría de "campesinos urbanos" que, para la mirada de nosotros, son aquellos campesinos que habitan en los alrededores de los principales centros urbanos de la región, donde se mueven ciertas dinámicas sociales y culturales propias de las ciudades que obligan al campesino, en muchas ocasiones, a cambiar el sistema de valores propio de las zonas rurales para adaptarse al ritmo de vida de las ciudades, alejándose del imaginario de que el campesino solo habita las zonas rurales del país:

Sí, uno es un campesino urbano porque uno tiene la ciudad aquí cerquita, entonces uno de cada rato baja a la ciudad y compra la comprita y mantiene uno yendo y viniendo casi todos los días uno va, pasa uno yendo y viniendo, entonces uno más bien es campesino urbano porque mantiene en la ciudad, a cada rato está uno allá (J. De La Cruz, comunicación personal, diciembre del 2016). 



\section{Vereda Altos de Don Jaca}

Mapa 14. Vereda Altos de Don Jaca

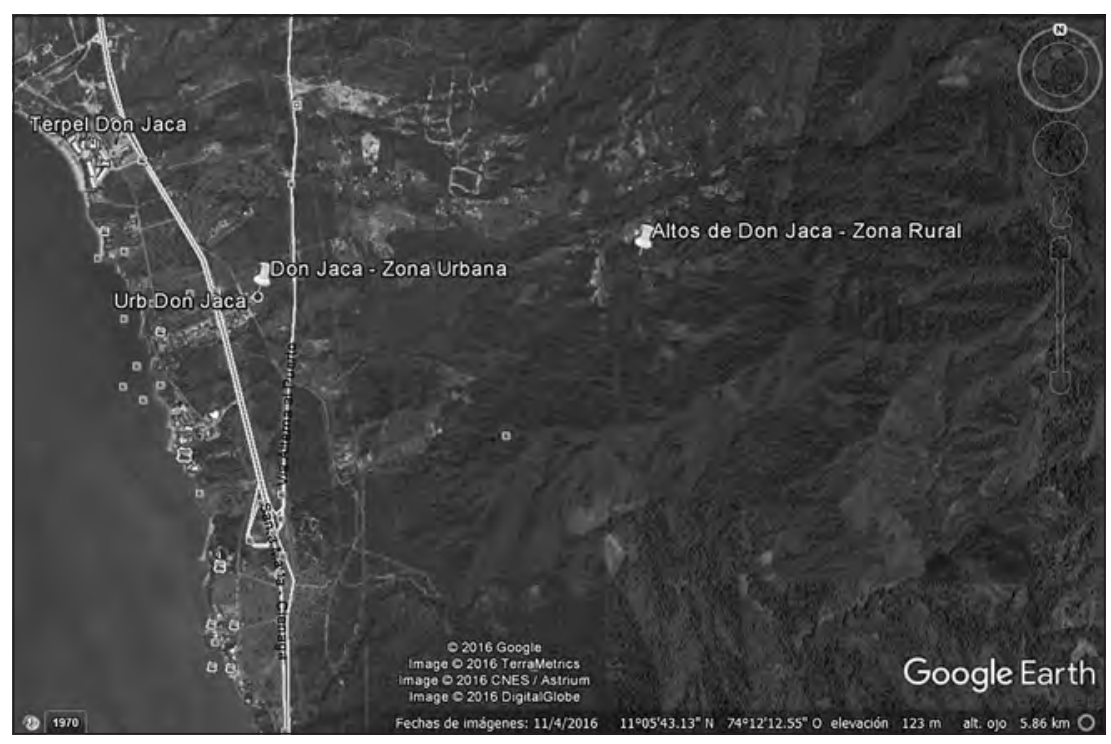

Fuente: Google Earth (2017).

Don Jaca se encuentra conformada tanto por una zona rural como por una zona urbana. Los habitantes reconocen la parte urbana como el lugar de mayor conformación de casas que cuentan con una estrecha cercanía a las vías de acceso de la ciudad, como es la Troncal del Caribe, que comunica el interior de Santa Marta y el municipio vecino de Ciénaga. Asimismo, esta parte tiene mayor cercanía con los hoteles de destino turístico de la ciudad de Santa Marta, los barrios circunvecinos del aeropuerto, la Paz 
Vida campesina en el Magdalena Grande

y Cristo Rey, y las zonas tradicionales de pesca en el mar Caribe. La parte rural inicia desde la calzada vial - donde termina el conjunto de casas - y sigue hacia las estribaciones de la Sierra Nevada. Sin embargo, esta división territorial no solo tiene sentido en los límites geográficos espaciales, sino además en las actividades económicas de quienes los habitan y en el acceso a los servicios públicos (de electricidad, gas y acueducto). Así, se distingue el ordenamiento del territorio de la siguiente manera: Don Jaca (urbano) y Altos de Don Jaca (rural) como forma de diferenciación:

Bueno, Don Jaca es todo: de la playa, allá al cerro que colinda con San José, ese globo de tierra se divide en dos sectores porque en la parte de los pescadores tienen servicios públicos, tienen acceso a busetas, tienen agua del acueducto (claro que no les llega, tienen tubería, pero no les llega), tienen su servicio de luz, servicio de gas, entonces esa parte, de la vía alterna hacia abajo, es urbana. Anteriormente, con la resolución de la junta de acción comunal, "Don Jaca parte alta", que es la que se identifica como "vereda parte alta", era de la doble calzada hacia arriba, desde la bomba hasta allá, casi al puente el doctor. Cuando ya eso se pobló de la parte de arriba de la carretera entonces ya ese globo de tierra ahí pertenece a la zona urbana y de ahí para acá [a la] zona rural. Entonces, ¿cómo nos identificamos? [La] parte baja [es] urbana y [la] parte alta, rural (E. Osorio, comunicación personal, febrero del 2017).

No importa, la[s] direcciones acá en la parte alta, la rural, siempre la[s] manejábamos, como junta de acción comunal, por el nombre del predio, por lo menos aquí mi predio se llama los Robles, entonces ese es la dirección que nosotros le colocamos. De pronto, para cualquier cosa, la dirección es: kilómetro 2, vía alterna, Don Jaca parte alta, y el nombre del predio. Anteriormente, cuando no había esa de los colonos, sino que había un solo sector, entonces uno colocaba "kilómetro 17, vía CiénagaDon Jaca. Ahora ya nos identificamos por la nueva vía que cruzó, hay un kilómetro 2 en la entrada, entonces colocamos: vía alterna, kilómetro 2, Don Jaca parte alta, y el nombre del predio. Don Jaca parte alta es una extensión grande, pero si a usted le dicen: vaya donde la señora Edilia, en la finca los Robles, en Don Jaca parte alta, usted ya trae una indicación de 
Vida campesina en el Magdalena Grande

una dirección más o menos de dónde puede llegar. Usted le pregunta a cualquiera: mire, yo voy para donde la señora fulana de tal, para la finca tal. Eso fue una metodología que nosotros sacamos cuando había las asambleas: la dirección eran el nombre del predio, número de teléfono y eso para de pronto ubicar la persona cuando uno necesita una información o algo; entonces uno buscaba ahí, llamaba y mandaba la información (E. Osorio, comunicación personal, febrero del 2017).

Las actividades económicas que distinguen a la población son la pesca, la oferta de servicios turísticos de restaurantes y la actividad agrícola. Gran parte de la población fue, en algún momento, agro pesquera o, en su defecto, transitó en esas transformaciones económicas, tanto de la pesca a la agricultura, como viceversa. Muchas de esas transiciones, principalmente en el caso de la pesca hacia la agricultura, se debieron a la construcción del puerto de carga carbonero de la empresa Drummond Ltda., que afectó medioambiental y culturalmente muchas zonas donde se había practicado la pesca de manera tradicional por más de cien años; esto, en consecuencia, ocasionó el debilitamiento en la soberanía alimentaria y produjo la migración de los pescadores a otros sitios que no estuvieran mayormente afectados por el polvillo del carbón —que se ha extendido tanto en las aguas como en los suelos de la parte rural y urbana de Don Jaca - para realizar sus faenas de pesca.

En la actividad de la agricultura, Don Jaca figuró como una de las grandes productoras de tomate en la región, abasteciendo los mercados de Maicao, Santa Marta y Barranquilla con este producto; no obstante, dentro de los elementos de poblamiento que la distinguen hay una estrecha relación con el cultivo de marihuana en los años setenta, años en los que hizo parte de la bonanza marimbera del Caribe colombiano. Sin embargo, como es un territorio que pertenece a los límites de la Sierra Nevada, ha podido producir yuca, maíz, mango, aguacate, café, ají y cilantro; estos dos últimos son, actualmente, su cultivo de mayor producción y comercialización:

Pues sí, es lo que más se ve ahorita porque hay una empresa ahí de gallinas, pero todo tiene que ver con la parte del campo porque, como le digo, hoteles en ninguna parte, playas tampoco; o sea, eso más que todo 
le concierne a la parte de abajo, urbana, que son los que viven ahí, que pueden salir a la playa, llevar, vender el pescao, vender el frito, hacer la sopa, la comida pa' los turistas que de pronto que van o que llegan a la playa. Sí, aquí más que todo se maneja lo que es la zona agrícola. Hay una empresa donde [hay] un molino de piedra, está más abajo del colegio, bueno, esa empresa cuando llegó ilusionó mucho a las personas: "vamos [a] hacer, vamos a tener oportunidades de trabajo, vamos [a] hacer esto", van hacer lo otro. Bueno, se nos arregló porque la gente cuando deje de cultivar puede trabajar en la empresa o viceversa: uno puede trabajar en la empresa, el otro puede trabajar en el campo, todo lo que nos pintaron era maravilloso... que iban a capacitar la gente, que les iban a dar tejido social, que les iban a dar ayudas, capacitaciones en muchas cosas. Pero resulta que después eso no funcionó. Pusieron a trabajar a muchas personas, sí, [pero] no estaban puntual con el pago, no les pagaban seguridad social, no tenían esto, no tenían lo otro, querían como explotar al trabajador; [tanto] que muchas veces nos tocó hasta traer abogados y oponernos a muchas cosas porque dijimos que así no. Un trabajador que entraba de seis a seis y no les querían pagar horas extras ni nada, sino por un sueldo básico, donde trabajaban de lunes a lunes, no tenían descanso; de pronto por ahí cada mes le daban un domingo, pero eso no. Hay personas que se retiraron y todavía les deben, no les han pagado. Nos perjudicaron muchísimo porque eso era entrada y salida de vehículos pesados, donde nos han dañado la vía, donde hay un polvero cuando hay brisa y eso... o cuando hay esas entradas de carros constantemente, que están sacando y cortando la piedra, eso es en la parte de allá, cerquita, vea, eso es un humo, ese polvero. Dentro de las casa[s] eso no se ve de tierra, todo [lo] tienen que mantener cerrado, y usted sabe que en la parte rural no es como en la ciudad que está perfectamente sellado, sino que hay calados, ventanas, hay puertas medio puestas, y eso la gente se enfermó, los niños se apretaban de gripa. Una noche la gente se tomó la entrada porque era demasiado y entonces llegamos [a] hablar con ellos. Le[s] dijimos: "Mira que aquí nos están perjudicando por esto y esto. Si ustedes ven que van hacer un movimiento de carro a esta hora o a cualquier hora, ¿por qué no riegan un carro tanque y humedecen la carretera para que el polvillo se aplaque y el carro pueda entrar y salir?". No, eso lo hicieron una vez, pero no lo volvieron [a] hacer. Prometieron que iban a pavimentar de la 
Vida campesina en el Magdalena Grande

vía alterna hasta el colegio [y] tampoco se vio. Entonces, en lugar de venir [a] hacer un bien a la comunidad y a traer desarrollo, lo que nos ha hecho es un daño y un perjuicio. Cuando uno baja en un carro y viene toda esa cantidad de mula uno no halla, eso es un camino muy angosto donde no halla para separarse uno, abrirse al camino, y eso nos tiene muy mal, en lugar de beneficiar a la comunidad (E. Osorio, comunicación personal, febrero del 2017).

Su territorio cuenta con la quebrada Don Jaca, que alimenta en gran proporción a los canales de riego en los cultivos de los campesinos de la zona, pero cuyo caudal, en la actualidad, es reducido debido a la falta de lluvia y a los nuevos propietarios de finca que captan el agua a desnivel, lo que ha generado que los campesinos construyan sistemas tubulares de largas extensiones a través de los cuales puedan transportar el agua de los ríos vecinos, como la de Minca o la del río Don Diego:

A veces, por el problema del agua, porque cuando esa quebrada se seca esto es un desierto,, entonces el que tiene plata se hace sus pozos profundos, de 30, 40 y 50 metros de profundidad y sale el agua, porque ellos las tienen ya, y aquí cuando esa quebrada queda como así tiene usted que saber robarse el poquito de agua, porque usted viera a la gente con los focos en todo, usted le mide el tiempo, tan siquiera tres canecos y si ven el mojado: ¡ah!, cogiste el agua, ombe’ no teníamos, ahí vienen los problemas, sí señor (L. Rudas, comunicación personal, febrero del 2017).

Sus calles y vías se encuentran sin pavimentar. Los primeros kilómetros se encuentran despejados para el acceso de vehículos; sin embargo, a medida que nos adentramos en la vereda el acceso queda restringido a senderos por los que solo es posible trasportarse caminando o en mula. A su vez, a medida que subimos a la parte más alta, tanto los cambios ambientales como el ejercicio del cultivo es diferente. En las llanuras mucho más cercanas a la ciudad- es usual encontrar cultivos de ají y cilantro, pero en sus alturas se encuentra mayormente café y col. 
Vida campesina en el Magdalena Grande

Imagen 142. Sendero en Altos de Don Jaca

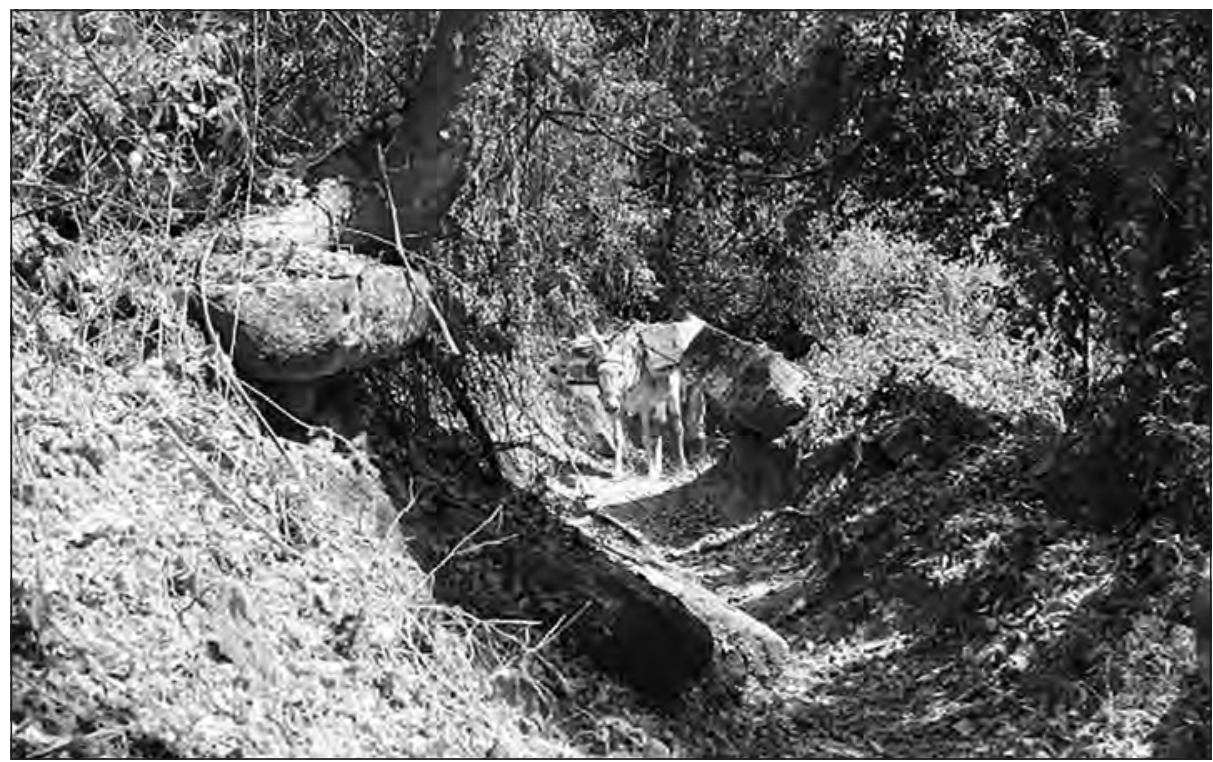

Fuente: Archivo Oraloteca (2017).

Las casas que conforman las fincas de la vereda son, en su mayoría, hechas a ladrillo y arena, pero asimismo hay casas de madera y bahareque que comparten los sitios de cultivo, el mantenimiento de los animales para la comercialización o para el consumo humano y los perros que son el elemento principal de seguridad de cada una de las fincas.

En este caso sucede lo mismo que en las veredas que se conforman alrededor de la ciudad de Santa Marta, en las que la mayoría de los propietarios de las fincas donde se cultiva pertenecen a dueños pudientes que viven en la ciudad y en las que, por tanto, muchos de los que cultivan en el territorio son arrendatarios o empleados contratados para mantener, producir y cosechar lo que la finca genere: "Bueno, sí, hay digamos que la mitad, hay algunos que viven en comodato, arrendamientos, otros que cuidan, pero y el otro cincuenta sí como que es propietario" (E. Osorio, comunicación personal, febrero del 2017).

Como sucede en gran parte de los territorios que hoy se conforman por desplazados del conflicto armado que van de las zonas rurales de dentro y fuera del departamento del Magdalena hacia Santa Marta, sus 
habitantes se ven enfrentados a nuevas formas de economía que les permiten solventarse, en un tiempo inmediato, una necesidad, provocando así la transformación del ejercicio de la agricultura y encontrando en las dinámicas de trabajo en que se organiza la ciudad una salida a las insuficiencias económicas que padecen. Por este motivo, el mototaxismo no solo se ha articulado como medio de transporte principal de las veredas cercanas a la ciudad, sino que además se ha convertido en el importante trabajo de las nuevas generaciones de familias campesinas que han encontrado nuevas alianzas - tanto familiares como económicas - fuera de su vereda:

Sí, por aquí sí se ha perdido mucho... por lo mismo que te digo, porque es que ya la gente muy poco trabaja porque el sistema de las motos... todo el mundo [dice]: "voy es a ganarme una plata porque voy a comprarme una moto" y el que consigue la moto pues se va para el pueblo a manejar la motico y adiós el campo, porque es que el campo es duro, el campo no es cualquier pendejada (F. Rodríguez, comunicación personal, febrero del 2017).

Imagen 143. Cultivo de col en la vereda Altos de Don Jaca

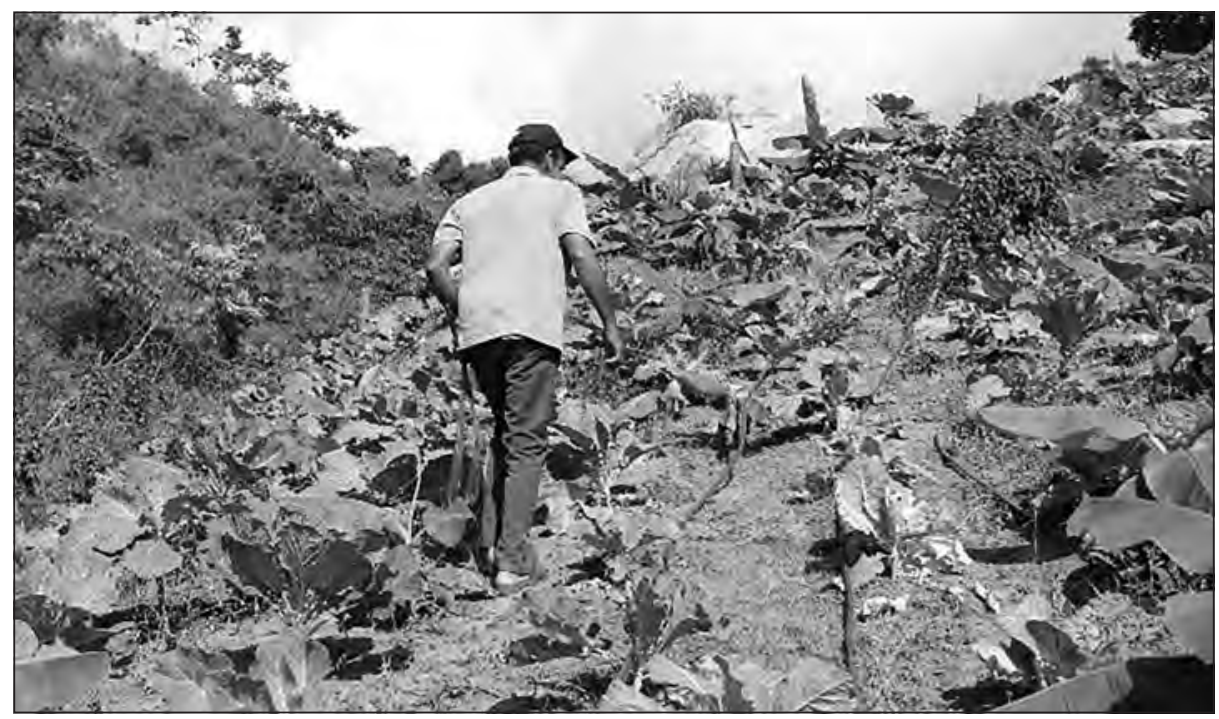

Fuente: Archivo Oraloteca (2017). 
Los cambios climáticos se han visto reflejados tanto en la transformación de los cultivos, como en las redes de abastecimiento hídrico y en la calidad de las cosechas. Muchas de las bonanzas de los cultivos que han marcado un precedente comercial en Don Jaca han ido cambiado por la cercanía a los puertos carboneros de la vereda y a los cultivos ilícitos que estuvieron en la zona; estos últimos pasaron un proceso de erradicación con glifosato que produjeron que muchos de los cultivos que antes se cultivaban en las llanuras de la vereda hoy solo se encuentren en sus zonas más altas.

\section{Historia de poblamiento de la vereda Altos de Don Jaca}

Muchos de los territorios en Colombia, a finales del siglo XIX y principios del XX, fueron tierras baldías que carecían de un dueño formal (con su escritura como propietario); este es el caso de la tierra en la historia del poblamiento de Don Jaca. Estos territorios fueron, como lo dicen sus habitantes, invadidos por los colonos del interior del país. Al hacer parte de la Sierra Nevada de Santa Marta esta vereda cuenta con pisos térmicos aptos para el cultivo de algodón, café, cacao y, por supuesto, de marihuana, pero además para entonces la situación climática e hídrica de esta vereda era realmente favorable: fue una época de menos afectación ambiental por la no presencia de los puertos, lo cual hacía relevantes y atractivas estas tierras para el cultivo. Aunque, en simultaneidad, la relación con el mar predominaba, también existían habitantes en las llanuras de la vereda que se dedicaban a la pesca antes de que llegaran los puertos de embarque de carbón. No obstante, traer a colación la historia de poblamiento es, sin lugar a dudas, recordar tanto el cultivo y tráfico de marihuana como los momentos de gloria de otros cultivos que dan cuenta de la transformación del territorio:

Las familias más antiguas pueden ser los Quintero, los Zapata, los Paredes, de este lado; pero cuando eso, ya los muchachos nuevos se van para Santa Marta. Ahora estamos acá los propios campesinos mayores, la juventud se ha ido para Santa Marta, ahora solo estamos los mayores (D. Prado, comunicación personal, febrero del 2017). 
Vida campesina en el Magdalena Grande

Nosotros prácticamente nos criamos fue aquí. Entonces, estas tierras fuimos adquiriéndolas, fuimos comprándolas por lotes y, después, hicimos un solo lote... y así fue que adquirimos estas tierras acá, porque antes teníamos tierra era allá abajo, junto al mar, pero los padres de uno antes que no pensaban en el futuro, que iba a tener las tierras para al lado del mar, por el asunto del turismo eso adquirió una gran importancia. Ellos vendieron supremamente baratas esas tierras, hacen años ya, entonces compramos acá arriba y nos trasladamos acá (R. Martínez, comunicación personal, febrero del 2017).

Cuando nosotros llegamos por aquí, como te digo, eran extensiones de tierra, no había tanta gente; o sea, eran de pronto dos o tres fincas solamente y hubo unas dos casitas al borde del camino. En la parte del caserío de los pescadores solamente había como dos, tres, cinco casas en la parte de arriba; en la parte de abajo, había como unas diez y esa era la población de acá de Don Jaca. En el noventa y dos o noventa y tres llegó un grupo de colonos e invadió unas tierras que pertenecían, que aparecían como baldías. Un señor decía que era dueño, que no sé qué, pero llegaron ellos e invadieron de la vía alterna, donde está la vía alterna hacia arriba toda esta zona así, hasta llegar como a quince minutos [de] aquí [a] un globo de tierra grande. Bueno, entonces ellos tuvieron ahí luchando y el INCORA les adjudicó, ellos ganaron ese proceso y por eso es que hoy en día se ve toda esa cantidad de casitas, de parcelas - porque ya son parcelas- de una hectárea, de media hectárea, de tres, de cuatro, la que mucho tiene de pronto tenga unas diez o quince hectáreas, pero el resto son pequeñas parcelitas. La mayoría son propietarios que viven en Santa Marta, entonces tienen alguno que cuida. Es muy poquito el poseedor de la tierra que está dentro de ella trabajando por lo mismo, porque no tiene cómo trabajar por la cuestión del agua (E. Osorio, comunicación personal, febrero del 2017).

En los años iniciales de la vereda, Don Jaca contrastaba en simultaneidad con las implicaciones políticas en el uso y tenencia de la tierra, que legitimaron el desplazamiento de muchas familias tanto en el interior del país como en el departamento del Magdalena. Grandes terratenientes se instauraban de manera tajante en los territorios; sobre todo para el caso 
Vida campesina en el Magdalena Grande

del Magdalena, el monocultivo de banano y todas las construcciones de infraestructura fueron factores de desplazamiento forzado de la zona. Por este motivo, muchos de los desplazados encontraron en la vereda Don Jaca un lugar en el que pudieron continuar su actividad agrícola. Sin embargo, confluyendo de manera común con la vereda el Mosquito, el mayor desplazamiento campesino registrado ocurre para los comicios de los años setenta por el recrudecimiento del conflicto armado entre grupos paramilitares, guerrillas y fuerzas del Estado, que desató que las poblaciones buscaran lugares fuera de esas zonas de tensión armada:

Yo digo que son los desplazamientos por la guerra, que vienen muchos sectores donde se ve la tranquilidad, porque la mayor parte de acá de la gente que llegaron a invadir esas tierras era gente cachaca, como decimos, casi de aquí de la costa no, sino que ahorita de pronto los que invadieron han vendido y se ven de aquí de la costa algunos, pero la mayoría eran colonos de Santander, de Barichara, de Cundinamarca, de Funza, de Ocaña, de distintos sectores. Entonces yo digo que influyó mucho la guerra que había, usted sabe que cuando eso estaba bastante conflictivo el país, que eso había guerra en todas partes, en cualquier parte se enfrentaban y todo, entonces yo digo que eso fue lo que atrajo al personal hasta acá, la violencia, y buscando otros medios de vida, porque sabe que Santa Marta es una maravilla [de ciudad] para uno vivir. Entonces yo digo que por eso la gente busca este sector, es un sector muy sano. No sé si ustedes de pronto oyen en las noticias, pero por aquí, que yo recuerde, en mis treinta y pico de años de vivir en esta zona, solamente muerte[s] violentas por acá en este sector dos, que yo recuerde, acá en la parte alta de la vereda, dos personas por muerte violenta, pero de ahí no; de pronto un accidente sí, ya eso es otra cosa. Entonces, es un sitio muy tranquilo, muy ameno, uno puede salir. Claro que, de todas maneras, uno a veces con todo lo que está viviendo y la inseguridad uno nunca deja la casa sola, porque nosotros somos uno que nosotros no salimos si no dejamos a alguien acá, pero sí hay parcelas donde salen todos y dejan las cosas ahí y no pasa nada. Entonces, de pronto, esporádicamente, atracaron, o cuando abrieron la ruta, la vía alterna, cuando eso sí se nos presentaron atracos y cosas ahí porque venían, atracaban... como hay una como una entrada por el porvenir y sale por acá, entonces como que ellos hacían sus 
Vida campesina en el Magdalena Grande

fechorías allá, llegaban y entraban por un lado y salían por el otro, pero en vista de eso mandaron vigilancia, la policía estuvo patrullando más y eso se fue controlando, no se ha visto más (E. Osorio, comunicación personal, febrero del 2017).

Los primeros cultivos que se dieron en la zona alcanzaron un mayor grado de favorabilidad en la producción debido a que había mejores condiciones para su desarrollo. Después del cultivo de marihuana, el tomate era uno de los productos que más se comercializaba en la vereda (el "tomate criollo", como le dicen los habitantes). En la actualidad, no se consiguen parcelas donde haya gran cultivo de tomate debido a la presencia de cultivo de marihuana (el cambio de producto comercial) y a la persecución estatal por erradicarlo (las fumigaciones, que provocaron la infertilidad en los suelos). Uno de los habitantes de la zona recuerda con nostalgia los tiempos de la tomatera de Don Jaca:

Uh... esto era por aquí, Don Jaca era el mayor productor de tomate de aquí en Santa Marta. Aquí todas estas vías de lado y lado lo sembraban de tomate, se sacaba tomate por camionadas. Ya como se ha ido poblando se ha dejado la siembra de tomate por escasez de agua, ha habido mucha destrucción en la Sierra y, a raíz de eso, la quebrada se fue secando, produjo una erosión como en el ochenta y cinco creo que fue, no recuerdo bien. También eso hubo una avalancha que eso arrastró piedras, caracolíes, todo eso se lo llevó para allá para el mar y de manera que la gente fue dejando de cultivar por eso, a raíz de la sequía que comenzaron a ver, porque antes la quebrada mantenía agua, cuando venía el siguiente invierno todavía tenía agua, pero ahora no. Este año pasado como nos llovió bastante es que todavía tiene agüita por ahí, pero el año antes pasado fue crítico y el principio de este que pasó eso aquí no había agua casi que ni para tomar. Aquí en el colegio, por ejemplo, traían en carro tanque que la mandaba creo que era la Alcaldía o la Secretaría de Educación, algo así, pero la traían a Don Jaca.

Aquí se sacaba. Había un mayorista que era Jaime Guardiola, habían otros de Ciénaga (que era Víctor Silva), y se llevaba para Barranquilla, para el mercado de Barranquillita, y allá se lo vendíamos a un señor Hugo 
Vida campesina en el Magdalena Grande

Díaz, se lo vendíamos allá el tomate y, más que todo, para Santa Marta, para Maicao se llevaban tomate de aquí, lo llevaba una señora de llamarse Carmen (R. Martínez, comunicación personal, febrero del 2017).

Sí, sembrábamos cilantro, yuca, maíz, pero cuando eso era muy, muy variable el clima. Había un tiempo por lo menos de noviembre a enero que de pronto hacía verano o, máximo, febrero, pero ya a partir de marzo, Semana Santa, ya empezaban las lluvias, entonces ya uno ya podía cultivar, uno arreglaba sus tierras y, a partir de marzo o abril, comenzaba su labor de siembra. Pero ahora no, ahora han cambiado muchos los tiempos, aquí hubieron tres años que si llovió dos o tres aguaceros fue mucho, pero por acá no llovía. El agua cuando yo estaba de presidente el año pasado y el antepasado nos tocaba pedirla a la Alcaldía para suministrarle a toda la gente que está en la parte baja. No sé si de pronto observaron el colegio... ahí en el colegio hay un tanque que lo dio la Alcaldía para depositar ahí una parte del agua para repartirle a los que estaban cerca y los demás con el poquito de agua de los nacederos era con lo que nos podíamos medio alimentar (E. Osorio, comunicación personal, febrero del 2017).

\section{Saberes, siembras y cultivos: el campesino y su relación con la naturaleza}

Los campesinos y campesinas de Altos de Don Jaca trabajan la agricultura teniendo en cuenta los diferentes pisos térmicos que hay en la zona; en esa medida, además de una vegetación diferente, es posible encontrar sembrados de todo tipo: unos para climas cálidos como ají, yuca y sábila y otros para climas más húmedos como el café, la naranja, etcétera:

Yo empecé a sembrar con yuca, ya yo sabía sembrar. Aquí tienen varios conocimientos de sembrar una matica de esa, pero es que resulta que si uno se va por la luna, ahora no puede sembrar porque la luna está en creciente, pero resulta que si usted siembra en creciente la plantación se va en vicio y no le pare. Entonces usted siembra y busca siempre la luna, luna llena ya, usted siembra en luna llena, cuando la luna llena es que está redondita: siembre, siembre, eso le pare mucho (L. Ruda, comunicación personal, febrero del 2017). 
Imagen 144. Cultivos de col en Altos de Don Jaca

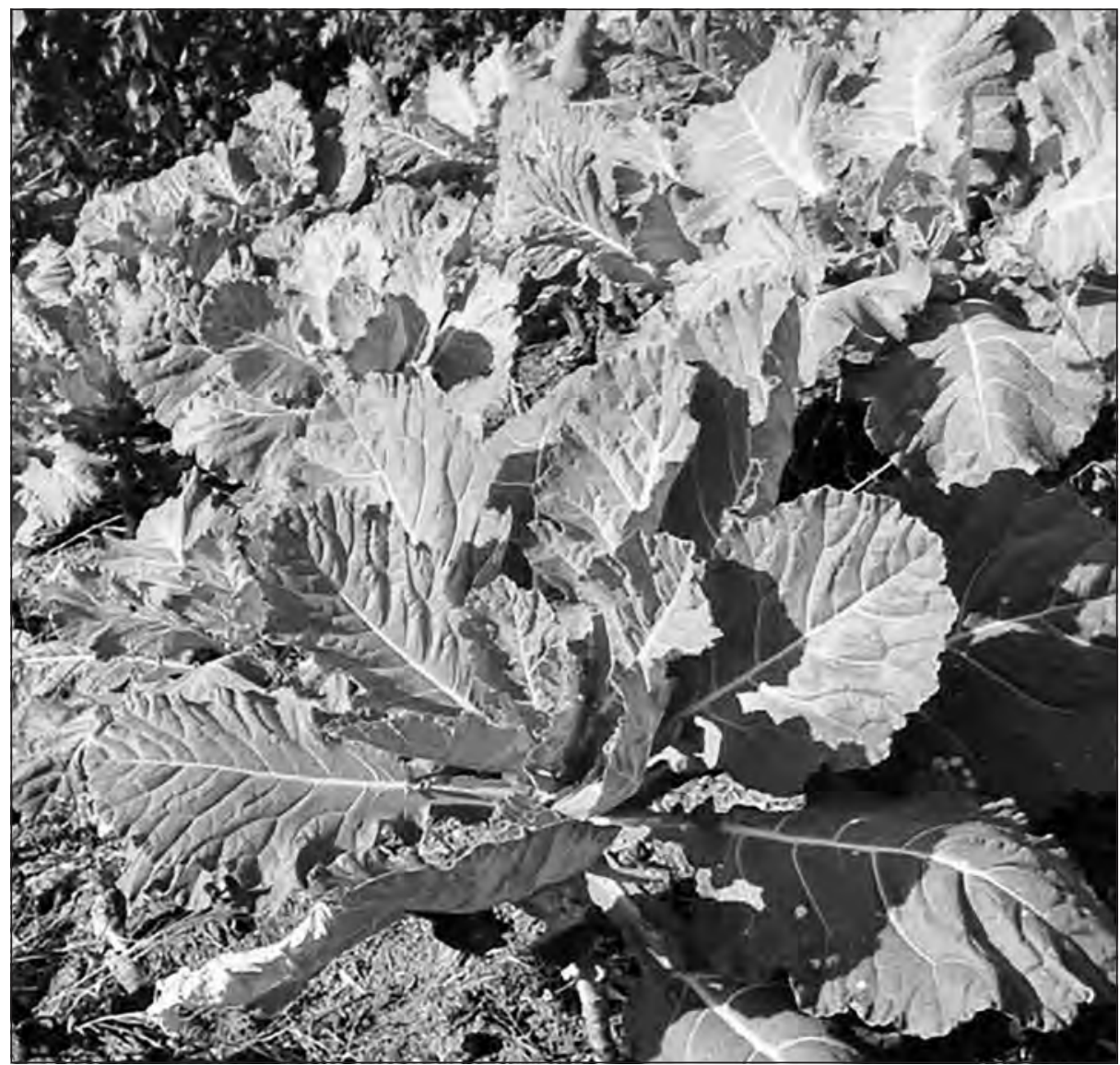

Fuente: Archivo Oraloteca (2017).

Los conocimientos y la relación con la naturaleza que adquieren los campesinos son significativos a la hora de sembrar, limpiar y recoger el producto. Las fases de la luna siempre están presentes en la vida de los agricultores, por lo cual se puede incluso decir que la luna es determinante a la hora de la cosecha. De igual forma, los campesinos adquieren saberes relacionados con la salud y el cuerpo: logran descubrir diferentes tipos de plantas medicinales que serán suministradas a las personas y a los animales enfermos del lugar; además, la vida espiritual es aprendida de los ancestros: 
Vida campesina en el Magdalena Grande

Por lo menos por aquí hay mucho, por lo menos ahora la sábila. Usted coge, si es [el] caso, la pepa de aguacate y hace medicina con eso. Hay muchas contras, inclusive yo tengo muchas botellas de contra, que yo cojo un palito (ya yo sé cuál es) y lo meto en contra y todo. El muchachito me lo traen bastante malo, vomitando y eso; entonces yo llego y le doy un rezo y yo le digo a la mamá o al papá que se va a ensuciar, o se va a orinar, o se va a vomitar, alguna de las tres cosas. Ahorita mismo, ayer me trajeron uno para rezarlo y anoche pregunté por él y está normal (F. Rodríguez, comunicación personal, febrero del 2017).

En las partes más altas de la montaña se cultivan plantas que puedan adaptarse a un clima más húmedo, mencionando que en este sector el problema del agua no es tan grave y se realizó una construcción vial que baja por el pueblo de Minca (Magdalena):

Pues el café se siembra y si es nuevo pues al año y medio, dos años, ya comienza a dar los primeros fruticos... y en lo otro eso demora un poquito más, tres, cuatro años para seguir dando, tres años, dos años y medio, pero este nuevo ahora sí está dando muy ligero, pero dicen que no es rentable porque se acaba muy ligero, por ahí cinco, seis años ya hay que mocharlo y entonces... en cambio, el otro, ese viejo, de típica mata, hasta de cuarenta y cincuenta años dando café; claro que eso lo acabó la roya, eso fue el problema (F. Rodríguez, comunicación personal, febrero del 2017).

Asimismo, deben enfrentarse a nuevas enfermedades que aparecen con los cambios climáticos y a la contaminación producida por empresas de extracción de carbón en el departamento; a pesar de que los campesinos crean medicamentos artesanales para alivianar los hongos, estos no son suficientes para evitar las pérdidas de hortalizas y demás:

La roya es una enfermedad que eso se le cae la hoja y se vuelve la mata puro chamiz y la mata se seca. No eso es difícil combatirla, solamente es renovándolo. No, esa enfermedad ha sido muy vieja, pero no sé, por los cambios climáticos fue que se, se puso así tan, tan agresiva como hace dos o tres años para acá, que eso acabó con las cafeteras (F. Rodríguez, comunicación personal, febrero del 2017). 
Todas esas extensiones de tierras las cultivaban en hortalizas, tomates, ají, patilla, ahuyama, melón, ahora ya no se puede cultivar porque ya la tierra no sé qué problema habrá tenido, dicen que de pronto fue lo del carbón que afectó el suelo y eso como que ya no sirve: el limón sale con una mancha, [en] la papaya la hoja se deteriora, se pone como amarilla y se pica, la yuca también, el limón desde que nace sale con unas pinticas blancas. La otra vez hicieron una investigación de una universidad y decían que eran los efectos que había producido el polvillo del carbón y que había perjudicado la parte agrícola, entonces no sé.

Los muchachos que estuvieron aquí decían que ese problema del limón que nace con una mancha lo producía el carbón. En sí yo no sé porque yo desconozco de eso. Lo que era la papaya que se le mancha la hoja... acá abajo ya no se puede sembrar hortalizas porque todas se dañan. La gente decía que era a raíz del carbón, por ahí hay una demanda, no sé en qué quedaría eso porque se empezaron a jalar para allá y para acá; a la final yo no quise entrar porque yo vi que no iba a beneficiar mucho al campesino, entonces no me voy a poner desgastar en esto porque uno no sabe. Si uno tuviera la certeza [de] que nos van a pagar por daños y perjuicios a los campesinos, pero yo vi que eso tenía mucha falencia y yo dije "no, yo no me voy a comprometer por aquí".

No sé si de pronto ustedes observaron ahora árboles de mango que tenían cincuenta, treinta años... limones, esto era una limonera... todo se acabó. Entonces la gente, pues al ver eso, ellos de pronto emigran para otros sector[es] a conseguir mejor vida. Nosotros aquí nos mantenemos porque mi esposo es pensionado, tiene un sueldo mínimo, pero de todas maneras eso de pronto es lo que lo ayuda a uno a sostenerse aquí porque con cultivo y eso no tiene cómo sostenerse, no, no hay sobrevivencia. Si uno de pronto cría un animal tiene que comprarle todo, traer todo del pueblo para poder cría[r] el animal, la gallina, el cerdo, cualquier animalito, uno tiene que traer de allá. Aquí teníamos como cinco, seis reses, y la hija después compró como cuatro y con la cuestión del verano se nos mataron tres, se nos murieron y dijimos: "qué vamos [a] hacer para estar perdiendo". Tenemos la vaquita de leche, pero nos tocó salir de ellos. Ahora tenemos extensión de tierra, pero no hay cómo trabajarla (E. Osorio, comunicación personal, febrero del 2017). 
Vida campesina en el Magdalena Grande

Imagen 145. Pasos de campesina

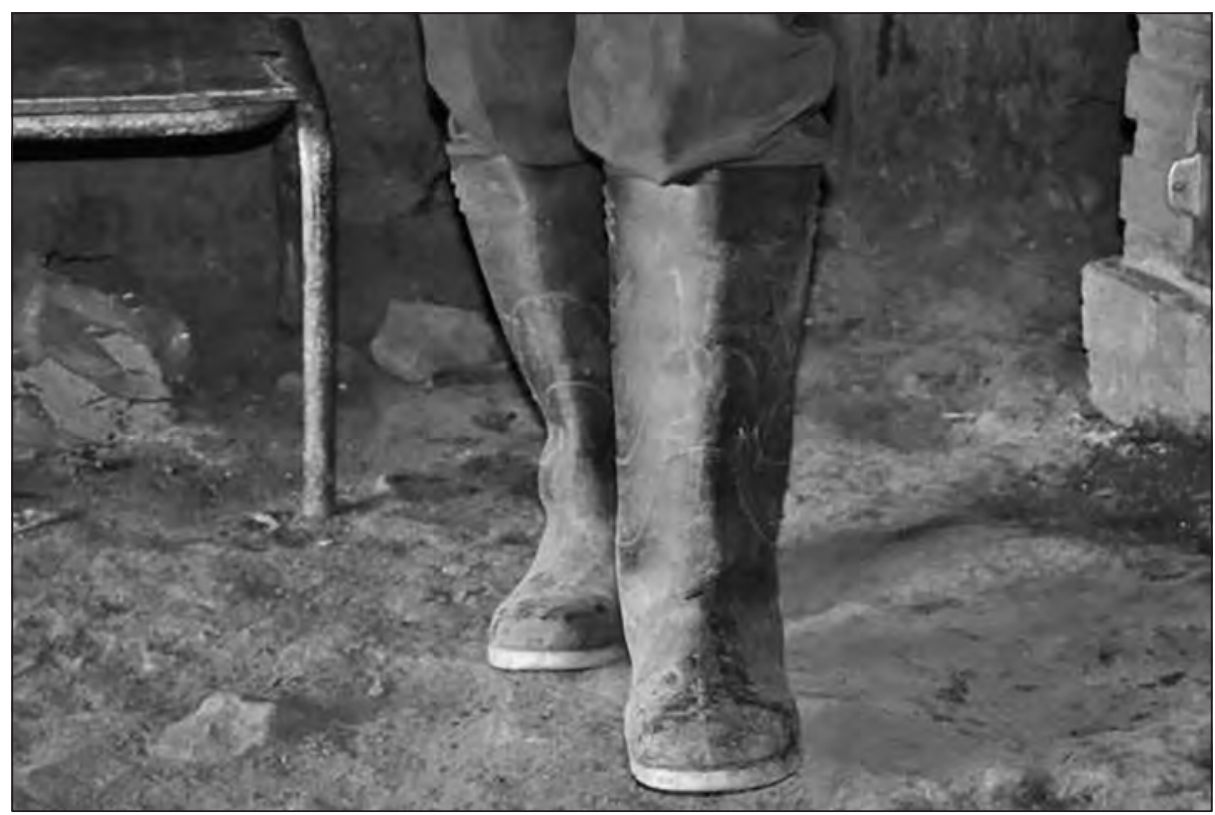

Fuente: Archivo Oraloteca (2017).

Así mismo, la mayoría de las mujeres campesinas de la vereda se dedica al trabajo del cuidado del hogar. Aunque las mujeres se consideran puntualmente campesinas, entre los hombres existen racionalidades que limitan la participación de las mujeres en ciertos espacios; por ejemplo, entre los campesinos hombres se tiene la creencia de que las mujeres no deben entrar a los cultivos durante la menstruación, si bien no existe una argumentación de fondo más allá de la creencia en las transformaciones que pueden sufrir los cultivos frente a la presencia de las mujeres en dicho estado:

Sí, es cierto eso, pero es [que] cuando la mujer está en estado de menstruación, si ella lidia el palo puede tener la menstruación y lo daña, eso sí es cierto. Aquí cuando estaba yo abajo llegó una señora, y no sabía que tenía la menstruación, y el palo triste y se secó; es algo que tiene mortal para la mata [...]. Bueno, eso de pronto hay cosas que son verdad, pero hay cosas que son mentiras. Con la planta que es más delicada más que todo para lidiar con la mujer, pero en ciertos periodos no es todo, a veces 
Vida campesina en el Magdalena Grande

es la patilla porque esa sí la viví yo: la mujer cuando tiene el periodo no puede pasar por donde hay una mata de patilla o de ir a coger el cilantro también, ella también dice que el cilantro también le pasa lo mismo porque eso sí es por experiencia que lo hemos vivido, pero de resto no. De pronto limón dicen que tampoco, no nos gusta tampoco dejar coger el limón de mujeres que lleguen: "regáleme un limón", nosotros se los cogemos porque nos matan los limones (E. Escalante y E. Osorio, comunicación personal, febrero del 2017).

Es necesario profundizar la relación de la mujer con la tierra pues es de vital importancia para la vida de los campesinos y las campesinas dignificar a la mujer, que ha sido segregada de los trabajos del campo a pesar de mantener conocimientos plenos y directos sobre la tierra, al igual que los campesinos hombres.

\section{Las paradojas de la vida campesina}

\section{La bonanza}

La marihuana, como dicen varios habitantes de Don Jaca, enriqueció a gran parte de los que la cultivaban en el territorio debido al despliegue del cultivo en esta región del país. Existía todo un sistema de cultivo y comercialización cuyos actores principales eran los campesinos de la zona, grupos armados y hacendados que controlaban la producción, como también la policía que daba el aval para poder sacar la producción a las ciudades. El cultivo de marihuana desplazó el cultivo de hortalizas y frutas en la vereda, pues en este se encontraba una mayor rentabilidad (dado su precio) y su producción era más constante: "Sí, eso fue para el año setenta y pico, no estaba por aquí. Abajo era la sede; bajaban de arriba y la depositaban acá abajo, porque aquí es el Gobierno, hasta la policía bajaba y custodiaba esa vaina" (E. Escalante, comunicación personal, febrero del 2017):

Aquí la gente vivía de la marihuana en cantidad, desde que usted pisaba los alcatraces para allá. Por eso es que la ley le estaba dando clavo, porque si usted, como dicen si... ¿para qué vamos a sembrar una mata de maíz cuando la libra vale 500 pesos y una libra de marihuana vale 150 mil? Es la verdad. Entonces todo mundo, si era allá en los alcatraces eran 8, 9 
Vida campesina en el Magdalena Grande

cabuyas, usted ahí no veía una mata [de] yuca, una mata de plátano, no veía una mata de fríjoles, no veía nada, pura marihuana compadre. Como a las 12 de la noche venía bajando esa catajarria de mulo, maletas por todo eso, esto fue por aquí, esta zona caliente.

Yo me ganaba mis pesitos también arriándola, pero de ahí fuera duré como 4 meses. Aquí la policía se compraba; estaba allá en la carretera vieja [y], por decir, si llegaban a embarcar 2 mil libras eran 500 mil pesos. Por aquí fue bravo, pero bendito sea Dios ya toda esa vaina se ha acabado y uno mejor porque si esto sigue así con esos negocios ilícitos... Por aquí había muertos porque eso es del diablo, eso sí, y mucha competencia porque si estaba a 150 y usted es un comprador duro, yo te la doy en 120 [y] ya ahí viene la competencia, ya aquel que se la ponía en 150 ya ahí viene el del fraude, él se la va a poner más barata, ya ahí venía[n] las malas interpretaciones y ahí era donde eran los muertos. Por aquí no hubo muerto, por aquí la policía correteaba mucha gente, habían motos por ahí regadas y la gente corriendo porque, ajá, ganaban... y la verdad era esa (L. Rudas, comunicación personal, febrero del 2017).

Eso había comisionistas como el café, tú ves que el café todo lo acaparan los compradores, entonces se lo venden al más importante que lo lleva para el exterior. Entonces, vamos a poner allá abajo, como en aquella casa allá abajo en la quiebra, ahí había un comprador y tú llegabas con un saco y te lo compraban, como comprar un saco de yuca, y entonces iba arrumando, arrumando hasta que ya él vio que había un poco para hacer un embarque, entonces la embarcaba y se la llevaba y como la policía ellos mismos le ayudaban, adelante la policía y el camión atrás (F. Quintero, comunicación personal, febrero del 2017).

Muchos de los habitantes que no se dedicaron al cultivo de marihuana relatan las transformaciones que ocasionó este cultivo, como las deforestaciones en la vereda y el riego de glifosato en el territorio. Además de que se intensificaba para esta época la influencia del carbón en la calidad de sus cultivos, tenían también que preocuparse por los rezagos que dejaba la marimba en la zona: la presencia de fuerza pública y la continuidad de un corredor con condiciones favorables para el tráfico de la marihuana: 
Eso fue lo que acabó con la Sierra. Sí, aquí hubieron más de trescientos cachacos que se vinieron del interior a sembrar marihuana aquí, eso fue lo que peló la Sierra y, a raíz de la deforestación que hubo a causa de la marihuana del año setenta para acá, ahora es que no se cultiva, pero antes eso eran extensiones: el que menos sembraba, sembraba dos o tres hectáreas. Entonces, eso fue lo que acabó con la vegetación aquí en la Sierra y, a raíz de eso, ha venido la sequía [...]. Cuando la época de la marimba todo se destruyó, la[s] gente[s] comenzaron a roza' y cuando eso ninguno le paraba bolas, ni Corpamag, ninguno, entonces no ve cómo está despejado todo y entre más días calienta más (R. Martínez y F. Quintero, comunicación personal, febrero del 2017).

Muchos de estos factores - tanto ambientales como sociales- ocasionaron el desplazamiento y la venta de las fincas, que pasaron a ser propiedad tanto de los que contaban con capital en la ciudad como de familias que tradicionalmente han estado en el poder en el departamento del Magdalena.

Imagen 146. Campesino cultivador de ají

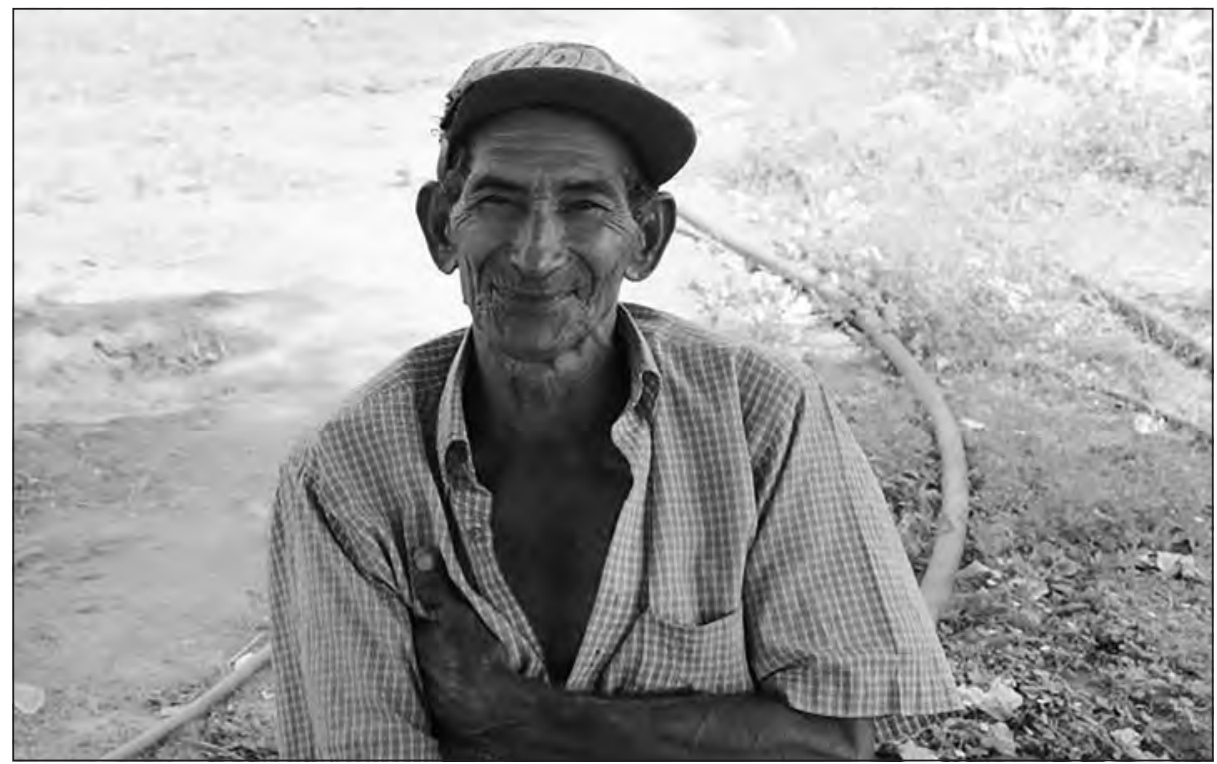

Fuente: Archivo Oraloteca (2017). 
La mayoría, como son gente que tienen dinero, ellos no viven aquí, ellos tienen sus negocios en Santa Marta. Aquí los pobres somos los que nos ponemos a sembrar ají, y eso, y por ahí a veces tomates y vainas así, pero la mayoría de las tierras como son de gente adinerada, ya no se siembra nada, casi no siembran por aquí. Este cultivo que ves aquí, por ahí no has visto más cultivos, pero por allá afuera no ves más cultivos porque son de gente, como te digo, que tienen su situación económica resuelta y tienen otros negocios. Entonces, por ejemplo, al frente se sembraba tomate también; eso es de un señor antioqueño, ahí van hacer unas cabañas, ahí tienen un proyecto de un complejo turístico que se llama "Punto Majagua" (tú te metes [a] puntomajagua.com y ahí consigues todo el proyecto de eso, maqueta y todo), sí... ahí van [a] hacer una cantidad de cabañas, ya lo que le falta es un papel por ahí que es lo único que le falta para arrancar con el proyecto e iniciarlo. Después, sigue allí arriba que ese también [es de un] coronel retirado del ejército, el señor Elías, y si es allá, la casa aquella, también son [de] unos terratenientes en todo el país, que tienen ganadería en casi todo el país, tienen plata; allá abajo, el señor Julio Vargas, él tiene sus canteras y sus fábricas de mosaico y toda esa vaina... entonces así la mayoría de la gente que tiene sus comodidades, sus trabajos, sus vainas, sus empresas, no necesitan de ponerse a sembrar ahí. Aquí los que sembramos ahí somos los llevados, como se dice vulgarmente, pero sin ayuda de nada ni de nadie. Aquí, por ejemplo, esa organización, que Umata, es inoperante, aquí ninguna de las instituciones de Santa Marta sirven para nada, no sirven sino para robarse la plata que da el Estado para los proyectos, para los campesinos y esa vaina, ahí sí son buenos, para robarse la plata que manda el Estado y así. Como te digo, por eso es que aquí la agricultura aquí en el Magdalena, nada más los que tienen plata son los que la pueden ejercer con toda influencia, que a esos sí los apoyan porque están dentro de la rosca, porque aquí en Santa Marta es una sola rosca. No ve que ahora por lo menos últimamente los dos alcaldes que han habido (este Caicedo y ahora este Martínez) y eso le han querido hacer la rosca, porque como eso no se está permitiendo que se roben el poco de plata que se robaban antes que manejaban a Santa Marta, los Dávilas y los Díaz-Granados, todo ese poco de bandidos (R. Martínez, comunicación personal, febrero del 2017). 
Vida campesina en el Magdalena Grande

\section{El problema del agua}

La subregión del Magdalena Grande ha padecido, en todos los municipios que la conforman, una carencia en el acceso al agua para poder cultivar. Muchas razones se encuentran implicadas en esta problemática; la principal tiene que ver con el hecho de que sea una subregión con gran presencia de monocultivos en el territorio, terratenientes que han creado sistemas de reserva de agua para garantizar el mantenimiento de sus plantaciones. Asimismo, las condiciones climáticas han empeorado con el paso del tiempo y, en el caso de Altos de Don Jaca, cuya fuente más cercana es una quebrada, la lluvia se ha convertido en la única forma de abastecimiento para sus cultivos; esta es cada vez es menos frecuente:

Esto es una vereda que sufrió mucho por el agua. Ahorita porque ven el poquito de agua que está corriendo, pero en tiempos de escasez ella se seca totalmente, quedando unos pequeños nacederos donde uno coge el agua para el consumo nada más, pero no se puede cultivar porque no alcanza el agua. $Y$ es muy rica porque lo que uno siembre se da: yuca, plátano, guineo, cilantro, café. Aquí a hora y media ya tenemos finca de café, a dos horas están la finca San José (que pertenece a Minca), Tigrera... sale por acá por este camino, este es un camino que conduce a Minca, Tigrera, al Campano, a la Central. Hacen excursiones, caminatas, no sé si habrán oído un programa que hay de unas caminatas que hacen de mil y pico de personas, trecientas, quinientas suben en motocross también por acá, bajan por Minca, por Tigrera, o viceversa: suben por allá y bajan por acá.

Hay muchos que quieren hacer huecos, a mí me han dicho que haga huecos para sacar agua y aquí no se puede porque estas son lomas y encuentra muchas rocas abajo y sería mucha profundidad para encontrar, pero sí mis hijos me van a echar una ayudadita con una manguera porque arriba hay bastante agua y vienen por toda la orilla del cerro ( $\mathrm{J}$. Manjarrez, comunicación personal, febrero del 2017).

Esto lo comencé a sembrar en el mes de noviembre, este pedacito aquí porque el agua no es continua porque nosotros no tenemos agua, sino que yo puse una manguera al dueño de esa finca y le dije: "yo le voy a poner esa manguera porque usted me buscó que la pusiera, pero no le voy a cobrar 
Vida campesina en el Magdalena Grande

ni un peso para que me regale un poquito de agua un día por media" y con eso es que estoy levantando esta migajita. Porque cuando esa quebrada se seca esto es un desierto, entonces el que tiene plata se hace sus pozos profundos, de 30, 40 y 50 metros de profundidad, y sale el agua, porque ellos las tienen ya (L. Rudas, comunicación personal, febrero del 2017).

Una de las causas asociadas a la insuficiencia del agua para el cultivo ha sido la monopolización de la misma en muchas fincas en las zonas más altas de Don Jaca, las cuales crearon un sistema de cobranza para que las fincas de abajo puedan acceder al recurso:

Aquí usted sabe que esa quebrada no la hizo nadie, eso lo hizo la naturaleza, eso lo dispuso Dios. Aquí cobraban la postura de una manguera 20 mil pesos mensuales. La difunta Olga, ella sacaba la manguera si veía que usted no pagaba la mensualidad, pero como yo no tenía nada que ver con el agua, sino el dueño de las tierras, cuando voy a llegando a la piedra miro un papel, cojo el papel y miro: "señor Alfredo, si no paga los 7 meses de agua a 20 mil no hay agua para usted". Yo digo: "bueno, la manguera está afuera, yo la voy a poner para regar", sin darme cuenta [de] si esa señora estaba ahí... cuando veo una machetilla y una 16. Cuando yo cojo la manguera para ponerla, me dice: "No, señor Lucho, qué pena con usted. Usted que la pone y tenemos problemas". Y yo le dije: "pero yo no soy dueño de tierra, tengo casi una cabuya de yuca y media cabuya de maíz y la batata". Me dice: "vea, ponga el agua que yo bajo con usted en la mula para que riegue lo que es de usted". Imagínese usted, compadre, la cogieron en Santa Marta y la metieron en una bolsa de esas negras, no la mataron... ya días antes le habían quemado la silla, a la montura de la mula, y se la quemaron en la carretera porque nadie debe cobrar agua ahí, porque eso es obra de la naturaleza, eso nadie hizo quebrada ahí, eso lo dispuso Dios (L. Rudas, comunicación personal, febrero del 2017).

\section{Tecnologías de subsistencia y adaptación al clima}

Existen problemáticas comunes entre los campesinos del Magdalena Grande. Una dificultad específica en Don Jaca es el difícil acceso al agua: además de su escasez, muchas veces no es apta para el consumo 
Vida campesina en el Magdalena Grande

humano. En algunos casos este problema es tan dramático que la siembra se paraliza durante épocas enteras del año, lo que conlleva a que los campesinos deban vender sus animales y erradicar todos sus cultivos de manera inmediata:

Es que el agua es por todas partes, eso no es solamente aquí en Altos de Don Jaca ni en Santa Marta: toda la Sierra Nevada ha sufrido la sequía, en toda la Sierra Nevada han mermado las aguas, la ciudad ha estado sin agua porque por el mal tiempo. Entonces, la sequía es la que lleva a un extremo de que no hay muchos cultivos, no puede uno comparar un punto con otro, esta vereda con aquella, porque cuando hay sequía es normal en todas partes... si fuera en una sola parte que hubiera sequía, pero es en todas partes (H. Moreno, comunicación personal, febrero del 2017).

En Don Jaca los apuros en relación con el líquido vital son de carácter extremo. Además de su ausencia total en determinados momentos, no hay un acueducto que facilite la llegada del líquido a los territorios de los campesinos; por este motivo, es necesario crear estrategias o tecnologías artesanales que logren extraer el agua del río y transportarla hasta las parcelas.

Imagen 147. Transporte de agua hacia las parcelas

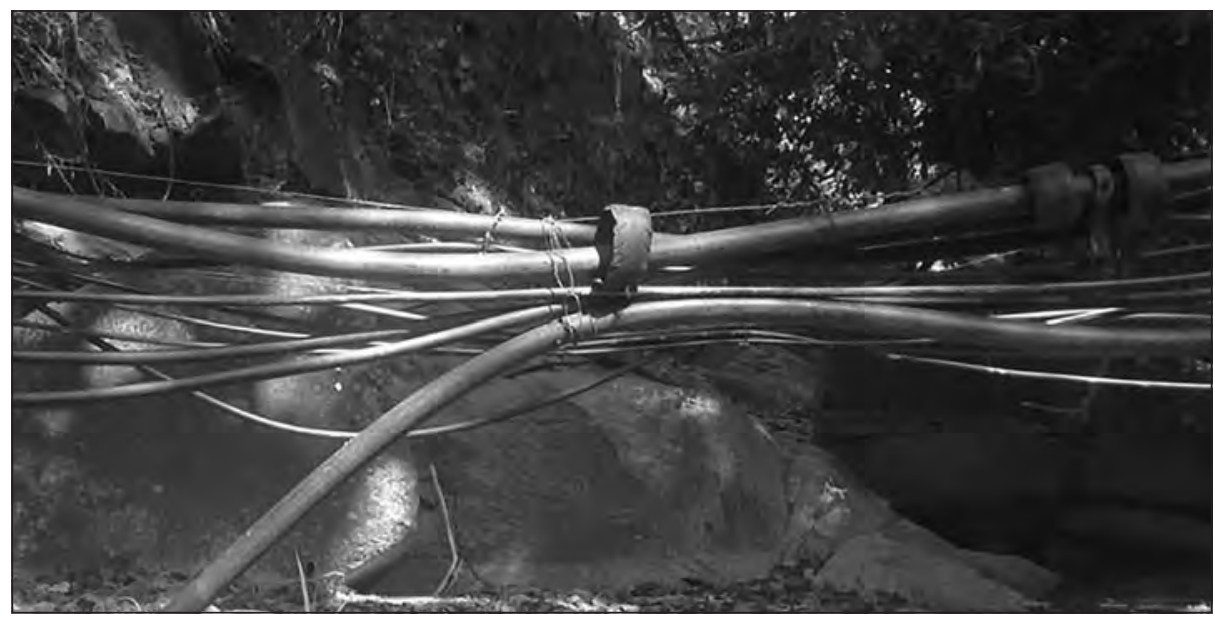

Fuente: Archivo Oraloteca (2017). 
Vida campesina en el Magdalena Grande

Los campesinos y las campesinas de Altos de Don Jaca deben generar medidas tecnológicas para extraer de manera artesanal el agua de una corriente diminuta que se encuentra ubicada en las partes altas de la montaña; esta quebrada está notoriamente lejos de las parcelas, por lo cual se ven obligados a conseguir determinados implementos como mangueras, tubos, o a crear postes para transportar el agua de manera aérea. Además, estos procesos tienen incidencia en la economía de los pobladores pues no es fácil conseguir los metros de mangueras necesarios y no todos tienen acceso a ello:

Cuando yo entré aquí a la vereda solamente había dos mangueras que eran: [una], de la cancha de golf que está allá en la carretera en la doble vía y, otra, de la familia de los berrocales. Solamente [había] dos mangueras; el resto del agua corría por ahí, pero, como le digo, anteriormente no había la población que hay ahora. A partir de que se aumentó la población, la gente quiso organizarse como para hacerse un acueducto, pero nunca llegaron a un término de ejecutar y hacer un proyecto para el acueducto. Entonces, cada quien que tenía su lote de tierra, compraba sus mangueras, las traía y la instalaba al lado de la quebrada y llevaba su agua a la casa. Entonces, ese es el manejo que se da aquí: cada quien dueño de parcela que tiene la facilidad compra su manguera y coloca su agua, por eso es que ahora se ven tantas mangueras que deben de haber como cincuenta más o menos y las que no se ven aquí, que se ven de otra parte más abajo donde hay unos nacederos que salen para allá abajo (E. Osorio, comunicación personal, febrero del 2017).

Asimismo, la convivencia se ve afectada, pues solo algunos pobladores poseen los implementos necesarios para acceder al agua; los demás se ven obligados a acudir a sus vecinos, lo que no siempre es fácil y muchas veces puede alterar la convivencia con los mismos. De esa manera, también es necesario aclarar que no siempre las personas aledañas a los que no tienen el recurso vital están dispuestas a brindar la ayuda. Esto no solo problematiza las relaciones, sino también el trabajo de la agricultura; además, genera nuevas tecnologías de recolección del agua mucho más difíciles que la anterior (un ejemplo de ello es comprarla o bajarla de la montaña): 
Vida campesina en el Magdalena Grande

Aquí en tiempo de sequía, aquí vinieron tres o cuatro vecinos míos, me decían: "nosotros no tenemos agua, necesitamos un turnito". Yo le pasaba su turnito de agua, yo de parte mía no les cobré, de pronto hay otras personas que sí. [Uno] debe de colaborar porque de allá prácticamente desde donde ustedes vienen caminando y de aquí para arriba para tener agua en tiempo de sequía hay que caminar una hora, hora y pico, entonces mira el trayecto que hay. Entonces, una persona echando el agua y otra que venga y la coja de pronto el otro no se va aguantar, entonces de pronto tienen que dar y ellos tienen que hacer mantenimiento a la manguera, hay que ponerle caucho, hay que remendarla, hay que hacer. Entonces de pronto tenga un costo, pero no sé qué costo le pondrá entre, entre el arreglo que cada quien haga (E. Osorio, comunicación personal, febrero del 2017).

Pese a implementar las técnicas antes mencionadas, existen determinadas épocas del año en las que ni siquiera las tecnologías que utilizan los campesinos son suficientes a la hora de recolectar el agua, pues las condiciones climáticas cambiantes tienden a proporcionar un menor nivel de pluviosidad en esta zona. Con el tiempo, los campesinos han identificado los meses del año en los que se observa en menor medida la lluvia y en mayor medida la sequía; a pesar de ello, sus conocimientos no bastan a la hora de hacer frente a la crisis natural, lo que los conduce a tomar medidas radicales.

Imagen 148. Cría de cerdos

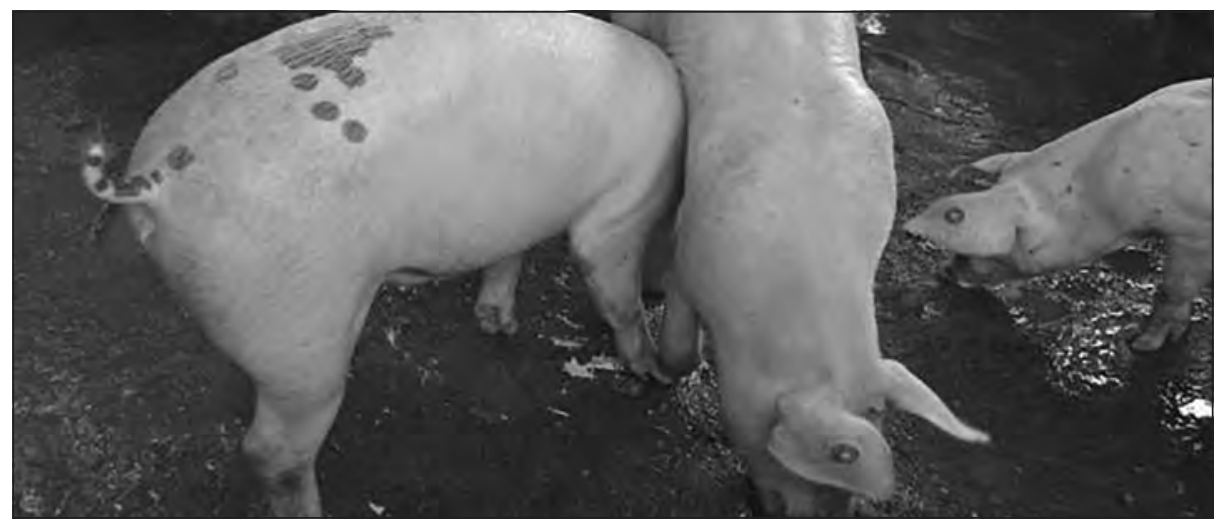

Fuente: Archivo Oraloteca (2017). 
Vida campesina en el Magdalena Grande

La escasez de agua no solo afecta la producción agrícola en la vereda. Aunque la cría de animales es una de las alternativas de subsistencia de los campesinos y campesinas, sin agua se hace imposible sostenerla. En esa medida, cuando llegan las temporadas de sequía los campesinos se ven obligados a matar todos sus animales y, al hacerlo, ponen fin a los recursos que obtenían para el manteamiento de sus familias:

Pues sí, Dios quiera que siga [la lluvia], que haya agüita en la quebrada pues los tenemos ahí [los animales], pues cuando ya vea que el agua está mermando y que ya no llueva los corrales hay que sácalos. Esos chivos que están bonitos los vamos vendiendo para la comida y para ayudarnos acá y los puercos, los que están grandes sí los vamos matando (G. Ruiz, comunicación personal, febrero del 2017).

\section{Vías de acceso: limitaciones para la comercialización}

El agua no es el único componente que perturba de manera directa al campesinado de Altos de Don Jaca. Además de este problema, el campesinado sufre grandes afectaciones como consecuencia del abandono estatal; una de ellas es el mal estado de las vías de acceso, que se va deteriorando a medida que nos alejamos más del casco urbano. El trabajo de la construcción de la carretera principal se ha generado de manera artesanal y comunitaria entre los campesinos y campesinas del sector, siendo palpable la afectación que esta problemática genera en la vida de los agricultores del lugar, debido a la dificultad del transporte de los productos para su comercialización:

Bueno, las vías aquí nos ha tocado a nosotros con pico y pala para arreglarlas. Aquí solamente esas vías están construidas porque los dueños de predios fueron los que hicieron toda la vuelta para hacer la vía. Para mantenerla nos ha tocado entre pico y pala, entre todos ayudar para que se vaya arreglando, lo que nos decían la otra vez del transporte, decían que de pronto podían implementar hasta el colegio una ruta, después dijeron que no, que por los atracos, que atracaban para ir a Don Jaca, para ir a Decamerón, que si se metían [a] esta trocha eran más peligrosos, entonces eso se frenó, se quedó ahí, pero sí tuvimos varios acercamientos, varias 
Vida campesina en el Magdalena Grande

reuniones donde nosotros solicitábamos que de pronto se colocara una ruta para que la gente, de pronto en la mañana, al medio día, en la tarde, que fueran como tres veces en el día - que era que había la movilización del personal: en la mañana, al medio día y en la tarde-, pero no, no se ha llevado a cabo. Si hay barrios en Santa Marta y no entran las rutas... ahora una parte de aquí... aquí de pronto hay carritos que uno necesita de pronto llevar un[a] carga y traerla, los llaman y ellos vienen y de aquí mismo. También hay motos, pero ahorita quieren cobrar una cantidad de plata para venir [a] hacer una carrera, entonces la gente más bien han hecho el esfuerzo y compran una moto para tener... casi la mayoría de parceleros tenemos una motico como para transportarse uno más rápido y tener el transporte uno ahí a la mano (E. Osorio, comunicación personal, febrero del 2017).

Habitantes de la zona como la señora E. Osorio relacionan el problema de las vías con la inseguridad que, según ellos, se puede generar por estos espacios denominados "urbanos" (que se encuentran cerca de las parcelas); sin embargo, estas rutas se convierten en un problema no solo para el comercio de las frutas y animales, sino también para el transporte mismo de las personas que residen en el lugar, por lo que se deben implementar diferentes maneras individuales para solucionar el transporte de la entrada de Don Jaca a las partes altas (entre esas está comprar una moto, pero eso solo para los que tienen los recursos para ello):

Hay un señor en una moto que le pone dos bultos, uno de cada lado, y hace hasta cuatro viajes, ese es el transporte por aquí, porque no hay más nada y no hay una carretera para decir: "vamos a meter el carro para sacar la agricultura", no se puede porque no sé qué le pasa [a] esta vereda. Ahí compró un señor cocotudo y ya tiene sus calles, tiene su venido, y eso lo va a enchapar. Compró desde la alterna todo esto, yo no lo conozco, yo oigo los comentarios; si ese hombre compra todo esto, ¿para dónde vamos a coger nosotros? (L. Rudas, comunicación personal, febrero del 2017).

Los campesinos de Altos de Don Jaca no solo están olvidados por los gobiernos nacional y departamental en relación al agua y a la energía eléctrica, sino también en relación a las vías de acceso que, para ellos, son 
Vida campesina en el Magdalena Grande

fundamentales para el transporte de las frutas y vegetales resultado de sus esfuerzos en la tierra. Por este motivo, además de tener que lidiar con las no muy favorables condiciones climáticas, deben buscar alternativas para "bajar" su cosecha de las partes altas; esto se debe hacer, primero, caminando, y, después, alquilando un vehículo (los que tienen la posibilidad) para transportar y comercializar los productos.

\section{Los retos y ganancias de la asociatividad}

Tanto en la vereda el Mosquito como en Altos de Don Jaca las festividades tienen grandes insuficiencias. Una de las causas de esta falta de compadrazgo en los territorios tiene que ver con que estas veredas se conforman en su mayor parte por desplazados del departamento del Magdalena y del interior del país, donde las relaciones han sido complicadas debido a la trascendencia del conflicto armado como un factor de debilitamiento de las relaciones interpersonales. Sin embargo, en comparación con la vereda el Mosquito, Don Jaca guarda mayor tradicionalidad en sus elementos organizativos, desde las relaciones de actividad de pesca hasta las cooperativas y usuarios campesinos referidos a la vereda.

Imagen 149. Tostando café en Altos de Don Jaca

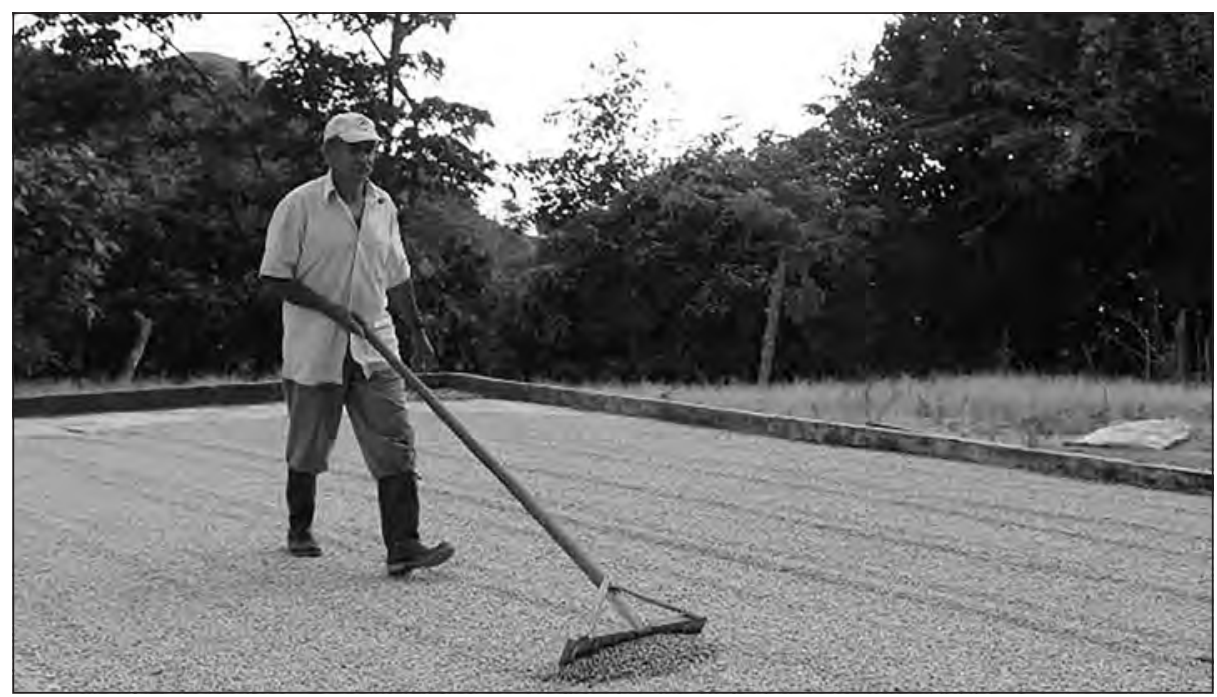

Fuente: Archivo Oraloteca (2017). 
Vida campesina en el Magdalena Grande

"Lo único que yo recuerdo es que esto era muy bonito: llegaba diciembre, visitaba a mi vecino, no me tocaba ni llevar ron porque allá tenían; ahora no, porque ahora lo que no hay es plata... y todavía es sabroso, yo nunca he tenido problema. Ya las fiestas se han acabado... yo por los menos un 25 de diciembre tengo mis fiestecitas; ya eso por aquí no se ve ya" (D. Prado, comunicación personal, febrero del 2017).

Los campesinos recuerdan con melancolía la celebración del Día del Campesino, en la que lograban crear un sistema de redes tanto comerciales como de la situación que atravesaban los territorios circunvecinos a Don Jaca. Estas actividades eran dirigidas por el Distrito, pero con el paso del tiempo fueron desapareciendo:

Una vez abajo se celebró el Día del Campesino, que iban a repartir herramientas y eso; ni más se dio eso. Ese día se vio que los dirigentes son corruptos, la corrupción siempre, aquí nunca han dado nada para campesinos. Aquí una vez la Federación de Cafeteros, de ahí ni más, nunca han vuelto a dar nada (E. Escalante, comunicación personal, febrero del 2017).

Aquí se iba hacer lo del Día del Campesino, pero nunca se festejó; aquí íbamos a otra parte, pero aquí nunca se festejó. Era el cumpleaños del sector, pero estuvimos trabajando en eso y no se pusieron de acuerdo, que no les parecía esto, que lo otro. También les decíamos que, como yo que era la presidenta de junta de acción comunal, le decía a los campesinos: "vamos a cambiarle el nombre de Don Jaca parte alta, identifiquémoslo con otro nombre", [y ellos] "que no sé qué, que no"... unos cuantos sí y otros no, entonces tampoco se llevó a eso. Aquí las festividades que se hacían, porque ya tampoco las hacen, un señor que festejaba San Martín el 11 de noviembre, pero de ahí en la vereda no (E. Osorio, comunicación personal, febrero del 2017). 
Imagen 150. Pisadas campesinas en Altos de Don Jaca

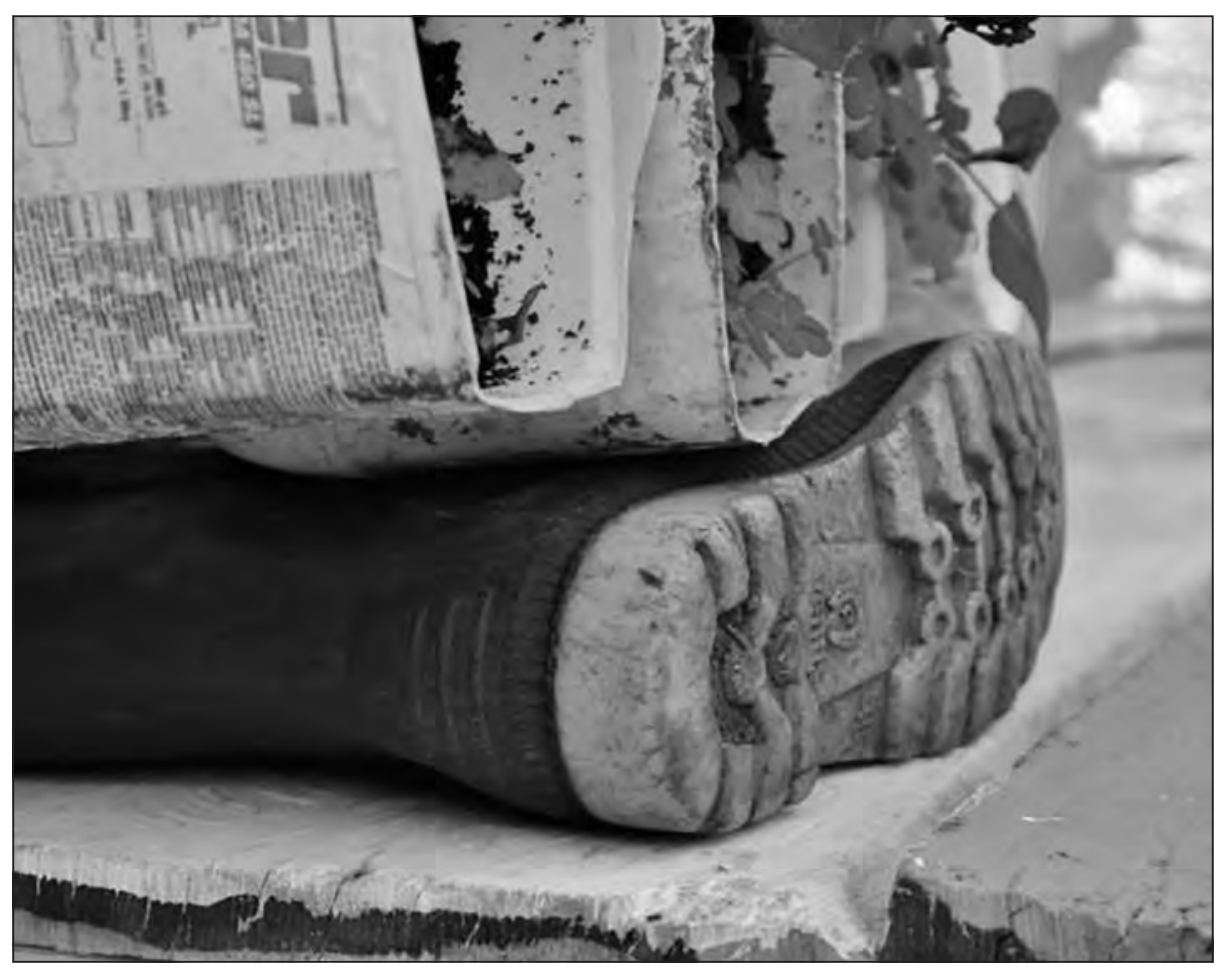

Fuente: Archivo Oraloteca (2017).

Aunque en la actualidad existe la junta de acción comunal de Altos de Don Jaca, aún hay cierta apatía por estos espacios de organización; existe una constante deslegitimación de estas organizaciones en los procesos de apoyo a campesinos:

Aquí se organizaron desde que iniciaron la invasión los colonos allá. Ahí se formaron una junta de usuarios campesinos, sacaron su personería jurídica, su junta de acción comunal. Primero fue [la] asociación de usuarios campesinos y luego sacaron su junta de acción comunal, y pues hasta la presente está ahí funcionando la junta. Yo duré dos periodos; ya renuncié porque ya estaba como muy agotada para seguir con esos trotes. Ahorita es una muchacha que vive más abajo, donde la señora Rafaela, una señora, y entonces ahí está la organización. 
Vida campesina en el Magdalena Grande

Cuando yo fui presidenta estuve en Bonda hablando con la presidenta, donde sí habían construido un acueducto comunitario que les había ayudado una universidad, para ver si aquí se implementaba eso, pero entonces la gente no quiso, dijeron otros que no. Primero trajimos a Corpamag porque dijeron que teníamos que hacer la asociación con Corpamag y el acercamiento, porque tú sabes que las quebradas son de... del Estado, entonces uno debía de pagar un impuesto a la nación o al Estado por coger el agua, eso no venía siendo mucho, eso era como 19 mil pesos al año y uno tenía el derecho al agua. Entonces, ¿qué pasaba? Que ellos dijeron: "bueno, si usted, todos como campesinos se asocian, nosotros buscamos los medios por medio del cual a ustedes les ayuden a construir un... un acueducto". Entonces la gente se alarmó cuando dijeron que iban a cobrar por el derecho que cada quien tenía que hacer una afiliación y [que] debíamos pagar por año más o menos 19 mil pesos. Entonces la gente ya cuando dicen que uno tiene que pagar ya la gente empieza a desertar. Entonces vinimos trabajando 3 meses, como 4, citamos a otra reunión, la gente ya no quiso acercarse, dijeron que yo los iba a perjudicar, que esto y que lo otro, porque iba a ver un proyecto con Corpamag e Incoder para hacer un, un acueducto, pero eso nunca, nunca se llevó a cabo porque la gente no aceptaron. Entonces, por ese motivo, cada quien, y el que no tiene agua bien le pide al vecino o, como las mangueras pasan por ahí, cada quien desconecta y llena, y luego conecta la manguera para que siga (E. Osorio, comunicación personal, febrero del 2017).

La organización en Don Jaca ha permitido la creación de actividades para el fortalecimiento del territorio: las cohesiones en el mejoramiento de vías de acceso y propuestas enfocadas a la formulación de cooperativas de líneas comerciales son algunas de las tantas conversaciones que han figurado en las reuniones paulatinas de los campesinos. Sin embargo, la mayoría de los temas y retos organizativos de la comunidad están atravesados por la insuficiencia hídrica del territorio, por lo que reclaman un acompañamiento continuo en los procesos de mejoramiento y búsqueda de mecanismos para la solución de sus problemas, intervenciones que no han sido realizadas por las instituciones encargadas; por el contrario, cada vez más se fortalece la expansión de los puertos de carga de carbón y la contaminación de los suelos: 
Se hacía[n] actividades dependiendo de la situación: de pronto, para el Día de las Madres, un evento, para el Día de la Mujer, para el Día de los Niños, el Día de la Familia, en diciembre toda la novena de aguinaldo donde se conseguían los regalos para los niños [y] el veinticuatro se les repartía[n], se les hacía una misa, se hacían primeras comuniones, bautizos; este año no se hizo, no sé qué pasaría. Lo otro era[n] capacitaciones a jóvenes de la[s] zona[s] rurales que maneja el SENA: se les traía su curso de construcción, de hortalizas... bueno, cualquier cosa que saliera, lo traían y lo dictaban en el colegio. Ecopetrol mandaba también la Cruz Roja, prevención de desastres, eso se hacía esporádicamente, dos veces al año, brigadas de salud (cuando se ameritaba una brigada) o lo del Sisben se traía también al colegio.

La mayoría, todos están inscritos en el libro porque deben de aparecer en el libro de la junta de acción comunal, porque aquí con Ecopetrol se llevó un proyecto en el que le daban trabajo a las personas de acá. Por ser zona de influencia, Ecopetrol estaba obligado a brindarle unos empleos a las personas y como nosotros le decíamos que las empresas por aquí... [que] la gente no tenía acceso a las empresas por... lo[s] uno[s], porque estaban más lejos; los otros, porque trabajaban en el campo y eso... ellos aquí les dan un chance o les dieron bastante trabajo a la gente y se llevó un proceso durante el cambio de la nueva tubería e hicieron un proyecto muy bueno en el colegio, construyeron el comedor, terminaron la cocina y mejoraron toda la planta física del colegio, un proyecto de 200 millones de pesos que ellos invirtieron ahí con dotación de todo: de sala de internet y cocina, estufas, neveras, lo que es para los niños, para cosas didácticas, el amueblamiento del salón para el comedor y todo, nos ayudó mucho. Ecopetrol ayuda mucho en esta zona gracias a Dios. La gente que pudo entrar, trabajó; [a] algunos que ya les quedó su casita y ya tienen hoy en día mejoraron su calidad de vida; otros no porque de pronto... todos no pensamos de la misma manera y gastaron su plata y no hicieron nada, pero hay algunos que sí aprovecharon (E. Osorio, comunicación personal, febrero del 2017). 
Vida campesina en el Magdalena Grande

\section{“Dejar el sombrero": la emigración como consecuencia de la apatía gubernamental}

Imagen 151. Sombrero campesino

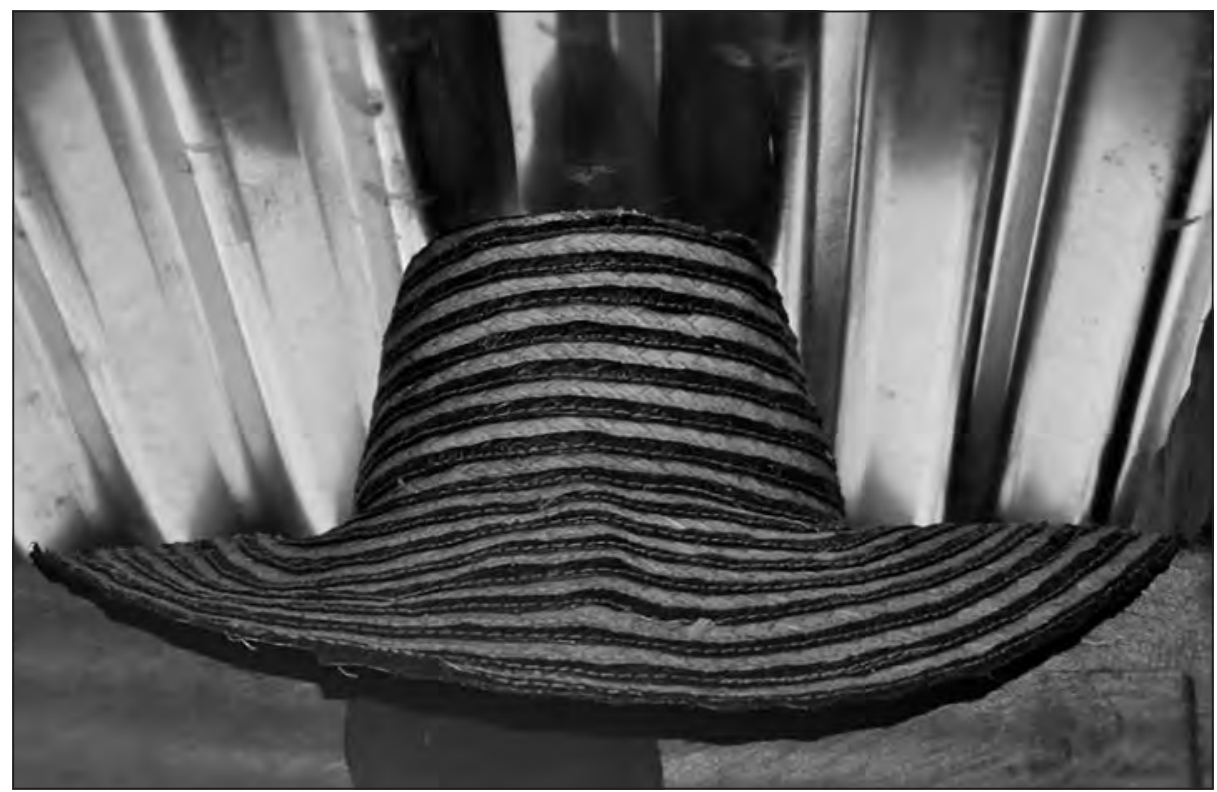

Fuente: Archivo Oraloteca (2017).

Hoy, a medida que se recorre la carretera principal desde Don Jaca hasta Altos de Don Jaca, es una realidad palpable la venta indiscriminada de parcelas: letreros de "se vende" abundan en la zona como consecuencia de los problemas que hemos mencionado hasta ahora, la falta de recursos producto de una segregación política, económica y social, las vías en mal estado y el clima cambiante hacen que los campesinos piensen en abandonar las parcelas y dirigirse a la ciudad en busca de una mejor calidad de vida:

Caramba, si el Gobierno no se pone las pilas [para] ayudar al campesino. Te cuento que lo veo crítico porque todo el mundo, porque como ahora está llegando tanto gringo y tanta vaina la gente está vendiendo a los gringos, a quien puede, para salirse para el pueblo a comprar casita y vainas para arrendar y vivir mejor, porque el campo ya casi no da; porque 
Vida campesina en el Magdalena Grande

el gringo no necesita trabajar, sino que ellos quieren dejar las cosas como para que se vuelvan bosques, como tienen de qué vivir (F. Rodríguez, comunicación personal, febrero del 2017).

Lo anterior es una realidad a la que no solo se enfrentan los campesinos más adultos, sino también los más jóvenes; las esperanzas de ser campesino en el territorio de Altos de Don Jaca se mantienen conforme a la resistencia de los mismos. La transmisión de los conocimientos tradicionales de los campesinos de la vereda se ha llevado a cabo desde que eran pequeños: los traspasos de esos saberes se hacían en relación a la crianza. Los campesinos no solo se centran en traspasar de una generación a otra las formas tradicionales que se deben saber para la agricultura y cualquier tipo de lógicas relacionadas con el campo, sino que los campesinos más adultos también se concentran en la crianza y utilizan la tierra como método de enseñanza para la vida adulta; según ellos, con esta metodología se aprenden los valores de la responsabilidad, amor por la vida, respeto, admiración, trabajo, etcétera: "Si ellos eran campesinos también, figúrate, por eso uno hereda lo de ello[s], el campesino es campesino porque los viejos han sido campesinos y uno busca la misma rutina de los viejos" (F. Rodríguez, comunicación personal, febrero del 2017).

Los padres acostumbran a llevar a sus hijos a los sembrados para que trabajen con ellos y juntos siembren la yuca, el plátano o lo que haya que sembrar; sin embargo, los trabajos que hacen los niños no son de esfuerzo: para ellos resulta incluso una forma de recreación en la que se divierten mientras aprenden. Aunque el aprendizaje y la trasmisión de los conocimientos de adultos a jóvenes se da hacia hombres y mujeres, en su gran mayoría siempre son hombres quienes trabajan en los cultivos; es probable que esto suceda por la idea de la "fuerza". Así también, es notable la división del trabajo: las mujeres asumen las labores propias de la economía del cuidado mientras los hombres el trabajo de la tierra.

Los hijos míos nunca han estado en el campo porque siempre fueron criados en Gaira. Ellos vienen aquí al monte, hay unos que les gusta, pero no les hace estar acá... van y vienen. Por lo menos mañana vienen y se están aquí conmigo, hacen unas cosas, hacen otras, y se va otra vez. No es como yo que sí me nace. Yo me voy para Santa Marta, para la casa, y 
Vida campesina en el Magdalena Grande

no duermo por estar pendiente de venirme para acá y al otro día les digo: "denme un tinto que ya me voy para el monte" (J. Manjarrez, comunicación personal, febrero del 2017).

Ahora bien, la búsqueda de una mejor calidad de vida ha llevado a que las personas más jóvenes abandonen el territorio y se dirijan a las zonas denominadas "urbanas"; esto sucede también por la necesidad que tienen los padres y madres de brindarle a sus hijos una "vida diferente", como ellos dicen: la educación es uno de los condicionantes importantes que obliga a los pobladores a salir, incluso muchas veces toda la familia o, en otros casos, el padre se queda trabajando en el campo para poder suplir las necesidades económicas del círculo familiar.

Para los campesinos que habitan en Altos de Don Jaca es un orgullo tener los conocimientos agrícolas que les fueron impartidos por sus padres, pues hoy pueden vivir del campo, no con las mejores condiciones, pero adquieren alimentos que ellos mismos sembraron, lo que evita que se tengan que comprar en la ciudad de Santa Marta:

Mano, pues hoy en día para uno de campesino es como una honradez porque para la edad que yo tengo y no tengo problemas, yo salgo para cualquier parte y no tengo problema, yo salgo para cualquier parte y no tengo problema con nadie. Es un trabajo como cualquier trabajo, lo que pasa es que como yo me descuidé, no soy ningún tipo de empleado de ninguna empresa ni nada, nada para una pensión ni nada (F. Rodríguez, comunicación personal, febrero del 2017).

La alegría de uno como agricultor es ver el cultivo que esté bien. Nosotros aquí cerquita, como a diez minutos, teníamos hace dos años una platanera y unos guineos que, sin mentira ninguna, uno tenía que partirlo porque eran unos gajos así y uno iba allá cerquita, a diez minutos, y había yuca, había malanga, guineo, plátano... y uno con llegar allá uno sentía como que esa alegría, como que "ay, Dios mío, gracias Padre porque mira todo lo que tenemos aquí a la mano". Pero la tristeza más grande es cuando llegó el verano y uno vio todas esas matas paridas y todas se fueron secando, se fueron cayendo, se siente uno una impotencia de saber aquí [la] cantidad de limones [que] se nos murieron, les echamos el 
Vida campesina en el Magdalena Grande

poquito de agua, pero eso no era suficiente, entonces eso digo que es una frustración para uno, ver que el trabajo de uno y se acaba en un momento (E. Osorio, comunicación personal, febrero del 2017).

Un orgullo, un orgullo, porque bonito es que usted venga aquí y teniendo yo y no lo conozca: este muchacho vino, vamos para que te lleves dos matas de yuca, vamos para que te lleves unos fríjoles, esa vaina es hermosa... pero no habiendo nada, ¿qué le podemos brindar? Nada. Una persona que tenga ese corazón y usted lleve de esa agricultura, ¿cómo se sentiría usted? Contento, vea... entonces ya se lleva a esa persona aquí en la mente y para olvidarlo es difícil (L. Ruda, comunicación personal, febrero del 2017).

No obstante, hay campesinos y campesinas que no aprendieron los conocimientos solo de sus padres. Así también, es una realidad que debido a la escasez económica los miembros de la familia, incluyendo los niños, deben trabajar, ya no como metodología educativa, sino como mecanismo de adquisición de dinero para el sostenimiento del hogar:

Trabajaba con los Dávila, de ocho años tirando machete y yo sé qué es pasar trabajo, lo que es la necesidad. Por eso yo a veces me siento en cualquier piedra en la madrugada y se me salen las lágrimas en vista de que yo no le puedo dar lo que la mujer mía quiere. Desde pelado, desde que fui adulto y yo digo: ¿por qué, Señor, tienes este castigo conmigo? (L. Ruda, comunicación personal, febrero del 2017)

Las oralidades son un componente de suma importancia para la conservación de los saberes que fueron impartidos de generación en generación y, de esa misma manera, hoy se conservan y se crean nuevos conocimientos como alternativa de adaptación al clima. Las relaciones con campesinos que llegan de otros lugares también hacen que se construyan charlas en las que se comparten tanto instrucciones sobre siembra, mantenimiento y cosecha de los cultivos, como de medicinas tradicionales, anécdotas y demás elementos culturales cargados de saberes locales. La preservación de la memoria en la vida de los campesinos es de suma importancia en la relación directa con su entorno. 
A lo largo de este escrito, que ha sido construido con los campesinos y campesinas, encontramos elementos claves de las cotidianidades de los mismos; entre esos, las dificultades que deben padecer por la falta de la presencia de políticas que se construyan pensándose hacia el beneficio de estas comunidades. A pesar de que la vereda se encuentra cerca de la ciudad, las relaciones que los campesinos tienen con la misma no es muy profunda, a no ser que haya una lógica laboral en algún lugar de la ciudad (lo que no es muy común, pues los que laboran en unas zonas urbanas residen en ellas); sin embargo, muchas veces también se acude a la ciudad para adquirir los elementos necesarios de la comida diaria que no se pueden sembrar como el arroz, el aceite, el azúcar, entre otros. No obstante, el mal estado de las vías impide la relación directa y constante entre campo y ciudad. 



\section{Conclusiones}

Durante la realización del presente trabajo tuvimos la oportunidad de recorrer diversos territorios campesinos - en los departamentos del Cesar, Magdalena y La Guajira-, en los cuales pudimos recoger significados, narrativas y sentidos comunes de campesinos y campesinas que habitan el territorio desde hace mucho tiempo y que pueden por tanto interpretar de una manera distinta las situaciones sociales percibidas como "problemáticas".

Para la construcción de estas conclusiones se realizó un encuentro con delegados y delegadas de los territorios campesinos que fueron visitados, el cual se desarrolló en la Universidad del Magdalena durante el mes de abril del 2017. En este encuentro se recogieron elementos que, junto a las experiencias de los investigadores en cada uno de los territorios, permitieron elaborar un diagnóstico de las principales problemáticas que vienen aquejando a este sector de la población en el Caribe y, de esta manera, elaborar algunas propuestas que buscan esbozar lineamientos para la construcción de una política pública para el campesinado del Magdalena Grande y, por qué no, para toda la región.

Para esto, tanto los elementos del diagnóstico como las propuestas fueron divididos en cuatro dimensiones de manera que nos permitieran organizar, sistematizar y proyectar de mejor manera la información aportada por las comunidades, siendo estas dimensiones: la socioambiental, la socioeconómica, la sociopolítica y la sociocultural. 
Vida campesina en el Magdalena Grande

\section{Mesa socioambiental}

En los territorios que conforman el Magdalena Grande encontramos una gran diversidad de paisajes y ecosistemas que determinan la vida de las comunidades que los habitan. Por esta razón, para el desarrollo de este trabajo se dividió este amplio territorio en subregiones geográficas, de modo que nos permitiera abordar de mejor forma la realidad de los territorios campesinos y las relaciones que sobre ellos se construyen. Es así como encontramos la Sierra Nevada de Santa Marta, el desierto de La Guajira, la Serranía del Perijá, los valles y sabanas de los ríos Cesar y Magdalena, la ribera del río Magdalena y la Ciénaga Grande de Santa Marta.

Sobre estos territorios existen diversas figuras jurídicas y administrativas que los cargan de significados y construyen territorialidades, regulando el ordenamiento territorial, el acceso a los recursos y las formas de ser y existir de las poblaciones que los habitan. Así, por ejemplo, encontramos que, para el caso del Magdalena Grande, el Sistema Nacional de Parques Naturales registra la presencia del Parque Nacional Natural Tayrona, la Vía Parque Isla de Salamanca, el Santuario de Fauna y Flora los Flamencos, el Parque Nacional Natural Macuira, el Parque Nacional Natural Sierra Nevada de Santa Marta y el Santuario de Fauna y Flora Ciénaga Grande de Santa Marta; territorios sobre los cuales esta entidad ejerce control y administración.

Así mismo, encontramos la declaración de Reserva del Hombre y la Biosfera que la UNESCO hace sobre la Sierra Nevada de Santa Marta y las declaraciones RAMSAR sobre la Ciénaga Grande de Santa Marta en el Magdalena y la Ciénaga de Zapatosa, en el departamento del Cesar, territorios que por su importancia ecosistémica para el mundo están protegidos por acuerdos y convenios internacionales que el Gobierno ha suscrito y que lo obligan a garantizar su protección y preservación.

Por otro lado, encontramos territorialidades correspondientes a los diferentes grupos étnicos que habitan estos departamentos, como el resguardo de la Alta y Media Guajira; ocho resguardos en el Sur y Media Guajira y la Reserva de Carraipía, pertenecientes al pueblo wayuu; seis resguardos en la Serranía del Perijá, pertenecientes al pueblo yukpa; los resguardos Issa Oristunna, Itti Takke' y Nara Kajmanta, pertenecientes 
al pueblo ette-ennaka; el resguardo kogui -Malayo- Arhuaco, perteneciente a los pueblos wiwa, kogui, arhuaco y kamkuamo, de la Sierra Nevada de Santa Marta; el resguardo de Businchama, también en la Sierra Nevada, perteneciente al pueblo arhuaco, y el resguardo de Campo Alegre, en la Serranía del Perijá, perteneciente al pueblo wiwa.

En lo referente a las comunidades campesinas, por el hecho de no contar con un reconocimiento constitucional que les permita la gobernabilidad de sus territorios, sus dinámicas se desenvuelven en las intersecciones generadas por las territorialidades anteriormente mencionadas $y$, en muchas ocasiones, se ven empujadas al auto reconocimiento como miembros de las colectividades étnicas; de esta manera, pueden garantizar su derecho a permanecer en el territorio. A pesar de esto, en estos departamentos encontramos algunos territorios que buscan constituirse bajo la figura de "Zonas de Reserva Campesina", amparadas en el Capítulo XIII de la Ley 160 de 1994. De esa manera, los territorios que se proyectan como territorios aptos para constituirse como Zonas de Reserva campesina son: ZRC Piedemonte y Zona Bananera, ubicada en el departamento del Magdalena; la ZRC Mesa Regional Campesina del Perijá, ubicada en el centro del departamento del Cesar; la ZRC Asoperijá, ubicada al norte del departamento del Cesar, en las estribaciones de la Serranía del Perijá; la ZRC del Sur de La Guajira, ubicada en las estribaciones de la Serranía del Perijá en el sur del departamento de La Guajira; la ZRC del Centro de la Guajira, ubicada, como su nombre lo indica, en el centro de La Guajira, entre la Serranía del Perijá y el río Ranchería, y la ZRC del Norte de La Guajira, ubicada entre los Montes de Oca, el río Ranchería y a frontera con la República Bolivariana de Venezuela. Así mismo, encontramos el territorio denominado "Sustracción Cesar", ubicado en el centro del departamento y que ya se encuentra en proceso de constitución como Zona de Reserva Campesina. 
Vida campesina en el Magdalena Grande

Mapa 15. ZRC en el Magdalena Grande

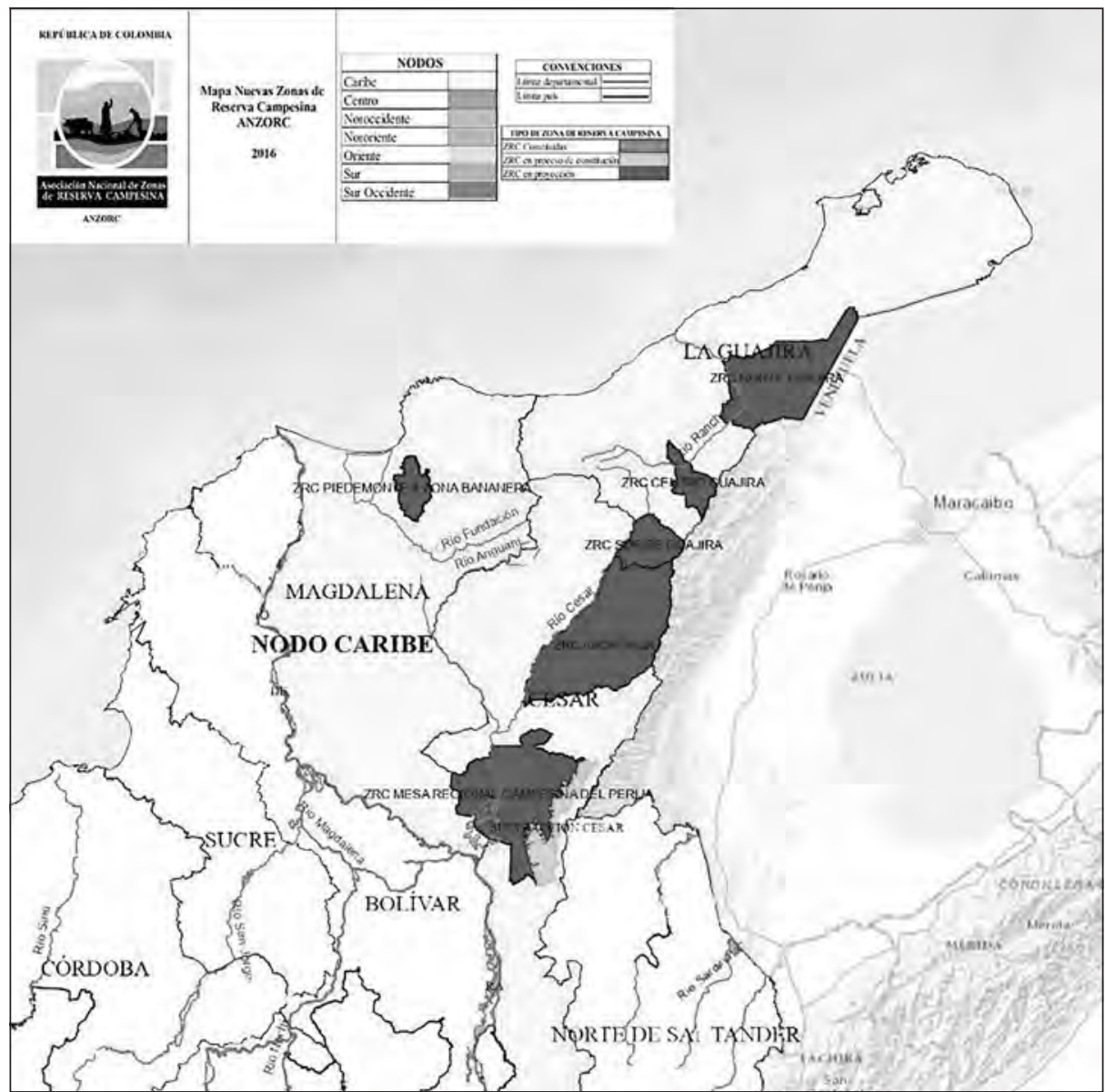

Fuente: ANZORC (2016).

Frente a este escenario, las comunidades campesinas no tienen mecanismos de gobernabilidad que les ayuden a controlar las afectaciones ambientales que sobre el territorio se generan a raíz de la intervención de grandes megaproyectos y actividades ilegales como la minería, la deforestación, entre otras. De esta manera, no tienen más herramientas que la de denunciar frente a las autoridades competentes, las cuales, en muchos casos, hacen caso omiso a estos problemas o, como manifiestan las mismas comunidades, en muchos casos están involucradas en estas actividades. 
Precisamente durante el encuentro realizado se pudo identificar que un problema central en los territorios en materia ambiental es la "permisividad gubernamental", al considerar que las instituciones no hacen valer las medidas y estrategias que desde hace años se han diseñado para la protección del medio ambiente, los convenios internacionales y las disposiciones sobre los territorios étnicos o al señalar que, en muchos casos, las instituciones son selectivas en la aplicación de estas medidas y estrategias, lo que ha permitido fisuras sociales, políticas, económicas y culturales que, eventualmente, desencadenan en problemáticas ambientales.

En ese orden de ideas se identificó que dicha permisividad gubernamental consiente la deforestación de bosques y nacederos de agua, encontrándose como momento cumbre de esta práctica las épocas de la bonanza marimbera y cocalera, que incitaron la tala desmedida de árboles para el cultivo de estos productos. Sumado a esto, los grandes terratenientes ganaderos y la expansión de los monocultivos, en general, son responsables de gran parte de la deforestación en la región, sin desconocer la responsabilidad de algunos campesinos e indígenas que encontraron en la tala de ciertos árboles una fuente de mantenimiento para sus familias.

La proliferación de los cultivos ilícitos en los territorios por cuenta de los actores armados se convirtió en un problema ambiental no solo por la deforestación, sino también porque los programas de erradicación por medio de fumigaciones con glifosato- promovidos por el Gobierno esterilizan la tierra y no discriminan entre cultivos ilícitos y cultivos de pancoger; esto, sin mencionar que el glifosato hace poco fue reconocido por la OMS como un agente cancerígeno. En esa medida, tanto los cultivos ilícitos como las fumigaciones con químicos generaron deterioros en el medio ambiente y afectaron la salud de las poblaciones.

Por otro lado, la minería - legal e ilegal — es otra de las actividades que viene causando deterioro ambiental en los territorios y esto sucede ante la mirada complaciente de las entidades encargadas de regular esta actividad y sus impactos en el entorno. Esa misma permisividad gubernamental es la que consiente que la minería legal no cumpla con las disposiciones socioambientales a las que se ha comprometido, agudizando de esta manera las problemáticas que ya de por sí genera la minería. Así mismo, al no haber una presencia institucional constante en ciertos territorios, la minería ilegal se instaló en ellos, convirtiéndose en la fuente 
de trabajo para muchas familias, transformando la vocación productiva de las comunidades campesinas y generando, a su vez, contaminación de ríos, tala de bosques y debilitamiento en la productividad de los suelos.

Otra problemática identificada fue la cacería, la cual ha sido parte de las actividades de subsistencia de muchas comunidades campesinas en la región, siendo la principal fuente de obtención de proteínas cuando no se tiene cría de animales. Sin embargo, en los últimos años esta actividad viene siendo realizada por personas ajenas a las comunidades y que llegan de otras regiones a cazar animales propios de los ecosistemas como la guara, el zaino, el chengue, la iguana, el morrocoy, el armadillo, el paujil, el ñeque, el venado, entre otros, con el fin de comercializarlos en mercados donde tienen gran valor por su piel, por su carne o por ser exóticos; frente a esta situación las entidades ambientales no han tomado las medidas correspondientes para proteger la fauna de los territorios.

Así, tenemos un panorama en el que la deforestación, los cultivos ilícitos, la minería y la cacería indiscriminada son factores que profundizan el calentamiento global, actual crisis climática que vive el mundo y que se puede evidenciar en problemas concretos que afectan la producción campesina como la erosión de los suelos, la disminución de los caudales de los ríos y las cada vez más frecuentes catástrofes ambientales (como avalanchas, derrumbes, inundaciones, entre otras).

Por último, la contaminación de las fuentes hídricas se constituye como una de las mayores problemáticas ambientales que afectan los territorios debido a que la mayoría de las poblaciones campesinas de la región no cuentan en sus territorios con los servicios básicos, lo cual no permite tener un tratamiento adecuado de las aguas: estas no solo son usadas para el riego de sus cultivos, sino también para el consumo de las familias, lo cual constituye una gran amenaza para sus vidas.

\section{Propuestas}

Dentro de las propuestas identificadas a través del encuentro y los recorridos etnográficos encontramos que el reconocimiento de la territorialidad campesina es la principal herramienta para hacerle frente a las problemáticas ambientales en los territorios. Una vez identificado que la principal problemática es la permisividad de las instituciones, los 
campesinos y campesinas se encuentran en la disposición de ser agentes de conservación, siendo conscientes de que esto les garantiza la producción de sus cultivos y la permanencia en el territorio, como ya han demostrado en algunos ejercicios de parcelación existentes en los que el campesinado ha dejado áreas colectivas para la conservación de las fuentes de agua, siendo cuidadas por todos los miembros de la comunidad. Con el reconocimiento de la territorialidad el campesinado tendría el marco jurídico que le permitiría ordenar los territorios de acuerdo a sus necesidades, aplicando sus saberes para la mitigación de estos problemas y para potenciar la producción campesina con un enfoque ambiental de manera que se garantice la seguridad alimentaria de las poblaciones y de los centros poblados más cercanos, promoviendo a la vez la conservación como herramienta fundamental en la producción campesina.

En esa medida, frente al tema de la deforestación las comunidades proponen la ejecución de proyectos de reforestación de manera continua con el adecuado acompañamiento de las entidades encargadas de velar por la conservación del ambiente. Las comunidades campesinas deben ser veedoras de estos proyectos, trabajando de manera articulada con las instituciones, organismos y estamentos ambientales - como la UMATA - , la policía ambiental, entre otras, y simultáneamente las comunidades deben organizar grupos/colectivos ambientales para la defensa, ejecución y transparencia de los procesos, proyectos e iniciativas ambientales. Para ello, es necesaria la creación de un marco legal que respalde a este grupo de manera que se pueda promover de manera adecuada la educación ambiental y la formación profesional de los jóvenes para la defensa del ambiente.

Para la cacería se propone la integración, dentro de los espacios de formación, de cátedras relacionadas con la preservación de la flora y fauna nativa de cada territorio; para esto, se exige mayor presencia institucional y la realización de programas en los que se reconozcan incentivos a aquellas comunidades y poblaciones que integren, en sus dinámicas territoriales, la preservación de la fauna como elemento transversal en sus planes de vida comunitarios. Estos incentivos pueden estar representados en semillas y elementos propios de la producción campesina en la región, así como en capacitación y recursos técnicos para el reemplazo de la cacería por la cría doméstica de animales. 
Frente al tema de los cultivos ilícitos, y teniendo en cuenta que la vida del campesinado puede estar en riesgo si emprende acciones directas para desmontar los cultivos ilícitos, proponen que el Gobierno sea el mayor actor, por lo que consideran las siguientes estrategias: I) creación de una mesa de concertación en la que se lleguen a acuerdos sobre las formas en cómo deben ser eliminados dichos cultivos de los territorios; en ella deben participar: dueños de los cultivos, población de las comunidades, fiscalía, ejército antidroga y demás entidades competentes; II) a partir de allí proponerles actividades económicas que les permitan cambiar la actividad ilícita por una lícita, como el cultivo de frutales, y generar mercados con precios justos para que las personas no sientan la tentación de volver a este tipo de comercio; III) así mismo, debido a que los suelos quedan muy afectados, el Gobierno debe apoyar y garantizar su recuperación y adecuación para la realización de los nuevos proyectos económicos; IV) finalmente, el punto más importante de las acciones tomadas frente a este problema es no criminalizar al campesinado, ya que la mayoría de ellos no se encuentran sembrando cultivos ilícitos por voluntad, sino porque no existen más opciones económicas en los territorios.

En cuanto a la minería, para el caso de la explotación minera legal se exige a las entidades encargadas tener mayor control sobre las empresas y verificar que se estén cumpliendo los compromisos ambientales por parte de estas empresas, sancionando todos aquellos casos de corrupción que se presentan en el otorgamiento de los permisos de exploración a estas empresas. Así mismo, se exige no otorgar más títulos mineros en territorios campesinos sin antes realizar la respectiva consulta con las comunidades que los habitan, para lo cual se debe establecer la figura de consulta previa para las comunidades campesinas.

Ahora bien, frente al tema de la minería ilegal las comunidades se comprometen a ser veedoras en sus territorios siempre y cuando cuenten con el acompañamiento institucional y no las dejen solas afrontando la situación. También es necesario tener una oferta de proyectos productivos para aquellas personas que decidan no volver a hacer minería ilegal en los territorios y sanciones contundentes para todos aquellos que promuevan esta actividad en los territorios campesinos.

Ahora bien, en temas como la erosión de los suelos es necesario insistir en los programas de reforestación ejecutados por las comunidades con 
el acompañamiento institucional, como también capacitar a las poblaciones en el uso de fertilizantes y compuestos naturales que permitan la preparación de la tierra y la asistencia de los cultivos de manera orgánica. Así mismo, es necesario crear políticas públicas alrededor de la distribución del agua para el acceso equitativo de todas las comunidades; esto ayudaría a la recuperación de los afluentes teniendo al campesino como veedor de que los ríos fluyan libremente, monitoreando constantemente para que no se vierten basuras y, de esta manera, previniendo también su contaminación.

\section{Mesa socioeconómica}

Durante el desarrollo de la mesa de trabajo sobre las problemáticas socioeconómicas de la población campesina del Magdalena Grande se llegó a la conclusión de que estas problemáticas tienen su origen en las políticas que el Gobierno propone para el campo colombiano, ya que mientras el país es inundado por productos agrícolas del extranjero que se pueden producir en Colombia, en los territorios campesinos la financiación del Gobierno está orientada a fortalecer los megaproyectos extractivos como la minería en La Guajira y el Cesar, los monocultivos de Palma en la Zona Bananera y la ganadería extensiva en las sabanas del Magdalena y el Cesar.

El acceso a la tierra se constituye como uno de los principales impedimentos para el desarrollo de la producción campesina en la región, siendo el despojo y la concentración de la tierra las principales problemáticas en este tema. En la actualidad, la distribución de la tierra se ve afectada por diversos factores que, en lugar de asegurar el acceso equitativo a la misma, promueven su concentración y la transformación de su vocación productiva, valiéndose de la corrupción presente en las instituciones del Estado que, por medio de actos administrativos, dan vía libre al desarrollo de megaproyectos sin antes consultarlos con las poblaciones o haciendo uso de la violencia, en muchos casos, como herramienta de intimidación sobre las comunidades para que abandonen los territorios; de esta manera, imponen sus proyectos. Este tema es una constante en toda la región, pues el conflicto social y armado es uno de los principales dinamizadores del ordenamiento territorial en el Caribe, 
Vida campesina en el Magdalena Grande

obligando al campesinado a abandonar sus territorios, los cuales son ocupados actualmente con grandes extensiones de monocultivos, minas o haciendas ganaderas.

Aunque a nivel institucional se han creado programas que buscan el retorno de las familias desplazadas a sus territorios - como los programas de la Unidad de Restitución de Tierras-, estos se quedan cortos en el cumplimiento de sus objetivos debido a que no hay garantías para el retorno de las familias, ya sea por la presencia que aun hacen los victimarios en el territorio o porque no tienen cómo retomar sus proyectos de vida comunitarios debido a que la reparación, en muchos casos, se ha hecho de manera individual, fragmentando el tejido comunitario que permitía el desarrollo colectivo de sus vidas.

Por otro lado, el acceso al agua se convierte en otra de las grandes dificultades para las comunidades campesinas de esta región, ya que en muchos territorios no hay acceso al preciado líquido o este tiene que ser disputado con grandes empresas o terratenientes. Por ejemplo, los campesinos en la Guajira cuentan con algunos cerros que les proporcionan el agua y han desarrollado estrategias para la conservación de estos lugares, pero la mina los privatizó, llevándose toda el agua para la extracción de carbón y dejando a las comunidades campesinas sin posibilidades de acceder al recurso, haciéndolas perder sus cultivos y, en muchos casos, obligándoles a abandonar los territorios. Así mismo, en el Magdalena los ríos que descienden de la Sierra Nevada hacia la Ciénaga Grande son cooptados en su camino por las empresas bananeras, dejando a las comunidades sin acceso al recurso.

Otra de las problemáticas identificadas se presenta durante el ejercicio de preparación de la tierra y la asistencia a los cultivos, ya que en la mayoría de los territorios de la región este trabajo se hace de manera artesanal, lo cual pone en desventaja a las comunidades ante la creciente oferta de productos extranjeros, los cuales se producen de manera masiva en sus países de origen y son subsidiados por los gobiernos, lo que disminuye sus costos de producción y permite que lleguen a bajos precios al país, desplazando la producción interna. Los campesinos extranjeros están tecnificados; la producción es para el consumo propio del país y la sobreproducción se exporta: en esa medida, el consumo de productos agropecuarios en Colombia se reduce al consumo de 
sobreproducciones de otros países, evidenciando que no hay garantía para la producción interna.

En muchos territorios los campesinos han manifestado tener los conocimientos y la intención de incursionar en la producción de cultivos innovadores o de mayor demanda en los mercados nacionales e internacionales, pero no cuentan con las herramientas necesarias para el desarrollo de los cultivos: la maquinaria para la preparación de la tierra, los insumos para su mantenimiento, los sistemas de riego que aseguren la producción ni la infraestructura necesaria para la recolección y el transporte.

Así mismo, durante el ejercicio de comercialización de los productos el principal problema que presentan las comunidades campesinas son las vías de acceso, pues la mayoría se encuentran en mal estado y en muchos lugares ni siquiera existen. Esta situación no solo limita el ingreso de los insumos y elementos necesarios para la preparación de las tierras y la asistencia de los cultivos, sino que también incrementa de manera exponencial los costos de transporte a la hora de sacar los productos hacia los mercados. Frente a esta situación se han realizado solicitudes a las entidades encargadas, pero no hay respuestas favorables, por lo cual en la mayoría de las ocasiones estas vías son construidas y mantenidas por las mismas comunidades a través del trabajo colectivo.

Seguido a esto, el tema de los intermediarios se convierte en una constante presente en todos los territorios campesinos visitados, ya que la mayor parte de las ganancias obtenidas por la venta de los productos queda en manos de estas personas. Estos intermediarios se aprovechan de la necesidad de los campesinos, quienes tienen que vender al precio que se les impone debido a que no cuentan con centros de acopio donde puedan almacenar sus cosechas y esperar mejores precios; por el contrario, deben vender antes de que los productos se dañen y para no tener que regresar a sus territorios con la carga. En muchas ocasiones los intermediarios cuentan con los medios de transporte para entrar a los territorios a buscar los productos, lo cual es descontado del valor total de la carga. En esa medida, el campesino está vendiendo su producción a precios paupérrimos, mientras que el intermediario los comercializa en los mercados por un precio hasta cinco veces mayor.

Finalmente, se logró identificar que todas estas problemáticas se ven agudizadas en los territorios debido al abandono institucional en que el 
Vida campesina en el Magdalena Grande

Estado ha mantenido a las comunidades campesinas a lo largo de la historia, ya que, como manifiestan las comunidades, para muchas de estas problemáticas se han tocado puertas en instituciones y entidades encargadas, obteniendo siempre como respuesta: "no hay presupuesto". Esto se debe a la proyección que desde el Gobierno se tiene para el campo, pues en lugar de invertir en la producción agrícola (la cual se solventa con el ingreso de productos extranjeros a menor precio), se invierte en la adecuación de los territorios para el desarrollo de megaproyectos mineros y monocultivos.

Todo esto se debe a que estamos en un país en el que los mandatarios son, en su mayoría, inversionistas de los megaproyectos que se desarrollan en los territorios campesinos, por lo que se aprovechan de sus influencias para viabilizar la ejecución y el cuidado de sus inversiones. Esta corrupción es uno de los elementos que más degenera los procesos campesinos y la inversión económica en el campo, ya que las comunidades campesinas no cuentan con una entidad comprometida con la defensa de sus derechos y, menos, con el reconocimiento constitucional como sujeto político de derechos: una deuda histórica que tiene el país con estas poblaciones.

\section{Propuestas}

En la elaboración de las propuestas que desde las comunidades viabilicen las posibles soluciones para las problemáticas expuestas en esta mesa, las comunidades plantean que, en primera medida, se debe hacer un reconocimiento de las formas de producción campesina como herramienta fundamental para el desarrollo de las zonas rurales y garante de la soberanía alimentaria de los centros poblados y urbanos, ya que en estos momentos se prioriza la agroindustria en detrimento de la economía campesina.

Una vez la economía campesina logre este reconocimiento se debe garantizar un acceso equitativo a la tierra por parte de las familias campesinas sin tierra o con tierras insuficientes. Para ello, es necesario mirar la topografía de los terrenos, las vías de penetración y el acceso al agua, de manera que al acceder a una porción de tierra existan los medios para poder desarrollar los proyectos productivos en relación a las condiciones 
de cada terreno y con garantías de comercialización de los productos, ya que en muchas ocasiones se le entrega la tierra al campesino, pero son tierras que no tienen agua, que tienen una topografía escabrosa o que son infértiles; aunque al campesino no le queda otra opción que recibirlas porque "tierra es tierra", al poco tiempo debe abandonarlas al ver que no hay condiciones para la producción agrícola o pecuaria.

Frente al tema del acceso al agua las comunidades plantean que debe haber políticas públicas que garanticen un acceso equitativo al recurso y que este no sea monopolizado por las multinacionales mineras, los agroindustriales o las fincas ganaderas. Este acceso debe ser a un recurso hídrico de calidad que garantice la productividad de sus cultivos, la cría de los animales y la salud de las personas.

Por otro lado, se deben mirar las particularidades de la producción campesina en la región para generar, de esta manera, procesos de tecnificación de acuerdo a las particularidades de los territorios, procurando una mejor preparación de la tierra, una asistencia adecuada de los cultivos - de manera orgánica, amable con el ambiente- y el fortalecimiento de los procesos organizativos de las comunidades. Para esto se deben fortalecer aquellas instituciones encargadas de capacitar a la población campesina como el SENA, los centros de estudios agropecuarios y las demás instituciones que procuren el bienestar de las familias campesinas.

Otra de las propuestas expuestas por las comunidades es la creación de un sistema de comercialización articulado con todos los departamentos de la región a través de los supermercados, tenderos y plazas de mercado, generando una alianza entre productores y consumidores: evitando, por un lado, la invasión del mercado regional por productos extranjeros; eliminando, por otro lado, la especulación de precios por parte de los intermediarios (asegurando precios justos para todos). Para esto se debe fortalecer la asociatividad por parte de las comunidades que han perdido credibilidad en las organizaciones campesinas y de pescadores porque, en muchos casos, estas han sido cooptadas por las administraciones locales para otros fines; sin embargo, reconocen la importancia de las organizaciones campesinas en la creación de mecanismos de comercialización a precios justos.

Finalmente, las comunidades proponen que se creen los seguros de cosecha mediante estándares de cultivo, producción y comercialización, 
evitando así las pérdidas ocasionadas por los fenómenos naturales. Esto se puede lograr mediante la conformación de cooperativas, pagando el seguro de cosecha por medio de una personería jurídica frente a instituciones municipales. El SENA puede servir como institución encargada de formalizar los acuerdos entre cooperativas y las administraciones, encargándose de la capacitación y el manejo de los estándares para los seguros de cosecha.

De esta manera, las comunidades expresaron que todas estas problemáticas se pueden abordar desde iniciativas locales, pero estas deben tener un acompañamiento constante por parte del Estado y de las instituciones encargadas, pues el Estado es el encargado de garantizar mejores condiciones en los procesos de producción agrícola del campesino colombiano. Ese mismo llamado de acompañamiento se extiende a los sectores académicos que están distantes de las realidades de los campesinos y deben procurar estar vinculados con los sectores sociales de los territorios para construir, a partir de un diálogo de saberes, una ruta de trabajo que permita afrontar todas las dificultades manifestadas.

\section{Mesa sociopolítica}

Durante el desarrollo de esta mesa de trabajo, la cual tenía como propósito analizar las principales problemáticas en torno a las realidades sociopolíticas de las comunidades campesinas del Magdalena Grande, se identificó como problema central la falta de representación política del campesinado en los espacios de toma de decisiones sobre el sector rural y la población campesina.

Esta problemática no es nueva y ha sido una constante en la historia de las luchas campesinas de la región, pues a pesar de que en el Caribe se han gestado grandes procesos organizativos, estos nunca han sido reconocidos desde la institucionalidad y sus reivindicaciones siempre han quedado reducidas a tratados y acuerdos que el Gobierno nunca cumple. El hecho de que actualmente en la Constitución no se reconozca al campesino como un sujeto social de derechos es una muestra del abandono histórico del Estado hacia este sector de la población, pues el campesinado queda reducido a la categoría de "trabajador agrario", 
Vida campesina en el Magdalena Grande

desconociendo que, como grupo social, tiene una identidad y prácticas propias que deben ser protegidas.

Algunas de las razones que impiden esa representación del campesinado en los espacios de toma de decisiones son los señalamientos, la persecución y el hostigamiento constante hacia el ejercicio del liderazgo en las comunidades, siendo los campesinos estigmatizados como colaboradores de actores armados ilegales y poniendo, de esta forma, en riesgo sus vidas; por esta razón, en muchas poblaciones nadie quiere asumir ese rol y quienes lo asumen son desplazados y, en el peor de los casos, asesinados. A pesar de que la región Caribe siempre ha sobresalido por los ejercicios de liderazgo de la población campesina, los efectos del conflicto armado se evidencian hoy día en la poca participación de las organizaciones campesinas en espacios amplios o en el miedo de las comunidades a organizarse. Esto ha creado una brecha en el ejercicio de formación de nuevos liderazgos, generando un analfabetismo político y falta de legitimidad de las organizaciones en los territorios, pues la representación viene siendo ejercida por personas ajenas a los territorios y, muchas veces, impuestas por los grupos armados.

Así mismo, esta falta de representación del campesinado concibe que las políticas hacia el campo admitan la consolidación de una estructura de tenencia de la tierra que favorece a los terratenientes y multinacionales, mientras que la aplicación de políticas fiscales desfavorece la producción campesina, generando como resultado la falta de inversión en las zonas rurales y hacia la población campesina. Esto, sumado a la alta capacidad de incidencia que tienen los emporios económicos de la región en la toma de decisiones sobre el sector rural y a la corrupción y el clientelismo presente en toda la institucionalidad nacional, dejan sin posibilidad de acción al campesinado sobre las decisiones que se tomen alrededor de sus territorios.

Así mismo, la falta de acompañamiento en la construcción de los planes de vida comunitarios y una opinión pública desfavorable hacia el campesinado, el cual es señalado con imaginarios como "depredador del ambiente", "tosco", "ignorante", "subdesarrollado" y "subversivo", son elementos que le impiden al campesinado asumir un papel representativo en los espacios de toma de decisiones. 
Vida campesina en el Magdalena Grande

\section{Propuestas}

Por esta razón, las comunidades proponen como objetivo central, a la hora de afrontar los problemas sociopolíticos del campesino en el Magdalena Grande, garantizar la participación de las comunidades en los escenarios de tomas de decisiones sobre sus territorios, proponiendo como acciones específicas la inclusión del campesino dentro de la Constitución Política de Colombia como un sujeto político de derechos. Así mismo, tiene que haber una reforma estructural de las Fuerzas Armadas del Estado, eliminando viejas prácticas de creación, cooperación y encubrimiento de grupos armados para atacar a los líderes y lideresas campesinos, garantizando el libre derecho a organizarse.

También se deben establecer normas y hacer seguimiento a las influencias de los grandes emporios económicos de la región en las políticas hacia el campo. Finalmente, se propone que desde temprana edad los miembros de las comunidades tengan acceso a espacios de formación en temas como cultura de la democracia, participación ciudadana, derechos humanos, historia del campesinado; todo con un enfoque diferencial hacia la población rural.

Todo esto orientado a generar como resultado una reparación y resignificación del sujeto campesino frente al resto de la sociedad colombiana, reconociendo al campesinado como uno de los sectores mayoritarios de la población, poseedor de una historia, una identidad cultural y una función social y ambiental fundamental para el desarrollo del país. Así mismo, esto permitiría una ampliación de la oferta institucional dirigida al fortalecimiento de las iniciativas productivas de los campesinos y las campesinas; entre ellos: subsidios, maquinaria, insumos, tecnología, capacitación, equipamientos, etcétera. Y, por último, permitiría frenar el acaparamiento de las tierras para el monocultivo, la ganadería y los proyectos extractivos.

\section{Dimensión sociocultural}

Para hablar de la dimensión sociocultural del Magdalena Grande debemos tener en cuenta que en los tres departamentos que conforman este amplio territorio encontramos la presencia de comunidades indígenas como los yukpas, arhuacos, wiwas, koguí, kamkuamos, ette-ennaka, 
Vida campesina en el Magdalena Grande

wayuu y los recientemente reconocidos tagangas. También encontramos las poblaciones afrodescendientes que huyeron de la esclavitud en los puertos de Dibulla y Riohacha, así como aquellas que cruzaron el río Magdalena y se asentaron en las partes medias del departamento del Cesar y el Magdalena. Así mismo, encontramos algunas familias extranjeras que llegaron atraídas por las diferentes bonanzas económicas como la del banano, algodón, café, marihuana, coca y amapola, asentándose en diferentes territorios de estos departamentos. En medio de toda esta diversidad se encuentran los campesinos y campesinas que llegaron a raíz de la guerra bipartidista y lograron colonizar algunos territorios baldíos, como también una diáspora campesina sin tierra que recorre estos departamentos en busca del tan anhelado "pedacito de tierra para trabajar".

\section{Relación con la tierra}

El relacionamiento entre estos grupos poblacionales ha generado una hibridación cultural en estas poblaciones, dando origen a tradiciones y costumbres que comparten elementos culturales de una u otra población y que se manifiestan a través de los tejidos, las músicas, las formas de atender la tierra, interpretar la naturaleza, entre otros. Son precisamente estas tradiciones y costumbres las que llenan de significados los territorios, construyendo las identidades campesinas en cada uno de ellos, de manera que encontramos al campesino sabanero, al campesino ribereño, al campesino serrano, al afrocampesino, etcétera.

Sin embargo, es precisamente la pérdida de estas identidades campesinas la mayor problemática que presentan las poblaciones del Magdalena Grande, ya que estas se transmitían a través del trabajo en las parcelas, los juegos cotidianos, bailes, canciones, celebraciones, medicina tradicional, centros de estudio y demás espacios de socialización que han desaparecido y que permitían garantizar la permanencia de estas tradiciones, el fortalecimiento del tejido comunitario y la identidad campesina de las poblaciones.

Entre las principales causas de esta situación identificamos la falta de reconocimiento de estas prácticas culturales como parte fundamental de la identidad campesina, la cual queda reducida solo a su capacidad para producir alimentos de la tierra, desconociendo todo el acumulado de saberes 
y conocimientos que acompañan este trabajo: el conocimiento de los ciclos de la naturaleza, la conservación de las semillas, las formas de asistir los cultivos, los secretos para adecuar la tierra, entre muchos otros conocimientos que son subvalorados a la hora de comercializar sus productos y que no se tienen en cuenta a la hora de definir al campesinado como sujeto de especial protección para el desarrollo de nuestros territorios.

En lo referente al trabajo de la tierra, la falta de garantías para la permanencia en los territorios y el desarrollo de las actividades campesinas han generado el desplazamiento de la población joven hacia los centros poblados, abandonando las actividades del campo, pues no ven en ellas una opción de vida para sus familias; esto ha desembocado en "el envejecimiento del campo". En estos momentos, no hay población joven a la cual transmitir los saberes relacionados con la producción de la tierra; los mayores que aún quedan en el campo ya no cuentan con las capacidades físicas para desarrollar estas actividades.

Del mismo modo, la industrialización en los procesos de producción ha desplazado las formas tradicionales de trabajar la tierra, ya que las personas ahora prefieren meterle máquina a todo. Aunque la tecnificación de las formas de producción es necesaria para el desarrollo de los territorios campesinos, esto ha generado que la gente pierda la capacidad de identificar qué tipo de suelo es bueno para qué tipo de cultivo, pues ahora se le mete maquinaria a toda la tierra por igual y se quiere sembrar indiscriminadamente cualquier cultivo en cualquier lugar. Así mismo, las personas han perdido la capacidad de elaborar sus propias herramientas: ya la gente no sabe tejer una atarraya o un chinchorro porque ahora van al mercado y compran el trasmallo ya listo, sin importar las afectaciones que esto puede generar al medio ambiente.

Por otro lado, las variaciones en los ciclos de la naturaleza a raíz del cambio climático han generado la pérdida de tradiciones relacionadas con los tiempos de los cultivos y las cosechas y, aunque los campesinos y campesinas han aprendido a interpretar estos cambios y a adaptarse a ellos, cada vez es más difícil predecir los tiempos de las lluvias, el momento adecuado para preparar la tierra, entre otros.

En lo referente a la conservación y transmisión de las semillas, la necesidad cada vez más frecuente de tener que comprar semillas certificadas para poder acceder a sistemas de créditos y proyectos productivos ha 
generado la pérdida de semillas nativas. Por ejemplo, las comunidades campesinas de la Sierra Nevada de Santa Marta han tenido que reemplazar las plantas de café arábigo, las cuales fueron plantadas por sus abuelos y han durado por más de 30 años en el territorio, por semillas de café modificadas que deben ser reemplazadas cada 3 años.

En cuanto a la preparación de alimentos tradicionales, la llegada de nuevos productos y la desaparición de otros ha generado una transformación en la dieta de las poblaciones. Por ejemplo, como ya lo mencionan los campesinos de Carraipía, la migración de los habitantes de la actividad agrícola hacia el comercio ilegal del contrabando reemplaza los alimentos producidos en el campo por aquellos que se pueden comprar en los supermercados de cadena ubicados en los centros urbanos, de donde vienen y hacia donde van las mercancías contrabandeadas (por lo menos la desaparición paulatina del bagre en el río Magdalena ha hecho cada vez menos frecuente el popular sancocho de bagre, el cual ha sido reemplazado por platos preparados a base de cachama, especie introducida desde los llanos). Así también está el caso de los campesinos de la Zona Bananera, quienes a partir de la llegada de los cultivos de palma vieron disminuir poco a poco el banano en la preparación cotidiana de sus alimentos y este tuvo que ser reemplazado por alimentos traídos de otros lugares o el caso de los campesinos del norte del Perijá, quienes a raíz de las afectaciones ocasionadas al suelo por la fumigación con glifosato hoy sobreviven a base de los cultivos de mora.

\section{Cultura campesina}

Los elementos de la cultura campesina siempre han estado en una constante disyuntiva entre sus reivindicaciones populares y las interpretaciones que desde la institucionalidad se hacen de ella. En la memoria del campesinado del Magdalena Grande permanece la celebración del Día del Campesino como una fecha de gran importancia tanto para el encuentro y el intercambio de conocimientos y productos, como para el fortalecimiento del tejido comunitario y el reconocimiento de su identidad cultural. Sin embargo, al ser una fecha promovida desde la institucionalidad, no permite la autogestión de la celebración ni refleja la realidad de las poblaciones campesinas en los territorios; en muchos casos, se 
llega hasta a variar la fecha de la celebración dependiendo de las agendas políticas de las administraciones locales y no se permiten las expresiones culturales propias de las poblaciones locales. Aclaramos que no es una generalidad para todo el Magdalena Grande, pero en la mayoría de los municipios de este amplio territorio el Día del Campesino queda reducido a una reunión en la cabecera municipal (donde muchas comunidades no tienen la facilidad de llegar), en la cual se les da un almuerzo, un machete, una lima, y se les entregan algunas semillas que, muchas veces, no se dan en los territorios que habitan.

Por esta razón, el mayor espacio de integración, celebración y manifestación de sus tradiciones y costumbres es el de las fiestas patronales, las cuales son autogestionadas por las comunidades a través de las juntas de acción comunal, la casa parroquial y algún grupo de personas de la comunidad que, de manera voluntaria, se integran en el desarrollo de las fiestas. Son las fiestas más esperadas por todos los habitantes de la vereda, del corregimiento o del municipio, y en ellas podemos encontrar bailes, comidas típicas, juegos, misas y demás espacios de integración. Dentro de estas celebraciones de carácter religioso, pero que permiten la expresión de las tradiciones y costumbres de las comunidades en relación con sus cotidianidades, encontramos las de San Isidro Labrador, santo patrono de los campesinos y a quien se le encomiendan las cosechas y la prosperidad de los cultivos; las fiestas de San Martín de Loba o el "santo de los pobres", reconocido por representar la humildad del campesinado y su disposición de ayudar a los demás, y, finalmente, las fiestas de la Virgen del Rosario, presente en muchos pueblos ribereños y costeros, a quien se le reconoce la capacidad de aplacar las aguas y detener las inundaciones para que no afecten los cultivos.

De la misma forma, en las comunidades de la Sierra Nevada de Santa Marta es común ver las celebraciones de las fiestas de las colonias, en las cuales se reúnen las familias provenientes de otras regiones de Colombia y que se instalaron en esta parte del Caribe para desarrollar sus proyectos de vida. Así, encontramos las fiestas de la colonia cachirula, la colonia tolimense, la colonia ocañera, etcétera. En algunas comunidades encontramos festividades que se relacionan con los productos agrícolas que más se producen como el Festival de la Patilla, el Festival del Plátano o el Festival del Mango. 
Vida campesina en el Magdalena Grande

\section{Conflicto y cultura}

Una de las problemáticas que más efectos causó a las manifestaciones culturales de las comunidades campesinas es el conflicto social y armado, que ha generado otros fenómenos sociales como los desplazamientos forzados y despojos de tierras, agudizando la pérdida de tradiciones de carácter oral, religioso, musical, entre otras.

La manera de convivir y compartir en familia, las reuniones alrededor del río, las caminatas por los senderos de las veredas, la forma de narrar cuentos y leyendas fuera de las casas - reunidos con el abuelo cantando décimas- dejaron de ser cotidianidad en estas poblaciones a raíz del conflicto armado. La llegada de los paramilitares a los territorios campesinos impuso un nuevo control sobre los espacios de congregación de los habitantes: había normas y horas para reunirse, para ir al pueblo, para estar en la calle, incluso las congregaciones religiosas fueron prohibidas a menos de que contaran con el aval del responsable de turno.

Las fiestas mencionadas anteriormente también fueron afectadas por la llegada del conflicto; muchas de estas celebraciones fueron prohibidas y muchas otras fueron intervenidas, definiendo quiénes podían realizarlas, cómo debían realizarlas, y financiando su realización. De esta manera pretendían ganarse a la población mientras reproducían, a la vez, un sistema de valores que impedía a la población desarrollarse libremente: te decían cómo vestir, qué comer e, incluso, en muchos territorios llegaron a decidir qué se podía sembrar y qué no, afectando por completo la vida comunitaria.

También ha generado problemas de inseguridad, desplazando la alegría y la solidaridad e implantando el miedo y la desconfianza como valores esenciales para la supervivencia en los territorios; en palabras de los propios campesinos: ya no se sabe con quién está hablando uno. Esta situación ha generado que muchas familias prioricen conservar la vida, aunque esto signifique abandonar los territorios y dirigirse a las ciudades a pasar trabajo, hecho que ha generado en sus hijos apatía hacia el campo. Así mismo, el abandono de estas tierras ha permitido la implantación de proyectos económicos de gran envergadura, como la llegada de actividades ilegales como los cultivos ilícitos, la deforestación y la minería ilegal, entre otros. 
En expresiones como la música o las décimas aquellos temas que hablaban del cultivo, de la vida comunitaria, de la anécdota de la vereda, fueron reemplazados por temas que hablan de la muerte, el dolor; no es que ya no cantan al amor o a la esperanza, sino que los espacios donde se podían percibir esos valores fueron prohibidos o reemplazados por otros.

Así, tenemos un escenario en el que se evidencia la gravedad del despojo cultural sufrido por las comunidades campesinas del Magdalena Grande a través del conflicto, la implementación de megaproyectos mineros o monocultivos en sus territorios y la cooptación institucional de sus espacios culturales. Esto tiene como consecuencia la desintegración del tejido comunitario y, por ende, de los planes de vida en los territorios.

\section{Propuestas}

Como propuestas para superar las consecuencias de estas problemáticas y hacerle frente a futuro, las comunidades manifiestan que es necesario incluir el sistema de valores y conocimientos campesinos dentro de las mallas de estudio en las escuelas rurales; promover nuevamente el énfasis agropecuario de las escuelas rurales, incentivando el aprendizaje de las labores del campo de la mano de los mayores, a quienes también se les debe abrir un espacio para la socialización de sus conocimientos a las nuevas generaciones y, así mismo, procurar que en estas cátedras $o$ asignaturas dedicadas al trabajo de la tierra se tengan en cuentan los conocimientos sobre la producción orgánica, procurando una producción agrícola amigable con el entorno.

De igual manera, proponen que en las sedes de las organizaciones campesinas, juntas de acción comunal, casas de la cultura, casas campesinas, entre otras, se habilite un espacio dedicado específicamente al rescate y promoción de la cultura campesina, de manera que este espacio se pueda articular con los escenarios de integración y congregación de la comunidad para promover, de esta manera, la realización de fiestas, eventos, encuentros deportivos, diálogos de saberes y demás escenarios que procuren el reconocimiento de las culturas campesinas desde las comunidades, fortaleciendo su identidad cultural y proyectándola hacia el público en general. 
Celebraciones como el Día del Campesino, las fiestas patronales, las fiestas de las colonias y demás festividades que busquen este reconocimiento deben contar con el apoyo institucional, pero deben ser gestionadas desde las comunidades y para las comunidades, asegurando de esta forma la expresión real de sus manifestaciones culturales y el fortalecimiento de los procesos organizativos en los territorios.

Finalmente, los campesinos manifestaron que el campo necesita fortalecerse a través de la creación de políticas públicas que impacten, normas, decretos, acuerdos municipales y ordenanzas departamentales que guíen a la realización de programas y proyectos estratégicos que garanticen la inversión social y económica para tener condiciones dignas de vida y trabajo de la tierra; además de esto, es fundamental que se dé un desarrollo integral rural real en el Caribe colombiano, donde las instituciones del Estado y los campesinos puedan dialogar y generar propuestas comunes a partir de la concertación para 1) beneficiar integral y productivamente el desarrollo local de las pueblos campesinos; 2) trascender los muros de la politiquería y la corrupción, que poco aportan a la sostenibilidad de los modos de vida campesinos; 3) buscar, sobre todo, el reconocimiento cultural de sus tradiciones y la importancia que estas tienen para la conservación del medio ambiente, la soberanía alimentaria y el desarrollo de los territorios. 



\section{Referencias bibliográficas}

Alonso, L. (2018). Estudio socio-cultural de la población de caficultores campesinos de los distritos cafeteros de Palmor en el municipio de Ciénaga y Río Piedras en el municipio de Santa Marta en el departamento del Magdalena (Colombia) (Tesis de pregrado). Universidad del Magdalena, Santa Marta, Colombia.

Ardila, E., Acevedo, Á. y Martínez, L. (2013). Memoria de la bonanza marimbera en Santa Marta. Revista Oraloteca, 5, 54-79.

Avella, F. (2002). El Caribe colombiano: de la paz al conflicto. En G. Montañez, G. Cubides y S. Ramírez (Eds.), Dimensiones territoriales de la guerra y la paz (pp. 489-502). Bogotá, Colombia: Universidad Nacional de Colombia,

Camacho, M. (2020). Historias vividas del corregimiento de Siberia, Sierra Nevada de Santa Marta. Investigación no publicada. Santa Marta, Colombia.

Centro Nacional de Memoria Histórica (CNMH). (2010). La tierra en disputa. Memorias del despojo y resistencias campesinas en la Costa (1960-2010). Bogotá, Colombia: SEMANA-Taurus.

Centro Nacional de Memoria Histórica (CNMH). (2014). Guerrilla y población civil. Trayectoria de las FARC 1949-2013 (3ra ed.). Bogotá, Colombia: CNMH.

Colmenares, G. (1997). La formación de la economía colonial (15001740). En J. A. Ocampo (Comp.), Historia Económica de Colombia (pp. 21-60). Bogotá, Colombia: Tercer Mundo Editores- Fedesarrollo.

Corporación Autónoma Regional del Magdalena. (1993). Funciones de las corporaciones previstas por la ley 99 de 1993. Recuperado de $<$ https://www.corpamag.gov.co/index.php/es/quienes-somos/funciones-ley99>, acceso 15 de marzo de 2017. 
Vida campesina en el Magdalena Grande

Defensoría del Pueblo, Procuraduría General de la Nación y Pastoral Social (2003). Informe de la comisión de observación de la crisis humanitaria en la Sierra Nevada de Santa Marta. Bogotá, Colombia: Defensoría del Pueblo.

Defensoría del Pueblo. (2016). Tercer informe al congreso de la República sobre la implementación a la Ley de víctimas y restitución de tierras. Bogotá, Colombia. Defensoría del Pueblo. Recuperado (3 de febrero del 2017) de: <https:// observatoriofiscal.contraloria.gov.co/Publicaciones/Tercer\%20Informe $\% 20$ Comisi\%C3\%B3n\%20de\%20Seguimiento\%20y\%20Monitoreo\%20al\%20 cumplimiento\%20de\%20la\%20Ley\%201448\%20de\%202011.pdf >.

De la Pedraja, R. (1988). La Guajira en el siglo XIX: Indígenas, contrabando y carbón. En G. Bell (Comp.), El Caribe Colombiano, Selección de textos históricos (pp. 329-359). Barranquilla, Colombia: Ediciones UniNorte.

Díaz Uribe, E. (1986). El clientelismo en Colombia. Un estudio exploratorio. Bogotá, Colombia: El Áncora Editores.

Duncan, G. 2006). Los señores de la guerra. Bogotá: Colombia. Editorial Planeta.

El Tiempo. (03 de julio de 1991). Ejército frustra voladura de puente. El Tiempo. Recuperado de <https://www.eltiempo.com/archivo/documento/ MAM-113675>.

El Tiempo. (07 de octubre de 1991). Ciénaga, entre la euforia y el miedo. El Tiempo. Recuperado de <https://www.eltiempo.com/archivo/documento/ MAM-167830>.

El Tiempo. (16 de febrero de 1994). Asesinado otro concejal en Ciénaga. El Tiempo. Recuperado de <https://www.eltiempo.com/archivo/documento/ MAM-44617>.

El Tiempo. (24 de febrero de 1994). Matanza de 5 obreros paró ayer a Ciénaga. El Tiempo. Recuperado de <https://www.eltiempo.com/archivo/documento/ MAM-53850>.

El Tiempo. (16 de octubre de 1998). Asesinan a 14 campesinos en la Sierra Nevada. El Tiempo. Recuperado de <https://www.eltiempo.com/archivo/ documento/MAM-797697>.

Fals Borda, O. (1975). Historia de la Cuestión Agraria en Colombia. Bogotá, Colombia: Publicaciones de la Rosca.

Fals Borda, O. (1976). Capitalismo, hacienda y poblamiento en la costa Atlántica. Bogotá, Colombia: Ediciones Punta de Lanza.

Fals Borda, O. (1986). Historia doble de la costa (4 vols.). Bogotá, Colombia: Carlos Valencia Editores. 
Vida campesina en el Magdalena Grande

Figueroa, J.A. (2009). Realismo mágico, vallenato y violencia política en Colombia. Bogotá, Colombia: Instituto Colombiano de Antropología e Historia (ICANH).

Fiscalía de Justicia y Paz. (2010). Escrito para el desarrollo de audiencia concentrada de formulación y aceptación parcial de cargos. Barranquilla, Colombia: Fiscalía General de la Nación.

García, D. (2016). Cambios en la dinámica socio-laboral de las mujeres afro en Valledupar: el caso del corregimiento de Guacoche (Tesis de Maestría). Universidad Nacional de Colombia, San Andrés, Colombia.

Goldberg, D. y Mouton, F. (1986). Critique d'un Projet de developpment rural dans une zone d'agriculture traditionnelle au nord de la Colombie. Rennes, Francia: École Nationale Supérieure Agronomique.

Granados, M. (2014). Lo más bonito sería que la minería se acabara. Revista Oraloteca, 6, 6-16.

Helg, A. (2011). Libertad e igualdad en el Caribe Colombiano, 1770-1835. Medellín, Colombia: Fondo Editorial Universidad EAFIT-Banco de la República.

Herrera Ángel, M. (2002). Ordenar para controlar. Ordenamiento espacial y control político en las llanuras del Caribe y en los Andes Centrales neogranadinos, siglo XVIII. Bogotá, Colombia: Instituto Colombiano de Antropología / Academia Colombiana de Historia.

Jaramillo, P., Pérez, I. y Carvajal, D. (2010). Ejércitos irregulares y organización campesina: Guáimaro, el camino hacia la restitución del derecho a la tierra. Bogotá, Colombia: Universidad Nacional de Colombia.

Kalmanovitz, S. (1982). El régimen agrario durante el siglo XIX en Colombia. En J. Jaramillo Uribe (Dir.), Manual de Historia de Colombia, T. II. (pp. 211324). Bogotá, Colombia: PROCULTURA-INSTITUTO COLOMBIANO DE CULTURA.

Kalmanovitz, S. (Ed.) (2010). Nueva Historia económica de Colombia. Bogotá, Colombia: Editorial Taurus.

Krogzemis, J. (1967). A Historical Geography of the Santa Marta Area, Colombia. California, USA: University of California, Berkeley.

Meisel Roca, A. (1980). Esclavitud, mestizaje y haciendas en la Provincia de Cartagena 1533-1851. Revista Desarrollo y Sociedad, 4, 229-277.

Melo, J. O. (1997). Las vicisitudes del modelo liberal. En J. A. Ocampo (Comp.), Historia Económica de Colombia (4a. Ed.) (pp. 119-172). Bogotá, Colombia: Tercer Mundo Editores-Fedesarrollo. 
Vida campesina en el Magdalena Grande

Melo, J. O. (1982). La evolución económica de Colombia. En J. Jaramillo Uribe (Dir.), Manual de Historia de Colombia, T. II. (pp. 135-209). Bogotá, Colombia: PROCULTURA-INSTITUTO COLOMBIANO DE CULTURA.

Resolución 02 de 1973 [Ministerio de Gobierno] Por la cual se demarca la Línea Negra o zona teológica de las comunidades indígenas de la Sierra Nevada de Santa Marta. 4 de enero de 1973. Ministerio de Gobierno. República de Colombia.

Molano, A., Rozo, A., Escobar, J. y Mendiola, O. (1988). Aproximación a una historia oral de la colonización de la Sierra Nevada de Santa Marta. Santa Marta, Colombia: Fundación Pro Sierra Nevada de Santa Marta.

Múnera, A. (1998). El fracaso de la nación. Región, clase y raza en el Caribe colombiano (1717-1821). Bogotá, Colombia: Banco de la República - El Áncora Editores.

Múnera, A. (2005). Fronteras Imaginadas. La construcción de las razas y de la geografía en el siglo XIX colombiano. Bogotá, Colombia: Editorial Planeta.

Negrete, H. (2020). Significado de las huellas del café a través del tiempo en el corregimiento de Siberia. Santa Marta, Colombia: Investigación no publicada.

Ortiz, E. (2017). Poblamiento campesino en la Sierra Nevada de Santa Marta: un asunto de esperanza. Santa Marta, Colombia. Investigación no publicada.

Perozzo, C. (1986). Forjadores de Colombia contemporánea T. II. Bogotá, Colombia: Editorial Planeta.

Polo Acuña, J. (2009). Poblamiento y conflicto social en la frontera guajira 17001800. El taller de la Historia, 1(1), 27-73.

Reclus, E. (1861). Viaje a la Sierra Nevada de Santa Marta (Tomo 112). Bogotá, Colombia: Biblioteca Popular de Cultura Colombiana.

Reichel-Dolmatoff, G. (1953). "Contactos y cambios culturales en la Sierra Nevada de Santa Marta”, Revista Colombiana de Antropología, 1, (1), 15-122.

Reichel-Dolmatoff, G. (Comp.). (1955). Diario del Viaje del P, Joseph Palacios de la Vega entre los indios y negros de la Provincia de Cartagena en el Nuevo Reino de Granada 1787-1788. Bogotá, Colombia: Editorial ABC.

Revista Semana. (09 de enero de 2015). Los verdugos del Parque Isla de Salamanca. Revista Semana. Recuperado de < https://www.semana.com/nacion/articulo/ capturados-criminales-del-parque-isla-de-salamanca/440852-3>.

Rodríguez Navarro, G. (1990). Colonización y Medio Ambiente en el Caribe colombiano. Santa Marta, Colombia: CORPES Costa Atlántica.

Rojas, A. Las guerras del "negro" (09 de junio de 2009). Verdad Abierta. Recuperado de <https://verdadabierta.com/las-guerras-del-anegro-adan $>$. 
Vida campesina en el Magdalena Grande

Roldan, M. (2003). A sangre y fuego. La violencia en Antioquia 1946-1953. Bogotá, Colombia: Instituto Colombiano de Antropología e HistoriaFundación para la Promoción de la Ciencia y la Tecnología.

Sánchez, G. y Meertens, D. (1983). Bandoleros, gamonales y campesinos; el caso de la Violencia en Colombia. Bogotá, Colombia: Tercer Mundo Editores.

Sánchez, H. (2006). Haciendas y mano de obra en la Provincia de Valledupar. 1790-1880. En Gobernación del Cesar (Ed), Becas Culturales en Investigación sociocultural en Historia Regional y/o local del Departamento del Cesar (pp. 3-44). Cartagena, Colombia: Observatorio del Caribe colombiano.

Solano, Y. (2006). Regionalización y movimiento de mujeres: Procesos en el Caribe colombiano. San Andrés, Colombia: Universidad Nacional de Colombia, Sede Caribe.

Vargas-Reina, J. (2010). Guerreros y campesinos. El despojo de la tierra en Colombia. Estudios Socio-Jurídicos, 12(2), 381-387. Recuperado de http://www.scielo.org. co/scielo.php?script=sci_arttext\&pid=S0124-05792010000200012\&lng=en\&tl$\mathrm{ng}=\mathrm{es}$.

Viloria, J. (1997). Café caribe. La economía cafetera en la Sierra Nevada de Santa Marta. Cartagena, Colombia: Centro de investigaciones económicas del Caribe. Banco de la República.

Viloria, J. (2019). Aroma de café: economías y empresas cafeteras en la Sierra Nevada de Santa Marta. Jangwa Pana, 18 (2), 163-181.

Zambrano, F. (2002). Guerra y Paz en el Caribe colombiano. En G. Montañez, G. Cubides y S. Ramírez (Eds.), Dimensiones territoriales de la guerra y la paz (pp. 459-548). Bogotá, Colombia: Universidad Nacional de Colombia. 


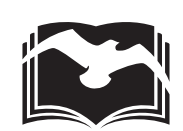

Se diseñó y diagramó en la Editorial Unimagdalena.

Se imprimió en los talleres de Xpress Estudio Gráfico y Digital S.A.S. carrera 69 H No. 77-40. Bogotá D.C., Colombia.

Esta publicación hace parte de la colección Ciencias Sociales, serie: Antropología y Sociología

En su composición se utilizaron caracteres Myriad Pro y Minion Pro. Su portada va en papel propalcote de 300 gramos y las páginas interiores en papel book cream 70 gramos.

Formato $17 \times 24 \mathrm{~cm}$. 